





\title{
THE DECLINE OF ARISTOCRACY IN THE POLITICS OF NEW YORK
}

\author{
BY \\ DIXON RYAN FOX, A. M. \\ Instructor in History, Columbia University
}

SUBMITTED IN PARTIAL FULFILMENT OF THE REQUIREMENTS

FOR THE DEGREE OF DOCTOR OF PHILOSOPHY

IN THE

Faculty of Political Science

Columbia University

NEW YORK

I918 




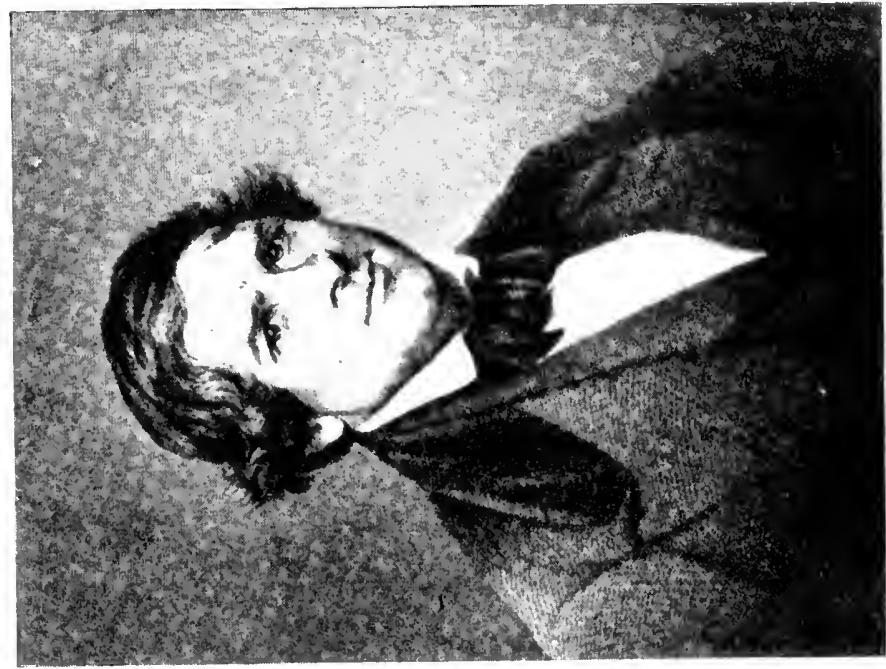

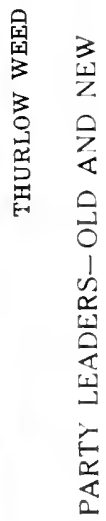

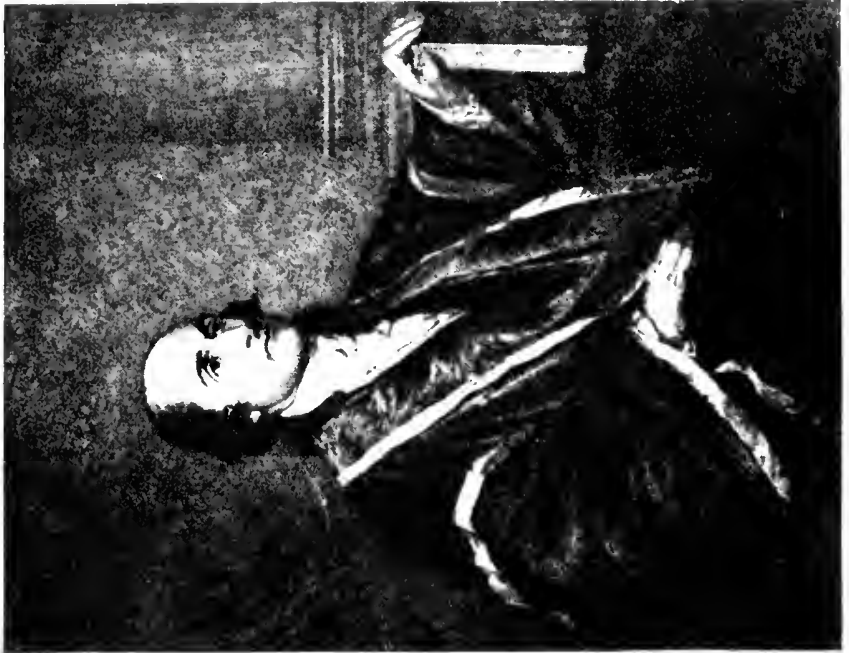

吕 


\title{
THE DECLINE OF ARISTOCRACY IN THE POLITICS OF NEW YORK
}

\author{
BY \\ DIXON RYAN FOX, A. M. \\ Instructor in History, Columbia University
}

\&UBMITTED IN PARTIAL FULFILMENT OF THE REQUTREMENTS

FOR THE DEGREE OF DOCTOR OF PHILOSOPHY

IN THE

Faculty of Poltical Science

COLUMBia Universtry

NEW YORK

1918 
Copyright, igig

BY

DIXON RYAN FOX

Iift

$$
\begin{aligned}
& \text { is: a : } \\
& 58 \text { :5 } 10 \mathrm{H}
\end{aligned}
$$

$\therefore \vdots$ 


\section{da \\ MY WIFE \\ MARIAN OSGOOD FOX \\ INSPIRING COMRADE}





\section{FOREWORD}

At the opening of the nineteenth century democracy was new; men were still described as gentlemen and simple-men, in America as well as in the monarchies across the sea. Disparities of rank were still sustained by those of property, but in a country such as ours, where the touch of energy could turn resources into wealth, prescriptive rights could not long remain unchallenged. In no colony had the lines of old caste been more clearly drawn than in New York; in no state were they more completely rubbed away. How an aristocracy of birth was changed to one of money and was often ousted from control, how Federalists became Clintonians and Clintonians turned into Whigs, is to be the theme of the following pages.

The history of New York state has been well told. Few contemporary narratives have been more full and fair than that contained within Judge Hammond's volumes published in the 'forties. Nor could the general reader want a more complete and readable account than that of Col. Alexander, published some ten years ago. These historians, however, in the manner of the older school, have dealt objectively with events and personalities, without giving much attention to the social and economic causes which went far to make them what they were. The present writer, with a narrower theme, has essayed to penetrate beneath the laws and party platforms in hope of explanations. It is a story he believes 
to be of interest, however haltingly related, tracing as it does the fortunes of a class, accustomed by training and tradition to the conduct of affairs, but forced to yield before what seemed to them the great disaster of democracy; it deals with their unpalatable compromises and slow liberalization, and the final welding of a business party appropriate to the conditions of America. It is hoped that thus it may throw another ray of light upon the evolution of society in the Empire State.

To Professor William A. Dunning of Columbia University, the author is under special obligation for the keen but kindly criticism which he has brought to bear upon this study, and for his sacrifice of many hours to the tedious task of reading proof. Professor Herbert $\mathrm{L}$. Osgood has patiently reviewed the manuscript and made valuable suggestions. The author desires also to acknowledge the co-operation of Mr. Victor Hugo Paltsits, Keeper of the Manuscripts of the New York Public Library, of Robert H. Kelby, Librarian of the New York Historical Society, of Dr. Austin B. Keep, and of Professors Charles A. Beard, Carlton J. H. Hayes, David S. Muzzey and Robert Livingston Schuyler, of whose counsel he has frequently availed himself. Notwithstanding this generous aid, he is aware that many imperfections still remain.

Columbin University, May, 1917.

Dixon Ryan Fox. 


\section{TABLE OF CONTENTS}

\section{CHAPTER I}

The Few, the Rich, AND the Well Born

The revolution of 1 sor turns out the governing class . . . . . . . I I

The pessimism of the leaders .. . . . . . . . . . . 3

"A spirit of innovation counteracts the best tendency of regular habits". 7

Hamilton, Jay, King and Morris . . . . . . . . . . 8

The elements of party strength in New York city ......... II

The lawyers (the Tories and the wealthy Whigs) ........ II

The merchants and bankers. ............. 18

The Episcopal Church and Columbia College......... 25

\section{CHAPTER II}

\section{The Country.Side}

The Dutch aristocrats of the upper Hudson valley are finally joined, in spite

of prejudice, by the New England immigrants ........... $3^{1}$

The whaling port of Hudson . . . . . . . . . . . . 39

The Columbia Junto. . . . . . . . . . . . . . 40

Business in Poughkeepsie. . . . . . . . . . . . . 46

Free-thinking Newburgh. ............... 47

The Great West of New York . . . . . . . . . . . . 48

Three classes of frontiersmen ............ 49

Village aristocracies ................. 5 I

Vermonters in the north ............... 52

The meaning of the revolution .............. 54

The bitterness of party strife at the opening of the century . . . . . 56

\section{CHAPTER III}

Rulers Deposed

Aaron Burr, condottiere................. 57

A war of pamphlets.................. . . 58

The "little band" and "the families"............66 60

The scurrilous campaign of 1804 ............ . . 6I

The Federalists get a bank charter and form a shame-faced union with the

"Quids" ..................... . . 6g

“ Demagogue Clinton \& Co. vs. Demagogue Lewis \& Co." . . . . . 70 
The Irish rail at Rufus King and vote for Clinton's men . . . . . . . 75

The American ticket of $\mathrm{I} 8 \mathrm{O} 7$. . . . . . . . . . . . 80

Mr. Jay's disgust at hesitating leadership . . . . . . . . . 82

\section{CHAPTER IV}

\section{New Mrthods and a Victory}

Old castes and new philosophy. . . . . . . . . . . . . . 84

General Hamilton's suggestion of a Christian Constitutional Society . . . 87

The Federalists go in for fraternity. . . . . . . . . . . . . 88

The Washington Benevolent Society. . . . . . . . . . 89

Rules and professions ................ 90

Growth and opposition ............... . . 91

The solemn ceremonies. . . . . . . . . . . . 92

Federalist oratory ................ . . 93

Washington Halls . . . . . . . . . . . . . . 95

The code of pageantry . . . . . . . . . . . $9^{6}$

Effective service .............. . . . 99

The first party " convention"............... 100

The embargo in New York. . . . . . . . . . . . . 102

The taint of Toryism ...... . . . . . . . . . 104

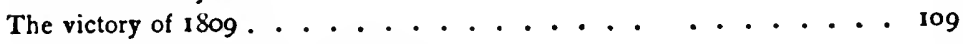

"Platt, Commerce and the Constitution"............ I14

Retrospect. ................. II

\section{CHAPTER V}

\section{IANDMOLders' Principles}

The wealthy Federalists speculate in the wild lands of the state, and in con-

sequence oppose a tax on real property. . . . . . . . . . I 20

The spread of Federalism from the city. . . . . . . . . . . . I22

The land agents. ................ 128

The ambitious lawyers. . . . . . . . . . . . 129

The younger sons. . . . . . . . . . . . 1 $13^{\circ}$

The Episcopal Church. . . . . . . . . . . . . . . 1 137

The power of the squires through intimidation of their tenants and grants of

"Fagot holdings" . . . . . . . . . . . . . . . I39

The encouragement of landowners to the building of canals, an element in making possible the coalition of the Federalists with Clinton. . . . 148

\section{CHAPTER VI}

Mr. Madison's War

"Abimelech Coody" . . . . . . . . . . . . . . . 160

The riotous commencement of $1811 \ldots . . . . . . . . .163$

Mayor Clinton's "detestation of mobocracy" . . . . . . . . . . 164 
He loses some old friends and gains some new . . . . . . . . I65

Mr. Clinton as a peace-war candidate in $1812 \ldots \ldots$. . . . . 165

General Van Rensselaer is honored with the leadership of a forlorn hope. . 172

Senator Rufus King . . . . . . . . . . . . . . . . 173

Middle-way Federalism successful in New York in 1813. . . . . . 174

Free speech in war time . . . . . . . . . . . . 178

Praising the enemy. . . . . . . . . . . . . . 179

"The guardians of our commerce" ............. 181

Home defence.................. . . 183

Capitalizing discontent................ I85

The magic name of Rufus King does not charm Democrats in I816 . . . I91

He admits himself a visionary man . . . . . . . . . . I 92

\section{CHAPTER VII}

\section{Clinton, Divider of Parties}

Mr. Clinton becomes governor by the force of an idea. . . . . . . . 194

A statesman-like address attracts the lovers of strong government. . . . 197

His " cold, repulsive manner," his nepotism, and his pedantry . . . . . 200

"The Coodies". . . . . . . . . . . . . . . . . . 203

Federalists and patronage .............. 206

Clinton vs. King . . . . . . . . . . . . . . . . 207

A literary enterprise : the New York American. . . . . . . . 209

A Martling Man, or Says I to Myself, How is this . . . . . . . . 213

The Bucktail Bards. . . . . . . . . . . . . . 215

Clintonian corruption ................. 216

The learned societies ................ 218

"Epaminondas". . . . . . . . . . . . . . . 219

King's sudden popularity . . . . . . . . . . . . 220

The "High minded Federalists" . . . . . . . . . . . . . . . 222

The Columbia Junto in disgrace. . . . . . . . . . . . 226

A broken party . . . . . . . . . . . . . . . 228

\section{CHAPTER VIII}

\section{Property or Prople?}

The Constitution of $\mathbf{1 7 7 7}$ is outgrown, but the Bucktails, pressing for reform,

encounter Governor Clinton's opposition . . . . . . . . . . 229

The Council of Revision attempts to sare its life . . . . . . . . . 235

Universal suffrage is seriously proposed. . . . . . . . . . 237

The delegates. . . . . . . . . . . . . . . . 239

The Council of Revision is destroyed and the veto given to the Governor. . 244

A ppointive offices become elective . . . . . . . . . . . 246 
TAGE

The governor the people's minister. . . . . . . . . . . . . . . 247

The suffrage is the subject of a fierce debate. . . . . . . . . . . 248

The "sacred turf" . . . . . . . . . . . . . . . . 256

Federalist merchants and landlords fear manufacturers. . . . . . . . 257

The freehold qualification as a stimulus to thrift. . . . . . . . . . . 259

The menace of the city mob. . . . . . . . . . . . . . . . 26 I

Property loses its constitutional privilege. . . . . . . . . . . . 263

The aristocrats in ermine are driven from the bench. . . . . . . . . . . 264

A gerrymander. . . . . . . . . . . . . . . . . . . 266

\section{CHAPTER IX}

\section{Old Comrades and New Banners}

"Remnants of royalty" are brushed away. . . . . . . . . . . . . 27I

Rivalry in praising the people . . . . . . . . . . . . . . . 273

Federalists are not welcomed as Republicans . . . . . . . . . . 274

The philosophy of parties. . . . . . . . . . . . . . . . 276

Governor Yates mistakes an uncontested election for the millennium . . 280

The Albany regency. . . . . . . . . . . . . . . . . . . 281

The party with a program, and the party with a creed . . . . . . . 285

The presidential campaign of 1824 . . . . . . . . . . . . . 286

The People's Party hold a convention . . . . . . . . . . . . . 290

A candidate is thrust upon them. . . . . . . . . . . . . . . 292

Clinton routs "King Caucus" . . . . . . . . . . . . . . . . 298

The Solidarity of Federalists . . . . . . . . . . . . . . 299

Thurlow Weed shows himself a clever man . . . . . . . . . . 300

\section{CHAPTER X}

\section{Manufacturing Becomes Respectable}

New York becomes the Empire State . . . . . . . . . . $3^{\circ 2}$

The astonishing growth of towns along the water route from New York to

Buffalo. . . . . . . . . . . . . . . 303

Business men extoll the enterprising Clinton. . . . . . . . . 305

A lobby party engages in " $\log$ rolling". . . . . . . . . . . 307

John Quincy Adams seeks to make the nation rich and wise..... . 308

Clinton suspected by the business men . . . . . . . . . . $3^{\text {II }}$

He fails to deliver his party to General Jackson. . . . . . . . $3^{14}$

Van Buren makes haste slowly in recommending Jackson...... . 317

Steam and steel and politics ...... . . . . . . . . $3^{18}$

Some Federalists find manufacturers are on the right side. . . . . $3^{22}$

State aid for mills. . . . . . . . . . . . . . . . $3^{24}$

Staple farmers look for a home market. . . . . . . . . . 325 


\title{
CHAPTER XI
}

\author{
Political Distraction
}

The Federalists at first condemn protection . . . . . . . . . $3^{27}$

But are allured by manufacturing profits. . . . . . . . . . . 329

The Democrats are non-committal. . . . . . . . . . . . 331

They defer to Virginia. . . . . . . . . . . . . 333

Sectionalism in the state-road controversy. . . . . . . . . . 334

The fanatical enthusiasm of anti-masonry . . . . . . . . . . 337

Uncertainty as to Clinton. . . . . . . . . . . . . . . 343

His death makes possible clearer party lines. . . . . . . . . . . . 344

He was deficient as a politician . . . . . . . . . . . 345

But a statesman. . . . . . . . . . . . . . . 346

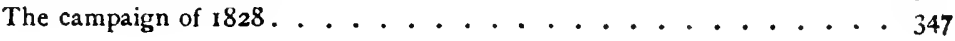

\section{CHAPTER XII}

\section{TOM, Dick and Harry Take a HaNd}

The workingmen's demands . . . . . . . . . . . 352

They form a party. . . . . . . . . . . . . . 355

Internal quarrels ................. . . . 356

The wage argument for protection. . . . . . . . . . . $35^{8}$

The "Siamese-twin scheme" of National Republicans and Anti-Masons. . 360

Senator Marcy wins . . . . . . . . . . . . . . 363

The United States Bank. . . . . . . . . . . . . . 364

The usefulness of Thurlow Weed ............ . . 365

The Whig Party.................. . 366

Nativism . . . . . . . . . . . . . . . . 37 I

The Whig attitude toward Abolitionists. . . . . . . . . $37^{8}$

\section{CHAPTER XIII}

Two Views of Vested Rights

The shrine of true democrats . . . . . . . . . . . . . $3^{81}$

The turpitude of bankers. . . . . . . . . . . . . 382

Loco Focos. . . . . . . . . . . . . . . . $3^{8} 3$

Labor as a radical faction of the Tammany Society. . . . . . . $3^{86}$

Anti-clericalism. . . . . . . . . . . . . . $3^{88}$

Strikes . . . . . . . . . . . . . . . 390

Fusion of the discontented in 1836 . . . . . . . . . . . 392

The literature of protest. . . . . . . . . . . . . . . 395

The Democratic party "converted" in the days of panic. . . . . . . 397

The Conservatives. . . . . . . . . . . . . . . 398 
PAGB

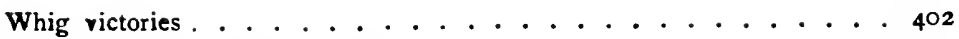

The "forty-million-dollar party". . . . . . . . . . . . . . 403

Changing sentiment on internal improvements. . . . . . . . . 405

\section{CHAPTER XIV}

WhO WeRE THE WhIGS?

Mr. Webster defines the issues for 1840 . . . . . . . . . . 409

Whigs deprecate the cry of aristocracy. . . . . . . . . 4 4 II

Van Buren, the sybarite . . . . . . . . . . . . . . 412

Singing for a ploughman President. . . . . . . . . . . . 41 3

American society adrift without an aristocracy. . . . . . . . 4 416

Why the class war did not come. . . . . . . . . . . . 418

The core of Federalism. . . . . . . . . . . . . . . 420

Other constituent elements of the Whig party . . . . . . . . 422

The infuence of personality. . . . . . . . . . . . . . . 423

The west ................ . . . . . . 4424

The merchants. . . . . . . . . . . . . . . 4425

Whigs read expensire newspapers . . . . . . . . . . . . . 426

The witness of statistics . . . . . . . . . . . . . . 430

Anti-rent riots. . . . . . . . . . . . . . . . 4 437

Emerson on parties . . . . . . . . . . . . . . . 4439 


\section{ILLUSTRATIONS}

JoHN JAY. . . . . . . . . . . . . . Frontispiece

By Gilbert Stuart ; in Metropolitan Museum of Art

ThuRlow WeED. . . . . . . . . . . . . Frontispiece

By Chester Harding; by permission of William Barnes, Esq.

Opposite page

Elisha Williams ..................4 4 I

Artist unknown; reproduced from P. F. Miller's Group of Great Lawyers of Columbia County (N. Y., I908)

Gulian C. Verplanck. . . . . . . . . . . . . 89

By John Wesley Jarvis; owned by Miss Eleanor Fitz Gerald, New York City

DeWrtr Clinton. . . . . . . . . . . . . . 165

By S. F. B. Morse; in Metropolitan Museum of Art

StrPhIn VAN Rensselare . . . . . . . . . . . . 323

Artist unknown; reproduced from K. S. Baxter, A Godchild of Wash. ington (N. Y., 1897)

WILLAM H. SEWARD................. 37 I

From old print

JAMrs KRnT. . . . . . . . . . . . . . . . . 4233

By Rembrandt Peale; owned by the Kent family, Tuxedo Park

xiii 



\section{CHAPTEK I}

The Few, the Rich, and the Well Born

"WE are all Republicans, we are all Federalists"-the word of peace was spoken by the bland philosopher of Monticello, as he took the chair of state in the spring of I80r. But as it issued irom the presses of the great towns to the north, it was not a soothing word; it carried no assurance to the merchants and ship-masters; to them it heralded a peace. not of reconciliation, but of surrender that was bitter in its hopelessness. They had scarce need to read through Jefferson's inangural to know that agriculture was to be a chief concern of his administration and that commerce would gain attention only as its handmaid.' To these Federalists the removal of the seat of government to the Potomac was but the ontward sign that the nation's center of sravity had been shifted toward the south, leaving them in their remoteness a benumbing sense that henceforth their portion was to be neglect. The new leader had declared that great cities were but sores on the body politic. ${ }^{2}$ and he had indicated to his friends that were he to indulge his own desire. he would wish these staten "to practice neither commerce nor navigation, but to stand with respect to Europe precisely on the fonting of China." "

'J. D. Richardson, Messages and Papers of the Presidents (Washington. 1899), vol. i, pp. 322-323.

" J. P. Foley. The Jeffersonian Cyclopedia (N. Y., I900), pp. I $+1-\mathrm{I}+2$.

3 Jefferson to Count Van Hogendorp. Paris. 1785, Jefferson's Writings (Ford edition), vol. iv, p. Iof. 
Ship-yards and counting-houses were no longer likely objects of the nation's patronage: in the vanity of ignorance, it seened, wealth and enterprise in trade were fallen into disrepute.

But the troubles that seemed imminent were still more deeply based. The government which Federalists had nursed to robust promise, had, by this sad caprice of fate, been handed over to the ungentle stewardship of its notorious foes. It might now be reasonably expected that the official theory of the United States would be that of the Kentucky resolutions, whose author was exalted to the highest place. This was the man who had complained of using force to curb the Whiskey Insurrection, ${ }^{1}$ and had said of Shays's exploits in western Massachusetts: "God forbid that we should ever be twenty years without such a rebellion." Here was a chief magistrate whose loud simplicity seemed calculated to neglect all canons of decorum. What was to become of decency and order under such a man? Had the Fcdcralist been written all in vain? Were those achievements so dearly wrought by Washington and Hamilton to be tumbled into an ungrateful memory and this nation fall without a protest, simply that a full experiment be given to this fatal doctrine of democracy?

When the word was brought to Hamilton, in the spring of 1800 . that the legislature of New York would be "AntiFederal" and thus the vote of this great state make inevitable the choice of Jefferson. ${ }^{3}$ he wrote to Governor Jay

'Jefferson to James Madison, May 1793, Writings (Ford), vol. vi, p. 26I, and December I794, ibid., p. 518; to James Monroe, May I795, ibid., vol. vii, p. 16.

'Jefferson to W. S. Smith, 1787 , ibid, vol. iv, p. 467 .

${ }^{3}$ The presidential electors in New York were chosen by the two houses of the legislature until after the election of $1824-1825$; see J. D. Hammond, History of Political Parties in the State of New York (Albany, 1842 et seq.), vol. ii, p. I54 et seq. 
that the "scruples of delicacy and propriety . . . ought not to hinder the taking of a legal and constitutional step to prevent an atheist in religion and a fanatic in politics, from getting possession of the helm of state," 1 and advised the governor forthwith to call a special session of the old Federalist legislature to pass a law which, by redistricting the state. would probably insure a Federalist triumph for New York and thereby for the nation. General Schuyler had likewise urged this trick and assured the governor that

your friends will justify it as the only way to save a nation from more disasters, which it may and probably will experience from the mis-rule of a Man who has given such strong evidence that he was opposed to the salutary Measures of those who have been heretofore at the helm, and who is in fact pervaded with the mad French philosophy. ${ }^{2}$

There were others who joined in this desperate advice, ${ }^{3}$ but Jay's good sense withstood more firmly the behests of anger and disgust; he refused thus to conspire to defeat the people's will and rejected this proposal for "party purposes, which I think it would not become me to adopt." + That such an expedient could have been seriously talked of by the responsible leaders of the party, shows how critical they thought the juncture in our national affairs. Even Jay looked forward to a dismal iate for this people, whom

'Hamilton to Jay, May 7, I800, The Works of Alexander Hamilton (Lodge edition, N. Y., I886), vol. viii, p. 549.

${ }^{2}$ Philip Schuyler to Jay, May 7. 1800, Correspondence and Public Papers of John Jay (Johnston edition, N. Y., 1893), vol. iv, p. 273. General Schuyler feared that Jefferson would embroil the United States in a war with Great Britain.

${ }^{3}$ Schuyler mentions John Marshall as one, ibid., loc. cit.

"Jay Correspondence, vol. iv, p. 272. Lodge's note in Hamilton's Writings, vol. vii, p. 55I, and D. S. Alexander, A Political History of the State of New York (N. Y., 1906-I909), vol. i, p. 92. Both quote this passage inaccurately. 
lic saw "permitting their happiness to be put in jeopardy" by the worst passions, inflamed and directed by the most reprehensible means." Whether all the ills that threatened could be prevented no man could propinesy, but it was ecrtainly a most unhappy fact that the Federalists themselie. did not act together to ward them off. "If the sound and leading friends of their country," he wrote, "could concur in opinion as to men and measures, their efforts would probably be successful, but unfortunately there is too little unanimity in many points. and the want of it exposes us to the hazard of many evils." 1

The new legislature, meeting in November, justified the Ferleralists' fears. An electoral ticket had been fashioned which drew support from every faction that had forme. anong kepublicans, ${ }^{2}$ and they acted as a whole, while agreeing in their caucus with like unanimity to support Ceorge Clinton as their candidate for governor. ${ }^{3}$ The lederalists placed in nomination the Patroon. Stephen $V$ an Rensselaer, the social leader of the state, ${ }^{4}$ a dignified and knightly figure, and a public servant of honorable reputation." The state campaign of April. I80r, was vigorously fought, but the Federalists could make no headway against the spirit of the times: it was destined that John Jay was to be remembered as the last governor of his party

'Jay to 'Theophilus Parsons. July I, I 800, Jay Correspondence, vol. iv, p. 274 .

'J. D. Hammond, Political History', vol. i, pp. 135-137. Though ordinarily the legislature met in January, it was called in "presidential years" for November.

seremiah Van Rensselaer, the candidate for lieutenant-governor, was probably the only man of his name to be found in the Anti-Federal. or as it was now called, Republican party.

'D. D. Barnard, Discourse on Stephen I'an Rensselaer (pamphlet, Albany, 1839).

${ }^{5}$ N. Y. Civil List, 1889, p. $7+2$. He was then serving as lieutenantgovernor. 
in New York. After an earnest effort to save appointments for his partisans, ${ }^{1}$ he laid down forever the cares and dignities of office. There were no hymns of hope as the distinguished leaders in New York gathered at the banquet board to sound his praises; it was a sad rarewell, not alone to the beloved governor, but likewise to the exercise of power and control by their "party of the talents," and as they believed, to the prosperity which such care insured."

Now in I80I, as later, one hears in their pronouncements a constant minor undertone of deep discouragement; the structure of society seemed suddenly turned upsicle down, with what result no one could foretell.

In New York the rights \& the property of the city and state are subject to the vice and folly and poverty of the society [wrote Fisher Ames to Rufus King, in London]. We are now in the Roland \& Condorcet act of our Comedy-Whether we go on to the Danton and Robespierre acts depends on time

${ }^{1}$ This controversy was with the majority of the Council of Appointment, which under the Constitution of 1777 , consisted of one senator from each of the four great districts of the state, chosen by the assembly and under the presidency of the governor. This officer by the prescription was to appoint all officers, who were not elected, "with the advice and consent of said council" (Article xxiii). The majority in the winter of I\&o I were Republicans, and claimed that any member had a concurrent right of nomination with the governor, a contention which Jay would not allow. The deadlock which resulted from this opposition was the principal cause of the Convention of $180 \mathrm{I}$, which in a constructive amendment to the constitution supported the opinion of the majority of the Council. See H. L. McBain, "DeWitt Clinton and the Origin of the Spoils System in New York" (Columbia University Studies in History, Economics and Public Law, vol. xxviii, no. I), and Charles Z. Lincoln, The Constitutional History of New York (Rochester, I906), vol. i, pp. 56, I78, I9I, 531, 600-602, 610-6I I.

${ }^{2}$ Robert Troup to Rufus King, May 27, I8o1, The Lifc and Correspondence of Rufus King (Charles R. King, editor, N. Y., I $894-1900$ ), vol. iii, p. 458. Inasmuch as letters in this work, as well as in the Jay Correspondence, are arranged in chronological order, this source will be frequently cited by date only. 
and accident and not on the discernment energy or force of the Feds. ${ }^{1}$

Just as six years before, the Federalists had cleansed the govermment of most of those who stood with Clinton, so now, by revolution, the Federalists found themselves proscribed." "In this state." wrote Robert Troup, "all power and all the offices are also engrossed by the Democrats." : Seriously to contemplate democracy as at kind of government was absurd, wrote Gouverneur Morris in I8OI, "for I hold that it is no government at all, but, in fact, the death or dissolution of other systems, or the passage from one kind of government to another." 4 Soon. it might well be, as Hamilton predicted, we should have a despotism, " for a courtier and a demagogue differ only in forms, which. like clothes, are put on and off as suits the occasion." 5

In the speech and correspondence of the Federalists there recurs the prediction of the final failure of the American experiment, to end in no one knew what form of government. They seemed sorrowfully certain of their destiny to outlive the nation they had labored earnestly to build. "Old Gates used to tell me in 1776 ," wrote Judge Peters to John Jay. " that if the bantling Independence lived one year, it would last to the age of Methusaleh. Yet we have lived to see it in its dotage, with all the maladies and imbecilities of

${ }^{1}$ Fisher Ames to Rufus King, May 27, I801, King Correspondence.

${ }^{2}$ H. L. McBain, $o p$. cit., successfully combats the claim advanced by Schouler, Henry Adams and others, that the spoils system was invented in I 80 I by De Witt Clinton and his Council of Appointment, pointing out that the practice was inherited from the Jay administration.

${ }^{3} \mathrm{R}$. Troup to King, April 9, I802, King Corrspondence.

4 Anne C. Morris, The Diary and Letters of Gouverneur Morris ( N. Y., I888), vol. ii, p. 469.

${ }^{5}$ Ibid., p. 475. "Democracy is the first step toward despotism," said the New York Spectator, March 5, I804. 
extreme old age." 1 Society itself was showing symptons of decay; the unnatural genius of equality was sapping the foundations of all that had been built in the knowledge and the virtue of the past. ${ }^{2}$ Such influences were admitted through a reckless zeal for novelty which brought on all the troubles. "Among the evils, which periodically flourish amongst mankind," remarked an essayist, " is a spirit of innovation, which has lately gained strength in our borders. and now counteracts the best tendency of regular habits." " Jay and King might counsel firm resistance to this innovation, ${ }^{4}$ but it seemed sadly clear to many honest Federalists that "Reason, common sense, talents and virtue, cannot stand before democracy. Like a resistless flood, it sweeps all away: and it has, probably, not yet spent its force." 5 The leading editorial of the New York Commercial Adicrtiser, on New Year's Day of I8OI, concluded:

We have no grounds to felicitate ourselves on advancing a single step in the theory or practice of government within two thousand years. The opinion that we have advanced, is derived from our pride, founded on our ignorance-an opinion that is a burlesk on an education in pretended science, and our variity. ${ }^{6}$

As one reads these jeremiads of pessimism, no doubt of their sincerity intrudes to break their force. Here was a

${ }^{1}$ Judge Peters to Jay, July 9, I808, Jay Correspondence.

${ }^{2}$ Rufus King to Noah Webster, June 30, I807, King Correspondence.

${ }^{3}$ N. Y. Spectator. April 2I, IS06, "Speculations of Decius," published serially.

"Jay to Richard Hatfield, November 8, ISoo, Jay Correspondence. and Rufus King to Christopher Gore, March 2I, $188_{15}$, King Correspondence.

5 "Candidus" in N.Y. Spectator, January I8, ISO4.

${ }^{6}$ See also the Rev. Samuel Osgood, New' York in the Ninitecuth Cintury, a discourse before the New York Historical Society (N. Y., I867), pp. 14-15. 
company of gentlemen accustomed to the power and direction of the government, suddenly reduced to private station and the consciousness of unimportance; but they obviously spoke from larger motives than those of personal resentment. They believed themselves the spokesmen of a class as indisputably fit to rule a state as those guardians to whom Plato entrusted his Republic. One turns with interest to inquire who made up this class thus brought down by the leveling wave of I Sor.

For the most part in New York, since the adoption of the state constitution in 1777 , the Federalist party had controlled the state, ${ }^{1}$ and the Federalist party had been itself controlled from New York city." Here lived the brilliant leader, Alexander Hamilton, who not only had done most to formulate the party's principles and to set forth its political philosophy, but had been its foremost champion on the public platform, its chief exponent in administration and the most effective organizer of its victories. In IBOI he had been for several years in private life and, by untiring exertion. had built up a practice at the bar which brought in a yearly income of some fifteen thousand dollars, ${ }^{3}$ yet he was still regarded as the chiei directing mind of the party he had founded. The "lttlabies" of the new President were but added irritation to his drooping spirit. "Perhaps no man in the United States has sacrificed or done more for the present Constitution than myself, and contrary to all my anticipation of its fate. as you know

'J. D. Hammond, Political History, vol. i. p. ín.

2 O. G. Libby, "The Geographical Distribution of the Vote of the Thirteen States on the Federal Constitution" (Wisconsin Studies in History, Economics and Political Science, vol. i. Madison, 1897), p. 18; C. A. Beard, An Economic Interpretation of the Constitution (N. Y., 1913), p. 268 et seq., and H. L. McBain, De Witt Clinton and the Spoils System, p. 105.

3 H. C. Lodge, Alexander Hamilton. Boston, I882, pp. 234-235; D. S. Alexander, Political History of the State of New York, vol. i. p. 132. 
from the very beginning, I am still laboring to prop the frail and worthless fabric."

Next in dignity among these New York Federalists was Governor Jay, now retiring to the country home that he had built at Bedford, studying the science of the soil from Columella to Sir John Sinclair and busying himself with new breeds of stock and new varieties of melons. ${ }^{2}$ Yet his absence from the form seemed almost to enhance the value of his counsel and he was to be frequently consulted as a grand old man acquainted with the purposes of the founders of the government, and a stalwart foe to all that savored of democracy. "It is not a new remark," he wrote to Canon Wilberforce, "that those who own the country are the most fit persons to participate in the government of it. This remark, with certain restrictions and exceptions, has force in it; and applies both to the elected and to the elector, though with most force to the former." 3 Jay seemed to Federalists a very proper governor; the only vice for which he had been seriously criticized by his opponents, that of prodigality, was in their theory of politics almost a virtue. ${ }^{*}$

Scarcely less important in the early days of the new government was Rufus King. In I SoI he was still minister to England, but long surviving other leaders, he was to become the foremost of his party in the state and in the

'Hamilton to G. Morris, February 27, I802, Works (Lodge), vol. viii, p. 59I ; and to C. C. Pinckney, December 29, I8o2, ibid., p. 606.

${ }^{2}$ Jay to Judge Peters, July 24, I809, and March I4, I8I5, Jay Correspondence; Jay to Sir John Sinclair, December I6, 1800 and August 8, I8I6, ibid.; Robert Bolton, History of the County of Westchester (N. Y., I848), vol. ii, pp. 88-9I ; J. G. Wilson, Memorial History of the City of New York (N. Y., I 803 ), vol. iii, p. 156.

${ }^{3}$ Jay to Judge Peters, July 24, 1809, and to William Wilberforce, October 25, I8Io, Jay Correspondence.

${ }^{4}$ Alexander Hamilton, Address to the Electors, pamphlet, (N. Y,, I801), pp. 19-20. 
nation, throughout the first quarter of the century. Four times elected to the Senate of the United States, ${ }^{1}$ he represented not alone the great state of $\mathrm{New}$ York, but likewise the old caste of gentlemen. A man of wealth and family," the " high model of courtly refinement," appearing always to the last in the small-clothes and silk stockings of the days of Washington, he had in manner a formal courtesy, and something of hauteur and pride, the bearing of a true aristocrat. ${ }^{3} \quad$ As to other Federalists of the older school, so to him the ideal statesman was the leader of measures and not the leader of men, administering a government large in power, respected anong nations and liberally benevolent in purpose. "With Hamilton devoted to the law and money-making, and Jay in deep retirement, the call went forth to King, in Londoni. to hasten home to lead the party in New York, a leadership which, once assumed, remained long undisputed. ${ }^{5}$ Like Hamilton and Jay, even after death he lived on in his sons, to aid in leading later parties in New York, the Whig and the Republican. ${ }^{6}$

${ }^{1} N$. Y. Ciril List, 1882, p. 446.

${ }^{2}$ He was, among other things, interested in government securities, as is evidenced in the letter to his broker Nicholas Low, June I5, 1802 . Life and Correspondence of Rufus King, vol. iv, p. I 40 . See also ibid., vol. i, p. I32; and C. A. Beard, Economic Interpretation of the Constitution (N. Y., I913), pp. II8-120.

${ }^{3}$ See the description by $\mathrm{T}$. H. Benton, in his Thirty Years Vicw (N. Y., I886), pp. 57-58, and King Correspondence, quoting from Faux's Tracels, vol. vi, p. 670 ct seq.

${ }^{4}$ William Sullivan, Public Men of the Revolution (Philadelphia, 1847), p. 59. For personal description, see in Delaplaine's Repository (Philadelphia, I8I5 et seq.), the article by William Coleman (Coleman to King, February 5. $1_{1} \mathrm{I}$, King Correspondence), and in Homes of American Statesmen ( N. Y., I859), the sketch of King Park by Charles King.

${ }^{5}$ Robert Troup to King, May 6, ISO2, King Correspondence.

- Article on John A. King in Appleton's Cyclopedia of American Biography; James A. Hamilton, Reminiscences (N. Y., I869), p. 3I4, and N. Y. Tribune, Norember 6, i8 8 . 
The last member of this famous four was Gouverneur Morris, who likewise had been distinguished in the effort to establish and to carry out the principles of an aristocratic government, somewhat moderated and toned down to fit conditions in America. It requires no rehearsal here to call to mind the theories of this bluff and testy squire. In his opinion "there never was, and never will be a civilized Society without an Aristocracy," 1 and aristocracy found no more admired exemplar than Morris in his generous service for the public good. In ISO he was to serve two years more as senator in Washington, ${ }^{2}$ then was to give his energies as propagandist for the internal improvement of the state. As public orator and adviser of the party, he was to continue in importance for fifteen years until his death.

These statesmen-Hamilton, Jay, King and Morris, were the models after which the younger generation of Federalists might seek to pattern their social and political careers; but such lordly gentlemen could not be counted on in New York city to do the hum-drum arduous work of ward meetings and inspection at the polls. Turning from the great apostles of Federalism to take note of lesser leaders, we do not, however, reach outside the same exclusive and aristocratic class.

The bar of New York city that argued cases in the old court house on Broad Street at the turning of the century numbered scarcely a hundred. ${ }^{3}$ It was a small company, indeed, compared with the tens of thousands that crowd the enormous hives that now weigh down those almost

1 Max Farrand, Records of the Federal Condention (New Haven, I9I I), vol. i. p. 545 .

${ }^{2}$ V. Y. Civil List. I882, p. 446.

${ }^{3}$ C. H. Hunt, Life of Edward Lizingston (N. Y., I863), p. 48 : T. E. V. Smith, The City of New York in the Year of Washington's Inauguration (N. Y., I889), p. 61 ; and C. H. Truax, History of the Bench and Bar of Neze York (N. Y., 1897), vol. i, p. 103. 
priceless acres; but within it there were men of gifts and power, some black-letter lawyers skilled in the confusing mazes of the common law and some who grasped the larger principles of polity and rose to high distinction in the field of jurisprudence. Of all these, the leaders, excepting the greater Liv. 'rstons, who were often absent from the city, and the erratic Aaron Burr, were of the Federalist party, and, incleed. not a few had evidenced their conservative regard for the old king's law by remaining king's men throughout the IVar of Independence. Many Tories in their anxiety that no experiment should interrupt George Clinton's policy of easy tolerance, had in 'eighty-seven and 'eightyeight taken ground against the national constitution; but when their Anti-Federalist associates shouted applause of Robespierre, "degenerated into democrats" and, for a season, lost the ascendancy in the state, the old Tories came to the conclusion that no good could come from such a party and quietly came over to the safer company of Mr. Jay. Such was the course that brought to the Federalist ranks the Samuel Joneses, father and son, both distinguished jurists. ${ }^{1}$

One who at first was burdened with the record of a loyalist was Richard Harison, ${ }^{2}$ the son of a Tory councillor who

'W. A. Duer, Reminiscences of an Old New Yorker (N. Y. I867), p. 23. This interesting book is made up of a series of letters signed "Peregrine Mindful," first printed in the New York American Mail during the summer of 1847 . The elder Mr. Jones was soon appointed comptroller of the state by Governor Jay when that office was created (N. Y. Civil List, I882, p. 160). The son served three terms in the assembly as a Federalist (ibid.. pp. 300-30I) after several unsuccessful attempts at election ( $N$. Y. Commercial Advertiser, April 21, 1806). He was in 1826 appointed chancellor, in which office, with his fairness and his learning he ably carried on the traditions established by James Kent. J. D. Hammond, Political History, vol. ii, p. 2I3.

${ }^{2}$ E. B. O'Callaghan, "Biographical Sketch of Francis Harison,” N. Y. Genealogical and Biographical Record, vol. ix, pp. 49-5I. This article notices the descendants of the subject; N.Y. Civil List, I88I, p. 240. 
had fled to England; but he had regained the public favor by his kindness and urbanity, spiced just frequently enough with dashes of sharp wit. When Washington appointed him a federal district attorney, there had been some who questioned the propriety of calling to official station one who, however sound in law ar scholarship. had given comfort to the enemy. But the appointment was defended on the very ground that his Toryism had been so notorious. It was thought necessary that, if all of this class were to be won to the support of the new government. the Federalist party must evince a liberality which might equal that of Governor Clinton, who, with the coming of the peace in 1783 , had foreborne to execute those drastic laws which would have banished Loyalists to Nova Scotia. ${ }^{1}$ But Harison was well fitted in many other ways to contribute to the prestige of the party, and celebrated no less for his piety and public spirit than for his strong and constant lovalty to the principles of Federalism, he was often called upon to make the statement of the party faith in public meeting. ${ }^{2}$

The eloquent Josiah Ogden Hoffman, who long survived the others of this company, adding the wisdom of a rich experience to the councils of the Whigs three decades later. had also in the War of Independence "lived within the lines." as the phrase described those loyal to King George." Although a lawyer of remarkable astuteness, like others of this Federalist gentry, he was a man of fashion, and, while deciding cases as recorder of the city, was likewise a court of last resort in the quiddities of minuets and precedence at

'W. A. Duer, op. cit., p. 25.

"Morgan Dix, The Parish of Trinity Church in the City of New York (N. Y., 1898-1906), vol. iii, p. 431; Memorial of St. Mark's Chursh in the Bozery (N. Y., 1899); N. Y. Erening Post, Warch 26. $180 \%$.

'Robert Troup to Rufus King, April 4, I800. King Corresbondence. 
table. ${ }^{1}$ No less adroit than energetic, and always vehement and voluble, this young beau had early won the lead of the state assembly and served as Jay's attorney-general until the hecatomb of office-holders in IBor. ${ }^{2}$ The partner of Hoffman in the practice of the law was a somewhat graver person, Cadwallader D. Colden, whom the Federalist Council of Appointment had selected for the state's attorney for the counties neighboring New York. ${ }^{3}$ He also came of stock distinguished for its loyalty to the king, for he was the grandson of that lieutenant governor who, when thrown into the Ulster jail, desired to be remembered as one who had opposed "independency with all his might, and wished to the Lord that his name might be entered on record as opposed to that matter and be handed down to the latest posterity." * With the firmness of this venerable grandsire he had inherited certain of his scientific sympathies which led him later to the cause of Clinton; but he ranged himself no less with others of the bar, to carry on the conservative tradition of the old official class. ${ }^{5}$

Not all the Federalist lawyers were of Tory families. Colonel Robert Troup, the close associate of the great leaders, ${ }^{6}$ is a fair example of those cautious patriots who went

${ }^{1}$ M. A. Hamm, Famous Families of New York (N. Y., 1902), vol. i, pp. $177-178$.

${ }^{2} \mathrm{~J}$. D. Hammond, Political History. vol. i, pp. 80-81.

${ }^{3}$ N. Y. Ciril List, I889, p. 506.

A. M. Keys, Cadzuallader Colden (N. Y., 1906), pp. 358-369; Lorenzo Sabine, Biographical Sketches of the Loyalists of the American Revolution With an Historical Essuy (Boston, I864), vol. i, pp. 328-330; A. C. Flick, Loyalism in Neze York During the American Rerolution (N. Y., 1901), pp. 19, 212 .

${ }^{5}$ See his many letters in the DeWitt Clinton Mss, 1810 et seq.; A. C. Flick, op. cit. He was so fair a man, however, that he sometimes won the support of Tammany Hall.

${ }^{6} \mathrm{Jay}$ to Hamilton, August 30, 1798, Jay Correspondence; Troup to Rufus King, King Correspondence, vol. iv, pp. 27, 102, 120, 135, etc.; L. Sabine, Loyalists, vol. i, p. 367 . 
the middle course with Hamilton. He was, like almost all his friends, a zealous churchman, ${ }^{1}$ a gentleman in tastes and manners, and a conservative in politics, with small enthusiasm for the spirit of republican institutions." Though called to service by the Federal government as the first district judge in New York state ${ }^{3}$ he soon forsook the ermine for the fat fees of the bar, and later settled into a still more incrative activity as agent for the Pulteney estate in the Seneca region." There he lived for many years, rich and respected, and, though not in public station, an important influence for Federalism in the West." He served his clients not only in the office at Geneva, but perhaps with more effect in the lobbies of the legislature. Here he spent a good part of his time, and. thoroughly acquainted with the custons of the capital, a master of the friendly hint and suave suggestion, he shrewdly helped or hindered legislation that might bear upon his special interest." He was not the last distinguished lawyer thus to spend a winter month in Albany.

Colonel Richard Varick, who had been recorder and then mayor for a dozen years, until swept out in the overturning, was another leading Federalist in his profession. ${ }^{\top}$ Austere

${ }^{1}$ Troup to Bishop Hobart, May 23, I827, Hohart Correspondence in Morgan Dix, Trinity Church, vol. iv, p. 4 .

2 In his letter to King, June 6, I802, King Correspondence, he speaks of "those who do not admire (and I confess myself among the number) the republican system."

"He had given valuable help in the propaganda for the Constitution, as a member of the Federal committee of correspondence, J. D. Hammond, Political History, vol. i, p. 39.

4V. A. Duer, Reminiscences, p. 26.

"For example his name healed the nomination for presidential electors in $\mathrm{I} 808, N$. Y. Assembly Journal, 1808 .

- Troup to Ruíus King, March 12, I\&o7, etc., King Correspondince.

i V. Y. Cizil List, I882, p. +15. 
and lofty in his manner, ${ }^{1}$ his tall figure striking in its closely fitting broadcloth breeches, silver-buttoned coat and spotless stock," renowned no less for his philanthropies:" than for the entertainments in the ball-room of his house on Broadway, ${ }^{4}$ he sustained the dignity of the old Federalist directorate and added to the prestige of his class.

The erudite, sententious Egbert Benson "was one whose early Federalism had brought about his choice as delegate, with Hamilton, to the conference at Annapolis in $1786 .^{\circ}$ He now saw the long-awaited judgeship on the Federal bench snatched away by Jefferson's refusal to confirm his predecessor's midnight appointees. ' Benson served his party in the state in many offices and, in the trying days of 1813 , was to stand with those in Congress who poured out indigna-

${ }^{1}$ C. H. Hunt, Life of Edreard Lizingston, p. 51 .

- His portrait by Henry lnman may be seen at No. 6 Bible House. New York City, in the rooms of the American Bible Society, of which he was a founder and supporter.

${ }^{3}$ W. A. Duer, Reminiscences, p. 29; J. S. Schuyler, Institution of the Society of the Cincinnoti... in New York City (N. Y., I886), p. 533.

'Longworth's American Almanac, New York Register, etc. (N. Y., I800), p. 362; Walter Barrett (Jolm A. Scoville) The Old Merchants of New York City (N. Y., 1863), vol. i, p. 215. This quaint, gossipy miscellany was printed originally, in part, in the columns of the $N$ ere York Leader about the beginning of the Civil War. The papers were collected and republished with additions in book form in 1863 and several subsequent editions (see foreword to vol. II, edition of I885). Other cliapters were added, published and republished until the standard edition of five volumes was issued in 1885 . It is an invaluable work of reference, though, naturally, in its comments upon hundreds of old merchants it is not entirely free from inaccuracies.

${ }^{5}$ C. H. Hunt, Life of Edirard Livingsion, p. 52 .

${ }^{6}$ See his account of this mission given in an address before the New York Historical Society of which he was the first president, quoted in extenso by A. B. Street, The Counsil of Revision of the State of New York (Albany, 1859), pp. 183-184, note.

iTroup to Rufus King, April 9, 1802, King Correspondence. 
tion and contempt upon ". Mr. Madison's war." He, too. was a convinced aristocrat who believed that govermment could best be carried on by the wealth and talent of society for the benefit of the rest.

Besides these leaders full of public honors. there were many barristers whose standing in the law and in society. made appropriate their membership in such a party-John Wells, a man whose eloquence and wit enlivened party meetings, and whose learning qualified him as the editor of the Federalist Papers, when those essays were prepared for publication: ${ }^{2}$ Nathaniel Pendleton, who, after he had stood with Hamilton on the fatal morning of the duel with Burr. rose to prominence in the legislature and on the bench:" and John Lawrence, who served as district judge, and as congressman and senator in Washington." And there were younger men who formed opinion under such tuition: Robert Bogardus, for example, still important in the part: when forty years had passed," and the Ogdens, David B.. the favorite nephew of Gouverneur Morris, and whom the historian Hammond, generally so temperate in praise, recalled as the "gigantic-minded," "and his cousin David A..

'J. S. Jenkins, History of Political Parties in New York State' (Auburn, 1846), pp. 27. 35, 51 et seq. This book is largely a summary of Hammond's Political History with some additions.

2 Memorial of the Life and Character of John Wells (N. Y., 187+): J. D. Hammond, Political History. rol. ii, pp. I35-137. David Hosack in his Memoir of DelVitt Clinton (N. Y., I829) says Hamilton, Wells, Emmett and Clinton were the four most accomplished speakers the state had produced, p. 41.

"Appleton, vol. iv, p. 729.

${ }^{4}$ N. Y. Civil List, 1889 , pp. $598,603,6.8$.

"General Bogardus was grand marshal at the obsequies of President Harrison in $18+1$.

6 Morris, Diary and Letters, vol. i,. pp. 549 ct seg.; J. D. Hammond, Political History, vol. ii, p. 480 . Were it not too tedious, of course. the roll could reach much further. 
whom we shall trace far to the north. Of those who practiced at the bar of the metropolis in the first years of the nineteenth century, small though their number was, the chief part of the talent, which commanded large well-paying patronage, was exerted in the Federalist cause.

Although the actual administration of this party, as well as the public business, was for the most part then, as well as now, left to the skill of the distinguished lawyers, the weight of its support was largely borne by wealthy merchants; we have it on the best authority that the great majority of those extensively engaged in trade a hundred years ago were numbered on its rolls. ${ }^{1}$ As one glances over the array of names upon a party ticket, for example that of I 806, and pauses to refresh the somewhat faded memory of these old-time worthies, he soon perceives a certain balance in the interests of the bar and of business. ${ }^{2}$ Of the two men named for Congress, one was Nicholas Fish, the banker, ${ }^{3}$ and the other, John B. Coles, a flour merchant with large ventures over-seas, who had as alderman for six years represented the wealth and aristocracy of the old first ward." As candidates for the assembly one finds lawyers like Judge Benson, William Henderson and J. O. Hoffman, but their order was not left exclusively to represent the party; there are the names of Selah Strong, who had been alderman for the third ward, and dispensed advice upon the law along with bales and barrels of more material commodities at his Front Street warehouse, ${ }^{5}$ Wynant Van

'Barrett, Old Merchants, vol. i, p. 8 I.

${ }^{2}$ See in N.Y. Commercial Advertiser. April 21, IRo6.

${ }^{3}$ Barrett, vol, iii, pp. I3\&-r 39 .

"Ibid., vol. ii, pp. 4I-45, 68-7I, 32I ; W. G. Davis, "New York in I80I" in Views of Early New Y'ork (N. Y.. 1904); L. H. Weeks, Prominent Families of New York (N. Y.. I 898 ), p. 35. The candidates for the state senate were not residents of New York city.

${ }^{5}$ Barrett, vol. i, pp. 365,366 . 
Zaindt, another influential merchant who had sat among the city fathers, ${ }^{1}$ and John Townsend, an ironmonger with branch stores in Albany. ${ }^{2}$ The chairman of the meeting which had made the nominations was John B. Dash, important in the hardware trade, ${ }^{3}$ and the secretary, Robert Cheeseborough. was likewise eminent in business. ${ }^{+}$

It was the custom of the time that a ticket so brought forth in public meeting should be recommended to the roters by a long address subscribed by gentlemen of standing in the party. Cornelius Ray, whose name begins the list in 1806, was. perinaps the foremost funancier of New York state; for the president of the local branch of the Bank of the Lnited States, and likewise for a term of many years, of the chamber of commerce in the city, was a person of commanding infuence." Such a dignitary might well be selected as a proper representative of Federalism. and he was often called upon to serve as chaiman at the party meetings. ${ }^{6}$ Next comes the name of General Matthew Clarkson, who for almost an entire generation was the president of the Bank of New York, a friendly rival institution, whose principal directors for the most part, like those who served with Ray, were in political agreement with their chief. ${ }^{7}$ Clarkson was a man of consequence within the circle of Hamilton and King and Morris, while

1 Barrett, vol. v, p. 243 .

'Ibid., vol. i, pp. I8I-I83.

'Ibid., vol. v, p. 40; Longu'orth's American Almanac, New York Register, etc., I807, p. 63; I8IO, p. 62; I8II, p. II et seq.

${ }^{6}$ N. Y. Commercial Advertiser, April 25, I806; April I807, Albany Gazette, April 4, I808, N. Y. Evening Post, April 28, I809, April 16, $18 \mathrm{I} 3$, etc.

i See ms. notes on a petition for a St. Lawrence-Champlain Canal, Flagg Mss. (Miscellaneous papers) N. Y. Public Library; Appleton's Cyclopedia of American Biography, vol. i, supplement, p. 797 ; Barrett, vol. i, pp. 270-274; vol. v, p. 40 . 
his generosity in time and money had made him by a wider world admired and beloved as an edifying example of the fine solicitude which the rich might sometimes exercise in the interest of the poor. ${ }^{1}$ Closely following is Isaac Sebring, whose extensive shipping business, as we shall see. did not exhaust the ingentity and enterprise he loved to bring to bear upon his probleins as a party manayer." Next is John B. Murray. whose captains trading in the Orient brouglit back their cargoes of rare and staple teas to increase his fortune. Like others of his station. in the "thirties he will still be found engaged against the might and strategy of Tammany as alderman for the fifteenth ward, the northern stronghold of his party. ${ }^{3}$ Fifth on the list is Archibald Gracie, whose ventures touched in every harbor of the world. ${ }^{+}$a proper member of a company that enrolled such names as Sherred, Minturn, Hone, Le Roy, to pick almost at randon, all famous in the annals of the city's trade.

But if those whose business was to fit out ships and barter groods at auction, had found expression of their ideas in the policies of Hamilton, the same was still more true of those who won their fortunes in the skilful management of that less tangible, symbolic wealth of paper. of dividends and mortgage bonds, and those uncertain rights and values so ineptly named securities. Among the presidents of banks. there were not only Ray and Clarkson and Nicholas Fish. twice named for liettenant governor and several times for

${ }^{1}$ Morris, Diary and Letters, vol. ii, p. 458 ; W. W. Spooner, Historic Families of America (N. Y.. I908), vol. iii, pp. 282-284; The Clarksons of New York (N. Y., 1875); Barrett, vol. i, p. 206.

= Barrett, vol. iv, pp. 18-20: and infra, ch. iv.

slbid., vol. i, p. 292 ; vol. ii, p. 107; vol. v, pp. 190-101.

4 Ibid., dedication to vol. ii, p. 5 .

${ }^{5}$ Ibid., vol. iii, p. 65 ; vol. iv, pp. 151, 242: vol. iv, pp. 240-244; vol. ii, pp. $160-162$. 
the assembly, ${ }^{1}$ but Henry Remsen, Oliver Wolcott, Varick and Verplanck, who were ranked as party leaders at the beginning of the century. ${ }^{2}$ Likewise in this list of 1806 are names of brokers like Nicholas Low ${ }^{3}$ and presidents of insurance companies like Gabriel Furman and Elisha Tibbits (who were now and then put up for members of the legislature), Charles McEvers, Frederic DePeyster and Iilliam W. Woolsey. It is evident that the wealthy merchants of New York were strongly Federalist. For example, if one foregathered with them in the Tontine Coffee Honse, which served as the city stock exchange as well as tavern." he would have found in I8O I that four of tive trustees of that important institution were members of the party, and even this small minority of one was to be swept away at the next election which brought in a unanimous board. ${ }^{\circ}$ Or if one visited the more ambitions and elaborate merchants' exchange built in later years, he would have seen

1 Barrett, vol. iii, p. 229; J. D. Hammond, Political History, vol. i, p. 294.

2 See mss. note on petition for St. Lawrence-Cliamplain Canal, supra; Barrett, vol. ii, pp. IO-I3; vol. v, 254-255. Gulian Verplanck was the father of Johnston Verplanck and the uncle of Gulian C. Verplanck, both of whom will figure in these pages.

${ }^{3}$ King Correspondence, vol. v, p. 40.

${ }^{4}$ Ms. note, supra; N. Y. Commercial Adacriser, April 2I, 1806 ; Barrett, vol. i, p. 383 ; vol. ii. p. 266 ; L. H. Weeks, Prominent Families of New York, p. 220.

'John Lambert, Travels Through Canada and the United States of America in the Ycars $1806,1807,1808$ (London, 1815), vol. ii, pp. 55 et seq. "An English traveller, who visited New York in 1794, writes that: The Tontine Tavern and Coffee House is a large brick building: you ascend six or eight steps under a portico, into a large public room which is the Stock Exchange of New York, where all bargains are made. Here are two books kept, as at Lloyds of every ship's arrival and clearing out." It remained the stock exchange for many years, IV. H. Bayles, Old Taverns of New York (N. Y., I9I5), pp. 360-36I.

- Abram Wakeman, History and Rominiscenecs of Lower Wall Stroct and Vicinity (N. Y., I9I4), pp. 55-63. 
enshrined within the place of honor in the great rotunda, the statue of Alexander Hamilton. ${ }^{1}$ In such resorts as these the Sage of Monticello was not mentioned with respect. There was still a merchants' party just as there had been before the Revolutionary War." These men of business did not think themselves discharged from public duty when they had set their names to an address. As one fingers over the old directories the names appear again as aldermen: Philip Brasher, Samuel M. Hopkins, Peter Mesier, Nicholas Fish. John Slidell and others are recorded as the representatives of the first four wards, in the opening decades of the nineteenth century."

In I8o I the city had over-reached the mark of sixty thousand and stretched northward from the Battery somewhat beyond a mile to the partly wooded hills that sloped back from the Collect or Fresh-water Pond. ${ }^{4}$ The picturesque old names of Out-Ward, Dock-Ward and Montgomerie's had passed into memory and the wards, now simply numbered. were seven in all, reckoning from the south." There was no Hadrian's Wall that ran through Reade Street from the Hudson to the Park and through Chathan and Catharine to East River, to set the pale of civilization, but the assessor's figures and electoral returns could furnish evidence that somewhere near those streess

${ }^{1}$ W. A. Pelletreau, Early Nez' York Houses (N. Y., Igor), p. 22.

${ }^{2} \mathrm{C}$. L. Recker, History of Political Parties in the Prorince of Neze York, I760-1776 (Madison, I909), p. I16.

'J. F. Jones, New York Mercantile and General Directory (N. Y., I 805): Elliott \& Crissey, New York Directory, I8II; D. Longworth, American Almanac, New York Register and City Directory, I801, I802. I803, $1805,1807,1808$.

- A New and Accurate Map of the City of New York in the State of New York in North America, N. Y., I797 (New York Public Library). Cf. Plan of the City of New York, I79I, in D. T. Valentine's Manual of the Corporation of the City of Neze York (N. Y., I85I), for scale.

${ }^{5} \mathrm{~J}$. F. Jones, op. cit., pp. III-II3, for boundaries. 
there was a barrier, no less present because it was invisible, which, speaking with the standards of this world, marked off the "better" from the "worse." 1 And within this favored southern half itself, as one walked toward the Battery, there steadily increased and multiplied all those signs of affluence that flowed from business. Likewise one remaiked the aspect of refinement and prestige which that affuence in part maintained, until with the stately houses by the side of Bowling Green one reached the very sacred inner court of New York gentility. ${ }^{2}$ These mansions with their pilasters and porticos were known as "Quality Row," "3 and in their simple grace made a pleasant background for the fashionable promenade flanked by the greensward and the flowerbeds of this old park. ${ }^{*}$

But the aristocratic quarter of the town included other streets near by, extended up Broadway and to the Pearl Street region, north and east." It is interesting to observe

${ }^{1} C f$. wards in D. Longworth's Actual Map and Comparative Plans Showing 88 Years' Growth of the City of New York (N. Y., I8I7), and in L. A. Risse, New York in I80o (N. Y., I900).

${ }^{2}$ Spencer Trask, Bowling Green (N. Y., I 898 ), pp. 4I-46; W. A. Duer, New York as It Was, During the Latter Part of the Last Century, an address before the St. Nicholas Society, (N. Y., I849), pp. I1-I2, notes.

${ }^{3}$ See drawings in Emmett Collection (N. Y. Public Library), and W. A. Pelletreau, Early Neze York Houses, p. 217.

${ }^{4} \mathrm{~J}$. M. Mathews, Recollections of Persons and Eichts (selections from his journal, N. Y., I865), p. 26; Washington Irving and others, Salmagundi Papers, no. xii. Saturday, June 27. I807; A. C. Dayton, Last Days of Knickerbocker Life (N. Y., I897), cl. ii.

5" The aristocratic quarter for residences at this period [the opening of the century] was Whitehall, Bearer. Broad. Water. and Pearl Streets, and the lower part of Broadway. Cherry, Roosevelt, Oak. Madison. Oliver, Harman (East Broadway) and Market Streets were occupied by many people of position and fortune." C. H. Haswell, Reminiscenecs of an Octogenarian, I8I6-I860 (N. Y., I\&g6), pp. 13-I4, 2I-25; Stephen Jenkins, The Greatest Strect in the World, The Story of Old Broadzuay. etc. (N. Y., I9II), p. 43; List of Houses and Lots, valued at $£ 1000$ 
that this was the section which with monotonous fidelity returned its Federalist members to the board of aldermen and the legislature of the state, ${ }^{1}$ until about the middle of the 'forties when it became "the test of gentility to live above Bleecker." " The fourth ward was less wealthy than its neighbors to the south and east, and became less regular, though eren this was still to be relied upon in any party crisis; but with the growth of the city another ward came to take its place. Even before 1800 the gentry about the Green, those few of them who had their carriages, ${ }^{3}$ had occasionally driven out to visit country friends who lived more spaciously among their groves and orchards, their gardens and cow pastures, in the open reaches of the farnland. ${ }^{4}$ These suburban residences, some of them of great cost and dignity." grew in number and filled in the meadows toward the Hudson, each new resident content with fewer acres. In 1805 , when some readjustments were in process in districting the upper sections of the city, a new ward was created, the ninth, which took in the remainder to the north. This region also for the next quarter of a century though not populous, was fairly constant in the balance against the

and over in 5799, J. G. Wilson, Hemorial History of the City of New York, vol. iii, pp. 150-152: J. F. Mines, A Tour Around New York, and My Summer Acre, Being the Recreations of Mr. Felix Oldboy (N. Y., I893), pp. 124-127.

${ }^{1}$ For example, N. Y. Eacuing Post. Nowember 18, 1801, April 30, 1802. April 28, I803; N. Y. Spectator, April 29, I804, etc.

${ }^{2}$ W. A. Pelletreau. Early Niw J'ork Houses, p. 78.

${ }^{3}$ Appleton's Cyclopedia of National Biography, article Herman LeRoy.

${ }^{4}$ Charles King. Progress of the City of New York During the Last Fifty Years (N. Y., 1852), pp. 6-8.

${ }^{5}$ List of Houses and Lots, etc. Wilson, loc. cit.; William L. Stone (Jr.), History of Ncw York City (N. Y., 1872), p. 319.

${ }^{-} C f$. Map of city in I804, D. T. Valentine's Manual, 1849, with I. F. Iones, Directory, etc., I805, p. I 16. 
democrats who made their homes in the less lovely purlieus of "the Swamp." " From this rehearsal it is plainly to be seen that those districts, where wealth and social standing made their citizens anxious to encourage commerce upon the one hand and to conserve the old traditions of a ruling class upon the other, were, as should reasonably have been expected, found upon the side of Jay and Morris and Van Rensselaer.

Another source of power in supporting the tradition of strong government was the Episcopal Church, whose clergy in the trying days before the war had met the cry for armed rebellion with the stern and certain doctrine that God had stablished states and commanded the obedience of peoples to authority. ${ }^{2}$ The sentiment and preaching of the

${ }^{1}$ In 1806 the Fourth Ward is missing from the Federalist column; in 1809 the Ninth Ward is added to it, N.Y. Spectator, May 6, 180\%, November 23, I809, May I, I8I2, etc. The following table from the Census of the Electors and Total Population of the City and County of New York, pamphlet (N. Y., I 807 ), p. 5, giving the ratio of the two may serve, under qualified suffrage, as an index of the intensity of wealth :

\begin{tabular}{|c|c|c|}
\hline Wards & Inhabitants & Electors \\
\hline Ist $\ldots \ldots \ldots \ldots$ & 7,954 & 1,086 \\
\hline and $\ldots \ldots \ldots \ldots$ & 7,551 & $1,0.42$ \\
\hline $3 \mathrm{rd} \ldots \ldots \ldots$ & 7,709 & 1,118 \\
\hline$\ldots \ldots \ldots$ & 9,236 & $\mathrm{I}, 33 \mathrm{I}$ \\
\hline$\ldots \ldots \ldots \ldots$ & 12,739 & $\mathrm{I}, 90 \mathrm{I}$ \\
\hline$\ldots \ldots \ldots \ldots$ & 9,861 & $1.42 \mathrm{I}$ \\
\hline 7 th & 10,487 & 3.140 \\
\hline 8 th $\ldots \ldots \ldots$ & 6,067 & 1,023 \\
\hline 9th $\ldots \ldots \ldots$ & 2,926 & 339 \\
\hline
\end{tabular}

The small number of electors in the Federalist ninth ward were owners of considerable property; it usually returned the smallest Federalist majority, see $N$. Y. Herald, May 2, 18 Io.

${ }^{2}$ Dr. Myles Cooper, The American Qucrist (N. Y., 17/4), queries 90-100; A. C. Flick, Loyalism in New York During the Revolution, p. 9, note; and the pamphlets of Bishop Samuel Seabury and the Rererend T. B. Chandler. 
church had been deeply loyal, and it was not surprising that when news reached New York that the fateful step of separation had been taken. Trinity parish had been torn with bitter strife, and that many, if not most, of its inAuential members had taken ship for Nova Scotia when the British troops departed from the city, ${ }^{1}$ or stayed behind in a precarious hope of toleration at the hands of the new government. If republics, according to the ancient proverb, were ungrateful. perhaps (and the outcome justified the trust) they might not be vindictive. The Whig Episcopalians to whom fell the conduct of the parish, and in consequence, perhaps a controlling influence in the church of New York state, had differed from the rest of the communion as to the right of independence, but they were little less opposed to any deep and sudden change in the powers of the state. It was an article of faith that the mandates of the civil power should be obeyed, without the church assuming responsibility for their righteousness. A republic it might be, but subjects should be taught obedience and support to those whom Providence had called to government. Years had not stayed the force of Hooker's stern injunction:

Sometimes it pleaseth God hinself by special appointment to choose out and nominate such as to whom dominion shall be given, which thing he did often in the commonwealth of Israel. They who in this sort receive power have it inmediately from God, by mere divine right ; they by human, on whom the same is bestowed according to men's discretion. when they are left free by God to make choice of their own governor. By which of these means soever it happen that kings or governors be advanced unto their states, we must acknowledge

${ }^{1}$ M. Dix, Trinity Church, vol. i, ch. xxiii, and vol. ii, ch. i; Flick, op. cit., p. 36 (an obviously exaggerated statement); and United Empire Loyalist Convention (Toronto, r884), p. IIo. 
both their lawful choice to be approved of God, and themselves to be God's lieutenants, and confess their power His. ${ }^{1}$

Robert Troup, one of the committee that brought the parish through the war, could understand the soundness of suci teaching. The more he saw of the progress of Jacobinism in his state, he wrote to King long after, the more he realized the need of setting up a college for the training of the clergy of his church, and it was this impulse that urged his interest and support in the founding of the institution at Geneva. ${ }^{2}$

It was not surprising that the clergy beheld with apprehension the ominous rise of Jefferson; for not only had he beaten down the power of the establishment in Virginia," but of late there had grown up a cult of deism around this bold profaner of the sacred word, who applied the gauge of human reason to the inspired history of Genesis and criticized the accounts of the creation and the deluge. ${ }^{*}$ It is possible that like their Calvinist neighbors to the eastward they deemed this rather liberal Unitarian little better than an atheist. In their consciences they no doubt shared the awful anger of the Congregational ministers who from their pulpits thundered wrath upon "the Jereboam who drave Israel from following the Lord, and made them sin a great $\sin$;" " yet they never acquired the political influence claimed and exercised by these leaders of New England.

${ }^{1}$ Richard Hooker, Of the Lawe of Ecclesiastical Polity (1665), bk. viii, ch. ii, verse 5; (N. Y., I845), vol. ii, p. 228.

${ }^{2} \mathrm{R}$. Troup to R. King, June $\mathrm{I}, \mathrm{I} 807$, King Correspondence.

${ }^{3}$ Thomas Jefferson, Works (Ford edition), vol. i, p. 52, and Notes on Religion, ibid., vol. ii, p. 95.

"Jefferson to Charles Thomson, 1786, ibid., vol. iv, p. 338, and Notes on Virginia, ibid., vol. iii, p. I16-1 18.

${ }^{5}$ Henry Adams, History of the United States (N. Y., I889), vol. i, p. 80; H. S. Randall, The Life of Thomas Jefferson (N. Y., 1858), vol. ii, pp. 648-652. 
With Episcopalians Mr. Jefferson might be wrong in his opinions but he was President; with the eastern clergy he might be President but he was a vicious and a pestilent man. Massachusetts had been founded as an ecclesiastical experiment. It was a place where those who worshipped rightly might worship undisturbed, but the clergy with their knowledge of the Scriptures were expected to make clear the ways and means by which this might be accomplished. John Calvin himself had declared that the function of the state was merely to produce conditions under which the ministers might work out the ideal commonwealth of the elect, and thus they were regarded to be oracles above the civil law. ${ }^{2}$ The absolute authority of these early days of sainthood had dropped away somewhat, but still the ministers were expected. now and then, to give suggestions to the state, and in the crisis precipitated by the change of ISoI they made a stubborn fight to preserve their influence.

With the Episcopal divines the case was different. The Erastian tradition of their church deterred them from too active meddling in affairs of state, and though personally favorable to Federalism, as no doubt their order was, they put forth no pamphlet fulminations against the lawful government and undertook no prominent rôle in party contests. The contrast in theory was sharp; in New England the clergy were responsible for the state, the New York Episcopalians responsible to it: while the battle raged between the former and the arch-blasphemer at Washington, the latter confined their active work in politics to the ballot on election day. Yet, as we shall see in the city and elsewhere in the state, the Episcopal Church was a quiet stronghold of the "decency-and-order" party, and a parish vestry might easily adjourn from talking abont tithes and charities, to have its

'Institutes of Christian Theology (edition of 1539), bk. i, chs. vii, viii ; bk. iv, chs. viii, ix, $x$. 
members meet again in some neighboring long-room as a Federalist caucus.

The influence of Columbia College in this respect must not be neglected. To its foundation half a century before. Trinity parish had contributed a tract of land with the understanding that the president of the new institution was ever afterward to be a member of the Episcopal communion, ${ }^{1}$ - a provision which was incorporated in the college charter and ever afterwards observed. Under Dr. Cooper and his fellow teachers, the college had taught loyalty to the king, and after it assumed the name Columbia it was far from the extreme in its preaching of new doctrines. Liberty it certainly expounded, but its fraternity savored of benevolence, and equality was not commended. The trustees. anong whom Federalism was almost unanimous, kept an anxions eye upon the teaching: when a president was sought, Alexander Hamilton, in some inquiries, made it clear "that his politics must be of the right sort." " Of the four great Federalist leaders of the state three were its sons. and the fourth, Rufus King, a trustee for eighteen years. ${ }^{3}$ After speaking of such men as these and Robert Troup and Egbert Benson, an early historian of the college goes on to say: "The foremost lawyers at the bar, and jurist: on the bench of our State and city, and in the United States courts, have been among the alumni of Columbia; such asto select a few names not before enumerated: Harison. Jones, Ogden, Hoffman, Wells, Robinson, Lawrence," *

$1 \mathrm{~J}$. H. Van Amringe and others, History of Columbia College (N. Y., 1904), pp. 84, 97; M. Dix, Trinity Church, vol. i, p. 280; and the interesting letter of Dr. J. M. Mason to Rufus King, February io. I8Io, King Correspondence.

${ }^{2}$ Hamilton to James A. Bayard. August 6, I800. Hamilton's Writings (Lodge), vol. viii, pp. 559-560.

"W. A. Jones. "The First Century of Columbia College," Knicker. bocker Magazine, February, 186.3.

+ Ibid. 
which, with the exception of Beverly Robinson, who, as a Tory, was obliged to change his residence to Nova Scotia, ${ }^{1}$ almost calls the roll of the important Federalists practicing at law in New York city. This tradition was to be continued under the presidencies of two leading Federalists and Whigs, William A. Duer and Charles King; it long remained a "family college" for old New Yorkers who cherished the memory of Hamilton, Morris and Jay.

'E. Ryerson, The Loyalists of America and Their Times (Toronto, 1880), vol. ii, pp. 197-I98. 


\section{CHAPTER II}

Politics and Prejudice Throughout the Countryside

Although Federalism had flourished chiefly in the city of New York, there were other sections of the state. where, as in those which centered in Albany and Hudson, it was the ruling philosophy of politics. The influence of old families like the Schuylers and Van Rensselaers, reinforced by the economic power of the wealthy merchants who moved across from Massachusetts and Connecticut, persisted in unquestioned strength long after the prestige of the aristocracy in the metropolis had been challenged and reduced. ${ }^{2}$ Albany had recently been made the permanent capital of the state, ${ }^{2}$ and though it boasted then but five thousand people, it was destined partly through this dignity to add an extra thousand every year for many decades. ${ }^{3}$ In isor, however, it was a third or fourth rate town, as a captious chronicler declared, penned in upon its hills by endless thickets of pine, and "indeed Dutch, in all its moods and tenses; thoroughly and inveterately Dutch." " The old fam-

${ }^{1} C f$. O. G. Libby, The Geographical Distribution of the Vote of the Thirteen Statcs on the Fedcral Constitution, p. 18, for the vote in 1788 .

${ }^{2}$ In 1797; A. J. Parker (editor), Landmarks of Albany County (Syracuse, 1897), p. 301 .

${ }^{3}$ See table in Joel Munsell's notes to G. A. Worth, Random Recollections of Albany, I800-I 808 , p. 20. These interesting reminiscences were first published in Albany, I 849 , soon followed by a second edition in 1850 entitled Random Recollections, ctc. With Some Additional Mattcr, the large appendix being recollections of Hudson. In 1866 Munsell published the work referring to Albany with copious notes. in large and small paper editions.

Jbid., pp. 20, 27. 
ilies gained their income largely from their spacious holdings granted in the years gone by, and, in their leisure, they were not averse to taking part in the political contests of the day. ${ }^{1}$ The venerable General Philip Schuyler, of whose services to Federalism we shall speak again, was soon to make over to his heirs his home and his six thousand acres. ${ }^{2}$ Shattered by the shock of the tragic death of one son-in-law, the admired Hamilton, he sank into a decrepitude that found a speedy end in death, leaving the leadership of the Dutch aristocracy to another daughter's husband. Stephen Van Rensselaer, called by universal courtesy, the Patroon. ${ }^{3}$

This new leader in society and politics was, at the beginning of the nineteenth century, the richest man in New Fork state, ${ }^{5}$ and the largest landlord in the country, with his scores of square miles parceled out on leasehold tenure. yielding a large income from the rents and quartcr-sales. ${ }^{6}$ He had been elected to the first assembly summoned under the new Federal Constitution. two years later had been pro-

${ }^{1}$ Random. Recollections of Albany, pp. $42-49$.

${ }^{2}$ C. Reynolds, Albany Chronicle (Albany, 1906), p. 396; O. Tilghman, Vemoir of Lt. Col. Tench Tilghman (Albany, 1876), p. 23.

"B. J. Lossing, The Life and Times of Philip Schuyler (N. Y., 1860), vol. ii, pp. 474-475; Bayard Tuckerman, Life of General Philip Sehuyler (N. Y., 1904), pp. 260-271. Schuyler died November 18, 1804. Since lordships, manors, etc. were abolished by the legislature of the new government just before Stephen Van Rensselaer became of age, he could not with accuracy be called the sixth lord of the manor or the eighth patroon. Although local custom gave the title of patroon to others like the Knickerbockers and the Van der Heydens, when used alone it was always understood to refer to Van Rensselaer. See G. W. Schuyler, Colonial Neze' York (N. Y.. 1885), vol. i, pp. 227-231; John Woodworth, Reminiscences of Troy from its Settlement in 1790 to 1807 (Albany, 1860; published first in pamphlet form in 1853), pp. 90-93: and A. J. Weise, Troy's One Hundred Ycars (Troy, 1891), p. 23.

'Henry Adams, History of the United States, vol. i, p. 27.

'E. P. Cheyney, The Anti-Rent Agitation in the State of New York (Philadelphia, I88;). 
moted to a quadrennial term in the senate of the state, and had then served six years as lientenant-governor. In the spring of I80 I the Federalist party had rallied with genuine enthusiasm to make him governor, but to no avail. The influence he wielded in the party both before and after this first disappointment was, as we shall see, not unconnected with his power as landlord, but his reputation as a man was such as to draw the homage of men's hearts. Even in relations with his tenantry he was generous to a fault; courteous and affable in manner, with an habitual expression of kindness and good will in language and in countenance that seemed never to forsake him, ${ }^{2}$ he seemed the blameless model of the old nobility that would have pleased Lord Chesterfield or Mr. Lecky. For he added to these personal attractions, a sound judgment and a character that marked him within the Dutch church and without as one of highest standards of morality:. He was a gallant champion to whom the partisans of the rule of aristocracy could point with comfortable pride.

Beside him in the leadership of the old Dutch families stood Abraham Van Vechten, descended from a lesser landed squire." He was a fine "specimen of a class he loved to represent. If he was somewhat heavy in appearance

${ }^{1}$ G. W. Schuyler, op. cit., vol. i, pp. 227-231 ; S. W. Rosendale, "Closing Phases of the Manorial System in Albany," Proceedings of the New York State Historical Association, vol. viii, p. 243. It was his leniency which produced the long accounts whose claims in enforcement brought on the Anti-Rent troubles after his death in 1839 , sce Cheyney, op. cit.

2 J. M. Mathews, Recollections of P'crsons and Er'ents. p. 6 .

${ }^{3}$ Ibid., p. 70.

'L. H. Weeks, Prominent Families of Nezv York, p. 592. He was not graduated from King's College as erroneously stated in A. J. Parker, Landmarks of Albany County. part i, pp. I $47-\mathrm{I} 48$, and G. R. Howell and J. Tenney, History of the County of Albany (N. Y., I886). p. I33; cf. Catalogue of Officers and Graduates of Columbia I'nizersity (N. Y.. 1912). 
and slow in his movements, he had all the staid solidity and strength which marked the Hollanders in their best days, and he never appeared either in public or private without commanding universal respect." ${ }_{1}$ He refused an appointment to the bench tendered to him, while yet young in practice, by Governor Jay, but during the first two decades of the century he spent a part of nearly every year in the senate or the assembly, finding joy in fighting for his Federalist principles. ${ }^{2}$ It was in accord with the conservatism of his well-to-do constituents that by argument and vote in the convention of I82 I, he gave all his support to the dictum of Chancellor Kent, "that to the beneficence and liberality of those who have property, we owe all the embellishments and the comforts and the blessings of life." 3 Logical in reasoning and eloquent in speech, famous for his faith in old theories of government by men of wealth and social standing, no less than for his mordant sarcasm in attacks upon the new. he held an independent course quite to the last and scoffed at the intrigues by which his party sought to play with factions of the enemy. ${ }^{4}$ Supported by such strong lieutenants as Johan Jost Dietz. ${ }^{5}$ Dirck Ten Broeck, ${ }^{6}$ Hermanus Bleecker, and Colonel James Van Schoon-

1 J. M. Mathews, op. cit., p. 71.

${ }^{2}$ Howell and Tenney, op. cit., p. 133; Munsell's notes to G. A. Worth, Random Recollections, pp. 6I-63; N. Y. Civil List, 1889, pp. 374-377, $420-424$.

${ }^{3}$ J. D. Hammond, Political History, vol. ii, pp. 21, 3o.

D. S. Alexander, Political History of the State of New York, vol. i, pp. 168-169; J. S. Jenkins, Political Partics, p. I99. See especially his speeches after the Van Ness charge, January 26, 1820 , as reported in the Albany Daily Register.

${ }^{5}$ N. Y. Cizil List, 1889 , pp. 416-422, J. S. Jenkins, op. cit., p. 59.

- Civil List, pp. 415-418, and Jenkins, p. 64.

'Civil List, pp. $424-425$, and Bleecker to Rufus King, February 16 , 1816, King Correspondence. 
hoven, ${ }^{3}$ he showed how the Dutch aristocracy could join hands with the merchants in New York to oppose the party of the artisan and little farmer. ${ }^{2}$ Through Albany. Rensselaer and Columbia counties, the wealthier of the old stock were Federalist in politics.

The Dutch, however, were not left in undisputed sway within these upper river counties. In I790 in Albany there were not more than five New England families, ${ }^{3}$ but in the following decade the westward movement set in from Massachusetts and Connecticut, and "the detested word improvement was on every lip," for the New Englanders brought in an enterprising, innovating spirit and set about buying and selling to such purpose that many merchants made their fortunes. These men, for the most part, reare 1 in Federalism near the sea-coast, attached themselves again to the party now under Van Rensselaer and Van Vechten.. Yet this alliance was not made without some swallowing of old resentments, as the easterners brought with them an ancient jealousy of all things Dutch.

Throughout their home-land thirty years before, there had broadly spread a conviction that the Dutch New Yorkers who laid claim to the Hampshire grants beyond the proper bounds of Lake Champlain were something less than honest, and old prejudices had been renewed and deepened in the last days of the colonies; it was this feeling which had, in part, brought on the bickerings of the Revolutionary officers and the undeserved disgrace of

${ }^{1}$ Civil List, pp. $367,373-375,412,413$, and Jenkins, p. 84 .

${ }^{2}$ Compare the list of 220 signers of a Federalist petition in the Albany Gazette, April 18, 1808 , with a similar list of Republicans in the Albany Argus, April 0, 1813. The Yates family were an exception to the rule.

${ }^{3}$ Munsell's notes to Worth. Random Recollections, p. 33.

4 Worth, pp. 42-44. 
General Schuyler. ${ }^{1}$ The antagonism had survived and oftentimes the feeling was expressed with hearty emphasis. A politician recently arrived in the Mohawk valley, was asked how starting with a Yankee one could make a Dutchman. "Break his jaw and knock his brains out," was the quich rejoinder; and when asked how a Dutchman could be made a Yankee, he retorted with as little hesitation, "Can't do it. sir; ain't stock enough." 2 There were some of these New England Federalists who were induced with difficulty, if at all, to concur in the nominations of the Patroon, ${ }^{3}$ but as the leaders grew in consciousness of common interest, these differences were composed, so that the party was finally pitted in full strength against the party of the mechanics, already recognized as such, at the beginning of the century, and led by Benjamin Knower. ${ }^{4}$ However this adjustment was accomplished, Albany and Rensselaer have. from that day to this, been ranged in opposition to the forces led by the sachems and the chiefs of Tammany Hall.

In the region about Troy much the same conditions prevailed. When New York was still New Netherland, certain

- B. J. Lossing. Life and Times of Philip Schuyler, vol. i, pp. 198-203: vol. ii, chs. xvi and xvii; Bayard Tuckerman, Life of General Philip Schuyler, pp. 223 et seq.; G. W. Schuyler, Correspondence and Remarks upon Bancroft's History of the Northern Campaign of 1757. and the Character of General Philip Schuyler (N. Y., 1867), p. 25.

"M. M. Bagg. The Pioneers of Utica (Utica, 1877), p. 64.

" There is a knot of Jacobins at Albany among the federalists. formed of New England people (of which our friend Lovel is I believe one) as opposed to the Dutchman, who have been able to prevent the nomination of the patroon for a member of assembly, to which he had consented merely because he thought it might bring out more governor votes at the Election. It was this factious view that nominatcd Southwick as a federal Senator." Win. Coleman to Rufus King, April 16, 1816 , King Correspondence. The name "Jacobins" here seems merely an abusive epithet.

4 G. A. Worth, Random Recollections, pp. 50-52. 
pioneers with the consent of the Van Rensselaers had purchased lands from the Mohegan Indians, eastward from the town of Beverwyck, now Albany. ${ }^{1}$ The country lying somewhat off the lines of travel was but slowly settled, until, near the beginning of the eighteenth century, much of it fell into the possession of two notable Dutch families, the Van der Heydens and the Knickerbockers, who, though simply landlords, and, indeed, at one time holding only under lease, were commonly styled patroons. ${ }^{2}$ With their large holdings, like their neighbors across the Hudson, these landed families gave their support to the conservative party. In I8O young Herman Knickerbocker, then in his early twenties, was coming into prominence and, being "possessed of wealth and great personal influence, he was soon chosen to fill important offices." He was elected to Congress and then to the legislature where. hailed by all as the Prince of Schaghticoke, like Van Rensselaer and Van Vechten he represented the old caste. "Bred from his childhood to association with some of the most distinguished Men of an Age remarkable for its high-toned Courtesy, and to the Controul of a large family of Slaves, his Manners acquired the blending of Suavity with Dignity peculiar to those accustomed to early Intercourse with the World, and the early Habit of Command." It is not surprising that

${ }^{1}$ A. J. Weise, History of the City of Troy (Troy, I876), pp. 8-II.

2 Derick Van der Heyden purchased in 1707 , ibid., p. I4, and Johannis Knickerbocker in 1709; John Woodworth, Reminiscences of Troy from its Settlement in 1790 to 1807 , p. 9I, note. The name was originally spelled Knickerbacker, but Washington Irving's orthography made up in popular acceptance what it lacked in historical accuracy and is not now to be gainsaid. The second edition of Woodworth's Reminiscences (here cited) contains the valuable notes of Joel Munsell and others. Judge Woodworth was competent to write of political life, having held a variety of offices from loan commissioner in 1792 to justice of the supreme court of the state; see A. B. Street, Council of Revision of the State of Nere York, pp. Ig6-198. 
such men from their land offices and family seats exerted influence for Federalism. ${ }^{3}$

As in Albany, however, the Dutch aristocracy were obliged, with better or worse grace, to welcome immigrants who came across the Berkshires. As soon as the settlement of Van der Heyden's Ferry grew into a village and in 1789 took the name of Troy, homeseekers of the better class, largely from the middle parts of Massachusetts, made their appearance, building shops and bringing in commercial habits that transformed it into a thriving town. ${ }^{2}$ The more important of these newcomers were Federalists in politics, and their success in merchandising confirmed their old allegiance to the party of the creditor; all or nearly all the larger merchants of Troy and Lansingburgh. near by, were of this party. George Tibbits, who came in from Rhode Island and who became the wealthiest among this class, was for a quarter of a century the political leader of the county, relying always on the strong support of his fellow men of business." In I80I, then. the power had been wholly in their hands for more than a decade, and though overwhelmed at the next election, they soon regained control with fair continuance, and with the help of the farmers who traded with them, gave the Rensselaer region a rather firmly fixed political character.

To this, however, there was set no county boundary. In

1 Woodworth, p. 85 (notes), pp. 9I-93: A. J. Weise, op. cit., p. I6, ch. ii, and Troy's One Hundred Years, pp. 21-26. For more detailed description of the ancient splendor of the Knickerbockers, see W. B. Van Alstyne. "The Knickerbocker Family," in N.Y. Genealogical and Biographical Record, vols. xxxix and xl; Knickerbocker Magawine, vol. i, p. I et seq., and vol. xl, p. I et seq.; and particularly General E. C. Viele, "The Knickerbockers of New York Two Centuries Ago," Harpers' Nc $\boldsymbol{i}^{\prime}$ Monthly Magazine, vol. liv (1876-1877), pp. 33-43.

${ }^{2}$ L. K. Mathews, The Expansion of New England (Boston, 1909), ค. I53; A. J. Weise, Troy's One Hundred Years, p. 29.

${ }^{3}$ Woodworth, op. cit.. pp. 36-40. 42. 
Washington County, to the north, the Federalists likewise acquired an ascendancy almost unvarying. General John Williams, the friend of Philip Schuyler, was the largest landholder the county ever knew, ${ }^{1}$ and was (perhaps because of this) the leading Federalist." Owing to the influence of such men as Williams and the Duers of Fort Miller, and to the numerous settlements of old Scotch stock, who had held to England throughout the Revolutionary War and whose sympathies could not be enlisted to support the Frencl enthusiasms of Jefferson, as well as to the New Englanders who made their homes in Kingsbury and Salem, the region east of Lake George and the Upper Hudson was started on its path of straight and constant regularity in opposition to the Democratic party. ${ }^{3}$ Federalism became a kind of fixed religion; nearly half a century after the “Revolution of ISoo," when party politics in New York had undergone strange, bewildering mutations, Washington was still referred to as an old "Federal county." *

Probably no settlement was made in New York state with higher hope of a great commercial future, than was Hudson. When in 1774 the Congress met in Philadelphia and drew up an agreement to cut off trade with England, a measure which soon provoked retaliation, the whalers of Nantucket saw their business slide from bad to worse, until war and the appearance of the British frigates brought on complete annihilation. With the restoration of peace, when hope revived, some of them decided to seek out a new por $\mathrm{t}$ far enough removed from main roads of travel to be safe

${ }^{1}$ The Salem Book (Salem, N. Y., I896), pp. 77-78; History and Biography of Washington County and the Torn of Quecrsbury (Richmond, Indiana), I894, pp. 393-400.

${ }^{2}$ C. H. Hunt, Lifc of Edward Livingston, p. 69; N. Y. Commercial Advertiser. March I8, 1816.

${ }^{3}$ History and Biography of Washington County. pp. 4I, 44, 80.

${ }^{4}$ N. Y. Tribune, November 14, I846. 
irom visitation by the enemy's Heet, if ever war broke out again. Acting on this resolution, certain brothers Jenkins prospected along the Hudson River and finally picked out Claverack Landing as blessed with harborage for ships of any likely depth and surrounded by a country rich and iertile. A company was formed to conduct this enterprise and was joined, among others, by several Quakers from Providence, Newport and Martha's Vineyard, it being provided by the specifications of agreement that all must be whalers or merchants of good standing. ${ }^{1}$

Here was a community which naturally gave support to the business party in their domestic policy and in their overtures toward England in the interest of commercial friendship. It had cast a heavy vote for the new Federal Constitution, ${ }^{2}$ and had applauded all the measures for strengthening the navy and establishing the nation's credit in the ports across the water, so that the election of Mr. Jefferson seemed to its merchants, in the words of one of them, the wealthy Reuben Folger, " a signal to the nation to heave to, under bare poles." ${ }^{3}$ Columbia County, of which Hudson was the small metropolis, though yielding later, now and then, to the blandishments of its distinguished son, Van Buren, was long known as a Federalist stronghold, the object of whole-souled affection or of fear, according to one's sympathies, in the days when the party was controlled by the "Columbia Junto." Of these nuen who played such prominent parts in the triumphs and vicissitudes of Fed. eralism, it is necessary to speak in some detail.

${ }^{1}$ A. R. Bradley, History of the City of Hudson (Hudson, 1908), chs. iii, iv, and viii: Franklin Ellis, History of Columbia County (Philadelphia, 1878), pp. I52-165; L. K. Mathews, The Expansion of New England, p. 155; S. B. Miller, Historical Sketches of Hudson (Hudson, 1862 ), p. 6-8.

${ }^{2}$ O. G. Libby, Geographical Distribution of the I'ote, etc., p. I8.

${ }^{3}$ G. A. Worth. Random Recollections of Albany (and Hudson), p. 53. 



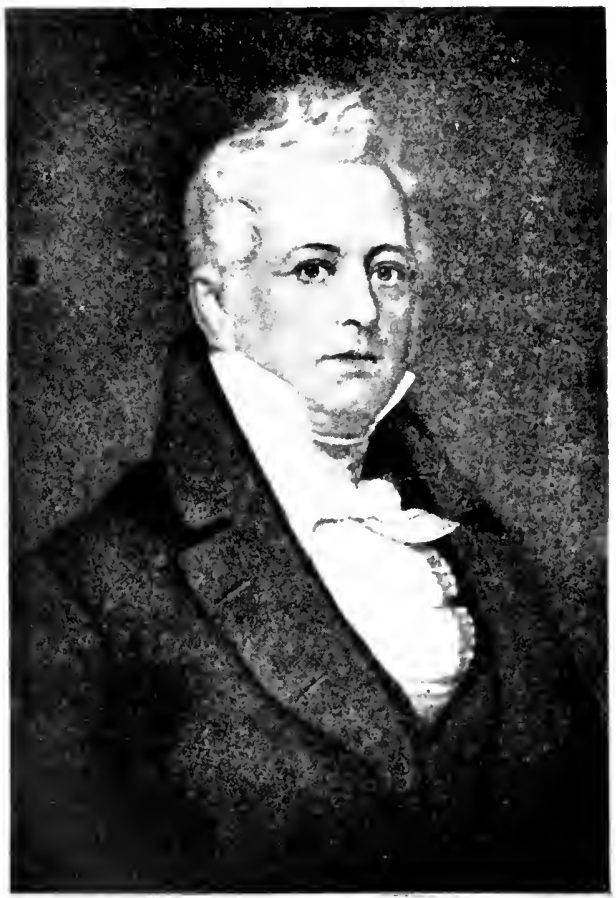

ELISHA WILLIAMS 
Oliver Wendell Holmes, moved by his incorrigible curiosity, once inquired of Gulian C. Verplanck who was the most remarkable person he had ever met.

Now it must be remembered [writes the essayist] that this was a man, who had lived in a city that calls itself the metropolis, one who had been a member of the State and National Legislatures, who had come in contact with men of letters and men of business, with politicians and members of all professions, during a long and distinguished public career. I paused for his answer with no little curiosity. Would it be one of the great ex-Presidents whose names were known to all the world? Would it be the silver tongued orator of Kentucky or the "Godlike" champion of the Constitution, or our New England Jupiter Capitolinus? who would it be? " Take it altogether," he answered, very deliberately, "I should say Colonel Elisha Willians was the most notable personage $I$ have ever met with." 1

The man to whose memory such tribute could be paid came to Hudson as a young attorney in I80o. ${ }^{2}$ Unlettered. saving what professional knowledge he had gathered in the courts and in his rather superficial preparation for the arguments of particular cases, he had certain native talents that marked him out as a leader. ${ }^{3}$ In a young community physical attractiveness is no doubt of far more importance than in those larger and, by social experience, more sophisticated; Williams, as his portrait shows, was a man distinguished in appearance, tall and broad of chest. his forehead, nose and chin, such as pass with physiognomists

${ }^{1}$ O. W. Holmes. The Poet at the Breakfast Table (Riverside edition, Boston, 1891), pp. 330-33r. Dr. Holmes was at fault in giving Williams a military title.

${ }^{3} \mathrm{Wm}$. Raymond, Biographical Sketches of the Distinguished Men of Columbia Couniy (Albany, 1851), p. I.

${ }^{3} \mathrm{~J}$. A. Hamilton, Reminiscences, p. 4I. 
as evidences of great strength of character." "He was indeed the most God-like form I ever beheld," records one witness; "it seems as if the Creator, in the formation of his body and mind, designed to make a magnificent display of skill and workmanship." " "His was a majesty of person and of mien," declares another." Chancellor Kent long remembered "his commanding eye and dignified and attractive person." * It was easy to think good of such a man. Then, too, his was a generation in which the spread of literary education had not kept pace with the interest in pubiic questions, ${ }^{5}$ and in such a time a gif $t$ of eloquence was of first importance. Testimony to his vivid fancy, ready wit, his easy, pleasant grace, and melodious voice, vibrant now and then with what admirers were wont to call a "soulsubduing pathos." comes to us from divers sources." Thomas Addis Emmett, whose experience in Ireland had been broad, declared him to be the greatest advocate he had ever met. ${ }^{;}$In such a man lapses in historical learning and occasional puerilities in political philosophy might be forgiven. $^{8}$

It is difficult to associate with Williams any great move-

'See portrait in S. W. Williams, The Genealogy and History of the Family of Williams in America, More Particularly the Descendants of Robert Williams of Roxbury (Greenfield, Mass.), 1847, p. I31.

${ }^{2} \mathrm{Wm}$. Raymond, op. cit.

${ }^{3}$ N. Y. Commercial Advertiser. June .30. 1833.

${ }^{4}$ Quoted in S. W. Williams, op. cit., p. 132.

${ }^{5}$ For illustration of the illiteracy then prevalent, one may examine the legal advertisements of the newspapers of the day, noticing how many are signed by mark.

'J. A. Hamilton, Reminiscences, p. 4I; P. F. Miller, A Group of Great Lawyers of Columbia County (based on his father's recollections), (N. Y., I904), pp. 118-125; Wm. L. Stone (Sr.) speaks of his inimitable grace of manner, quoted in S. W. Williams, p. 143.

'Franklin Ellis, History of Columbia County, p. 84 .

1. A. Hamilton, boc. cit. 
ment or reform; he was, in contrast to a leader such as Rufus King, a manager of men and not a man of measures. Yet his contemporaries, captivated by his sparkling wit and genial grace, or at times reduced to a submissive awe by his corroding sarcasm, believed that had he but decided to go himself to Washington, instead of finding satisfaction in nominating others to this mission, "he might have ranked with Adams, Webster, Clay, Calhoun and other illustrious Americans, for he possessed talents at least equal to any man in the nation." 1 But the more impartial witness soon observes that these talents were not suited to that theatre upon which beats a fiercer light. As we shall see, he was as effective when near to the state legislature as when sitting in it, for he and his colleagues of this Columbia Junto brought more things to pass by friendships and occult suggestions within the corridors of Albany, than by the driving force of argument. He wrote little and invented little; sucli effective service as he undoubtedly accomplished did not make for lasting fame; a generation later his name meant nothing to so well informed a man as Dr. Holmes."

Most of what has here been said of Elisha Williams might be said as well of William W. Van Ness, except that possibly he possessed more matter if not less art. "Thank God!" exclaimed his friendly rival at the bar, when Van Ness was elevated to the bench, "I have no longer an opponent to beat me by asking the foreman of the jury for a chew of tobacco." 3 Those who knew him pronounced him blessed with every gift which might bring popularity and

${ }^{1}$ Wm. Raymond, op. cit., pp. 4-5.

${ }^{2}$ Cf. S. W. Williams, op. cit., p. r35; testimony of Stone and McKinstry, ibid., pp. 137-I45, and of Chancellor Kent, p. 132; Elizabcth Cady Stanton, Eighty Years and More (London, 1898), p. 7.

${ }^{3}$ F. Ellis, History of Columbia County, p. 9o; D. Hosack, Memoir of De Witt Clinton (N. Y., I829), pp. 449-450. 
power, ${ }^{1}$ and though very young when he came to Hudson to begin his practice, just in time to take a part in the campaign against Jefferson, ${ }^{2}$ he was soon recognized to be a man of talent. He was at the age of thirty-one appointed to be a judge of the supreme court by a Council controlled by nembers of his party, and was soon accepted as the "leading spirit of the political clique which guided the Federal party in the middle and western districts of New York." ${ }_{3} \mathrm{He}$ was associated with Alexander Hamilton in the famous Croswell trial of ISO4 and became, in some degree, his successor as the brilliant party leader of the conservatives within the state. Yet here, too, it was a leadership due to personality; the charm of his urbanity, the fine sallies and imagery of his most ordinary conversation, endeared him to men's hearts. He, too, wrote little and can be judged only through the eulogies of his admirers and the arraignments of his enemies. ${ }^{4}$

The third member of this famous junto was Jacob R. Van Rensselaer, probably inferior to his associates, and yet recalled by one who knew his region well as the cleverest of his race and name. ${ }^{5} \mathrm{He}$ was somewhat older than Williams and Van Ness, but not less active in the arduous work of party politics, riding far and wide to check np votes, and spending many days and nights in Albany in an "unofficial way. ${ }^{6}$ He was elected to the assembly for nine terms, once serving as speaker, and for a year was attorney

${ }^{1}$ J. D. Hammond, Political History, vol. i, p. 217.

2 P. F. Miller, A Group of Great Laz'yers, p. 139.

${ }^{3}$ J. A. Hamilton, Reminiscenees, p. 42.

${ }^{4} N$. Y. Statesman, Proceedings of Columbia County Bar, and D. D. Barnard, quoted by Wm. Raymond, op. cit., pp. 21-31.

${ }^{5}$ G. A. Worth, Random Recollections of Albany (and Hudson), p. 52.

'N. E. Whitford, History of the Canal System of the State of Neri York, N. Y. Assembly Documents, igo6, vol. v, pp. 62-63. 
general. ${ }^{1}$ yet he made few speches and, though his letters show him to have been a cultivated man, he wrote no pamphlets or newspaper essays, by which his political philosophy may be judged. He was accounted a very popular man, an able parliamentarian, and "a bold, active and zealous politician."

"Thus personal attractiveness may account in a large degree for the importance of the junto, but there was not lacking a solid base of economic sympathy with Federalism. Williams was widely noted as appreciating the emoluments of his profession and gave much time to speculation, chiefly in wild lands. It was his custom to follow closely all the sales of land for unpaid taxes, to buy and hold until the price advanced, and then sell to the settler, thus founding, for example, the community of Waterloo in Seneca County. By this practice he earned from his opponents the epithet of "harpy," but earned as well a fortune of between two and three hundred thousand dollars, then regarded a great sum of money. ${ }^{4}$ Van Rensselaer, though belonging to the younger branch of that great family. ${ }^{5}$ held title to a substantial section of the town of Claverack, but his business

1.N. Y. Civil List, I889, p. 177 .

2 P. F. Miller, op. cit., pp. 114-117: F. Ellis, op. cit., p. 91; see also D. Hosack, De Witt Clinton, pp. 434-435. A fourth name sometimes associated with the three treated above is that of Thomas P. Grosvenor, Williams' brother-in-law, who came to practice law in Hudson in 1803 , and, with great size and roice, and a simple style of statement, was an able and tireless opponent in Congress of the policies of 1812; see Baltimore Fedcral Republican, quoted by Wm. Raymond, op. cit.. pp. 39-4I, Miller, pp. I44-145. For a sample of his invective see his oration at Hudson, July 4, 1806 , in New York Public Library.

${ }^{3} \mathrm{Wm}$. L. Stone (Sr.), "Narrative of a Journey in 1829 " in Publications of Buffalo Hist. Soc., vol. xiv, p. 258 .

4N. Y. American, Marcl 6, I0, May I2, I819. Wm. Raymond, p. 1.

'Appleton's Cyclopedia of American Biography, article Van Rensselaer. 
was not confined to rents and mortgages. For example, in 1817 he made an offer to the state to build the Grand Canal from the Hudson to Lake Erie on a contract calling for $\$ 10,000,000$. though inasmuch as arrangements were undertaken by which the canal was actually constructed for $\$ 7,602,000$, his offer was not deemed acceptable. ${ }^{1}$ Van Ness had no such passion for acquiring wealth as had Elisha Williams, ${ }^{2}$ but it was, as we shall see, his participation as a promoter and a beneficiary, along with iVilliams, Van Rensselaer and Grosvenor, in a Federalist banking scheme, that brought about the political downfall of them all. Though more intimately associated with the lawyers of the country towns, they had sufficient taste for speculation to understand the wants and prejudices of their fellow partisans in the markets and exchanges of the city. This sympathy enabled them to lead the party in the state.

There remains one other town along the river where Federalism had a following for many years. Poughkeepsie, which like Hudson was hopefully developed as a whaling port. ${ }^{s}$ James Emott, a member of an old Anglican and Tory family, and later one of the richest men of Duichess County, ${ }^{4}$ was the party leader. His fortune was not yet ascendant in the county, nor did he taste the fruits of triumph until the reaction due to the embargo in I 808 , when, as we shall see, his election to the

'J. R. Van Rensselaer to De Witt Clinton, March II, ISI7, De Witt Clinton Mss., and E. R. Johnson in Cyclopedia of American Government, vol. i, p. 675 .

'See remarks of Williams on Van Ness, Wm. Raymond, p. 30.

${ }^{3}$ P. H. Smith, Gencral History of Duchess [sic] County (Pawling, N. Y., 1877), p. 365; Edmund Platt, The Eagle's History of Poughkeepsie (Poughkeepsie, 1905), p. 96. Mr. Platt's book may be considered one of the best local histories in New York state.

4 P. H. Smith, p. 129; E. Platt, pp. 90, 115, 135; Appleton, vol. ii, p. 352. He was resident for a time in Albany. 
Eleventh Congress brought a leader to the House hailed as foremost of the opponents of the War of ISI2. ${ }^{1}$ In managing the party in Poughkeepsie, he had the constant and enthusiastic aid of Thomas Jefferson Oakley, who, having been christened before the author of the Declaration of Independence became a party leader, now did what he could to live down so embarrassing a name. ${ }^{2}$

As the story of the Federalist party is unfolded, the Dutchess County leaders will appear in company with Barent Gardenier, who lived across the river in old Ulster County and joined with Emott in the attack on "Mr. Madison's war." ${ }^{3}$ Gardenier had no easy task after Ulster changed to Jefferson in I804, and for a season was obliged to yield the honors to his astute antagonist. Lucas Elmendorff, whom Van Buren was said to claim as his preceptor in the art of politics. ${ }^{*}$ In this county, no less than in the neighboring Delaware and Dutchess, was felt the influence in politics of the great landlords, especially the Livingstons, whose fortunes were for many years combined with those of Jefferson. ${ }^{3}$

The country south of Ulster, that lay along the river toward New York was, to the Federalist eye, quite hopeless.

1 Platt, pp. 9I-92 quoting Poughkerpsi: Jourmal; N. Y. Cirril List, I882, p. 450 .

${ }^{2}$ Platt, p. 83 .

' J. J. Levinson in History of Ulster County (A. T. Clearwater, editor), Kingston, I907, p. 484.

4 N. B. Sylvester, History of Ulster County (Philadelphia, I88o), pp. 102, I03; W. Barrett, Old Merchants of New York, vol. iv, pp. 63-64; A. T. Clearwater, History of Ulster County, p. 484.

'History of Delanure County, W. W. Munsell, publisher (N. Y., I 880 ), ch. viii; Jay Gould, History of Delaware County and Border Wars of New York, Containing a Sketch of the Early Settlenents in the County and a History of the Late Anti-Rent Difficulties in Delaware with Other Historical and Miscellaneous Matter Never Before Published (Roxbury, N. Y.), 1856, chs. xi-xiii. 
Here at the beginning of the century were men of many sorts. The great holdings had, most of them, been broken into modest farms - the bouzveries of the Dutch and the scattered lands tilled by the descendants of the Palatines. whom, more than a century before, Louis XIV had harried out of western Germany, and the well-disposed (and thrifty) government of England planted in this region to gather naval stores. ${ }^{1}$ And here and there were little farmsteads of those who had moved across from Westchester or come in from the uplands of Connecticut. Such people had not been impressed with Hamilton's commercial policies. in 1lation and in state, and cherished no transplanted sentiment in favor of the Adams family. Even Newburgh which might, like Poughkeepsie, have put some trust in the party of the trader. had, interestingly enough, fallen under the influence of some free-thinking foreigners, with their Society of the Druids and their paper, The Rights of Man. and had become a citadel of infidelity. Here the seed of Jeffersonian democracy fell upon a fertile soil. ${ }^{2}$

The "Great West" of I8or began not far from Albany. and it was known for many years as largely Democratic, or,

1 Many of these, as is well known, had tired of their labor for an alien state and migrated first to set up for themselves in the fertile Mohawk region, where their presence is remembered through such names as Palatine Brirlge and German Flats, and then moved again to the still more inviting valleys of Pennsylvania: see S. H. Cobb. The Story of the Palatines (N. Y., I 897 ).

${ }^{2}$ E. .M. Ruttenber and L. H. Clarke. History of Orange County (Philadelphia, I88I), pp. I27, 245. 250-25I, 254-255. The works of Thomas Paine and Matthew Tyndall enjoyed a surprising vogue in the Newburgh district, while the Congregational Church, the sign and substance of New Englandism, never gained a foothold, ibid.. pp. 260-270 In the time of the embargo Orange County was overwhelmingly Republican, ibid., 73-74. When the doubtful Col. Burr could not be elected to the legislature or the Constitutional Convention of $180 \mathrm{I}$ from New York city, Orange County was selected as a constituency which would elect anyone who bore the name Republican. I. D. Hammond. Political History. pp. I36, 141. 
to use the official naure, Republican. The rutinless march of General Sullivan against the Iroquois, and the treatien which the vanquished chiefs had subsequently signed, had opened up the comntry to the Genesee, and during the last decade of the eighteenth century, a growing number of white men, many of them from the hills just west of the Connecticut, had penetrated far into this wood-land. Much has been written of the frontiersman: often in times past he has been pictured as a Cooperesque, romantic hero. something more than common stock, with his flashing eye and supple, graceful form; perhaps it is as well that thi figment of the fancy with its impossible heroics, has been laid aside as the dead material of literary archaeology. Sometimes he appears as turbulent and lawless, finding better fellowship with wolves and foxes than with decent people in the settled region, or again he is described as a man of faith and courage. carrying the torch of civilization. building his academies and churches, the best manhood that the east had to contribute. Of these latter pictures both must be accounted accurate, though of two separate divisions in the westward march. Following the first and giving way before the last, Timothy Dwight in his extensive travels detected an intervening group, steadier in habit than the outcast trapper, clearing land and building their rude cabins, though for want of capital, quite as often losing them again to meet the heavy mortgages. ${ }^{1}$ Finally there came from the east thrifty, energetic immigrants moving frequently in large companies of neighlors or religions congregations. New England was, as every student knows, as far from a democracy as was Scotland, which it so much resembled. and among these last newcomers there were many families

${ }^{1}$ Timothy Dwight, Trazels in New England and New Jork (New Haven, I82I), vol. ii, p. 459 ef sca.: L. K. Mathews, Expansion of Vere England. p. I p. 
from that precious fraction of society that by tradition ruled those commonwealths. ${ }^{1}$ This third element in the expansion of New England was largely Federalist in politics, and one may find pure democracy somewhat frowned down in such communities as Troy, Utica and Canandaigua, where it settled."

The stories of the soldiers who had fought against St. Leger and Burgoyne, had, as retold in Connecticut, attracted favorable attention to the Mohawk Valley. Judge Hugh White's company of settlers who founded Whitestown in the following decade, were the pioneers of such civilization in the old west of New York," though they were soon joined by similar communities who settled Kirkland, Utica and Rome. Here in Oneida County at the beginning of the century there flourished a group of towns having the air and aspect of New England. Yet there were other elements. for one leading citizen was a Van Rensselaer ("the elegance and profuseness of his domestic courtesies" were matters of town pride), and the other was Colonel Benjamin Walker, who had come from London to New York before the war, during which he had become an aid to Washington, and had taken up his home in Utica as land agent for the Earl of Bath. He was, as might be expected, a stout Episcopalian and a Federalist, and had been elected in 1800 for a term in Congress. " The enterprise of Utica soon expressed itself in manufacturing, so that by the War

'H. L. Osgood, The American Colonics in the Seventeenth Century (N. Y., 1904), part ii, ch. i.

2 L. K. Mathews, op. cit.. p. I so (map).

${ }^{3}$ Pomroy Jones, Annals and Recollections of Oneida County (Rome, N. Y.), I85I, pp. 786, 790; James Macauley, The Natural, Statistical, and Civil History of Ncw York (Albany, I829), vol. iii, pp. 420, 425.

4M. M. Bagg. The Pioneers of Utica; Being a Sketch of Its Inhabitants and Its Institutions, with the Civil History of the Place, From the Earliest Settlement to the Year 1825-The Era of the Opening of the Erie Canal, (Litica, 1877), pp. 68-69, I16. 
of 1812 industry was well begun. ${ }^{2}$ It was fitting that one who invested in these enterprises a fortune gained from speculation in land values, Thomas $R$. Gold, was to be for many years a tower of strength in the party of the state. ${ }^{2}$ Almost as influential was Julge Morris S. Miller, who was soon to nove to Utica from his land agency for Nicholas Low in Lowville. By marriage to a daughter of the Bleeckers (who somewhat resented this intrusive Yankee) he acquired a quarter of a million dollars, and, fastidious in dress, eloquent in speech, and unfailing in support to the Episcopal Church, he soon engaged the favorable attention of a Federalist town, and was sent to serve in Congress."

But Judge Jonas Platt was the county's foremost party leader. When in I809 he carried the western district which throughout its ample mileage was thought to be reliably Republican, it demonstrated two unquestionable facts: That Judge Platt was the strongest candidate his party could present the following year for governor, and also that more settlements of the Whitestown type were being founded in the west." Certainly in the first years of the century that type of settlement was rare, the conspicuous exceptions being Canandaigua and Geneva, which were still the outposts of the new civilization. The country was yet new in its society: Buffalo was scarcely founded (though even here a bitter contest had begun $)^{6}$. Rochester was yet an unnamed wilcler-

'M. M. Bagg, "The Earliest Factories of Oneida," in Transactions of the Oneida Historical Society, 1881, p. II 4 .

${ }^{2}$ P. Jones, Annals, p. 795; M. II. Bagg. Pionecrs, p. I99: N. Y. Journal, April 7, I810.

${ }^{3}$ M. M. Bagg, Pioneers, pp. 236-237; M. S. Miller to John Jay, May II, I809, Jay Correspondence.

4P. Jones, Annals, p. $79 \mathrm{I}$.

${ }^{5}$ G. S. Conover, History of Geneva (Geneva, 1879), p. 34.

- Crisfield Johnson, Centennial History of Eric County (Bufialo, 1876), pp. 106-108, І16, І17. 
ness, ${ }^{1}$ and of modern Syracuse there was then but the neagre hamlet of Bogardus Corners, straggling out beside the salt wells of the Onondaga Marshes." Of those who lived along the jagged, changing line of ultimate settlement, many must have shocked good Dr. Dwight, and no doubt carned the epithet given them by one impatient witness. a " heathenish and dissolute crew." "s They had no traditions which could be opposed to the doctrine of equality.

An old historian of Oneida. Judge Pomroy Jones, summarizes thus the early politics of his own section and the country to the north:

After the formation of the county in 1798 , it was found to contain a Federal majority. Subsequent to the organization of St. Lawrence County in 1802 , the Democratic party for the next two or three years was in the ascendent. In 1805 the Counties of Jefferson and Lewis were taken from Oneida, which left it with a Federal majority of twelve to fifteen hundred. This was a powerful majority, when it is recalled that scarcely one-half of the citizens were voters, as the old Constitution of the State contained that most aristocratic and odious provision requiring a freehold qualification of $\$ 250$ to entitle the citizen to the privilege of the elective franchise. ${ }^{4}$

St. Lawrence County, whose loss the Oneida Federalists no doubt bewailed, was settled almost entirely by companies who came across Vermont and Lake Champlain, bringing with them a respectful memory of old New England and the

${ }^{1} \mathrm{~J}$. M. Parker. The Opening of the Genese' Country, Publications of the Rochester Historical Society, 1892, vol. i, pp. 59-66.

"C. E. Smith, Pioncer Times in the Onondaga Country (Syracuse, 1904), pp. 223, 220-230.

${ }^{5}$ G. H. McMaster, History of the Scttlement of Steuben County (Bath, I853), pp. 25-3I, 78, 89. Much of the land of the so-called Hodland Patent was opened for settlement only after 1800, Arad Thomas, Pioneer History of Orleans County (Albion, 1871), pp. 23-25.

'P. Jones, Anuals and Recollections of Oneida County. Pp. 54-35. 
principles of the Adams family. ${ }^{1}$ 'They had able learler: of their own, like Rosweil Hopkins, who had been a Federalist judge in Vermont." besides those who had come northward from New York to lead in politics as well as sell them land." It remained, like the counties to the east. largely Federalist for many years. ${ }^{4}$ Jefferson and Lewis Counties, named, it will be noticed, for two distinguished Republicans, and little mourned when severed from Federalist Oneida, had been settled in a considerable part by foreigners, including Germans, Swiss and Irish, as well as a group of Frenchmen who came later, led by the famous LeRay de Chaumont, the treasurer of Napoleon. ${ }^{5}$ Since most of these people had taken leave of Europe to escape oppression, they were naturally inclined in this new land of liberty to take their stand, as soon as they were qualified, against those who had supported the Alien Laws of 'ninetyeight.

In this age of printed paper, when books and periodicals have come from luxuries to be a commonplace of life, when travel is within the compass of the leanest purse, when education is not only offered freely but is forced upon the citizen, it is not easy to imagine how gross and glaring were the inequalities among mankind a century ago. Without the common school. government by all the people might seem to sober sense a reckless and a dangerous experiment (though it might be well observed that popular government is what has brought the common school). The doctrine of

' L. K. Mathews, Expansion of New England, pp. I60-6r.

'F. B. Hough, History of St. Lazurence and Franklin Countics (Albany, I852), p. 595; N. Y. Civil List, I889, pp. 422-424.

see infra, ch. v.

4 $N$. Y. Spectator, May 16, I809, May I3, I8i2, May I2, I8i3. May Io, 1815, Nay 15. I815, etc.

${ }^{5}$ F. B. Hough, History of Lezwis County (Albany, I860), pp. 70-73. 75, 107, II9. 
democracy had but recently been preached, and men were intensely partisan upon the question of its merits; it seemed then a bold innovation and, to those to whom a change might mean a loss, a dubious one indeed. But the democrats who had shouted their huzzas at the phrase, "All men are created equal," had been mightily impressed with the new doctrine. They were determined to wrong nobody, but to gain their just share of a birthright which the aristocrats, in deliance of all the axiomatic principles of the rights of man, selfishly withheld.

The contest in which these lines were sharply drawn was made more bitter by reflection from across the sea. For once opinion on domestic and on foreign policy so merged as to make division perfectly complete. The enthusiasts for the equality of man, which contemplated, by the way, ample protection for the debtor, were ardent partisans of revolutionary France where all their theories seemed justified by accomplished facts. The wealth of Federalist merchants, on the other hand, could be continued and increased only when the way was easy to and through the English ports, where by tradition of two centuries they found their customers. They reasonably desired the triumph of the mistress of the seas, and a cordial understanding with the British admiralty as to the customs duties and the rules of trade. But to be a partisan of England meant to be a partisan of Burke; no one should tamper with the old safe ways by which wealth was preponderantly represented for its own protection, and the government so properly conlucted by learned men of leisure should by no fatuous philosophy be given over to them that drive oxen and whose talk is of bullocks, nor to the carpenters and workmasters. To some, at least, not all occupations were of equal honor. ${ }^{1}$

${ }^{1} C f$. Edmund Burke, "Reflections on the French Revolution," Works (Boston, I884), vol. iii, pp. 296-298. 
This disparity of views, so easily infused with deep emotion, was the basis of a bitter party strife, that had certain elements of a war of classes.

Whether one were a Federalist or a Democrat was not merely a question of election day, but a matter of concern throughout the year, a consideration that entered into the commonest business of life. There were permanent political clubs that met in frequent conclave in their favorite taverns; ${ }^{1}$ and sometimes in small communities where accommodations were somewhat limited, the contrast was significant. A citizen of Hudson described the quarters of the village Democratic Club as in the lower regions of a dingy general store; there, "round a red hot stove in an atmosphere blue with smoke, seated on old pine benches and wooden bottomed chairs, with the dust and cobwebs of twenty years undisturbed on the shelves, met the great Anti-Federal fathers of the city." But "the Federal Club, of which Elisha Williams, one of the most influential men in the State was the acknowledged leader, always met in the best furnished room of one of the public houses." " Each party was a social as well as a political organization, and each maintained a well-trained instrumental band drawn from its membership. ${ }^{3}$ Prejudice struck very deep in Utica; as the gentry of the town, mostly well-to-do and several of them college graduates, gathered in the home of Colonel William Williams to sip Madeira furnished by that hospitable publisher, ${ }^{4}$ they liked to chant a ballad written by a member of the group, beginning:

'W. H. Bayles, Old Taverns of New York, p. xvi.

${ }^{2} \mathrm{G}$. A. Worth, Randon Recollections of Albany (and Hudson), pp. 48,51 .

'A. R. Bradley, History of the City of Hudson, pp. 7I-72.

The mss. diary of William Williams is now in the possession of Miss Nellie Williams, Utica, N. Y. 
"The rabble all in council met

To plan a democratic fète."

It was not considered "elegant" to be a Democrat in Utica. But sometimes the feeling went much further. There were certain banks in New York and Allany where a follower of Jefferson could not be accommodated. ${ }^{2}$ When in Trenton Falls a woolen factory was begun in 1812 , wheis good cloth could fetch ten clollars a yard, it was expressly stated that no Democrat would be permitted to buy stock." In Rhinebeck, Dominie Romeyn refused to give the name of Thomas Jefferson to an infant presented at the font. The dominie was a follower of John Adanis, and the helpless parents had to stand by while their son was christened John." In the country districts life was, in its isolation, somewhat primitive. There were few of those diversions which to-day enrich existence, and emotional energies seeking for expression might easily be confused witl political conviction, to make well-marked and lasting feuds. Especially was this true in a generation trained to religions dogmatisn and sharp categories of wrong and right. Judge Woodworth who, in the first years of the nineteenth century, had seen boycotts and frequent violence grow out of party hatred in the town of Troy, wrote gratefully loing after of the improvement he lad witnessed. Wheri friends complained that conditions in the early 'fifties were not ali they should be, the pious man repeated the comnsel of Solomon: "Say not then, what is the Cause that former Days were better than these? For thou dost not inquire wiselv concerning this." 5

'M. M. Bagg, Pioneers, p. 159.

'J. D. Hammond, Political History', vol. i, pp. 325. 332.

${ }^{3} \mathrm{~J}$. F. Seymour, Centemnial Address Delizered at Trenton, N. Y. (Utica, 1877), p. 28.

"H. M. Morse, Historic Old Rhinebeck (Rhinebeck, I908), pp. 240-24,3"

"John Woodworth. Reminiscences of Troy. I790-1807, p. 41. 


\section{CHAPTER III}

\section{Rulers Deposed}

IT was once observed of Aaron Burr that his sole claim to virtue lay in the fact that he himseli had never claimed it. ${ }^{1}$ 'The frankness of this gifted man as to his rules of private conduct, no doubt retained the loyalty of friends who had been won by his engaging manners, yet the historian cannot but wish that he had left behind some serious defence of his political career, that a beiter case might be made out in his behalf than seems warranted by the evidence of deeds. In want of any such, the judgment of his motives must be formed on inference, and complete agreement here may scarcely be expected. That in I8O I he intrigued for the presidency, when by an accidental tie he seemed to have as many votes as Jefferson, is to be gathered only from a train of circumstances. He held mysterions conferences with Federalists, arrangements were concluded by his followers with that party's congressmen from doubtful states, his chief lientenant was allowed to spread a false report as to opinion in New York, while he himself assumed a shifting and equivocal position and took no steps to check the movements which he must have known were managed in his name; this ill-timed reticence may have thwarted his ambition. When the choice of the electors of the country was properly expressed by Congress and Jefferson declared elected, Aaron Burr took up his humbler duties with his party's confidence in his integrity hopelessly impaired. ${ }^{2}$ It

'W. A. Duer, Reminiscences of an Old New Yorker, p. 24.

${ }^{2}$ James Parton, The Life and Times of Aaron Burr (Boston, 1876), ch. $\mathrm{xvi}$; and the excellent account in J. D. Hammont, History of Political Parties in Now York State, vol. i, pp. 139-143. 
was known that certain New York Federalists, like Judge Cooper and David A. Ogden, had been his active agents in the contest at the capital; ${ }^{1}$ when. early in the following year, he was put prominently forward at a Federalist banquet, to the surprise of his enemies and the consternation of his friends, ${ }^{2}$ it was obvious that his Republicanism might well be called in question.

In the state campaign in ISor the followers of Clinton, Livingston and Burr stood united," but the new government had scarcely been inaugurated when the proscription of the Burrites. along with the Federalists, was begun. The new Council of Appointment, directed by DelVitt Clinton. the ambitious nephew of the governor, and Ambrose Spencer, recently apostatized from Federalism, left few offices in the hands of those who had served the late arministration, and consistently refused appointments to all followers of Burr." A pamphlet warfare was begun, not surpassed in all the annals of American campaigns. A certain Iohn Wood, who had written a History of the Altministration of John Adams in the Republican interest, particularly of Burr, was now requested by his patron to suppress the most offensive passages, for the purpose, it

" Aristides," An Examination of the Various Charges Exhibited Against Aaron Burr, etc.. pp. 56-57 (see infra).

${ }^{2}$ A full account of this episode is given by I. P. Van Ness in a letter to his brother W. P. Tan Ness, April 2, I\&02, Van Ness Mss., N. Y. Public Library.

${ }^{3}$ A broadside ( $\mathrm{N}$. Y. Public Library) "To the Independent Electors of the State of New York," I80I, is signed, among others, by John Swartwout and Oliver Phelps, who became Burrites; Elisha Jenkins and Adam Comstock, who became Clintonians; and Ebenezer Purdy and Erastus Root, who became Lewisites. Burr, had, of course, been very active in the campaign, Hamilton to J. A. Bayard, February 22, 1\&oI, Hamilton's W'orks, (Lodge edition), vol. viii, pp. 589-590.

'J. D. Hammond, op. cit., vol. i, pp. I jo-r84; Henry Adams, History of the United States, vol. i. pp. 288-289. 
was charged, of making easier Burr's approach to the New England Federalists. This charge was published early in I802 in A Narratioc of the Suppression by Colonel Burr of the History, ctc., by a Citizen of New York, who turned out to be James Cheetham, the editor of a paper lately started in the cause of Clinton. Wood and others replied defending Burr, while the author of "the Narrative" returned not only an Antidote to John Wood's Poison, but likewise a full View of the Political Conduct of Aaron Burr, Esquire, purporting to trace (not always with nice accuracy) his partisan irregularities during the past twelve years. IVood published a rejoinder, but Burr's cause found an abler champion in William P. Van Ness, whose arraignment signed "Aristides" was marked by ferocity no less than by finesse. It has been declared unrivalled since the days of Junius, and it circulated more widely through the country than any earlier pamphlet except Common Sense. ${ }^{1}$ That these editors and pamphleteers looked upon

'J. D. Hammond, op. cit., vol. i, p. I 89 ; see also the analysis and criticism of the pamphlet by D. S. Alexander, A Political History of the State of New York, and New York Spectator, January II, I804. This contest, of course, belongs only incidentally to the present narrative and the contents of these brochures, however illustrative of the political writing of the time, cannot here be summarized. The order of appearance of the principal items is as follows: "A Citizen of New York" (James Cheetham) A Narrative of the Suppression by Colonel Burr of the History of the Administration of John Adams (N. Y., I802); "A Yeoman," Strictures upon the Narrative of the Suppression by Col. Burr of IVood's History, etc. (N. Y., I 802 ); A View of the Political Conduct of Aaron Burr, Esq., by the Author of the "Narrative" (N. Y., 1802); John Wood, A Correct Statement of the Various Sources from which the History of the Administration of John Adams was Compiled and the Motizes for its Suppression by Col. Burr; with Some Obseriations on a Narratic' by a Citizen of New York (N. Y. 1802); "Warren" (Cheetham) An Antidote to John IVood's Poison (N. Y., I802); John Wood, A Full Exposition of the Clintonian Faction (Newark, I\&02); James Cheetham, Nine Lctters on the Subject of Aaron Burr's Political Defection (N. Y., I803); "Aristides" (W. P. 
their controversy as something graver than a war of rhetoric, was evidenced by two duels fought among them, and by other challenges which were with difficulty satisfied outside the code. The Republican party in New York was cloven squarely into two unequal parts-the Jeffersonians. now in complete control, and the followers of Aaron Burr.

The "little band," as Cheetham called his enemies, contained some politicians of good reputation, who found much to admire in the undoubted talent of the Vice-President; but with then were associated, by common acceptation, "nearly all the needy and desperate adventurers in the community,". augmented, one by one, by those who failed of offices at the hand of the discriminating Clinton Council of Appointment." By most of the distinguished leaders of the Federalist party Burr was despised and spurned. Hamilton. in 1800 , had called him "as true a Cataline as ever met i 11 midnight conclave;" "Morris, as Senator in Washington. had "greatly disapproved and openly disapproved of the attempt to choose Mr. Burr:" 5 Robert Troup had scored him as a sneak. ${ }^{6}$ They had exulted at beholding the breach he made among their enemies, until they saw how dangerous was the fascination of this outcast Democrat when turned toward their own following.

Van Ness), An Examination of the larious Charges Exhibited Against Aaron Burr, Esq., I ice-President of the United States: and A Development of the Characters and Views of his Political Opponents (Philadelphia, I803): James Cheetham. A Reply to Aristides (N. Y., I804).

'Clinton's Letters to Henry Post, Harper's Magawine, vol. 1, p. 565 , and Alexander, op. cit., p. 128.

${ }^{2}$ Theodore Sedgwick to Rufus King, August 24. 1802, Life and Correspondence of Rufus King.

'Cheetham's View, p. 94.

'To James A. Bayard, August 6, I80o. Works (Lodge), vol. viii, p. 562.

'A. C. Morris, Diary and Letters of Gowerncur Morris, rol. ii, p. 404.

- To R. King, April 24, I\&o2, King Correspondence. 
Federalism itself seemed dead; to call it from the tomb would need a sorcerer. It is not surprising that in their extremity the great mass of Federalists were giving ear to such a man as Aaron Burr. In spite of Hamilton and others an understanding was effected. "The long anticipated coalition between a few pretended Republicans and the Federalists," wrote Cheethan in the spring of ISO2. "appears at length to be cormed." ' The old leaders might seek to brand this as a falsehood, and recite sarcastic requiems over the Vice-President as a "gone man," bu Hamilton admitted that, " unluckily we are not as neutral to the quarrel as we ought to be." = Yet nothing more could rightly be expected, for, sulking in defeat, these leaders had failed to keep their party firm in doctrine. In many districts now no candidates were named for Congress $n$; the legislature; ${ }^{3}$ and it was not surprising that lieutenants and subalterns would bring in that mean, enfeebling policy of offering themselves as makeweight between the factions of the enemy. Nothing could more strikingly illustrate their consciousness of bankruptcy; such wretched huckstering soon cost them the respect of everyone. not leaving an themselves. ${ }^{*}$

In $\mathrm{I} \mathrm{O}_{4}$ the Federalist leaders determined on a rally. Rufus King. who had recently returied from England. was a man on whom as candidate for governor they night unite with full enthusiasn. He was besought by letters and addresses, including those from old associates in Massachu-

'.T. Y. American. Citizen, May 3, I80.2.

${ }^{2}$ To R. King, June 3, 1802, King Correspondenct: and Troup tr King, June 6, and December 12, 1802, ibid.

'N. Y. Evening Post, April 27, 1802.

${ }^{4}$ When in 1803 the Federalists in New York City were cheered into putting up some candidates for the assembly, the Burrites rallied ostentatiously to their support, N. I: Evening Post, April 26, I\$8.3. anci American Citizel, April 28, 1803. 
setts; but in these last he soon detected that a Federalist governor of New York would be expected to take part in a conspiracy, already hatched and well developed in New Engiand, for a secession of the northern group of states. To such proceedings he would give no countenance and, though personal ambition might thus have been well served, concluded to content himself with the barren honor of the nomination for Vice-President. ${ }^{1}$ In this disappointment to the party Burr saw his opportunity. Full of sounding promises, he had himself put up for governor. Overtures were made to him by the most desperate of the intriguers, who found him ready for co-operation. ${ }^{2}$ Some substantial county leaders of the Republicans also, such as Peter B. Porter of Ontario, John Van Ness Yates of Albany, Senator James Burt of Orange and others, came out strongly in his favor. ${ }^{3}$

The Livingstons and Clintons, who still could be considered Jeffersonians (for the Virginia interest was always joined against the most powerful Democrat in New York state), hearing that George Clinton now sought the vicepresidency as a kind of respectable retirement, nominated as their candidate for governor, Chancellor John Lansing, who had been prominent in public life since colonial days. However, when he subsequently found that if successful he would be expected to be but a passive instrument in the hand of DeWitt Clinton, this gentleman refused to be continued as a nominee, although his reasons were kept secret for three years. After some deliberation and balancing of

IT. Sedgwick to Hamilton, and Hamilton to King, Hamilton's IVorks (J. C. Hamilton edition), vol. vi, p. 553; King to Hamilton, February 24, and March I, I804, King Correspondenec; H. C. Lodge, Lifc of George Cabot (Boston, I878), p. 447.

'Henry Adams, Documents Relating to New England Federalism (Boston, I877), p. 354.

${ }^{3}$ J. D. Hammond, op. cit., vol. i, p. 203. 
names, there was selected as a substitute, Chief Justice Morgan Lewis, the brother-in-law of Chancellor Livingston, a man whose three score years and amiable and easy-going temper seemed to promise pliability. Of one thing Hamilton was certain, that no honorable man could vote for - Jaron Burr. In a meeting of his partisans convened in Mlbany, he had advised them, in case they could themselves put up no candidate, to give support to Lansing, upon whose honesty at least they might rely. ${ }^{1}$ When the chancellor was no longer to be had, he tried again to induce Rufus King to stand." His efforts were in vain, he then advised his friends to vote for Lewis, although the prospect of success under such a leadership seemed far less bright. ${ }^{3}$

The campaign was one of the most hotly fought the state has ever seen. How many Republicanis Burr could pull away from Clinton and how many Federalists from Hamilton, was the question to be answered. Some papers of the latter party, like the New York Commcrial Advertiser, had been willing to support Lansing as one who stood superior to his associates, though they still would have preferred a nomination of their own; ${ }^{+}$but when his name was exchanged for that of Morgan Lewis, who was looked upon as a mere place-man of the Livingstons, they slowly drew away. First there was some criticism of the manner of his nomination, for it had been by legislative caucus, a mode not yet familiar. The next month they were speaking of Burr's strength in the west; and two weeks later were

${ }^{1}$ N. Y. Morning Chronicle, February 17, 1804.

${ }^{2}$ Hamilton to King, February 24, I80, Hamilton's Works (I. C. Hamilton), vol. vi, p. 559 .

${ }^{3}$ J. D. Hanmond, op. cit., vol. i. p. 200.

${ }^{4}$ N. Y. Spectator, February 25, 1804; "The Livingstons are at all events to be excluded... The family has seen its day, and has served its purposes," ibid., January 18,1804 , see also in this issue their reasons why a Federalist ticket would have been preferahle. 
among his strong supporters. ${ }^{1}$ The greatest single inAuence in producing this opinion was a broadside signed "Plain Truth," which appeared early in March. When newspapers were scarce and costly, the broadside was of great importance as an instrument of propaganda. A handbill, circulated from a corner store or pasted to a tree or ience post at a cross-roads, was sure to reach an audience which party orators could seldom gather; important politicians driving out among constituents did not disdain to stack the dodgers carefully beneath their gig-seats to parcel out among the faithful.

The author of "Plain Truth" declared that "we already. see the extent of power and of influence possessed by families who monopolize most of the valuable and influential situations in the state; who are sufficiently numerous and sifficiently eager to officer the whole of them." He enumerated in two columns fourteen such places held by members of the Clinton family with $\$ 53,500$ paid as salaries, and twelve held by the "Noble Family of livingston" worth $\$ 33.950^{2}$ This species of attack was nothing new; "Lord Livingston's" rapacity had been a theme of scribblers even before the war." Ever since the chancellor, disappointed at being overlooked by Vashington in apportioning the major offices of state. had, in 1791 . called in his numerous kin and renounced the Federalist party, the obloquy of the apostate had been settled on this house. ${ }^{4}$ The

\section{'N. Y. Spectator. Narch to. 24. 1804.}

This broadside is in the collection of the $\mathrm{N}$. Y. Public Library. These tigures were corrected in a subsequent cdition to read $\$ 49,750$ and $\$ 33,950$.

"1. M. Keys, Cadzallader iolden, p. 302.

"It was a "House of Republican Nobility of which one of the younglings had been heard to say, with irtie democratic humility, that to be born with their family name is a fortune to any man." $N$. $y$. Eacring Post, Fehruar: -6. 1802 . 
Clintons, though without the prestige of their high-born colleagues, had won political success and married wisel:. until to be a cousin of DelWitt was thought to be a passport to high station. The Federalist papers had long intveighed against these two ambitions families and their greed for salaries ; ${ }^{1}$ men of that party had themselves been so berated as aristocrats, they seized upon this opportunity to turn the epithet upon their foes. The figures of "Plain Truth," then, gave the theme of the campaigil.

Colonel Burr was introduced by his supporters as one whose chief clain to the public confidence lay in the fact that he was nnencumbered by comnections." He was a single man, like Mr. Jefferson, having no family, should he be chosen Governor, to provide for out of the public Treasury, of to distract his executive attention from the calm, undisturbed contemplation of public utility, and who by the late sale of his property, for the honest paynent of his debts, is become now free from all pecuniary embarrassments, with a comfortahle residuary independency. ${ }^{3}$

Surely such an introduction would fall strangely on a modern ear. Against Morgan Lewis the Burrites brought up not only his membership in a "numerous and pride-bloater! family," but also his caucus nomination. The public seemed yet to consider party politics, with its inevitable discipline. as something vicious in the state.

Our representatives were sent [complained another handbill] not to make our governors, hut to make our laws; and with

${ }^{1}$ For example. N. Y. Exening I'ost. April 15. May 1, 1802; April 28, i\&o3.

"See broadside, "To All Independent Electors" (N. Y. Public Library).

${ }^{3}$ Broadside. "Pretentions upon which Colonel Burr merits the free suffrage of his Fellow-Citizens," and "Jefferson \& Burr against the Clinton \& Livingston Combination." Of course Jefferson was, in fact, a widower with married daughters. 
blushes have many of them confessed, that they were drilled like soldiers, and compelled to sign the nomination, uncer pain of being denounced and calumniated in the newspapers and incurring in every shape the persecution of DeWitt Clinton. ${ }^{1}$

That Lewis once had been a Federalist, abandoning a declining party and attaching himself to the strongest, was further cause to hate him." "Toby Tickler's" campaign paper The Corrector thresheci the charges over day by day.

This shower of bills was returned in kind by the Lewisites. "Plain Truth's" statistics were branded as a fabric woven half of lies. "A Republican and no Burrite" declared the total of the "family" salaries cited would not foot to more than $\$ 35,000$, which he claimed was less than was received from the state treasury by the nearest minions, or the "little band," of Colonel Burr himself. The writer then attempted an elaborate rebuttal to the estimates of his opponents, maintaining, certainly with want of candor or of information, that the appointive office of the mayor of New York (remunerated, as it was, by every kind of fee) was worth scarcely a third of the stated $\$ 15,000 .{ }^{3}$ "Republican Economy," declared that all freeholders jealous of the public trust should refuse support to Colonel Burr, as he was in truth the candidate of the spendthrift Federalist party. Other broadsides then rehearsed, with gross paiticularity, Burr's miserable amours (that is, a number of them), naming streets and houses." All that had been said

1 Broadsides, "An Elector," “ To All Independent Electors."

2 Broadside, "Republicans Attend."

${ }^{3} C f$. N. Y. Spectator. February I , I804; J. D. Hammond, of cit., vol. i, pp. I80, 263, 29I ; Robert Troup to Rufus King, January I2. I8Io, King Correspondence. One broadside went further, declaring that the Burrites, among them, got $\$ 59.000$, and as to the mayoralty "the predecessor of the present mayor lost money by the office, and $\mathrm{Mr}$. Clinton may not have a cent"; from "Republican Measure" (loc. cit.)

"Broadside, "The Following Hand-bill" (loc. cit.) 
against "the Cataline" by Federalists in I8OI was now reprinted in great glee by their opponents. Men that he had cheated, and men that he had bullied when he served as colonel in the war, were induced to write their wretched statements, to be scattered broadcast through the state. On the other hand, the Burrites claimed that office-holders were generally laid under contribution to provide a fund for bribery, and were warned that, in case of victory for Burr. they would all, as Judge Spencer had biuntly said, be obliged to go to work. ${ }^{1}$ Clintonian broadsides printed lists of disappointed office seekers who now joined the "little band." Clinton sent his agents through the state who discovered a trick that afterward became more common: "In the Southern Counties it is rumored that the Western Counties are favorable to their candiclate. In the western parts the same falsehood is related of the Southern. The middle is informed of his ascendancy in the Eastern and the Eastern is told of his prodigious force in the Middle." 3

Such was the character of a campaign which many thought would lead to bloodshed: ${ }^{4}$ a quarrel of men for profit, in which apparently no word was spoken as to measures or the larger concerns of public policy. Its sordid details make unpleasant reading, and yet may no doubt be studied with instruction by those who cry decadence in our modern day, and grieve because our politics has lapsed from pristine purity. In the decade of which this year was near the middle, the civic honor of New York fell to a bottom not passed between the times of those two models of corruption. Lord Cornbury and Grand Sachem Tweed. In

3. D. Hammond, op. cit., vol. i. p. 17\%.

"Sce, for example, a list of forty-one in "To Genuine Republicans" (A. T. Public Library).

3 Y. Witt Cinton Miss., Letierbook I, March 14. I804 el seq.

4. Y. Spectator, January 25, 1804 . 
this adversity King, Jay and Morris spoke unheeded, while weaker partisans forsook their leaders to run after a god strange indeed.

The Clintons and Livingstons were victorious by a vote of nearly three to two. A comparison of the returns with those for senators in 1803 , discloses that for every Republican who cast his vote for Burr, a Federalist, convinced by Hamilton, supported Lewis. ${ }^{1}$ Burr was now a man without a party. He had been taken by the federalists only as a war-chief, as the towns of Italy had taken Braccio and Sforza. to fight their battles for them. In such arrangements victory alone may be a ground of permanence; and Burr had lost. Before the final canvass the relations beiween Burr and his Federalist following were becoming strained, and after it the ieeling grew into an open quarrel." Burr himself well knew that although Hamiton had not been often in the public prints, his had been the hand that had withheld sufficient Fereralists to compass the defeat. Before the campaign had been fairly started he had written to his daughter, Theodosia, that Hamilton would favor anybody "who could have a chance against A. B." " Apparently this strange and reckless egotist now thought the world too small a place for two such rivals; the duel that he provoked. with its tragic end, is too well known to be recorded here. But if the enlightened leadership of Hamilton was taken from the Federalists, so likewise was the baleful influence of

${ }^{1}$ D. S. Alexander, Political History, vol. i, p. 138.

${ }^{2}$ F. A. Bloodgood to John Tayler, March 26, I\&o4, Tayler Mss. (N. Y. Public Library); "Already do the Burrites \& the Federalists begin to quarrel among themselves. The former charge the latter with deception, \& they retaliate with saying that the Burr party are a 'Little Band' indeed." Maturin Livingston to Charles D. Cooper, April 30. 1804, Cooper Mss. (N. Y. Public Library).

"To Theodosia Burr Alston, February 16, I804, M. L. Davis, Memoir of Burr (N. Y., 1837), vol. ii, p. 277. 
Burr, who in the scorn of a whole generation soon became a man without a country.

It was characteristic of the Federalist leaders that their next united effort should be in the interest of a bank. in 1803 a number of gentlemen belonging chiefly to that party had, as a private company, begun a banking business in the city of New York. The legislature, believing that such enterprises should not be carried on without a charter. at their next session had passed a restraining act on private banking, though excepting the Merchant's Bank, as this was called, until the spring of I $805^{.}$Now the Clintons (which is to say DeWitt) had acquired control of the Manhattan Company, a bank in New York city, and their spokesmen in the legislature soon gave notice that no charter would be granted to a rival if their opposition could prevent it. The able agents of the Merchant's Bank, however, by liberal use of money, as a subsequent investigation clearly showerl, succeeded in their project, and it was a matter of no small interest to the state that Governor Morgan Lewis forsook his old Clintonian associates to express his full approval of the charter. No exception could be taken to the arguments upon which he defended his opinion, but to Mayor Clinton and his brother-in-law, Judge Ambrose Spencer, all argument was frivolous; the Livingstons had revolted, the coalition was at an end, henceforth these "two lordly families" were to be as Capulet and Montague. To allow the leader to be with his following in person. DeWitt Clinton was made senator from the southern district. ${ }^{2}$ The Livingstons were declared schismatic and were denominated Lewisites

${ }^{1} C f$. broadsides, "Anthropos" and "Wm. I. Vredenburgh to his Constituents" (N. Y. Public Library); N. Y. Spectator, April 17, 1805: J. D. Hammond, op. cit., vol. i, pp. 332 et seq.

${ }^{2}$ See broadside, "Address to the Republicans of the State of New York, April 23, I805" (N. Y. P. L.), giving the resolutions of a public meeting of Clintonians in New York city, Theodorus Bailey, chairman. 
or Quids. For years the state would see-saw back and iorth, at each turn dumping out the office-holders of the iaction which could not hold the Council of Appointment. ${ }^{1}$

The Federalists at first looked on with impartial exultaion at the troubles of their opponents. "Our State concerns continue to be an object of contest with the Demagogues of the day." wrote Robert Troup. "Demagogues Clinton \& Co. by the superiority of the manoeuvres, have carried a council of appointment against the wishes and efforts of Demagogues Lewis \& Co." 2 In different sections, notably in New York city, Federalist groups appeared with apparently the health and vigor of old times, and called to mind their former glory:

Who rescued the nation from the imbecility and anarchy of the old confederation? Who proposed and advocated the constitution of the United States? Who carried that constitution into operation, and by whose efforts was the country raised in a few years, from a state of disorder and bankruptcy, to a proud eminence of dignity and prosperity? ${ }^{3}$

Yet shrewd spectators doubted their ability to cope with Clinton by themselves. "The feds. appear sanguine here," wrote John Swartwout to his fellow Burrite, William P. Van Ness, "but I think lave not the stamina of exertion in them. Their strongest men have held back, Rufus King for instance. This I think evinces that the leaders do not believe in success." " The Burrites had themselves been sadly split. In December I805, some of their leaders effected a bargain of peace with the Clintonians. but in

${ }^{1} E$. $g$. the office of secretary of state between 1793 and 1813 , as recorded in the N. Y. Civil List. I88I, p. 157.

${ }^{3}$ To Rufus King. February 3, 1806, King Correspondence.

${ }^{3}$ Address in the N.Y. Commercial Adiertiser, April 19, 1806.

${ }^{4}$ J [ohn] S[wartout] to W. P. Van Ness, April I8, I806, Van Ness MIss. 
February, four days after this was publicly announced, many who could not stomach such a feast of union met with New York city Lewisites in Martling's Long Room, to pledge undying hatred to Clinton and his men. These "Martling Men," soon finding their direction in the sachems of the Tammany Society, seldom faltered in their fight until their foe had passed beyond this life. ${ }^{1}$ When war was thus openly declared between Clintonians and Lewisites, Swartwout's prophecy was proved correct. The Federalists under William W. Van Ness (the brilliani cousin of "Aristides"), despite all pleas for strict neutrality. " began to give support to poor Governor Lewis, whose endowments were not those of a self-reliant leader and who already had sought their counsel in private conferences. ${ }^{3}$ All this. the Clintonians declared, did not surprise them; they had seen "men having a great interest in the community" gravitating toward the Livingstons, and it was to be expected that the Livingstons would turn toward the Federalists. ${ }^{4}$

More and more the Federalists were convinced that their

'J. D. Hammond, Political History, vol. i, passim. The Burrites who negotiated with Clinton soon found that he recognized no obligation on his part, and came to hope that the Federalists would try a contest independently, thinking that they might detach the governor from his family shackles, and, with their better art and energy, become themselves the leaders against Clinton.

2 "Another Federalist" in N.Y. Spectator, March I, I\&o6, and "Fabricius," ibid., May 3, I8o6.

" "Judge Benson will tell you the precious confessions which Lewis is constantly making when alone with federalists. I have listened until my contempt for the governor has been lost in my pity for the man." Robert Troup to Rufus King. February II, I\&o6, King Correspondence.

"See broadside "To the Republicans of the State of New York" April 3, I806 (N. Y. P. L.) signed by DelWitt Clinton, Adam Comstock, Iohn Tayler, Nicholas Staats, Jedediah Peck and 55 other members of assembly. 
pulicy of opportunism must be continued. Colonel Robert Troup, a well-informed observer at the capital in the early days of I807. came to this conclusion:

As to the situation of the Federalists, although it is better than it was, yet it is by no means such as to enable us to elect a Governor from our own party. For the present we must be content to rest our hopes of a future Federal State administration on the fall of the Democratic party by the weight of its own vices and divisions. To let the former take their natural course and to give root and vigor to the latter seem to be the melancholy course which genuine patriotism presents. ${ }^{2}$

Too much must not be expected of the governor. Excommunicated from the Democratic fold, he must realize that what support he might receive from Federalists would not come from any personal respect, but in the hope thar he might be a useful means to bring again the reign of Federalism. Although they might set hope on being sranted a supreme court judge, let them look for little more from the Lewisite Council which would soon be chosen. since

Federal appointments would stamp the Governor's administration with so strong a character of Federalism, as to shake the confidence, and endanger the support of his democratic friends. It is said that the union in the $5^{\text {th }}$ ward at the last election in New York, and the subsequent voting of the alderman and assistant alderman of that ward with the Federalists. has much injured the Governor's cause in the country.

Troup thus suggested that King warn his too high-tempered friends that they ought to bear inevitable disappointment with proper fortitude. This view Van Vechten and others of the calmer leaders were well known to share." On the

${ }^{1}$ Troup to King, January 6, 1807 , King Correspondence.

Ibid. 
other hand some aspirants were resiless, like Peter Ja! Munro, who "squinted at the Mayoralty of New York."

The Council went to Lewis, the Federalists, as prophesied, supporting all his candidates, thus making possible success. ${ }^{2}$ In equally avoiding the Clintonians and the Federalists, the Council's choice was limited, and many of the appointments gave good ground for ridicule. One member of the Council, John Nicholas, lately from Virginia, was for a straight-forward open course, choosing always that supporter of the administration who might seem best qualified: but, observes Judge Hammond, the historian, "it was im. possible for him to understand the sinuosities of New York politics." " Some Federalists in disappointment were for breaking off entirely with Lewis, though Tron1, on his part. was as much disgusted with some who had lemeaned themselves in office-seeking. ${ }^{+}$Judge Van Ness, who in his war on Clinton through the eastern counties, now and then grew impatient because not all the Federalists would discover genuine enthusiasm for the cause of Lewis, admitted that "If we lose the election it is because the temper and views of our party have been entirely misunderstood and wantonly sported with by the Council." :

By the middle of March 1807 , there was begun a movement to throw off their connection with the Lewisites and

1 Troup to King, January 26, 1807 , King Correspondence.

${ }^{2}$ Ibid., January 27 , 1807 .

${ }^{3}$ J. D. Hammond, Political History, vol. i, p. 245.

- Troup to King, February 17, I807, King Correspondence. Lewis' reappointment of his son-in-law, Maturin Livingston, who was unpopular among the better lawyers, as recorder of New York city; and Dr. Thomas Tillotson, his brother-in-law, as secretary of siate. provoked much opposition.

${ }^{3}$ W. W. Van Ness to Sol. Van Rensselaer, March I\&, I807, Airs. C. V. R. Bonney, A Legacy of Historical Gleanings (Albany, 1875), vol. i, pp. 158-159. 
give all attention to the party candidates for the legislature. "Let the Federal Republicans once more rouse from their siumbers," it was urged. ${ }^{1}$ A pamphlet soon was circulated as Hamilton's Advice; or an enquiry into the propriety and consistency of Gou. Lex'is' being supported by the Federalists, while they oppose the elcction of all his fricnds; ${ }^{2}$ but the party papers answered, that the author "ought to weigh well the consequence of putting forth any opinions, which, so far as they may have any effect, may divide, distract, and of course, weaken the Federal party in this crisis." Individuals might decide their courses as they liked, but he who would detach others from the body of the party, would so far scatter and diffuse its energies. ${ }^{3}$ Support to Lewisites was justified upon high grounds of patriotism.

Are the duties of the Federalists [inquired an editor] confined to the welfare of the party? Are our professions of regard for the general good, false and elusive?... On the contrary are we not bound in duty to ourselves and to the public, to give our votes in favor of the party or the man, who, in our view would do the least mischief to the state. ${ }^{4}$

"To give our votes to neither," it was later said, "was to permit the stronger of the two to succeed, and was equivalent in its consequences to our giving him our direct and effective support." "Their consciences thus quieted, they proceeded very gingerly to give their aid to Lewis against Daniel D. Tompkins, who was thought to be a figure-head for Clinton. In what would now be called the keynote speech, Richard Harison refrained from mentioning the

'N. Y. Spectator, March I8, 1807 .

${ }^{3}$ N. Y. 1807 , cited in A. Y. Ez'ening Post, March 22, 1807.

${ }^{3}$ N. Y. Evening Post, March 22, 23; N. Y. Commercial Advertiser, March $23 ; N . Y$. Spectator, March 24.

'Zachariah Lewis in the N. Y. Spectator, March 28, I807.

${ }^{5}$ N. Y. Evening Post, March 26, 1807. 
governor by name, but in a hesitating and half-hearted way suggested that of their enemies one part was better than the other. ${ }^{1}$ During April Federalists in Albany acted ostensibly as individuals in joining Lewisites against the other faction, as for instance, in the rescue of the charter of Columbia College from destruction by the Clinton men. But the combination wore the aspect of something shameful and clandestine; the Lewisites were pledged to the support of Federalists in the west, but the arrangement was hinted at in whispers as if those who knew were all conspirators. ${ }^{2}$ It was in a brief resurgence of their self-respect that the Federalists named Rufus King to head their ticket for the assembly. As soon as the name of this distinguished statesman was presented to the public, the columns of the Clinton press were solidly drawn up against him; but to understand their principal attacks one must consider an issue which came to play no little part in New York state, the alien vote and its antagonism to the Federalists.

England's long misgovernment of Ireland has been of consequence to many nations in driving Irishmen across the seas; but to none more than to our own, and here to no state more than to New York. These immigrants wino could so easily adapt themselves to novel circunistances, did not need the mutual support of great embarkations and close settlements; they came in steadily, family by family, scattering here and there, though many stayed within the city. so that in the last days of the colony Irish names were becoming conmon. ${ }^{3}$ With the setting up of the new nation

1 N. Y. Evening Post, March 26, 1807.

${ }^{2}$ Troup to King, April 7, ISo 7, King Correspondcuce.

" "Irish Colonists in New York," Proceedings of the Nca' York State Historical Association, vol. vii, pp. 94-123. The roster of provincial troops of New York in the French and Indian War shows a number of pages where a fifth are Irish names, see Collections of the Neze York Historical Society, I\&gI. 
it seemed clear that many more would come, and in the apprehension that political rights so dearly bought might be too cheaply shared with aliens, the Tammany Society, as early as May I2th. I79I, refused its offices to the "adopted citizens." 1 The troubles of 'ninety-eight sent more exiles to America, some of them, like Thomas Addis Emmett and William James MacNevin, gentlemen of tinest culture. whose tastes, perhaps, would have allied them with the aristocracy, but whose revolutionary training as United Irishmen directed all their sympathies toward the policies of individualism. It was not surprising that they should enter with enthusiasm into the war on "Anglomen and monocrats" like Adams and the other sponsors for the Alien Laws. By the party of their choice, not only in the city but throughout the towns and villages of the state, they were welcomed as efficient leaders. ${ }^{2}$

Such men as these became supporters of DeWitt Clinton, himself of Irish blood and through his life a friend of Ireland. $^{8} \quad$ In later years an Irish citizen of New York city in an address recalled that

while a Senator of the United States you stood foremost in preparing and carrying into law the existing mode of naturalization... When many of us fled from despotism, and sought refuge in this emancipated land, the spirit of intolerance pursued us across the Atlantic and spared no effort to embitter our existence, and prolong our sorrows $;.$. you rebuked with

${ }^{1}$ Gustavus Myers, History of Tammany Hall (N. Y.. IgOI), pp. 30-37.

${ }^{2}$ Cf. M. M. Bagg, The Pioneers of Utica, pp. 137-1 $142,376-379$, on John C. and Nicholas Devereux and John Devlin.

B In 1789 we find him reading, before a literary society, a faper called "A Dream of Ireland" (DeWitt Clinton. Mss. Miscellaneous Papers). In 1822 he wrote a series of letters which he signed "Hibernicus" (Letters on The Natural History and Internal Resources of the State of New York, N. Y., I822). There are among his papers many addresses from groups of Irishmen. 
effect that churlish and savage jealousy. from which professed republicans are not always exempt ... Even here, a qualification oath was required from members of the Legislature, which could not be consistently taken by members of the Catholic faith! On this as on every other occasion, reason and justice found you their able and successful advocate.

The recipient of this praise admitted in reply that he had not been " insensible to those natural predilections, which every man must entertain for the country of his ancestors."

The Irish voters became the center of lively partisan controversy. Charges passed from side to side. It was claimed that when the naturalization law was changed, Clinton'; friends assembled a society to school the immigrants in party politics to swell his following." On the other hand Clintonians accused the Federalists of cautioning their inspectors at the polls to refuse the suffrage to twenty-six new voters unless they bought their stamped certificates-which would cost five dollars-and then purchasing for sequestration all available stamps. ${ }^{3}$ Certainly the Irishmen proved no disappointment to their teachers in New York city and elsewhere in the state, their loyalty to Clinton was so acceptably expressed. ${ }^{4}$

The jealousy of strangers is nothing new in human

1 DeWitt Clinton Mss., March 16, I816.

"John Wood, A Full Exposition of the Chimunian Faction, 11. 2o; "Aristides," p. 17.

"N.Y. American Citizen, May 1, r80z. To meet this subterfuge, the court records themselves were brought to the polls, see Joln Wood (loc. cit.): "It is needless for me to mention the ridiculous and irregular proceeding of Wortman, in running to the poll with the books of the Mayor's Court under his arm, and with a troop of ragged aliens at his heel, when stamp certificates could not be procured."

"The Irish and other immigrant voters turned the election from the Federalists to Clinton's man, for example, in Saratoga County: John Taylor of Chariton. Saratoga County, to John Tayler of Albany, April 9. 1803 . Tayler Mss. 
history, and here the feeling of antipathy for those whose ways were different was intensified by the glaring inferiorities in the standards of living among the newcomers. Not only were they different in race. religion, and political tradition, but uncouth, uncleanly, ignorant, unskilled, and frequently immoral. ${ }^{1}$ Besides all this the prejudice against the Catholics, that had expressed itself in the Lord George Gordon riots in England, was widespread in America as well. ${ }^{2}$ On Christmas, I8o6, near St. Peter's Church in Barclay Street, mobs of nativists and Irishmen set upon each other with such savage force that much hlood was spilt, one man was stabbed to death, and many houses would have been sacked had not Mayor DeWitt Clinton arrived at the height of the tumult. ${ }^{3}$ Here surely was sufficient ground for animosities in politics, and an occasion was soon forthcoming for their expression.

When in I8O7 Rufus King was induced to head the Federalist ticket for the assembly in the city of New York, his name was scarcely printed in the party papers, when Thomas Addis Emmett in the columns of the Citizen began a virulent attack upon him, as one whom he and every other Irishman had just cause to hate." It seems that in 1798 when King was minister of the United States in England he heard that the British government contemplated banishing the Irish state prisoners to America. He straightway protested on the principle that the United States should not be considered as a Botany Bay for those whom England stamped

\footnotetext{
1L. D. Sciscn, Political Natioism in New York State (N. Y., isor), p. 18 .
}

'J. G. Shea, History of the Catholic Church in the United States (N. Y., I888), vol. ii. p. I58.

SAmerican Register, vol. i, p. I4, cited by L. D. Scisco. On Clinton's hold on the foreigners, see his Letterbook, February i3, 1808, DeWitt Clinton Mss.

'N. Y. American Citizen, April 9, 1807. 
as undesirable. ${ }^{1}$ Emmett now charged that King was so confirmed a royalist that he desired no more real republicans admitted to America, and branded him before the state as the acknowledged foe of liberty. When Coleman of the Evoning Post adduced a set of documents to prove that Emmett's conduct while in Ireland had merited severesi punishment, the accused replied that these papers must have been supplied by King, and that in such a sonrce of information no confidence could well be placed." Other "state prisoners " in New York expressed their hatred of the Federalists, ${ }^{3}$ and the cry against their ticket was taken up by the Hibernian Provident Society, which had recently been incorporated for social and charitable purposes, and which entered the campaign with a regulation that any member who should vote for certain candidates should be expelled. thus forfeiting his claims upon the common funds. ${ }^{4}$ Of all this the Federalists expressed a deep abhorrence; James Kent and others talked of having Emmett disbarred, ${ }^{\circ}$ and resolutions were unanimously passed in party meetings, " that the prompt interference of the honorable Rufus King, late minister of the United States at the court of Grear Britain, and the timely remonstrance made by him... were wise and prudent. a decisive evidence of his patriotiom and fidelity to his public trust." "

The challenge of the Irish received a formal answer. On April . 8, I807, the Federalist Commercial Advertiser came

'See King Correspondence, vol. ii, appendix iv, pp. 635-648, for King's account of this note.

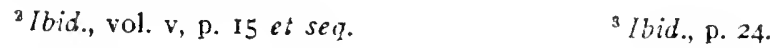

"Report of the Trials of Jonkins i's. I'an Rinsselaer, pamphlet (Albany, 1808), p. 15.

${ }^{5} \mathrm{R}$. Troup to R. King, April $\mathrm{n}, 1807$, King Correspondence.

'Jenkins a's. Var Rensselaer, pp. 15-16. 
iorth with columms headed with the "American Ticket." The uame was taken up with great enthusiasm; it announced that nativism was accepted as the leading issue and it was used as the party designation for several years.' "I observe that your ticket in New York is called the American ticket," wrote Colonel Troup to King. "Would not this be a favorable occasion for our party to assume a popular and significant name, iree from the hobgoblins attached by many to Federalism? This is a subject worthy of consideration." : By the Republicans the name was generally scorned. "The present American Ticket." declared a broadside, " was once the ficderal ticket, next the Fecieral Republican ticket. One hitch more and it will be right-the Tory ticket-then with great propriety they might put a King on it.": But the menace of the immigrant was not molerrated by King's folinwers. "The naturalization bill in New York," wrote Troup again. "I fear will defeat our assembly ticket." “ The Federalists might address the Tompkins men with their "Warning to the Gallico-Hibernico-Tom-Clintonians," " but they could not win upon so lean an issue. ${ }^{6}$ James Cheetham, refugee from England, and the rehement Em.

'Abany Ciazette, April 18, 180s: N. J'. Spectator. April 30, I8os; ․ Y. Commercial Adrertiser, April 28, 1809 .

2 Troup to King, Albany, April 11, 1807, King Correspondence.

${ }^{3}$ T. E. V. Sulth, Political Parties and their Places of Aleting in Vew Vork City. pamphlet (N. Y., r8o.3). an amplification of an address before the N. Y. Historical Society.

+ Troup to King, April 24, I8O;. He referred to easier mode of naturalization revived under Jefferson.

'.1. I. Spectator, April 29. 1807.

"Irish imnigration from about 180 " to 1816 was much reduced because of the dangers of travel due to the Napoleonic and American wars; see for these years, Stephen Byrne, Irish Emigration iN. Y. 187.3), and W. J. Bromwell, History of Immigration to the linted itaics (N. Y., 1855$)$, p. 14. 
mett, to whom he loaned his columns. were not the only leaders in abuse. Citizen Genet, who as George Clinton: son-in-law now lived in Greenbush.' assailed King not only as an English synrathizer, but as downright dishonest 111 the administration of a will, ${ }^{2}$ and others raked up charges equally absurd. "Should I congratulate or condole with you on the loss of your election?" wrote Charles Jared Ingersoll when the report of King's defeat reached Pennsylvania. "I imagine if it was not the wish of others, it conld not be your awn to be put up and pelted at by I rishmen and Frenchmen."

Mthough New York city and the fecleralist counties save majorities to Lewis, the Clinton ticket was successfui. All that the Federalists had to show for their strange atliance was the place of William W. Van Ness in the supreme court. ${ }^{*}$ which the Lewisites had granted before the election. They bore no testimony for their principles. they came forward with no program, they seemed in truth lout pitiful Epigoni of the old party of the masters. Such was the sad condition of the Federalist party in America. Disheartened by defeat. and well realizing that their doetrine of strong. paternal govermment would not again be asily accepted by the voters at the polls, they dimmed their lamps, that once had hurned so brightly, in hope to steal in unobserverl within the shadow of some faction more reputable with the scorned, but now all powerful, "average men " who held the gates. In Massachusetts they were following the same ignoble, paltering course of surreptition-

${ }^{1}$ G. A. Worth, Random Recollections of Albany (A1bany, 1865), p. 70 .

${ }^{2}$ 'This was the famous case of Staats Long Morris' widor, $N$. $r$. American Citisen. April 27, 1807 .

${ }^{3}$ To Rufus King, May I4, I\&o7, King Correspondence.

'J. D. Hammond, Political History. vol. i. pp. 240-247. 
coalition; ${ }^{1}$ in Pennsylvania the case was worse. ${ }^{2}$ Such procedure was but little less destructive of what prestige the party had retained, than the policy of rule-or-ruin which the easterners had tried in I8O4 and would attempt again.

By such men as John Jay these tendencies were deplored. When the news reached Bedford he wrote to an old friend :

As to the election, it is not clear to me what will be its precise effect in relation to the Federalists. If as a party they judged it to be expedient to favor Mr. Lewis, I think they should as a party have openly and decidedly declared and resolved that they would support him. The language of the Federal leaders to the party seems to amount to this, viz.; On this occasion you may leave your standard; you may go home, and every man is at liberty to do what may be right in his own eyes, but we nevertheless intimate to you, as an opinion to which we incline, but do not explicitly adopt, that it may be better for us to have Mr. Lewis than Mr. Tompkins for our Governor. I do not like measures of this kind. I fear that they tend to disorganize and sever us, and that they do not manifest that degree of resolution, self-respect and dignity which our motives, objects and situation demand. Had the party resolved to support Mr. Lewis, I certainly should have voted for him. As a mere individual, judging what was proper for me to do, I declined voting for either of the candidates. ${ }^{3}$

The disgrace of this intrigue weighed heavily upon the older men, but to the young disaster had a tonic value. The

${ }^{1}$ Christopher Gore to King, December 25, 1807, King Correspondcnce. 'The Federalists never captured the state of Pennsylvania, see W. M. Cornell, History of Pcnnsylvania (Philadelphia, 1876), p. 469.

${ }^{3}$ To Peter Van Schaack, May 4, I807, Jay Correspondence (Johnston's edition). This letter shows how much in error was Hammond's information that after his retirement. Jay never read the papers. Cf. Political llistory, rol. i. p. 155. 
very shame to which the party of their fathers had descended. stirred in them a resolution to forget those things that were behind, and throwing off all secret and despised connections win triumph, if they could-at least, regain their self-respect. Their problem was how to adapt their methods to the spirit of the times. We may turn, then, with no little interest, to study how they tried to draw supporters to their cause. 


\section{CH.APTEK IV \\ New Methods and a Victory}

Wнат has been called the "Democratic Revolution" produced small difference in the outward aspect of our institutions, but in forwarding some tendencies and curbing others it registered a fundamental change in our political philosophy. It was not a judgment in the rivalry of favorite fads: the forces matched were not suddenly discovered, but had been developed in the conflict between the ofl tradition and the new enviromment, which makes the slow and painful metamorphosis we know as progress. Inertia in history does not have to be accounted for; it is an axiom in sociology no less than physics that things must stay till they are moved, and mankind would have givei 110 surprised attention if the idea of aristocracy, that the few are born to rule the many, hallowed by centuries of custom in the "old country," had been transplanted to the new. ${ }^{1}$ Indeed, one reads but scantily among the records of the colonies who is not impressed with how much of this idea was carried over to America. There were accepted barriers between gentlemen and simple-men, between those who wore their periwigs and silks and those who dressed in homespun. Such was the normal system of society: since nuder it the social peace had been preserved, it seemed entitled to continuance, at least so thought the comfortable classes. The Federalists like all conservatives seemed justified by time.

But there were factors in the making of America that

'Cf. Leon Fraser, English Opinion of the American Constitution and Gowermuent (N. Y.. 1915). 
were bound to modify this system. The settlers of thi: comtry had come across the sea to found new homes where they might have a larger opportunity ior unhampered worship or well rewarded work. The essence of separatism and ambition is self-reliance, which, since with few exceptions they came of their own will, was common to then all. The free land of America had made then selidependent and made control imposed upon them seem against all natural right. For a variety of causes they hau determined to be free from England, justifying their boldness ipon the doctrine of the equal dignity of men. But the Declaration of Independence, as has often been remarkel. was written as a campaign document; equality was postulated only as a basis for the claim of liberty, a philosophy which the conservatives were willing to endorse when intended only for the export trade. It was some twenty years before they were embarrassed by this memory. But philosophies insist on being universally applied. The American success sent out a stimulus that was received in France. tremendously increased and then sent back again across the sea. What Jefferson had written when George the Third brushed aside the guards of liberty, seemed suitable to quote when Hamilton and Fisher Ames made their great affirmations of the privileges of property. Democracy was becoming a national ideal. The Federalists with their busines program failed to recognize this fact. or, if they did perceive it. they would not stoop to mingle with the common folk. scorning arts by which they might have thrived. In this they were more nice than wise; the last decade had marle that clear, at least to younger members of the party.

The old system of following policies irrespective of popular opinion was gone forever, wrote J. Q. Arlams w Rufus King in $1802 ;^{1}$ " it never can and never will be re-

'J. Q. Adams to King, October 8. 1802. King Correspondencr. 
vived. The experiment, such as it was, has failed, and to attempt its restoration would be as absurd as to undertake the resurrection of a carcass seven years in its grave." Noah Webster writing from Connecticut took the sanie position.

There is one particular in which, I think, the leading gentlemen of the Washington School have uniformly erred. They have attempted to resist the force of current opinion, instead of falling into the current with a view to direct it. . . Between the unbending firmness of a $\mathrm{H} \longrightarrow n$, [and] the obsequiousness of a $J-n$, there is a way to preserve the confidence of the populace, without a sacrifice of integrity. ${ }^{1}$

One reason why the people had rebuked the Federalist leaders was founded on the impression that they were leading toward a monarchy. Many of the opposition papers ceased to use the name Federalist in their editorials, and preferred to talk of the "Aristocrats," 2 whereas their own name Republican seemed to invoke the loyalty of all those who believed in the existing form of government. Something must be done to set the people right.

The change of rulers [declared a writer in the New York Spectator, in 1804] which this state and the United States have experienced, may be ascribed more to names and to the charm of words, than to any conduct or meastire of the federal administration. It is probable that nothing has tended so much to alienate the affections of the people from the federal administration as the malicious insinuation, that the federalist. are friends to monarchical government . . These Machiavellian politicians by the same magic have annexed a peculiar

${ }^{1}$ Noah Webster to King, July 6, I807, King Correspondence.

${ }^{2}$ Poughkeepsie Journal in $\Lambda$. Y. Evening Post. November 24, I8or : V. Y. American Citizen, May I, I802, etc. 
property to the name republicanism. . . . It now stands thus, republicans can do 110 wrong. ${ }^{1}$

A shrewd reform was already under way, for two years before, certain papers had rechristened the party with a reassuring title; Federalists were gone, they said, and Federal Republicans had come to take their place." In the botany of politics a rose may change its perfume with its name. Now the Federalists took counsel as to the designation of their enenies.

Jacobin [they thought, was] too offensive to obtain currency as a universal name, and excepting to the leaders of the party. unjust; the appellation of republican is claimed in common by both parties, and therefore is not the least discriminative; whereas democrat being the name taken by themselves and liable to no objection on our part, is that which alone should be used in writing of our political opponents.

Most Federalist editors accepted this advice, though the change offended certain stalwarts of the old régime.

The Jeffersonians in New York city had early learned the use of various social aids to partisan fidelity. Societio were formed where motual encouragement might circulact with pots of ale, and plots be laid against the enemy. But since this enemy controlled the goremment, hose plots were said to smack of treason. Washington hat issued hiwarning against such secret clubs, and ffamilton, "the

'N. Y. Speciator, March 31, isou.

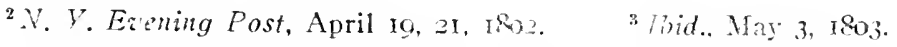

"Speaking in 1816 , Judge Benson referred to "ny um party, the Federal party, by their primitive perfect name without the subsequently invented addition of Republican. Is it not in the Constitution itself, that those who formed it were Republicans? Suppose, yes - then 'the expression of it wholly inoperative.' Suppose, no- will calling themselves so make them so?" Memoir, read before the Historical Society, ets., pamphlet (N. Y., i8I7), p. 5 I. 
servile copyist of $\mathrm{Mr}$. Pitt (so wrote Thomas Jefferson) thought he, too, must have his alarms, his insurrection," and had joined his chief in condemnation. ${ }^{1}$ But the Columbian Order, or as it was more generally known, the Tammany Society, soon stripped of Federalist members. survived to menace Federalism in New lork. This famous order had been founded. it was professed, for charitable and social purposes, and now that it assumed a more anzbitious role it by no means forgot its earlier functions; for under any govermment approaching a democracy, bounties to the poor and entertaimments are well mixed with party politics. The Federalists in 1800 saw with confessed dismay the effectiveness of their opponents' methods, and Hamilton himself, who through the late campaign had berated Tammany and all its sons, now quietly proposed the flattery of imitation. Writing to James 1. Bayard in 1802 , he set forth a plan of a "Christian Constitutional Society," shrewdly propagandist even in its title, which should have its branches in all cities to promote true patriotism. The party must become the patron of the poor; one proposition was to "institute in such places-Ist, societies for the relief of immigrants: 2nd, academies, each with one professor, for instructing the different classes of mechanics in the principles of mechanics and the elements of chemistry. The cities have been employed by the Jacobins to give an impulse in the country." = Apparently this well-laid scheme was not put into practice. but the suggestion was not lost.

Jefferson's embargo, in 1807 . so stiffened the resistaiice of the business interests that the Federalist party in New York, as elsewhere, shook off its lethargy of hopelessiless and entered into the contest for control. No expedient

'Jefferson to Monroe, May 1, 1795 (Ford edition), vol. vii, p. 16.

$\because$ Hamilton to Bayard, April I 802 . Hamilton's Wrorks (Iodge) vot. viii. pp. 598-599. 



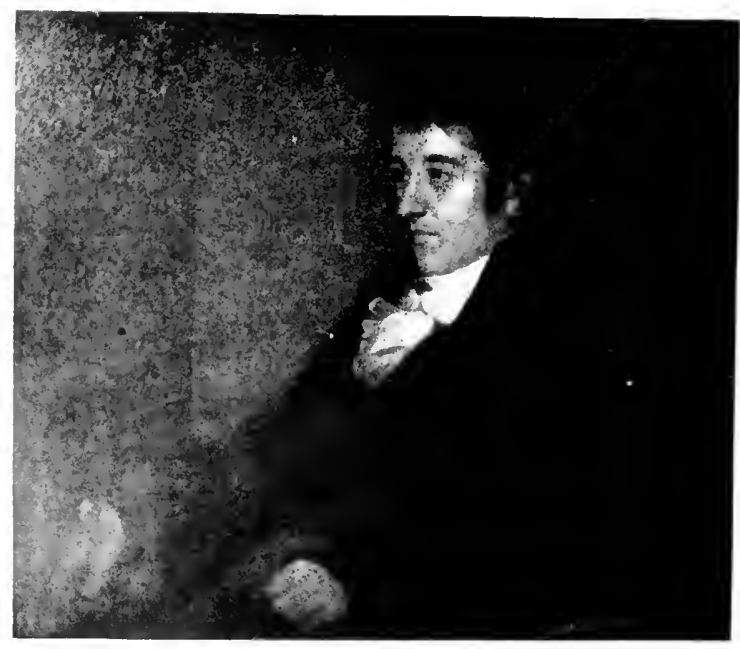

GULIAN C. VERPLANCK 
which bad bronghis success to their opponents might be lef: untried. They had observed by what devices the Tamman? Society had drawn support from classes who had no ear for studied argment. They had seen this organization in it: menacing vitality spread to other cities and register nen victories. Such methorls seemed adapted to a democracy: taste could not be considered, the Federalists resolved to adopt them before it was too late. In the spring of r 80 s. Isaac Sebring. a prosperous merchant of the city, with the aid of Gulian C. Verplanck and Richard Varick, conceived a project by which he thought this might be accomplished. If the Federalists had no leader who could rival Jefferson in winning the great mass of men, at least they had the name of Washington, whose potency grew with the years. and to turn this asset into current value. on fuly 12th. A society was formed to keep fresh his memory and carry ont his principles. For its foundation, it is not at all unlikely. Mr. Sebring forwarded the money; Colonel Varick gave the prestige of his patronage: and Verplanck, then but twentyiwo years old, supplied the ardor and enthusiasm of youth. Whatever were the sources of its early strength, the Washington Benevolent Society was immediately successful. The new society, like that of Tammany, held its meetings in secret and engaged to promote good fellowship among its members and to relieve those who were in want. It was particularly hospitable to old soldiers of the Revolution, bu:

'Sebring was born in Dutchess County, but moved to New York before the Revolution. He had enlisted in the army as a quartermaster and fought in some campaigns about the city. He had become wealthy and prominent in the Federalist party in the city, sitting as alderman for the first ward (see supra, ch. i) and frequently as chairman of public party meetings (e.g.N.Y. Conmeriat 1dvertiser, February 27, 1809). He later lost his fortune and was glad to be appointed to a clerkship in the Custom House under Samuel Swartwout; W. Barrett. Old Merchants of Ncw York, vol. iv. Pp. $18-20 ; \mathrm{J}$. A. Roberts, Nere York in the Rconlution (N. Y. I898), 0. 135. 
through its charm of mystery and picturesqueness it appealed to men of high and low degree; no workman was too humble to be welcomed to its ranks to march for Federalist principles. Its pose was of impartial patriotism-a harmless affectation, since no one was deceived.

The society held its first public celebration on February zend, I8og, marching to the Zion Church to hear a discourse by Samuel M. Hopkins; and such support had been accorded to the enterprise that, in the evening of that day. more than a thousand sat down to supper in five taverns. the president and his honorary staff appearing several times at each, that no one might feel slighted. ${ }^{1}$ The plan was soon adopted in other cities and villages of the state. Everywhere appeared the little manual called Washington's Legacy, which contained his portrait, his Farewell Address (not leaving out his solemn warning against secret political clubs!), and sometimes a "Chronological Sketch of the Life of the Author of the Foregoing Address." " Often, too. the constitutions of the nation and the state were printed," and a blank certificate of membership to be filled in by the local officers. The statement of the constitution of the society is not uniform, but that of the town of Galway, in Saratoga County. may serve as an example. ${ }^{4}$ Besides "mmemorating Washington, "It is to promote harmony and unity of sentiment among the members; to endeavor to whlect and diffuse correct information on matters respecting

3.. Y. Commercial Adiertiser, February 23, 1804.

'See edition for Essex County (N. J.) Washington Benevolent Society, 1812 (N. Y. P. L.)

${ }^{3}$ For example, edition for Augusta, N. Y. (Albany, 1816). Sometimes the society served a town, sometimes a county, and sometimes both together. See Private Journal of DeVitt Clinton, p. 86, in W. W. Campbell, Life and Writings of DeVitt Clinton (N. Y., I849).

${ }^{4}$ Constitution of the Washington Benevolent Socicty of Galway, in the Cownty of Saratoga (Albany, 1812). 
our state and national affairs, as a means of inculcating sound political principles . . . and a constant watch fulness against the intrigues of men to whatever political party they belong." An indirect attack was made on Jeffersonian. when it required that. "No person that is an atheist, a deist, a profane swearer, a drumkard, or doth not respect the Christian Sabbath, shall be received as a member of this society." Benevolences from the common chest were to be granted to poor members, but to guard against abuse it was provided that not more than two dollars a month should be given to an applicant without a general rote. Largely ior this purpose each member paid a dollar as initiation foe and fifty cents a year as dues.

The society spread far beyond the boundaries of the state. ${ }^{1}$ It followed Tammany to Rhode Islanr," and was taken up in Connecticut, Massachusetts, New Hampshir., and especially Vermont, while Pennsylvania and New Jersey each had their local organizations, that in Philadelphia enduring until after $1820 .{ }^{3}$ It had " runners" who spent their time in organizing branches, and developing such fraternity and loyalty among the members that Republican conventions roundly condemned the society as dangerous to

'Cf. Harlan H. Ballard, "A Forgotten Fraternity" in Collections of the Berkshire Historical and Scientific Socicty, vol. iii, no. 4 (1913). pp. 279-298; and E. F. Hanaburgh, "News for Bibliophiles" in The Nation, October 30, 19r3.

${ }^{2}$ W. A. Robinson, Jeffersonian Democracy in Ncre England (New Haven, I916), p. 89, citing M. W. Jernegan, The Tammany Societies of Rhode Island.

${ }^{3}$ T. E. V. Smith, Political Parties, etc. The New York Public Library has the best collection of "Washington's Legacies" orations, poems, etc. known to the author; other collections are to be found in the N. Y. Historical Society Library, the Boston Athenaeum (see Catalogue, part v, p. 3264) and the American Antiquarian Society Library. In the last named is a satire called The First Book of the Washington Bencvolchts, etc. Many items are scattered among town libraries. 
the nation. becanse of secrecy and friendship for Great Britain.?

It was the elenent of secrecy that most perturbed the Madisonians; no guess was too extravagant as to what took place behind locked doors and curtained window's. In New England after I 8 I2. when recruiting officers were baffled by mysterious counsel to the young, the Republicans cried out in wrath against the "Washington Benevolents." Desertions and escapes were charged to their cabals; and when ime candidate for Congress or the legislature whose outlook had been hopeful was overwhelmingly defeated by a Federalist at the polls, ontraged partisans of Madison averred that the records of this pestilent society, if they were once forthcoming, would lay bare a scandalous conspiracy. Fantastic fabrications were made to pass as the awful oaths required of its members, and committees were appointed to watch closely for some overt act on which to base a charge of ireason. The Federalists, of conrse. exulted at the furor their society created. each new outcry proving its effectiveness. ${ }^{2}$

Yet their secrets were imocent enongh. Several years ago, by accident, there was discovered in Berkshire County. Massachusetts, an ancient volume of ledger-like appearance. which. after pasted clippings had been steamed away, disclosed in fair round writing the ritual of the Washington Benevolent Society: There was provided for their monthly meetings a punctilious ceremonial requiring ten officers, and. 10 insure a uniformity in the conduct of their business. regular reports were forwarded to the parent society in New Iork. The neophyte was solemnly assured that

Vermont Republican, January I2, I810 and February jo. I812, quoted by Robinson, loc. cit.

${ }^{2}$ H. H. Ballard, loc. sit., pp. $279,290$.

"Ibid.. pp. 285-287: this discovery was made by Mr. Ballard. 
during the alministration of Thomas Jefferson " our right has been impaired, our constitution disregarded, and dissensions and distress have prevailed among our citizens." As he was examined for the last induction. he was asked as to his country. "Are you willing to use your exertion to preserve it against the inroads of despotism. monarchy. aristocracy, and democracy?" "

It was custonary for the society on IIashington's Birtiday and the Fourth of July to listen to patriotic oratory, more or less frankly Federalist in Havor; the great departed chieftain was commemorated as summing up the civic virtues. He it was, said Samuel M. Hopkins, making the first of these addresses in February. 1809,- - he it was, who prevented us from rushing into the abyss of French fraternity. What had been the fate of most republics in the world? "Where were Switzerland. Genoa, Venice and Holland? Where had been America but for Washington?" " One year later. Peter A. Jay, speaking when America had felt the pinch of Napoleon's Continental System, thought it timely to berate the French and the ideas of revolution so dear to Jeffersonians.

Washington [he said] was not to be fascinated by the syren song of equality . . . and uninfected with the absurd and pernicious sophisms of these modern days, he never apostasized

'It is likely that in devising this ritual, the authors had taken sone suggestion from the Society of the Cincinnati, then entirely Federalist in sympathy (see toasts as given in $Y$. Y. Erening Post, August 14. I8I1) and of whose New York chapter, Col. Varick was the president when he co-operated in the foundation of the Washington Benevolent Society: see John Schuyler, The Society of the Cincinnati in Nert York (N. Y. I886), p. 333. There was usually an oration at the monthly meeting, see Abimelech Coody (G. C. Verplanck) Letter to Dr. Samuel L. Mitchill, M. D., etc. (N. Y., i811), p. II.

'S. M. Hopkins, An Oration delizered before the llashington Beneiolent Society, in the City of New York, at Zion Church, on the Treentysicond of February. 1809 (N. Y., 1800), in N. Y. Hist. Soc. Collections. 
[sic] from the belief of his fathers and thought it was no matter of importance either to individuals or to the public. whether there were one God or twenty.

But many orators were not content with these indirei attacks. Gulian C. Verplanck, the society's young secretary, had the previous July delivered an oration wherein he fir $\mathrm{t}$ recalled the prosperous days of Federalism. But at length the wisdom of the nation slept;

so completely were the people drugged with the opiates of flattery and fair profession, that they lay in stupid lethargy, and saw their navy dismantled and their commerce left to the mercy of every petty pirate. They saw without indignation, the temples of justice broke open and the judiciary, the foremost bulwark of our liberties, thrown down and trampled under foot. Unmoved, they beheld a system of executive corcuption and unconstitutional influence sprouting forth from the head of the administration, spreading through every department of the state, and enveloping the representative majesty of our nation in its broad and poisonous shade.

Madison, now come to power, if not himself destiuctive, was the patron of the admirers of French licentiousness. ${ }^{2}$ Josiah Quincy, who somewhat later addressed the Boston branch, inquired of "Our rulers-who are they, and what is true of them? Mr. Madison is President; Mr. Monroe, Secretary of State; Mr. Gallatin, Secretary of the Treasury; Mr. Armstrong. Secretary of War. Every man of them

1 P. A. Jay, An Oration delizered before the Washington Bencuolent Society in the City of Nere York (N. Y., I810), in N. Y. Pub. Library.

${ }^{2}$ G. C. Verplanck, An Oration delivered July 4 th, 1809 , in the North Dutch Church, before the Washington Bencvolcnt Socicty (N. Y., I 809), in Columbia University Library; a somewhat inaccurate quotation is to be found in C. P. Daly, Biographical Sketch in Procecdings of the Century Association in Honor of the Mcmory of Gulian C. Verplanck (N. Y., 1870). 
in Washington's day the enemy of his policy." " Such was the style of oratory addressed to this society in its various branches throughout its dozen years of life; most famous Federalists were glad to speak before it, from Gouverneur Morris, who gave the counsel of the passing generation, to Daniel Webster, who vouchsafed the promise of the new."

The Tammany Society had a home in Martling's 'Tavern, which the Federalists were wont to call contemptuously "the Pigpen." Sebring and his colleagues in the enterprise boldly set about to shame their rivals by building a great hall, to be maintained exclusively for party purposes. At the evening meeting, February 22, 1809, it was decided to sell Soon shares of stock at ten dollars each. During the spring a plot was purchased on the cormer of Reade Street and Broadway, and on the Fourth of July, the society proceeded, with much pomp and pride, to lay the corner stone of Washington Hall, probably the first edifice in America so built for party purposes." The stone was set in place by the president, Isaac Sebring, with all formality. "Built by the friends of Washington," he said, "may it never be polluted by the enemies of that illustrious and revered statesman." " This solemn cermony then completed, the

${ }^{1}$ Quincy's speech is reprinted in full in the New York Spectator, May 12-15, 1813.

${ }^{2} \mathrm{G}$. Morris, An Oration delizered July 5 th, 1813 before the Washington Benevolent Socicty in the City of New York (N. Y., I813), in N. Y. P. L.; see also in same library addresses by Noah Webster, Isaac C. Bates, etc. and by Sedgwick in N. Y. Evcring Post, July 5 . I8I ; The Writings and Speeches of Danicl Webster (Boston, Ig03), vol. xv, p. 583 . In the New York Society Library there is An Oration delizered at Washington Hall, February 22, 181.7 before the Washington Renerolent Society of the City of Nezu York, in commemoration of the natizity of George Washington, by H. W. Warner. Cf. Ode iead with this, $\lambda$. Y. Comnercial Advertiser, February 23, 1814.

"Tammany Hall was not begun until the following year.

4. Y. Commercial Adzertiscr. July 5, 1809 . The inscripion was 
company marched to the North Dutch Church where an ode was sung, and the oration we have mentioned was pronounced by Gulian C. Verplanck.

The imposing building with high pediment and decorated cornice was hailed as a monument to Federalist enterprise; but although some well-to-do members like Philip Hone, bought twenty-five shares or more, ${ }^{2}$ only about hali the necessary funds to pay for its erection were subscribed. sebring was obliged to borrow heavily, and, in $18 \mathrm{I} 7$, the hall was sold as a hotel, though still considered as the headquarters of the party, and the stopping place for most New England Federalists passing to and from the nation's capital." But what was done by the "Benevolents" in New York city was orthodox for all the chapters, and soon other Washington Halls were built as temples for the faithful. Such were those in Albany and Troy, in Stockbridge, Massachusetts, ${ }^{3}$ and the more commodious structure put up in Third Street, Philadelphia. ${ }^{4}$

The pageantry of the society was likewise snon reduced

as iollows: "This Corner Stone of Washington Hall was laid July 4th, 1800, being the 33rd Anniversary of the Independence of the United States of America by the Washington Benevolent Society. Instituterl I th July, A. D. MDCCCVIII."

1 Diary of Philip Honc (edited by Bayard Tuckerman. N. Y., I889), vol. ii, p. $24 \pi$.

${ }^{3}$ The last puhlic celebration of the society in New York City was held in 1817, although meetings are spoken of as late as 1820 , T. E. V. Smith, op. cit.. p. It et seq. The hotel was renovated in 1827 and burned in 1844. See also W. Barrett. Old Merchants of Neze York, vol. iv, pp. $18-19$.

: H1. H. Ballard, op. cit., pp. 282, z90: Mrs. C. V. R. Bonney, Legacy of Historical Gicanings, vol. i, p. $28 \mathrm{I}$. Fiven the negroes had their "Washington Benerolent Association of Africa." see Aralectic Magasine, vol. xiii (1819), p. 279.

'B. J. Lossing, Cyclopdia of l'niled States History (N. Y.. 1881), wh. ii. p. 1478 . 
to code, following the New York precedent. The memiers always marched in thirteen grand divisions, each precedei by a banner with the name and, possibly, the "cotntericii presentment " of a hero of the Revolution, the choice not left to chance but specified in order-Hancock, McDongall, Putnam, on to Hamilton, the last. The chief standard of the line was always that of Washington, richly fringed and mounted, and generally escorted by the war-worn veterans of the Revolution. ${ }^{1}$ The cultus of the lather of His Country had in one short decade reached to such development that "relics." like his gorget, were sometimes carried in the honorable place of the procession." It was customary for an officer, perhaps the first vice-president, to carry in his hand the sacrosanct Farewell Address, while others bore the Constitution and the Declaration of Independence. There were other flags and pennants commemorating each some glorious event, such as the Christmas victory at Trenton or the surrender of Burgoyne, until with bands and banners. mounted men and carriages, and the thousands four abreast. the eye was surfeited with splendor. The ceremonies of Rogation Week in mediaeval Rome could scarcely have been more nicely ordered. It was the public ritual of nationalism-performed, ironically enough, by the party of the Hartford Convention."

In a letter to his father, Peter . I. Tay describes the ceremonies in which he bore a part:

The Celebration of yesterday occasioned much exultation

${ }^{1} N$. Y. Commercial Adzertiser, July 3, 5, 7, 1800, July 3, I8II. July 3, I8I3; H. H. Ballard, loc. cit.

${ }^{2}$ Massachusetts Historical Society Proceedings, 1876-1877, pp. 401-404.

${ }^{3}$ The credit for this success should doubtless go to Col. Richard Platt who was the marshal of the society's model celebration on July 4, 1809. It was he who had managed the great "Federal parade" of 1789. N. Y. Commercial Advertiser, July 5. 1809 and W. A. Duer. Rcminisccuces of an Old New Yorker. 
among the Federalists. The Society walked in procession and amounted to more than two thousand. Many Gentlemen kept aloof, but it was one of the most respectable assemblages of people that I have ever seen. It consisted of substantial Shop keepers and Mechanicks, of Men of the middling Class, and of a considerable Number of old Revolutionary officers and Soldiers. Almost all of them possess Influence and can bring to the poll other votes besides their own. ${ }^{1}$

All this meeting and marching and dining was not without effect in New York city. The recovery of the majority in the common council, which had been lost in 1804, was attributed to the efforts of the society, and it was natural that they should conduct an elaborate illumination." The "Washington Benevolents" and their friends of the Hamilton Society, which met in Hamilton Hall in Cherry Street," let no occasion pass without a parade and a feast with :ts innumerable toasts. ${ }^{4}$ When in 1834 William Sullivan was writing an account of the celebrations of the various branches in I 8 I2, he remarked, "If ever the day shall come when like perils shall overtake the good citizens of the United States, let them remember this example." ' In this connection, then, it is apposite to note the observation of a pamphleteer in 1840 , that the Tippecanoe Clubs of that

${ }^{1}$ P. A. Jay to John Jay, February 23, 1810, Jay Correspondence.

${ }^{2}$ I. N. Phelps-Stokes, Iconograply of Manhattan Island, (N. Y., 1915), vol. i, P. 406, and T. E. V. Smith, loc. cit.

"N. Y. Eiening Post, July 3. I81 ; W. H. Bayless, Old Tacerns of New York (N. Y., I9I5), pp. 408. 423.

4 Members of Congress were always specially invited. It is interesting in $I \delta I I$ in New York to find a mechanic toasting the merchants, and a merchant the mechanics. The sentiments grew bolder at these banquets as the night wore on. For the order of march of the Hamilton Society, see $N$. Y. Spectator, July 6, 1811.

${ }^{5}$ William Sullivan, Familiar Letters on Public Characters and Public Eients, from the Peace of 1783 to the Peace of 1815 (Boston, 1834), p. 348 . 
year, with all their extravagances, were but lineal descendants of the Washington Benevolent Society. ${ }^{1}$

Such were the new devices by which Young Federalism sought to make its fellowship attractive. For a season they enjoyed success, ${ }^{2}$ but this was due, in large part, to a measure of the national government, inevitably so unpopular as to give the opposition a cause of dignity, and. therefore, once again respectful hearing. Shortly before Christmas in 1807 , a docile Congress passed the President's embargo bill, and by thus "regulating" commerce made the first of that long series of convincing demonstrations that the Jeffersonian party could not serve and could not understand the economic interests of the north. In New York, as in New England, the Federalist merchants and their friends recognized it as a stroke so patently impolitic that, in the reaction, which was sure to follow hard upon its execution, they took hope of permanent relief. They could suffer, almost with enthusiasm, if their plight might break the patience of the public. Although in the winter and spring of 1808 the suffering was yet chiefly in anticipation. all realized that here was an issue on which the party might appeal no less to patriotism than to self-interest. Essays on the gloomy prospect now filled the columns of the Federalist prints, ${ }^{3}$ sharing space with resolutions and

${ }^{1}$ C. G. Greene and B. F. Hallett, The Identity of the Old Hartford Convention Federalists with the Modern Whig-Harrison Party Carefully illustrated by Living Specimens, and Dedicated to the Young Men of the Nation (Boston Morning Post, extra, August, I840, in Cornell University Library).

${ }^{2}$ It had scores of branches and tens of thousands of members. Its decay began with the declaration of peace in 1815 . William Cobbett, in his Weekly Register, May 13, 1815 , said that this society in the Federalist states was like the British Literary Fund. "a scheme for attaching hack writers to the government under the guise of charity." See S. E. Morison, Harrison Gray Otis (Boston, I913), vol. i, p. 301.

${ }^{8} \mathrm{~A}$ good example is the series of letters by Rufus King appearing in the Evening Post, see King to T. Pickering, February 5, I808, King Correspondence. 
petitions; and this was by no means confined to New York city. What were "the army and navy of John Adamsthe eight per cent loan-stan1) act, direct tax, carriage, loaf sugar, and whiskey tax, all the old so-called abominations," to this new monstrosity. ${ }^{1}$ Campaign songs appeared which recalled the glorious days a decade since.

"When federal men did stand at helm.

We shipped off many a cargo--

When Wheat and all produce was high,

'Cause there was no embargo,--."

the good uld days of Tom Truxton and Toby Lear, when America had struck the enemy and not herself."

The New England Federalists saw here an opportunity to discredit the President and his " official candidate," James Madison, whose election had been ordered for the autumn. The Essex Junto of Massachusetts called a convention to discuss the nomination for the impending contest. The "delegates " were self-selected or chosen by small groups of gentlemen in council. In the party methods here Otis and his colleagues did not contemplate a reference to the people: it was, as usual, a movement for the people, by the wise and good. To bring about the meeting, which was scheduled for New York. Judge Egbert Benson suggested committees of correspondence, which were formed for states and counties. and engaged in some preliminary discussion. Otis thought the Clintons, feeling slighted in the preference for Madison over George Clinton, then Vice-President, might be supported by the Federalists. But the committees of New York would not endorse a coalition. "We have condescended twice." wrote Abraham Van Vechten, "to tamper with Democratic candidates, and in both instances

${ }^{1}$ Albany Gazette, March I7, 1808.

'Ibid, February 29, 1808. 
have been subjected to severe self-reproach . . Our experimental knowledge of the Clintonian system is a powerful antidote against affording it any iacility here." When the Federalists met, from the south as well as north, C. C. Pinckney was selected as the candidate for President and Rufus King for the second office. The New York committee sent out announcements to their correspondents in the different states. ${ }^{1}$

Jefferson's subservience to France was held up to indignation, while England holding out against Napoleon was pictured as the champion of liberty. Even her impressment of the sailors on our ships, which, since the encounter of the "Leopard" and the "Chesapeake" had occasioned bitter protest. was now easily excused.

If England abandon the right, the British sailors would desert. ... They would engage in our service for less wages than their own (for engage they must, there being no other way for them to gain a livelihood). Our native American sailors, of course. would be thrown out of employ. Which ought we to encourage, foreign sailors or our own? . . In case of war no reliance could be placed on foreign sailors."

There was widely published through the state a speech of Barent Gardenier, a congressman from Ulster County, who complained of Jefferson's diplomacy as wrapped in secrecy, and for the boldness of his charges was challenged to a duel." The Federalists of New York city announced a

${ }^{1}$ Van Vechten to Otis, S. E. Morison, Otis, vol. i, p. 307; Jacob Radcliffe, J. O. Hoffman, C. D. Colden and S. Jones, Jr. (the N. Y. committee) to the Federal Republican Committee of Charleston, S. C. ibid., pp. 31.4-3I5; also ibid., p. 304. In spite of the mode of designating lelegates, this may be called the first national nominating convention.

"See "Peace" in N. Y. Spectator, April 13, 1808.

"N. Y. Evening Post and Albany Gazctle March 3, I8oS. In this duel with G. W. Campbell, Gardenier was severely wounded, see Alban.: Gavette, March I4, 1808; H. von Holst, The Constitutional and Political IIistory of the United States (Chicago, I8;6), vol. i, pp. 210-21 I. 
motto which might have been developed into the first party platform in America: "No Embargo-No Foreign Influences-No Mystery-Freedom of Debate-Freedom of Suffrage-Freedom of Navigation and Trade-Liberty and Independence." ' The Republicans realized that now they" had a foe no longer to be scorned." When the vote was takein the Federalists had not only their old districts by the upper Hudson and the Mohawk, but a number of new counties, though not including New York city. ${ }^{3}$ The ardent efforts of Williams, Van Ness, and J. R. Van Rensselaer gave the party a larger majority in Columbia County than it had ever known before." The party delegation sent to Congress, including James Emott, Barent Gardenier, K. K. Van Rensselaer, Herman Knickerbocker and Robert LeRoy Livingston, was a credit to the state.

Each new law conceived to stiffen and complete the embargo, threw more numbers and more strength into the Federalist opposition. In New York the conditions soon grew intolerable. The port was full of shipping, but the masts stood gaunt and bare of sails through the spring and summer. The wharves and quays were clean of boxes, bales or casks; counting-houses which had been scenes of bustle and activity were now deserted, many vainly advertised for rent. Of all the carts that had rattled through the streets, scarcely one in ten was now offered for employment; while idle clerks com-

'N. Y. Evening Post, quoted in Albany Gazette, April 25, I808.

:See DelVitt Clinton to George Clinton. April 3. 1808, DeWitt Clinton Mss.

'Albany Gazette, May 1-5, 1808.

4 Martin Van Buren to DeWitt Clinton, April 16 and April 30, 1808, DeWitt Clinton Mss.; W. W. Van Ness to Sol. Van Rensselaer, April 3o, I808, vol. i, p. 484 .

${ }^{5}$ Albany Gazette, May 5. I808. 
miserated seamen, and merchants gathered in the Tontine Coffee House to frame petitions. ${ }^{1}$

The effects were by no means limited to New York city. At Albany, when no canvas was unfurled upon the river at the melting of the ice in ISo8, the carters and the bargemen joined the sailors in their complaint. ${ }^{2}$ The farmers about Utica, led by Thomas $R$. Gold and Jonas Platt, protested that the value of their land depended on the free way for their surplus produce to the European markets. Without this they could not make their payments to land agents. With respect to the Mohawk Valley, they said in a petition! to the President, where the foreign sale of potash and flour was the chief source of their ready money, this measure in its rigid execution would "arrest the further progress of those settlements, blast the experiments of the husbandmen. and ruin the flourishing frontier counties of the state." Although the Oneida Federalists three years later gladly put their money into manufacturing, in I 800 they professed to fear its drawing off of labor from its customary pursuits. ${ }^{*}$ The same complaint came from the districts further west. When wheat dropped from two dollars to seventy-five cents the bushel, Colonel Troup, in Geneva, as agent for the Pulteneys found difficulty in collecting rents."

${ }^{1}$ John Lambert, Travels through Canada and the United States of North America in the Ycars 1806, 1807, 1808 (London, 1814), vol. ii, p. 55 et seq.

2Albany Gazette, March 17, I808.

${ }^{3}$ N. Y. Spectator, September I3, I808. +M. M. Bagg, op. cit.

${ }^{5}$ Troup to King, Albany, March $7,180 \$$, King Correspondence; J. D. Hammond, Political History, vol. i, p. 265. For a time it seemed likely that DeWitt Clinton might make common cause with the Federalists on the embargo. Since the beginning of Mr. Jefferson's second term, Clinton had been chafing at the natural preference of Virginia for Madison rather than his uncle, the Vice-President, as party leader. He at first opposed the embargo, and letters came to 
Although some Federalists, like Gouverneur Morris, were still pessinisic.' most of the leaders, howsoever they might suffer in their private purses, saw here the flood tide of fortume for the party. They affected to consider any laborers who were employed by Republicans as doubtless bullied into voting for embargo policies. It was the sense of a meeting held in New York city

that all electors who shall be deprived of employment, or otherwise persecuted, in consequence of the free exercise of the right of suffrage, are entitled to the protection of the Federal Republicans of this city, and we hereby pledge ourselves to these and the public, that to the utmost of our power we will countenance, encourage, and protect all citizens who may thus be persecuted."

It was in the spirit of the new attempt to make the party popular with the lower classes, that some enthusiasts were anxious to silence for all time the irritating cry of Toryism. To understand this imputation it is necessary to revert to an earlier campaign.

The contest of 1807 had been enlivened by an episode, which recounted may suggest a commentary on the ways of politics a hundred years ago. On April 2, 1807, the Hlbany Register, a Clinton paper, produced an afficlavit which read as follows:

Col. Nicholas Stats of the County of Rensselaer, being duly sworn deposeth-that he the said Nicholas was a member of

him which hinted at Federalist support for the venerable George Clinton (see his Mss.., September 16,1808 ), but he subsequently changed his mind on the commercial policy though he was never reconciled to the Virginia dynasty.

"He spoke of doubts as to "whether to make an effort to put good men in power or remain quiet spectators. I am of the latter opinion." Diary and Letters, vol. ii, p. इ12.

2. Y. Eiening Post, April 25, Ison. 
the House of Assembly for the County of Rensselaer in the session of I8or-that in the month of Janiary of the same year, and on the day before the Assembly proceeded to the choice of the Council of Appointment, he the deponent was waited upon by Solomon Van Rensselaer, adjutant general of the State-that said Van Rensselaer intimated to him, thic said Nicholas Staats, that the Governor was his (the sail Nicholas') friend; that he, the Governor, had appointed the sheriff of Greene County to gratify him:- That the said Van Rensselaer requested the deponent to call at Mr. Skinner's Coffee-House and see Mr. Van Ness and Mr. Shurtleff, two federal members of the house, who, the said Van Rensselaer assured him wished to converse with him, as this deponent understood, upon the subject of choosing the Council of Appointment .. That the said Van Rensselaer further pressed the subject of the Council. and intimated unequivocally to the said Nicholas, that if he would vote for the ticket which wat to be supported by the Governor's friends, mentioning the name of Mr. Woodworth in particular, as one who would be on the said ticket, that in that case he, the said Nicholas, would be promoted to or made a Brigadier General. . . .

Solomon Van Rensselaer, who was a cousin of the Patroon, apparently aware what useful service cond the rendered by a good red herring, declared some four days later that this affidavit had been extracted under pressure by Citizen Genêt, a man who should be given small consideration, inasmuch as he had recently been threatening the United States with an attack by General Bonaparte." Genet denied this charge, ${ }^{3}$ whereupon a Federalist general meeting.

1 Shurtleff was a member of assembly from Albany County, $N . Y$. Assembly Journal, 1807 , p. 3. The proceedings of the trials later con ducted in Albany may be found in a pamphlet Report of the Trials of Jenkins i's. Van Rensselaer (Albany, I808, N. Y. State Library). See also Albany Gasctte, March 14, IEo\&.

"Supplement to the Albany Republican Crisis, April 6, ISo7.

${ }^{3}$ Albany Register, April I3, I807. 


\section{ARISTOCRACY IN THE POLITICS OF NEW YORK}

at the capitai, expressed its full confidence in Van Rensselaer's word. The Republicans, not so to be discredited, likewise gathered to declare, on motion of Judge Tayler, that they wholly disbelieved that the ex-ministe: had made the threat. ${ }^{1}$ Van Rensselaer, as might have been expected, took this as a passing of the lie. The chairman of the meeting, Judge John Tayler, being too decrepit to be dealt with, he sent the secretary, Elisha Jenkins, a challenge to a duel, to which, to his chagrin, no response was made. Soon seeing Jenkins on the public street. he stole up behind, struck him to the ground insensible, and then walked on without concern. On passing toward the State House square, some angry words were exchanged with old Judge Tayler, who, with the more efficient help of Dr. C. D. Cooper, his son-in-law, and another, set upon Van Rensselaer to such purpose that he was all but killed, and rept in bed for half a year. It was charged that Governor Lewis standing by allowed Van Rensselaer to use his cane."

It was long before the echoes of this brawl had died away. As in r8ot when Burr's following had been called "the sons of sworn king's men," " so now again was raised the stale reproach of Toryism.

Republicans, [admonishes a curious old handbill] see the Reign of Terror revived with all its violence and horror-see young tories attacking old Whigs-because they are Republicans! Judge Tayler, whose head is white with the hoar of years, fought the battles of our independence, and has ever since been a firm and undaunted whig. But what shall we say of Morgan Lewis, the Governor of the State? Behold him, encouraging cumult and violence! Behold him lend his cane to an up-

${ }^{1} J e n k i n s$ vs. Van Rensselaer, pp. I3-17.

${ }^{2} I$ bid. At the trials the most eminent counsel in the state appeared. Verdicts were awarded to both sides.

a Benj. Howe to John Tayler, September 17, 1804, Tayler Mss. 
start Tory; behold him assisting that tory to do violence to Judge Tayler, a revolutionary soldier-a Senator in this State -an old man and an inflexible Republican. Is such a man fit to be the Governor of a free people! Republicans! rise in your might, and put down this infamous composition of Toryism and Apostacy. ${ }^{1}$

This was a generation which was sensitive to such appeals. Men then in middle life remembered Tories as the terror of their childhood. Grizzled " skinners," in recounting sufferings and adventures, still kept bright the fires of hatred in what had been the neutral ground. Citizens of New York city could with bitterness recall their seven years of banishment while Loyalists enjoyed their property within the lines. Cherry Valley and Oriskany were names still hideous with the memory of murder. Broadsides written by Republicans in ISO7 which called to mind the horrors of the scalping knife and prison ship did not fail of their effect; it would never do to let the Tory-Federalists regain control.

In 1809 , when the Federalists were again the objects of this old hue and cry, some daring spirits urged the cleansing of their party of this stain by the ostracism of all those to whom the charge of Toryism might be applied. But such proposals stirred the indignation of the older leaders. Colonel Troup in Albany, writing to Rufus King, made no secret of his heat."

On the subject of unanimity [he wrote] permit me to remark, that we are alarmed with late reports from New York. We are told that our friends are divided into two parties who have become, or are likely to become, open enemies to each other; the one contending that persons liable to the charge of toryism, from having resided within the British lines, or from

${ }^{1}$ Quoted in T. E. V. Smith, Political Partics, etc., p. 9.

${ }^{3}$ Albany, April 4, 1809, King Corrcspondence. 
being descended from those who did so reside, ought to be excluded from the ticket about to be formed; and the other contending that the exclusion of such persons would be illiberal, unjust and impolitic. If these reports be well founded it would be highly gratifying to your friends here, if you would be kind enough to employ your weight and influence, and endeavor to heal the division and restore harmony ... The advocates of exclusion, besides incurring the imputation of illiberality and injustice, stand opposed by a long and uninterrupted course of practice. Soon after we regained possession of New York, we permitted the Tories to enlist under our banners: and they have since manfully fought by our side in every important battle we have had with the democracy; some of them in the character of officers, and others in those of common soldiers. And when monies have been necessary to support our cause, many amongst them never scrupled to pay their quota of the general tax. Noreover we ought not to forget their zealous and useful service in our great contest for the constitution; which I presume was intended to lave the effect of putting us on an equal footing with regard to the rights and honors of citizenship. Why therefore should these our good friends be now branded with the odium of "British sensibility" and drummed out of our ranks? My soul revolts at the very idea of a measure so illiberal-so unjust-and indeed so excessively cruel!... We often had on our tickets men denominated tories. In this list. I name our worthy friends Mr. Harison, Mr. Cornelius I. Bogert and Mr. Josiah O. Hoffman and to their names we may add those of Mr. John Watts, Mr. Jolnn De Lancy and Mr. IVilliam Cock with several others. What would the generous heart of our ever to be lamented friend Hamilton induce him to say of this excluding project, if he were capable of participating with us in our present patriotic and noble struggle? But the mere mention of his name calls to my mind and fills my breast with emotion, which prevents my enlarging \& compels me to conclnde with assuring you of the pure and exalted esteem, with which I am,

My dear sir,

Your humble Servant.

RoBt. 'Troup. 
It is probable that King's good sense responded to his iriend's suggestions; at least there was no further talk of reading out all those who had been Loyalists.

In the following campaign the Republicans revived the charge which proved so useful. In an address issued from a meeting held in Albany, they accounted for the wealth of Federalists on the ground that as Tories in the Revolution, they had saved their property unimpaired while the IVhigs impoverished themselves in patriotic sacrifice.

And as property is too miversally the basis of influence [they said] these Tories soon took the learl in onr affairs; their brethren who had been expelled from our shores returned to take advantage of our maganimous clemency, and to strengthen the party against liberty. Some distinguished apostates from the Whig ranks went over to this party-and by this artful combination the people were deluded ... These gentlemen were for a govermment of energy . . . and as the tory principle is that of arbitrary power, it was natural for the friends of that principle to side with ranks of the latter gentlemen.

The election in 1809 in New York gave the Federalists their first victory for a decade." Five senators out of eight, representing the eastern and western districts. were returned, and a majority of the lower house. Especially gratifying was it that the contest had been waged squarel as a single and united party. "It is with peculiar pleasure. I inform you." wrote Morris S. Miller of Ltica. to John

${ }^{1}$ Procecdings of the Republican Mecting of the Citizens of Albany, March 13, I8IO (Albany, 1810). This address was written by Solomon Southwick. The $N$. Y. Journal habitually referred to the "Federalist Tories;" for example, April 7, 21, I810.

3 This was in spite of a slight reaction in public sentiment in faror of the national administration, which followed the publication of the so-called Erskine Treaty. King claimed they were published when they were, to influence the New York election. King to C. Gore, April 27. I809. King Correspondence. 


\section{IO}

Jay, " that in every part of the District the election has been bottomed and conducted on decided Federal principles; in no County has there been any arrangement or concert with either section of the Democratic party." ${ }^{1}$ But the cautious Jay would not suddenly become too sanguine.

How few of the favorable changes which have taken place are imputable to patriotic and correct principles, time and experience only can decide ... Personal and pecuniary considerations appear to have acquired a more than ordinary degree of influence; many sacrifices of public Good have and will yet have to be made to them. ${ }^{2}$

Although the Federalists, in gaining a majority of the assembly, had won the right to name the much-desired Council of Appointment, the circumstance that there were no members of their party sitting for the middle or southern districts in the senate caused them some embarrassment. The Councillors from these districts, therefore, must be Republicans. But of the two, of which necessity compelled selection, one, to the scandal of his party, when chosen proved amenable to their persuasion and was content to join with the two Federalists to make a majority of the five. ${ }^{1}$

The professions of abhorrence at the system of partisan proscription, which the Federalists had made throughout the decade. had not been taken very seriously, for it was charged with much show of truth that it was Abraham Van Vechten in Jay's administration. and not Clinton, who

\section{'May II, I8c9, Jay Correspondence.}

¿Jay to M. S. Miller, May 22, ISog, ibid.

${ }^{3} \mathrm{~J}$. D. Hammond, Political Ilistory, vol. i, pp. 280-282, for a discussion of the "Robert Williams Council," which this treachery gave to the Federalists. It will be remembered that the Council consisted of the governor, and one senator from each of the four great senatorial districts, these latter chosen by the assembly. 
should have the credit or the blame of its invention. It was therefore no great surprise that the new council straightway set out to expel the officers of government, from the well-remunerated mayor of New York to the inspector of staves and lieading in the smallest hamlet in the state-in all six thousand more or less. The disposition of the nayoralty elicited a contest. Some men of higher principles among the party, like Van Vechten, proposed a self-denying measure of cutting down the compensation, known to be some fifteen thousand dollars, to a figure more proportionate to the pay of other state officials, and Richard Harison, who was familiar with the city charter, promised to prepare a bill to serve this purpose. Troup, who was first recommended as a candidate, was quite in favor of reduction, but when because of his engagements as land-agent he withdrew his name, the other applicants were not as generous and the matter was soon dropped. Jacob Radcliffe was at last appointed, though the supporters of Colonel Richard Varick and Nathaniel Pendleton well nigh broke up the party in the city. ${ }^{2}$ As to other lucrative appointments there was likewise much loud disagreement, and Troup writes that in disgust he had "withdrawn all communion respecting appointments. $^{3}$

1 Procecdings of the Republican Mceting of the Citizens of Albary. p. 8 et seq.; cf. H. L. McBain, op. cit.

${ }^{2}$ Troup to King, January I2 and February 27 , 1810, W. W. Van Ness to King, February 8, I810, King Correspondence; also De Witt Clinton Mss., March 17, I810.

3 "It is asserted by some who pretend to know, that Williams will not agree to Morris's appointment to the clerkship; and that nothing will be done with this office until after election. From appearances Gardenier now stands a better chance for that office than Morris-Benson is here asserting the claims of his brother to the same office; but I conjecture without any probability of success. Benson says he would not have the office himself if offered to him. He is contending for principle, and this demands his brother's restitution. A more ob- 
This patronage was but the first comrse of a feast which the Federalists hoped might be continued. They determined for the first time in a decade. to name a candidate for gov. ernor, and nearly four months before the spring election of 1810, a meeting held in Albany nominated Jonas Platt of Oneida, recently elected to the senate by a large majority. Colonel Nicholas Fish, the banker, was selected for lieutenint governor. It was generally understood that the amiable Tompkins, whose suspected preference for Madison and the Virginians had not as yet cost him the support of Clinton. would stand for re-election, and the campaign was soon under way. The Federalists warned solemnly against the return of Clinton's nepotism, claiming that in the first two years of Tompkins' administration many comsins of the fanily had been pensioned from the school thind. ${ }^{1}$ Republicans, united for the moment as to Clintonians and Martling Men, disdained to talk of favoritism while the Federalist Council carried out its own proscription. and as we have seen, they again trumped up the charge of Toryism to make odious their enemies. Labored essays by the Federalists were produced to demonstrate that this charge was quite unfair, ${ }^{2}$ and in their songs they carefully addressed themselves as Whigs, but for all this it was easy ior their enemies to charge them with the prejudices of aristocrats. Their candidate who, when in Congress, had supported the Sedition Law ${ }^{3}$ had recently proclaimed his por opinion of democracy:

jectionable doctrine than that of principle could not be broached. To urge it is to make yourself ridiculous-and accordingly the Judge is laughed out." Troup to King. February 27, I810, King Correspondence.

'See broadside, "Platt and Liberty. A New Historical Song for the New-York Election, I819, 22 verses, to be sung slowly to the tune of Yankee Doodle or of Wilkes' Wriggle," Emmetl Collection, II,400: see also V. F. Eacning Post, April 12, 1810.

"For example, X. Y. Earning Post. April 16, 1810.

3 Hashington Register, quoted in $N$. Y. Journal, April 24, 1810. 
Where two or three are met together for factious purposes [he said ironically] even there is the Majesty of the People in the midst of them. To a man of common sense and honesty it is a stumbling block; to a man without ambition it is foolishness ... Within the limits of the constitution, I may occasionally be willing to be employed, but the office of your serrant I will never submit to. ${ }^{1}$

"If you want a master, vote for General Platt," responded the Republican newspapers. ${ }^{2}$

The Federalists later claimed that their enemies stirred up class prejudice: they said the voters were assured

that the rich and the poor had separate interests; that the cartmen and the mechanics were held cheap by the merchants: and that the buying and selling part of the community were always opposed, in all things to the laboring part: That, let what would happen, it must be the poor only who would be sufferers : but as to the federalists they were all rich and the natural enemies of republicans. ${ }^{3}$

The imputation of such theories the Republicans did not deny, but rather justified them by appeals to the dignity of laborers. The cartmen and the mechanics were as necessary to their haughty masters, they maintained. as the Tory lordlings were to them. ${ }^{4}$ Such exhortation moved the Evening Post to say, that in its apprehension democracy and republicanism were not convertible terms. "The tendencr. of the former is to anarchy and misrule, whilst that of the latter is to produce order, to cultivate natural liberty, protect the rights of citizens, impart to the rovernment stability. honor and virtue."

'Quoted in Proceedings of Republican . Feeting ... Albany. ... 1810, p. 8.

${ }^{2}$ N. Y. Journal, April 7. 18 ro.

N. Y. Evening Post, May 3, I8I i.

${ }^{4} N$. Y. Journal, April 7, 21, 1810.

$\therefore$ N. Y. Herald, May 2. I8io. 
General Platt had once in the senate called for applause for British magnanimity in the spontaneous disavowal of the attack upon the "Chesapeake," providing thus another text to his opponents. The Federalist traders and their friends, of course, made no secret of their strong aversion to a breach with the "mother country," and their cause was watched with much solicitude by British agents in New York and Washington, yet there were no charges of a treacherous connivance such as those which passed so freely to the east ${ }^{1}$ In the campaign they tried to turn the scale against their enemies by fastening upon them the awkward and absurd name of "French Tories." to counteract the sentiment of gratitude borne toward France as our ally in the Revolution." A campaign song explained:

"The French, 'tis true, in their own way,

Look'd steady on : but seem'd shy; Until we fought; and gain'd the day;

Then soon became our ally." 3

The embargo was, of course, still a major issue in party politics, and the merchants and the farmers were advised to vote for "Platt, Commerce, and the Constitution," "

1" In spite, however, of the vehemence of the Senate, Mr. J[ackson] states that Federalism is constantly gaining ground in New York, and that the sentiments of all Classes of People are every day becoming more favorable to $\mathrm{H}$ [is] M[ajesty's] Interests." Mr. Jackson (the British agent) to Earl Bathurst, February 16, 1810, in mss. Precis Book kept by "The Most Noble the Marquis Wellesley \&c. \&c. \&c." (in N. Y. P. L.), p. 55. Later the agent saw that there was small chance of electing a Federalist governor or legislature in New York, but said, " if the democratick Party evince no greater Talent or Energy than has been hitherto seen in their measures their Power will be formidable only to their own country." Ibid., p. 78 . See also Jackson to the Marquess of Wellesley, ibid., vol. ii, pp. 86 and 162.

$2 N$. Y. Journal, April 24. 18 ro. 3 "Platt and Liberty," loc, cit.

4.N. Y. Erening Post, April 16, I81o. 
while attempts were made to rally to the standard all shipwrights and rope-makers, mariners and smiths. ${ }^{1}$ The Republican newspapers would not forget the story of Emmett's martyrdom, at the hands of Rufus King; ${ }^{2}$ but, although the Federalısts again in New York city offered an American ticket, ${ }^{3}$ a serious attempt was made throughout the state to get some voters from these "imported patriots." as their song suggests:

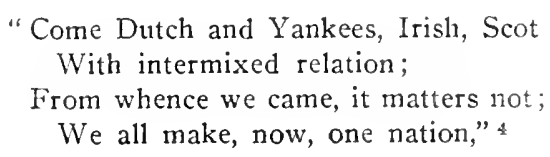

and other groups were especially addressed as, for example, the Quakers of Columbia County. ${ }^{5}$ The Federalists appealed to the glories of twenty years before, and though they admitted that Adams' presidency was in some ways regrettable, denied that the party should be generally charged with that responsibility. ${ }^{\circ}$ Since John Adams had stood by his son in support of the embargo, his name, never glorious in New York state, was now mentioned at best with apology. Indeed their doggerel well sets forth the opinion of the party as to the presidential record:

${ }^{1}$ N. Y. Herald, April 21, 25, 1810.

2N. Y. Journal, April 21, 1810.

'N. Y. Hcrald, April 7, 11, 1810.

" "Platt and Liberty."

${ }^{5}$ Elisha Williams and J. R. Van Rensselaer of that county had worked earnestly to prevent a tax of \$1o a head on Quakers for exemption from military duty, Hudson Balance, quoted in Albany Gazetle, April 7, 1808. During the campaign of 1810 Van Buren reports his efforts to capture the Quaker vote for the Republicans, Van Buren to Clinton, April 19, I8ro, DeWitt Clinton Mss.

${ }^{6}$ N. Y. Eriening Post, April 7, i8ro.

' J. T. Morse, John Adams (Boston, I896), p. 326. 
"Through eight bright years the Federal Sun

Maintained his glorious station:

While we were rul'd by Washington

How happy was our nation!

Yankee Doodle, we were free:

Our rights were all protected,

Our trade was safe in every sea;

At home we were respected.

"Then Adams 'rose and took the helm

But could not steer so nice, long:

That Man's not fit to rule a realm

Who once goes right-but twice wrong.

Yankee Doodle; fire and tow;

How can that man e'er hit right;

Who's sometimes fast-and sometimes slow-

Who'll sometimes run-and yet fight?" 1

But Federalism in New York could not be saved by ballads of poetical disclaimer. The unpopular embargo had been given up for the milder system of non-intercourse; the ancient grudge against Great Britain was now deepened by that government's renunciation of the Erskine treaty; the Republicans, then at a truce among themselves, stretclied every nerve to regain their power of appointment. As a result the Federalists lost heavily except in New York City and the Albany and Mohawk districts ${ }^{2}$ and the Republicans swept the state.

So closed a decade properly enough, in which humiliaton and defeat had been the portion of the Federalists. Their tradition and their theory of politics had been repudiated by the people of this country, though many of their policies were well continued. Fortunately the party, with its bold projects of construction, did not die with its defeat. It lived on under other names and leaders to supply the

1 "Platt and Liberty."

'J. D. Hammond, Political Partics, vol. i, pp. 285-28j; John T. Irvine to W. P. Van Ness, May 3. I810, Van Ness Miss. 
courage of great undertakings, but not until it had responded somewhat to the spirit of America and been liberalized into a forbearance as to goverument by all the people. That the party in New York had thus persisted in the face of its adversities well shows the impulse of its old enthusiasms. It had ordained the system of our government and by its energy and skill in solving the initial problems of its conduct, had compelled the admiration of the world. Because of this achievement, as with the "grand old party," which two generations later was considered to have saved the fabric from destruction, the cause of Federalisin could and did command a loyalty amost romantic in its sentiment. The memory of great personalities like Washington and Hamilton made any slowing down of party zeal seem much like treason. But the reasons for continuance did not all grow out of history. There was a consciousness of common interest among the business classes, who, as we have shown, made up the unchanging core of the Federalist party. In commercial centres like New York these men were bound to act together in defense. against the antagonisn of the planters of the south upon the one hand and their allies, the wage-mechanics, on the other. In local contests on the chartering of banks as in the greater issue of the embargo, the party of the merchants and investors had a part to play, but, as we have also seen, this group was held together by other ties than those of business. Comprising as they did a social class, they realized that a weakening of political organization would appear as a surrender of pretensions to consequence and rank, which they were not prepared to yield.

From the morning when John Jay gave up his office of governor, the Federalists of New York state were found in the minority, forming often a scarce moiety of that. Yet in certain sections of the state their dominion was retained. 


\section{II8 ARISTOCRACY IN THE POLITICS OF NEW YORK}

almost never to be seriously challenged. In Albany and Rensselaer Counties, for example, elective offices were kept within the party. While Van Rensselaer, Williams and Van Ness retained their power in Columbia. no Democrat of whatsoever faction could look forward to advancement by his neighbors. Certain wards in New York city would have voted for a branded thief as soon as for a Jacobin. In other counties in the east the balance was so even that the excitement at elections never slackened. It was natural that in all these regions any talk of giving up the Federalist party would have been greeted with derision. The success these leaders won at home stirred their ambition to keep firm the organization in less fortunate localities, in hope of larger victories. It urged them to intrigues by which some Federalist measures might be smuggled through the legislature, or some small bit of patronage be granted by the five great arbiters at Albany. Throughout the score of years, or more, which marked the slow decline of Federalism, it elected 110 executive to carry on the policies of Jay; yet party effort seldom flagged. newspapers were founded and sustained. tireless politicians rode through every county from the Hudson to the lakes, pamphleteers wrote reams of argument. and enthusiasts invoked the halting muse of campaign poetry. The secret of this obstinate vitality is found in the constant hope of capturing the Council of Appointment. I 810,1813 and 1814 were years of nourishment, at other times the prize was tantalizing in its nearness; there was always a prospect of electing a majority of the assembly.

If this appetite for office moved small men to action, the statesmen of the party did not despair of bringing in again the rule of Federalist principles. The juggling tricks of management which had already made the state a by-ivord. the utter lack. as yet, of any larger constructive program. that had distinguished those who held control, seemed to 
them too sad afflictions to be long endured. They rested their hopes, as Troup had said, upon the fall of the Democratic party by the weight of its own vices and divisions. How, by the adoption of a Democratic leader, they drew a sharper line between themselves and the Democracy, is to be the theme of another chapter. 


\section{CHAPTER VI \\ Landholders' Principles}

THE hypothesis that economic interest was the inner cause of party struggle in the early days of the republic has taken on the dignity of an "interpretation." " Assume a broact antipathy between those whose property" was in the soil and those who drew their profit from enterprise in trade and industry, and a surprisingly long array of facts seem dutifully obedient in illustration. From the coming of the peace of $I_{7} 83$ into the first years of the new century, the conflict grew more bitter as these diversities with all their implications, embodied in the personalities of Hamilton and Jefferson, became more clearly realized. Though no one would postulate a reasoned, selfish calculation as the only basis of partisan allegiance, nor refuse to see the many other forces that lift and sway the minds of men, certain it is that underneath the surface passion in the cause of France or England, deeper, perhaps, than the philosophy that formed itself in labored essays in defence of liberty or order, and more stable than the personal affection toward one champion or another battling in the field of politics, was this consciousness of dirergent economic interests to be helped or hindered by new laws. But in New York, at least, as we shall see, the lines of party clemarcation throughout the first decades of the nineteenth century, seemed to fade somewhat and grow uncertain. For this also there were many causes, but one seeking for a diagnosis of conditions which allowed this softening of an

${ }^{1}$ C. A. Beard. Economic Interpretation of the Constitution and Economic Origins of Jeffersonian Democracy (N. Y., I915) ; and "Politics and Education," Teachers College Record, vol. xvii, no. 3, pp. I-I2. Professor Beard presents the antithesis as between farmers and bondholders, but the capital of the latter was generally applied as well to other enterprise. 
animosity but recently so virulent, reasonably turns to an examination of this economic factor, to which so much has recently been traced. Was there in New York the same well marked opposition between the man of lands and the man of bonds and shares of stock as has been noticed in some sections of the country?

A hundred years ago the city of New York, now the doorway of a nation. was a great commercial city in its promise rather than as yet in its achievement. ${ }^{1}$ Though the merchants' ships were turning toward the Orient ${ }^{2}$ and their wharves were piled with bales from over all the seven sea; the path of the trading schooner did not seem the only way to wealth as it did from Massachusetts. ${ }^{3}$ But there were fortunes for hazard in New York, saved from the wreckage of the war and ready for what investment would secure the largest income. One attractive prospect was furnished by the wide and unmarked lands, wild, perhaps, but reported to be fertile, that stretched out to the north and west within the boundary of what was to become the Empire State. The state itself was rich in land, even before it compounded with Connecticut and Massachusetts for their claims and holdings. ${ }^{*}$ Those officers like the Morrises, ${ }^{\circ}$ whose war claims were paid by grants of land, saw

${ }^{1}$ Cf. E. E. Pratt, Industrial Causes of Congestion of Population in New York City (Columbia University Studies in History, Economics and Public Law, vol. xhiii, I9II), p. I3.

${ }^{2}$ T. Pitkin, Statistical View of the United States (Hartford, 1816), p. 208.

${ }^{3} \mathrm{Ibid}$., see tables of tonnage owned in the different states in 7810 , pp. 391-392. New York City was just coming to the lead.

${ }^{4} \mathrm{~J}$. H. Hotchkin, History of Western New York (N. Y., IS48), pp. I-10. This work is less useful to our purpose than its title promises, being concerned almost exclusively with the progress of the Presbyterian church.

${ }^{5}$ Richard and Lewis Morris were so granted three thousand acres in what was then Montgomery County. M. A. Hamm, Famous Fasmilies of New York, vol. ii, p. 34 . 
in these the bases for a larger business that might be prudently increased by purchase.

The men of wealth in New York city had no settled prejudice against holding real estate; not only were there close comnections with the Schuylers and Van Rensselaers, but in most families of the gentry there were large-acred cousins, of whose prosperity there could be no doubt. $\Lambda$ description of the great estate at Duanesburgh with forty thousand acres in Albany County, ${ }^{1}$ must have stirred the fancy as related in Judge Duane's drawing room in Nassau Street; " or that of "Hoffman's Castle" at Red Hook in Dutchess County, owned by relatives of the fashionable IVall Street Hoffmans; ${ }^{3}$ or of the princely home at old Fort Miller where reigned the famous Lady Kitty Duer," " who now and then came down to bring new splendor to the balls at the Assembly Rooms." The attention of large investors was already fixed upon these lands while they were still dispensed by the colony land office, and the bidding grew far brisker in the early days of statehood. As one glances down the pages of the Calendar of Land Papers"

'A. A. Yates, Schencctady County, Its History (N. Y., 1902), pp. 410-412; M. A. Hamm, of. cit., vol. i, p. I23. James Duane retired to this estate after his failure in business in 1792 . Duanesburgh was included when Schenectady County was formed.

${ }^{2}$ New York Dircciory (I793), p. 44; see Emmett Collection, number 13,246 .

${ }^{3}$ F. Hasbrouck, Hisiory of Dutchess Couniy (Poughkeepsie, 1909), P. 428; J. H. Beers, Biographical Record of Dutchess County (Chicago, I\$97), p. 57I; N. Y. Genealogical and Biographical Record, vol. v, p. II7; New York Dircctory, I80o: M. A. Hamm, of. cit., vol. i, pp. 173. 178. The Hoffman holdings in Ulster County also were extensive.

'Wm. L. Stone (Jr.). Washington County ( X. Y., I90I), p. I3I.

${ }^{5} \mathrm{C}$. W. Bowen, History of the Centennial Celcbration of the Inauguration of George Washington, pp. 57-59.

${ }^{B}$ The full title is Calendar of New York Colonial MIss. indorsed Land Iapers, 1643-1803 (Albany, I86.4). 
one sees many familiar Federalist names, William Bayard, the Bleeckers, C. D. Colden, Duane, James Emott, Nicholas Fish, and many others, who held land by grant or purchase from the state. Alexander Hamilton invested all his surplus earnings in the lands about Oswego ${ }^{1}$ which would pay a rich dividend only after years of waiting, so that his tragic death left his widow "land poor," as the phrase went, and a fund had to be subscribed by friends to make sure her comfort. ${ }^{2}$ His friend, Cornelius I. Bogert, ${ }^{3}$ had large holdings in what is now Hamilton County, while the Roosevelts * had purchased largely in what is now Oneida." James Watson, the Federalist United States senator. held over sixty thousand acres, somewhat to the north. ${ }^{6}$ The extent oi

${ }^{1} \mathrm{~J}$. C. Churchill, Landmarks of Oswego County (Syracuse, 1895), p. I3.

${ }^{2}$ Gouverneur Morris to Robert Morris, July I4, I804 (A. C. Morris, The Diary and Letters of Gouverneur Morris, vol. ii, p. 459): "Our friend Hamilton has been suddenly cut off in embarrassments which would have required years of professional industry to set right: a debt of between fifty thousand and sixty thousand dollars, a property which in time may sell for seventy or eighty thousand, but which if brought to the hammer, would not in all probability fetch fifty." Matthew Clarkson to Rufus King, August 20, 1894, King Corrcspondence, vol. iv, p. 404, speaks of the subscription. The following from J. A. Hamilton, Reminisccnces, p. 78 , is interesting: "At a dinner party in New York, shortly after the close of the Revolutionary War, at which were present Messrs. G. Morris, John Jay, Richard Harison, John Delafield, Robert Lenox, Nicholas Low, J. O. Hoffman, and Alexander Hamilton, the question was discussed whether the purchase of wild lands or of lots in the suburbs of the city would be the more profitable. [Some, including Hamilton] invested in lands in the northern counties of the state."

${ }^{3}$ Land Papers, p. 923.

"Cf. C. A. Beard, Economic Interpretation of the Constitution, p. 270.

${ }^{5}$ D. E. Wager, Oneida County (Boston, I896), pp. I19-121.

'Documentary History of New York (Albany, I850), vol. iii, pp. 647 . 653, 654; Jenkins, Political Parties, pp. 50, 67, 73, 84. Watson was also candidate for lieutenant-governor in I80I, (A. Hamilton) Address to the Electors of the State of New York (pamphlet, N. Y., I80I), p. 3, and for Congress, C. H. Hunt, Life of Edreard Lizingston, p. 74. 


\section{ARISTOCRACY IN THE POLITICS OF NEIY YORK}

speculation in mnsettled land that centered in the counting rooms of a Federalist firm like LeRoy, Bayard and Co. seems hardly credible; ${ }^{1}$ no considerable section of the state remained unmentioned in their ledgers. The subject of Federalist land holding in New York, indeed, could be properly examined only by a long laborious research.

Let us take for our example a single county, St. Lawrence, almost the farthest and then the least accessible from the city of New York. Here great tracts of land were held by General Knox," John Delafield, ${ }^{3}$ Nicholas Low, J Josiah Ogden Hoffman, ${ }^{5}$ Frederic DePeyster, ${ }^{\circ}$ Philip Brasher, Garrett Van Horne. ${ }^{\text {s }}$ Stephen Van Rensselaer, ${ }^{\circ}$ Philip Schuyler, ${ }^{10}$ David M. Clarkson, ${ }^{11}$ and. greatest in the area of his holding. Gouverneur Morris. ${ }^{12}$ These were men

${ }^{1}$ This was the greatest private commercial enterprise New York ever knew up to the eighteen-thirties, Barret, Old Merchants of New York ( N. Y., I862), pp. 3I, 46, I60-164, 302-305, etc. There are thirteen boxes and more than two thousand unassorted pieces of manuscript, together with twenty-five volumes, dealing with the operations of this company, in the collection of the New York Public Library.

${ }^{2}$ F. B. Hough, History of St. Lawrence and Franklin Counties, pp. 241,246 . The section of Dr. Hough's work which deals with early land arrangements is fully documented.
I Ibid., pp. 243, 246, 247, ctc.
Ibid., loc. cit.

${ }^{B}$ Gates Curtis, Mcmorial of St. Lawrence County (Syracuse. I894). p. 84 .

'J. H. French, Historical and Statistical Gazetieer of New York State (Syracuse, 1860 ), p. 576 . The DePeysters were intermartied with the Van Hornes, Clarksons, etc. W. A. Duer, Reminiscences of An Old Neze Yorker, p. 37.

'T. Weed, Autobiography, ctc., vol. i, pp. 394, 40I.

Hough, op. cit., p. 244.

- French, op. cit., p. 578. There are towns in St. Lawrence County naned Depeyster, Brasher and Rensselaer.

10 Article in N.Y. Times, June 7, 1903.

"Hough, p. 244. ${ }^{12}$ French, pp. $577,580$. 
of wealth and influence in the Federalist party, but they were as keenly interested in the politics of land as in that of trade or banks or industrial securities. Neither the one nor the other could be neglected by lawmakers at Washington or Albany without grave havoc in the counting books of these investors.

No statesman of New York had been heard with more respect in party councils than Gouverneur Morris. Learned in the lore and technic of governmental science, acquainterl with the courts of Europe, gencrous in service for the public good, possessed of an enormous fortune, he seened a type of what was best and most respectable in Federalism; and 110 one more than he was representative of that party': landed interest in New York. The boundaries of his own estate of fifteen hundred acres at Morrisania ${ }^{1}$ did not limit his concern in the welfare of real property. He purchased heavily not only in the St. Lawrence region, where the towns of Gonverneur and Morristown now remain as monuments," but also in the western wilderness." With a rlauntless zeal to see and know, he made his way time and again by forest trail and bark canoe along the Mohawk Valley and slowly westward to Niagara, or through the woodlands of the north to Montreal. ${ }^{*}$ When in January I8 16 . Congress addressed itself to the problem of a permanent revenue in time of peace, ${ }^{5}$ the New England Federalists, in the interest of the shipping class, arrayed themselves against the great plantation owners of the south "

${ }^{1}$ Diary and Letters of Gondern'ur Morris, vol. ii, p. 378; J. A. Hamilton, who settled the estate, gives an account of Morris's property in his Reminiscences, pp. $46-47$.

"French, loc. cit.

Diary and Letters, vol. ii, p. 370 .

${ }^{4}$ Ibid., vol. ii, pp. 390, 439, 513, 520, 591, etc.

'Annals of Congress, $18 \mathrm{i6}-18 \mathrm{17} 7$, p. 687, etc.

${ }^{6}$ Henry Adanıs. History of the United States (N. Y., 1891), vol. is, pp. I12-115. 
in the contest as to whether land or imports should bear the burden of taxation. The New York Federalists, encumbered by much unproductive land, were by no means at one with their Massachusetts friends. Many, it cannot be doubted, subscribed to the doctrine laid down by Gouverneur Morris in a letter to Rufus King: ${ }^{1}$

I fear we differ in opinion on the subject of taxation... Some patriots (sans terrcs, if not sans culotte) cry out "Tax land-speculators and oblige them to sell." Take care, gentlemen patriots. If taxing speculators should become fashionable, stocks may perchance be annoyed. . . Speculators, as such, are not respectable, but they are necessary and in no case more so than in the settlement of wild land. It has been tried to prevent accumulation of large tracts in few hands by confining grants to small tracts, but experience has proved that, until rich men purchase up these small tracts, the country cannot be settled. It is absurd to suppose a person with scarce a second shirt to his back can go two or three hundred miles to look out a farm, have it surveyed, travel back again to the office for a patent, etc., clear the land, cut a road, make a settlement, and build house and barn, and then an owner under a prior grant may come forward and take possession. ... As things now stand, the conflict of title is generally between men able to stand the shock. ${ }^{2}$

'Jared Sparks, Life and Correspondence of Gouv'erncur Morris (Boston, 1832), vol. iii, pp. 343-344. Of course this attitude was by no means new in 1816 , as the following from the $N$. Y. Spectator. January 4. I804, dealing with the action of the New England Federalists and others in the Congress, ISO3, makes clear: "We do not here intend to charge the individuals who have conducted the business in this, or in other states, with any intentional mismanagement. But, that the Proprietors of uncultivated lands have, contrary to the spirit and intent of the law, sustained immense losses, no one, at all informed on the subject, can doubt. And it would gratify the feelings of the friends of justice to see a Bill passed in Congress, that would cut up the evil by the roots."

2In a letter to Randolph Harrison, May 3, 1816, Niary and Letters, 
His argument, it seems, was not in vain, for King later changed his mind and cast his vote against so disagreeable a discrimination. ${ }^{\prime}$ If the interpretation of real and personal estate as the basis of our parties be correct, some explanation of the waning vigor of the Federalism of New York may proceed from this uncertainty in so important a political division.

There is another phase of Federalist land holding which must not be neglected. The conquest of the wilderness by pioneers from the old communities along the sea coast has been the stirring theme of much of our historical writing We have followed with keen interest the great migration from New England with its stalwart men of thrift, of fearless thought and deep religious purpose, ${ }^{2}$ and those who threaded through the southern Alleghenies to lay out broad plantations beside the Mississippi. ${ }^{3}$ In a smaller and more intimate way there is much of interest in the expansion of the New York gentry, and in how Federalist families came to build their homes in lands cleared from the forest. We have formed some notion of their purchases. sometimes a hundred thousand acres, sometimes more. To convert their holdings into a more manageable wealth they sent promising young friends into the wilderness, as agents, who could bargain with the settlers. Then, full of faith in their great

vol. ii, p. 599, he says: "Observe, I pray you, that in England there is no unproductive land. Even their pleasure grounds yield something in venison and the pasturage of cattle, besides the increase of timber. The British land tax, therefore, falls on a revenue. But not a fifth part of our land yields anything." See also his letter to Moss Kent, March 3, 18i6, Sparks, op. cit., vol. iii, p. 350.

${ }^{1}$ R. King to G. Morris, March I5, I816, King Correspondence.

${ }^{2}$ L. K. Mathews, The Expansion of Ncw England (Boston, 1909), ch. vii.

${ }^{3}$ Documentary History of Amcrican Industrial Society (Cleveland, Igog), vol. ii, pp. 219 et seq. 
enterprise, they advised their law clerks to essay the opportunities of a new country; then, lastly, younger sons themselves set out with wives and families to build stately houses on their great domains. It is a story not without romance, and certainly of great importance in accounting for the spread of Federalist influence throughout the inland counties of the state. ${ }^{1}$ 'This subject, also, in its scope forbids a general treatment within our compass, and for convenience's sake we may turn again to St. Lawrence County to trace this second phase of Federalist connection with the land.

In 1792 Samuel Ogden 2 with Josiah Ogden Hoffman bought an extensive tract of land sloping northward to the shore of the St. Lawrence. and two years later sent a young iriend, Nathan Ford, to explore it and conduct its settlement." A mall of force, like most of his profession, and a Federalist like John Delancey ${ }^{4}$ and John Delafield who hail gone before him to this St. Lawrence Valley," he rose to prominence in the politics of the county of which he was the pioneer, ${ }^{6}$ as a public official " and as a leader of his

'Here, in the early days of the republic, the influence of the Federalist party was very small; see O. G. Libby, Distribution of the Vote of the Thirteen States on the Federal Constitution (Wisconsin Studies in History, Economic and Political Science, Vol. I), p. 18. It is interesting to compare the party's fate beyond the Alleghenies, see H. C. Hockett "Federalisn and the West" in the Turner Essays (N. Y.. (910), pp. 113-135.

${ }^{2}$ The Ogdens were a great land-owning family. David A. Ogden purchased about 200,000 acres of the Indian lands in western New York, "The League of the Six Nations," in New' York Ciril List. I88n. p. 2i 2, et seq.

:E. B. Hough, op. cit., p. 589 .

4 Robert Troup to Rufus King. April 4, I809, King Correspondence.

5 Land Papers, pp. 748-766. $\quad$ G. Curtis, op. cit., p. 155.

'V. Y. Civil List, I889, p. 492. 
party.' Riding far and wide through this sparsely settled country, the arbiters of rents and payments, often in position to be of service to the settler, the influence of land agents like Judge Ford, or Benjamin Raymond, the agent and surveyor for Clarkson and Van Horne. ${ }^{2}$ was considerable indeed. But the land agents were not left insupported. In the offices of the distinguished lawyers of the city there were other young men of ambition. Louis Hasbrouck, a student under J. O. Hoffman and Cadwallader D. Colden, by the counsel of his patrons and of his iriend, Judge Ford, set forth from New York City in 1804 to build a home in far St. Lawrence," wending a slow way with family and slave, wagons and pack-horses. Here, agreeable to inis political training, he served as the first clerk of the county. as assemblyman and senator, and was a leader of his party. Federalist, National Republican and Whig. ${ }^{*}$ In that same year, encouraged by the progress of his brother Nathan. David Ford, a zealous politician of the Federalist school. came in 1804 to be the pioneer of Morristown." John Fine. a graduate of Columbia in the class of 1809 with Murray Hoffman, Bishop Onderdonk and Dr. Francis, likewise came northward six years later to grow rich in land and

'E. 4 . he was the delegate to the Federalist meeting. March I8os: Albany ciazcte, April I 808 , and to the convention that nominated Rufus ling for Governor in I816. W:n. lienderson to R. King, February 20, 1816, King Corrspondence. Judge Ford's Federalism was so well known that when in the sack of Ogdensburg in the War of 1812 . his honse escaped pillage, wise-acres drew an inference, see. Albany Irgus, April $9.18 \mathrm{I} 3$.

${ }^{2}$ Letter from William Raymond, Ksal., to the author. Benjamin Raymond was made "Judge and Justis" by the Federal Council of Appointment of I 813 . Albany Argus, Warch 5, 1813 .

${ }^{3} \mathrm{~F}$. B. Hough, op. cit. p. 594 .

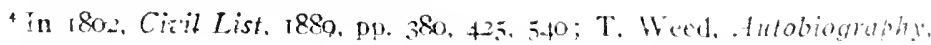
eic. p. 41 i.

Iough, or. cit.. p. 580 . 
piay his part in politics. ${ }^{1}$ Young lawyers like land agents contributed to build a modest aristocracy. ${ }^{2}$

But these were not all. The gentry who centered in the drawing rooms of those fashionable streets running eastward from Broadway, all had their coats of arms, and history of knights and squires and manor houses with widestretching acres in the counties of old England. ${ }^{3}$ To lord it over docile tenantry, and ride at hunt through one's owi forest, made up a part of what was most attractive in the family legencls of a storied past. It is not surprising, then, to see some younger sons of these land holders fascinated by the prospect of reproducing in open reaches of the north something of the dignity and spaciousness of the life of the country gentleman they so naturally admired. David $A$. Ogden, who had been the partner of Alexander Hamilton in law-practice, gave up his professional connection in $18 \mathrm{I} 2$ to carry into execution a plan which he had for some years cherished, to remove to the St. Lawrence, and fix his permanent residence on its beautiful shores. In pursuance of this, he built a fine and substantial dwelling on the island opposite the village of Waddington and commenced its improvement as a farm, which comprises nearly eight hundred acres. He was at this time in the prime of life and carried with him those tastes for rural employments, which he had imbibed in early life, which with his favorite literary pursuits, were well calculated to

1 Hough, op. cit., p. 586. A town was named for him. For various reasons Judge Fine subsequently became a Democrat.

${ }^{2}$ There is no attempt to prove here that all land agents or that all young lawyers from New York city were Federalists, but many who were of that tradition contributed, in association with the resident proprietors, to bring a political influence alien to the frontier spirit. Cf. F. J. Turner, The Significance of the Frontice in Anerican History (Madison, I894), pp. 27-29, where the frontier democracy is discussed.

${ }^{3} N$. Y. Gencalogical and Biographical Record, vol. v, pp. 115-118.

- In this he was associated with his brother. Appleton's cyclopioit of American Biography, vol. iv, p. 560 . 
render his residence agreeable, not only to himself, but to those who might associate with him. ${ }^{2}$

But the great stone house surrounded by its grove of maples was renowned not only for its gracious hospitality and atmosphere of an exotic culture; the plans of Federalisi politics were often there matured in council. The proprietor represented the county in the assembly two years after he took up his residence, twice was county judge and served a term in Congress. ${ }^{2}$ while younger relatives were prominent, Gouverneur Ogden as a Federalist congressman." and William Henry Vining, a nephew of the latter, elected to the assembly in $1821{ }^{4}$

The Ogdens in the splendid isolation of their island were not left to be the only county family; other names familiar in Federalist annals were to be transplanted to St. Lawrence. Soon after the close of the War of I 8 I 2 came the Clarksons, to improve their holdings by the Racquette River, "building noble houses, "Holcroft," "Homestead," "Woodstock," clearing forests into meadows reminiscent of the fields of Yorkshire whence their ancestors had come. ${ }^{6}$ Next came

${ }^{3}$ Hough, op. cit., p. 600 . See also Ogden-Ford papers, printed, in part, ibid., pp. 372-40r.

2 Civil List, 1882, pp. 302, 363, 451. He did not serve as senator, in spite of the misprint of his name for that of Isaac Ogden, the Democrat from Walton, N. Y., in the N. Y. Senate Journal, isi6, p. I. Cf. Civit List, 1882, p. 254 .

${ }^{3}$ W. W. Van Ness to R. King, January 31, 1816, King Correspondcnce. Gouverneur Ogden also served as Surrogate, Civil List, 1882, p. 370.

'Civil List, I882, p. 307, and Hough, op. cit., pp. 6r I-6r 2.

${ }^{5} \mathrm{G}$. Curtis, St. Lawerence County, part ii, p. 34; The Clarksons of New York (N. Y., I875, in the New York Genealogical Society Collection).

${ }^{\circ}$ W. W. Spooner, Historic Families of Ancrica (N. Y., I908), vol. iii, pp. 276-286. The Clarksons had begun early in land speculation, an entry in the Land Papers, p. 49, recording a title taken by Hatthew Clarkson, the immigrant, in 1697. 
the son and namesake of Richard Harison, the Tory-Federalist leader in the city of New York, ${ }^{1}$ laying out a manor house, with high wall and cobbled court, looking down upon the long rapids of the liver Grasse." Here he too strove to reproduce old England and give the country-side its atmosphere. I have before me a score of volumes from that portion of the family library which was so laboriously carried with wagon-loads of furnishings to the seat established in this country won so recently from wilderness. Mill's Husbandry," impressive in five volumes, and Patoun's Treatise on Suricying, these had no doubt been brought from old Berkshire, years before. with Pope and Gibbon; the poems of Si. John Honeywood and I. G. Brooks, they had bought as good New Yorkers; and in bound files of agricultumal magazines throughout the thirties the final phase is represented. Thus in a library we see the outline of a family history. Some miles to the south and west : spacious home was built by Henry Van Rensselaer, fourth son of the Patroon," and near Ogdenshurg there lived the Parishes, the friends of Gonverneur Morris. ${ }^{6}$ Though

'E. B. O'Callaghan. "Biographical Sketch of Francis Harison," N. Y. (icucalogical and Biographical Record, vol. ix, pp. 49-51: J. S. Ienkins. History of l'olitical Parties in Nezl Y'ork, p. 33 it seq.; Rob't Troun to R. King, April 4. I809, King Correspondence: X. $Y$. Civil List, 1850, pp. 124, 412. 413.

"The community that grew around this nansion they named Horley from a relative of the Harison fanily. J. H. French, Gazetter of the Statc of New York, p. 575 .

"Loncion, 1,65.

- Archibald Patoun, i Complete Treatise of Practical Varigation: ...to which are addid the useful theorics of Mensuration, Surrying, and Ganging (London, 1762).

6G. Curtis, St. Lawence County, p. 325. He served a term in Congress, I84I-I843, N. Y. Cizil List, 1889. p. 605.

- Morris, Diary and Letters, rol. ii, pp. 74. 380, 407, 415. 418, 431, 44. stc., ctc. The Parishes had come to America on Morris suggestion. 
themselves but indirectly interested in party struggles, they had many a line of influence that ran through the county from their homes-those mansions looking ont upon extendel parks and prim and formal gardens, lenced in by a long-remembered great brick wall over-grown with roses." Here President Monroe was entertained " and distinguished visitors from Washington, New Jork or Albany always stopped to spend a night or two in a gentleman's establishment of the traditional type." ".ll had an old baronial air, and one could easily imagine the entire place brongin bodily from some foreign country and set down in the midst of this quiet town."

So these families came, bringing in a spirit of aristocracy which left its mark, as we have seen, upon the county politics. That now they have for the most part disappeared adds a tonch of pathos to the story. Theirs was a spirit foreign to the custom of the comtry; while others made their way into the wilderness to be rid of every vestige of the feuclal system, these came to perpetuate so much of that tradition as conld be saved. But the aloofness of this gentry. so proper to their social theory, could not be comfortably preserved, and, bound by an inflexible endogamous rule. these branches of the families slowly withered and passed into memory, though leaving after them an influence that increased respect for " the few, the rich and the well-born."

But it should not be thought that St. Lawrence County was singular in these respects, or has been unfairly taken as a type. Change the names of Ogdens and their town of

1 Curtis, of. cit., p. 153.

$=N . Y$. Times, June 7,1903 .

${ }^{3}$ Curtis, loc, cit.

${ }^{4}$ H. G. Spafford, Gazetteer of the State of New York (Albany, 182.1), p. 404.

${ }^{5}$ Curtis, op. cil.. p. 35 . 
Ogdensburg for the Platts and Plattsburg, ${ }^{1}$ or trace the fortunes of the Lows of Lowville, settled by the son of Nicholas Low, ${ }^{2}$ or of their neighbor, Moss Kent, brother of the chancellor, ${ }^{3}$ or of William Henderson, whose lands lay along the shore of Lake Ontario ; ${ }^{4}$ turn to the three LeRoys, brothers-in-law of Daniel Webster, ${ }^{5}$ who gave their name to a town near the Genesee ${ }^{6}$ and the same condition is observed. Instead of Nathan Ford insert the name of Egbert Benson. Jr., as land agent, or that of Colonel Robert Troup, who at Geneva managed the great Pulteney estate, and who bore a leading part in the Federalism of New

${ }^{1}$ D. M. Hurd, History of Clinton and Franklin Counties (PhilaJelphia, 1882), pp. 149-156, 176. Zephanial Platt settled here, bringing his family and slaves in I8OI. The town had been founded under his direction about twenty years before, see $N$. I. Assembly Jorrmal. $1792-1793, i \% .4$.

${ }^{2}$ F. B. Hough, History of Lewis County, pp. 135, I37, I42, 163; also DeWitt Clinton to Cornelius Low, November 25, I820, Clinton Mss. (Letterbook V).

${ }^{3} I$ lbid., p. I63. Jenkins, Political Parties, p. 7I, and N. Y. Genealogical and Biographical Record, vol. iv, p. 85.

"Henderson was an important politician in $\mathrm{New}$ York having been the party candidate for assembly in 1807 ( N. Y. Spectator, April 2z, 1807) and for Congress in 1808 (Albany Gazette, April 25, 1808). He settled in what is now Jefferson County, F. B. Hough, Lezris County, p. Sz.

${ }^{\circ}$ G. T. Curtis, Life of Danivl W'bster (N. Y.. I87o), vol. i, p. 345.

${ }^{6} \mathrm{~F}$. W. Beers, Gazetteer and Biographical Record of Genesee Counly (Syracuse, I890), p. 480. Daniel LeRoy was the son-in-law of Nicholas Fish, M. A. Hamm, Famous Fumilies of New York, vol. i. p. 139 .

i He was the nephew of the famous Federalist judge, and became a man of importance in the west. F. W. Beers, loc. cit.; letter to DeWitt Clinton, December 30, 18I8, Clinton Mss.; to P. G. Childs. February 5, 1822, Childs Mss.: and to John Tayler, Miarch 1., 1815. Tayler Mss.

"O. Turner, History of the Pionecr Scttlenent of the Phelps and Gorham Purchase (Rochester, I\$51), pp. 279-280. 
York, ${ }^{1}$ and the story is repeated, varying in details but broadly similar to that we have rehearsed. Sometimes, as with the stock of General Jacob Morris" who, like General North of Duanesburgh, ${ }^{3}$ had gone inland to improve his family hoidings, an offshoot was sent far to the westward to reprodice in a second and a third series, as it were, the landed gentry of New York. ${ }^{4}$ The Morrises had increased their grant so that when the General made his slow way up the Susquehanna valley as a herald of civilization, his share amounted to five thousand acres." Setting his slaves ${ }^{6}$ to fell the trees and saw them into boards, he built a home in what became the town of Morris, and then turned much of his attention to the politics of that young country. He was the first Otsego County clerk, served three years in the assembly and four years in the senate of the state. In the early days of the new century the county was the scene of bitter struggles at elections. ${ }^{8}$ Jedediah Peck, the shrewd itinerant preacher, organized the new democracy, while General Morris and Judge Cooper were the Federalist leaders. ${ }^{2}$

${ }^{1}$ His name headed the Federalist nominations for presidential electors in $1812, N . Y$. Senate Journal, 1812, p. 23. There were of course some Republican land-holders and land agents, but they were not numerous.

'M. A. Hamm, Famous Families of New York, vol. ii, p. 34.

'Ibid., vol. i, p. 123, and Appleton, op. cit., vol. iv, p. 534.

- History of Danc County, Wisconsin (Chicago, 188o), p. 1016. W. A. P. Morris, son of General Jacob, went to Madison, Wisconsin, in 1870 . His daugliter married and went to live in North Dakota.

${ }^{5}$ E. F. Bacon, Otsego County (Oneonta, 1002), p. 32.

${ }^{6} \mathrm{H}$. Child, Gazetteer of Otsego County (Syracuse, I8;2), p. 79. for examples of manumission.

${ }^{\top} N$. Y. Civil List, 1889, pp. 373, 374, 414, 539.

${ }^{8}$ See Political Wars of Otsego County; or the Downfall of Jacobinhism, pamphlet (Cooperstown, 1796).

${ }^{9}$ F. W. Halsey, The Old New York Frontier (N. Y., IgoI), pp. $365-367$. 
William Cooper was the mirror of partisan perfection as a Federalist squire. ' Coming north soon after the RevoIution, he became the master of great estates but vaguely bouncled: when the country grew in population he recalled with honest pride that " there were 40,000 souls holding land, directly or indirectly, under me." In ISoo he set up a claim to having placed the plough upon nore acres than any other man in all America." Having bronght his family and a retinue of slaves and other servants, numbering fifteen. " he built Otsego Hall, a great rectangular stone house with castellated roof and gothic windows," surrounded by box hedges and wide lawns trimmed precisely by black gardeners, far surpassing any other home in the old west." This was the citadel of Fedalism and the council-place of party methods for the Otsego country, for not only did Judge Cooper serve nine years as first judge of the county and two terms in Congress, ${ }^{6}$ but he rode far and wide in the cause of Jay and later Aaron Burr. always preaching the old and musty

1 Ulike all others mentioned in this chapter he came from New fersey rather than New York city and the near-by counties, but he represents the same trend in all particuiars.

${ }^{3}$ See quotations from letters in F. W. Halsey, op. cit., pp. 359. 360, ctc.

${ }^{3}$ S. M. Shaw, History of Cooperstown (Cooperstown, I886) and Malsey, of cit. p. $35^{8}$.

- This was built in 1799. taking the place of the so-called manorhouse whicl was the original home. Views of its exterior and interior may be seen in the volume of the Cooperstown Centennial (Cooperstown, 1908), and Halsey, p. 362, and especially in Mary E. Philips' copiously illustrated James Fenimore Cooper (N. Y., I9I3). The grounds are now the village park.

s. T. Livernore, History of Cooperstowe (Albany, 1862), pp. 45-45. The Hall was built on the lines of the Van Rensselacr manorhouse, where Cooper was a frequent visitor, but seems to have surpassed its model, Philips, of cit., p. 8.

"N. Y. Cizil l.ist, I881, pp. 359.446. 
doctrine that government had better be left to gentlemen. and that simple folk should vote as they were told.

The influence of this squirearchy was thus sucially contservative, looking backward to the Tory models across the sea: and in no particular, perhaps, was its expression more clear and unmistakeable than in its cherishment and patronage of "the Episcopal mode of worship, so iriendly to Government, so hostile to Jacobinism." " Let us turn again to the Federalist families we have cited as examples. The Parishes, as true English gentlemen, laid out a plot for the churchyard and a little glebe, and were the principal contributors to an edifice and an endowment." The Ogdens. long vestrymen of Trinity, set up a modest church in the hamlet by their island. ${ }^{3}$ The Clarksons, who in New Yor's city had likewise worshipped there for generations, erected near their homes another Trinity, now beautified by rich memorials of the family. ${ }^{4}$ The Harisons, descended from the comptroller of the mother parish, built another of that nane at Morley." The year that young Connelius Low arrived in Lowville, another Trinity was begun. " The LeRoys, far to the westward, endowed their St. Mark's with land and money, ${ }^{7}$ while their neighbor, Colonel Troup.

'Robert Troup to Rufus King, King Correspondence, vol. v, p. 37.

"Curtis, St. Lawerence County, p. 383 .

"M. Dix, The Parish of Trinity Church in the City of New Fork (N. Y., 1905), vol. iii, p. 30 , extracts from the parish minutes wherein aid is promised for its support. The Ogders were among the founders of the Protestant Episcopal Society for Promoting Religion and Learning in the State of New York, see Appleton, loc. cil.

${ }^{4}$ Curtis, op. cit., part ii, p. 34. They also built and patronized churches in near-by towns.

${ }^{5}$ M. Dix, op. cit., vol. iii, p. 429 ; Curtis, p. 459 .

${ }^{6} \mathrm{~F}$. B. Hough, History of Lozeis Connty', pp. 137, 150. The date is 1818.

'F. W. Beers, Gasetteer and Biographical Record of Geinser Coustas. pp. $480,491$. 
was a steadfast champion of Episcopal tradition and amon's the founders of Geneva College (later Hobart) where it; ministers were to be trained. ${ }^{1}$ In Otsego County the two Federalist leaders were likewise the supporters of the church. Judge Cooper was chiefly instrumental in building: up its influence in the town that bears his name and sent his son, the future novelist, to the old Tory rector of St. Peter's in Albany for a schooling that no one nearer was thought fit to give. ${ }^{2}$ General Morris, as a zealous Anglican built a church in I 80 I to make provision for his parish in the town that bore his name, continuing its leading patron; and his children at the home, some distance from the village, set up a memorial chapel. ${ }^{3}$ There is no intention here to prove the old English church a school of Federalism, yet that cast of thought which for three hundred years had made a poin' of holding "it to be the duty of all men who are professors of the Gospel to give respectful obedience to the Civil Authorities, regularly and legitimately constituted " could not have been hospitable to the doctrines of the Constitution of $182 \mathrm{r}$. It is safe to suppose that not many Jacobinical Democrats were confirmed as Bishop Hobart made his round of visits. ${ }^{5}$

All the families we have instanced were important in the party of the state: among the Federalist nominations for the electors of i8i6. for example. are found the names of Jacob Morris, William North, Matthew Clarkson and

${ }^{2}$ M. Dix, op. eit., vol. iii, p. I97; see also many letters from Troup to Rufus King on church matters, King Correspondence.

$2 \mathrm{~S}$. T. Livermore, History of Cooperstown, p. 5I; T. R. Lounsbury, Life of James Fenimore Cooper (Boston, I882), p. 6; and letter from the Reverend Ralph Birdsall of Cooperstown, N. Y. to the author.

${ }^{3} \mathrm{H}$. Child, Gazetleer of Otsego County. pp. $111-113$.

"Articles of Religion, XXXVII, Book of Common Prayer.

see M. Dix, op. cit., Hobart Correspondence in vols. iii and iv, for the extent and numbers of these visits. 
Gouverneur Ogden." At home this landed "quality" stoon as reminiscent Catos praising, in a day of innovation, the older stable English way. Slowly but surely this influence of conservatism was distributed through the counties of the state, contributing somewhat, it cannot be doubted, to cheik the spirit of democracy," and affording support respectable in character if not great in its extent, to the party that traced its evolution under Joln Quincy Adams. Henry Clay and William Ienry Seward.

A hundred years ago throughout the countryside men were still described as Gentlemen and Yeomen; ${ }^{3}$ the social and political prestige of landed property, of the "proud, polished, and powerful aristocracy deep-rooted in the soil," " was a familiar fact to be decently acknowledged as a beneficent provision for the welfare of the race. Judge Cooper's son, the famous novelist and the heir of this prestige, in the preface to The Chainbearer, his story of the anti-rent disturbance, adverted to the dangers that must follow in the train of any change:

The column of society must have its capital as well as its base. It is only perfect while each part is entire, and dis-

${ }^{1} N$. Y. Senate Journal, 1816-1817, p. 16.

"Of course their kind of settlement was but partially similar to the Hudson River manors. Lands were sold for profit in fee simple, instead of held in lease with annoying dues. Hence settlement was encouraged, not retarded, by the presence of these proprietors, since they offered opportunities that self-respecting Yankees could embrace without disgrace. Cf. F. J. Turner, The Old West (Madison, 1909), pp. 195-198, and his authorities, for a discussion of the effect of feudal tenures and the exploitation of the settlers.

${ }^{3}$ See, for example, the certificate of admission to the bar of Dominick I. Blake, the friend of Hamilton (see signatures on Hamilton's will, Hamilton, Works, Lodge edition, vol. viii, p. 634), preserved in the Emmett Collection in the New York Public Library, Document II310; a deed, ibid., Document II337, and numerous deeds in the Schuyler Mss., Land papers.

"Theodore Roosevelt, Gouvermeur Morris (Boston, I8gr), p. I4. 
charges its proper duty. In New York the great landholder: long have, and do still, in a social sense, occupy the place of thicapital. On the supposition that this capital is broken, and hurled to the ground, of what material will be the capital that must be pushed into its place! We know of none half so likely to succeed, as the country extortioner and the country usurer! We would caution those who now raise the cry of feudality and aristocracy, to have a care of what they are about. In lien of King Log, they may be devoured by King Stork. ${ }^{1}$

But the influence extolled, and often properly enough, as so kindly and paternal, might not be exerted with the finest scruple and could be bent to purposes sinister indeed. As to how these great Federalist landlords could play an ugly pari in politics if so disposed, no better example conld be found than in the case of Judge William Cooper.

In I792 an . Inti-Federalist legislature saw fit to notice some of his irregularities, in the conduct of late elections in his county, with a resolution for impeachment. ${ }^{2}$ Scores of atdresses and petitions were received, and the major portion of the time of the assembly for a weary month exhausted in the examination of the witnesses. Although no sufficient evidence was found to warrant his removal as an official, enough was learned to leave no doubt as to what might be accomplished by a great landlord with teinants in arrears. One testified that the judge "had been round to the people and told them that they owed him, and that unless they voted for Mr. Jay, he would ruin thenı." "Judge Cooper then said to me," testified another, " what, then, young man, you will not vote as I would have you-you are a

'J. Fenimore Cooper, The Chaisbearer (N. Y., 1846), pp. viii-ix.

${ }^{2}$ N. Y. Assembly Journal, I792-1793, pp. I40, I41, 145, I46, I49-152, $155,156,170,184,186,204,206,240,244-246$ (citations are given in full as the Journal is not indexed). The Federalists by a virtually solid vote did what they could to prevent the inquiry, but without avail. ibid., p. 150. 
fool. young man. for you cannot know how to lote as weil as I can direct you, for 1 am in public office." "He was a testy and choleric gentlenan easily wrought into passion, and his debturs, knowing that he took his politics as a serious husiness, were constrained to form opinions on his model. It was thought that seven hundred rotes wern brougint into the Federalist columm by this squire's well- upprorted threats.'

() f comse not every landlord took these high-harder means. In the campaign for the election of governor it. 1801. some over-zealous friends of the Patroon. who led the forces of the lederalists, gave out that those of the tenantiy of Rensselaerswyck who owed for rent, of which there were probably thousands, would be prosecuted if the railed to cast their ballots for the manor-lord. Credulity was nothing strained by this report, but Steplien Vais Rensselaer won wide praise for generosity by publishings assurance that no such proscription was intended. "After such a noble and magnauimous declaration." wrote Judge Hammond, who was much impressed. "I an not at all surprised that in the county of. Mbany the patroon received two thousand one hundred and thirty-cight rotes, while Gov. Clinton received but seven hundred and fifty-five." -

${ }^{1}$ N. Y. Assembly' Jourhal, 1792-1793, pp. 186-187, 189, 191. 193. Judige Cooper's partisan activities were not estopped by this publicity. We later hear complaints of his having gerrymandered ()tsego County, J. D. Hammond to Martin Van Buren, January 23, 1816, Van Buren Mss.

2J. D. Hammond, Political History, vol. i, pp. I6I-I62. In the campaign of $\mathrm{IS}_{3} 3$ when Van Remnselaer ran for governor, a letter was raked out of some private fle, which had been written twenty years before during the campainn of 1793 . The Federal $A . Y$. Comusercial Adertiser, April 23, 1813 , quoted the Albany Register as follows: "It purported to offer to such of his tenants as were his 'real friends," the remission of his 'quarter sale' privilege or right; and will anyone deny that he had not the right of doing what he pleased with his property? And will anyone have the hardihood to censure a landlord for a measure calculated to ameliorate and improve the condition, and promote the happiness of his tenants?" 


\section{ARISTOCRACY IN THE POLITICS OF NEW YORK}

At any rate, whether from admiration, fear or gratitude, the tenants of the Van Rensselaers had uniformly been accustomed to select the proprietor. some member of the family, or some designated friend, to represent them in the legislature. ${ }^{1}$ and for more than half of the first forty years of the republic a Van Rensselaer sat in Congress as the member for the district of the upper Hudson. ${ }^{2}$ Such was this family influence that in I82 I Judge Van Ness could write to General Solomon Van Rensselaer:

I saw the Chancellor [James Kent] yesterday and had a long talk with him on the subject of the Convention. I am authorized in saying that if you think proper to nominate him as one of your candidates, he will not decline. We all here think he ought to be in the convention and I hope you will send him if you can. ${ }^{3}$

The influence of the land-holders, however, did not operate alone in the fear or loyalty of tenants. Limitations on the suffrage in America, as but a hasty view makes clear," have been removed with much delay and hesitation;

'D. D. Barnard, Discoursi on the Life and Serices of Stephen Van Rensselaer, with an Historical Sketch of the Manor of Rensselaeriyck, pamphlet (Albany, 1839), p. 68. Mr. Barnard speaks especially of the colonial period, but the practice was continued. The $N$. $Y$. Ciril List, $18 \&$, p. 742 , has nearly a column of the names of offices held by the Van Rensselaers.

2"It is mentioned as illustrating the influence formerly exercised by the Dutch landed proprietors that during the first forty years following the organization of the federal government under the Constitution (from 1789 to 1829 ) the district embracing Albany was represented for iw'nty-two years by gentlemen bearing the name of Van Rensselaer and connected with the family of the Patroon, that is to say Jeremiah Van Rensselaer, two years, Kilian K., ten years; Solomon and Stephen ten years in the aggregate." Mrs. C. V. R. Bonney, A Legacy of Historical Gleanings, vol. i, p. 393.

3 W. W. Van Ness to Gen. Solomon Van Rensselaer, May 16, 182I; Mrs. Bonney, op. sit., vol. i, p. .367 .

'C. A. Beard, Ancrican Politics and Government (N. Y., I912), 1P. \&-1i. 
that the holding of real property was indispensable in making a wise citizen was generally believed throughont our thirteen colonies." When the suggestion of equality of rights that followed irom the Declaration of Independence expressed itself in new demands for the extension of the suffrage, the conservatives, the Federalists, made firm remonstrance. Gouverneur Morris speaking in the convention of 1787 warned his colleagues that any innovation hers was fraught with peril. "Give the votes to the people who have no property," said he, "and they will sell them to the rich who will be able to buy them." " Apparently as long as suffrage was restricted to the holders of the land, virtue would retain her throne; this was an article of faith with those who took their stand against democracy. "It is impossible," saici Chancellor Kent, long after," "that any people can lose their liberties by internal fraud or violence. so long as the country is parcelled out among freeholders of moderate possessions, and those freeholders have a sure and efficient control in the affairs of government." No one

'A. E. McKinley, The Suffragc Franchise in the Thirtecn Englisit Colonies in America (U. of Penn., Philadelphia, 1905), passim; see pp. $208-226$ for the discussion of the franchise in colonial New York. "In New York City in the elections of $1735,176 \mathrm{I}$, and 1769 , the actual voters numbered about eight per cent of the population." This was a much larger proportion than in many other colonies, p. 487. That in the country districts of New York must have been considerably smaller, as the Constitution of 1777 allowed the franchise to all of the "freemen" of New York city and Albany (Article VII) among whom there were mechanics and others without real property while all landless men outside these cities were excluded.

'Max Farrand (editor), The Records of the Federal Coniention, vol. i, p. 545. Several other times he advocated a freehold qualification for the vote for congressmen, ibid., vol. ii, pp. 20I, 202, 207, 209. See also J. Allen Smith, The Spirit of American Govermment (N. Y., I 907 ), p. 37.

${ }^{3}$ Carter, Stone and Gould, Reports of the Procecdings and Dibates of the Concention of 1821 (Albany, 182I), p. 220 . 
may doubt that both these gentlemen and many others of their party, spoke from the conviction of their hearts; no doubt they felt that universal suffrage would be the fertile cause of all electoral chicanery: yet when the chancellor delivered his memorable defence of the old qualification, experience had shown that this alone had not provided against human weakness. Landholders in New York state while this qualification was in force, ${ }^{1}$ were no more severely upright than their prototypes across the sea.

The student of the elective franchise as it developed in England is familiar with the practice known as "fagot holdings," whereby the wealthy politician, possessed of many acres in his county, was wont to cut them into strips. more or less exactly equal to the qualifications of a voter. and then carefully assign them to his landless neighbors, to make them legal and indubitable freemen for the three or iour days of election only. Such practices, of ancient origin, became the subject of considerable legislation as late as i 832." The example of these squires had not been lost.

The Constitution of 157 provided that the senators, governor and licutenant-governor were to be chosen indirectly by freeholders "possessed of frecholds of the value of one hundred pounds, over and above all debts charged thereon," F. N. Thorpe. Federal and Statt Constitutions (50th Congress, Hnuse Document. No. 35\%, Washington. ro09), vol. $1.1 \%$. 26.30, 2632. (Articles $X$ and XVII). To vote for member of assembly, and hence for congressman, one "slall have heen a freeholicer, possessing a frechold of the value of twenty pounds, within the said county, or have rented a tenement of the yearly value of forty shillings." and becn rated and actually paid taxes to the state, Article VIl, ibid.. p. 2630 . The pounds referred to are in the American estimation, not English, and hence the sums are to be understood as two humired and fifty dollars and fifty dollars respectively se C. 7. Lincoin. Constitutional Hisfory of liew York State, rol. i. p. 0.40 .

E. g. Act $7 \& 8 \mathrm{Wm}$. I11. c. 25: 10 Ame. c. $23 ; 2 \& 3 \mathrm{Wm}$. IV, c. 45 $\therefore$ 2o. The abuse has been lefined as "conveyance not intended to give any real interest. made for the purpose of a particular election. and 
Martin Van Buren has left a reputation for a matchless erudition in the devious ways of party management. In his younger days he served out a novitiate as a local leader of Clintonians. ${ }^{1}$ later his implacable foes, with a success that marked no ordinary promise. In his native county of Columbia, however, he found one practice in which his Federalist rivals, land owners as they were, could easily excel. His summary sent to his chief aiter the election of I 8 IO is worthy of quotation: ${ }^{2}$

I have once more with shame to inform you that this county has given 527 majority for Platt \& about the same for assembly \& Congress-all the made voters voted for assembly \& Congress-if you will look at the Voters between this year \& last you will find that there have been rising of 600 votes made in the County of which our friends made about one-third-in Chatham our friend Dorr after he had made about a Dozzen got one of the Judas Brecd into his Camp who gave up his Deed to the Federalists - this broke us up there-in Claverack our friends made more than they did-in this city they made more than us- $\&$ in the lower town where we had no body to make or to be made they played the very devil with us-in the single town of Gallatin Robert LeRoy Livingston ${ }^{3}$ this

with an understanding that the property should be reconveyed where the transaction had served its turn." W. R. Anson, The Law and Custom of the Constitution, Fourth edition (Oxford, 1909), vol. i. pp. Io6, 127. The Act of $1832,2 \& 3 \mathrm{Wm}$. IV, c. 45 , required that property cited in qualification should have been held a year.

${ }_{1}^{1}$ That is from 1807 to 1813 ; E. M. Shepard, Martin V'an Buren (Boston, I888), pp. $45-59$.

'Martin Van Buren to DeWitt Clinton, April 28, 1810, Clinton Mss. If President Van Buren kept a copy of this letter it may not be surprising that he did not include it among the papers he desired to be preserved, cf. Calcndar of Van Buren Manuscripts (Washington, Igro).

${ }^{3}$ The Livingstons, of course, as a family had left the Federalists in 1790. "It is, however, to be remarked, that some of the Livingstons who resided in Columbia County, did not change with the shancellor, but continued their adherence to the federal party." J. D. 


\section{I46 ARISTOCRACY IN THE POLITICS OF NEW YORK}

morning admitted to me that he had made $190-$ Elisha Williams ${ }^{1}$ was there during the whole election to fill up the Deeds-So that upon the whole we have reason to felicitate ourselves it is no worse. . . [ [Here follows a sentence difficult to decipher claiming, apparently, that the Fedalists had sent in eight hundred deeds] . . . I am sorry for Columbia but have done all I could-King George has issued too many pattents for us. If some friends had laid off their scruples earlier we would have reduced their majority to about 250 which is all they are honestly entitled to.

King George having " issued too many pattents " to the aristocracy, the Federalists could make two fagot voters where their humbler rivals could make one. Republican solicitude at their success-for the practice was probab!y well known in more counties than this one ${ }^{2}$ - was no doubt a motive in carrying through a law at the next session of the legislature, entitled "An Act to prevent Frauds and Perjuries at Elections," etc. ${ }^{3}$ To discourage this kind of manufacture it specified that anyone offering to vote for governor, lieutenant-governor or senator, who fell under the suspicion of the inspector at the polls, must swear that he was

possessed of a freehold in my own right, (or in the right of my wife, as the case may be) of the value of two hundred and fifty dollars, within the state, over and above all debts charged thereon, and that I have not become such freeholder fraudu-

Hammond, Political History, vol. i, p. 107. Robert LeRoy Livingston was one of these, Albany Gazette, May 2, 1808; he served as congressman from 1809 to 1813 , see $N$. Y. Civil List, I889, p. 603.

'See supra, ch. ii.

2 For two examples of how the Republicans had themselves used this device in the campaign of 1801 , see Barrett. Old Merchants of Nerv York, vol. i, p. 28I, and E. Vale Blake, The History of the Tammany Society (N. Y., 1901), pp. 50-51.

${ }^{3}$ Laze's of the State of New York, Thirty-fourth Session (1811), p. 287. 
lently, for the purpose of giving my vote at this election, nor upon any trust or understanding, express or implied, to recol1vey such free-hold during or after election ... and further, that I will true answers make to any interrogatories which shall be put to me by inspectors of election, touching the situation and boundaries of such freehold, from whom and by what conveyance I derive title to the same.

But it was in the voting for the members of assembly (and by that same test for Congress), where the property qualification was much lower, that most trouble was expected. Here the provision was still more exacting; the voter must take oath that "I am and have been for six months next and immediately preceding the election, a freeholder, and am possessed .. . of the value of fifty dollars." It was thought unlikely that any landholder would give up six months' rental that the Federalist vote of his district might be enlarged.

For it was the Federalists who feared the operation of the law; theirs they recognized to be the loss if voters were no longer to be "made." When the proposition came before the senate, Judge Platt, aware how hopeless would be any opposition to the bill against the immovable Republican majority, catching at what straws he could, moved a proviso " that it should not take effect until after the next election." " Possibly in this way one year, at least, might be salvaged. But the majority must have smiled at such a hope; the proviso was supported by eight senators, of whom all but one were Federalists. ${ }^{2}$ When the act was passed the seven who stood fast against it were Hall, Hopkins, Paris, Phelps, Platt. Stearns and Williams, all men of the old party who had been elected in the great revolt of 1808

${ }^{1} N . Y$. Senate Journal, 181 i, p. 163.

${ }^{2} I b i d .$, p. 164 . This minority constituted nearly one-third of the members present. 
and $1809 .^{1}$ In the assembly there was a similar alignment. $^{2}$ The landholding Federalists had done what they could to save a useful practice, but the Zeitgeist had gone on. ${ }^{3}$

The Federalists as landlords found their largest common interest in the projects for the inland waterways which would enhance the value of their property throughout the siate. Intelligent observers had early seen great possibilities. Washington had written in the first year after the Revolution:

I then traversed the country to the head of the eastern branch of the Susquehanna, and viewed the Lake Otsego, and the portage between that lake and the Mohawk River at Canajoharie. Prompted by these actual observations, I could not help taking a more contemplative and extensive view of the vast inland navigation of the United States... [and] the goodness of that Providence, which has dealt her favors to us with so profuse a hand. Would to God we may have wisdom enough to improve them. ${ }^{4}$

'J. S. Jenkins, History of Political Parties in New York State, pp. 126. I31-133. Robert Williams had been chosen as a Republican, but after his election as a member of the Council of Appointment he had uniformly acted with the Federalists. thus giving them a majority, and was henceforth called an apostate by his former party, Jenkins, pp. 121, I33. Williauns, unlike the others, had been elected in 1807 . For party affiliations see also the $N$. Y. Seute Journal, I811, p. 196.

"N.Y. Assembly' Journal, I8II, pp. 315, 360.

"It is probable that the practice did not entirely disappear, until the extension of the suffrage in 1821. "Tammany [in 1820] charged that in the construction of the Erie Canal, land had been cut up in slips to make additional voters for Clinton and cited the county of Genessee [sic], which, though polling but 750 freehold votes in 1815 , gave nearly 5,000 votes in this election." Gustavus Myers, The Histor of Tammany Hall, p. 66, note; Myers cites no authority for this statement.

${ }^{4} \mathrm{G}$. Washington to the Chevallier de Chastellux, 12 October. 1783. Horks (Ford edition), vol. x, p. 325. See also his letter of the same tate to Iafayette, loc. cit. Elkanah Watson, who claimed to be the 
But for the statesmen or the capitalists who had witnessed only the first steps in our national development, nothinis was harder than to take a "contempiative and extensive view" of the improvement of other people's land at the general cost to taxpayers. Perhaps even the Father of his Country found this enthusiasm easier when he recalled his property between the ranges of the Alleghenies. ${ }^{1}$ Though a liberal interpretation of constitutions, state and nationa!. was needful to the policy of internal improvement by appropriation from the public chest. Federalists, as sucil. were not of necessity committed to these schemes. It was not until New England saw her destiny in manufactures. and recognized the need of quicker transportation for the bales of raw and finished goods carried back and forth to pay her dividends, not until the presidential speeches of John. Quincy Adams, that the old Federalists of Boston voted for canals and turnpikes in the regions far beyond the fall line. In 1817 , in Congress, when Calhoun's persuasive prophecies almost carried through the principle in its most liberal application, the Federalists from Massachustts votel no. ${ }^{2}$ Cyrus King, the brother of the senator from New York, voiced their protest in a short and simple phrase: "The post roads of New England are now good . . . If they are not so elsewhere let those concerned make them so." 3 And thronghout the first and second decades of the century this was the attitude, in general, of the coastal cities toward the clamorous frontier. ${ }^{4}$

originator of the plan of a long western canal, says it was a conversation with Washington which tended to "kindle a flame in his mind" and start his explorations, E. Watson, History of Canals in New York State (Albany, I820), p. 9.

${ }^{1}$ See his Will, Works (Ford edition), vol. xiv, p. 283, and A. B. Hulbert, Washington and the West (N. Y., I905).

2 Annals of Congress, I8I7-I8I8, pp. 230, 398, 922, 1062. 3 Ibid., p. 914.

${ }^{4}$ Professor F. J. Turner has prepared maps (not yet published) showing how the favorable vote on such propositions steadily increases westward from the coast. 
On the other hand the Federalists of New York city and the Hudson River counties seemed more anxious for the progress of appropriations at Albany or Washington than were the followers of Jefferson, a fact of no small interest in accounting for their later coalition with the Clinton forces. They too engaged their fortunes on the sea, but not exclusively; unlike their fellow partisans of Boston they had lands to settle and develop. It was Gouverneur Morris in the tent of General Schuyler, one evening in the long campaign of Saratoga, who pictured the not distant day when connection would be made between the Hudson and those "great western seas." I Plilip Schuyler, shrewd, enterprising, public-spirited, was not a man to lose this vision; he became the Father of Canals in New York state, ${ }^{2}$ though to Morris goes the credit for the project of the Grand Canal itself. While on his visit to England in I 76 I Schuyler had seen the great canals that Brindley had but lately finished, and had been impressed with what such a work might mean connecting the Hudson near his home with Lake Champlain. $^{3}$ Learning of Elkanah Watson's plan of a canal between Lake Ontario and the Mohawk, in $1791,{ }^{4}$ he be-

' Jared Sparks, Life etc. of Gouverneur Morris, vol. i, pp. 495-504.

2In the New York Public Library there are preserved nearly a thousand pieces of his manuscript papers dealing with canals. General Schuyler's importance as a landholder needs hardly to be mentioned. There are preserved eleven boxes of his land papers, beside several volumes and many extra items. See also J. C. Hamilton to A. C. Flagg, July 26, I826, Flagg Mss. (Misc. Papers).

${ }^{3}$ B. J. Lossing, The Life and Times of Major General Philip Schuyler, vol. i, pp. 40, I80; vol. ii, pp. 464-47I. On his return he prevailed upon the governor Sir Henry Moore " to look into the matter of rendering the Mohawk River navigable by the construction of such canals as might be necessary to overcome the rapids at the Little Falls and elsewhere." H. W. Hill, "Waterways and Canals in New York State," Buffalo Historical Society Collections, vol. xii, p. 37.

${ }^{4}$ See E. Watson, op. cit. 
came the chief patron of internal improvements in New York. His efforts in the legislature produced "An act for establishing and opening lock navigation within the State," and he organized two companies to build canals to Ontario and Champlain, presiding over both."

Capital to sustain such large enterprises would naturally be sought within the "party of merchants and commercial men," ${ }^{3}$ but these might well have been as skeptical as the merchants in New England, had it not been for the landed interests of themselves, their reiatives and friends. Certainly these moneyed men of New York City did not hesitate. A partial list recording eighteen holders of the stock of these two companies is preserved with General Schuyler's papers. ${ }^{4}$ Besides the Holland bankers "we find mostly names of Federalist landholders, or their close associates. Robert Troup and Richard Harison lead with ten shares each. LeRoy

${ }^{1}$ Lawes of I792, ch. xl; see also David Hosack, Memoir of DelVitt Clinton (N. Y., 1829), Appendix S. The bill was managed in the assembly by John Williams, a Federalist from Washington County. See Elkanah Watson, History of Canals in Nezv York State and "Warren" (James Cheetham) An Antidote to John Wood's Poison, pamphlet, (N. Y., I802), p. 47, and C. H. Hunt, Life of Edward Livingston (N. Y., I863), p. 69.

${ }^{2}$ The Western Inland Lock Narigation Company and the Northern Inland Lock Navigation Company. The stockholders seem to have been almost identical, see Schuyler Mss., "Canals" box I. Schuyler proposed the route actually followed by the Champlain Canal, H. W. Hill, op. cit., p. I31. The report of 1792 of the "Committee to Explore the Western Waters...f for... Inland Navigation," is reprinted in the Documentary History of Nere York (Albany, 1850), vol. iii, pp. 659-67o.

"Levi Beardsley, Reminiscences (N. Y., I852), pp. II8-II9.

4 "List of Stockholders in the Western Inland Lock Navigation Company who have made payment agreeable to the requisition of the board of the IIth of April, I793;" the same for the Northern Company shows but two variations in names. Schuyler Mss. "Canal Papers."

${ }^{5}$ Of these there were four firms mentioned, naturally interestad in the western lands by reason of the Holland Purchase. See Journal of the Assembly of N.Y., I792-1793, p. 22. 
and Bayard, ${ }^{1}$ and Rufus King ${ }^{2}$ come next with five. Then John Lawrence, King's successor in the Senate, who was anong the most extensive landlords, ${ }^{3}$ and Gilbert Aspinwall, ${ }^{*}$ the wealthy merchant whose relatives held land." Other names, like those of William Inman who owned a inundred thousand acres in the north ${ }^{\circ}$ and Frederick Scriba whose vast holdings stretched along the shores of Lak Ontario," piece out the list; and as one turns over the voluminous correspondence, many Federalists of the same kind are mentioned as stockholders-General Abraham Ten Broeck, $^{8}$ Jonas Platt. ${ }^{9}$ Colonel I. Van Schoonhoven, ${ }^{10}$ Goldsborough Banyar (John Jay's son-in-law)." and

${ }^{3}$ They later donated 2,500 acres for the Erie Canal, and Robert Troup for Sir William Pulteney made also a large grant, S. H. Sweet. "Documentary Sketch of New York Canals," in Annual Report of the State Engineer, N. I. Assembly Documents, 1863, vol. i, p. 99.

${ }^{2}$ King became quite active, dispensing much of the company's money and planning with the engineers, see Schuyler to $\mathrm{Wm}$. Weston, February II, I793, and R. King to Schuyler, February 17, 1793. Schuyler Mss.

"Land Papers, pp. 503, 506, 55I, 560, 658, 668, 796, etc., etc.

4. A. Aspinwall, The Aspinarall Gencalogy (Rutland, Igor [?]), p. 72 .

${ }^{5}$ Land Papcrs, p. 689.

${ }^{6}$ Documentary History of Nere York, vol. iii. 1. 647.

'J. C. Churchill, History of Oswego County, see account of the town of Scriba, etc.

${ }^{\star}$ To Schuyler, June II, I793; Schuyler Mss. He was the Federal candidate for mayor of Albany in 1790, J. D. Hammond, Political History, vol. i, p. 48 .

${ }^{\circ}$ To Major de Zeug, May 21, 1793. Schuyler Mss.

10 B. Bleecker to Schuyler, May I7. I793. Schuyler Mss.; J. A. Roberts. Vew York in the Revolution (Albany, I\&g8), p. I20; Jenkins. Politicai Parties, pp. 63, 84, r30, etc.

${ }^{11}$ B. Bleecker to Schuyler, January I, 1793, Schuyler Mss.; IV. WV. Spooner, Historic Families of Amcrica, vol. iii, pp. 152, 163. For the lands held by Banyar, see Land Pafers, pp. 731, 736, 970, 1017, etc. He later turned Republican. 
Dominick Lynch, the founder of Rome, ${ }^{1}$ most of them large proprietors of land.

In the movement for the Grand Canal the initial step was taken by Gouverneur Morris. ${ }^{2}$ In $\mathrm{I}_{80} 3$ his plan recounter to scientists and engineers produced a deep impression, and began an enterprise which was later aided by the Clintons. That he held great tracts along the Genesee, and sought to interest others in their purchase. must have been a factor in his propaganda. ${ }^{*}$ His name came first among the original canal commissioners of I $810,{ }^{5}$ of whose report he was the author, ${ }^{6}$ and it was Morris who with Clinton went to Washington in a vain attempt to get a federal grant. ${ }^{7}$ But there were other leading Federalists who made common cause with him and

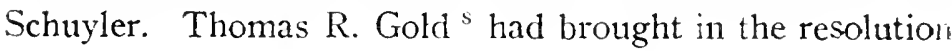

'To Schuyler, July 24, I792. Schuyler Mss.; Walter Barrett, Old Merchants of New York, vol. i, p. I7I. Diary of Philip Hone, vol. i. pp. 5, 18, 35, etc. Samuel Jones was also a stockholder, Jones to Schuyler, July 14, I792.

${ }^{2}$ His enthusiastic letter to John Parish, December 20, 1800 , is quoted in part by D. Hosack, Memoir of DelVitt Clinton, p. 252, et seq.

"By 1803 he was also projecting a shorter canal "from the head of the Onondaga River and carried on the level as far east as it will go, and, if possible, into the Mohawk River; then, in a direct course as circumstances will permit to Hudson's River, making locks as the descent may require." Diary and Letters, vol. ii, p. 390 . Clinton himself in a letter in his papers (no date) gives Morris credit for originating the scheme, Hosack, p. 30I, and A. B. Hulburt, Historic Highways (Cleveland, 1904), vol. xiv, ch. ii.

'F. W. Halsey, The Old New York Frontier, p. 370, and Sparks. Life etc. of Gouverneur Morris (To Jefferson, February 26, I79I, and December 2I, I792), vol. ii, pp. I2I, 249.

${ }^{3}$ N. Y. Civil List, 1889 , p. 224.

${ }^{6} \mathrm{H}$. W. Hill, “Waterways and Canals," pp. 72-73.

'Morris, Diary and Letters, vol. ii, p. 535.

* See Robert Troup to Rufus King, April 11, 1807, King Corresponience; F. A. Bloodgood to John Tayler, April 5, ISo4, Tayler Mss.: and supra, ch. ii. 


\section{54}

of 1808 looking toward a full survey ${ }^{1}$ and Jonas Platt revived the subject in the senate during his campaign as candidate for governor in r8Io," while the Patroon and Abraham Van Vechten carried through the measure in the assembly. ${ }^{3}$ Of the first canal commissioners four out of eight were Federalists and three Clintonians. ${ }^{*}$ Apparently the interest in such improvement, connected as it was at first with land values, had become a settled party policy.

When the war was over, at a great New York mass meeting that sought again to forward the canal scheme, William Bayard, the great Federalist proprietor, was the chairman." J. R. Van Rensselaer, the party leader from Columbia County, was the most active lobbyist at Albany ${ }^{6}$ for the canal, and sought the contract for its construction at $\$ 10,000,000 .^{7}$ Robert Troup was the most effective propagandist in the west, ${ }^{s}$ and Cadwallader D. Colden formed opinion in its favor in New York city. where support was sadly needed. ${ }^{9}$ In the assembly Judge Pendleton

${ }^{3}$ N. Y. Assembly Journal, I808, p. 297.

${ }^{2}$ N. Y. Senate Journal, 1810, p. 99 . " Be assured Sir, it will ever be to me a subject of just pride, as well as the most pleasing reflections, that I had the honor of coöperating with You in initiating and promoting our great system of internal navigation." Jones Platt to DeWitt Clinton, Oct. 4, I823. See also Thomas Eddy to Clinton, Oct. 4, 1823, DeWitt Clinton Mss.

${ }^{3}$ N. E. Whitford, History of the Canal System of the State of New York, N. Y. Assembly Documents, Igo6, vol. v, pp. 62-63.

${ }^{4}$ Gouverneur Morris, Stephen Van Rensselaer, DeWitt Clinton, Simeon DeWitt, William North, Thomas Eddy and Peter B. Porter. Only the last came to be known as a Tammany man, and he, in the 'thirties, became a Whig. See Follett Papers.

'See petition in New York Canal Laws, vol. ii, p. I22.

${ }^{5}$ N. E. Whitford, op. cit., p. 81.

'J. R. Van Rensselaer to DeWitt Clinton, March II, I8I7, Clinton Mss.

'Hosack, op. cit., p. 423; also see letters to DeWitt Clinton, Feb. 25, Dec. 3, 5, 9, and Jan. 13, 1819, Clinton Mss.

${ }^{9}$ Encyclopcdia Britannica, IIth edition, under Colden. 
(who had been Hamilton's second in the duel with Aaron Burr), IVilliam A. Duer, Abraham Van Vechten, T. J. Oakley, James Emott and especially Elisha Williams were leaders in support of the measure, while Lucas Elmendor and P. R. Livingston, two of the foremost Democrats, led the opposition. ${ }^{1}$ In the senate George Tibbits ${ }^{2}$ was its champion, and it was he who devised the plan adopted by the state to pay for the canal. ${ }^{3}$ When the vote of 1816 was recorded, said a broadside issued to the voters of the west. it was observed that but two Federalists had voted against the project, which received a treatment so unkind from their opponents. "The Federalists as a body have adhered closely to our interests." " In I8I7 no member of the party in the senate voted nay. No eleventh-hour repentance of the

'N. E. Whitford, op. cit., pp. 83, 93, 94.

${ }^{2}$ A Federalist from Rensselaer, see Jenkins, Political Partics, p. 171.

3 D. C. Sowers, Financial History of New York Statc (N. Y., 1914), p. 62.

"The Grand Canal Defeated by a Democratic Senate (in the collection of the New York Public Library). "The first step towards its destruction was a motion by Mr. Van Buren to strike out a large portion of the Bill which the House had passed-and the second was to form a new one, which leaves the business in a worse condition than if it had never been taken up.

"Will the electors support men who are thus regardless of their most important interests? It appears that but 2 federal senators voted in favor of Mr. Van Buren's motion to strike out the bill from the Assembly. The federalists as a body have adhered closely to our interests. To the permanent interests of the Western District especially. while the Senators from this part of the state have generally voted against them. Let us turn our attention to a different set of men." Van Buren later came to the support of a measure which proved so popular, and made a speech in its favor at the following session. He even for a time considered internal improvements at national expense. see C. E. Dudley to Van Buren, Dec. 23, 182I and I. C. Hamilton to Van Buren, Dec. 21, 1826, Van Buren Mss.

${ }^{5} N . Y$. Senate Journal, 1816-181 $\%$, cf. votes on presidential electors and on the bill, pp. 16,356 . The bill when passed was nearly vetoed 
Tammany leaders could erase this memory. ${ }^{1}$ So the Federalists, whose interest in canals had followed their concern in lands, won the gratitude of the western section. which, in contrast to its former practice, ${ }^{2}$ became a stronghold of the opposition to the Democratic party.

When other canals were projected it was to be expected that land-owning Federalists would be active in support. It was natural that Nicholas Low ${ }^{3}$ and Henry Remsen (once John Jay's private secretary) ${ }^{*}$ should desire their great properties improved, when the Black River Canal was proposed in Clinton's administration, and that mans wealthy members of the party in the city of New York should ask for the connection between Lake Champlain and the St. Lawrence, which the governor had so warmly ad. vocated." In 1824 a petition was presented in the interest

in the Council of Revision. The story of how Chancellor Kent flouted the advice of Vice President Tompkins, in voting for the bill, is to be found in William Kent, Memoirs of Chancellor Kent (Boston, 1898), pp. 168-1;0.

'The Tammany party " ridiculing as a ruinous and visionary project, the efforts which have been made for connecting our Atlantic seaboard with our great inland seas,-and when driven from their hold, by the torrent of public opinion, affecting to be all at once the great patrons of the undertaking, and seizing into their own hands its officers and its patronage." Broadside, Address to the Electors of Oneida and Oszergo (signed Bill Sinith, chairman, 2oth March I82I) in the New York Public Library; C. G. Haines to De Witt Clinton. Sept. Io, I819. Clinton Mss., and letters in I821, Childs Mss.

${ }^{2}$ See supra, ch. iii.

${ }^{3}$ Levi Peardsley, Reminiscences, p. 285.

${ }^{4}$ Henry Remsen had purchased heavily in the lower Adirondack region, see Land Papers, pp. 65I, 671, 725, 731, 743, 748, etc., D. E. Wager, History of Oneida County, p. I19, and M. A. Hamm, Fanous Families of New York, vol. ii, p. $;$.

${ }^{5}$ C. Z. Lincoln, Messages from the Governors (Albany, 1909), vol. iii, pp. 68, 69. See also N. Y. Canal Law's, vol. ii, p. 228, and H. W. Hill, op. cit., p. 146 . 
of this latter enterprise by certain citizens of the city.' Among its less than two score names there are those of many Federalists that can thus be easily explained. Richard Harison," Herman LeRoy," Daniel McCormick, "Thomas Morris, Garret Van Horne, ${ }^{6}$ Hezekiah B. Pierpont, ${ }^{7}$ R. M. Lawrence," Matthew, Thomas S. and Levinus Clarkson," Philip Brasher, ${ }^{10}$ Frederick Depeyster. ${ }^{1}$ LeRoy, Bayard and Co., ${ }^{12}$ Charles McEvers, ${ }^{13}$ Elisha Tibbits. ${ }^{1+}$ Henry Remsen and Nicholas Low. There were others who though not owning land in this vicinity were glad to give approval to the principle: for example Nicholas Fish, ${ }^{15}$ who at one time owned nearly fifty thousand acres in Broome County and much more beside, and Cormelius Ray, ${ }^{16}$ a proprietor of several square miles in Chenango. This list may help explain how it was that Federalists began a policy of large expenditure for such improvement in New York. Mss.

1 A copy is preserved among the Miscellaneous Papers of the Flagg ${ }^{2}$ See supra, ch. i.

${ }^{3}$ His family held land in St. Lawrence County, see Cr. Curtis. St. Lazerence County. part ii, p. 34.

"Land Papers. e. g., p. Ions.

5Ibid., p. 65 S.

${ }^{+}$Curtis, op. cit. p. 462 .

'F. B. Hough, St. Laurence and Franklin Countics. D1). T1,3-7.t.

*A relative of Senatur John Lawrence.

${ }^{4}$ Curtis, part ii, p. 34 .

10 Thurlow Weed, Autobiography. ets., vol. i, pp. 394. fol.

"J. H. French, Gazctteer of New York. p. 5z6: W. A. Duer. Reminiscences, p. 3\%.

${ }^{12}$ Ilough, op. cit., p. $\$ 29$.

1. Associated with LeRoy, Bayard and Co.

${ }^{14} \mathrm{He}$ and his family held land in this section. see J. H. Frencir: Gasetteer, p. 578 and Land Papers, p. 921.

${ }^{15}$ Land Papers, pp. 737, 810.

16id.. pp. 714. 720 . 
In this brief survey we have sought to trace the influence and counter-influence of the frontier and Federalism in Nerv York state. We have seen the venture of these old New Yorkers in the wild lands of the west and north, vast and princely in extent, and have heard their protest when that section of their party that saw hope alone in trade and manufactures, sought to fix the burden of taxation upon the land. We have followed friends and younger members of the families to new homes close beside the wilderness itself, and seen the strange distinction of plebeian and patrician in these far outposts of civilized society. We have seen them socially conservative-in manners, in religion and in the theory of politics-but bold in planning for industrial en. terprise; and heard them preaching the gospel of a generous development of the imperial resources of the state, which sounded to the ears of the mechanic and his party in the city, as vague, star-misty stuff. ${ }^{1}$ This interest in canals and waterways became a mighty factor in the fortumes of their party after it took on the names, Clintonian and Whig.

The enthusiasm of the Federalists in New York city and the Hudson Counties, for these artificial waterways, was not based wholly on their landed interest. Calculating business men. who foresaw the independence of this country in manufacturing, realized how such connectioil would contribute in transportation to and from the fields and markets. ${ }^{2}$ They understood the arguments that issued from the western counties, ${ }^{3}$ by reason of " the simpathy of

${ }^{1}$ National Adrocate, June 1o, 17, 24, 25, 27, July 10, August 4, 19, Sept. 6, 17, 1817; N. Y. Asscmbly Journal, 1818, p. 120.

2 Philip Hone is a good example of such Federalists; he was heavily interested in the Delaware and Hudson Canal, see letters to A. C. Flagg, January 9, 1827 and October 17, 1828, Flagg Mss. Miscellaneous Papers, and DeWitt Clinton to Philip Hone, October 6, 1826 , Clinton Mss. (Letterbook VIII).

3 It was certainly not surprising that the west should desire an improvement that raised the price of wheat fifty per cent before it was completed. D. C. Sowers, Financial History of Nerv York State, p. 60. 
mercantile pursuits and the friendship bred by dependence." 1 Yet at first, we have seen, it was probably their natural concern in the prices of the land they had for sale, that fastene their attention on these projects for development. We fin? five senators who represented New York state in Washington, the last three party candidates for governor, two score of leaders in the state, and their respectable supporters, foremost in the prosecution of canal construction. All were wealthy Federalists, and all, or nearly all, possessed of lands enormous in extent. It seems an inference not un. warranted, without uncharitably charging them with want of public spirit (since the common good was forwarded at once with theirs), that there was some connection in these facts.

The importance of this Federalist paternity for the canal schemes brought to final triumph by Clinton, transcends that of a mere episode. By reason of the issue often joined with Tammany on one side and their opponents on the other. there grew up in the western counties a doctrine that no good thing could come from counsels of the Democrats. Because the party of Schuyler, Morris and Van Rensselaer had served their interest far more faithfully than those who listened to the sachems in New York, they developed a habit of constant opposition to the latter's candidates. A decade or so later, when the Whigs took up the party struggle, in a manner more in keeping with the spirit of the time, but still imbued with Federalist traditions, these counties each November, quite regardless of gains and losses in the other sections of the state, voted their support with perfect regularity. Acting on the "friendship bred by dependence," the Whig leaders made it a cardinal point of faith, that the state should be internally improved though, as the Democrats maintained, it might entail a debt of forty millions. ${ }^{2}$

${ }^{1}$ T. N. Butler to DeWitt Clinton, March I2, I809, Clinton Mss.

${ }^{2}$ F. W. Seward, William H. Seward (N. Y., I891), vol. i, pp. 503-504. 


\title{
CHAPTER VI
}

\author{
Mr. Madison's War
}

GLliAN C. VERPLANCK was a disappointment to the older Federalist leaders. No one of the rising generation hal shown brighter promise than this young founder of the Washington Benevolent Society; his eloquence and energy. it had been supposed, were permanently dedicated to that party's cause. Hence it was with some concern that, in January, I $8 \mathrm{I}$, they read through a pamphlet signed by one "Abimelech Coody, Ladies' Shoemaker," known to be Verplanck. ${ }^{1}$ For here, against all usage, the ardent politicians of both sides were held up to an impartial ridicule in their raw-head-and-bloody-bones recitals of French spies. Old Tories and the Prison Ships. The pamphlet set forth that the simple shoenaker had won ten thousand dollars in a lottery and sought counsel as to how he might invest his "funs." A Federalist schoolmaster warned him solemnly against the Manhattan Bank: its president, he knew, was in the pay of Bonaparte. He had it recently from Dr. Dwight and Oliver Wolcott that a French spy had tried to sta!, sood Colonel Fish for fear if he became lieutenant-governo: he might remove the bank's French clerks. The school-

1 This is now a rare pamphlet. The full title is as follows: Letler to the Hon. Samucl L. Mitchill, M. D., Kepresentatize in Congress from the City of Nea York; Professor of Natural His. Ec. on the Danger of Putting Moncy into the U. States and Manhattan Banks, with Sindry Norcl Spcculations on Insurance Stock, Domestic Manufactures and the Best Mode of Iresting a Capital, "So as to Make Both Einds Mcet." The author has used the cony in the Library of the New York Society, endorsed as presented by "C. Clims, Gent. 22nd January i8ri." 
master advised him to put his money in the "Branch Bank" under Mr. Ray, but he was soon stopped by a Democratic friend who told him that the Bank of the United States was about to be blown up, as was proper since the cashier was a nephew of the Lord Mayor of London. He was prepared to risk his fortune in a ropewalk, when he heard the building had been burned by British agents. New York insurance stocks he understood were but the playthings of the French. In his extremity he thought of going into politics and possibly become a "congress-man, for $\mathrm{Mr}$. Baron Gaudenier says that's the best trade going."

This ridicule of the idea of a French party and this impertinent jibe at Barent Gardenier were resented by the Federalist papers.

Mr. Coody calls himself a Federalist, [wrote William Coleman in the Evening Post] because he votes on the Federalist side. and sometimes, I believe, contributes alms to the Federalist purse, but if honest Abimelech would go over to the other party at once, his open apostasy would be of more service to us than either his vote or his money, and for this plain reason, because he now has some little influence among certain Federalists, and he exerts it only to do mischief. ${ }^{1}$

The independence of Verplanck was all the more astonishing when one called to mind his Tory-Federalist ancestry, ${ }^{2}$ yet a trace of heresy might have been discovered in his oration of July 4 th, I809, when he had said that the protection of their rights conld always be confided to the common people. ${ }^{3}$ Perhaps it was the influence of Edward Livingston, with whom he studied for two years, that was

${ }^{1} N$. Y. Herald, April 6, 1811 .

"W. C. Bryant, A Discourse on the Life and Writings of Gulian Crommelin Verplanck, delivered before the New York Historical Society (N. Y., 1870), pp. 5-14.

${ }^{3}$ Supra, ch, iv. 
responsible for these developments; ${ }^{1}$ he was evidently out of patience with the stiff-necked Hamiltonians, and his democratic tendencies were soon to be dramatically revealed.

On the morning of the sixth of August, I8II. Trinity Church was crowded to the doors with relatives and friends of the seniors of Columbia College, who were that day to receive their degrees. Upon the temporary platform set up before the chancel were seated the professors, the president, and the doughty provost, Dr. John M. Mason, on whom, in fact, devolved the conduct of the college. ${ }^{2}$ One by one the young men, in balanced and sententious periods, delivered their orations on the glories of the arts or the message of the past, possibly without producing deep impression, until there came the speech of John B. Stevenson. He had been assigned to be respondent in a brief discussion as to the right of representatives to disregard instructions and, being a Republican in politics, it had been suspected that his zeal might outrun decorum. Acting under an old by-law of the trustees. certain of the faculty, which was almost wholly Federalist in sympathy, had examined the draft of his oration, and suggested a more temperate statement. They would not have their students, they declared, "pronounce any sentiments which might injure themselves or dishonor the institution." 3

${ }^{1}$ A correspondence was kept up between Verplanck and Livingston after the latter went to Louisiana, see Verplanck Mss. in possession of W. E. Verplanck, Fishkill, N. Y., also Biographical Address of Chief Justice Daly in Proceedings of the Century Association in Honor of the Memory of Gulian Verplanck (N. Y., I870), pp. 24-25.

2 J. H. M. Knox, “John M. Mason, S. T. D," in Columbia University Quartcrly, vol. iii, pp. 26-34. Dr. Mason preached the funeral sermon on the death of Hamilton (Morris, Diary and Letters, vol. ii, p. 352) and was first designated as the biographer of that statesman (King Correspondence, vol. vi, p. 165 ).

${ }^{3}$ Statement of the Faculty of Columbia College, N. Y. Spectator, 
But on Commencement Day, young Stevenson, to the consternation of the reverend gentlemen behind him, spoke right on without regard to any of their emendations. As he closed he was quietly advised by one of the professors that his degree could not be granted on that day. However when the parchments were distributed, egged on by certain friends, he came forward, but to meet refusal. Hugh Maxwell, a relative by marriage, ${ }^{1}$ leaped to the platform to voice a loud objection, and "a species of riot commenced, with hissing. clapping, and noisy exultation." 2 Verplanck now ran forward with some others, demanding of the provost an explanation of his course with Stevenson. The reasons were not satisfactory, and he harangued the now excited audience, moving that the thanks of the meeting be given Mr. Maxwell for his spirited defense of an injured man. The motion was lost in uproar. An Irishman proposed three hearty groans for Dr. Mason; young Republicans threw up their hats and were for hustling out the officers. Colonel Varick crying "Order," was insulted; Oliver Wolcott was silenced; Mr. Dunscombe, their colleague in the board of trustees, declared that the degree would not be conferred, if he answered with his life-an announcement greeted with a general laugh. No valedictory was delivered; the president pronounced no benediction, but hastened from the church. Party indignation now flamed

July 10,1811 ; the account in the text is based chiefly upon the evidence presented at the subsequent trial for riot, and reprinted in a pamphlet (now marked "very rare") called: The Trial of Gulian C. Verplanck, Hugh Maxwell, and others for a Riot in Trinity Church at the Commencement of Columbia College in August, 1811 (N. Y., 1821). I have also used the newspapers of the day.

${ }^{1} \mathrm{G}$. A. Morrison, Jr., History of St. Andrea's Society of the State of New York (N. Y., I906), p. 104.

2 Statement of the Faculty. 
high, and Verplanck and Maxwell with some others were soon haled before the mayor's court for riot. ${ }^{1}$

The mayor was DeWitt Clinton, who seems fully to have realized the political importance of the trial. He had been uarrowly elected lieutenant-governor in the spring,incumbent, General Broome, had died-though the Republicans of his own district had voted chiefly for Marinus Willet, as the Martling candidate, or even for Colonel Fish, the Federalist." The spirit of the Clinton papers sagged, and it was known that his enemies within the party would spare no pains to put him out of power. ${ }^{3}$ His ill-disguised contempt for Madison and the national administration had lost him popularity, yet in this opposition it seemed quite possible that he might win the confidence of his old foes the Federalists; at least the time seemed opportune for an attempt.

When the trial for riot came, the witnesses were duly questioned, and Dr. Mason, smarting in his wounded pride, rolled out his invective against the Jacobins; then the mayor's time had come. In his denunciation he far outdid the Federalist champions: the learned counsel for defence had wasted time when they declared the matter was a mere affray or rout; their authorities were bad. "We have no hesitation in declaring that the disturbance which took place

1 The friends of Mr. Stevenson (who later became famous as a physician) on seeing the Statement of the Faculty published an elaborate reply in the $N$. Y. Commercial Advertiser, August 12. The trial, after a speedy indictment by the grand jury, was held on August 17 before what was officially known as the Court of Sessions, see C. P. Daly, $o p$. cit., and E. Vale Blake, The History of the Tammany Society, pp. 50-5I.

$2 N . Y$. Herald, April 3, 6, 13; N.Y. Columbian, April 19; N. Y. Spectator, May I8, 18I . The Constitution of 1777 allowed this plurality of offices.

" O" to Clinton, March 14, I8II, DeW. Clinton Mss., and J. H. Douglass to W. P. Van Ness, Feb. 15, 1811, VanNess Mss. 



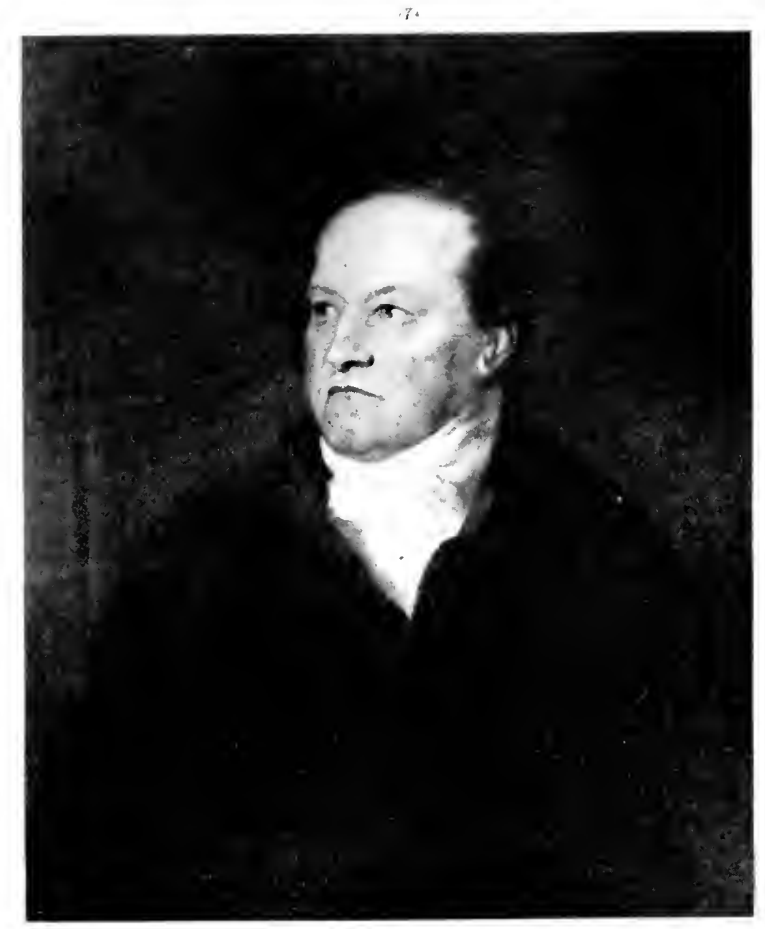


on the occasion alluded to, is the most disgraceful, the most unprecedented, the most unjustifiable, and the most outrageous, that ever came within the knowledge of this court." Toward Verplanck, "shaping himself with all the self created importance of a second Daniel," he was especially severe. Readers of the Federalist papers the next morning learned that the mayor " after a very conciliatory but impressive address (which we think should be laid before the public)," had been content to fine Verplanck and Maxwell two hundred dollars each. ${ }^{1}$ The tirade from the bench had a wide political effect. "You have," a friend assured him, "become extremely popular with the Federalists for your charge and sentence on the rioters at the late commencement." : But he had as well, as we shall see, won the undying hatred of Gulian C. Verplanck.

Few men were more informed as to the doings of the Federalists than were the British agents in America. In September I8rr, Mr. Foster wrote to the Marquess of Wellesley that no candidate for president was generally talked of ; in November he reported certain rumors of strange coalitions; before Christmas he had learned that DeWitt Clinton was to be proposed. The new ratio of representation in the Congress made New York the most important state and much might be risked to gain it." The "detestation of mobocracy," which had so marked his censure of the rioters, had favorably impressed the party to the east, and they were willing to support the mayor of New York, expecting as reward appointment to some foreign embassy or financial

\footnotetext{
${ }^{1}$ N. Y. Commercial Advertiser, Aug. I8. I8II. There were five others also tried, convicted and fined.

${ }^{2}$ Ambrose Spencer to Clinton, Sept. 23, I8II, DeW. Clinton Miss.

${ }^{3} \mathrm{Mr}$. (afterward Sir) A. J. Foster to Marquess of Wellesley, Sept. I7, Nov. 29, Dec. 21, 18I I, Precis Mss. Books (N. Y. P. L.), vol. ii.
} 
favors from the government. ${ }^{1}$ The rapprochement in New York state daily grew more manifest as the winter wore away.

Certain Federalists had made application for a charter for a bank. It soon became a party question; Governor Tompkins opposed it with all the power of his office, resorting to the extreme expedient of proroguing the legislature lest the bill become a law. In the spring campaign of I8I2 it was the universal theme of conversation from the taverns to the senate chamber. Meetings for and against the Bank of America were held throughout the state. ${ }^{2}$ Republicans accused its agents of buying a majority by unstinted bribes. Yet in all this DeWitt Clinton showed surprising unconcern, even though the fortunes of his own Manhattan Company were to be affected; while his party clamored loud against the Federalists and their project, he refused to make opinion on this question any test of regularity. His brother-in-law, Judge Ambrose Spencer, who had been his closest coadjutor, now shook off connection with one who had such nice respect for the feelings of the Federalists. John Armstrong, soon to be appointed to the cabinet, and Judge Tayler, both old Clintonians, likewise refused their countenance. "The body-guard of Clinton was tainted with the odor of the bank." Although the legislature had a strong Clintonian majority, it was with difficulty that a

"Wm. Sullivan, Familiar Letters on Public Characters (Boston, 1834), p. 349. "Some of the leading Feds," wrote Christopher Gore in Massachusetts, "are sanguine that by associating with Democracy, they may obtain an immense Bank, and amass princely fortunes," to King, Feb. 17, also Feb. 7, I812.

'Albany Republican, April 18, 22, 29, May 6, 13, 27, 1812. For an interesting bank proposal on the part of the Republicans, see letter from Samuel Osgood. Feb. 22, I812, Osgood Mss. (N. Y. Historical Society). 
caucus was induced to nominate the leader for the presidency. ${ }^{1}$

On the nineteenth of June war with Great Britain was proclaimed. The Federalists declared their worst fears realized; the French democrat, Thomas Jefferson, and his imbecile successor had in their mismanagenent made disgrace and bankruptcy inevitable. Peace must be restored as soon as might be; as to the presidency, which must be decided in the autumn, any change would be for the better. ${ }^{2}$ Clinton's agents were in Washington and in New England, peace men with the Federalists, and with Republicans complaining of the need for more vigor and efficiency in the conduct of the war, all things to all men, careless as to means so long as Clinton's fortunes were advanced. ${ }^{3}$ The Federalists of the most extreme temper. like the Essex Junto which had so harassed John Adams, were ready, as with Burr, for any dark conspiracy. But in New York the party was divided. Gouverneur Morris, now convinced that the Union must sooner or later be divided on the queston of the " negro votes," thought it desirable to support his friend of the canal board, so as to assert the independence of the north. ${ }^{4}$ J. O. Hoffman, who had conducted

']. D. Hammond, History of Political Parties in the State of New York, vol. i. pp. 305-310, 312-315; J. S. Jenkins, Lives of the Governors of the State of New York, pp. 257, 260; D. D. Barnard, A Discourse on ... Ambrose Spencer, Albany, pp. 84-89; Ambrose Spencer, Defense, etc., Albany, I843 (N. Y. State Library): King Correspondence, vol. v, p. 265 ct seq.

${ }^{2}$ Wm. Sullivan, Familiar Letters, p. 349.

${ }^{3}$ King Correspondence, vol. v, p. 265 et seq. This series has been used by D. S. Alexander, Political History of the State of Neze York, vol. i, pp. 202-206.

${ }^{4}$ Morris to B. R. Morgan, Aug. 20, 1812, J. Sparks, Life and Writings of Gourerneur Morris, vol. iii, pp. 273-274; also Morris, Diary and Letters, vol. ii, pp. 542-543. The reference here is to the "three fifths" compromise in the Federal Constitution. 
some private negotiations, pledged the city delegation to the mayor. Emott, D. B. Ogden, Jones and several congressmen conferred, hesitating somewhat (for they knew the mayor well), but finally agreeing to support their Massachusetts colleagues in the cause of Clinton. The candidate spared no promises, referring to himself as an American Federalist, when occasion suited. At the same time some Republicans came to his support under the impression that he would carry on the war much more effectively than Madison. ${ }^{1}$

The Federalists themselves were active in the cause of peace. Rufus King, Gouverneur Morris, General Clarkson, Colonel Varick and Richard Harison drew up a set of resolutions for a meeting to be held in Washington Hall. Other meetings were conducted through the southern counties with large attendance. On the last day of July, Dr. Mason of Columbia came to King with a proposal from the mayor. He was, the agent said, prepared in all ways to resist tne influence of the south, and desired, if it were possible, to have a conference with the Federalist leaders that New York might be united in the cause. King went to Morrisania to report the plan to Morris, Jay and Clarkson. King himself was loath to hold an interview with Clinton, but consented to be present provided that nothing more than the welding of a peace party be made a subject of the conversation. Dr. Mason was apprised and the conference arranged. On the appointed day, again at Morris' home, the little company was gathered. The resolutions for the coming meeting in New York were read to Clinton, and he observed. writes King,

that he supposed that he did not differ from us in opinions

'J. D. Hammond, op. cit., vol. i, pp. 353, 449-450. See Hoffman's letter to $\mathrm{H}$. G. Otis, July 17,1812 as printed in S. E. Morison, Harrison Gray Otis, vol. i, pp. 316-317. 
respecting the public affairs and that he entirely approved of the Resolutions that had been read to him. But as his friends, comprehending a great majority of the Republican Party in the State, were divided in their opinion respecting the war-prejudices against England leading some of them to approve the war,-Time was necessary to bring them to one opinion ... [and] that for these Reasons the proposed Peace meeting in the City should be deferred for four or five weeks. ${ }^{1}$

The candidate desired no untimely publication of his various professions.

Rufus King opposed this dubious connection; when Clinton said that if elected President, he would administer the government upon the principles of Hamilton, King, for one, was not impressed. ${ }^{2}$ Talking to his friends he made certain observations which illustrate his good sense.

I observed to them [he writes] that I looked upon Mr. Clinton as upon every Leader of a Faction; that so long as he went on according to their views and bias, so long he wd. lead them, but as soon as he opposed their views, and more certainly as soon as he united with the rival Faction for any purpose, he would be deserted by his own.

With Spencer, Tompkins, Armstrong and Tayler all against him, it was doubtful if he could bring over much Republican support, yet unless he could bring numbers he was not worth accepting. It was of less importance, said King, that the party gain a transitory power than that their reputation and integrity should be preserved unblemished. Coalition with a foe they had so long reviled would tarnish all concerned. Clinton and his partisans would publish such reports of the arrangement as might suit their purposes. and when the mischief had been done, the Federalists

${ }^{1}$ King Correspondence, loc, cit.

${ }^{2}$ J. A. Hamilton, Reminiscences, p. 44. 
might be obliged to answer with ill-credited denials. ${ }^{1}$ After the conference King went to town, saw Harison, Egbert Benson, Peter Radcliffe and some others, and the peace meeting was arranged for the following week. "Gentlemen of the very first standing in society" were there; Colonel Fish was chairman, and the resolutions, which suggested a convention of the friends of peace, presented by John Wells and D. B. Ogden, were passed with great enthusiasm. ${ }^{2}$

Shortly after the declaration of war, Willian Sullivan, the president of the Boston branch of the Washington Benevolent Society, was at Saratoga Springs to take the waters. While walking in the groves one day with some New England friends, a project was conceived of calling a convention of Federalists to meet in New York city in the early autumn, and the gentlemen went home to prepare opinion and arrange the delegations of their respective states. $^{3}$ Agreeable to this plan more than seventy representatives gathered on the fifteenth of September as a party convention, though keeping the close privacy of a caucus. ${ }^{4}$ King was in attendance; lest since his own name had been

'King Correspondence, vol. v, pp. 270-27I.

${ }^{2} N$. Y. Eacning Post, August I8, 1812. One resolution was "that representatives be chosen in the several counties, discreet men, friends of peace. These representatives can correspond or confer with others, and coöperate with the friends of peace in our sister States in devising and procuring such constitutional measures as may secure our independence and preserve our Union, both of which are endangered by the present war." See H. C. Lodge, Lifc and Lettcrs of Gcorge Cabot (Boston, I875), p. 523.

${ }^{3}$ Wm. Sullivan, Familiar Letters, pp. 350-35I.

'N. Y. Evening Post, Sept. I9, I8I2. The convention like that of I\& $\$$ was organized by irregularly chosen committees of correspondence. The New York committee was Jacob Radcliffe, C. S. Riggs, J. O. Hoffman, D. B. Ogden and John Wells; S. E. Morison, Otis, vol. i, 19. 308-309, note. 
mentioned for President his absence might be misconstrued. He stated his desire that a true Federalist be nominated, even though it meant defeat. Mr. Madison could not ruin the country in four years, and at the expiration of that period, the country, tired of mis-rule, would bring the Federalists to power with as much support as Jefferson's in 1800. Against Clinton, he is said to have pronounced a most impassioned invective, becoming " so excited during his address that his knees trembled under him." The meeting dragged on for three days and was about to be dispersed with no agreement, when Harrison Gray Otis, rising in behalf of Clinton and speaking at first with hesitation, hat in hand, delivered an appeal so eloquent in summing up the troubles of the country and the crying need for change, that his candidate, though not formally endorsed, was generally accepted. ${ }^{1}$

The controversy grew bitter in the press and on the platform, for Clinton's enemies were not tender of his sensibilities. His apostasy was scornfully proclaimed and his opinions on the war set up in vitiating parallel. " "Washington" and "Hamilton" addressed the country to his prejudice, and King was quoted as desiring no aid from treachery." When the legislature was convened on the second of November to choose presidential electors, three tickets were presented, the Martling Men or Madisonians, the followers

'Sullivan, p. 350 , says he was regularly nominated, but it appears from evidence adduced by S. E. Morison in his Otis, vol. i, pp. 310-3II, that the resolutions were ambiguous, and that the nomination of Clinton was not understood by a number of members. John Jay was mentioned as a candidate, but it was objected that, superannuated and unpopular, he "could no more be president than Seneca could Emperor." S. Dexter to H. G. Otis, Sept. 12, I812, Morison, Otis, vol. i, p. 319.

${ }^{2}$ E. g. pamphlet, The Coalition, N. Y., I812 (N. Y. P. L.).

"Washington to the People of the United States (Boston, 1812), p. 28, and Hamilton to the People of the United States (N. Y., I812), pamphlets in the N. Y. P. L. 


\section{I72 ARISTOCRACY IN THE POLITICS OF NEW YORK}

of Clinton, and those Federalists who had taken King's advice to stand alone. The spring election had retained a small Federalist majority in the lower house, ${ }^{1}$ but since they voted in joint session with the Democratic senate, their cause was hopeless as a party. Enough, then, cast their ballots with the Clinton men to give him the vote of the state, though many stalwarts voted for their old associates. ${ }^{2}$ In the total electoral vote of the country, however, Madison defeated him, though by no great majority; all his balancing and shifting had been useless.

Meanwhile attention in the state had been fastened on the conduct of the war, which might mean an invasion into the region by the lakes and the St. Lawrence. The President had scarcely called upon the governor for the quota of New York, when it was announced that Stephen Van Rensselaer, the Patroon, had been called to lead the troops. No little comment was aroused. It was generally understood that this distinguished Federalist was to be his party's candidate for governor at the election in the spring. Why had Tompkins picked him ont for this responsibility? It is true he had been adjutant general of the state, but this had been an office more of dignity than practical importance; he was no military man. ${ }^{3}$ Was he tendered this position as a compliment, in hope of winning Federalist support to the war policy? Some were ungenerous enough to think that Tompkins did not dislike to put his rival in a place of danger. Considering the difficulties of the service a failure seemed inevitable and the General's eulogists have not neglected to suggest that Tompkins was quite willing

${ }^{1} N$. Y. Speciator, May 6, and N.Y. Commercial Advertiser, May 25. give the returns by counties.

${ }^{2} N$. Y. Senate Journal, I812-1813, p. 8; J. S. Jenkins, Lives of the Governors, p. 265 .

${ }^{3}$ Mrs. C. V. R. Bonney. A Legacy of Historical Gleanings, vol. i, pp. $195,260$. 
that that failure should be fixed upon the Federalists. ${ }^{1}$ Acceptance or refusal would alike entail disgrace, the Democrats were watching for a sign of cowardice. Whether or not these charges were well founded, the event gave them some color; Van Rensselaer sought to lead his men across the Niagara River to gain the field at Queenstown; as state troops for defence they would not follow into Canada; the detachment which obeyed commands was cut to pieces: the failure was complete. ${ }^{2}$ The Patroon had suffered all that Tompkins could have wished.

The Federalist majority in the lower house, as has been pointed out. was not enough to carry a joint session; hence when his party nominated Rufus King for the Senate of the United States, many thought it but a courtesy. He was a "Federalist of the old school," as those were called who would not join with Clinton, ${ }^{3}$ and consequently he could not hope for much support from the old adherents of the latter. It was, then, a matter of no small surprise to those outside the arcana of the leaders that the vote was found to give him the election. Certain evidence has been preserved that connects the result with a bargain made by the agents of the Bank of America the year before, ${ }^{4}$ but surely few more happy consequences have proceeded from so wrong a cause; it was the restoration of a statesman to the councils of $a^{\prime}$ nation. He went to the Senate with the prestige of some "democratical assistance," announced the maxim that to

'D. D. Barnard, Discourses on Stephen Van Renssclaer (Albany, 1839), p. 27; J. W. Redway, "General Van Rensselaer and the Niagara Frontier," Proceedings of the Nez' York State Historical Society, vol. viii, (Albany, I909), p. 20; N. Y. Spectator, Nov. II, I812.

${ }^{2}$ See the excellent account of the battle, with reports and correspondence, in Mrs. Bonney's Legacy, vol. i, pp. 256-298.

${ }^{3} \mathrm{~J}$. D. Hammond, op. cit., vol. i, pp. 349-350.

"Ibid., p. 344. Hammond claims to have direct knowledge of this bargain but exonerates King from any connection with it. 
end the war, however unjust and deplorable it was, was now to fight it to a decent finish-and by this stand became an oracle with the Democracy. ${ }^{1}$

Whatever may have been the Federalist power in joint session, their control of the assembly gave them the Council of Appointment. As three years before, the spoils of victory were portioned out among the party, but a special interest was shown in the question of the mayor of New York. Mr. Clinton had discharged his duties with much energy and spared no pains to put the city in a posture of defense, yet he was still in name a member of the opposition. $^{2}$ If he were named for reappointment it would offend the Federalists of the old school; if he were refused, those Federalists who had recommended him to other states for the highest office of the nation would be stultified. General Platt, then sitting on the Council. had been among the latter group, and, though knowing it would be offensive in some quarters, proposed the mayor for renomination. Peter Radcliffe, another member, claimed the office for his brother Jacob who had served in I8Io; Radcliffe was passed by for Clinton and, as we shall see, became embittered toward his party. ${ }^{3}$ But the clemency accorded Mr. Clinton was not extended to his friends in office; the time had not arrived for a general party coalition.

The acceptance of this Federalist patronage by the mayor himself seemed a final insult to Judge Spencer and the Madisonian or Martling faction. They nominated Governor Tompkins for re-election and for lientenant-governor, they ignored Clinton, the incumbent, for Judge

${ }^{1}$ King to Gore, Feb. 14, I813. King Correspondence; see also ibid., vol. v, pp. 292, 310, and John Lovett to Col. Sol. Van Rensselaer, June 22, 1813, Mrs. Bonney's Legacy, vol. i, p. 301.

'David Hosack, Memoir of DelVitt Clinton, p. 52.

"Wm. Henderson to King, Feb. 21, 1813; Hanmond, vol. i, pp. 346-350.

4 It will be remembered that he held both this office and that of mayor. 
Tayler. The Republican party was now definitely broken; Clintonians soon published an address declaring that they would not support the Tompkins ticket, and inveighing against Virginia domination and its agents in New York, they charged that the bounty of the general government " has been lavished on the most unworthy objects; the most uniform, decided, influential, virtuous and able men of the republican party have been proscribed; George Clinton, the father of his country-yes, George Clinton, was publicly denounced at a meeting of these Martling Men." 1 Never again would Clinton bring together the Democracy; his paper the Albany Register was abandoned by the Madisonians and the Argus set up in its stead."

With the opposition so divided the Federalists were sanguine of success. The Patroon, as had been expected, was proposed for governor. There had been some opposition to his name because he had ordered state troops to cross at Queenstown. Some wanted his kinsman Colonel Solomon Van Rensselaer, who had won the laurels of a hero on that fatal day, but he would not stand against the leader of his family. ${ }^{3}$ General Van Rensselaer was an amiable man, a friend to both "schools" of the party, and with a record for honesty and service that made his name attractive."

1 Address to the Republican Citizcns of the State of New York (Albany, 1813), also noticed in the Albany Argus, April 30. The address was supposed to have been written by Clinton. It was signed by him, Pierre Van Cortlandt, Simeon DeWitt, Archibald McIntyre and thirtyseven others. George Clinton had recently died.

2"I an highly pleased that the Albany Argus is established at the seat of our Govt as it is of Greatest importance that such a paper should be established at Albany to buck the Albany Register and to prevent the Republicans being misled by such a Vile paper as the federals formerly called it but now they say it is the best in the State." Caleb Hyde to C. D. Cooper, Feb. 7. 1813, Cooper Mss. (N. Y. P. L.).

${ }^{3} \mathrm{Wm}$. Henderson to King, Feb. 21, 1813.

'S. Van Rensselaer to King, Feb. I2, I813, George Huntington of Oneida was named for lieutenant-governor. 
The nominations were presented in the party papers as of the "Friends of Peace, Liberty and Commerce," ${ }^{1}$ but there was some difficulty in explaining the candidate's position on the war. Some said he had opposed it, but there was his record at the crossing of the Niagara. Federalists maintained he had not volunteered, but had responded to the governor's commands; they were answered that as a free manl, he had gone without compulsion." The Federalist; said that Tompkins had neglected Colonel Solomon Van Rensselaer when he lay wounded in the hospital at Buffalo -was this the soldier's friend?" The governor's prorogation of the legislature on the question of the bank was now recalled against him, and it was charged that he was controlled by Virginia and the west. ${ }^{4}$ The Federalist arguments again won a majority of the assembly, but Van Rensselaer could not overcome the popularity of Tompkins. "The Farmer's Boy" was chosen for another term."

When John C. Calhoun and his young colleagues forced the peaceful Madison to attempt the conquering of Canada, the concurrent majorities in all of the co-states were not deemed indispensable. It was professedly a war for the freedom of the seas, to which the shipping states seemed obstinately indifferent. "Free Trade and Sailors' Rights" was a cry that rallied to the government's support every class throughout the country-save the traders and sailors. New England merchants and ship-captains preferred to rum their risks to the closing of all commerce on a point of

'N. Y. Commercial Advertiser, April 7.

"Albany Argus, April 9, 16.

"Albany' Gazette, April Io, I8r3, and Mrs. Bonney's Legacy, vol. i, pp. 282, $292,293$.

' $N$. Y'. Commercial Advertiser, April 26, 28, 1813 .

${ }^{5}$ N. Y. Spectator, May 5, 15; N. Y. Commercial Advertiser, May 8; and Albany Argus, May 7, 1813. The southern, middle and western senatorial districts went Republican. Hammond, vol. i, p. 358. 
dignity, and when defeated by the planters and frontiersmen, they resorted to "a larger patriotism" that sought to stultify the government. In their exasperating course they were not followed by New York.

Even the Federalists along the Hudson and the Mohawk, though resentful of Virginia domination, were less resolute in their defiance than their blue-light brethren to the east. Seafaring men, who so keenly felt the restrictions of the war, did not comprise so large a fraction of their population. They had no caste of clergymen to preach the holiness of hating southerners. Class prejudice was not so perfectly coincident with partisan division, for the Livingstons and their like could scarcely be included with the mob. But above all the circumstance that New York was in constant danger of invasion from the north (while New England for reasons military no less than moral was immune), made overt opposition to the government less popular in that state. Of course, there were some extremists who in their denunciation could vie with Otis, Strong and Quincy. Gonverneur Morris drew up a paper of some nineteen foolscap pages arraigning Jefferson and Madison in outrageous terms, and forwarded it to Albany in hope of having it adopted as a legislative report. ${ }^{1}$ In the first year of the war he urged his nephew, D. B. Ogden, to "get the ear of a committee of the whole House and draw in its own hideousness a picture of our administration" and then broach a scheme for a convention with delegates from all the counties in the state to decide whether they should join New England in any necessary measure. Ogden was much too sensible to follow this advice, but Morris made no secret of his strong convictions: to him secession seemed inevitable and the sooner it was done, the better for all concerned. ${ }^{2}$ On

'Wm. Henderson to King, King Correspondence, vol. v, p. 296.

'Morris, Diary and Letters, vol. ii, p. 562. He called the Hartford Convention a tame affair, J. Sparks, Life and Writings of Gowemeur Morris, vol. iii, p. 326 . 
the other hand, some Federalists boldly broke with the majority of their party, heartily supported Madison and Tompkins in their conduct of the war, were applauded as great patriots by the Republicans, and were elected to the legislature by Republican votes. ${ }^{1}$ The majority of Federalists in New York were between the two extremes.

Most leaders deplored the war and sharply criticized the administration, though one does not find the tendency toward treason that marked the utterance of their Massachusetts friends. The answer of the assembly to the governor's speech in November, I812, drafted by Elisha Williams, J. O. Hoffman, and Daniel Cady of Montgomery County, ${ }^{2}$ expressed their sentiment in language courteous but firni. They understood the dangers of the state, the exposed frontier, in parts quite unprotected, and the enemy's flotillas on the lakes. They appreciated the embarrassments of the governor, yet still they would rebuke him for too great a preference for the northern garrisons while New York city lay the prey of any British fleet. What glory might not rest upon the American cause, if the prudent naval policy of Washington and Adams had been carried on by their successors! The few redeeming honors of the year had been achieved by ships they had provided. "The burthen of this war has fallen on this state." they said, "and in proportion to our evident exposure ought to be our means of resistance." Yet they would not sanction any order of the forces of the state beyond its boundaries. They described the war as "sudden and unexpected." and, though opposed in this by the Republicans in debate, having the majority they made the phrase a part of the address. ${ }^{3}$

1 Hammond, vol. i, p. 376.

2 N. Y. Spectator, Nov. II, I8I2.

${ }^{3}$ N. Y. Assembly Journal, 1812-1813, pp. 30-32;N. Y. Commercial Advertiser, Nov. 9, 1812 . 
As the months wore on in discouragement they became more clamorous for peace. In their answer to the governor the following year, when again they held the power in the assembly, they took a higher tone. The government of the United States, they complained, did not desire peace; the delegation sent to Europe at the Czar's suggestion was but a ruse to raise the credit of the nation in the money market. Yet what money could be borrowed would be used to hasten ruin to the country. As to schemes of taxes in the state to support the general government, which Tompkins had outlined in his speech, they would not endorse them. New York needed her resources to protect herself; let no money leave the state. That the war had been a failure was no surprise to them, when they considered the shameful unpreparedness, which had been an article of faith with Democrats, and the character of the men who had been chosen as commanders.

"It is much to be regretted," they remarked, "that as the general government selected their own time to commence this war, they had not, if they believed the war necessary, first provided a respectable and efficient force with which to carry it on." There should have been no lust of conquest and no expeditionary forces, but as Americans, they were mortified to hear the governor exult " that our troops have shown prowess in defending our country eighteen months after the commencement of a war which the American people were told was to put the Canadas in our possession six months from the time it was declared." One draft of the address praised the magnanimity of England in suggesting peace "at a moment when the British nation, after a struggle of near twenty years, has succeeded by the aid of her allies, and the God of armies, in saving the world from universal domination and stands upon a high eminence among the nations of the earth." But not 
many thought such encomiums appropriate, and this sentence was struck out. ${ }^{1}$ Such sentiments were aired in public meetings, and the party papers set themselves no limits in their abuse of Madison and apology for England. Like all minorities they claimed an unrestricted liberty of speech." In tolerating all these calummies the government exhibited a self-restraint in harmony with the creed of I8or, although had they followed Federalist precedent and passed sedition laws, they might have added civil conflict to their troubles.

Of the navy (the old favorite of the Federalists) and the brilliant achievements of its commanders, the assembly wanted "words to express their admiration. Inhabitants of a great commercial state, the people of New York must rejoice to hear your Excellency speaking in terms of approbation of that species of national force which alone can be effectual to maintain and defend our rights upon the ocean." ${ }^{3}$ Scarcely had the legislature met when Charles King, the Senator's second son, then twenty-five years old. brought in a set of resolutions: "That though we cannot approve the disastrous and destructive war in which we are engaged, the House of Assembly of the people of the State of New York feel great satisfaction in expressing their admiration of the conduct of Com. Perry," of Burroughs, Lawrence and Allen and the other heroes who had lost their lives at sea; and "That. in the opinion of this house, the conduct of our naval commanders and seamen during this ruinous war, ought to satisfy every reflecting mind that our commercial rights are to be defended and

'N. Y. Assembly Journal, 1814, pp. 68-74, 98-ro4.

"See A. Van Vechten's speech and Sedgwick's resolutions at a meeting in Albany, N. Y. Ei'ening Post, Sept. 14, I812. In the first years of the war they held a number of such meetings to insist upon the right of free speech. But since the government did nothing to curb their utterance, the meetings were discontinued as superfluous.

N. Y. Assembly Journal, I8I4. loc. rit. 
maintained by a navy, and not by embargoes and commercial restrictions."

The Republicans had no objection to hurrahing for the navy, but they could not pass unchallenged the epithets which King and his supporters fastened on the war at large. William Ross declared them to be most impolitic in the effect which they would have upon the enemy, and others of his party claimed that to call the cause unjust affixed the guilt of murderers upon the fighters whether on the sea or on the land. To damn the war and praise the warriors seemed to them a curious confusion. But the Federalists would not subtract a word. They had called the war destructive and disastrous only, said D. B. Ogden, though he, before God and his country, would have voted for the resolutions had they said unjust as well. It was an iniquitous war, "commenced, as he believed, for the purpose of humbling the importance of the northern states." John B. Coles would praise the navy while he expressed his detestation of the war. Samuel Jones declared that seamen had no right to voice their own opinions, theirs but to obey commands; this spirit he would cordially applaud. William A. Duer maintained that they alone had rescued our flag from disgrace. Others acclaimed the honorable course of Perry who, like many other naval officers, was known to be at heart against the war. ${ }^{1}$ A few days after the resolutions were passed the Federalists of New York city, three hundred and fifty of them with Richard Varick at their head, gave a banquet in Washington Hall to Commodore Chauncey. There was manifested great enthusiasm for the "guardians of our commerce," but no word was said in honor of the army. ${ }^{2}$

${ }^{1}$ N. Y. Asscmbly Jounal, 1814, pp. 17-18, 23-24, 26-29; N. Y. Spectator, Feb. 9, I8ri4.

${ }^{2}$ N. I'. Commercial Adrertiser, Feb. 5, I8I4. At the meeting of the 
The Federalists let pass no opportunity to rail against Napoleon. When in I8I4 Holland was emancipated, the Dutchmen of the party were called to a meeting in Albany hy the Patroon, Van Vechten, J. R. Van Rensselaer and Hermanus Bleecker. Great satisfaction was proclaimed at seeing curbed this arch-disturber who had so well illustrated the inevitable tendency from demagogue to despot. ${ }^{1}$ When the emperor was sent to Elba the leaders of the party, Jay and King, with John B. Coles and General Clarkson, met at Mr. Gracie's and planned a solemn celebration. An assembly was convened and after a prayer of thanksgiving by Dr. Mason, Gouverneur Morris pronounced an "oration of triumph to celebrate the downfall of Bonaparte and the restoration of the Bourbons," while King presided at a public dinner in the evening. ${ }^{2}$ But soon these gentlemen had more serious concerns than toasting Louis XVIII of France.

Washington Benevolent Society in New York city, Feb. 22, 18I4, the navy was toasted, but not the army: and in the ode recited before the society on July 4 of that year, this distinction was again observed, ibid., Feb. 23, and July 5. 18I4. Like opinions were expressed by the New York Federalists in the Thirteenth Congress. Two-thirds of the thirty members of the delegation in the lower house were of that party. Moss Kent, Morris S. Miller, T. P. Grosvenor, Samuel M. Hopkins, and others, all known from their aged colleague as "Judge Benson's Boys." Thomas J. Oakley was especially effective. "He is prompt, luminous and pointed," said a member. "In the most shrewd and cunning manner he assails the President, yet in such cautious phraseology, that no old Foxes can check him." Another declared that if the Federalists in Congress had accepted his exclusive leadership the administration would have been prostrated. See John Lovett to Joseph Alexander, June I7, I8I3, in Mrs. Bonney's Legacy, vol. i, pp. 299-300, and Hammond, vol. i, pp. 357, 428. A rolume of their speeches, which were circulated as pamphlets, is now in the Cornell University Library.

${ }^{1}$ N. I'. Commercial Advertiser, Feb. I7, I8I4.

'Oration delizered June 29. 1814 in Celebration of the Recent Deliverance of Europe from the Yoke of Military Despotism (pamphlet, 23 pp. in N. Y. P. L.) ; Jay Correspondence, vol. iv, pp. 374-375; Morris, Diary and Letters, vol. ii, p. 565. 
In the summer of $\mathrm{I}_{\mathrm{S}} 4$ General Ross, after routing the militia at the "Bladensburg races," marched on to Washington, burned the capitol and plunclered the President's house. The sea-coast towns were set in a flurry. What Admiral Cockburn had done in Chesapeake Bay he might do again in the Delaware or in the Hudson. The city of New York was carefully made ready by Clinton, who remained as its efficient mayor until removed by the Madisonian Council the next winter; and Federalists, confronted with the prospect of bombardment, joined hands with the Republicans. No longer did they content themselves with giving money for relief of sufferers along the lakes. ${ }^{1}$ The rolls of "The New York Hussars" contained such names as Robert Troup, Nicholas Low, John A. King, Robert Ray, Herman Le Roy, Cornelius Schermerhorn and I. V. Coles. Charles King became a captain in the state militia, James G. King, his younger brother, became an aid to General Stevens, J. R. Van Rensselaer raised a troop of soldiers to march down from Columbia County. ${ }^{2}$ When some complained because the banks suspended payment, Rufus King addressed a meeting stating " that in such a time of peril and danger as the present it was the duty of all well disposed citizens to join in the defense of each other and the country;" the banks had been driven to this last expedient and should be supported. "The enemy is at our doors," he said, " and it is now useless to rnquire how he came there; he must be driven away and every man join hand and heart, and place shoulder to shoulder to meet him." 3

The enemy did not molest the city of New York, but the

${ }^{1}$ See letter from Clinton, Feb. 2I, ISt4. DeW. Clinton Mss., and N. Y. Assembly Journal. I8I4, p. 3.

${ }^{2}$ King Correspondence, vol. v, pp. 426-127, note.

${ }^{3}$ N. Y. Eicning Post, Sept. 2. ISI4. 
spirit of resistance which the rumor had developed did not easily die down; many Federalists who had joined the militia for home defense, remained in arms to fight in other quarters, and others cheered their new decision. "Things being what they are," wrote John Jay, "I think we cannot be too united in a determination to defend our country, nor be too vigilant in watching and resolutely examining the conduct of the administration in all its departments." 1 King in Congress led the Federalists to vote supplies and money to the troops, and pledged his private credit to the governor of New York state if he should need it to complete his budget. ${ }^{2}$ Though at first a sharp opponent of the war, he now bent all his energies to bring it to a close by stiff resistance to the foe.

This spirit was not shared by all the party. Morris wrote long and earnest letters of remonstrance.

How often, in the name of God, how often will you agree to be cheated? What are you to gain by giving Mr. Madison Men and Money?... I feel myself bound in Duty and Honor to declare that anything like a Pledge by Federalists to carry on this wicked War, strikes me like a Dagger to my Heart. $^{3}$

Many looked with hope to the Hartford Convention which was meeting in the autumn. Even King, feeling great confidence in the character and patriotism of the members of that body, rejoiced that New England was to speak in words that would be heard. Madison, he said, had been ignorant of the true opinion of that section, depending, as had George the Third, upon reports of sycophantic ap-

${ }^{1} . J a y$ Correspondence, vol. iv, p. 379.

${ }^{2}$ King Correspondence, vol. v, pp. 410-41I, 422-424; N. Y. Everning Post, Jan. 13, 1815.

${ }^{3}$ Morris to King, Oct. 18, $18 \mathrm{I}_{4}$, King Correstondence. 
pointees. ${ }^{1}$ But Morris hoped for more than a mere protest. There was, he thanked God, some sense in Massachusetts, and should the rest of New England join her, ail might be well. What was needed was "An Union of the commercial States to take Care of themselves, leaving the War, its expense and its Debt to those choice Spirits so ready to declare and so eager to carry it on." " As for the old Union, he considered it dead since the repeal of the Judiciary Act in I 80 I. $^{3}$ Judge Benson also hoped that the Hartford body would take a "federal course." Yet the majority of Federalists had been stoutly opposed to any scheme of secession.

Resolved, unanimously [ran the record of a public meeting in the spring of 1813$]$ that the friends of Peace, Liberty and Commerce, are also the friends of the union of these States; and that although they believe it was never the intention of the union, that the rights of any one part should be sacrificed to the prejudices, interests, or corrupt purposes of another, yet they consider a dissolution of the union as an event which can only be contemplated with horror. ${ }^{4}$

After a year and a half when it was proposed by Van Vechten, Tibbits, J. R. Van Rensselaer, William 4. Duer and others that a convention from the counties be held to consider a participation with the easterners, there was little or no response. ${ }^{5}$ One thing is very evident, as Judge Hammond says, that the Federalists of New York as a party never sanctioned the proposals of the Hartford Convention. ${ }^{6}$

The Federalists, who had capitalized discontent to such

${ }^{3}$ King Correspondence (memorandum), vol. v, pp. $444-4.46$.

${ }^{2}$ Morris to King, Oct. 18, No. I, I814.

${ }^{3} \mathrm{~S}$. Van Rensselaer to King, Oct. 25, I814.

' N. Y. Spectator, April 28, I8I3.

${ }^{5}$ N. Y. Ev'ening Post, Sept. 28, 1814.

${ }^{6}$ Political History, vol. i, p. 388. 
good purpose, refused, naturally enough, to be comforted by peace. By party politicians the prosperity of the nation while ruled by their opponents is dreaded as an affliction; old hardships must not fade from memory. "The storm is passed by," said they. "As peace men we rejoice at it; but humbly hope that our countrymen, with a due sense of the calamities they have escaped, will remember the guilty authors of their sufferings and dangers." Who could forget the miserable failure of the conquest of the Canadas, the threats of conscription, the deceits and tricks by which boys under age had been inveigled from their homes to join the army, or the oppression of an administration which had laid such taxes to pay usurious premiums. Lands and houses, carriages and harnesses, furniture, leather. paper, hats, tobacco-what had escaped the assessor's lists? ${ }^{1}$ Such memories as these, so potent in minds of moneyed men, built up the Federalists' strength in the spring campaign of I8I5, so that as the votes were counted for the members of assembly, it was clear that the Republican majority would be slight indeed. Only the almost solid west had made even such a margin possible, and the death or illness of some nembers from that section, made it likely, as the body was convened in January, that the Federalists would gain control of the Council of Appointment."

How this was circumvented is too notorious in the history of the state to need complete recounting here. ${ }^{3}$ The vote for speaker was carried by the Republicans by a majority of one, but the Federalists straightway charged that this one should be thrown out. The clerk of Ontario County had

\section{${ }^{1}$ N. Y. Commercial Adiertiser. April 21, 24, 1815.}

"Ibid., April 26, et seq.; N. Y'. Columbian, Jan. 4, I8I6; Wm. Henderson to King, Jan. 19. W. W. Van Ness to King, Jan. 3I, and T. Dwight, Feb. I0, I8I6.

${ }^{3}$ See Hammond, vol. i, pp. 413-418. 
" most corruptly and flagitiously" given his certificate to Peter Allen rather than to Henry Fellows, the Federalist opponent, because the ballots for the latter, though more numerous, had some of them borne his first name in abbreviation rather than in full. No one questioned the intention of the electors of Ontario, yet by repeated votes in which Allen's was decisive, it was determined to proceed to choose the council of appointment before the house considered Fellows' petition for instatement. A Democratic council, therefore, was selected, and then Fellows was admitted. It took a hardy partisan to say a word for such a naked fraud, and Federalists hoped for more profit from popular disgust, than could have come from capture of the council. An assembly, and a governor as well, might now be gained at the spring election of 1816 .

Judge William IV. Van Ness had promised the year before, with some reluctance, to resign the certain honors and emoluments of his position, and risk the contest as a candidate. ${ }^{1}$ But now that the Council of Appointment had been lost, his resignation would elevate a Democrat to the supreme bench, and by that office to the Council of Revision; ${ }^{2}$ hence another candidate for governor would be preferred. About a hundred politicians of the party were convened at Albany in no little agitation. A committee waited on the judge but he was firm in his refusal, and the body was with difficulty kept from adjourning without any nomination. A resolution was passed that the choice of the

1 "I am urged to consent to a measure which will ruin one if it succeds, and I am told the party will be ruined if I don't consent. I take it for granted I shall be compelled to yicld contrary to my wishes-my feelings-my interests-and my judgment." W. W. Van Ness to Sol. Van Rensselaer, Oct. I7, I8I5, Mrs. Bonney's Legacy, vol. i, pp. 325-326.

${ }^{3}$ This council under the Constitution of 1777 , composed of the governor, the chancellor and the judges of the supreme court, held the veto power, see A. B. Street, The Council of Revision. 
majority would be the choice of all, but none of the many names could gain support of a majority, although James Emott missed by only one. Once more adjournment was considered, or, what would be worse, a nomination of the judge with certainty of declination. when some one presented the name of Rufus King.

"It was impossible to describe the enthusiasm with which this nomination was received, when it was strongly urged to the Convention that under present circumstances we had every reason to hope that Mr. King would not decline." 1 Eight letters from gentlemen of wealth and station were that very night dispatched to the senator in Washington. "Your Acceptance of the Nomination," said one signed by five friends and leaders, "is essential to preserve the Harmony and Unity of the federal party in the State." : Without the magic of his name the convention would have broken up, wrote General Jacob Morris. Chancellor Kent saw in his action the success or ruin of the conservative element in the state. The Patroon urged him to deliberate, at least, before he came to a decision; if favorable, he would electioneer for him with all his zeal and influence. T. J. Oakley assured him that the leaders asked this favor only from the deepest sense of duty to the party. Theodore Dwight declared that if New York could not be redeemed Federalism in the United States was doomed. It was known that Clinton would be named, if King's refusal made it possible for Clintonians to count on Federalist support. It was charged by Democrats, indeed. that the Federalists had known that King would not accept and had announced him as a candidate merely to cover their design of later

${ }^{1} \mathrm{Wm}$. A. Duer to Wm. Henderson, Feb. I6, and J. R. Van Rensselaer to King, Feb. I6, I816.

'Signed by H. Bleecker, Peter A. Jay. I. G. Lansing. Jno. Duer. and J. R. Van Rensselaer. 
joining hands with Clinton. If the senator declined, sufficient of the party, it was feared, (for there were now more real Clinton men among the Federalists than among their opponents) would fulfill the prophecy of the Democrats.

King was not the only leader of unblemished reputation, but the others of that kind had not the force to win. On the other hand, as to the stronger men, scandals of the Bank of America charter were not forgotten and even Van Ness had been unpleasantly mentioned.

There is such a cloud over the character of several gentlemen, who may be considered the leaders of the party of this State [wrote D. B. Ogden to King] that I have long feared that the most respectable men of the community would withdraw in disgust from taking any interest in our politics, or any part in our elections ... Your election would be a new era in Federal politics and men of high character and honor would feel as they ought.

Stephen Van Rensselaer doubted if any man could stand against the popularity of Tompkins, " yet the accounts from the country induce me almost to believe in your success .. . If you were the Candidate, our best characters everywhere would be Candidates for the Legislature and with such men I think you could be of great service to the country." But one voice urged against it, that of Gouverneur Morris. The governorship as Jay and he had made it in I 777 was an office of some dignity, said he, but since Colonel Burr's convention in I80 I had cut it from a seventyfour to a razee it was not worthy of a first-rate man. Kine would leave the Senate with reluctance; he disdained the petty turmoil of state politics. He was at first indignant at the advantage that his friends had taken. Yet as in I 80.4 when from highest motives he declined the nomination which would have drawn him into a conspiracy, so now he accepted from the same compelling sense of duty. If he 


\section{0 \\ ARISTOCRACY IN THE POLITICS OF NEW YORK}

could rally once again to public service the old aristocracy, it was worth the sacrifices of his own ambition. After three weeks' hesitation, he accepted. ${ }^{1}$

The campaign was conducted with much spirit. The Federalists reviewed the record of the war, and claimed that with all the promises and fine professions nothing had resulted but a hundred million dollar debt; war had been a pretext to increase the patronage and power of the administration. Heavy taxes and depreciated paper made up its legacy. The Peter Allen legislature was the subject of their bitter scorn; "that a Council of Appointment should be chosen by the vote of a spurious member struck some minds with considerable force." The free negroes who had been the object of some Democratic legislation on elections, were complimented and defended. ${ }^{2}$ Of Tompkins, the candidate of the Democracy, it was declared he had misapplied state funds in carrying on the war, while as to King the foolish calumnies of 1807 were all revived. ${ }^{4}$ Charles King as a commissioner to investigate the conduct of an English military prison had recently reported in a tone considered too magnanimous, and this was used against his father. ${ }^{5}$

'See letters to him from T. Dwight, Hermanus Bleecker and others, J. R. Van Rensselaer, James Kent, Jacob Morris, W. A. Duer, T. J. Oakley, D. B. Ogden, S. Van Rensselaer, Wm. Henderson, Zebulon R. Shepherd, W. W. VanNess, John A. King, Gouverneur Morris, King Corrcspondence, vol. ii, pp. 502-522. Gouverneur Morris refers to the convention that took away the governor's exclusive right of nomination to the Council of Appointment, and gave concurrent right to any Councillor.

${ }^{2}$ See Addresses in Albany Daily Advcrtiscr, Feb. 14, N. Y. Commercial Advertiser, March I8, April 10, 19, N. Y. Spectator, April 24. 27, 1816; T. Dwight to King, King Correspondence, vol. v, pp. 502-503.

' N. Y. Spectator, Jan. 24, 1816.

'N. Y. Columbian, April 23, 1816; National Adrocate, etc., see King Correspondence, vol. v, pp. 529-534.

${ }^{3}$ This was the incident of the shooting of the mutinous prisoners at Dartmoor, cf. (Charles Andrews) The Prisoncrs' Memoirs (N. Y., 1815). 
In hope of catching votes from some Clintonians the Federalists complained that New York had not its proper hearing in the capital at Washington. ${ }^{1}$ But since it was rumored Tompkins would accept the nomination to the Vice-Presidency, and would consequently resign within a year, such support could not be hoped for.

The Clinton interest will all be thrown into the scale against us [said "Field-marshal" William Coleman of the Evening Post]. At the same time they will, with Machiavellian cunning, probably aid our assembly ticket upon the cunning calculation that a federal Council of Appointment would prepare the way for reinstating Clintonians in office, by removing past incumbents which they would not dare to do. DeWitt being chosen governor next Spring, according to promise, to fill the vacancy occasioned by Tompkins being elected to the Vice-Presidency, will come into power in due time and federalists, cleansing the stables the ensuing year, will make way for a glorious state of things which is to succeed at a subsequent election; a fine arrangement.

Though New York city went for King, he lost by nearly seven thousand votes through the state." "The federal party in the sense of a party aiming at political power no longer exists," said he ; "Victrix causa diis placuit, sed victa Catoni." ${ }_{4}$

Liberty is too dear to be voluntarily parted with [he wrote in

${ }^{1}$ E. g. address in N. Y. Commereial Advertiser, April ı, $18 \mathrm{I} 6$.

${ }^{2}$ To King, April 21, 1816, King Mss., N. Y. Historical Society.

It was hoped that Tompkins' opposition to the canal would arouse resentment in the west (Wm. Coleman to King, April 21, I8I6, King Correspondence, vol. vi, p. 20); at least the Federalists were resolved to check frauds in that region which they claimed had prevented Van Rensselaer's election in 1813 . There had been more voters in some counties than the census warranted (T. J. Oakley to King, March 29, 1816).

${ }^{3}$ N. Y. Spectator, May 8, I816; J. S. Jenkins, Lives of Governors, p. 198.

"King Correspondence, vol. v, p. 530. 
his discouragement, to Christopher Gore] and it must therefore be gradually weakened by making the People jealous of its wisest and most sincere Defenders; so that open force may in the end be used to destroy it. But why touch upon this subject to you, who have so often and so impartially considered it? We have been visionary men ... It has probably become the real interest \& policy of the Country, that the Democracy should pursue its own natural Course. Federalists of our age must be content with the past. It would be most unworthy to affect to have changed our opinions. I would not suffer the self-humiliation \& reproaches of the changelings, I could name, for the highest offices \& applauses, that could be given them. ${ }^{1}$

The Federalists now no longer to be active as a party, their opponents were sure to divide; the Federalists would be able "to assist the true interests of Freedom and of Justice by giving their influence to the least wicked Section of the Republicans." = Even Gotverneur Morris came to this opinion; a few weeks before his death he wrote, "If our country be delivered, what does it signify whether those who operate her salvation wear a federal or a democratic cloak?" " The northern aristocracy had come to realize that old times were past. With their professed regard for the people's good they had joined a high indifference to the people's will. For appearances they thought that honest men should cherish no concern. It was permissible for them to oppose a war which would interrupt their shipping; it was permissible for them to admire the English constitution; but when in their keen desire to see the administration wrecked. they celebrated the disaster at Detroit and ill concealed their glee at the failures of Wilkinson and Dearborn-was it a marvel that the body of the people came to think that the aristocracy were more British than American,

1 May 8, 15, 18I6, ibid.

$=$ To Edward King. May zI, I86r, ibid.

s Diary and Letters, vol. ii, p. 602. 
"And universal patriots grown

Feast for all victories-but our own?"1

It was clear that the party had no iuture; the leaders were discouraged by defections of two sorts. Many lesser chiefs had openly apostatized, renounced their creed and shouted raucous praises of democracy. These were visited with the ostracism of old friends. A meeting held in Washington Hall resolved:

That we are not disheartened by desertions which increase our purity more than they diminish our strength; and that we can have no wish to retain in the circle of our friends, whether political or social, any person who is capable of finding in the power, the pleasures or the emoluments of office, an adequate compensation for the loss of his integrity. ${ }^{2}$

It was, besides, a matter of no little irritation to the leaders that many men of property and social station were beginning to shun the forum of political debate. The indifference of this class to official honor at the hands of a democracy had begun to be observed. They who had so eagerly petitioned for such preference when it was the king who was the fountain of bestowal, now gave up old aspirations and seemed content to choose as ministers of their government men whom they would never think of welcoming to dinner. "Whence is it," inquired Egbert Benson, "that the same thing which was so sought, should now, and by the same class, those desirous to be distinguished for their wealth and otherwise for their condition, be so slighted? I leave this question to the learned scribe and the wise disputer." 3

${ }^{1} \mathrm{~J}$. K. Paulding. The Lay of the Scottish Fiddle: A Tale of Havre de Grace (supposed to be written) by Walter Scott (N. Y., I813). canto ii, stanza iv.

${ }^{2}$ N. Y. Commercial Advortiser, April 29, I816.

'Egbert Benson, Memoir, read before The Historical Society of the State of New York. Dec. 31, I8I6 (N. Y., I8I7), p. 52. 


\section{CHAPTER VII}

\section{Clinton, Divider of Parties}

WhEN in I I $5 \mathrm{Mr}$. Clinton was turned out of the mayor's office, his prospect seemed completely dark. His numerous foes had read him out of the Democracy, his Federalist friends seemed likely to continue in their helplessness. Financially embarrassed as he was, and bred to no career save that of politics, poverty might soon enforce humiliation. His personal adherents were men of such reputation that they injured more than aided him. ${ }^{1}$ In the winter of his discontent he was accused of seeking, with the pitiful aspiration of a ruined man, some understanding with the Federalists, whereby he might be named again for President; ${ }^{2}$ but he was, in truth, too shrewd a man to take the major rôle in a fiasco. He managed to get himself put up as an elector and voted for Monroe and Governor Tompkins, both uf

'J. D. Hammond, Political History, vol. i, pp. 399-400, 423-424.

${ }^{2}$ Roger Skinner to Clinton, March 21, I8I6, Clinton Mss., answering a challenge to prove a statement which Skinner was reported to have made: "With respect to you being a candidate for the next President of the United States, and of your having an understanding with the federal party for the attainment of that object, I have no knowledge, neither have I informed any one that such was the fact. It is, however, true that I have heard the subject mentioned and calculations made on the probability of success by a gentleman warmly attached to you and who appeared resolved on the measure, and in his calculations he placed to your credit all the federal strength of the Union, and although a professed republican, he appeared to regret that the federal [strength] was not greater." See also in ibid., letters to Skinner, Nov. 14, and to J. D. Hammond, April 19, 1816. 
whom he cordially disliked, to make a good impression on the Democratic party. He must if possible win Federalist support without offending his old followers. ${ }^{1}$

There was hope for Clinton because he could conceive and carry out great projects. He now organized meetings in $\mathrm{New}$ York and Albany to make popular the scheme of the canal that he and Morris had surveyed; legislators were addressed in memorials, well-written and convincing, that bore the trace of his connection. Such a man could not be kept in Coventry. The Federalists, whose interests lay in great land-holdings and in commerce, came to him for counsel on the project he had made his own. The west was deeply interested; liberal-minded men throughout the state were glad to offer their support. The Tammany Society, or Martling Men, who worked against the enterprise because of its promoter, soon realized that they had made an error." An element of strength for Clinton was found in the Irish of the state. Old predilections had been strengthened by the decision of the recent mayor when presiding as a judge, that a priest as a witness might withhold the secrets of the confessional. $^{3}$ The immigration which had come from Ireland in the last years of the European war and since, despite the restrictions of Great Britain, made this support important. ${ }^{4}$ It was clear that Clinton's star was rising; even his brother-in-law, Judge Ambrose Spencer, partly through Mrs. Spencer's mediation, now sought an interview, and a reconciliation was announced. ${ }^{5}$

The strength of Mr. Clinton, founded thus on popular

${ }^{1} \mathrm{~J}$. Emott to R. King, Dec. 28, $1816 . \quad 2$ Cf. supra, ch. v.

${ }^{3} \mathrm{~J}$. G. Shea, History of the Catholic Church in America, vol. ii, pp. $165-167$.

4 W. J. Bromwell, History of Immigration to the United States, p. 13, note.

${ }^{5} \mathrm{H}$ ammond, vol. i, p. 43 . 
support, was more general through the state than in the legislature. In consequence the gentlemen who favored him to take the place of Tompkins, when the latter should become Vice-President, planned and carried through a Republican state convention held at Albany, with delegations from each county, the first conforming to the modern standard. This was preferred by his adherents to a legislative caucus of the party. because it was well known that in most counties which sent Federalists to Albany, the Republicans desired Clinton. These would have their word in a convention. Judge Spencer's influence was rightly counted on to secure the proper delegates. and Clinton was nominated, in spite of Martin Van Buren and the men from Tammany Hall; ${ }^{1}$ and though these recusants insisted on supporting Peter B. Porter of Black Rock, ${ }^{2}$ their candidate received less than two thousand votes at the election. The strong man with an idea had won his way from humiliation to the highest honor of the state. It was significant that Van Ness. J. R. Van Rensselaer, Jonas Plat., Elisha Williams and other Federalist leaders gave strong support not only to Clinton for governor but also to Clintonians for the legislature. The New York Evening Post declared

In short, that in the western district federalism is abandoned. In explanation of their views, they say, that the democratic party having adopted federal measures of the Washington administration have thus reluctantly acknowledged these measures were right, and that there is therefore no longer anything to differ about ... The requisite capacity for government is, on all hands. acknowledged to be found in those who are about

${ }^{1}$ Hammond, vol. i, pp. $43^{6-444}$.

"This was Van Buren's policy, though other leaders of the old Madisonians objected; see E. T. Throop to Van Buren. March 15, 1817. Van Buren Mss. 
to succeed to power in this state . . To say more at this time would not consist with sound discretion. ${ }^{1}$

In the summer of $I 8 I 7$, then, party prejudice seemed softening. The program of the Democratic Congress with its projects of the bank, the bonus bill, and the high protective tariff, was made up of Hamiltonian measures to be carried out in a Jeffersonian spirit. Federalists could not easily object; it was for their opponents to meet the charge of inconsistency. ${ }^{2}$ In Albany as well, old Federalists found no little satisfaction. Clinton's inaugural address as governor, delivered when the legislature came together in January $\mathrm{I} 8 \mathrm{I} 8$, attracted more attention than was usually bestowed on such pronouncements. ${ }^{3}$ The new executive was nothing if not bold in his conception of the duties of the state. He urged the generous support of education from district school to college; agriculture and the arts should be encouraged by subventions; the militia must be drastically reformed upon new models of efficiency; the poor laws must be changed; far-reaching legislation with respect to banks was needed; the financial system of the state itself must be re-arranged. His most effective phrases were reserved to recommend his favorite scheme of inland navigation. " "To do" was the watchword of this leader now come to official power. The Federalist squires applauded his

"See in N. Y. Herald (edition of Evening Post "for the country") May 17, I8I7. "In this State, after a good deal of jockeying \& much of extraordinary coalition among men who have censured each other in the coarsest and bitterest language, Mr. Clinton will be chosen without opposition." R. King to C. Gore, April 17, I8I7.

2 King to Gore, June 26, I8I6. Gouverneur Morris had complained the previous year, that Calhoun and Clay went much too far. Diary and Letters, vol. ii, p. 595.

${ }^{3}$ D. Hosack, Memoir of Clinton. p. 75.

${ }^{4}$ Messages from the Governors [of New lork] (Albany, 1909), vol. ii. p. 807 et seq. 
remarks on agricultural societies; land holders in the west and north beheld their friend in the champion of canals. The fact that Clinton was not considered orthodox by the Virginia School in Washington made Federalist support more natural and appropriate. ${ }^{1}$ Opposition centered within Tammany Hall in New York city, and soon Clintonians and Federalists in consequence, issued warnings to the commonwealth against corruption from the great town by the sea. "A great commercial capital is seldom the chosen seat of liberty," they said in an address. "She oftener de. lights in the mountain fastnesses and in the cultivated plain." = The feud between "up-state" and "the city" was begun.

Those Federalists who had worked for Clinton in the canvass of 18 I2, of course again declared their friendship. Judge Jonas Platt exchanged most fulsome compliments with the governor, and worked for all his measures. ${ }^{3}$ Chancellor Kent and Clinton visited each other's homes and were on terms of confidential friendship. ${ }^{*}$ Josiah Ogden Hoffman was Clinton's firm supporter in the city, where support was needed. ${ }^{5}$ Thomas J. Oakley and the "Columbia Junto" -Williams, J. R. Van Rensselaer and Van Ness-were all Clinton men. ${ }^{\circ}$ Troup as a lawyer found enjoyment in

${ }^{1}$ J. Savage to Clinton, March I8, I8I8, M. B. Tallmadge to Clinton, Jan. 6, I8I9, DeW. Clinton Mss.

2 Address of the [Clintonian] Republican Members of the Senate and Asseinbly Adopted at a Meeting ... April 4, 1820, pamphlet (Albany, 1820 ).

${ }^{3}$ Clinton's Letterbook V, Jan. I4, I822, Fr. A. van der Kemp to Clinton, March 20, I823. Jonas Platt to Clinton, Oct. 4. I823, T. Eddy to Clinton, Oct. 4. 1823, Clinton Mss.

'DeWitt Clinton's Diary (N. Y. Hist. Soc. Coll.), numerons entries.

${ }^{5} \mathrm{Wm}$. A. Duer, Reminiscences, p. 27.

${ }^{6}$ John Duer to Van Buren, March 27, I8I9, Van Buren Mss.; M. B. Tallmadge to Clinton, Jan. 6, IS19, Clinton Mss. 
the governor's speeches, and as a western man he anxiously encouraged the movement for the canal. ${ }^{2}$ Cadwallader D Colden was his intimate correspondent. ${ }^{2}$ The Patroon, with whose family Clinton soon became connected by marriage, thought him satisfactory, though Federalism in Albany was quite strong enough to stand alone. ${ }^{3}$ The gov ernor exchanged friendly letters on politics and agricultural societies with the Jays at Bedford, including many expressions of esteem.* IVilliam L. Stone, who had edited the Northern Whig of Hudson and the Albany. Advertiser, and who took charge of the New York Commercial Advertiser in 1820 , was among his most valuable supporters. ${ }^{5}$

But it was not the leaders only who took up with Clinton; much of the body of the party in the counties could be counted on as well. After 1816 it was only in the ancient strongholds that Federalist candidates were presented under the old party name. ${ }^{6}$ Elsewhere the faitliful were exhorted to vote for the best man (provided he would stand with Clinton), and in many counties there was a frank and open coalition. ${ }^{\top}$ Clintonian and Federalist were often interchangeable terms, and the word Republican was reserved for followers of Van Buren and his coadjutors of the Tammany Society. ${ }^{8}$ Sometimes the factions which sup-

${ }^{1}$ Troup to King, Feb. 4, 1819, King Correspondence. It is true Troup deplored the necessity of supporting a Democrat.

"DeWitt Clinton Mss. passim. but especially Dec. 20, 1813.

${ }^{3} \mathrm{~S}$. Van Rensselaer to Clinton, Jan. 6, I8ig, ibid.

'July 27, I8I8, Letterbook IV; Aug. 6, I820, ibid., V.

5 "We have been attentive observers of Mir. Clinton's administration and measures," he wrote on coming to the city, "and frankly declare, that in general, both have met with our approbation," N.Y. Commercial Advertiser, April i I, I820.

"Albany Gazctte, April I3, 27, 1818.

'Albany Advertiser, March 31, 1818; Albany Gazette, April 13, 23, I8I8: M. M. Noah to Van Buren, July I3, I8I9, Van Buren Mss.

${ }^{8}$ George McClure to P. G. Childs, Feb. 13, I822, Isaac Pinson to Childs, Feb. 7. 1822, John Rugen to S. A. Talcott, Feb. 13, I822, Childs Mss. (N. Y. Public Library). 
ported Clinton were combined under strange and startling names, like the "Low Salary Men " around Cayuga Lake." Through the state there was no question where the chiei part of the old Federalists had gone. There were fourteen counties in the state which had voted for Van Rensselaer for governor in I8I3, and three years later for Rufus King. In the hotly fought election of I8I9, eleven of these were registered for Clintonians. ${ }^{2}$ Yet even in this triumph there were murmurings of opposition.

When in $18 \mathrm{I} 7$ Clinton was carried to the state house on a wave of popularity, he might have stayed a universal favorite had he learned the arts of affability. He was formed to be admired and obeyed, but not loved. In the designs of his imagination he was a mighty architect, but he failed to take account of means; he forgot that execution must depend on whims, on human loyalties and prejudices. He would not pause to make friends with men. A correspondent put the case concisely:

And let me tell you, Sir, if no one else has the candour or boldness to say it (I mean among your friends) that the charge of a cold repulsive manner is not the most trifling charge, that your political enemies have brought against you-you have not the jovial, social, Democratical-Republican-how-do-you-do Suavity of a Root; ${ }^{3}$ nor the honied and cordial, or cven the complaisat, , manners of a "beloved Tompkins." 4

Iudge Hammond, who long served him as attorney, writes that petitioners who came to Albany had declared that they

' J. S. Jenkins, Lives of the Governors, p. 508 et seq.

'See tables in Albany Advertiser, June 7, 1820.

${ }^{3}$ Gen. Erastus Root of Delaware Co., an Anti-Clintonian leader.

'John Brennan to Clinton, postmarked Sept. 23, 1823, Clinton Mss. Another writes (ibid., no date) of Clinton's enemies:

"Some of whom do accuse thee of being full proud.

There's some truth in this it must be allowed." 
preferred to be graciously denied by Tompkins, to having favors granted by the bearish Clinton. ${ }^{1}$

But his methods were as harshly criticized as were his manners. All deplorable devices which made New York politics a scandal were charged to his invention, because, no doubt, he was unusually adept in their employment. Rightly or wrongly, he was charged with having been the first to make public office family property. ${ }^{2}$ A hostile paper printed an elaborate catechism

calculated to show the faculty of providing for a family in an elective government, by the discovery of a drop of Clintonian blood; and how it qualifies a man for office or for any number of offices to the exclusion of his fellow citizens. whatever be their talents or merits. [Two samples out of thirty' questions will suffice]. Question: Why is Pierre C. Van Wyck Recorder of the City of New York, (and) Commissioner in Banliruptcy. and why is his brother Notary Public? Answer: Because his mother was the sister of Pierre Van Cortlandt, who married the daughter of George Clinton, who is the brother of James Clinton who is the father of DelVitt Clinton. Question: Why is Charles D. Cooper Clerk of the county of Albany? Answer: Because he married the adopted daughter of John Tayler, who is cousin of George Clinton, who is uncle of De Witt Clinton. ${ }^{3}$

His personal adherents who had followed him through lean years of defeat were largely men of broken fortune and dark reputation, and it. was generally charged that they retained his good will by playing a constant stream of compliment to satisfy his vanity. It seemed to many that the leader confused the success of republican principles with applause of himself.

'Political History, vol. ii, pp. 269-272.

${ }^{3}$ Cf. H. L. McBain, DeWitt Clinton and the Spoils System.

"Poughkeepsie Political Barometer, April 24. ISII.

'Hammond, vol. i, pp. 399-400, 42.3-424. 
The great governor in his appetite for praise was not discriminating, yet he found peculiar satisfaction in literary fame. He was eager for distinction as savant as well as statesman, claiming fellowship as near with Aristotle as with Pericles. In 1817 the Germans had not yet preached the doctrine that scholarship to be respectable must be confined, and Clinton tried to rum the range of learning. It was not by chance that his first biographer was a botanist, a physician and an F. R. S. and that the second was a professor of natural and experimental philosophy. ${ }^{1}$ The bewildering diversity of his scientific interests is illustrated by his correspondence. People wrote to him of new varieties of meteors and new varieties of clams; they sent him drawings of ships that could sail sidewise, of moundbuilders' remains, and of wonderful keyed harps; he was questioned on the arts of Athens, the theology of Calvin, the tribal dialects of Indians, blue clover and the recipes of cures for hydrophobia; gentlemen whom he had never seen wrote careful and minute descriptions of their travels, others proved the earth was hollow, and one sent a "confidential plan for the amelioration of mankind " by means of a society. ${ }^{2}$

This last proposal was fittingly addressed to hin, for he was at least vice president of all such enterprises in the state and corresponding nember of nearly all of those outside its bounds. He delivered long orations before the New York Historical Society, the Literary and Philosophical Society of New York, the American Academy of the Arts, the Society of Phi Beta Kappa and many others. ${ }^{3}$ In these discourses there was some contribution to the several

'David Hosack, Memoir of DeWitt Clinton (N. Y., 1829): James Renwick, Life of DeWitt Clinton (N. Y., I840).

${ }^{2}$ These letters grow in frequency after $18_{17}$, see Clinton Mss.

see pamphlet collection in N. Y. Public Library. 
sciences, but much of vain pomposity and parade of erudition. Frequently his illustrations and his classical quotations were traceable to common manuals and handy dictionaries. And there were graver faults, as we shall see. which critics who disliked his manners and the methods of his party management, were quick to seize upon. The societies, they said, which let themselves be gulled by such transparent frand, were themselves fair butts of ridicule. It is not surprising that among these keen lampooners the most conspicuous was " Abimelech Coody," Gulian C. Verplanck.

As Verplanck had listened to the mayor's stinging rebuke in the famous trial for riot, he had resolved to devote his pen from that day forth to the disgrace of Clinton. The coalition by which Federalists gave their votes to make the mayor President was abhorred by Verplanck, and he felt chagrined when Federalist councils of appointment retained this enemy in office. In I8I4 he wrote a series of attacks printed in a political sheet called The Corrector, ${ }^{1}$ but word: were not his only weapons. The Federalist party, he declarerl, nust be made clean of this defilement, and joined by Hugh Maxwell and the Radcliffes, who had been snubbed in applications for the mayor's office, he published a schismatic ticket for the assembly. The "Washington Federalists" was the name assumed by the associates in this enterprise: but by the hostile Evening Post they were hailed derisively as "Coodies." Judge Spencer, then at war with Clinton. thought he saw some possibilities in this little party, but the ticket was supported by a few score voters only, and the movement toward a new party was for a time abandoned."

In I $_{15} 5$ there appeared another Coody pamphlet called $A$

'W. C. Bryant, Discourse on Terplanck, p. I8.

'N. Y. Commercial Advertiser, April 26, May 2, 18I4; Hammond, vol. i, p. 308. 
Fable, wherein Clinton was portrayed as " a young Irish sreyhound of high mettle and exorbitant pretensions." ${ }^{1}$ In the Analectic Maga ine Verplanck and certain colleagues described in an irreverent humor the publications of the mayor's learned societies, and ridiculed their members, whose long lists of honorary degrees, they said, were monuments of vanity. ${ }^{2}$ Although the author had no word of praise for Tompkins or his Virginia overlords, the Tammany Society was much delighted by this round abuse of Clinton.

The object of all these attentions had not the gift of silence. He responded with a Letter from a Traveller, ${ }^{3}$ first berating James K. Paulding, whose recent Lay of the Scottish Fiddle had contained some bitter satire on the friends of Clinton in New England. ${ }^{4}$ Other writers in the group were then attacked, but the most savage thrust was saved for young Verplanck. This man (the letter ran) who had made his first exhibition in life as a rioter in a church and since, like Hannibal upon the altar, had sworn revenge upon the arm that punished him, was now

the head of a political sect called Coodies. of a hybrid nature, composed of the combined spawn of federalism and jacobinism. and generated in the venomous passion of disappointment and revenge; without any definite character, neither fish nor flesh,

1 A Fable for Statesmen and Politicians of All Parties and Descriptions, by Abimelech Coody, Esq., Formerly Ladics' Shoemaker (N. Y.. 1815).

"Analcctic Magazine, vol. iv (1814), pp. 349-350.

"(DeWitt Clinton) An Account of Abimelech Coody and other celebrated writers of Neav York; in a letter from a traveller to his friend in South Carolina (N. Y., I815).

- See especially canto ii, stanzas iii, iv, xi (note 9): canto iii (note 3): canto v, stanzas xri, xxvi and notes 9 and 12 . The fact that these young writers took remuneration shocked Clinton: "Almost in every other place men write for amusement or for fame-but here there are authors by profession, who make it a business and a living." 
bird nor beast, animal nor plant, but a non-descript made up of

All monstrous, all prodigious things,

Abominable, unutterable and worse than

Fable ..... 1

After the unkindest caricature of his enemy, the "The Traveller" described himself: "Mr. Clinton, amidst his other great qualifications, is distinguished for a marked devotion to science-few men have read more, and few can claim more various and extensive knowledge. And the bounties of nature have been improved by persevering industry." Such self-appreciation would be beyond beliei had not the manuscript in his own hand been preserved by the printer. ${ }^{2}$ After this performance he was, for a time. allowed to rest, for Verplanck spent the next two years in Europe. ${ }^{3}$

${ }^{1}$ Pages 12, 14-15. Clinton's unpleasant temper is revealed by his description of Verplanck, touching on physical peculiarities, such as are by custom immune from the pen of satire: "When I saw Abimelech Coody, he arose from his chair as I was announced and did not approach $m e$ in a direct line, but in a sidelong way, or diagonally, in a kind of echelon movement, reminding one of Linnæus' character of a dog. who he says always inclines his tail to the left. This I attributed at frst to diffidence, but I no sooner had a full view of him, than $I$ instantly saw

...' the proud patrican sneer,

The conscious simper, and the jealous leer.'

His person is squat and clumsy, reminding one of Humpty Dumpty on the wall. A nervous tremor is concentrated at the end of each nostril, from his habitual sneering and carping, with a look as wise as that of Solomon, at the dividing of the child, upon an old piece of tapestry."

That Verplanck deeply resented this indecorous attack is shown by his reference to Clinton as one who would

$$
\text { "-sneer at crooked back or gibbous breast;" }
$$

see his Bucktail Bards (noticed infra), p. I34, and note p. I50.

2 I have not seen this manuscript, but Chief Justice Daly, in his Biographical Sketch of Verplanck, speaks of its existence in 1870 .

${ }^{3}$ On this journey he was accompanied by his wife, the sister-in-law of J. O. Hoffman. Mrs. Verplanck died in Paris in $18 \mathrm{I} 7$. 
So far, among the Federalist party, the active opposition to Clinton had been limited, for the most part. to literary men, but they were soon supported by recruits from among the politicians. J. O. Hoffman had supported Clinton in I8I2, and since that time had been a constant worker in his interest. Having been appointed recorder of the city by the Federalist Council in I8Io, and turned out by the wheel of change, he looked for restoration when Clinton came to power. But though the governor professed his gratitude for Hoffman's many services, the office was bestowed upon another Federalist. No fault could be found with Peter A. Jay to whom he gave it, but this did not solace the defeated candidate who now joined the opposition. ${ }^{1}$ Several other Federalists were disappointed. The charge that Clinton favored Federalism would hurt him with old friends among Republicans, and the Council seemed extremely chary as to honoring the gentlemen of the "old party" even though their help produced Clintonian majorities. Most Federalists accepted this condition.

Let us await calmly and tranquilly a better state of things [admonished "Senex" in a letter to the Albany Advertiser]; talents and virtue will be certain to attract attention and gain notice. Gov. Clinton can scarcely be considered a free agent as regards those who have borne the name of federalists; the least indication of even a liberal treatment of one of us is seized upon as evidence that he is turning federalist. ${ }^{2}$

The Federalists were secretly welcomed by Clintonians, but except for a few like Peter A. Jay, they were officially ig-

'Wm. A. Duer, Reminiscences, pp. 27-28; N. Y. Commercial Adzertiser, April 9. 14, 1819; N. Y. American, April 14, 24, 1819.

"March II, I5, I819. "And would you," sarcastically answered a Federalist opponent of Clinton. "would you have Mr. Clinton subject to the possibility of incurring such a vile imputation?" N.Y. American, March 20, ISIg. 
nored. Yet the Coodies and their friends would have it that the party had been.sold out for offices by the Columbia Junto; the voters had been duped. Upon Oakley and his accomplices who hoped for personal reward, they fixed the name of Swiss, who fight for pay. ${ }^{1}$

The final, formal break within the Federalist party came upon the question of the re-election of Rufus King as senator. When, with the assembling of the legislature in I8I9 the matter was considered, it was assiduously whispered here and there by Tammany men that King was favored by the governor. those artful plotters hoping thus by bringing in a Federalist name to spread unrest among the old Clintonians. Some who had criticised Clinton for in. difference to his Federalist allies relented on this rumor, but were undeceived when they investigated. ${ }^{2}$ The governor had not forgotten King's speech in 1812 ; even if he had determined to extend the patronage to others than Republicans (which he feared to do), Rufus King would have been most carefully neglected. The malcontents, led by John A. King, the senator's son, and William A. Duer, declared this was enough to establish Clinton as the very monument of perfidy and selfishness. Henceforth the Coodies had energetic friends in Albany. There seemed hope that some Federalists, who had been supporting Clinton, would rally to their older leader, and Rufus King was nominated as an old party candidate. The Martling Men were glad to see the coalition threatened, and young King believed that he might count on some New York Republicans to support his father's interest; ${ }^{3}$ but he was over

'This name was first applied by Gen. Root in the legislature of i819, see Bucktail Bards, p. 59.

${ }^{2}$ Hammond. vol. i, pp. $482-483$.

${ }^{3} \mathrm{~J}$. A. King to R. King, Jan. I4, ISI9, and R. King to J. A. King, King Correspondence, vol. vi, p. I9I. 
sanguine; conditions were not ready for this strange alliance. As the Clintonians named John C. Spencer, the son of Ambrose Spencer, so Van Buren and his Martling followers selected Colonel Samuel Young, who was quarreiling with the governor about the canal funds. ${ }^{1}$ The votes were taken on February second; King had but twenty-eight, yet neither of his rivals had commanded a majority; the election was seen to be impossible in that legislature, and it was postponed until the following year. ${ }^{2}$

Most Federalists took the outcome calmly and helped to elect a Clintonian council of appointment in hope of a supreme court judgeship," but some were not so tolerant.

The manner in which the federal party [wrote John A. King] has been treated upon all occasions and most especially in the nomination of the Senator, by Mr. Clinton and his adherents, decided me never to give my support to a Council of his selection: not willing therefore to throw away my vote, and willing to bear my testimony against that gentleman's conduct, as well as to evince my disapprobation of the direction which has been given to the sentiments of the majority of the federal party by some of its interested and artful leaders, I voted for the Martling Council-Mr. Duer and Carman were the only federalists who voted with me.*

But the Clintonian Federalists determining on a closer coalition were ready to excuse the slight on Rufus King. The Hudson Whig, which voiced the opinion of the $\mathrm{C}_{\text {?- }}$ lumbia Junto. asked if a man who curried favor with the cabinet and justified the atrocities of General Jackson in Florida could deserve the honor of his party. ${ }^{5}$ Oakley and

${ }^{1} C f$. Clinton Mss. during I819. $\quad=$ Hammond, vol. i. p. $4^{86 .}$

${ }^{3} \mathrm{~J}$. A. King to R. King, Feb. 3. ISIG. In this hope they were disappointed.

'Ibid., also J. A. Hamilton, Reminiscences, p. 4 .

suoted in $\mathrm{A}$. Y. American, May I, I819. 
James Emott of Dutchess County deprecated all the unpleasant agitation for King. It was obvious that unity was past.

While John A. King was gathering supporters one by one in Albany, his brother Charles-the ebullient Charles, surnamed "the Pink" - was planning out another enterprise. Gulian C. Verplanck, now returned from Europe, his cousin Johnston, and some others of the same age and social station. joined with Charles King to found a newspaper. They were to call all honest men to their support, recreate the party of the talents and proscribe the renal Swiss, who had usurped the rule and maintained it by intrigue. These young men would not sit with their " hands folded while the character and best interests of the state are sacrificing at the shrine of a few profligate and ambitious leaders." : Thus the New York. American was begun on March 3. I 8 in, a sniall semi-weekly sheet with large type, no advertisements and little news-chiefly editorials against Dellitt Clinton and his band of followers.

Disapproving of the conduct of all parties in their native state [announced the editors] they will do their utmost to overturn a system of fraud and venality, and to rescue the character of New York from the disgrace, and its power from the abuses. consequent to the control of men, whose means are corruption and hypocrisy, whose ends are the gratification of their petty and selfish ambition.

The credulity of those poor dupes who made up the Fed.

'G. K. Schuyler, “A Gentleman of the Old School," Scribuer's Magazinle. vol. 1v, p. 612. References to his manners and his conversation can be found in numerous entries in Philip Hone's Diary.

${ }^{2}$ Charles King to Rufus King. Feb. 8. I8I9. This letter is not puhlished in full in C. R. King's edition of The Lifi and Correspondence of Rufus King. but was consulted in the King Mss., in the N. Y. Hist. Soc. Collection:- 
eralist majority, they averrel was pitiful; even Clinton's major triumph, the project of the canal, was the legacy of Gouverneur Morris. Clinton was but "the step-father of internal improvement." He had scorned them as traiturs in ISOS, then flattered them in I8I2 and since. Now after gaining the support of many and again in power he refused to requite any of his obligations. ${ }^{1}$

The other Federalist papers, attached to Clinton's interests, looked on with amused contempt.

A litíle, meagre, drivelling, skewing Tammany paper [scornfully renarked the Albany Advertiser] has been got up in the City of New York, by a knot of scribblers, who consider that the universe rests upon their shoulders, and the state of New York is a foot-ball which they can kick about with their neat little pretty morocco pumps ... We are told that Alexander Hamilton, the present leader of the Tammany delegation, and James A. Hamilton (another son of the late General Hamilton) are two of the editors. Mr. Barent Gardenier has declined. Mr. Hugh Maxwell and G. C. Verplanck, who we believe are both Tammany now, but who lately pronounced two Washington Benevolent Orations, ${ }^{2}$ we are toid are among the editors. ... The number of editors who conduct the American is not far from twelve or fifteen. ${ }^{3}$

The young editors resented all these charges of desertion to the enemy: they tried at first to be as independent of Van Buren as of Clinton. They desired a third party to which true Federalists might rally-- the " high-minded descendants of the great men "- -and put forth in March a ticket to attract such a following. But they were embarrassed by the applause of Clinton's foes within the Democratic party; a

${ }^{1}$ N. Y. American, March 3, I8I9.

"Maxwell hai spoken before the Hamilton Society, N. Y. Statcsman, Feb. 26, I8I4. For Verplanck's oration see supra, ch. iv.

${ }^{3}$ March 0.1819 . 
common enemy makes strange friendships, and the sympathy proved irresistible. It was not pleasant to go to Tammany Hall, for the sachems had been unwilling to join them in the fight for Rufus King, but it was inevitable. In April they compounded a mixed ticket; a new coalition was forming. ${ }^{1}$ Throughout the state at the election of I8I9, a surprising number of Federalists were chosen for the legislature. Yet the American was not sanguine that these victories would stimulate the party to self-reliance or that the trend toward Clinton would be checked. To co-operate with all opponents of the governor was deemed the editors' only course, since their own old partisans were so indifferent to their call. "Which side the majority of the Federal representatives will take, is, we hope, at least, doubtful; although we fear honesty will be no match for intrigue."

Clinton realized that some recognition now was necessary, and Thomas J. Oakley from Dutchess County, a Federalist leader in the legislature, was appointed to the lucrative and influential office of attorney-general. The Coodies and their colleagues were outraged; if Clinton was to win the loyalty of the Federalists by offices, why pass by the great King in February and pick out Oakley in July? "Answer ye timid creeping things, who fear the winter irosts, but whose activity and venom is warmed into life by the summer heats -answer if you dare." : Anything that the Clintonians would do or could do, simply proved a signal for more acrimonious philippics. Indeed as one reviews the writings of these young gentlemen, he is irresistibly drawn to the belief that they hugely enjoyed these opportunities for plain and ornamental rhetoric,--for literary self-expression with Clinton taken as the theme. One suspects they founded

'American, March 1o, April 7, 2I, 24, I8I9; J. O. H[offman] to W. P. Van Ness, Feb. 25, I8I9, Van Ness Mss.

${ }^{2}$ Anerican, May 19, I819.

${ }^{3}$ Ibiai.. July $2 \mathrm{I}$. 
their newspaper not so much that certain things should get done. as that they should have a chance to urge them in fair periods. Nor does this question their sincerity; youth in its egotism yearns to be of service, conspicuously and theatrically, but still honestly. The Verplancks, the Kings, the Duers, the Hamiltons, loved to do the service of unrestrained writing.

A sample of their style. it is believed, will not be wearisome: ${ }^{1}$

But quickly the election returns [of 1819 ] presented to the money changers a new and unexpected result: a return to the assembly of Federalists in number and character altogether unlooked for and unknown. It required the whole extent of the exercised talent of these versatile actors [the Clintonians] to adapt their language and their conduct to the new state of things. The old song of the absolute necessity of the dissolution of the Federal party could no longer be usefully said or sung; without a flush of shame they resolved to chaunt their palinode. But as the reputation of Lord Bacon [Elisha Williams?] was rank, and as the two other Bondsmen were not in sweet odour, the gentleman from Dutchess, the secret hand. was selected at the May term to sound the trumpet and beat the drum for the Federal muster; the ranks were thin-the service seemed not promising; and even among the known devotees of the Junto-among some of the enlisted lobby agents, the money changers,--there arose the voice of discontent, and a murmuring sound of dissatisfaction. It rang in the ears of the by-standers something like " point d'argent-point de Suisse." [But Oakley's appointment silenced all] ... . How idle it is to talk of words when Ecce homo-ecce signum, is an argument that speaks to the senses, and sets at naught the orator's art or the poet's power. Alas, Walpole, wert thou to arise. how wouldst thou weep to see thyself undone. Every 
man with thee had his price: yet even Walpole never knew the infinite advantage of having his own proper person a standing example, a speaking argument of the merit of recent works, and of the benefits of conversion. The device is ingenious, the effect ought to be assured, and the practice recorded. It is worth tomes of casuistry and volumes of newspapers..... Religious aspirants have no glimpse vouchsafed them of heaven but through promise and description; but the rulers of the State of New-York work not after ancient nodels, nor by types and figures and words; they point to the mant, they show you with their fingers the cause and the effect. They scorn the coldness of a verbal description, and distrust the uncertain power of promise; they put their seal of office on the forehead of their late convert and now proselyting minister, to give efficacy to his calls, warmth to his words. and point to his arguments. In the same manner the Justice [Spencer] that worketh unseen, and hath power and might for a day and a year and a season, points to his creature as the proof of his dominion: it is a sign for the times, nor is it unreasonable to expect from such a sign the gathering of both Jews and Pagans, the Clintonized Federalists and the unadulterated Clintonians.

Where such duplicity could flourish was no place for honest men. The loyalties of the Federalists, they said, could not be sold; the faithless leaders and their dupes should be abandoned and the honorable remnant join with Clinton's enemies; men like Martin Van Buren would properly appreciate their purpose and their service. By the middle of the summer it was generally known that there had been a thorough-going coalition between the Federalist malcontents and the sachems of the Tammany Society. ${ }^{1}$

There now appeared a pamphlet called $A$ Martling $M a n$. or Says I to Myself-How is This?, ${ }^{2}$ a satire which, with

I American, July 3, I., 21. Aug. 14. 1819.

${ }^{2}$ The series of letters comprised in this pamphlet was first printed in the $N . Y$. Columbian in the spring of 1819 . 
incisive wit like that of Abimelech Coody, presented an innocent inquirer to make the enemy absurd. But this was written by an old Clintonian, Pierre C. Van Wyck, with some revising, it was charged, by the governor himself. ${ }^{1}$ It took up one by one the strangers who had been received at Tammany Hall. Josiah Ogden Hoffman was the first. it said, because he had not been made recorder; Barent Gardenier, Philip Brasher and some others had followed for like reasons; Richard Hatfield and the Hamiltons had been persuaded to come in by promises and flattery, to gain the value of their names; Hugh Naxwell and "Gilley" Verplanck, who had hounded Clinton since the riot in Trinity Church, now tired of guerilla fighting had brough: their Coodies to the Martling army. William A. Duer and some others had joined with General Root. the old Madisonian chief, at Albany, " to go thorough in their opposition to $\mathrm{Mr}$. Clinton." The Democrats of Tammany were eager to extend a welcome to all the apostates; these, they said. were true patriots; whenever Mr. Bayard or General Clarkson said a word of praise for the governor, it was complained that such Federalists had purchased Clinton.

But in the literary contest the Martling Man was destined to be far outmatched. If he (as well as Abimelech Coody) suggests successors like Major Jack Downing and Hosea Biglow, a rival came into print far more pretentious, who

'The cony in the N. Y. Public Library is endorsed "by Pierre Van Wyck": sce also The Bucktail Bards (see infra), p. 48 :

"Retouched and interlined was here A Martling Man: 'twas sent by Pierre:

Hoping his Magnus would be willing

To help the wit, and mend the spelling.'

See alsu ibid.. note. pp. 73-74. He was at that time District Attorney, having been Recorder of the City of New York. He is described by Judge Hammond as poor and dissipated, but a man of talents. Poitical History, wol. i. p. $\$ 23$. 
recalls the Augustan age of Pope and Swift. Gulian C. Verplanck, with some aid from John Duer and from Radolph Bunner, a politician and a scholar who had been at one time a trusted colleague of the Columbia Junto, ${ }^{1}$ published in the Amorican during 1819 a series of seven poeti: satires on Clinton and his friends. Such was the interest they aroused that before the year was done, Verplanck had reproduced them in a volume of some two hundred page; entitled, from the ancient Tammany emblem, The Bucktail Bards. ${ }^{2}$ Possessing the urbanity and easy grace of the Knickerbocker school, replete with grave quotations from the lines of the Eneid, the Horatian Odes, Macbeth, Absalom and Achitophel, and the Dunciad, it was obviously written for an andience of cultivated men, in hope, no doubt, of winning them away from Clinton. The satire of the poems is so apposite and sharp. that they might have been important in the history of American literature were it not that their allusions are so hopelessly obscure to all but those familiar with New York a hundred years ago. It were pleasant, were there time, to regale the reader with the delicious foolery of Scriblerus Busby's Prolegonena, wherein the author with waggish impertinence pays respects to the critic Jeffrey, to Charles Philips, the Irish orator, and to Dr. Parr, the classicist, who is supposed to have sent a bit of doggerel. impressive in Greek transliteration, or to the

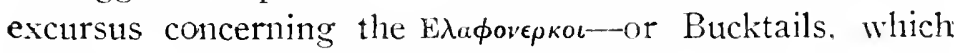
so cleverly pokes fun at the pedantic Clinton and his learned societies.

'W. C. Bryant, Discourse on Verplanck. P. I8; J. A. Hamilton, Reminiscences. ir. 2 .

2 The tail of the buck worn in the hat was adopted as the official badge in 17gr. and the name "i'ucktail" had heen fastened on the party; E. P. Kilroe, Saint Tamma'y and the Origin of the Socicty of Tammany or Columbian Order in the City of Neze Yorit (N. Y.. I9I3). pp. It. It?, 14, ז64. 165. 
The first poem portrays "The State Triumrirate," Clinton, St. Ambrose (Judge Spencer) and Fallacio (Judge Van Ness), and tells the story of an office-seeker, Dick Shift, who played to win their patronage by the demonstration of his talent in hypocrisy:

\section{"'Corruption?' True, his forte, his trade, And yet no word, no look betray'd His guilt; but acts of baseness name, He was the first to cry out, "shame'; Though prudent, doubting still the fact. The vice he blam'd, was vice abstract: the held the maxim quite sublime, To spare the sinner, lash the crime-." =}

The hero is presented to the stern St. Imbrose, who is won by flattery, he is brought within the chilling gloom of Clinton's presence, and gains Fallacio's ear by cumning plans for a conspiracy. Verplanck deplores the fall of Judge Van Ness. who has been Clintonized-

$$
\text { "O that a mind, }
$$

form'd to instruct or mend mankind.

Fy noblest arts to rule a state.

Or King's pure fame to emulate.

Py use, by habit, long deprav'd,

To low intrigue should be enslav'd!"

-and sometimes in anger or in shame at the disgrace to which Clinton and his men have brought the state, leaves far behind the sportive vein of satire.

There are three " Epistles of Brevet Major Pindar Puff." in heroic verse, supposed to have been written by the governor's salaried panegyrist, whose confessions, inserted here and there within the fulsome flattery assumed to be enjoyed by Clinton, envenom the point of the poet's sarcasm. ${ }^{2}$ Clinton's vain show of his learning and the solecism

\section{Page 35.}

3 "Of praise a mere glutton. he swallow's what came. And the puff of a dince. he mistook it for fame:

Till his relish grown callows, almost to disease.

Who peyprer'd the highest was surest to please." (p. 1 qn). 
of his turgid prose are subjects of the satire. ${ }^{1}$ For one who valued himself upon his literary reputation, this merciless dissection of his masterpieces was doubtless painful, but the Major must go further to admit the plagiarism of his bero in

"That fam'd discourse, of patches fram's From authors.

Quoted?

No, not named;

The stolen thoughts, the skill that suits.

The art that 'pilfer'd tropes transmutes,'

The passage chang'd, to nonsense leaning,

Retains the words, and drops the meaning;

'The flow'rs he seiz'd from Johnson-.

Well?

He caught the stalk, the blossoms fell!" 2

He offers in a deadly parallel a dozen excerpts from the learned lexicographer and Dr. Clinton to prove the latter's much too profitable reading. ${ }^{3}$

Of course the governor's fellow scientists like Dr.

"His skill in conch-shells, and his Indian lore:

His wondrous wislom in our state affairs.

Ilis curious knowlerge of the tails of bears." (p. 104).

See especially the comment on Clinton's ineptitude in classical allasion. on pages $143-14.4$. The author in a note thus characterizes Clinton's style; "His wit has a sort of partridge flight, always low, never light, gay or airy, or of long continuance, yet still with a good deal of activity and whirring rigor, as long as it is on the wing" (p. 173). The American printed an "account" of a paper upon "the Clintonian crabapple, which is produced by a graft of the Fyram Toricum, or biuelight pear, upon the Malum Jacobinum, or Jack-Cade pippin. It was for this discovery that Dr. Clinton was elected a member of the Londion Cockney Historical Society, as announced by Messrs. Lang lof the N. Y. Gazette], Lewis [of the Commercial idrertiscr], and Spones [of the Columbian]."

2 Bucktail Bards, p. 47; see also pp. 104, $13 \mathrm{I}$ and 155 .

"Pages 141-I46. A reference to like borrowings from Hume and Burke appears on page 131. The Albany Argus accused him of plagiarizing Frexlerick the Great (Dec. 18, i8ig). 
Mitchill, Dr. Hosack, Mayor Colden, and the rest, are likewise cleverly lampooned as partners of his pedantry, and the poet then speaks

"Of learn'd Societies, that nothing need, In every walk of Science, to succeed, Save more attention, and some more expense, And some more learning-and a little sense." 1

Other members of the literary group, besides the Bucktail Bards, contributed good verses, as when Halleck's gentler muse, in Fanny, played

"Around the many, whose exalted station Has been attained by means 't were pain to hint on, Just for the rhyme's sake-instance Cl*n*on." 2

To defend the governor a number of his friends now sharpened their pens

'Page 133, and note on page 149. This plase of Clinton is satirized also in a poem called The Pilgrims of Hope, An Oratorio for the Clintonian Celcbration of the New Year, which appeared first in the N. Y. American, Jan. I, I820, and afterwards in pamphlet form (N. Y. Pub. Lib.). The following quotation from Chief Justice Daly's Biographical Skotch of Verplanck will he interesting: "The Bucktail Bards' was at the time attributed to Mr. Verplanck, though it has since been supposed to be the work of several hands, and the names of Judge John Duer, and of Rudolph linnner, an active politician and a man of vivacity and wit, have been named as connected with him in the production of it. He was himself always very reticent upon the subject. When called upon, at the dinner given in the Century [Club] to FitzGreene Halleck, to respond to a toast complimentary to this satire, he evaded the question of authorship, but on other occasions implicitly admitted his connection with it, lut that was all. He probably felt (for he was not a man to bear animosities) that he had accomplished by his production at the time, all that he had desired, and was willing to let the controversy end with the causes that had produced it " (p. 46).

"This poem was published first at New York in ISig. See in i 839 edition, pp. 7, I4, 18, 21, 27. In "The Croakers" published I819 et seq. by Halleck and J. R. Drake, there are many such references, see I'octical Writings of Halleck and ... Drake (N. Y., I869), pp. 255-362. 
"Against those rude and foolish, angry boys, Who in th' American his fame assail, Daring against our country's pride to rail," 1

and none with more effect than Gideon Granger, who, after thirteen years as Postmaster-General, now lived in Canandaigua. In a pampllet signed "Epaminondas" he professed unstinted admiration for Clinton and his efforts in behalf of agriculture and the Grand Canal. ${ }^{2}$ (He was himself especially enthusiastic with respect to the latter project and had given a thousand acres as his personal contribution, though his ungenerous enemies would have it that the land was scarcely worth the taxes)." He said the governor was abused by small pettifoggers, extortioners and sharp practicers at law, because of some most salutary measures he had carried through. He filled many pages with invective against Tammany. To meet the charge that Clinton had appointed Federalists he told of those appointed by Madison himself, beginning with James A. Bayard as peace commissioner. Let there be no great concern as to this matter:

we have lived to see the federalists disband as a party, and in general retire from political strife. We have lived to see some of their bitterest leaders join the opposition of Mr. Clinton, and make the most vigorous efiorts to excite your prejudices against him, while at the same time a portion of the more thoughtful and moderate have given an honorable support to the administration. ${ }^{4}$

Granger was too canny and too cautious in speaking of

'Bucktail Bards, p. I32.

"Gideon Granger, The Address of Epaminondas to the Citincus of the State of New York (Albany, I81g).

${ }^{3}$ Report of State Surveyor, I863. N. Y. Assembly Doc. I. p. 99; Genez't Pulludium, quoted in N.Y. Americar, Jan. 22, I820.

4 Pages 28-29. 
the latter "portion," for they really constituted nearly all of the old party: they chose to vote for Clinton rather than court humiliation with a candidate of their own number. Clinton had become the leader of the aristocracy, with a few conspicuous exceptions, and with this group Granger was at heart right glad to be associated. He had grown rich by the proceeds of his fire-lands in the Connecticut Western Reserve, and with money invested in stocks and bonds, as well as land, he now lived near Federalist friends. in a mansion " full of servants." " His three sons married into Federalist families," and one of them, Francis, became an able leader of the Whigs in the state and nation. By such evidences throughout the state, the firmness of the coalition was revealed.

When the legislature met, in I820. Clinton knew that it would now be folly to deny his Federalist connections; his private spite against Senator King he straightway swallowed and in an address to the legislature announced himself a supporter of King's election. The interest focused on the

'Gideon Granger to Clinton. Dec. I3. I820, Clinton Mss. As to his friends see article under his name in Appleton's Cyclopedia, checked with references to John Greig. William Wood in N. Y. Commercial Adzertiser. March 18, 1816; he left his affairs in the hands of Jonas Platt. The author has examined Mr. Granger's will in Canandaigua. N. Y., and has computed that his property ran far above $\$ 100,000$.

"See J. Granger, Launcelot Granger.... a Genealogical History, Hartford, I\&93. The eldest son, Ralph, married the daughter of W. W. Van Ness (see marginal correction in copy in N. Y. Pub. Lib., pp. I8I-182); the second son, Francis, married a Van Rensselaer of Utica (p. 30I); and the third, John Albert, a daughter of Amasa Jackson (p. 305). To check Jackson, of. his toast at the Federalist banquet. New Yurk city. N. Y. Comnercial Adzertiser. Feb. 23, ISi5.

After Granger's quarrel with Madison, in which the redoubtable wife of the President was said to have had a share (see note to Pilgrims of $\mathrm{Hope}$ ), he was attracted to Clinton as the champion of the north in the fight against Virginia domination within the Republican party (see, for example, his interesting letter to Clinton, March 27, 1816, Clinton Mss). 
Bucktails. Would they dare to flout their new allies who wrote for the American, by neglect of their admired hero? Yet would they dare nominate a Federalist? Van Buren, Root, Young and others conferred with William A. Duer; all agreed that the Federalists had so far declined as a party. that he could safely be endursed. ${ }^{1}$ Van Buren, with the aid of William L. Marcy, the recorder of Troy, prepared a pamphlet in praise of $K$ ing as a patriot who had stood by the President in the War of ISI2." And so, as John Quincy Adams recorded in his diary, "King, who after ro trials last winter, could not get so many as twenty votes out of one hundred and fifty, now came in by a unanimous vote of the Senate and all but three of the Assembly." "This concession on the part of the Denocracy was considered as another sign that Federalism in its old organization was dead.

In a caucus of the party on the question of the speaker, Elisha Williams announced the policy of the Columbia Junto: "A committee should be appointed in belialf of the gentlemen then present to meet and state to the friends of Mr. Clinton that the candidate of their choice should receive the cordial support of the federal party." T. J. Oakley and others cordially approved. John . . King at last arose, confessing his amazement at such hardihood. A fair proposal had been made to name a Federalist; it had been heard in silence by these once respected leaders. He announced his intention to vote for the Republican, or if gentlemen pleased so to call it, the Tammany candidate. He would never meet with Federalists again at the behest of the

'J. A. King to R. King, Jan. 8, 1820.

'Van Buren Mss.. Dec. ${ }^{13}$, 1819 , for draft. Cf. Albany Arghis, in discussion, quoted in American, Dec. 18, I819, and E. M. Shepard. Martin Van Buren (Boston, 1888), pp. 60-62.

'J. Q. Adams, Memoirs, vol. iv, p. 517. 
wretched junto from Columbia County. He moved adjournment; and thus came to its end the Federalist party in New York. ${ }^{1}$

A few days later there appeared An Address to the Independent Federal Electors ${ }^{2}$ which declared the party broken up ${ }^{3}$ and even the ties of private friendship which had bound its nembers now finally severed. ${ }^{4}$

It is, therefore, after deliberate reflection [saici its signers] that we have resolved to unite ourselves, unequivocally, and without reserve, to the great republican party of the state and union ... With republicans we entertain a deep-rooted distrust of the views and character of Mr. Clinton as a politician ... He has endeavored to create a personal faction, and to surround himself with a band of low minded sycophants, and venal dependents ... Let others prostrate themselves before their sultan, in humble adoration; we mean not to enroll ourselves in the Janissary corps. [As to those Federalists who join with Clinton] we confess our inability to account for this union upon any other principles than mutual private interests of the parties.

To this address there were some fifty signers, including, besides the young men of the American, such prominent Federalists as Morris S. Miller and Zebulon R. Shepherd, who had sat in Congress," George Tibbits, who had been

${ }^{1} \mathrm{~J}$. A. King to Charles King, Jan. 6, 1820, King Correstondence.

2.An Address to the Independent Electors of the State of New-York, on the subject of the Elcction of a Goiernor and Lt. Governor of the State (Albany, I820).

${ }^{3}$ This announcement was received with consternation and reproach in states like Maryland, where the Federalist party had some hopes. Rufus King was obliged to explain in letters to such objectors that conditions in New York were "very peculiar."

"This threat of social ostracism had been made on the other side in $18 \mathrm{I} 6$, see $N . Y$. Commercial Adrertiser, April I9, I\&I6.

5 Mention had been made of Iudge Miller's importance in chs. ii and iii. 
the candidate for lieutenant-governor in 1816 , and many who had served in Albany. Judge Hammond remarked that he believed that in the annals of political parties there could be found no like number of men of talent, wealth. social position and personal worth, so scattered through the state, who combined for a single political object and yei drew after them so few voters of the party, as did these men of IS20. ${ }^{1}$ Their reasoning was dismissed as silly. While everybody knew that most good Republicans disliked the governor because he would consort with the Federalists, these protestants withdrew professing their belief that the Federalists, as such, had disappeared. In their florid rhetoric they had frequently referred to themselves as " high-minded men." The opposition mocked them with their own description; henceforth they were the "High-minded Federalists."

Their efforts, then, met small reward. Particularly anxious were the sons of Rufus King to have their father's blessing on their enterprise. but though several times addressed in terms affecting, but respectful, the seasoned statesman quietly refused to be a party to their plans. That he had a low opinion of the governor was certainly no secret, but he saw no cause to sow the seeds of bitterness between himself and Clancellor Kent, the Patroon, and Juclge Platt and others of his friends who had joined with Clinton. ${ }^{2}$ He would not have it seem that Vain Buren and

Shepherd was a well known lawyer of Granville, Washington Co., see C. Johnson, History of IVashington County, Philadelphia, 1878, pp. 202, 205, and N. Y. Civil List, I882, p. 45I. The name is variously spelled. Many of these men had attended the convention that had nominated $\mathrm{King}$ in $\mathrm{I} 8 \mathrm{I} 6, \mathrm{cf}$. N. Y. Commercial Adiestiser. March I\&, I 8 I6.

1 Political History, vol. i, p. 529.

${ }^{2} \mathrm{He}$ was no doubt infuenced in this direction hy a letter from Robert Troup, March 22, 1820. Van Duren's letter of March 23 to the senator 
himself were trading favors. There were others of the old party who disliked Clinton heartily enough but could not bring themselves to vote for Tompkins, who was named for governor by the Bucktails. The Vice-President as govemor throughout the late war had been careless in his accounts. The comptroller, Archibald McIntyre, drew up a lengthy statement of his derelictions, impressive in transcriptions from the ledgers. "The secretary of the navy, Judge Smith Thompson, was considered as a candidate by some Democrats, but to abandon the Vice-President would savor of disloyalty and he was retained in spite of criticism. ${ }^{2}$ The High-minded Federalists who had professed so nice a sense of honor, could scarcely all be won to Tompkins while his reputation bore this stain. For example, at a meeting of such gentlemen in Madison County, resolutions were passed disapproving Clinton and the Federalists in the legislature who had endorsed him. but likewise opposing Tompkins. and, as between the two. declaring their neutrality. ${ }^{3}$ It was doubtless these circumstances that made the schism less important. The majority of leading Federalists read the address of the seceders with boisterous derision.

Whereas, the fifty-one high-minded gentlemen [wrote "Jonathan Old School "in the Albany Advertiser . . have expressed a wish to be released from the federal party, and from all those who have heretofore been their political friends, in

is a model of courteous suggestion. John A. King's letters show Asnity in disappointment; see especially that of April I3. Charles was less patient; see that of March 18 . $\mathrm{Wm}$. Coleman also earnestly but vainiy sought King's active aid for Tompkins, see letter of March Ir.

'See especially (. I. McIntyre) A Letter to His E.rcellency Danicl D. Tompkins Late Governor of the Statc of New-York, II 2 pp. and typendix (Albany, i819).

${ }^{2} \mathrm{R}$. King to Van Buren, Jan. 31, 1830 , King Correspondence: Hennett Bicknell to P. G. Childs, Feb. 14, I820, Childs Mss.

"M. S. Miller to P. G. Childs. March 6: Bicknell to same, March :7, I 820 , Childs Mss. 
behalf of fifty thousand voters in the party I do hereby release, quit claim and discharge the above high-minded gentlemen from all allegiance.

granting all right, title and interest to the Vice-President and his Bucktails.'

It was believed that the break would not be serious outside of New York city, " but there the Federalist friends of Clinton must be active. The Commercial Adertiser after observing that in the calm of the last four years the Federalist freeholders had not deemed it necessary to give themselves political concern, now warned its readers that that time was past. ${ }^{3}$ At a neeting in Washington Hall, a motion to nominate an independent ticket was overwhelmingly defeated, and Clinton was endorsed with much enthusiasm. ${ }^{4}$ Elsewhere in the state old Clintonians averred that now that the Federalist party had been purged of noxious slanderers they were more anxious for a coalition." Judge Van Ness declared that, "There is not now an influential or respectable federalist who is not with us. The few few who have gone are objects of disgust and contempt." " The High-minder Men, or "Royal Party" as they were sometimes called, plaving on the name of their chief leaders, ${ }^{\top}$ were said to have their hope of due reward: and. in-

'April 2I, 1820.

"The Patroon to Sol. Van Rensselaer, March 7, I820, Mrs. Bunney's l.egacy, vol. i. p. 350.

"April I ; see also Albany Gazitte, March 20, 1820.

'V. Y. Spectator, April 25, 1820.

'E. g. The Pcople's Ticket, For Gozernor DelVitt Clinton, etc., pamphlet (Waterloo, N. Y., I820), pp. 7, II. Undoubtedly written under the influence of Elisha Williams, the founder of Waterloo.

${ }^{6}$ To Sol. Van Rensselaer, June 20, 1820, Mrs. Bonney's Legacy, vol. i. pp. 34I-342.

'J. Mckinstry, quoted in S. W. Williams, The Family of Willians, p. 14.3 . 
deed, they evidenced but little self-denial in taking offec at the hands of the Republicans. William $A$. Duer was made a regent and then judge, when the Democratic party came to power; ${ }^{1}$ Hugh Maxweil was made district attorney for New York. George Tiboits and Barent Gardenier carefully negotiated terms," while Gulian C. Verplanck, John A. King and others were elected to the legislature. ${ }^{3}$

To all attacks the editors of the Amorican responded with full vigor. Elisha Williams. T. J. Oakley and J. R. Van Rensselaer were riddled with what piercing epithets ingenuity could furnish." but their largest ammunition was reserved for Judge Van Ness, an officer of greatest dignity among the Swiss. Throughout I8I9 they branded him as ain unjust judge devoted chiehy to the damning of his enemies, truckling to the powerful, and always ready to be purchased." In May they spoke of an impending revelation. "Like the sword of Damocles," said they, with stagey. mystery, "it hangs over you. and but a hair sustains it; it will fall at a proper time; till then we bid you a temporary farewell; "we shall meet again at Philippi." " ${ }^{\circ}$ The longheralded exposure came at the last of January, I820. It was then charged that Van Ness, with Villiams and J. R. Van Rensselaer, had accepted a huge bribe in I8I2 for their support and influence in chartering the Bank of America.

${ }^{1}$ Mr. Van Buren to R. King, Feb. 2, I8zo, King Correspondence; John Duer to Mr. Van Buren, March 27, 1819, and Van Buren to Joseph C. Yates, Dec. 10, 1822, Van Buren Mss.

${ }^{2}$ Van Buren to George Tibbits, Oct., I820, and B. Gardenier to Van. Buren, Jan. 20, 1821, Van Buren Mss.

${ }^{3}$ N. Y. Civil List, 1881, pp. 304-305.

'E. g., March 6, I0, I3, Apri1 17, 28, May I2, I5, July 17, I8ı.

${ }^{5}$ March 24, 27, 31, April 14, 24, 28, July 24, 1819.

${ }^{6} \mathrm{May}$ 15, 1819. There were other hints as to what was coming, as for example in notes to the Bucktail Bards and to Pilgrims of Hope. 
The allegation was now direct and could not be ignoreu. ${ }^{1}$ The Bucktails seized upon it and General Root, their leader in the legislature, proposed a formal inquiry, which in spite of protests from Van Ness and fellow Federalists, was provided.

Judge Hammond, who was then a member of the legislature, who later served two terms in Congress and made numerous visits to the English House of Commons, maintains that the debate upon this question surpassed any that he heard in those more tamous hails. ${ }^{3}$ It was developed in Elisha Williams' deposition that his own enthusiasm for the charter had been stimulated by an offer of a very advantageous loan to his bank in Hudson, but when war became more certain a higher interest rate had been requested. President Oliver Wolcott, of the Bank of America, for this consideration then offered Williams twenty thousand dollars, but the arrangement was contingent upon two good sureties being found to secure the loan. J. R. Van Rensselaer consented to be one, provided he was given five thousand dollars of the money paid to Williams. Judge Van Ness agreed to be the other, but with him there was no knowledge of the details of the contract or any word of compensation until about a year after the charter had been granted, when Williams insisted upon paying him a similar five thousand. The judge, then.

${ }^{1}$ Suggestions toward an investigation had been made by Alexander Iamilton as long before as March 9, I8I9, see Albany Adzertiser, March 10, I819.

${ }^{2}$ N. Y. Commercial Advertiser, Feb. 4, 1820. Root claimed "pubiic fame" sufficient to warrant such procedure, citing the case of Judge Chase. The Clintonian Federalists realizing that the inquiry was inevitable insisted only upon a committee large enough to insure them proper representation. Van Ness replied to the charge, in Albany Adrertiscr, Jan. 29.

${ }^{3}$ Political History, vol. i, pp. 522-523. 
in his efforts for the charter, despite all charges by the Bucktails, had leen innocent of any hope of personal reward." On "I'illiams' evidence he was finally acquitted. but the imputations were not soon forgotten, and his power in the state was much impaired." Williams and Van Rensselaer by their own admissions lost much of their prestige, and the Columbia Junto did not again essay to play a leading róle in politics." Another testimony had been given that the political leaders of the aristocracy were not above the temptation to enlarge their fortunes.

With these leaders gone, Federalists could no longer, in any sense, be said to have a party organization in New York. Although in some districts like that of Albany the designation was retained. the members of the fallein party, like the other opponents of the Democratic organization. were known as Conservatives or, more frequently. Clintonians. Henceforth, until he yielded to Van Buren and abandoned Adams, Clinton could command the votes of most "old Federalists," but hardly the same enthusiastic loyalty that had been vouchsafed to Hamilton and Jay, true representatives of their interests and their class.

'. Y. Y. Assembly Journal, 1820, p. 833: Hammond, vol. i, pp. 520-521, note; F. Ellis. History of Columbia County. pp. 9I, I77-178. Before the arrangement in Hudson was completed, a fourth beneficiary had been added, T. P. Grosvenor, Williams' brother-in-law and debtor; J. A. Hamilton, Reminiscences, pp. 48-53.

"Dr. Jeremiah Van Rensselaer to Sol. Van Rensselaer, March I, I820, Mrs. Bonney's Legacy', vol. i, p. 345 .

'J. A. Hamilton, in his Reminiscences. 1). 54 of course exaggeraten Van Ness' humiliation. 


\section{CHAPTER VIII}

\section{Property or People?}

IT was a favorite tenet of the Jeffersonian philosophy that no law should outlast twenty years without revision. Change is so normal in the modern world, that in any fundamental compact which elaborates the duties and the rights of man within the state, there is luck as well as foresight in the choice of words which will suffice more than a single generation. The constitution which gentlemen like Jay, Livingston and Morris had drawn up in 1777 to meet the needs of freeholders within the Hudson valley, did not content the workmen in the cities, ${ }^{1}$ who after is $S_{2}$ increased in number, or the farmers of the western countie: who had taken up their holdings under mortgages withholding title until final payment.

In the three decades that followed the first census, the state of New York quadrupled in population-grew greater by a million - but more than four-fifths of this gain had come in lands that had been lately wrested from the Iroquois." Enterprising towns, like Rochester and Buffalo,

1 The workmen had been clissatisfied from the first; see the petition of "Mechanicks in Union" given by C. S. Lobinger, The P'ople's Lar' ( N. Y., Ig09), pp. 156-I6I.

"See tables in H. L. Young, "A Study of the Constitutional Convention of New York State in I82I" (unpublished, but filed in the library of Yale University). This dissertation (Yale, 1910) is valuable in its analysis of the social forces behind the parties in the convention. The earlier chapters setting forth the conditions of settlement are especially interesting. $C f$. O. Turner, History of the Phelps and Gorham Purchase (Rochester, 1851), and J. H. Hotchkin, History of Hestern New York (N. Y., 1848), chaps. i and ii. 
already challenged cities of the east for rank in trade and industry. Settling evenly from north to south, the counties west of Seneca Lake could boast a hundred to each two mile square, while the middle region, centering in Oneida, was now more than half as thickly peopled as the old colonial counties on the Hudson. Only in the Adrondack country were there less than ten to a square mile. Since the second war with England, ever growing numbers had taken up the westward march; the traveler Bradbury reported in I $8 \mathrm{I} 6$ that wagois carrying the household good; of emigrants passed across Cayuga Bridge throughout the snowless months at the rate of four or five a day. ${ }^{1}$

The sudden creation of prosperous towns, and highly cultivated farms in the center of those forests, in whose solitudes, within a very few years, the Indian hunter pursued his game [remarked another Englishman], appears rather more like enchantment than the slow result of progressive efforts with which in the old world savage nature has been subdued."

The city of New York had grown, chiefly in the "mechanic wards," ${ }^{3}$ from thirty thousand to four times that number. It was a new people who, in the last years of the secon! decade of the nineteenth century, demanded a revision of the constitution framed some forty years before.

There was one reform upon which all disinterested men agreed. The men who framed the first state constitution had engaged upon a war of protest against tyranny, which throughout the colonies had had its agency in the executive. A governor was an object of suspicion, and the common-

$1 \mathrm{~J}$. Bradbury, Trazels in the Interior of America (second edition. London, IS19), p. $3 \mathrm{I} 8$. His informant stated that more than fifteen hundred had passed within the last eighteen months.

"Adam Hodgson, Letters from North America (London, I824), vol. i, pp. $337-340$.

"J. Macauley, Natural, Statistical and Cicil History of New York, vol. ii, p. 89 . 
wealth would yield him power only with a niggard hand. He must not be allowed to fill the public service with his minions, and in consequence the power to name subordinate officers of state was entrusted to a Council of Ippointment Fy I\&I8 this body, chosen by the assembly, always on the strictent party lines, dispensed some fifteen thousand offices worth in fees and salaries more than a million dollars. ${ }^{1}$

\footnotetext{
"Before its witchery, of late,

Our proudest politicians trembled, When the five Heads that ruled the State

Around the Conncil-board assembled.":-
}

()ften obscure men, raised to transient power by a chance majority in the assembly and flattered by a horde of officeseekers, they met behind closed doors and voted usually without a record of the ayes and noes." "If the ingenuity of man," the governor admitted in a later message, "had heen exercised to organize the appointing power in such a way as to produce continied intrigue and commotion in the state, none could have been devised with more effect than the present arrangement." +

To appreciate the standards of the public service under this régime, one must review the private correspondence of

'Governor Clinton's message of I820, Messages from the Gozernors. vol. ii, p. 10I9, and Carter. Stone and Gould, Report of the Procecding: and Debates of the Convention of I\$2I (Albany, 182r), p. 297. The record compiled by Messrs. Wni. L. Stone, of the N. Y. Commcrcial Advertiser, and N. H. Carter, of the Albany Adertiser, with the help of the stenographer Gould, is more complete than that by L. H. Clarke, -ublished in Albany in the same year. Although Stone and Carter were strongly. Feceralist in politics, there was no criticism of partisanship against their work. Their edition will henceforth be cited as Debates.

2 Fitz-Greene Halleck, Writings ( N. Y., r869), p. 323.

${ }^{3}$ J. D. Hammond, Political History, vol. i, pp. 468-47o. Judge Hammond was a member of the council in isis.

4 Messages, vol. ii, p. ro43. He assigned this as the chief cause of the peculiarly malignant rivalry of parties in New York. 
the members of the council. Special competence seemed the last consideration to be urged for an appointment: applicants were usually presented un the ground of party loyalty, though indigence and bodily affliction were oftentimes remarked to touch those councillors of "philanthropick riews." " Please pardon the liberty I have taken," wrote "me applicant; "my poverty is the only apology I can offer for it "; others asked for help against the coming of the sheriff. " Candidates for town and county offices, of course unknown in Albany, were recommended, or, in fact, appointed by local party leaders entirely withont responsibility. This system cried lond for reform. The politicians with some reluctance joined in the demand, but neither Clinton nor Van Buren desired that the credit for improvement the suld ge to his opponent.

In February, 1818, Ogden Edwards of the Tammany society introduced a resolution in the legislature calling for a constitutional convention to provicle a new arrangement for appointment.: (Fovernor (linton. hoping to control the council son to be selected, against the advice of prudent iriends refused to sanction this proposal. ${ }^{3}$ General Root.

${ }^{\prime}$ B. Whiting to P. G. Childs, Feb. 24. I822, and W. B. Jones to same. Jan. IO, I822: see also letter from J. B. Pierce, Feb. 5, I822, S. Reardsley and others. Fet. 27. 1822 (Childs Mss.), and numerous entries in the Clinton Mss. ". Is I have no business and cannot get anything of employ here, although I would be willing to do any labour to make an honest living for my family-but find I cannot make a living here and am obliged to spend what little I have, I have reluctantly undertaken to write you to acquaint you that a number of my friends in the county of Albany induce me to apply for the sheriff's office. . ." G. C. Va Zandt to John Tayler, Dec. I8, I8I8, Tayler Míss.

${ }^{2}$ A similar proposal had been made in $18 \mathrm{II} ; c f$. C. Z. Lincoln. Constiutional History, vol. i, p. 615.

${ }^{3}$ N. Y. Ezening Post, Feb. 2, March 2. 1818 ; Hammond, Politiral History, vol. i, p. 469 . Some Clintonians anxious to forestall the Bucktails were ardently urging reform; $e, g$. C. G. Haines. An Appeal (pamphlet in N. Y. Public Library), and letter from same to Clinton. no date. Misc. Papers, Clinton Mss. 
nothing daunted by rebuff, then moved further to revise the fundamental law by amendments to abolish the Council of Revision and to extend the right of suffrage.' Committees of correspondence in the towns and villages nrged on the movement; orators and editors reflected and increased the popular enthusiasm." Clinton, silent for a year. finally recommended a convention to consider the appointing power, but the proposition was rejected; the Bucistails must have more. ${ }^{3}$

For many months the sachems in New York had hesitated in the matter of the suffrage: to qualify the landless in that city would be to enlarge the influence of immigrants from Ireland, and they well knew that Clinton had been popular among that class." But that politician, agile as he was. could not safely ricle two horses: he now leaned so heavily upon his Federalist support that he could scarcely hope to keep his hold upon the poor. The Tammany me believed that they might win these forces to their standard by taking up their cause, while, if they proceeded with caution, they need not fear to lose the prosperous mechanics and shop-keepers."

The re-election of the governor in the spring of 1820 made it clear to all his numerous foes that his influence

${ }^{1}$ N. Y. Evening Post, April I, I8I8.

Albany Advertiser, June 23. I8I9; N. Y. Spectator, June 25. I\$I9.

${ }^{3}$ They demanded a thorough-going general reform, which Clintonians in the legislature for a time successfully opposed. N. Y. Commercial Advertiser. Jan. 26, I820.

'G. Myers, History of Tammany /Hull, pp. 67-68; National Adzocaté, May Io, 1817.

${ }^{5}$ In this they were not disappointed; "after 1821 , the Irish member. bership and influence had become dominant, if the cordial toasts to Ireland's sons and the popularity of St. Patrick, who well-nigh supplanted Columbus as a patron, may he ascribed to genuine sentiments." E. P. Kilroe, St. Tammany, ctc., p. 145 . 
must be destroyed by some far-reaching means. ${ }^{1}$ Already. the "high-minded" Amcrican had come out for a general convention; now a meeting was convened in Tammany Hall and the policy determined. In September of that year the National Adrocate spoke for the society, and the Democratic press throughout the state echoed with a cry for wide extension of the franchise. ${ }^{2}$ When the legislature met in November to choose electors who would vote for James Monroe, the governor mildly recommended a convention for particular reforms, but the opposite party, in control, put through a bill providing for immediate election of the delegates with no limit as to powers. ${ }^{3}$

Clinton and the Federalists foresaw that a convention of some sort must be called; the next device of their defensive tactics had to be postponement. If they could but delay the project for a year or two, the census of I 820 might be made the basis of apportionment of the delegates, and this would weight the influence of western counties where Clinton, as the protagonist in the movement for the Grand Canal, could count on much support. In the elections which would intervene their party might be able to win back the legislature and the Council of Appointment. In case their prestige could be thus enhanced the bill might finally be drawn to protect those features of the old law which were

1 "They feel their defeat to the pith of their bones and the core of their hearts, but are recovering from their discovery and hope to revolutionize everything. . . They talk of dividing counties-calling a State onvention-extending the right of suffrage-abolishing the Council of Appointment-districting the State for Senators anew-and many other schemes." C. G. Haines to Clinton, May 29. I820, Clinton Mss.

${ }^{2}$ N. Y. American, March I3, I8I9; National Adrocate. Sept. I3, I820: V. Y. Ezening Post, Nov. 2, I 820.

${ }^{3}$ N. Y. Ez'ening Post, Nov. J3. 14. I8zo, and N. Y. American. Nov. 2o, 1820. 
so esteemed by men of property. ${ }^{1}$ Most of all they feared to lose the Council of Revision which the Democrats had destined for extinction.

This body, made up of all the judges of the supreme court, the chancellor and the governor, had long been hated as the guardian of all old Federalist principles. While Chancellor Kent, Chief Justice Ambrose Spencer, Jonas Platt and William IV. Van Ness, as a majority, could veto any law, denocracy might well complain. To save their power for a season the council determined now to use it. and with Clinton's acquiescence the Federalist judges refused their indispensable assent to the convention bill. It was necessary, they declared, that the people should cast ballots to decide whether a convention should be called." This objection, fantastic as it was, for no honest man conld doubt the people's will, had in their eyes the merit of delaying the ineritable day of death. In their statement it was suggested, likewise, that the bill await the coming census.

This was not the first time that the judges had denied a popular demand. In I8og they had disallowed a bill for setting off new districts in the state; in I8I2 they had refused permission for enlargement of the court (by a Democratic Council of Appointment). They had checked the "war-hawks" in their drastic measures for conscription and the treatment of deserters. They had extended their

1 "I am in favor of a Convention properly and fairly called, but not for one got up precipitately for bad purposes, under bad auspices, an: with a view to shake society to its foundations in order to sustain bati men." Clinton to Henry Post, Nov. 25, 1820, in J. Bigelow, "DeWitt Clinton as a Politician," in Harpers' Magazine, vol. 1, p. 4I4.

${ }^{2}$ Judges Platt and Van Ness found it expedient to be absent; consequently to defeat the Republicans, Yates and Woodworth. Clinton was -bliged to join the chancellor and the chief justice, and thus unmistakeably display his colors. The objections are set forth in A. B. Street, The Council of Rezision, pp. 450 et seq. Clinton was no doubt anxious to prevent, if he could, a convention with general power. 
protection to the negro allies of the Federalists. ${ }^{1}$ The council's temporary victory in 1820 but nerved the Democrats to fiercer resolution. Not only must the council be abolished, but every one of these aristocrats in ermine must be diriven from the bench.

The Federalist newspapers reopened the whole controversy. The Council of Appointment only, they declared. should be discussed, ${ }^{2}$ and addresses were prepared by the conservatives throughout the state. "Our constitution was iramed by wise and patriotic men," said one written in Ponghkeepsie, and it maintained " that no alterations ought to be made, except such as experience had made absolutely necessary, that no wild plans of innovation ought to be indulged, [and] that party spirit ought not to be suffered to intrude.": John C. Spencer rose in the assembly to present a measure of delay, but, for the first time in a score of years, the house refused to listen to the reading of a bill." Michael Llshoeffer, of the Tammany Society, reported on the action of the Council of Revision, in which he showed hin inconsistent were some members in this matter of preliminary reference to the people; but to speed the process of convention their principle was granted and a plebiscite of all who had paid taxes or performed some service to the state was decreed for February. I82I." The Clintonians.

${ }^{1}$ A. B. Street, The Council of Revision. pP. 362-364.

"Albany Statcsman, quoted in the Albany Argus, Jan. 2, I821.

${ }^{9} \mathrm{E}$. Platt, History of Poughkeepsic, pp. 97-98, 310. It is interesting to see the name of Morgan Lewis next to that of James Emott among the signers.

4le was joined in this movment by western men like Myron Holley and Samuel M. Hopkins, N. Y. Commercial Adrertiser. Jan. I3, I82I.

'Ulshoeffer's long speech may be rearl in A. R. Street. op. cit., np. 455${ }_{47}$; see also N. Y. Evening Post, Jan. 13, 15. 17. I8, 1820. All free males over twenty-one, who paid taxes or server in the militia or in work unon the highways, were given the rote for this election. 
to save appearances, were thus obliged to vote in favor. A convention was demanded at the polls by a majority of more than serenty-four thousand rotes.'

The canpaign for delegates revealed how hopeless wan the cause of the conservatives. The adherents of the governor assumed a tone of high disinterested patriotism and attempted, where they could, to have the nominations made without regard to party." Where this stratagem was not availing, they took the name of Independents." Matthew Clarkson, Nicholas Fish, Samuel Jones, Cadwallacler D. Colden. John Wells and William North went to defeat in New York city, and Stephen Van Rensselaer, Ambrose Spencer, James Kent and Abraham Van Vechten to victory in Albany-all as "Independent Republicans "! " Only in Columbia. a county where the "syren song of French equality" had never yet beguiled the freemen, could the proud old name of Federalist be safely Haunted in the press and on the platform." Here the leaders warned against the passion for experiment and novelty that so marked the times. "Fluctuation," they averred. "in any system of government is a calamity." "

But the Democratic papers pressed the issue of the suf-

'N. Y. Evening Post, May I, 5, 1821.

"N. Y. Commercial Advertiser. June I8, 1821; National Adrocate. May 15, I\&21; Batavia Times in Albany Argus, June 8, I82 1 .

"Albany Argus, May 18, I821.

'Ibid., May 29, June 18. I821 : 1. I. Commercial Aduertiser, June 20. I $82 \mathrm{I}$.

${ }^{5}$ Hudson Whig. June I8-23, I821. In Rensselaer County, also, the name was used (Plattsburgh Republican, in Argus, April IO, IS2I), but here the ticket was unsuccessful. In Dutchess County a circular bore the name but it was sent out secretly. Dutchess Obsirer quoted in Argus, May 29, I82I.

6 Address quoted in $N$. Y. Commercial Adropliser, June $18,1821$. 
frage to the front. "Publicola," in his essays in the Argus, defined the faith on this important question. ${ }^{1}$

Why [inquired the official spokesman of the party] should the men who have had the good fortune to ininerit property from their ancestors enjoy greater privileges than those honest and industrious citizens who earn their daily bread by the sweat of their brow? . . . As honest poverty is no disgrace, it ought to form no obstacle to the full enjoyment of our political rights."

But this free talk of universal suffrage stirred up unnecessary opposition, thought Van Buren, and "apprehension that the rights of property would not be sufficiently guaranteed." Selecting the Patroon as the most important landlord in the state, he vouched to him through Rufus King. their common friend, that such was not the program of the Democratic leaders. Extension there would be, but not transcending all restriction. ${ }^{3}$ Thus reassured, the Patroon had voted for holding a convention, a circumstance which now each party tried to use to its advantage." Some hoped

". Plain Thoughts on the Extension of the Suffrage," beginning May 29, I82I.

2 Albany Argus, April 24, 1821 .

s"The extent of his political infuence furnishes a strong temptation to $\mathrm{Mr}$. Clinton \& his desperate followers to infuse into his mind the strongest apprehension. . . I I have observed with much regret that those efforts have been in some degree successful, and am very anxious that Mr. V. R. should be undeceived in this particular, \& knowing your friendship for him and his respect for you, I hope you will embrace the opportunity presented by his visit to Washington to converse freely with him on the subject." Van Buren to King, Jan. I4, I82I, King Correspondence. Note Van Buren's text in enlisting King's aid ostensibly to circumvent the dishonest Clinton. Before the letter is ended he virtually asks King to try to make the Patroon a Bucktail. Van Buren's own caution with respect to universal suffrage is illustrated by a toast which he proposed, July 4, I82I: "The elective franchise; existing restrictions having proved to be as impolitic as they are unjust, it is the office of wisdom to correct what experience condemns." G. Bancroft, Martin Van Buren (N. Y., I889), p. 67.

"Hudson Whig, quoted in the Albany Argus, May 25, I821. 
a compromise might be developed in the deliberations; the returns of the election, however, showed how meagre was the prospect of concession. The personal adherents of Mr. Clinton elected but three delegates and their Federalist colleagues but thirteen, while the Democrats with one hundred and ten could carry their reforms to whatever lengths they might desire. ${ }^{1}$ There were many who now pledged "The Elective Franchise-The birth-right of every free citizen, to the enjoyment of which the law of nature and of nature's God entitles him."."

The convention, meeting on the twenty-eighth of August in the assembly chamber of the capitol, proceeded to elect the "Farmer's Boy," Daniel D. Tompkins, now second officer of the United States, as its president. Escorted to his high seat opposite the doors, he could regard with satisfaction a body whose "towering majority represented the interests, feelings and views of the friends of democratic government." " In the end seat on his right was Colonel Samuel Young, whom Tompkins in the late war had rewarded with a place upon his military staff in recognition

${ }^{1}$ The distribution of the Federalists and Clintonians elected was as follows: Westchester, I out of 3: Oneida and Oswego, 3 out of 5 ; Montgomery, 3 out of 5; Albany, 4 : Columbia, 4 : Schenectady, I out of 2. National Adrocate. July Io, Nov. I6, I821. The proportion of Fedieralists to Clintonian-Republican delegates was probably the same as that throughout the governor's supporters. "We felt that we were a mere handful of men dependent on the federalists for political existence, . . . but I confess I thought the federalists regarded us as an incumbrance upon them; or rather somewhat as the rich man regards his poor relations who have been cast upon his charity, and whom he feels in honor bound to maintain, although the expenditure for that maintenance goes to diminish an estate which he has a right exclusively to enjoy." Hammond, op. cit., vol. i, p. 534.

${ }^{2}$ Albany Argus, July 6, 1821.

3 The words of P. R. Livingston, Dcbates, p. 50. A large picture of the assembly chamber of the capitol of $I 808$ may be seen in P. A. Chadbourne, The Public Service of the State of New York (Boston, I882). 
of his trenchant satire on the Federalist sedition. In the prime of middle life and inclined to radical reform, he could be counted on for telling blows against all institutions that did not square with the new philosophy. Two seats behind, there sat another stout reformer, General ErastutRoot, much more renowned upon the field of politics as one who sought to break a lance with every champion of privilege. Forty-nine years old, he stood as yet unscarred by the dissipation that injured his good fame." and ready to take up the battle in his gay and taunting way for all revolutionary theories of politics or of religion. ${ }^{3}$ He would have graced the Mountain thirty years before in France. Behind hin in the rear row and a little toward the center sat the third of this extraordinary trio. Peter $R$. Livingston, a philisophical democrat of considerable wealth, harsh and forceful in his utterance and steadfast in allegiance to the principles of Thomas Jefferson. These led the mad-cap democrats of whom Van Buren said, " They thought nothing wise that was not riolent." 4

In front of Livingston was Ogden Edwards, who represented Tanmany and the influences of restrained reform: with him the president, in looking through the rows, might naturally associate the venerable Rutus King. sitting but it few feet distant. now the moderate spokesman of " highminded men," and then turn swiftly to the left side of the house where, in an aisle seat near the front, sat King's colleague in the national Senate, Martin Van Buren, blond and smilingly benignant, whose soft words and subtle indirec-

${ }^{1}$ G. B. Anderson. History of Saratoga County (Boston, 1899), p. 510.

2. M. M. Bagg, Pioncers of Uitica: N. F. Commercial Adzertiser. Aug. 7. 12, Oct. 15. 1824: Misc. Papers, Clinton Mss.; see testimony in Root i's. Editors, .. Y. American, Albany Argus. Aug. 25, I824. June io. July 4. 1826, etc.

' $\Lambda$. Y. Commercial Adiertiser. Nor. 2, 1821.

- Van Buren to J. A. King. Oct. 2\&. I\$21, King Correspondence. 
tions had charmed his way to leadership. No obstruction of the enemy would escape his notice, yet no vain enthusiasm would betray him to intemperance in speech. Doubtless Tomplins realized that here, and not in the stately presidential chair, sat the man whose prudent hand would hold the Democratic delegates in firm control. ${ }^{1}$

It was, as the president well understood, a delicate business. Although reforms might seem predestined by the I une election, they would not be accomplished without meeting from the Federalists an opposition no less grim than skilful. As he looked upon that little company-less than a score of men, " commissioned," as a great historian has said, " to impede the onward movement to a government of all men by all men " z- he might well have suffered some misgivings: for their talent was far more impressive than their numbers. In knowledge of the law, of history and institutions, they outmatched any group of equal size that could be furnished by the Democrats.

Midway down the right aisle sat the chancellor in the ripeness of his eight and fifty years, short in stature, but so vivacious and alert that in all the room there was no man less likely to be overlooked. He had come resolved to dedicate his learning in political science, gleaned from tireless study of the ancient classics and the works of modern commentators, to the task of saving for posterity those principles and practices which had been tried and sanctified by time. The aptest pupil of Judge Egbert Benson, he had surpassed his master in determination to defend the old dominion of the wise and good." Three seats from Kent.

'Van Buren's county, Columbia, being inveterately Federalist, he was elected by Otsego County.

"George Bancroft, Martin Van Buren, p. 66.

"J. Duer. Discourse on James Kent (N. Y.. I847). np. 9. 73: $11 \mathrm{~m}$ Kent. Memoir of Chancellor Kent (Boston, i8ga), p. I78. 
looking toward the left, there sat the Patroon, younger by two years than the chancellor and more fine of feature. He was not accounted eloquent, but his probity and public spirit, tniversally acknowledged, might so weight his simple word as to outbalance the most labored rhetoric of many an opponent.

In that same row, exactly in the center, towered the form of Chief Justice Ambrose Spencer, master of the law, somewhat supercilious in his deportment, and suspicious of political reformers. No man in the assemblage could cow this august person, and none there could convince him of an error in his logic: no man of small experience might safely challenge him in a debate. Sitting at his right was his associate upon the bench, IVilliam IV. Van Ness, whose brilliant, penetrating mind and ready wit have been remarked by readers of these pages; and beside Van Ness, his old friend, Elisha Williams, still " the most celebrated jury lawyer in the state and probably in the Union," inventive in conception, rounded and graceful in utterance, fertile and copious in diction, though now smirched in reputation and discounted by many of his hearers as too clever to be great. ${ }^{1}$ Some seats further to the left side of the house was J. R. Van Rensselaer, their colleague from Columbia County, and on his right Julge Platt, then fifty-two years old, pious. honest and intensely serious in his effort to check the ravages of demagogues. ${ }^{2}$ The president might turn away from such a row where clustered his opponents, but looking toward the rear he could not fail to recognize the formiclable Abra-

${ }^{1}$ On Williams, besides the references in chapters ii and vii, supro, see Levi Beardsley, Reminisccnces, pp. 208-210; IV. A. Butler, Martin Van Buren (N. Y., I862), pp. IO-II. The Albany Argus, May 25, 182I, had paid its respects to Williams " of bonus memory."

${ }^{2}$ IV. J. Bacon, Early Bar of Oneida (Utica, I876) ; J. D. Hammond, Political History, vol. i, p. 279. 
ham Van Vechten, " full of solid learning and solid sense," but with all the horror of a good Low Dutchman at any innovations whatsoever. " What has been said of conservatives in general, might be observed of him, that " his pigmy hope that life would some day become somewhat better, punily shivered by the side of his gigantic conviction that it might be infinitely worse." 2

There remained two men of some importance in that little group, Ezekiel Bacon and Peter A. Jay, both born in Independence year. The former has not figured in our narrative: he had entered politics a quarter of a century before in Berkshire County, Massachusetts, as an ardent Jeffersonian, and had once regaled the citizens of Williamstown with so strong an exposition of his doctrine that the college students burned a copy of his speech as a public condemnation. ${ }^{3}$ He had served as an official under President Madison, but upon removing to the Mohawk valley, being a man of enterprise, like Gideon Granger, he had struck hands with Clinton, planned to build a packet boat to ply the Grand Canal, and stood out against all policies of its opponents." As to Peter A. Jay, he was an able father's able son, inheriting his political philosophy together with his personal integrity, and called his adversaries quite impartially "the Jacobins," though certain radicals were singled out for

${ }^{3}$ D. D. Barnard, Discourse on Ambrose Spencer, p. 24, and J. D. Hammond, vol. i, p. 456 .

"Morley's Voltaire.

${ }^{3}$ E. Bacon, An Oration ... at Irilliamstown, July 4 , I799 (in N. Y. Public Library); F. B. Dexter, Yale Annals, I79.4.

"He was a noted lawyer, and though in debate " not ready or fiuent, speaking extemporaneously with embarrassment," when he prepared his discourse "he brought ample knowledge, sound logic and clear intelligible statement." M. M. Bagg, Pioneers of Utica, pp. 395-396; J. Q. Adams in H. Adams, New England Federalism, pp. 243, 301, etc.; E. Bacon, Recollections of Fifty Years Since (Utica, 1843). 


\section{IRISTOCRACT IN THE POLITICS OF NEW YORK}

special scorn. 'Such a galaxy of talent might well cause the president to wonder if in numbers there was strength. As frequently in history, the conservatives had learning on their side."

It was not surprising that the Council of Revision was marked as first to feel the power of the people. The judiciary, it was said, must be separated from the other branches, to supply the check demanded by the perfect scheme of Montesquieu; "the old council had acted ultra rircs when they retoed laws as inexpedient; they should have passed on constitutionality alone. ${ }^{*}$ But the chief reproach was founded on their Federalism and their arrogant attempts "to stay the march of progress." Oppusition to the will of the majority was hopeless, and the council was abolished without a dissenting vote, though not without a protest."

Judge Platt reviewed its long career of more than forty years with the eloquence of deep sincerity: it had server the right without regard to censure or applause: its members had shared the frailties of nature, but " when," said he. "I see the axe laid to the root of the tree which our fathers planted, watered and defended, a tree which yielded much good and wholesome fruit, and has long afforded ui shade and shelter, I confess, sir, that I witness its destruction with no ordinary emotions." ${ }^{6}$ The chief justice and

${ }^{2}$ P. A. Jay to John Jay, Oct. I0, 28, Nov. 15, I821, Jay Correspondence. His home town had been carried nearly three to one for " no convention." Debates, p. 679 .

"In number they were about one-eighth of the whole, yet in Stone': list of those who took important parts in the reliberations their names make up a third. Debates, p. 690.

3 Tallmadge, Dcbates, p. \&6.

- Tompkins, p. ir.

"Sept. 4. 1) 47.

"He warned his colleagues against those who applied their remediewith so little wisclom that "in curing one evil, they create others," pp. 53. 56. Van Vechten also pronounced a eulogium, p. 83: see for Kent and Spencer, p!. 87, 89. 
the chancellor also voiced a sad resentment at the slurs the council had received, but these threnodies were listened to with some impatience; the council was despatched, there let the matter rest. Some, like the president, would hide the wound by saying that it had been done in kindness to relieve the judges of these disagreeable distractions, ${ }^{1}$ but this was but a thin deception, for. as everybody knew, the judges were themselves to be cashiered. Others of a franker mind declared the action but a just rebuke to those whose characters deserved it. ${ }^{2}$

The moderate committee, which had discussed this question, advised that the negative be given to the governor, whose veto could be overridden by two-thirds of the legislature. Peter R. Livingston was for a mere majority. "Keep the power with the people," he adjured his hearers, " they will not abuse it." It appeared to him, he said, agreeing here with Bentham, "like a solecism to say that the people would assent to measures which would be injurious to their own good." " In this he had the aid of General Root, who observed that

in all ages, where free governments have existed, those have been found who would transfer to the minister or executive more power than was expedient for the good of the people. This tends to perpetuate the aristocracy which exists in the constitution, and instead of being fostered, should receive the firm opposition of those who advocate the cause of the people. ${ }^{*}$

Tompkins, the president, believed that no negative was necessary. "There can he no use for a veto on the passing

'Tompkins, p. 8i.

${ }^{2}$ Root, quoted p. 85 .

${ }^{3}$ He desired a majority of those elected to the houses, not merely of those present. Twenty-six were finally mustered for his plan, $p p .52,59$. II 6.

${ }^{4}$ Pages 62-63, 100. 
of laws," said he, "but to prevent violations of the constitution; and for this purpose your judicial tribunals are sufficient." ' The conservatives, on the other hand, would use the power especially in questions of expediency, but admitted that the plan of the committee was adequate if the governor were given a sufficient length of term to make him independent." Van Buren's " moderate men" were satisfied and the measure was adopted.

The "people"s adversaries" " thus shorn of power, the convention took notice of the Council of Appointment. No one could say a word in its behalf. The wanton partisanship of the Democratic council which had sat throughout that very spring had disgusted friend and foe alike; it was abolished by unanimous vote." Following the spirit of the times, the committee on this subject recommended that militia officers, except the very highest, be elected by the men-in-arms. The Federalist press might argue that popular elections would destroy authority: " but what authority, it was replied, should be obeyed that did not spring

1 Page 79. Tompkins afterward proposed a separate council made up of lawyers but not judges. This proposition received no attention.

${ }^{2}$ Bacon, p. 120. Mr. Dodge, of Montgomery County, took a middle position; he proposed that the governor's veto be overridden by a twothirds majority on constitutional objections, or by a majority on those of expediency, p. i 6 . On Federalist opinion on the governorship, see Spencer, pp. 47, 115; Van Vechten, p. 85; Kent, pp. 63-64.

"The characterization of the judges is John Duer's, the "high minded" delegate from Orange County, p. IO5.

4B. F. Butler to Jesse Hoyt, Feb. 20, 1821, W. L. Mackenzie, Life and Times of Martin I an Buren (Boston, 1846), p. 167; N. Y. Commercial Adiertiser, March 3I, 182I. It had swept out of office several men who had survived many changes, like Solomon Van Rensselaer, adjutant general, Archibald McIntyre, comptroller, and Gideon Hawley. superintendent of schools; for recorler of Hudson it appointed a man recently convicted of a felony. Hudson Whig quoted in $N$. I'. Commercial Adrertiser. April г3, I\&_т.

${ }^{5} N$. Y. Commercial Aducrtiser. Sept. 22, I $82 \mathrm{I}$. 
directly from the people? Many civil servants likewise were to be elective, and cities were to choose their own: certain officers of the state administration, like the treas urer, the comptroller and the secretary of state, were now to be selected by the legislature. while others, including ail the judges, were to be appuinted by the governor with the confirmation of the senate."

This last proposal introduced the question of the governor's term. As a minority party, the Federalists had favored the provisions fir home rule, but their theory of politics led them to desire the executive to be as independent as was possible in his retoes and appointments. Spencer. Kent. Jay, Platt, Willians, the Van Rensselaers, Van Vechten and Van Ness, together with obscurer fellow-partisans, ${ }^{3}$ vuted for continuation of the three-year term. At the opposite extreme were Colonel Young. General Ront, P. R. Livingston, and others who desired annual elections, following that "great principle of republicanism-rotation in office." " Again Van Buren, always anxious that the party

1 P. A. Jay, however, warned the delegates of the danger of mob rule in cities, p. $39 \mathrm{I}$.

${ }^{2}$ The full proposal, which was in general adopted, may be found in Debates, pp. 160-161. 3,643 civil officers were left to be appointed as the legislature might direct, p. 297 ; only 453 , out of the 14,943 , were now left to the central appointing power, p. I62. The common councils of the cities were to select mayors, etc., except in New York, where a special electoral council was provided. General Root's amendment providing for election of non-commissioned officers is found on pp. 30030I. Justices of the peace were to he appointed by local councils of officials. Election of judges, howerer humble, was not yet considerer safe.

${ }^{3}$ E.g.. Elbert Jones of Queens, Rhinelander of Montgomery, and Van Horne of Herkimer. The last named, though not originally listed with the Federalists, voted almost consistently with the leaders, thus making their certain voting strength seventeen. The vote on the governor's term is on page 148 .

'Pages I 18, I58, 547, 550; on one vote the single-year men were successful. D. I77. 
enterprise be nut wrecked upon excess. came forwari with a coilupromise :

As we have vastly increased the power of the governor, a strong desire is manifested to abridge his term, and in this sentiment I concur. But how abridge it? $\mathrm{We}$ wish the people to have the opportunity of testing their governor's conduct, not by feelings of temporary excitement, but by that sober second thought which is never wrong. Can that be effected if you abridge the term to onc year? No, sir. . . I hope the blank will be filled with two years. ${ }^{1}$

This provision was accepted by a scant majority:" P. K. I ivingston, however, was still determined that the executive be curbed whenever possible. Still following Mr. Jefferson, he wanted it laid down in the constitution that the governor should address the legislature only by a written message"the speech," said he, was " a relic of monarchy, founded in the love of pompl and splendrur and show." 3

But it was the question of the suffrage which elicited the sreat debates of the convention: it was held to be of more than lucal or temporary interest.

Mr. Chairman Lsolemnly remarked a member], the friends of rational liberty in all quarters of the globe have their eyes fastenerl upon independent, confederated Anerica; in the front rank of this confederacy, in the most conspicuous station, stands the great state of New-York, and the result of this convention will decille her fate, perhaps forever.*

The discussion som struck to the funclaments of politics

1 Pages $147-148$.

${ }^{2}$ Pages $531-552$.

${ }^{3}$ Pages $173-174$. Generai Root's motinn that the right of proroguing the legislature be taken from the governor. was narrowly carried, pp. 135-136.

${ }^{4}$ E. Williams, p. 247. 
and government. Problems of sovereignty, original and delegated, such as puzzled Plato and Rousseau, were reviewed at length by men who cherished theories as far apart as the poles. There were those to whom democracy was something more than a form of government-a destiny of perfection, indeed, proceeding " as uniformly and majestically as the laws of being and as certain as the decrees of eternity." "To these, man's right to rule himself appeared so natural and evident that instances and syllogisms seemed but impertinence. But there were others, whose fortunes we have traced fur two decades, who declared this was a novelty to be received, if at all, after closest scrutiny. Their philosophy we may with profit here examine before the argument is broached.

More than a century before. John Locke had stated it as well as it is likely to be stated. When one reads the solemn judgment of that essayist that " the great and chief end. therefore, of men's uniting into commonwealths, and putting themselves under government, is the preservation of their property." " one has the kernel of their thought. They believed that government by the wise and good was better than by the ignorant and vicious. But a larger proportion of the wise and good was to be found among the men of property than among society at large. Those who had it by inheritance had therefore more of leisure to acquire wisdom and were immune from passions of cupidity, while those who earned it did so by the exercise of those abilities which might be serviceable to the state: crgo, government by the part was preferable to government by the whole. It might be urged that experience did not bear out this logic. that many men of property were indolent and unproductive.

1 This is the phrase of Bancroft, History of the Unitid States, American Revolution, vol. i, p. I.

${ }^{2}$ Essay on Cicil Govermment, chap. ix, par. I24. 
But to this it could be answered that these, though numerons, yet were exceptional; it was better that some unworthy should enjoy the special privilege than to deny it to a class which as a whole would use it beneficially for all. In America estates were not entailed: ${ }^{1}$ there was plenty of cheap land which able men could easily acquire to use for the benefit of themselves and of society. Possession of property might here, certainly, be called a proper test of talent. Locke had said that men possessed of property must have despotic power over those who were not; " Elisha IVilliams now explained that those in whose hands sovereignty was lodged were trustees for the rest. ${ }^{3}$

It was natural that such men should be satisfied with the old constitution which limited the franchise to those who held the requisite anount of real estate or rented tenements of a considerable value. The old system had worked well, they said: the state had grown in business and in population." Was it, then, the "part of wisdom to substitute experiment for experience?" "5 Gentlemen were warned of "doubtful and dangerous innovations." "The delegates were there "convened to amond their constitution, not to" desiroy it." " Talk of social evolution showed a shallow understanding: " man has been," said J. R. Van Rensselaer. "and probably always will be, subject to the same passions and feelings, and under like circumstances the future will

${ }^{1}$ Entails were prohibited in New York by an act of July 12, 1782: see Consolidated Law's of the State of New York (1000), vol. iv. pp. 337o3.380 .

2 Irorks (edition of $175 \mathrm{I}$ ). vol. ii. p. 2 I7.

"Debates, p. 248 .

4 Kent, pp. 219-220.

- Van Vechten, p. 230.

- Van Ness, p. 266.

7 E. Williams, p. 252. 
strongiy resemble the past." ${ }^{1}$ But the majority were not impressed with these sententions sayings.

The committee on the suffrage reported for a very liberal extension; every white male citizen twenty-one years old. who had resided for six months within his district and paid taxes, or on assessinent had performed some work upon the public roads, or had been enrolled in the militia, might vote for any officer elected by the people." The chairman, Mr. Sanford, declared that this was what the electors had expected. The chancellor, however, roiced the protest of conservatives:

I cannot but think the considerate men who have studied the history of republics, or are read in lessons of experience, must look with concern upon our apparent disposition to vibrate fron a well-balanced government to the extremes of democratic doctrines. Such a proposition as that contained in the report, at the distance of ten years past, would have struck the public mind with astonishment and terror. ${ }^{3}$

Yet everyone was well aware that much had happened in the last ten years. Chief Justice Spencer, hoping that a remnant might be saved, now offered an amendment providing that only those possessed "in law or equity" of a twohundred-and-fifty-dollar freehold could vote tor senators." It was upon this proposition that the principal debate developed.

Although the holding specified was left unchanged, there was one element of novelty. Since the canal had actually

'Page 364. Compare J. R. Van Rensselaer's opinion of the French Revolution (p. 36.3) with that of P. R. Livingston (p. 224).

"Page 134. This is substantially the provision finally adopted, except that the new constitution required one year's residence within the state, p. $66 \mathrm{I}$.

\footnotetext{
3 Page 219.

4 Page 215.
} 
been beguil. the west was turning rapidly to Clinton; but under the old constitution many in those comnties were not yet enfranchised. It was the custom there, especially upon the Holland patent and the Pulteney estate, to purchase land on long-term contracts wherein the title did not pass until the entire obligation was fulfilled. ${ }^{1}$ Spencer now proposed that all holders who had invested the required sum in payments or improvements should be allowed the special senatorial franchise: "they ought thus to rote, because they represent portions of the soil, and because they have that attachment to the preservation of all the rights incident to real estate." " Other Federalists came forward to praise this feature of the proposition. Elisha IVilliams declared his own opinion that this injustice might have easily been remedied by a declaratory act of the legislature bringing such equity within the definition of a freehold; but this sensible suggestion, he complained. had been unheeded by the Denocrats, who would not stop with moderate reform. He believed that thirty thousand votes for the convention were referable to this cause alone. ${ }^{3} \quad$ Judge Van Ness could not agree with IVilliams as to what might have been accom-

1 This was true, likewise, in the case of settlers on the Hornby and the MicComb purchases. The contrast between east and west in this respect was striking. In some counties of the older region, like Rockland, Richmond and Suffolk, the majority of adult males who would be qualified by the committee, possessed a two-hundred-and-fifty-dollar freehold, and in most others, such as Westchester, Ulster, Washington. Saratoga, Montgonery, Schoharie. etc., the number was nearly half. In the west, however, the ratio was low. A few counties may serve as examples: Allegany, 325: 1797; Chautauqua, 629: 2266; Niagara. 276: I 421 ; Genesee, $1813: 6517$; Livingston, 1086: 2420; Monroe, 1737: 3972 ; Ontario, 4390 : 7055 , eic. In the state there were $100,8.39$ who could qualify under Spencer's provision and 159,262, admitted by the committee, who could not; see tables in Albany Arous. August 12, 1826.

${ }^{2}$ Spencer, p. 216.

\footnotetext{
"Page 247 ct seg.
} 
plished by a simple law, but he heartily approved the amendment which was now proposed, and pointed ont how beneficial it would likewise be to those respectable citizens who held the almost endless leaseholds of Trinity Church in New York city.' Spencer pressed his measure as in accordance with the purpose of the founders of the state. The senate had been entrusted with the guardianship of property. Why have two houses if they did nut represent two diverse interests?"

To the defense of the amendment in general there came an able champion. James Kent had fought throughout his whole career for the rights of the individual as distinguished from those of the people." He could never forget that he was "Lord Chancellor." commissioned to uphold true legal principles however unpopular they might be." Yet in all that company, when he arose, there was not one to sneer. "When I recall the suspicions that then prevailed," wrote a delegate in later life. "and the censure in which others were then involved. I doubt whether a similar case is to be found in history." "No abstract can do justice to the grave and solemm eloquence of the chancellor as he pleaded for the old order on that September afternoon in Albany. It demands quotation in long passages, for s' complete and so sincere was his defense that it touched on nearly every point that later was developed. "It was," as a member afterwards remarked. " an elegant epitaph of the old constitution." ${ }^{6}$

${ }^{1}$ Pages 265-266. These would he qualified by the "improvement" provision.

' 2 Pages 216-217.

"Wm. Kent. Memoir of Chanccllor Kent, p. Iso.

'Kent to Platt, Oct. 29, I821, ibid., p. I82.

sohn Duer, Discourses on James Kent, p. 6r. He sait that the case of Sir Natthew Hale possibly afforded a parallel.

6 Cramer. p. 237. 
Dare we flatter ourselves [he asked, when he had painted the calamities democracy had brought upon republics of the old world] that we are a peculiar people, who can run the caree: of history exempted from the passions which have disturbed and corrupted the rest of mankind? . . The men of no property, together with crowds of dependents connected with the great manufacturing and commercial establishments, and the motley and indefinable population of the crowded ports, may. perhaps. at some future day, under skilful management, predominate in the assembly, and yet we should be perfectly safe if no laws could pass without the free consent of the owners of the soil. That security we at present enjoy, and it is that security which I wish to retain. The apprehended danger from the experiment of universal suffrage applied to the whole legislative department, is no dream of the imagination. It is too mighty an excitement for the moral condition of men to endure. The tendency of universal suffrage is to jeopardize the rights of property and the principles of liberty. There is a constant tendency in human society-and the history of every age proves it-there is a constant tendency in the poor to covet and to share the plunder of the rich: in the debtor to relax or avoid the obligations of contract; in the majority to tyrannize over the minority, and trample down their rights; in the indolent and profligate to cast the whole burthen of society upon the industrious and virtuous; and there is a tendency in ambitious and wicked men to inflame those combustible materials. . . . NewYork is destined to be the future London of America, and in less than a century that city, with the operation of universal suffrage, and under skilful management, will govern this state. . . .

Society is an institution for the protection of property as well as life, and the indivilual who contributes only one cent to the common stock ought not to have the same power and influence in directing the property concerns of the partnership as he who contributes his thousands. He will not have the same inducements to care and diligence and fidelity. His inducements and his temptation would be to divide the whole capital 
upon the principles of agrarian law. . . We have to apprehenci the oppression of minorities, and a disposition to encroach upon private right - to disturb chartered privilege - and to weaken, degrade and overawe the administration of justice [especially since the delegates are] already determined to withdraw the watchful eye of the judicial department fron the passage of the laws... We stand. therefore, on the brink of fate, on the very edge of a precipice. If we let go our present hold on the senate. we commit our proudest hopes and our most precious interests to the waves. ${ }^{1}$

The sentinent that property rights must have particular protection was general among the Federalists. "Life and liberty are common to all," said Abraham Van Vechten. "but the possession of property is not. Hence the uwners of property have riglits which, in relation to those who are destitute, are separate and exclusive." 2 Those should have a greater voice who have a greater stake in society, remarked Elisha Williams. ${ }^{3}$

They are the patrons of your institutions, civil and religious [added Judge Van Ness]. They build your churches, and defend your altars and the country of which they are the protectors. They erect your school-houses, found and support your colleges and seminaries of learning, establish and maintain your charitable institutions, and construct your roads and canals. ${ }^{4}$

The chancellor declared again that life and liberty were seldom jeopardized; it was property which must be walled

1 Pages 2r9-222.

${ }^{2}$ Page 226. "Does it follow thence that a man who has only life and liberty to be protected, needs protection to the same extent with one who in addition to life and liberty possesses both real and personal property ?", p. 227.

3 Page 252.

1 Page 267. 
against assault.' General J. K. Van Rensselaer conjured up the gloomy prospect of agrarian laws; the poor had always coveted the goods of the more prosperous, and if they had the power they would gratify their criminal desires by a general distribution."

When Democrats declared that the franchise was $d c$ manded by the poor. Federalists becane impatient. If they demanded thus what was not theirs, how long, if it were granted, before they would demand the property itself. "Sir," said one. "if it be just and safe to confer this right, it should be bestowed gratuitously; nothing should be yielded to this menacing demand." " " Are we jealuns of property," inquired the chief justice, "that we should leave it unprotected?" * He was assured by Mr. Radcliffe of New York that gentlemen need not despair about the helplessness of property; it would always carry with it an intluence quite sufficient for its own protection: to give it artificial aid was to make it dangerous to other rights. If property must specially be represented, why should there not be two votes for the holder of five hundred dollars' worth, and twenty for a man who held five thousand? Society was not a money partnership, but an assuciation of all men for the common good."

But it was freehold property for which the Federalist: felt a singular concern. They assured their colleagues that here there was no danger of accumulation. Few estates would grow in size: on the contrary, by the operation of the laws for regulating descents, the holdings would grow smaller. Landowners, representing the most stable and in-

1 Page 286.

${ }^{2}$ Page 363 .

3 E. Williams, p. 254.

- Page 218 .

'Page 225. 
portant interest, should have a distinct weight in one branch of the legislature. Fersonal property night elude the eye, but theirs was always there, imperishable and immovable and ready for the tax assessor. It was because of this that they were called upon to pay a disproportionate amount into the public treasury. ${ }^{1}$ When danger threatened, the landless man might swing his pack upon his shoulder and disappear from sight, but the yeoman and his son must stay, abide the iraft and defend the state." They were the least dispensable of all society: prosperity was bottomed upon agriculture: its surplus products made possible the arts and the professions. Then, too, that ancient superstition that honesty is the peculiar quality of countrymen. was exploited in well-rounded periods. "Their habits, sympathies and endowments," said the chancellor. " necessarily inspire them with a correct spirit of freelom and justice: they are the safest guardians of property and the laws." "To hear the Federalists, remarked a Democrat, one would conclude that all rights were safe if thirty-two men from the sacred turf sat gravely in the senate. Knowledge or intelligence would not be needed if only they were chosen by the well-to-d, landholders. ${ }^{*}$

In another argument of the conservatives can be seen a faint reflection of the rivalries in England; as in 1832 and 1867, in the parliamentary contests. so here, was heard the warning that to qualify the landless would so increase the influence of selfish manufacturers as to create an aristocracy far more pernicious than that which it would supplant Single men employed in factories, and boarding here and there, would have the ballot: but, observed the chief justice.

1 Van Vechten. pp. 226-2.3I.

"F.. Williams, p. 253.

: Page 220.

'Cramer. pp. 238-230.

"E. I., Anmual Register. 1867, remarks of Lori Cecil. ?. $\infty$. 
inder the pretence of giving the right to them, we in fact give it to those who employ, clothe and feed them. I appeal to this convention whether they do not believe that a man who employs twenty, thirty or fifty of these persons, if on the approach of an election he tells them he wishes them to vote for this or that candidate - whether they will not feel themselves obliged to comply with his wishes. That man who holds in his hands the cubsistence of another will always be able to control his will.'

It was the influence of this kind of property so concentrated, said J. R. Van Rensselaer (though one suspects him of a want of candor), that he dreaded as a source of evil to the state."

Mr. Van Buren, on the other hand, declared the old arrangement most unjust; when three-eighths of all the property in the state was personal, why should real estate be so specially favored? ${ }^{3}$ In rejoinder, Judge Van Ness affected to regard with dread the battening money interest. The lines were to be drawn as distinctly as between the sexes: witness how parties were aligning on the question of the tariff." Commerce and agriculture, he declared, must intrench themselves against the manufacturers." As for

I Spencer, pp. I96-197.

${ }^{2}$ Page 363. General Root scoffed at such apprehension: a manufactory was real estate and was assessed as such for taxes; its owner had his interest in land and buildings, p. 223 .

${ }^{3}$ Page 257. "Large portions of the people, many of them persons of great intelligence and possessed of personal property ... were, so far as regarded the choice of these officers, practically disfranchised." B. F. Butler, Discourse on the Constitutional History of New York (read before the N. Y. Historical Society, N. Y., I847) ; G. Bancroft, Martin Van Burcn, pp. 86-87. Van Buren was not averse to a small property qualification. Debates, p. 258 .

4 Page $26 \%$.

${ }^{5}$ He was answered that if personalty were made a basis for the franchise, it would benefit the commercial interests, allies of the agricultural as much as the manufacturing. Buel, p. 243. 
the holders of securities and money whom Van Buren had commiserated, let them invest two hundred and fifty dollar in real estate. said Abraham Van Vechten; ${ }^{3}$ nineteentwentieths of them had done so already, added Van Ness. ${ }^{2}$ But J. R. Van Rensselaer finally admitted that these interests in New York state were not so disparate, and proposed a new amendment in which personal estate of the required sum was mentioned as alternative to freeholds held " in law or equity." 3

The Federalists found in the freehold qualification a stimulus to thrift.

If you bestow on the idle and profligate [asked Elisha Williams] the privileges which should be purchased only by industry, frugality and character, will they ever be at the trouble and pains to earn those privileges? No, sir ; and the prodiga! waste of this incalculable privilege - this attribute of sovereignty-like indiscriminate and misguided charity, will multiply the evils which it professes to remedy. ${ }^{4}$

It might be said, remarked Ezekiel Bacon, that property itself conferred upon its owner no talents and no virtue, hut in this country, at least, "it was a safe and general rule that industry and good habits did, in almost every instance. conduct the man who practiced them to some moderate share of property." " As to those who failed, said Judge Van Ness.

1 Page 227.

${ }^{2}$ Page 266.

${ }^{3}$ Pages $359-360$. Van Buren confronted his opponents with a dilemma "If they [the dependents of the manufacturers] were so influenced. they would be enlisted on the same side, which it is the object of the amendment to promote, on the side of property. If not-if they were independent of the influence of their employers, they would be safe lepositories of the right," p. 263.

4 Pages 253-254.

- Page 285. 
by an irreversible decree of Providence, it was pronounced that "the poor ye have always with you." . . But what was the character of the poor? Generally speaking, vice and poverty go hand in hand. Penury and want alnost invariably follow in the train of idleness, prodigality, intemperance and sensuality. Was it not wise to discountenance these vices by encouraging their opposite virtues?

General Stephen Van Rensselaer, the Patroon, would not insist upon two hundred and fifty dollars as a minimum for qualification, but the payment of some money tax he thought quite indispensable: " he opposed the clanses which would qualify under road work and militia duty. Yet. responded Dr. Ross of Genesee, this proposition would leave unenfranchised many, if not most, of those the general had commanded in the IVar of ${ }_{1} \&_{12} .^{3}$ In that trying day, who came forward into service? inquired ex-Governor Tompkins. "Not the priesthood-not the men of wealth-not the speculators: the former were preaching sedition, and the latter decrying the credit of the govermment to fatten on its spoil." " Mr. Sharpe explained the importance of the militia clause to the constituencies in the city of New York, where there was no public work upon the highways." Genral Root, always disconcerting in his frankness, revealed a cogent reason for the Democrats' support: "They will not vote for peace-party men, but for men who are willing to bare their breasts to the arms of the enemy. . . . Not one in ten of these young militiamen would vote for a haughty, proud, domineering aristocrat: they will wote for repub-

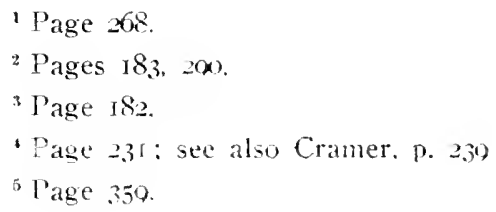


licans." " "The cry of aristocracy has been too firequently addressed to this convention," complained Abraham Van Vechten." "I trust the old names of Aristocrat and Republican will persist," was General Root's response, " till the former shall be bound to the footstool of the latter." 3

Recurring in the Federalist argument. like the motif in a fugue, came the fear of New York city. While among the citizens of that community, they said, there were some who had as much of virtue and more of wealth, talent, refinement and acquirements in literature than any corresponding number elsewhere in the state, there were also those more ignorant, more wretched, more vicions and miserable. the instruments of any demagogue. ${ }^{4}$ And these by immigration would increase out of all proportion.

They have fled from oppression, if you please [said Elisha Williams], and have habitually regarded sovereignty and tyranny as identified; they are men whose wants, if not whose vices, have sent them from other states and countries to seek breal by service if not by plunder; whose means and habits. whose best kind of ambition, and only sort of industry, all forbid their purchasing in the country and tilling the soil."

The chancellor and Judge Van Ness reviewed the city's growth and contributed their dismal prophecies." Van Vechten said that the average of the senatorial votes under the old system in the wards of the metropolis was some four thousand: the proposed extension wonlt increase this

1 Page 360.

${ }^{2}$ Page 372.

${ }^{2}$ L. H. Clarke, Report of the Debates, p. 185 . Practically all the conservatives voted against the militia clause, pp. 369. 554. and the highway clause, p. 554 .

"J. R. Van Rensselaer, p. 362.

${ }^{5}$ E. Williams, p. 252.

- Pages 221, 268. 
by more than threefold. ${ }^{1}$ The agricultural interest would be outweighed quite completely.

But the radicals were warmed by their own oiatory and, impatient of obstruction by these voluble conservatives, they soon advanced to more extreme positions. General Root brought in an amendment which would qualify the suns of those provided for by the committee,, 2 and Melanchthon Wheeler, a nember from Washington County, moved further to include all citizens who had been three years within the state, and one within the town in which they registered." In late September such confusion came t" mark the voting that no man could prophesy what the next hour would bring forth. Certain Federalists like Williams. Bacon and Van Ness fanned the flame that had been kindled by the root-and-branch Republicans, and apparently were willing to participate in any movement that would run to such absurdity as to disgust the voters at the polls with the whole constitution." "That gentleman," said Van Buren of Elisha Williams. "expressed a beliet a few days ag" that we had already made the constitution worse, and he probably would not regret to see us go so far as to have all the amendments rejected by the people." s

One day the convention voted to withdraw the franchise from those who merely worked upon the highways," and

1 Page 228. Of the adult males in New York city, $3.88 \mathrm{I}$ had a twohundred-and-fifty-dollar freehold and 16,044 who would be qualifiel under the new provision had not. Albany Argus, Aug. 12, 1826.

2 Page 202.

"Page 276.

' Pages 275, 278, 284, etc.

${ }^{5}$ Page 275 .

6 This was by a vote of 68 to 48 . p. 28.3 . General Tallmadge liad previously introduced an amendment to qualify those who labored on the highway only if they also rented a $\$ 5$-a-year tenement. It was not carried. 
the next day roted by about the same majority to make it universal, on the plan of Mr. Wheeler.' The moderate Democrats expostulated at this "phrenzy:" Van Buren said this wonld increase the electorate of New York city t" twenty-five thousand men, enough to outweigh several counties in the west." Ogden Edwards thunght the time would come when those who now opposed demands for universal suffrage would be remembered as the benefactors of the state." "High-minded men," like Duer, now comnselled once again the exclusion of militia-men: ${ }^{*}$ their organ, the American, warned solemnly against excess." In a Sunday recess, Rufus King, weary of it all, wrote to his son Charles that "should the right of suffrage be made universal, the foundation of the constitution will be such as to impair my safe reliance on the superstructure." Edwards finally was able to carry through a resolution to commit the whole question of the suffrage to a select committee, who might formulate an article more consonant with the deliberate judgment of the delegates. ${ }^{i}$

The committee brought in a proposal very similar to that

1 This rote was 63 to 55. p. 237 . Dr. Young, $o p$. cit.. discovers that the country members carried this provision against those from the towns.

"Page 367 . J. R. Van Rensselaer said this would increase the comparative influence of New York city to six times what it had been in 18 i. p. 360 .

${ }^{3}$ Page 282.

- Pages 27r-272. General Root retorted: "It has been said that my ameniment would not suit the sober-minded part of the community: i suspect it is more obnoxious to the high-minced than to the suberminded," p. 272.

¿N. Y. American, Oct. 20,1821 .

- Sept. 30, 1821, King Correspondence, vol. vi, pp. fo5-406. He wrote Charles on Oct. 15. "I often wish that I had not come hither," ibid.. Pr. $+16-417$.

T Pages $289-289$. 
which had originally been offered. ${ }^{1}$ It was fought through. clause by clause, and finally carried by a vote of nearly two torone." It was hoped by the comservatives that some privilege might still be kept for property by a requirement, which was once accepted by the convention," that candidates for senator must have a thousand dollars worth of real estate, but even this small relic of the old restrictions was denied? them, for, by a resulution of Colonel Yuung. a simple freehoid was at last declared sufficient." The conservatives had again been routed.

Iny who had stood between the people and their will were tw feel the heavy hand of the convention. The judges who had made up the old Council of Revision must know their masters scorn. Early in the discussion of the juclicjary the plan for their clismissal was revealed." Ippointments to the supreme bench had run until the judge was sixty years of age: under this arrangement the eldest, the chief justice, had four more years to serve, while the youngest. Judge lan Ness, would not be superseded until I 836. The chancellor would retire the following year. likewise at the age of sixty, unless considering his unique capacity the convention would extend the age of service in the equity court. But. in spite of lederalist appeals, there was apparently but little disposition so to do. In juclicial duties he

1 T'age 320.

"Page 378 . The final passage, in perfected language. cante Uct. 29. p. 588.

3 Page 582. Van Buren and his friends were not averse to this.

4 Page 625.

5 See discussion by Tompkins, p. 528, and Edwards, p. 534.

"The terms of the others would expire as follows: Yatcs. is 28 : Woodworth, I828: and Platt, r820. C. Z. Lincoln, Constitutional History. vol. i, pp. 675-676. There was no injury to Woodworth and Yates when the judges were "constitutionalized out of office." as Mootworth was soon reappointed and Yates marle governor. 
was unassailable, admitted the "high-minded " Peter Jay Miunre, but outside the court-room, retaining the prestige of his high office, he was a menace to the liberty and safety of the masses. ${ }^{1}$ As to the other judges, a scheme was cunningly devised which provided for immediate retirement.

It was in vain that Abraham Van Vechten protested that nu man had understood that the convention had been called to turn out officers of govermment: a remedy was always ready for misconduct on the bench, in the process for impeachment. General Root responded that like other officers, if they merited the public confidence, they might expect at reappointment, and added with his scathing sarcasm: "The honorable chancellor has told you, and doubtless with truth. that he has no fear of an investigation. And if others have an equal security in the conscionsness of rectitude, they are in no danger of being injured by the indignation of the people." " $\quad$ P. R. Livingston declared these Federalist judges had come into office by disgraceful coalition or by party treachery within the Council of Appointment; they had been well paid and had already had far more than they deserved. ${ }^{4}$ 'The judges, on their own behalf, did what they conld with dignity to stay the tide. ${ }^{5}$ Henry Wheaton, a moderate from New York city. presented an amendment to protect the present judges, but it was voted down by the

' Page 6r5.

"Tompkins, p. 528: Erlwards, p. 534.

${ }^{3}$ Pages 5.3 I-5.33.

'Page 520. Livingston's reference to coalition concernerl the Quir! council which had named Van Ness, and his reference to treason that of Robert Williams which had named Platt. Spencer had been apminter with the expectation that he would stay a Democrat.

${ }^{5}$ C. Z. Lincoln, Constitutional History, vol. i, p. 676. General Carpenter's amendment calling for an entirely new court was acopted, p. 624. This was said to have been suggested by Colonel Joung and General Root, Hammond, vol. ii, p. 63. Some moderates like Van Buren and Sanford. voted to retain the judges. 
usual majority. ${ }^{1}$ The Federalist party left high office in the state forever.

That some leaders were quite willing to exclude the remnant of that party from any influence in the legislature, is shown by a proposal of Van Buren. The Federalist majority in Columbia County would be sufficient to carry the third senate district as planned by the committee." Van Buren moved to take Columbia away from Albany, Rensselaer, Greene, Schoharie and Schenectady, and attach it to the Demucratic second district running down the Hudson River; and to take from this in compensation the safe and constant counties of Sullivan and Ulster, and transfer them to the third. A prompt remonstrance came from Elisha Williams (on whom Van Buren lavished no affection ) :

In the third district you have a Gerrymander. The monster will curl its tail on the mountains of Jersey-coil along the borders of Pennsylvania, wind its scaly and hideous carcass between the crooked lines of counties, and finally thrust his head into Bennington. Disguise it as you will, the object will be visible, and the people will understand it is to exclude federalism from every senatorial district. ${ }^{*}$

Van Ness presented an amendment to the prejudice of New York city, but both were soon defeated in the rote."

Devices to humiliate the Federalists were scarcely needed; their favorite theories had been as thoroughly discredited as those of astral influence and the philosopher's stone. Al-

1 Pages 621, 624.

"The new constitution increater the senate districts from four to eight.

: Page 264.

4 Page 560. E. C. Gritith, in his Kise and locelopment of the Gerrymander (Chicaso, 1907 ). MI. $5(6-1)$ i. discusses attempts at such redistricting in the first two decades of the century, lnt though he steakof Bacon's proposal for single-member senatorial districts (Clarke edition of Dibates, p. 213) he does not mention Van '3uren's pian.

5 '?ages 560,561 . 
though there was some carping at the constitution as not giving quite enough to popular cuntrol, ${ }^{\perp}$ it was accepted at the polls by a majority of over thirty thousand." So certain was the victory that many did not take the trouble to vote. ${ }^{3}$

The extension of the suffrage was not achieved by the eloquence of advucates: it came because it accorded with an American ideal. " From our cradles," said Judge Hammond, "we had been taught that a zealous support of equal rights and an extension of equal civil privileges to all was an evidence of our devotion to liberty and the true principles of a republican government." * The impulse was not wholly spent in the convention; four years later there were abolished what restrictions yet remained upon the manhood iranchise. ${ }^{5}$ No longer was there in New York a thenry

'[Benjamin Romaine], A Comparative View and Exthibition of Reasons opposed to the Adoption of the New Constitution, etc., by an Old Citizen (N. Y., I822). This pamphlet speaks of "the princely prerogatives of our future governors," due to the appointing power (p. 5). checked only by an "aristocratic senate" without reference to the popular branch ( $\mathrm{p}$. I7). This critic may be suspected, however, as he was a Clintonian, and therefore quite naturally opposed to this " child of the Republican Party." $C f$. the following from P. A. Jay to John Jay; Nov. I5, I82I (Jay Correspondence, vol. iv, p. 455): "There seems to be a passion for universal suffrage pervading the Union. There remain only two States in which a qualification in respect of property is retained. When those who possess no property shall be more numerous than those who have it, the consequence of this alteration will, I fear. be severely felt."

"J. D. Hammond, Political History, vol. ii, p. 94.

"The N.Y. Commercial Advertiser on Jan. 21, I822, apologized for having forgotten to print the news of the election when it had been received four days before. Albany, Columbia, Greene, Montgomery, Schenectady, Ulster and Queens counties voted against the constitution. In Ontario and Rensselaer the vote was very close; see $N$. $Y$. Spectator, Feb. I9, I8z2.

'Political Hislory, vol. ii, p. 49.

Albary Argus, Jan. 21, I\$25. Under this provision all adult male: 
that any class of men was wiser, abler or better than an other in the public business. A political democracy had been established, that "perversion" of which Aristotle warned, "in which the mechanics and the hired laborers must needs be citizens." " The ballot in the Jeffersonian opinion was a weapon of defense to protect the individual's rights: a lecade must elapse before it was considered as an instrument of sucial progress." Yet to recognize and to define his rights, the young citizen must be enlightened by a systematic course of training, for Jefferson's whole theory rested on a "strong faith in the teachableness of the great mass of the people." " The framers of the constitution realized that democracy and education must make their progress hand in hand, and their generation in New York showed an unexampled interest in the common school."

who had lived a year in the state and six months in the county could vote. See infra, ch. ix. Of course, the qualifications concerning age and residence were retained. In 1833 the constitution was amended so that qualified voters in New York city might vote for mayor, and in $183^{\circ}$ this provision was extended to all other cities of the state; C. Z. Lincoln, Constitutional History, vol. ii, p. 3 .

1 "Hence there is a particular polity, aiz., the extreme Democracy, in which the mechanics and the hired laborers must needs be citizens, while there are others in which it is impossible, $e$. g., wherever there exists the polity commonly called aristocratical, in which virtue and desert constitute the sole claim to the honors of state; for it is impossible to live the life of a mechanic or laborer and at the same time devote oneself to the practice of virtue." Aristotle's Politics. J. C. Walden translation (London, 1905), p. II 4 .

${ }^{2}$ C. E. Merriam, American Political Theorics (N. Y., rgo3), chap. iv: E. D. Adams. The Pocer of Ideals in American History (New Haven. (1) 3 ) , chap. v.

"Inhn Fiske, "Thomas Jefferson, Conservative Reformer." Essays, Historical and Litcrary (N. Y., I902), p. I45 ct seq.

"Remarks of Mr. Buel, Debates, p. 242. "Obviously a society to which stratification into separate classes would be fatal, must see to it that intellectual opportunities are accessible on equable and easy terms. ... Otherwise, they will be ovcruhelmed by changes in which they 
They cunld fervently repeat the words of Danton: " Ipreic le pain, l'éducation est le premier besoin du peuple."

are caught and whose significance or connections they do not perceive." John Dewey, Democracy and Education (N. Y., I916), pp. Io1102. ( $f$. E. A. Fitzpatrick. The Educational l'iez's and Influence of Dell itt Clinton (Teachers College, Colunbia University, 1911).

Note on the Negro Vote.-In an article entitled. "The Negro Vote in Old New York," Political Scicnce Quarterly, vol, xxxii, no. 2, pp. $25-275$, the present writer has presented the evidence which supports the following conclusions:

Slaves were introduced into the Hudson River region before Manhattan houses were a decade old. When the English took control a generation later the trade in "negears" was solicitously fostered by the government. They were scattered about in the houses of the aristocracy, who were Federalists, for the most part, in the early national period. Yet slave-holding did not pay, and was so expensive that Federalists themselves supported the Manumission Society, and finally by their party vote carried through a scheme of gradual emancipation. Their slaves, who had been well treated, stood by "the families" after freedom almost as faithfully as before; and as soon as any were qualilied for the suffrage by owning $\$ 100$ worth of property, they voted the Federalist assembly ticket. The mechanics had opposed emancipation. for they did not like to see the negro change his butler's coat for cap and jeans or his salver for a saw. The proportion of negroes in New York was then several times larger than now, and they were massed in doubtiul wards in New York city and Brooklyn. In spite of all the Republicans could do. they actually decided the state election of 1813 in favor of the federalist party. When in the convention of $182 \mathrm{I}$ property qualifications were removed for whites by the DemocraticRepublicans, a high qualification was retained for negroes, against the earnest protest of the Federalists led by Peter A. Jay. After this the negro vote was of less relative importance for a time, but it was steadily Clintonian, National Republican and Whig. In the preliminary discussion before the convention of 1846 . Democratic papers ani? pamphleteers favored complete disfranchisement of the negroes, while. the Whigs, as a whole, favored equal suffrage. The Whigs were almost unanimous, in the debates, against disfranchisement. but could not get equal suffrage provided for in the constitution, and hatd to be satisfiel with a separate submission of this clause. A Democratic majority in the electorate defeated it. It was almost wholly a party question: abofitionist or frec-soil sentiment had little or nothing to fo with opinion 
[Note continued.]

on negro suff rage. Tammany Hall, supported chiefly by mechanics, opposed any favors to the negroes, as they would attract others of that race to New York, and this would depress wages. The negroes voted Whig because of old loyalties and the fear of the mechanics. "For the last five or six years before I left New York," testified a witness in lowa in 185 , in speaking of the negroes, "their votes were deposited sometimes for the third-party candidate, but most generally for the oldi Whig party." They were Whigs because their fathers had been Federalists. If there had never been a negro south of the Potomac, still the negro in New York would not have voted for the Democratic ticket. 


\section{CHAPTER IX}

\section{Old Comrades and New banners}

THE sovereign people were exacting masters; they would not tolerate one souvenir of dynasts whom they had supplanted. Relics of prerogative, it mattered not how hoary their antiquity, were jealously resented by " the lordly mob of God-wise folk." After I821, there being then no question as to the theory of government acceptable to New York state, the triumphant Democrats, like the Jacobins of ninety-three demanding heads, set out to purge the state of all those practices which might recall the old régime. The chief party contest of the legislature which soon followed, was on the question of the governor's speech. For a hundred and thirty years it had been customary for the executive to come in person to the legislature as soon as it was organized, a procedure which Clinton had recently defended as more deferential to the people's representatives than the sending of a message as had been proposed. On this the Denocrats rook issue with him, and refused to make the usual formal answer; these pomps and ceremonies they declared to be but "remmants of royalty," and won their point in a debate which exhausted almost an entire day and in bare abstract filled four columns of the Argus.'

The propriety of other old-tine customs soon became the subject of cliscussion. The next year, Mr. Morss of New York city introduced a resolution, that the titles of 
"his excellency," by which the governor was known, and "homorable," bestowed on many officials of the state. should "he discontinued and abolished, as incompatible with the republican form and principles of the constitution." "The resolution passed the assembly, but met derision in Clintonian newspapers. To the Eaning Post it seemed "degrading and ridiculous," " and Colonel Stone of the commercial Adzertiser observed, in a sarcastic humor, that equality would be extended soon to size and weight. and in the interest of the new ecommy no one should grow fat cheeks or clonble chin." But after some reflection the legislators came to the conclusion that they had gone ton rar. and within a week the precinus titles were restored, t", the peremnial delectation of humorists and foreign visitors. ${ }^{+}$ In February, I823, the "high-minded" John A. King. acting in the spirit of the time, attracted much attention and support by a resolution in the senate to make the executive journal of that body a pullic record. " The tendency toward new ideals of popular control was plainly to be seen.

The vanquished Federalists realized the futility of any. protest; they had spoken all their mind in 1821, with little more result than to intensify the prejudice against them. Thu ugh some intransigents were never reconciled," most old-party men now joined with other followers of Clinton as fully in accord with the new theory. For the

'N. Y. Commerial Adeertiver. Jan. I3. 1823.

2. V. I. Earning Post, Jan. 18. 1823.

${ }^{3} N . Y$. Spectator, Jan. 17, I 82,3 . He har poked fun at the debate the year before, see $X$. Y. Commerciul Advertiser. Jan. I7. 1822.

- See the comment of Judge Hammond. Political History, vol. ii, p. I24.

${ }^{5}$ N. Y. Scitate Journal. 1823, p. 129: J. A. King to R. King, Feb. 21, 1823. King Correspondence: N. Y. American. Fel. 24. March 3, 182,3.

- See Wm. L. Stone, Jr.. " I.ife and Writings of William Leete Stone," bound with Win. L. Stone. Sr.. I.ife of Red Jacket (N. Y.. I 866 ), P. 25. 
next few years in New York state, factions strove in their contentions each to prove itself more friendly to the people than its rival. We shall see conservatives assume the name of "People's Party" and demand of the reluctant Democrats the choice of the members of the electoral college by voters at the polls. "Resolved, That all power emanates from the People," ran a broadside issued by the leaders of Clintonians and Federalists, "and that they alone can safely be trusted with its exercise." 1 while another held that the doctrine "that the farther the appointing power was removed from the people the better." was opposed to all republican tradition." In return, their enemies exhumed the past of Federalism. Its candidate in 1824 was scored as one who had retoed the convention bill." When, shortly after, a Senator of the United States was to be chosen, Silas Wright wrote Azariah C. Flagg: "Make a dash at Spencer in your paper for his conduct in the convention ": " it was important to remember that it was St. Ambrose who had argued for a landlord senate. ${ }^{5}$

To counteract the prestige of the People's Men, the Democrats in the spring of 1825 presented an amendment which provided for the popular election of justices of the peace and brushed aside the few restrictions on the general

1 "Republican Fellow-Citizens of Albany," Dec. 23, 1823 (N. Y. P. L.). "Resolved, That the people, being the true source of power, are entitle. to the enjoyment and exercise of that power in such a manner as they deem consistent with their interests and privileges," Broadside, "Albany County Convention ... J. Alexander, Chairman," 1824 (N. Y. P. L.).

'Broadside, "Young Men's [Albany] County Convention," Oct. I8, I824 (N. Y. P. L.). This same bill recommended Dellitt Clinton for governor and Stephen Van Rensselaer for senator.

3 Broadside, "Calumny Refuted," ${ } \Omega_{2+}$ (N. Y. P. L.).

‘ Feb. I, I825, Flagg Mss.

${ }^{5}$ Wright to Flagg. Jan. 18,1825 , ibid. 
'ufirage which had smrvived four years before.' These well-phrased resolutions introduced by Senator John Lefferts, though the work of Silas Wright (for "Brother Lefferts did not draw a long quill ")," were accorded a support almost unanimous, for few dared to rote against them, and. passed again in 1826 , were then accepted at the polls. As when in 1822 it had been recalled by Democrats that Henry Huntington, named for lieutenant governor by the conservatives, had opposed extension of the right of suffrage, ${ }^{3}$ so in 1826 Clintonians warned voters to beware of General Pitcher. a candidate for the same office, as he had stood against the election of the local justices. ${ }^{*}$ In the arsenal of journalistic epithets, the word "aristocrat" was thought the deadliest of all, and when the contest grew most bitter it was hurled by either side against the other. New York state, as we have said, was now for all time committed to the doctrine of political democracy: this had ceased to be a question of dehate. No leader conld profess minions such as those of Judge Platt sixteen years before: reputations were now searched as with a microscope to detect a trace of such a taint.

As the party of the landed aristocracy, the liederalists had been defeated and humiliated. Their name had such a

'Oi course, a residential qualification was retained.

"Wright to Flagg. loc. cit.

"Hroadside. "Falsehood Exposed" (N. Y. Historicai Suciety).

"Broadside. "Republican Nomination [in Washington County]" ( $\mathrm{N}$. $Y$. Hist. Soc.). They also found some profit in herating Van Buren and his followers with respect to the electoral bill, and their organ, the Albony Daily Adacrtiser, printed editorials with the title-head. "The Aristocracy against the People" (c. g. Oct. 20, 1826; Albany Daily Adiertiser, Extra, Oct. II, I824: circular of Albany Daily Adiertiser and Albany Gazctte, 1824 (N. Y. P. L.). Van Buren was attacked in 1825 for having opposed the election of justices of the peace in $18_{21}$ : see Broadside. "Caucus Mirror," Chenango Co., $18 z 5$ (N. Y. P. L.), and " Young Men's Convention," Coeymans, Oct. I4, I825 (X. Y. P. L.). 
woeful connotation that it was discarded. They declared their party lived in history alone, insinuating that they should now be enrolled as good Republicans, relieved from stigma and eligible to any office. ${ }^{1}$ In the summer of 1822 . the Clintonians by a general, though a tacit, understanding, for a tine disbanded." Its special enemies thus retiring from the field, the "high-minded" American joined in the spinion that the struggles in New York were at an end, ${ }^{3}$ admitting that " the Federal party having no longer any sround of principle to stand on, has necessarily ceased to exist as a party." "The Evening Post and the New York Gawette declared that now the only contest was between the city and the country. ${ }^{5}$

But all this was far from grateful to the organizers of the Democratic party who had brought these things to pass. Were they, after years of planning and achievement, now to share their hard-earned fruits with those they had defeated? "This new-light political creed," scathingly remarked the Argus, "which pretends to disregard all political distinction. and to place all on the same footing, we regard as the offspring of the most detestable hypocrisy." " It had no patience with those smirking unctuous Federalists who prated of an era of good feeling. Let no one think that Federalism had passed away: the divisions in the body politics were not like village factions, formed in personal ruarrels and dying in a year.

'N. Y. Evening Post, Nov. 2, 1822.

${ }^{2}$ J. D. Hammond, Political History, vol. ii, p. qI.

- M. Van Buren to R. King, Feb., I822, King Correspondence.

'N. Y. American, Sept. 6, 1823 .

${ }^{5}$ Quoted in the Albany Argus, Feb. 28, 1823.

Ibid., Jan. I8, I822. 
It is not so with the parties of which we speak. These, though they originate in single points of difference, take deeper root; they outlive the causes of their commencement, and those who constitute them are led to opposite sides upon all questions which may arise in the progress of public transactions. The classes of men of which they are composed, each alike, are bound together by a thousand affinities and antipathies; real or fancied persecutions rivet the bonds of union; the succession of generations renders them more enduring, and the transmission of sentiments and feelings of the father to the son is generally regular and unbroken. Notwithstanding the change of interests and of name, the same individuals and families have been found after the lapse of years, acting in concert on all questions of a public nature. Such has been the character and such the history of parties everywhere. ${ }^{1}$

The Argus in this editorial was not the first or last to set forth a philosophy of parties; yet why among the Englishspeaking peoples there should be two parties, apparently immortal, is a thorny problem which lies athwart the pathway even of the student of New York throughout the 'twenties. "The idea of an amalgamation of parties in a free state." said Judge Hammond, writing of an earlier condition, "is chimerical, and the notion that three parties can for any considerable time exist is ridiculous." " Long habit had played its part in enforcing this opinion. Englishmen had steadily developed an interest in their government some centuries before their continental neighbors; but soon after I600 it became a question whether this interest should be kept and possibly increased, or should be wholly quashed by an officer of state who claimed to be above all human law. This question developed two important parties-the one, at least in name, standing for the country

1 Albany Argus, Sept. 12, 1823.

'Political History, vol. i, p. 476 . 
and the diffusion of control, the other for the court and its prescriptive privileges - which with certain changes have persisted almost to today. Though some rivalries which strengthened this alignment were by their nature limited to England, the tradition of two parties was brought by colonists across the sea, was strengthened in the Revolution, when the voteless backwoodsmen and proletariat first tasted power, and was then transmitted to the nation, for a time to be deplored and then accepted as inevitable. ${ }^{1}$

These parties have endured while heroic leaders rose and fell. Antipathies so deep are only superficially explained by reference to the legal dialectics on a written constitution. The explanation frequently advanced, that they represent the cautious who rely on order and the bold who seek for liberty, conservatives who would not tamper with the major institutions - church, state, property and family - and reformers who see hope in change, has much to recommend it, yet the circumstances of the individual's position, whatever be his temperament, will oftentimes provide him with a secret bias. When property is not evenly distributed, it is the men who have the largest share who cherish a calm sense of legality, because as a minority they could not make appeal to force. ${ }^{2}$ Yet with an open continent before them

1 "In all free countries parties will exist; they necessarily arise from different views of public measures; and when confined within the bounds of moderation, they are calculated to awaken inquiry, to promote virtuous emulation, and to prevent the approaches of tyranny and oppression," Address to the Republican Citizens of the State of New York (pamphlet, Albany, I8I3, N. Y. P. L.; supposed to have been written by DeWitt Clinton), p. 3. For a comment on the sectional character of party strife, see H. C. Hockett, Westcrn Influcnce on Political Partics to 1825 , Ohio State Univ. Bulletin (Columbus, I9I7).

"That rich men were found in either party in the early nineteenth century, but that those whose property was in great plantations were, broadly speaking, in one party, along with the debt-burdened farmers, while those who held much personal estate were in the other, is the 
the landed and commercial aristocracy had lost in relative importance and could not save their law in the face of the challenge of 1821 . They must wait some years till, joining others in a reinvestment of their property, they found an economic issue in which their protit and the people's weifare seemed again to go tugether. Neanwhile as individuals they trok up the name of those who had defeated them. It was. however, as Jefferson assured Van Buren, " an ama!gamation of name but not of principle. Tories are tories still, by whatever name they may be called." 1 The Democratic leaders feared the Federalists bearing votes and were resolved to share with them no patronage.

An incident in 1822 contributed to keep alive this animosity. When the Albany post-office became vacant by is summary removal, Solomon Van Rensselaer promptly filer: an application." Tompkins, the Vice-President, and Senator Van Buren brought all their influence to bear to conpass its rejection, solely on the ground that he had been a Federalist: but after grave discussion by the cabinet, the appointment was announced." The conservative news-

thesis of C. A. Beard's, Economic Origins of the Jeffersonian Democracy. Of course many party men vote with economic interest sub-consciously apprehended, and a saving remnant in spite of it. As for the fact of there being parties at all, it is, perhaps, sufficiently accounted for in the natural combativeness of man.

' Jefferson to Van Buren, I824, Jefferson's Writings (Ford edition ', vol. $\mathrm{x}$, p. 316 .

${ }^{2} \mathrm{He}$ had been turned out of his post as adjutant general the year before, was now in Congress and therefore had an advantage in proximity to the appointing power. His falling fortunes (for he belonged to a less wealthy branch of the family) would be repaired by the stipend of $\$ 2,000$ and the patronage of $\$ 1,750$. Solomon Van Rensselaer to the Patroon, Dec. 26, I821, Mrs. Bonney's Legacy, vol. i, p. 369 , and to De Witt Clinton, Nov. 22, I\&24. Clinton Mss.

" The principal charge against you, and I believe the only one, was that you were a Federalist, and opposed to what they called the Repubiican party" S. L. Gouverneur (Monroe's private secretary in Is 22 ) to 
papers were elated, but the Democratic officeholders gathered in Albany to protest." "A more ubjectionable selection could hardiy have been made," complained the Argus, "than that of General Van Rensselaer. He has alway" been a violent opposer of the republican party-republicair men and republican measures have at all times been assailed by him, with the most bitter and acrimoniuus hostility." " A few days later the general's house was burned by some incendiaries." Old party feeling had not passed away.

Though elections had been changed from April to November, the Democratic legislators met in caucus as was customary in the early spring, and fixed upon Judge Joseph Yates and General Root to head their ticket. Conditions being what they were, Clintonians withheld their chief from standing for a re-election, but did oppose Root for lieutenant governor, with Henry Huntington, a wealthy banker from Oneida County. With no contest as to gov-

Solomon Van Rensselaer, March 23. 1839, Mrs. Bonney's Legacy, vol. ii, p. IIo. Rufus King protested at first on the ground that it would interrupt the harmony of New York state, but after this statement he retired from the contest. Cf. R. King to R. J. Meigs. P. M. General, Jan. 3. I822; to Charles King. Jan. 8, and Jan. It I822; to Egbert Benson, Jan. 20, I822; and W. A. Duer to R. King. Jan. 13, 1822, King Correspondence; D. D. Tompkins to Jonathan Thompson, Jan. 4, I822, Mrs. Bonney's Legacy, vol. i, p. 373; Sol. Van Rensselaer to the Patroon, Dec. 26, I821, ibid., p. 37o; and J. Q. Adams, Hemoir, vol. v, p. +79. Judge Hammond, Political History, vol. ii, p. 96 et seq., and Hugh Hastings, in his articles in the N.Y. Commercial Advertiser, Oct., I8.3. scold Fing for his conduct, but in view of all the circumstances perhaps uniairly. Hastings, without mentioning his authority, says that the whole matter was quietly engineered by Clinton.

'. I. Y. Commercial Adzertiser, Jan. Io. 11, I5, r822, Albany tryms, Jan. $15,22,1822$.

'Jan. I5, 1822 .

"N. Y. Statesman, February 20, I822.

4 N. Y. Commercial Adrertiser, Oct. 26, I822: J. D. Hammond. I'olitical History. vol. ii, p. 231. 
ernor, the campaign seemed to signalize the nadir of the fortunes of conservatives, yet Huntington had more than half as many votes as Root, scattered generally throughout the state, and the old Federalist districts, as usual, sent their opposition members to the legislature. ${ }^{1}$ " The ship and the crew are precisely the same that they were formerly." it was remarked, "with the same commander on board; but without exhibiting any colours." 2 The new governor, of a benevolent temper, sent a sapless message to the legislature, intended to be soothing, and naively nominated Jonas Platt and Ambrose Spencer as supreme court judges, for confirmation by the senate. ${ }^{3}$ They were. of course, promptly and overwhelmingly rejected. The governor must have had a genius for credulity to have taken seriously the Federalist pronouncements as to amalgamation." Because he had been unopposed it did not mean the dawn of a millenium: it was fatuous to think while Clinton lived that he would listlessly retire from the field. ${ }^{5}$

1 Albany Argus, Dec. I0, I822; Solomon Southwick polled a few votes for governor. $N$. I. Commercial Adiertiser, Nov. 7, I822, Jan. It, 1823; N. Y. Er'cning Post. Nov. 4. 7. I822; N. Y. Spectator. Nov. 19. 1822; Albany Argus, Nov. 8, 12, I822.

${ }^{2}$ Albany Argus, June 21, 1822. For a comment on the virulence of party contests, $c . g$. in Canandaigua, where the Ontario Messenger owned by J. C. Spencer, Granger, etc., disputed with the Ontario Repository, see $\lambda$. Y. Commercial Adcertiscr. Jan. It. IS22.

${ }^{3}$.Hessages from the Gozernors, vol. iii, p. 2 ; J. D. Hammond, Politieal History, vol. ji, p. 10 ; N. Y. Evening Post, Jan. 10, 1823.

${ }^{4} \mathrm{Cf}$. comment in N.Y. Ei'ening Post, Jan. 27, 30, I823.

${ }^{5}$ Clinton had retired with reluctance (J. D. Hammond, Political History. vol. ii, p. 98), for though his more intelligent and prudent friends had discouraged him, others had given different counsel. Gidieon Granger had urged him to stand as the candidate of the west: "The conclusion of the coming wheat harvest will be time enough to begin to act. We should stand cool, easy \& collected and when the season of action arrives we should display an wergy hitherto not exhibited. It 
But a stronger influence toward vitalizing party spirit lay in the character and policies of the Democratic leaders. They desired an opposition firm enough to keep their followers in discipline. The "Holy Alliance" they were called at first, but this title did not indicate their permanence and mutual responsibility as well as one soon afterward bestowed upon them and accepted, the "Albany Regency"." Van Buren was, of course, their leader, a man uncommonly endowed with common sense and a shrewd and accurate jutge of men: Trilliam L. Marcy should be numbered next, a bluff New Englander, who in intervals between his fighting in the war of 1812 had attracted notice by some able articles defending Tompkins, and had since instructed Rensselaer County in the doctrine through the columns of his Northern Budget. ${ }^{2}$ Azariah C. Flagg, who had led his troops to battle by the Saranac as Marcy had by the St. Regis, had likewise served the party in his Plattsburgh $R \mathcal{c}$ publican. and had come to the assembly marked for leadership. ${ }^{3}$ Silas Vright, of St. Lawrence County, was elected to the senate in 1823: he had graduated from Niddlebury College as one of four Republicans in a class of thirty, and

should be manifested by vigorous personal efforts rather than by newspapers vociferations. If it suits your convenience to explore the canal, the connexions between Seneca and the Susquehanah, the iron beds of the North and the reasonable evidence of the West, as well as the infant fishery on the East of Long Island perhaps it would not be without usefulness," April 4, I822, Clinton Mss.

${ }^{1}$ E. E. Hale, Jr., in his interesting IFilliam H. Secoard (Philadelphia, I9IO), p. 44, note, states that the first use of this word that he had found was in the Albany Adicrtiser, Jan. 17, is24, which speaks of " the cabinet council of Van Buren, or rather the regency whom he has appointed to govern the state in his absence."

${ }^{2}$ For sketches of Marcy, see J. S. Jenkins, Liz'es of the Gozernors, pp. 546-606, and I. B. Moore, "A Great Secretary of State," Political Science Quarterly, vol. xxx, pp. 377-396.

steleton's Cyclopedia of American Biography. 
since risen to importance as a lawyer in his town of Canton. Competent and winning, and inflexible in his allegiance to the principles of Jefferson, though not conspicuously daring. he easily found place among the Regency. ${ }^{1}$ The brilliant Samuel A. Talcott. a "high-minded" man from Utica, was three times attorney general after I82I, could argue as an equal with such advocates as Vebster, and might have had a national career had he not mistaken dissipation for a sign of genius. ${ }^{2}$ In this he was in contrast with his friend. Benjamin F. Butler, whose Puritan piety was mocked at by incredulous foes, and whose diligence and public spirit bronght him high distinction. ${ }^{3}$ Dr. Michael Hoffman, a German from the town of Herkimer, educated in the law as well as medicine, was of more importance in the group than has ustally been recognized. The letters which he wrote from Washington. where he served eight years in Congress, are full of sound advice on large concerns of policy, while his financial plans and measures for the state, in their wisdom and consistency, should give him with historians something of the character of statesman. ${ }^{4}$ Edwin Croswell, whose name concludes our catalogue, was the spokesman of the party. By his address and tact, aided by nice literary taste, he made the Albany Argus for a time the most influential paper in the northern states."

There are lives of Wright by J. D. Hammond (Syracuse, 1848) ; J. S. Jenkins (Auburn, I847) ; R. H. Gillett, two volumes (Albany, I874).

2 Bacon, Early Bar of Oncida County; M. M. Bagg, Pioneers of Utica. pp. 4I8-424.

${ }^{3} \mathrm{~W}$. L. Mackenzie. Liz'es and Opinions of Benjamin F. Butler, ctc. (Boston, I845).

'Letters from Hoffman to A. C. Flagg. constitute one volume in the Flagg Mss.; N. S. Benton, History of Herkimer County (Albany, 1856), pp. 323 et seq.; Ancrican Almanac for 1950 (Boston); G. W. Smith. "The Career of Michael Hofman," Papers of Herlimer Co. Hist. soc., I896 (Herkimer, I899), pp. 5 it seq.

${ }^{5} \mathrm{~J}$. D. Hammond, Political History. vol. ii, pp. 154, 204, $524 \mathrm{n}$. The 
That this gruup should stir opponents to a bitter condentnation, is not surprising, especially when in the absence of dramatic contests in national politics, attention was contined within the state. ${ }^{1}$ They were formidable in solidarity. Wright in S $_{23}$ would have preferred John Quincy Adams for the presidency, while Flagg favored Clay, or possibly Calhoun; " but when their colleagues had decided, they were ardent Crawford men. Flagg was for a popular election of electors until he was instructed," and then became the chief defender of the older method: Huffman later did not care for Jackson, but sank his prejudices in deference to the general party will. ${ }^{*}$ If they could not always reach the Greek ideal of harmony, they could achieve a Roman concurd. Yielding individually to what they thought the practical demands of leadership, they insisted on a like subordination throughout the party. They deplored self-nominations, and insisted on the authenticity of

N. Y. American, Feb. 2, 1827 . charged that the "gentleman pensioners" of the Regency wrote articles which were sent out to affiliated papers in the state, from which later the Argus copied them as evidence of popular sentiment. The Argus denied this on Feb. 5, 1827. Benjamin Knower was called a member of the Regency, and also Roger Skinner. though he died in 1825. J. A. Dix, James Porter, T. W. Olcott, and C. E. Dudley were also regularly associated with the leaders; $c f$. Thurlow Weed, Autobiography, p. 103.

${ }^{1}$ See N.Y. American, Nov. 22, 1823. Van Buren seemed not quite able to understand why there should be so much hostile criticism: "Why the deuce is it," he wrote to Rufus King, "that they have such an itching for abusing me. I try to be harmless, and positively goodnatured, \& a most decided friend of peace." Sept. 2r, I822, King Corresponderce.

2 Wright to Flagg, Dec. 20, 1827; Flagg to Wright, Oct. 28. 1823; Flagg to Van Buren, Nov. 12, 1823.

"Plattsburgh Republican, Nov. 8, $1823 ;$ N. Y. American, Jan. 27, 1824.

4.'I don't like the Jackson frolic very well, but I suppose we must have it," Hoffman to Flagg. Flagg Mss. He makes numerous other comments to the same effect. 
all done in a calicus. ${ }^{1}$ To question this was wrong, they saic: it had a bad effect on future contests: " an opposition on the ground of principle will be used to authorize an opposition on the ground of caprice." "

They did not look for harvest where they had not sown, and carefully apportioned their appointments. ${ }^{3}$ The toughminded William L. Marcy in debate with Clay admitted that, " They saw nothing wrong in the rule, that to the victor belong the spoils of the enemy." * They seemed to hold an absolutist. almost mystical, conception of the rights of the party, so important and so precious as to be beyond the laws of private ethics. "Don't be too fastidious," write Marcy; "when party feeling is strong almost anything that is done is right. I have not time to carry out fully my ideas on this subject, but a hint is enough to such a wise and experienced body as the Albany Regcncy." "

They were so successful that their bewildered enemies, in search of explanation, could think of nothing less than sorcery." Silas Wright had little patience with the party managers he met in Wrashington: "They do not under-

${ }^{1}$ E. g. in Argus, Oct. 23, 1823. Adams men heartily approved of self-nomination; $c f . \mathrm{N} . \mathrm{Y}$. American, Oct. 4. 1825 . "At no period before or since, has caucus law been more readily acquiesced in, and more promptly enforced than the present," J. D. Hammond, Political History', vol. ii, p. 114 (writing of 1823 ).

${ }^{2}$ W. L. Marcy and Edwin Croswell to A. C. Flagg. Oct. 20. 1825. Flagg Mss.

3 On the subject of appointments you well know my mind. Give them to good true \& useful friends, who will enjoy the emoluments if there is any, and will use the influence to our benefit, if any influence is conferred by the office. This is the long and short of the rule by which to act," Silas Wright to A. C. Flagg, August 29, 1827, ibid.

"Marcy on Van Buren's nomination to England, Annals of Congress. vol. viii, pp. 1313, 1325, 1356.

${ }^{5}$ Marcy to Flagg, Feb. 6, $1830[\%]$, Flagg Mss.

${ }^{6}$ Wright to Flagg. Oct. 10, 1827 . ibid. 
stand doing these things, after all," said he, " as well as the Albany Regency." " Yet they were not often charged with gross corruption, and when taxed with having turned out officers whose competence could not be questioned, in order to make room for friends, they might correctly cite a long line of precedents." They exchanged the higher offices and honors of the state among themselves, but they faithfully performed the duties which attached to them. They were virtuosos in the arts of party management, but they had a theory of government and, as long as they remained together, a consistent policy.

The conservative party in the north, though it long opposed all social changes, has been the party of business enterprise, the party with a program, while the Democracy has been the party with a creed." It was to the latter that the Regency belonged, and hating public debt they steadfastly adhered to a policy of strict economy, to the disgust of the Clintonians and Whigs. ${ }^{+}$They were not a mere cabal of politicians; three men of this small group took place among the able governors of the state and represented it as Senators in Washington; one became a President, and another refused a nomination for that office; four cabinet positions were distributed among them: the others were

1 Wright to Flagg, Dec. I3, I827, Flagg Mss.

${ }^{2}$ Proscription in New York goes back certainly to the times of Corernors Fletcher, Bellomont and Cornbury, when Leislerians and their opponents were alternately turned out of office. Marcy in the senatorial debate mentioned Spencer as a worse offender than the Regency in this regard. It has been customary to trace the beginning of the practice to the Council of Appointment of I8or of which De Witt Clinton and Spencer were members, but H. L. McBain (cf. supro. p. 6, note) has plausibly ascribed it to their Federalist predecessors.

${ }^{3}$ J. F. Jameson, History of Historical Writing in America (Boston, I891 ), pp. 93-94.

'D. C. Sowers, Financial History of New York State (N. Y.. IgI4), pp. $64,66,67,69$. 
remembered as public men of principle and useful service. There was no possibility of "amalgamation" while stuch men determined otherwise: they had not long to wait before an issue was presented which silencer any talk of the catholicity of the great Republican party.

As the election of $182+$ drew near, the contest for the presidential nomination grew exciting. Clay, Crawford. Adams, Jackson and Calhoun were all comsidered candidates, but Adams seemed to be the favorite in New York at first. by reason of his northern birth as well as of his public record: ${ }^{1}$ since Virginia had furnished Presidents for eight administrations out of nine, many were determined to stand out for a northern man, who never had held slaves. ${ }^{2}$ The Kings and their American brought most "high-minded men" to this decision. ${ }^{3}$ The Commercial -Adertiser, no doubt speaking for the majority of old Federalists. expressed regret that Clinton was not then available, and soon came out for Alams:" But agreement could

'Albany' Argus, Nay I3, I\&23.

'R. King's memorandum, King Correspondence, vol. vi, p. 508; Stephen Van Rensselaer to De Witt Clinton, Jan. 25, I823, Clinton Mss. On the other hand, the Argus deprecated "the misguided attempts of the editors of the American to array the north against the south, and sow the seeds of disaffection and jealousy in the union," Aug. 15, 1823. On May i, I823, Johnston Verplanck retired from the editorship of the American leaving Charles King in sole charge. On the matter of slaveholding, $c f$. Amcrican, August 15, I823. and Argus. July 29, 1823.

${ }^{3}$ J. Verplanck to M. Van Buren, Van Buren Mss.; R. King to J. A. King, Jan., I823, and to C. Gore, Feb. 0, 1823, Fing Correspondence. The Argus now begins to call the American a "Ferleral paper"; it was apparent, they observed, "that deep-rooted predilections were not easily controlled," Aug. 1, 15, $1 S_{2 .}$.

"Jan. 21, 1823: Aug. 13, 1824. It deprecated reference to "the now insignificant circumstance of his having been a federalist, or the still less important one, as concerns merit, of his now being a republican"; if. likewise the Poughkepsic Journal, and. according to the Argus (Aug. 26, I823). all the other "ultra-federal" journals in the state. 
not be expected: the Argus now observed that true Democrats would leave the Secretary of State when they saw what kind of men supported him, while the Adams papers railed at Crawford as the candidate of Radicals and Jacobins. ${ }^{1}$

In national affairs, for more than twenty years, the New York Democrats had won their trimphs as the colleagues uf Virginians. Disliking Adams for his friends, the leaders naturally chose Crawford as the candidate of their old allies, and because he stood for an authentic caucus nomination, a principle which they considered very precious. As early as January, I822, they had come out strongly for this procedure. deprecating all irregular and premature announcements in the state. ${ }^{2}$ The leader of the Regency long afterward explained that the Democratic party had always had more need of these devices than their adver. saries, since the program of the latter wonld either fascinate the voters by its dramatic content or draw them by their economic interests.

In 1823 it was apparent that the senators, most of whom

1 Albany Argus, Aug. 24, I824. "Mr. Crawiord is the head and chief of the Radical party whose object it is to beat down and destroy all the most useful instiutions of the Federal Government-the Aimy the Navy, and fortifications, and Military Academy," $N$. I. Commercia! Adzcrtiser, Nov. 4, I823. The American prinied much the same opinion, February 20, I824. The name Rarlical had recently been introduced from England. "To prostrate the reign of jacobinism," wrote Clinton to C. G. Haines, on April 22, IEz3 (Clinton Mss. Letterbook r). "we must arrange a party for the ensuing campaign on the ground of measure." The following day he wrote again of thc levelling principles of the dominant faction. C $f$. also John A. Dix's letters to Dr. George C. Shattuck, I822-I824, Mass. Hist. Soc. Proc., vol. 1 (Boston, 1917), pp. 143, 144, I.47.

${ }^{2}$ Albany Argus. Jan. 29, 1822, March 25, 1823.

3 Mlartin Van Buren. Inquiry into the Origin and Course of Politicat Partics in the Irited States (N. Y. Is6-), pp. 4-5. 
had been brought into office on the Democratic wave that followed the new constitution, were so completely under Regency control, that the majority of the legislature, no matter what the issue of the next elections, would probably declare for Crawford. ${ }^{1}$ Since the presidential electors were then chosen by the legislature in joint session, this would surely mean the choice of Crawford by the state, which might turn the balance in the Union, and thus enormously increase the prestige of Van Buren and his coadjutors. Yet of all the candidates. Adams was no doubt most popular throughout the state, and his supporters, joined by those of Clay, Calhoun and Jackson, took counsel as to how such a triumph could be circumvented. By April a plan had been devised to change the law, if possible, so as to give the choice directly to the voters." The personal followers of Clinton, who had been reticent upon the presidential question, but who here saw an opportunity to embarrass their chief enemies, instantly took ground in favor of this measure. $^{3}$ and there soon was organized a "People's Party" on the issue of the Electoral Bill.

The story of the ensuing contest is not unfamiliar: yet certain elements so clearly show how old partisan antipathies were strengthened, that it must not be passed over. While old Federalists maintained with all their eloquence

1 A caucus of "regular Republicans," on Jan. 13, 1824, did formally support the congressional caucus proposals, Albany Argus, Jan. I6, 1824. The best account of this campaign is that of C. H. Rammelkamp, "The Campaign of $182+$ in New York," in Annual Report of American Hist. Ass'n., I907 (Washington, I905), pp. I17-201.

${ }^{2}$ J. D. Hammond, Political History, vol. ii, p. 127. "By offering the Bill now you are sure to attract attention." R. King to J. A. King: April 20, 1823. On this matter Rufus King and Van Buren parted company; $c f$. the courteous letter of Van Buren, May 2, 1823. King Correspondence.

Hammond, vol. ii, p. rzi. 
that the common people must be trusted, the party known: as Democratic declared that " intermediate elections were recognized as a general principle of our system," that instructions to assemblymen and senators were most improper, and that our institutions were not lightly to be changed.' This debate engaged the legislature through the winter of 1824 . The Democrats, led now by Major Flagg, and still in the majority even in the lower house, entrusted the proposal to a committee safely hostile to a change." In amendment to the federal constitution was recommencled, but this could not be passed so as to affect the election of 1824 : a shrewd Democrat brought in a plan by which if no candidate was given a majority at the polls, the matter would be settled in the legislature, knowing that among so many aspirants no one could get more votes than all the rest together: Senator Wright proposed a scheme complicated with such ingenuity that under it, as well, the legislature would have had the final choice. The session closed according to instructions, with nothing done.

These obstructions and evasions aroused a protest through the state that conld not be mistaken, and the vacil. lating Governor Yates, who had in January counseled caution and delay, now, to the disgust of all the leaders of his party. called a special session for the coming August.

"Like a war elephant, his bulk he shows.

And treads down friends, when frightened by his fore.":

${ }^{3}$ Albany Argus, 2 . g.. June 27 . Sept. 23, 1823; Wright to Flagg, Nov. 12, 1823, Flagg Mss.

2 The report of the debate may be found in the Argus, Jan. 9. I8 24. ef $s e q$.

${ }^{3}$ Toast at a dinner in Utica, Argus, July 9. I\$2.4. For an example of the art of invective, one should read a two-column editorial in the Argus of June 8, 1824, beginning: "It is a painful duty to expose to the world the errours and the inconsistencies of a man in whom the com- 
The sullen company that gathered on this summons in the sweltering midsummer of 1824 resolved to make their stay as short as cunld consist with parliamentary law. Silas Mright announced to Flagg that he expected "to be at Allany, Cod willing, Snnday evening with the Utica stage. at the capitol at 12 o'clock Monday, to adjourn on Tueslay, and to start for home on Wednesday morning at the farthest." " let in spite of resolutions introduced by Flagg, who complained that every extra day cost the state at thousand dollars, the session dragged on for a week." Henry Wheaton of Xew York and Isaac Ogden of Walton, leaders of the People's Party, tried hard to force the question to a vote, but when at last the assembly passed the bill, the senate had adjourned. and joint action was impossible. Mcanwhile excitement through the state grew day by day: it was clear that the election in November would increase the power of the People's Men. ${ }^{3}$

A caucus in the spring had chosen Colonel Young as candiclate for governor, but it was unlikely in those troubled rays that he conld, like lates, come unopposed to office

munity has reposed confirince...." The govermor had in January advised waiting for a ferleral amendment; now he said that since Congress had adjourned, there was no hope of that. Thurlow Weed claims the credit for inflencing the sovernor to hic lecision. Autobiography. p. II5.

Dellitt Clinton wrote as follows to Francis Granger, Jan. 25, 1824 (Granger Mss., Library of Congress): "The executive is hors de combat-Wotan's horse, Balaan's Ass, Livy's ox and Mahomet's Camel all harnessed together could not draw him out of the kennel of public indignation."

1 July 24, 1827, Flagg Miss.

2 Albany Argus, August 5, j8za.

"For a description of the extra session. see the Argus. Aug. 3-ro 1824 , and letters from an Albany correspondent to the $N$. Y. Eaening Post. Ang. 4, 6, 7, 1824. The letters have some interesting comment on the "high-pressure" oratory of "little Major Flagg." 
Early in April the Argus bitterly remarked that those malignants who could not rest content with regular nominations, had planned a "delegated convention," acting on the single and unfortunate precedent of $I 817 .{ }^{\circ}$ This observation was correct; the delegates were soon chosen and came to Litica the following September six score strong, to settle on a nomination." All but five counties in the state were represented, though unfriendly critics poured derision on the tiny local meetings, which in many places had commissioned these agents of the people. ${ }^{3}$ Conventions, they declared. were a favorite stratagem of Fecleralists: they had held one once at Hartford. ${ }^{4}$ Fut in fact the work of the convention was not difficult, for there was little question as to whom they would select.

The personmel of the new party had been no surprise to Democratic leaders. "With scarcely an exception," wrote Croswell of the Argus to Azariah C. Flaggr, "those who have been elected on the pretended 'Prople's ticket' are the one and implacable enemy under a new name. The enmity will never die: and it is the more dangerons, becanse it is insidious and comes under an artful disguice." "The cloak could not conceal from them the hoof of Clintonism. and unsteadied by alarm some now suspected the whole enter-

'April 6, 9, 1824. The Argws calied this procedure "irregular," but E. E. Hale, in his Servard, p. 65 , points out that as the catucus nethou is natural to a party in power, so the convention is a natural expedient of an opposition.

${ }^{2} N$. Y. Ezening Post, Sept. 24, 25, 1824.

3 Argus, Oct. I, 1824 .

- See toast at Hudson, reported in ibid.. July 16. 182.4 . Oi course. there had been quasi-conventions in the state before $181 \%$. In 1792 , for example, George Clinton was nominated for governor at a Republican meeting held in New York city, said to have been of "gentlemen from various parts of the state;" see C. A. Beard. American Goa'ernment and Politics (N. Y. 19I 7 ), p. 128 .

${ }^{5}$ Dec. 9, I823. Flagg Mss. 
prise as but a scheme to place their arch-opponent in the presidential chair. "I am fully satisfied." wrote one. " that if the law alluded to is changed, Mr. Clinton will get the vote of this state, and in that event he is sure of Ohio too." " Others, however, knew that though the majority of People's Men were old Clintonians and Federalists, a majority likewise, albeit these two segments might not coincide, were now supporting Adams to succeed Monroe. Yet these agreed that Adams and the electoral bill would lose prestige by any public joinder with a fallen hero. To force alignment of the People's Men with the former governor, just before adjournment they introduced a resolution to remove that gentleman from his office as canal commissioner." Though the minority, excepting a small number especially opposed to Clinton, protested vigorously, the resolution was easily put through."

This was the one capital blunder of the Regency. The act was so ontrageous that it could not be defended under the most liberal interpretation of the common law of parties. Clinton had served gratuitously for fourteen years in this office, which he filled with a unique propriety. This wanton and vindictive stroke revealed how cumning had developed in these managers at the cost of their morality. The resentment of the personal followers of Clinton confirmed and strengthened their allegiance: old Federalists

${ }^{1}$ Roger Skinner to A. C. Flagg, Dec. 9, I823, ibid. The N. Y. American, Feb. 3, 1824. ridiculed this fear, yet said that the principle was so important that no individual should be considered. Some Democrats feared the law would aid Clinton in 1828; see Onondaga Repository. quoted in Argus, Sept. 23, 1825. Cf. Thurlow Weed, Autobiography.

- A good account of this is found in W. L. Stone's letter printed in David Hosack. Memoir of Clinton, p. 48 . et scy. The senate passed the resolutions with only three opposing rotes.

'See Henry Wheaton (an Anti-Clintrnian Penle's Man) to R. Kins. April 12, $18_{24}$. King Correspondence. 
expressed a ready sympatly with their adopted leader who enclurerl rebuke apparently for what they thought most honorable in his career: the western connties saw here another evidence that the Regency had no concern in their affairs. It was on this occasion that young IVilliam $H$. Seward threw off connection with the Democratic party.' Addresses of respect and confidence assured the late commissioner that New York would not content herself with those splendid services which he had rendered in the past. ${ }^{2}$ In New York city the park was thronged with those who met to protest, and Matthew Clarkson, William Bayard, Nicholas Fish, Carlwallader D. Colden. Philip Hone and whers drew up resolutions." At Albany there was a similar meeting and committee. ${ }^{4}$ Wheaton, Ogden. Tallmadge and some other People's Men who had sought to keep their party clear of Clinton, now realizerl that this conld not be done.

At a meeting in the Tontine Coffee House in New York city his name was formally presented as a candidate for governor." He had proposed an amendment to the federal constitution as long ago as I 802 embodying the principle of the electoral bill, and had recommended such a law in his

${ }^{1}$ Frederic Bancroft, Life of William H. Secerard (N. Y., Iøßo), vol. i, pp. I\%-I9.

${ }^{2}$ See answers in May 19, 1824 in Letterbook ri, pp. 90, 103, and two addresses from Buffalo, May 10, i8. Clinton Mss.

${ }^{3}$ N. Y. Evening Post, April I9, 20, I824.

- This included Samuel M. Hopkins. J. H. Wenciell and other Federalists, as well as Clintonians like J. D. Hammond, Elisha Jenkins, Gideon Hawley, John Tayler, etc., ibid., April 21, 22, 1824.

"N. I. Evening Post, Aug. 12, 1824. Clinton consenter "from information that this measure will ensure victory, and with a view to crush intrigue." Clinton to Uri Tracy, Aug. I0, I824. He had given up his presidential aspirations for the time being: see Stephen Van Rensselaer to Clinton. Dec. 25. 1822, Clinton Mss. 
message of $1820{ }^{1}$ The Clinton movement grew throughout the state," and many delegates to the Utica convention were instructed to support him and no other. Consequently it was no surprise that, in spite of able opposition, he was given more than twice as many votes as his nearest rivai. ${ }^{3}$ There was then presented an address from the trenchant pen of Gerrit Smith, complaining that the insult of the Regency disgraced the great " state of New-York-the first in population, the first in commerce, the first in wealth and resources, possessing her full portion of talent, and deeply interested in the administration of our national government." He spoke of the ensuing election of a President, but cleverly avoided any odious comparison of the competitors of Mr. Crawford: "it would be idle and preposterous," said he, "to recommend candidates to disfranchised men." 4

Positive proposals must always lose some members to a coalition. and this nomination, satisfying as it was to the majority, alienated certain elements. Whenever Mr. Clin-

'Albany Daily Aderertiser, Extra, Sept. 27, 1824; Messages from the Governors, vol. ii, pp. Io39-1040. Clinton had written Francis Granger, Jan. 6, I824: "An unhallowed attempt is now making to continue the usurpation of the election franchise from the people. How shall this be defeated? Let the people without reference to men but principles assemble at pullic meetings and speak in a language that cannot be misunderstood." See also to same, Jan. I8. I824, Granger Mss.

"See, e. g., Ithaca Journal and Cayuga Republican quoted in X. I. American, Aug. 18, 1824, and citations in Albany Daily Adicriser.

3n the first ballot Clinton had 76 votes: General James Tallmadge. 31; Henry Huntington, I3; with scattering votes to five others. A few discontented delegates seceded from the convention, N. Y. Spectator, Sept. 28, 1824. Sometimes the title "People's Men" was applied exclusively to those who opposed both Clinton and the Regency; see J. D. Hammond, rol. ii. p. Igg. Tallmadge was selected for lieutenant governor.

+Albany Daily Adzertiser. Fxtra, Sept. 27. 1R24. There was also 1 set of resolutions. 
ton was accepted as their leader by the und conivervative party, he adked his constructive and administrative talent to their treasury, but, with the exception of the western districts. he usually brought a personal following scarcely larger, if at all, than the number which he drove away. When the choice of the convention was annonnced, the Nezer fork. American declared that it could take no further part in the campaign,. and there were others of the "highminded " group who, having hesitated, now refused to vote the Peuple's ticket." Yet most of these anti-Clintonian Federalists were Adans men, and some Bucktails now complained that they had mingled with the Democratic party only to destroy it." On the nther hand, the Ezoning Post, which since it had been founded as a Hamiltonian paper had nursed a lively hatred of the Adams family, would not continue fellowship with those who preached the cause of the Secretary of State, whom they stigmatized as "the Benedict Arnold of Federalism." \& Finding Clinton's fortunes linked with such as these, it regretfully abandoned him, to be an independent Democratic journal from that day to this. ${ }^{5}$

Nevertheless most People's Men were well content, and they began a spirited campaign. They held a multitude of meetings, in every county in the state. and issued broadside

'Sept. 25. 1824.

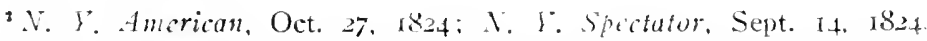
Others are mentioned in Clinton's Clippings, vol. iii, on the campaign of 1826. This scrap-book collection of clippings made by his own hand, if we may judge by the endorsements, is in the collection of the $\mathrm{N}$. $\mathrm{r}$. Historical Society.

'Watertoan Independent Republican, in Clinton's Clippings, vol. ii, p. 90 .

- Oct. 29, 1824.

${ }^{5}$ N. Y. Ez'ening P'ost, Aug. II, Nov. 1, 12, 30, 1844. It favored fackson but was content with Craw ford. 
manifestues, in a tumid style of rhetoric then not quite yet out of fashiom, shrewdly adding names of discontented Democrats whenever possible. ${ }^{1}$ There was quiet work among canal contractors who had control of many votes." bemocrats recalled the record of the Federalists in the late war, and the shifting course of Clinton. That this candilate deserved appreciation for unpaid service as canal commissioner, they declared ridiculous; he had received state noney since I797 amounting to over a hundred and sixty thousand dollars."

In return the People's Men cited with a proper pride their leader's efforts in the cause of education, his many contributions to science and the arts. as well as the beneficent design of the canals." They said if the electoral bill had passed. the November special session to choose the electors would have been unnecessary and thirty thousand dollars saved the state. ${ }^{\overline{0}}$ They charged crimes against "King Caucus " in plurases with a reminiscent ring: "He has refused his assent to laws the most wholesome and necessary for the public grod. He has forbidden his governors to pass laws of inmediate and pressing importance. . . ."

1... 9., "The Regency in Despair" (Albany Daily Adartiser, Extra. Oct. 19, 1824): "They will weep and wail and gnash their teeth, when the storm of popular fury shall overtake and utterly destroy them." See also "Republican Fellow-Citizen of the city of Nhany," 1824 (N. V. P. L.).

${ }^{2}$ I. C. Siencer to Dell. Clinton, Oct. 21,1822 . ( $f$. National ddrocate. Oct. 4,1823 .

"Albany Argus, Extra. Oct. 15. I824, answered in Albany Daily Adertiser. Extra, Oct. I6, I824; $c f$. "Gratuitous Services," Oct. 18. I824 (all in N. Y. P. L.).

" Circular of the People's Committee, P. Cassiday, chairman," Albany. Oct. 22, 1824: "Thomas Jefferson's Opinion of DeWitt Clinton" (N. Y. P. L.).

6" Circular of People's Committee."

- Albany Daily Advertiser, Extra, Oct. I8, I824. 
This was the first campaign in New York state where an appeal was especially directed to young ment, as only since the freehold qualification had been taken off the franchise could they play an important part in politics. There were "Yorng Men's Conventions" and "Young Men's Vigilance Committees" in many towns and connties, forming thus a precedent for years to come." Likewise $182+$ was the year when the convention system was accepted by the state. Seven years before, Republicans had gathered at Vhany to name a candidate for governor, but delegates had been received without much scrutiny of their credentials, and the whoke proceeding. looked upon as quite irregnlar, was not repated in the next campaign. Now the People's Men in city wards and villages held meetings to name delegates to the conventions for the connties; at these, committees of correspondence were selected and ballots taken as to Congressmen and members of the legislature. as well as delegates to the great convocation at Utica. Here, after Clinton and Tallmadge had been chosen as the leaders, and an address and resolutions drawn and carried, there was appointed a committee whose duty it would be to call another state convention to meet in 1826 . In that year we shall see their Regency opponents follow their example, and for decades Ltica and Herkiner were known as the respective meeting places."

'Advertisements in N.Y. American, Jan. 4, 1824; Albany Daily Advertiser, Extra, Oct. 18, 1824, "Young Men's [Albany] County Convention," speaks of similar conventions held by the Regency party in Schenectady and Troy. See also Broadside, "Young Men's Convention," I825, which speaks of committees for towns and villages, and "Address of the Democratic Republican General Committee of Youns Men," Albany, Oct. I825 (N. Y. F. L.).

? Thurlow Weed, Autobiography. Popular ratification meetings were held; see, $c$. g., N. Y. Commercial Advertiser. Oct. 2, I2, 1824. Utica and Herkimer were respectively appropriate. "While the eastern population seated within Oneida County, almost unaninously acied witi 
The election gave a large majurity to Clinton. It clearly showed what was the core of the new People's Party, in that the widest margins of this victory were in the uld Ferieralist districts. In New York city the southern wards were registered for Clinton, and the northern wards for Young. ${ }^{1}$ Albany went overwhelmingly for its old favorite." The largest majorities were here, and in Columbia, Washington and Rensselaer counties, all Federalist strongholds, and in the west. Ontario, Genesee and Erie, where the canal made Clinton popular. ${ }^{3}$ The Argus now found vindication of its claim that though the principles of Federalism had been repudiated, the members of that party still voted as a unit by a general understancling. It had been much the

the federalist party, the immigration to Herkimer seems to have ben more equally balanced ..." and to have followed the natnral democratic tendencies of its early frontier life, N. S. Bentun, History of Herkimer County, p. 259. The Germans were Republicans, ibid., p. 261 The Democrats presented the following ingenious explanation for their adoption of the system: "The new constitution placing the election in the fall, has extended the interval between a legislative recommendation and the election. from a few weeks to more than half a year. The interval would be continued to be employed by our opponents, as heretofore, in intrigues and factious combinations to deceive the people. From notions of expediency, then, the mode of nomination has been changed," Albany Argus, Oct. 9, r826. However they made no provision in 1826 for another convention in 1828 . saying that the caucus system might be revived, Albany Daily Adicrtiser. Oct. 20,1826 .

${ }^{\prime} N$. Y. American, Nor. 4. 1824. Federalists were elected aldermen and assistants in the first three wards, N. Y. Earening I'osi. Nor. 5. 6. 1824 .

$$
\text { 2 Albany Daily Adiertiser, Nov. 4. } 1824 .
$$

${ }^{3}$ N. Y. Euening Post, Nov. 15. I824. The following counties went for Young: Chenango, Delaware. Greene, Lewis, Orange, Otsego, Putnam, Rockland, Saratoga, Schuharie, Sullivan, Tompkins, Warren and Westchester, all old Republican counties: see Albany Argus, Dec. 7. i 82. The Argus in its editorials always called its opponents "the Federals." 
same in 1823 , and would be true again in $1825 .^{\prime}$ Aiter the Albany city elections of the latter year, the state paper laconically announced: "Average majority for the aristocratic ticket for aldermen over the republican ticket, $246 . " 2$ "There is not a prominent member of the party whom they serve in this city," it said, the following month, " who has not been member of the Washington Benevolent Society. and continued such during its existence." "3 It printed in its columns similar reports from many other papers. ${ }^{t}$ All old leaders like Williams, Spencer, Kent. Platt, D. B. Ogden. Colden, Benson, the Jays, Van Rensselaers and Van Vechten were People's Men. A caustic writer of the town of Lansingburgh, in Rensselaer county, remarked: "The old Dutch power-proud aristocracy of the place are of the bluelight order of Federalists, real Tories in grain, call thenselves what they may." ".

The presidential contest in the legislature after the election was marked more by bargain and intrigue than by the ascertainment and expression of the public mind. Though some conservatives declared for Clay or Jackson, " most

${ }^{\prime}$ N. Y. Commercial Adzertiser, Oct. 31 , Nov. 6, I823; Albany Argus, Nov. 14, 1823. Cf. N. Y. Evening Post. Oct. 30, 31, Nov. 4, 7, 1822, N. Y. Commercial Adiertiser, Nov. 7,1822 , and N. Y. Spectator, Nov. 19, 1822 .

'Albany Argus, Sept. 30, 1825.

${ }^{3}$ Ibid., Oct. 20, 1825 .

4 See J. Platt to Clinton, Jan. 3, I823; Kent to Clinton. Dec. 3i. 1822, Nov. 9, I824. Jan. 23, 1826, etc.; Clinton to Van der Kemp, Oct. 6, I82.4 (Clinton Mss.) ; N. Y. Evening Post, April 20. I824; and Clinton's Clippings, Oct. 16, I826, vol. iii.

${ }^{5}$ H. G. Spafford to A. C. Flagg, March 3. I 826 , and April 1.3. 1827. Flagg Mss.

- Most of Clay's support seems to have come from Republicans in the People's Party; but other conservatives stood for Jacksot!, $e^{\prime}$. $\%$.. C. D. Colden, Robert Bogardus, J. B. Murray, etc. (sec handbill oi Jackson meeting over which Morgan Lewis presided, bound with filagn 
I'eople's Men supported Adams, a preference now reflected in the legislature. But neither he nor Crawford could le chosen without the help of followers of Clay. How by printing a split ticket behind closed shutters on a Sunday nurning, and promising some seven electors to the Kentucky candidate, in case they could be used effectively, Thurlow Weed secured these needed votes, is all set forth in his own remarkable account. ${ }^{1}$ By a clever trick of this journeyman mechanic who held no public uffice, John Quncy Adlams became sixtl President of the Lnited States. I'et the technical details of how a practical psychologist accomplished his first triumph need not concern us here; such tours d'esprit of party managers may for a time accelerate, retard or modify the tendencies of nations, but they canmot start or stop or permanently direct them. ${ }^{2}$

As one surveys the progress of political affairs in Ner York state throughout the early twenties, he observes that these years, as properly as any others in its history, deserve the well-worn title of "transition period ". The eighteenth century closed in 1821 : its problems, most of them, had now been settled. What Mr. Marlison believed "the most common and durable source of factions" - the various and un-

Mss.) ; Nicholas Fish. Ezekiel Bacon, etc. (... Y. Esoning Post, Nov. 12, 1824): J. C. Spencer and T. J. Oakley. W. A. Duer to R. King. Fel. 17, 1825, King Correspondince.

'Autobiography, chap. xiii.

${ }^{2}$ All factions (according to Weed) agreed in attributing to him the election of Adams, ibid., p. 79. A somewhat similar stroke was accomplished in 1825 by the Democrats, whereby the senators of that party introdnced so many candidates for United States Senator, that no nomination could he made in that house, and hence no joint ballot could lie taken. Thus instead of Ambrose Spencer being chosen, the election was deferred until the following year, when with a Democratic majority the Regency secured the election. Though not generally known, this Ulan was wholly the work of Silas Wright: see Wright to Flagg. Jan. 2. I824. Flagg Mss. 
equal distribution of property '- - still was present, and yet less clearly apprehended in those prosperous years when new land areas so welcomed settlers, than before or after. Parties were continued more from memory and habit than from calculated differences of interest; then, too, the joy of combat and the jealous competition for the honors of the state, guaranteed, as ahways. against an otiose contentment. One harbinger of what the future would bring furth, however, was seen in the altiance of the surviving Federatist group, rounded w by moderate Republicans, with the voters of the growing west.

This region was no longer a frontier addicted to a doctrinaire demucracy. As a Puritan community, somewhat changed by transplantation, it still was earnest, activeminded and fond of enterprising measures; composed of immigrants from other states, it did not easily respond to state-rights sentiment; and with each new mile of the canal. its farmers and its millers felt more sympathy with the commercial men along the sea-coast. Here were the bases of permanent co-operation. How economic issues were developed which deepened the divisions of the electorate with respect to sections, classes, temperaments and legal theories, is to be the theme of the next chapter.

'The Federalist, no. $x$. 


\section{CHAPTER $X$}

\section{Manufacturing Becomes keppectabe}

"The internal concerns of New Yurk," remarked an eilifor in I 822. " extensive as it is in territory, and with new resources unfolding themselves to public view, appear like those of a mighty and flourishing empire." 1 The simile which was to furnish the great commonwealth with its accepted name already seemed appropriate. The following year. when the easterin section of the Grand Canal had been completed. - Ubany received the first small tow-boat with acclaim, as it previsioned what prosperity and dignity to New York state this simple herald announced." In 1825 , as the Seneca Chief brought Clinton through the last loci to the Hudson. " the thunders of cannon proclaimed that the work was done, and the assembled multitude made the welkin ring with shouts of gladness." 3 When the governor's party finally reached Manhattan Island. the demontration, with parades. illmminations and exulting oratory. aime to its climax.

${ }^{1}$ N. Y. Spectutor, Jan. 8, 1822.

"Broadside, "Celebration of Passage of the first Boat irom the Grand Canal into the Hudson, at the City of Albany, on Wednesday, October 8, $1823 "$ (N. Y. P. L.). See also I. Munsell. History of Albany (Albany, 1867), vol. ii.

3 Albany Daily Adicrtiscr, Nun. \&, I825. See the excellent account of the celebration along the canal, in W. L. Stone. Narrative of the Festirities in Honor of the Completion of the Grand Erie Canal, etc. (N. Y., 1825), and A. B. Hulbert. Historic Highadys (Cleveland, 1904). vol. xiv. 
"Such strains shall unhorn millions yet awake.

While with her golden trumpet, smiling Fame Proclaims the union oi the Main and lake

And on her scroll emblazons Clinton's name;"

handbilis setting forth these florid sentimeints were struch off from a press mounted on the printer's float drawn in the pageant, and were scattered through the admiring crowds. ${ }^{1}$

The profits of the western farmers soon surpassed their expectations. Whereas before it took a hunlred dollars and about three weeks to bring a ton of goods from Buffalo to New York city, now eight days and fifteen dollars were sufficient. ${ }^{2}$ Land west of Seneca Lake almost immediately advanced in price four-fold. ${ }^{3}$ The number of lake ships clearing from the port of Buffalo doubled in a year or two." Rochester grew quickly from a little hamlet to a thriving city, and while risitors in their astonishment recalled the stories of Scheherazade, shrewd speculators who had marked the woodland into building-lots amassed considerable fortunes. ${ }^{3}$ The pioneer who had cut his painful way

1"Ode, by Samuel Woodworth, Printer," Emmett Collection, no. 11,422 (N. Y. P. L.).

${ }^{2}$ E. L. Bogart, Economic History of the United itotes (N. Y., 1914 ed.), p. 2 II.

${ }^{3}$ James Renwick, Lifc of Dellitt Clinton ( N. Y., I840), p. 268. Julitic Winden. "The Influence of the Erie Canal upon the Population aions its Course," a Mss. Thesis, University of Wisconsin, shows how much greater changes in population followed from the canal in the western counties than in the Mohawk region. Property value likewise increased relatively toward the west, and over a wider area than the population. Because shipments may be made irom any point on a canal the influence in property value was fairly continuous. Hany foreigners settled in the towns because of the opportunity for unskilled labor.

'Buffalo Gazettc, in Clinton's Clippings, vol. iv, p. 20.

${ }^{5}$ James Stuart, Three Years in North America (Edinburg?, 2ne? edition, 1833), vol. i, p. 8I; Basil Hall, Tracels in North America th the "ears $1 \mathcal{S}_{27}$ alid $1 \$ 2 \&$ (Edinburgh, I\&30), rol. i, p. 53. It had "sprung 
into the wilderness had lived to see a mighty transformation. "He can close his eyes," declared an orator, " and the unbroken forest is dark and waving before him; he wakes and the fruit of every clime is proffered for his acceptance." I Two and a half million bushels of wheat now found their way to . Albany each year. ${ }^{2}$ In the decade after 1820 the increase of population in New York surpassed that in New England by over half a million, but the growth in the western comnties was twice as rapid as in the older Hudson River region."

More than two hundred boats. by i 826 . were towed each week into the Albany basin from the Erie and Champlain canals, while a dozen steamers plied on scheduled time between that city and New York. some of which could make the journey entirely within a summer's day : yet neither these nor tugs and barges conld exclude the white-sailed sloops from their accustomed pathway." But if Albany, now seventh city in the country, profited by trading with the west and Canada, and occasionally despatched a brig to the Antilles," the metropolis at the river's month by its new connection with the teeming hinterland beyond the Alleghanies, became the foremost city of the western world.

up like Jonah's gourd," remarked Col. Stone as he risited here in 1829 . W. L. Stone, "From New York to Niagara," in Buffalo Historical Society Pub.. vol. xiv, p. 233. The gain in population between $1 \$ 20$ and 1830 for Rochester was 121 per cent; Buffalo. 314 per cent; and Syracuse, 282 per cent; see L. K. Mathew. "The Erie Canal and the Settlement of the West," in ibid., p. 195.

"Speech of Judge Timothy (hild, Rochester Telegraph, quoted in Albany Argus, Jan. 17, 1826.

2Abany Patriot, in Clinton's Clippings, wel. ii, p. 2.3.

'U. S. Census, 1870, vol. ii, p. .3.

- Albany Argus, April 12. June 14, 1825, Sept. 12, 1826; H. G. Spafiord.

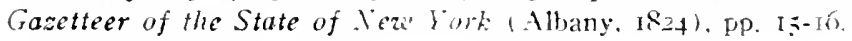

s Albany Patriot, loc. cit. 
The years of painful readjustment following the Peace of Ghent. were now forgotten, and prosperity had come. When, in the spring of 1824 , the canal had penetrated only through the Mohawk valley, three thousand houses were erected in the city of New York in anticipation: and the following year the papers spoke of capitalists moving hither in considerable numbers from the other states. ${ }^{1} \quad A$ sanguine young man hazarded a prophecy, that with the passing of the generations New York might reach a population of five hundred thousand, and in a century, perhaps, a million. ${ }^{2}$ The merchants, clearly realizing the benefit of cheap carriage of commodities, sent a large committee under Philip Hone to Albany to take a part in the formal opening of the canal, ${ }^{3}$ and then expressed their gratitude to Clinton in a present of two handsome silver vases." With the resources of the state and nation waiting for conversion into wealth through any agencies that could command sufficient credit, the men of business might well be expected to endorse improvements through the government's co-operation, with small regard t constitutional objections."

When the governor, in his almost endless message of 1825 .

${ }^{1}$ Francis J. Grund. The Americans in their Moral, Social and Political Relations (Boston, I837 edition), p. 276; N. Y. American, Jan. 4, I824. Sept. 10, 1825. The value of imports at New York in 182I was \$24.000,000 , and in 1825 , when the canal was completed, $\$ 50,000,000, F . J$. Turner, Rise of the New West, p. 35.

${ }^{2}$ C. G. Haines in Washington Hall, N. Y. Commercial Adtertiser, Nov. 13, I823.

${ }^{3}$ J. D. Hammond, Political History, vol. ii, p. 205.

${ }^{4} \mathrm{D}$. Hosack, Hemoir of Clinton, pp. 190-192.

'The confidence thus developed was probably an important reason why the American merchants weathered the English panic of 1825 : see Broadside, "To the friends of internal improvement generally." I 826 (N. Y. P. L.). "I am told that property has Rissen in New York very considerably in consequence of the Cannal," wrote John Jacob Astor in Switzerland to DeWitt Clinton, in Oct. I824, Clinton Mss. 
advised the building of a dozen new canals at state expense. with a turnpike and a railway here and there between, the merchants knew that they would profit by each enterprise. and were confirmed in their Clintonianism. ${ }^{1}$ With lateral canals branching from the Erie, and those connecting lakes and river systems, the prospect of development seemed limitless: Delaware Bay, the Gulf of Mexico, the St. Lawrence and the Hudson could interchange their commerce through the waterways of New York state. ${ }^{2}$. convention was arranged at which enthusiasts discussed these possibilities. $^{3} \quad$ Railroads were considered by some forward-looking men as a means of conquering space perhaps superior to canals, and John Stevens published an announcement that he planned to organize a company which with state subventions would lay tracks along the Hudson." "This will doubtless be stigmatized by some as a wild, impracticable project," he admitted, "but before pronouncing judgment, let the thing be tried." And although this enterprise was long delayed, in 1826 , a road was chartered between Albany and Schenectady, soon followed by another built from Ithaca to Owego. where horses for a time supplied the motive power. ${ }^{6}$

1 Albany Argus, Ertra, Jan, 5, Jan, 21, 1825: Janes Renwick, Life of Clinton (N. Y., I\&4o), pp. 274-276, 292.

${ }^{2}$ See papers of "Hercules," reprinted from the Westcrn Star, in the Albany Daily Adz'crtiser, in Sept., 1836, particularly Sept. 13.

"Broadside. "Convention Notice to the friends of Internal Improvement throughout the State," dated at Angelica, Oct. 22, I827 (N. Y. Hist. Soc.). The convention was held at Utica, Dec. 5, Le Ray de Chaumont, of Chaumont, chairman, Albany Argus, Dec. I3, I827.

${ }_{4}^{4}$ N. Y. American, April 4, 1825 .

${ }^{5}$ See Albany Argus, March 30, 1826, for the debate. Clinton was much interested in railroads; see his Clippings, vol. ii. See also S. Dunbar, History of Travel in America, vol. iii, chaps. xxxix-xlii.

${ }^{6}$ Report of the President and Directors to the Stockholders of the Ithaca and Owego R. R. (Ithaca, I838) in Cornell University Library. When the Syracuse and Auburn R. R. was opened in 1838 , the rude cars were drawn by horses; see W. H. Seward, Autobiography, p. 356. 
As far as parties in the state took sides upon these numerous requests for grants of money, the Regency were less enthusiastic than Clintonians. Erastus Root. the speaker of the assembly for three terms after I 826 , opposed with skill and firmness such appropriations, though he made exception of a state road which would run across his county.' Silas Wright suspected many if not all these projects, and other leaders tried to narrow the expenditures whenever possible." It was claimed, upon the other hand, that the People's Party were more favorable to business men who wanted charters for their corporations, than suited the best interest of the state. While the Democratic legislature of ${ }^{8} 8_{24}$ would grant but three bank charters, ${ }^{3}$ the assembly of the following year, controlled by People's Men, allowed eighteen, though most of these were negatived when offered to the hostile senate; twenty-five insurance charters met a like fate. ${ }^{*}$

The Argus scornfully referred to opposition papers as the

${ }^{1} \mathrm{He}$ had voted against the Bonus Bill ten years before in Congress, and had steadily opposed the Erie Canal plan, J. D. Hammond, Political History, vol. ii, pp. 242, 262, 3I9. 325. We shall see that local projects frequently brought sectional rather than partisan alignments. $N$. $Y$. Commercial Advertiser, Oct. I8, I823; Fitz-Greente Halleck, Writings. p. 265 .

${ }^{2}$ Albany Argus (supplement), Feb. $x$. I824, and M. Floffman to A. L. Flagg, passim in Flagg Mss. The Argus claimed to be impartial.

${ }^{3}$ Thurlow Weed, Autobiography, p. Io6. Two of these were granted under extraordinary conditions. It must be remembered that from 1791 to 1838 banks were chartered by special acts of the legislature, D. C. Sowers, Financial History of New York State, pp. 48. 49. R. E. Chaddock, History of the Safety Fund Banking System of New York (Washington, 1910), p. 247, shows that notwithstanding the growth of the state, from 1821 to 1825 , when the Democrats controlled the legilature, there were only Io banks chartered.

"See comments in Schenectady Cabinet, quoted in Argus, May 15. 1825, and Oncida Patriot, ibid., May 13, 1825. The Argus credited Wright with successful opposition, Oct. 30. I826. For insurance charters and for loan associations, see ibid., Oct. $26,1826$. 
servants of the monied corporations, and its editors warned loyal readers that no effort could be spared to insure a legislature "which will preserve us from an inundation of Banks and chartered speculations." ${ }^{1}$ Much was said about the "Lobby Party," and it was charged that Henry Post, the governor's confidential agent in New York, was too often found in Albany in the interest of some Lombard or insurance company, and was a master of "log-rollers." " The Democrats declared that their opponents displayed the old Federalist recklessness with the people's money, and pointed out that their assembly had spent almost as much in one session, as had been spent by all the five preceding, which had been controlled by sounder counsels. ${ }^{3}$ Jeffersonians who held that governments are instituted among men solely to assure the rights of life, liberty and the pursuit of happiness, might well look askance at such active aid to business.

It was not surprising that such men should look upon John Quincy Adams with some disapproval. In his inaugural address he called to mind the roads and aqueducts of Rome as among the imperishable glories of the empire, and suggested that this nation might well plan like means to great material development. No sooner had the Congress met than he came forward with a program: Chesapeake Bay should be connected by canals with the Ohio and the Delaware: Lake Memphramagog should be joined with the Connecticut; the National Road should be extended, and another built from Washington to New Orleans; islands should be sea-walled. lighthouses built, and harbors deepened. Our commerce should be guarded by a stronger navy. and na-

$\therefore$ Argus, March 30, Aug. $17,1826$.

2N. Y. American, Nov. 31, 1825: John Bigelow, "DeWitt Clinton as a Politician," Harper's Monthly, vol. 1 . Lombards were a species of loan association.

3 Argus, Oct, 19, 1826. 
tional defense should be secured by military schools and state militia equipped and trained according to the national prescription. A great university, surveys, observatories, and exploring parties, were to advance the cause of science at national expense. An item later added to the scheme was a Home Department which would superintend all these activities, encourage manufactures, and counsel states in their co-operation. ${ }^{1}$

With the announcement of these bold proposals. in New York, as elsewhere, papers took sides for and against the administration, and old cleavages were deepened. ${ }^{2}$ Although a small minority of Federalists, like certain fellow-partisans of Boston, could not be reconciled to an apostate, ${ }^{3}$ most of those who had composed that party now supported Adams, and pronounced against those politicians who would cramp the proper function of the central government in the interest of so-called states rights. ${ }^{4}$ At least three quarters of the Clinton following were for the President." The voters of the western comities gave him their support, not alone because of their New England memories or their old suspicion of the Regency. but because they realized that his program

${ }^{1}$ Upon the publication of Adams's speech of Dec. 25 (J. D. Richardson, Messages and Papers, vol. ii, p. 319). Jefferson wrote to Madison, including a draft of "The Solemn Declaration and Protest of the Commonwealth of Virginia," which was to have been published, had not Madison advised against it; see Jefferson, Writings, vol. x, pp. 348-352, and Madison, Works, vol. iii, pp. 511-514.

"Argus, Dec. 17, 1825. M. Hoffman to A. C. Flagg, Dec. 22, I826 and Jan. S, 1827. Hoffman charged that Adams men favred internal improvement partly on account of patronage expected.

"The N. Y. Evening Post represented this minority. See for conditions in Massachusetts, J. T. Morse, John Quincy Adams (Boston. I899), pp. 209, 217.

4N. Y. American, Jan. I, II, 14, May 1, 3. 16, 1826

5 J. D. Hammond, Political History, vol. ii, p. 252. 
of appropriations for canals and roads throughout the farther west, would, if carried out, bring more commerce through their section and more grist to their flour mills. ${ }^{1}$ If the city merchants had endorsed a policy of state improvement for the lower cost of transportation that it would bring, they enthusiastically approved these larger plans which promised much at small cost to themselves.

The orthodox Democracy of New York state regarded this broader American system with aversion, if not horror. ${ }^{2}$ They cordially disliked the debts, monopolies, corruption, favoritism, and centralized control, which they alleged would follow from its operation. In I824, Senator Van Buren took his stand against the policy in Washington, and after Adams' pronunciamento in December, 1825 , he introduced a resolution stating that the Constitution gave no power to Congress to construct roads and waterways within the states. In April, I826, he said that Congress could not vote appropriations for such purposes, even if it left the building and the jurisdiction to the local legislatures. In May, he said that it could make no permanent arrangements for or with those private capitalists who might undertake such enter-

1 Clay men had followed their leader into the Adams ranks. Clay had liked Crawford, but disliked his principles, as far as he knew them, and had disliked Jackson's personality, though he had no great fault to find with his principles; see H. C. Hockett, Influence of the West on Political Parties to 1825 , p. I39. It was typical that James Stuart, the English traveler, should find the canal agent with whom he talked an Adams man, Three Years in North America, vol. i. p. 75.

${ }^{2}$ This is true after 1823 , though not so clear before. The Argws, Jan. I4, 1822, had said: "We rejoice to find that a bill making an appropriation for repairing this [Cumberland] road has passed the Senate of the United States by a vote of 26 to 9." The Democratic assembly of 1822 passed on April Io a resolution asking government aid in improving the navigation of the Hudson. See also attempts to get aid for canal huilding, in D. Hosack, Mcmoir of Clinton, p. 102, and remarks, J. C. Spencer, Argus, Feb. I, $1 \$ 26$. 
prises. $^{1}$ These views were shared by the other members of the Regency." "The very power claimed to make these canals," wrote one, "is opposed to our Democratic principles." 3

The governor's opinion on these matters was the object of wide-spread interest and anxiety, especially among his followers, the great majority of whom endorsed the Presidential program. Not only had he gone with Morris in I8r I to solicit aid in Washington, but the following year the legislature on his urging had persuaded Ohio to petition for a grant of federal money for the Grand Canal in New York state. $^{4}$ Speaking to the senate and assembly in 1822 , he had intimated that the western states then beginning waterways should be "assisted by the general govermment in carrying into effect the magnificent plans they had projected." "In 1824, there had been a movement to name Clinton for Vice

1 Congressional Débate's, I825-1826, vol. ii, pt. I, cols. 20, 619, and $7 \mathrm{I} 7-$ 718. See W. N. Holland, Life and Political Opinions of V'an Buren (N. Y., 1835). pp. 269-274. George Bancroft, Martin Van Buren, pp. I I6-гzo, and E. M. Shepard, Martin I an Buren, p. Ir3; Van Buren to B. F. Butler, Dec. I2, I826. Van Buren Mss.; Van Buren to J. A. Hamilton, Dec. 20, 1826, J. A Hamilton, Reminiscences, p. 6.3 .

:Hoffman-Flagg correspondence, Jan. 8, 18, 22, 1827, Flagg Mss. Silas Wright, in the state senate, introduced a resolution similar in spirit to those passed in South Carolina and Virginia sustaining these contentions (see H. V. Ames, State Documents on Federal Relations (U. of Pa., 1906), no. iv,. He was successfully opposed by some old Federalists like C. D. Colden, and some People's Men like J. C. Spencer. Senator Jordan, a People's Man, then introduced a moderate resolution that Congress could not begin an enterprise within a state without the state's consent, and must yield the jurisdiction over the improvement to the state when finished (Argus, Feb. 2, 6, 7, 1826). It seems never to have come to a final vote $(N, Y$. Senate Journal, p. 170).

${ }^{3}$ Hoffman to Flagg, Jan. 8, I\$27. Flagg Mss.

4W F. Gephart. Transportation and Industrial Development in the Ifiddle West. Columbia University Studies in History, etc., vol. xxxiv. pP. I IO-I I I.

${ }^{5}$ Hessages from the Gozernors, vol. ii. 
President, so that he could more conveniently assist in national development. ${ }^{1}$ But since the state, in answer to his perseverance, had built its own canal, he professed to see grave danger in any interference by the federal govermment in such concerns, and in his message of 1825 , he bitterly complained of the new doctrine that Congress must control exclusively the commerce " among the states." " It was not till I827, however, that he spoke clearly on the power to construct canals and roads: "I think it due to a sense of duty and a spirit of frankness to say, that my opinion is equally hostile to its possession or exercise by, or its investment in the national authorities." " But by this time, we shall see, Clinton and Clintonians had parted company; this pronouncement was one signal of the separation.

In 1826 , however. the governor's prestige had suffered no decline, and the delegates who were convened at Utica nominated him by acclamation to continue in his office. ${ }^{*}$ The Democrats, at Herkimer, though some believed it inexpedient to name a candidate." chose William B. Rochester, a

${ }^{1}$ B. V. Tyler to DeW. Clinton, Feb. 2, 18z4, and T. A. Emmett to same, March 22, 1824, Clinton Mss.

2 Albany Argus, Extra, Jan. 5, I825. Clinton had spoken of himself as a states' rights man before, but not specifically upon this point (e. g. Clinton Clippings, vol. ii, p. 48 ).

${ }^{3}$ Message of 1827. Albany Argus, Jan. 2, 1827: Letter to Moses Hayden, Jan. I 4 , I827. Clinton Mss.

'Utica Sentincl and Gazctte, Sept. 22. 1820. The convention was attended by most of the same Clintonian-Federalist delegates that had met in 1824 . Gen. Tallmadge was not renominated for lieutenantgovernor, as he had ruined his prospects by his action in the senatorial contest the year before (Kingston Plebcian. Oct. 4, I826), and Henry Huntington was finally selected for that office. C. D. Colden, P. A. Jay and James Emott were mentioned, among others, for the place. The Argus was outraged because the convention used the name "Republican" (Sept. 25, 1826).

${ }^{5} \mathrm{~S}$. Wright to A. C. Flagg, Nov. I8, 1826, Flagg Mss.; Thurlow Weed to Francis Granger, July 5, 1826 , Granger Mss. 
young man from the town which bore his family name. He was known to favor all the doctrines preached by Henry Clay, and his selection was clearly in accordance with a principle, since oftentimes remembered, that a party by a nomination may, perchance, attract some whom its principles and record would repel. "Availability" was further illustrated in their choice for second place, Nathaniel Pitcher, who lived within the valley of the Erie Canal, but who had a following through the "southern tier" because of his reconmendations as a state-road commissioner. Judge Hammond, the historian, who took an active part in the campaign, asserts that many politicians knew that Senator Van Buren, albeit outwardly agreeable, desired Rochester's defeat (though not that of General Pitcher), planning thus to form a coalition against Adams, with the re-elected governor. The "Little Magician," with clairvoyant apprehension, may have plotted the event which issued from the contest, but most of his associates, in ignorance or disapproval. gave their best support to Rochester and were chagrined when he was beaten. ${ }^{\text {I }}$ As champions of the state road, Clinton and Pitcher were elected, thongh on opposing tickets, through the almost solid vote of certain southern counties. ${ }^{2}$ Most old Federalist districts gave reduced majorities for the governor, and Rochester made inroads in the west. In account-

'S. Wright to A. C. Flagg. Nov. 18, 1826, Flagg Mss.. shows that the Regency were not entirely in accord with Van Buren in this matter as implied by J. D. Hammond, Political History, vol. ii, p. 232. Cf. W. B. Rochester to A. C. Flagg, and all letters from Hoffman to Flagg, between Oct. 7 and the election, Flagg Mss. Geneva Palladium and Monroe Republican, quoted in Argus, Jan. I, 1827. M. M. Noah, the Democratic editor in New York city, at that moment in charge of the New York Enquirer. was neutral in the campaign. see Argus, Nov. 6. 1826.

${ }^{2} \mathrm{Cf}$. return in Schenectady Cabinet, Nov. 23, 1826 , and .4lbany. Argus, Nov. 20,1826 . 
ing for this change of sentiment, the student must take careful note of these suspicions that the builder of the Grand Canal did not longer represent the party of business enterprise.

Since his uncle had retired from the field of politics. Clinton's favorite candidate for President had been Clinton. In I 822 and I823, he had been hopeful of the nomination, and bitterly censorious of those who questioned his capacity for that exalted office: and for several years thereafter this possibility was ever in his mind. ${ }^{1}$ His tour through Pennsyl. vania, Ohio and Kentucky, in 1825 , with its public dinners and receptions, was thought to serve these high ambitions. When, however, it was seen that the great contestants of the next campaign would be the President and General Jackson. he discountenanced for the time the hopeless efforts in his own behalf and came out strongly for the latter." Adam. he considered as his rival in the north, ${ }^{3}$ while the mutual esteem between the military chieftain and himself dated back half a dozen years. ${ }^{4}$ In this preference, the governor, Van Buren, and the Democrats of southern states, were now

'Letters in J. Bigelow, "DelWitt Clinton as a Politician," Harper's Monthly, vol. 1, pp. 4I5-4I7. The clippings collected by Clinton at this period show his assiduous interest.

${ }^{2} N$. Y. Statesman, Oct. 2, I 827 : Dell. Clinton to C. L. Livingston, Nov. 22, 1827 , Clinton Mss.; J. D. Hammond, Political History. vol. ii, p. 256.

3 W. H. Smith, Charles Hammond and his Relations to Henry Clay and John Quincy Adams (Chicago, I885), p. 32.

"Clinton wrote compliments to Jackson in 1819 , and defended him against the strictures of General Scott (Clinton Letterbook, vol. iv, pp. 366-377), while Jackson replied: "To receive such an expression of friendly feeling from so distinguished a man as yourself is peculiarly gratifying" (March 9, I8I9, Clinton Mss.). In I8I9 the general as the guest of the Tammany society threw the meeting into consternation by a toast to Clinton; see Gustavus Myers, History of Tammany Hall (N. Y., IgI7 edition), p. 52. 
in accord; the Argus, which in 1824 had charged Jackson with designs to ruin the Republican party, ${ }^{1}$ the following year expressed a complimentary judgnent, though earnestly deploring, here again with Clinton, all premature discussion of the presidential contest. ${ }^{2}$ For two more years it held to this position of benevolent neutrality." The "Federalist charges" of Van Buren's secret aid to Clinton in the state campaign, however. seemed substantiated in unwonted favors now exchanged between the old antagonists, and by I 827 the coalition was divested of its clouds of mystery. ${ }^{4}$

But it was a personal arrangement. If Clinton thought the great majority of his adherents who had applauded Adams and his enterprises, would follow with docility to the support of one whose policies were well suspected to be different, ${ }^{5}$ he merely evidenced again his old confusion as to his party and his person. Only a few old Federalists had favored Jackson in I824, and, since Adams program had been understood. these few had grown still less." The edi-

${ }^{1}$ May 18, I824.

'May 20. Nov, 11, 1825, March 30, I826, and Clinton's Clippings, yol. iii, p. 31.

${ }^{2}$ Argus, Jan. 30 (supplement), April I2, June 2, 30, July 4, August 14, 20, 1827. It finally came out definitely as a Jackson paper on Sept. 27,1827 .

'W. C. Bouck to Van Buren, Nov. 17, 1826, Van Buren Mss. Van Buren endorsed Clinton's appointments to important judgeships, and by the support of Clinton, Van Buren was re-elected to the federal Senate: see J. D. Hammond, Political History, vol. ii, pp. 212, 214, 246, 255.

${ }^{5}$ Silas Wright wrote to Flagg, Dec. 20, I827 (Flagg Mss.), after consulting with Van Buren, Hoffman and two other New York congressmen that it was understood that Jackson would oppose the American System and appoint orthodox Democrats to cabinet positions. He said the appointees of Adams in New York state had nearly all been Federalists.

'See supra, chap. ix; cf. N. Y. Commercial Advertiser, Jan. I4, I822, and Hoffman to Flagg. Dec. 22, 1826 and Jan. 8, 1827. Flagg Mss. Thurlow Weed for a time feared otherwise; see to Francis Granger, March 29, I827, Granger Mss. 
torial pen of Thutrlow Weed betrayed a trace of gall when he observed: "If we could for a moment credit the story that the Governor cherishes a thought of support for both parties, we would admonish him of the folly of such hopes." " Papers like the Albany Advertiser and the New York Statesman, whose personal loyalty to the governor had resembled vassalage. now announced that this relationship had passed. and printed "Adams" at their column heads."

There is no room for hesitation [decided the Buffalo Journal], for however an exalted opinion the people of the state may have for the talents and services of Mr. Clinton, they cannot, in a question affecting the prospective welfare of the nation, sacrifice their own judgments in a blind reliance on his preference-honestly formed, perhaps, but evidently founded in errour. $^{3}$

Of sixty "federal newspapers" in the state, fifty-one remained with Adams. ${ }^{4}$

It is clear that Federalists, and most of those associated with them. were disappointed in the governor. For ten years they had understood him to be pledged to policies according with the interests and philosophy (tempered now by some experience), which had been theirs time out of mind. Whatever Van Buren may have thought. at least some menbers of the Regency quite clearly saw how futile was the hope of winning Clinton's party to the cause they stood for.

'Rochester Telegraph, quoted in Albany' Argus, March $30,1826$.

2. Albany Daily Adicrtiser, June 22, 1827: Argus, June 23, July 2, 1827.

${ }^{3}$ Oct. 9. 1827 .

- Argus, March 10, 1828. This paper said that of 49 Bucktail papers all but 7 were for Jackson. It spoke of the Adams party being made up of Clintonians and old Federalists like Elisha Williams, the Van Rensselaers, Col. Stone, Mr. Dwight, of the Hartford Convention, Charles King, of Dartmoor memory, and thousands of others. The Evening Post was a Clinton-Jackson paper; see on Sept. 24, 1827 , and Wm. Coleman to Van Buren, -..., I827. Van Buren Mss. 
To some the course of caution and neutrality, by which this merger was to be effected, was obnoxious; such subleties bewildered honest Democrats, and merely for the gain of Clinton, even though he night be followed by a "little band," they were not worth the hiding and the plotting they entailed. Some questioned the integrity of their old enemy and thought at last he would announce himself for Adams These were for a bold profession of the principles of 'ninety-eight, and to let those join them who found these attractive. If their party came to power it would have to be with the old creed acceptable to the south. They believed that Jackson could be easily converted to this faith, if he did not cherish it already, and urged an early cautcus to present his name.

Van Buren yielded slowly (delay, though never dalliance, marked his technic). for he thought these very notions as to Jackson's orthodoxy were percolating through the state, and he had learned in 1824 that caucuses can follow better than they can command. ${ }^{\prime}$ On the thirty-first of January', I 828, a Democratic cancus nominated the Old Hero. ${ }^{2}$ No one knew precisely what were his principles, but the party

${ }^{1}$ Charles Butler to Flagg, Geneva, Dec. 15, 1827. " Even Adams himself will for our sake read the doctrines of Thomas Jefferson-and Mr. Jackson rather than not be President will reduce them to practice. Let us assert our principles. If it had been done when it ought to have been, we should have been followed by Virginia, S. Carolina \& Georgia. Let us not wait until we must folloze either C. \& his Brotherhood-or the old Feds." "The Argus man is in favor of neutrality. Ask him which he will follow. Write me a categorical answer to that question." Hoffman to Flagg, Jan. 2, I827; see also same Dec. 22, I826, Jan. 8, 22. Dec. 21,1827 . "If Clinton is going to come out Adams as I have expected he would, in God's name let him do it soon, and then we can put our rudder," Silas Wright to Flagg, Aug. 29, 1827. For Wright's impatience of neutrality, see letter to Flagg, Dec. 20, 1827: Flagg's like feeling is mentioned in Hoffman to Flagg, Jan. 22, 1827. See also $N . Y$. Evening Post. Sept. 24, 1827, and Albany Argus, Sept. 26. 1827. and Coleman to Van Buren, April I7, 1828, Van Buren Mss.

'J. D. Hammond, Political History, vol. ii, p. 281 . 
leaders had assured themselves by this time that he shared their deep antipathies, and that his sympathies were with the frontier farmers and town laborers, rather than with the commercial capitalists and the old professional ruling class. ${ }^{3}$ As to the manufacturers, recently observed to have an interest in the game of politics, these leaders lad hestitated for a time, but with the influence of allies in the south, they were coming to a definite conclusion.

Steam and steel, which in the last years of the eighteenth century, had brought to England sudden wealth and want. cheapening goods and men, were introduced on this side of the Atlantic somewhat later with less convulsive readjustments of society. As household industries were crowded out in country districts, fertile land was readily available to nse the energies released. Yet because no cataclysm marked those years, one must not overlook the changes in the life and thought of common men that followed from the great development of manufacturing in New England and the middle states throughout the quarter-century after the embargo. Cotton spindles, for example, could not be increased from eight thousand to half a million in seven years, ${ }^{2}$ withont some economic consequences which would sometime register themselves in politics.

In this development New York was second only to its neighbor, Massachusetts. In ISo8, the Oneida Manufacturing Society set up at Whitesboro the first cotton-spinning mill in New York state, ${ }^{3}$ while two years later woolen yarn

${ }^{3}$ See Hoffman-Flagg correspondence, January to April, I827.

2 E. L. Bogart, Economic History of the United States (N. Y., 1916 edition), p. 164 . This gain was between 1808 and 1815 .

${ }^{3}$ M. M. Bagg, "The Earliest Factories of Oneida and their Projection," in Oneida Historical Society Publication, I881, pp. I12, et seq., "The New Hartford Centennial," ibid., I887-1889, pp. 52-53. The first woolen mill in this section was begun in $18 \mathrm{II}$, and the first power-loom in 1817 , Bagg, p. I17. See also Evarts and Ferris, History of Oneida County. pp. 243, 623 . 
was spun in two mills near Poughkeepsie. ${ }^{1}$ Although no revolution was immediately effected. and in 1822 the governor could still report that the leachers in their asheries furnished the chief export of the state," the progress was continuous and steady till, with the middle 'twenties when canals and roads brought the material to mills and finished articles to customers, it was clear that a new epoch had begun. New industries were introduced even in the west and north. where the clangor of the factory bell. shattering the morning peace, might startle some stray panther roaming throngh the purlieus of the forest. ${ }^{3}$ No one conld tell how great a change could yet be wrought, or what unsuspected energies could be applied. It was a proud day when, in I824, the Commercial . Advertiser could announce that $\mathrm{Mr}$. Ayres of Ithaca, who manufactured imitation Leghorn hats. would soon employ " one hundred females, some of whom are not more than eight years of age." 4

Industrial enterprise, especially in iron, hats and textiles. combined with lower cost of transportation to bring prosperity to Albany, where in the three years after 1823 rents

' E. Platt, History of Poughkeepsic, pp. 83-85.

${ }^{2}$ Messages from the Gozernors, vol. ii, p. I093.

s After the Erie Canal was opened the western counties began to manufacture somewhat for the New York city market, V. S. Clark. History of Manufactures in the United States, 1607-1860 (Washington. 1916), pp. 347-349. Watertown grew rapidly because of the new cotton and woolen mills built there by Le Ray de Chaumount, Jefferson Republican, quoted in N.Y. American, Feb. 21, I823. House Documents, 22nd Cong., Ist sess., no. 303, shows the influence of the Erie Canal on the distribution of industrial plants by 1833 .

"In Clinton's Clippings, vol. ii, p. 5I. Ithaca at the hearl of Lake Cayuga had a position not unlike that of Chicago, and it expected that the construction of railroads and of the canal to Sodus Bay in Lake Ontario, would make it the important center for central New York and Pennsylvania. But the hilly country immediately to the south deterred the railroad builders and they later surveyed easier routes and laid their tracks to make connection with Rochester and Buffalo. 
advanced by half, and four-story business buildings were put up as fast as laborers could be secured.' By I827 there were sixteen textile factories in Oneida County giving work to seven hundred hands; ${ }^{2}$ in five more years there were twenty cotton mills alone, with three times as many employees, ${ }^{3}$ and though Utica itself contained but few, "every stream from the neighboring hills was covered with such speculations." + Rensselaer and Dutchess Counties were not far behind. Iuburm might have seemed like Goldsmith's loveliest village of the plain, observed an English traveller in I 828. " but for its numerous manufacturing establishments." " The Genesee at Rochester ran spinningmules and power-looms, as well as flour mills." Industrial statistics do not fascinate the general reader, but when in scanning the long columns of the census figures, one notices that while the total ouptut of the state was more than doubling in the decade after 1825 , the per capita production of textiles in the households fell from 8.95 yards to 4.03 . he has come upon a fact of some significance. ${ }^{\text {? }}$

${ }^{1}$ Albany Daily Adzertiser. Sept. I. 1826; Albany Aryus. Sept. 9. I2. 1826.

${ }^{2}$ From a table in a Utica paper noticed in the Rochester Telegraph and quoted in Argus, July 4, 1827,600 of these hands were children.

${ }^{3}$ In Oneida, 2,354 were employed; Dutchess. I.974; Rensselaer, I,621 ; Columbia, 1,285. Dutchess had also 6 woolen mills, Orange 6 and Rensselaer 5. T. F. Gordon, Gazetteer of the State of New York (Philadelphia, 1836), pp. 334, et seq. See also C. Benton and S. F. Barry, Statistical View of the Hoolen Manufactures (Cambridge. 1831 ), p. 12.4 .

'E. T. Coke, A Subaltern's Furlough (N. Y. edition, I833), vol. i, p. 215 .

5James Stuart, Three Hears in North America, vol, i, p. 8I.

-Ibid., loc. cit.; also Basil Hall, Trazels in North America. vol. i. p. 53 .

${ }^{7}$ R. M. Tryon, Household Wanufactures in the United States (Chicago, 1917), pp. 304-307. The decline in household manufactures was naturally most sudden in Oneilla County, where the figures ran 
Iron manufactories-bloomeries, blast furnaces, and mills for nails and hoops-so grew in number that soon after $183^{\circ}$ about ten thousand people were dependent on their operation. ${ }^{1}$ In 1827 there was opened in the city of New York the first hardware store dealing mainly in . Imerican goods." After 1825 , it was seen that " fossil coal " would soon conle into common use, making possible new processes and increased production. while charcoal-burners working in the wexdland, one by one allowed their pits to col and whiten. and in disgust sought out some other means of livelihood. ${ }^{3}$ Fertile land so cheap and so accessible in New York necessitated higher wages than in many other states, and these in turn gave stimulus to the invention of machinery." In the

from 12.65 yards to 4.83 . Other counties where the change was rapid were Schenectady, Columbia, Orange. Washington and Ontario. Statistics for I 820 are also given by Tryon, p. 288.

1 T. F. Gordon, Gazetter. The iron workers in the decarie after 1825. doubled in number, increasing especially in Essex County. At the same time capital was withdrawn from old-fashioned industries like asheries (due to easier transportation of the lumber itself by canal), distilleries. grist and oil mills.

$2 \mathrm{~J}$. L. Bishop, History of American Hanufactures (Philadelphia. 1864), vol. ii, p. 387 , note.

${ }^{3}$ F. J. Grund. The Alitericans, p. 284. quotes a Pennsyluania state senate report of March 4. 1835: 9.541 tons were used in 1824: 33.6009 in 1825 . This sudden increase was due to the opening of the Schuylkill mines: another sudden increase came in 1828 when the Lackawanna mines were made available. Anthracite was first used in the iron industry itself in 1838 , C. Wright, Industrial Evolution of the United States (Meadville, Pa., I897), chaps. x, xi.

'In Massachusetts and New Hampshire, only, were wages higher. Fishing and shipping doubtless had an effect similar to the Genesee lands in New York; also the greater development of manufacturing marle a greater demand for labor. In New York the average wage was $\$ 1$ per day. Timothy Pitkin, Statistical l'iene of the Commerce of the United Siaies of America (Hartford, 1835 edition): see charts in textile industry. See also F. J. Grund, The Americans, p. 274: Bishon's lists of patents for I\$30, cited in J. R. H. Moore, Industrial History of the American Peoplc (N. Y.. 19I3), p. 415. 
last years of the twenties it was realized that industry was changing; in the closely settled districts spinning-wheels and cottage looms were carried to the garrets, and apprentices and journeymen gave reluctant place to " hands". "

In the constitutional convention the chancellor, J. R. Van Rensselaer and Van Ness. had spoken their opinion of the manufacturer as a menace to the established order of the state, not as safely to be trusted with political influence as the merchant and the landlord. He could not then be counted on as an ally of Federalists. He was not as yet the personage that he became a generation later. He was not as yet a gentleman distinguished by inherited wealth, family portraits and a liberal education. but was still a glorified mechanic, merely, who had worked up from the bench. The prominent manufacturers like Benjamin Knower, who made hats in Albany, Peter Sharpe, the whip-maker, and Clarkson Crolius, the potter, were then thorough-going Democrats. ${ }^{2}$ Fedleralists, it would appear, were not yet interested in the enginery of mills. But in the middle 'twenties. when industrial profits became the subject of the gossip of the court-house and the banking office, their attitude was changed, and such old partisans as J. R. Van Rensselaer. Ambrose Spencer. Kobert Troup. Platt. Gold and Philip Hone, began to take a part in the movement for " domestic industry." "and George Tibbits wrote an Essay' on the Home Markets, charged with high enthusiasm. ${ }^{+}$

1 As late as 1815 upon satisfactorily completing anprenticeship, a young man without property might be received as a ireeman of the city of New York. N. Y. Historical Socicty Collections. 1885, p. 399. cited ly R. F. Seyboldt, The Colonial (itizen of liwe lork City (Univ. of Wisconsin, 1918).

Albany Argus, Jan. 25. 18z5; 1. 1. North, Ruidom Recolloctions "f Albany. p. 52 .

3.1rgus. April y. 1824 .

* Essay on the Expediency and Practicability, of Improsing or 



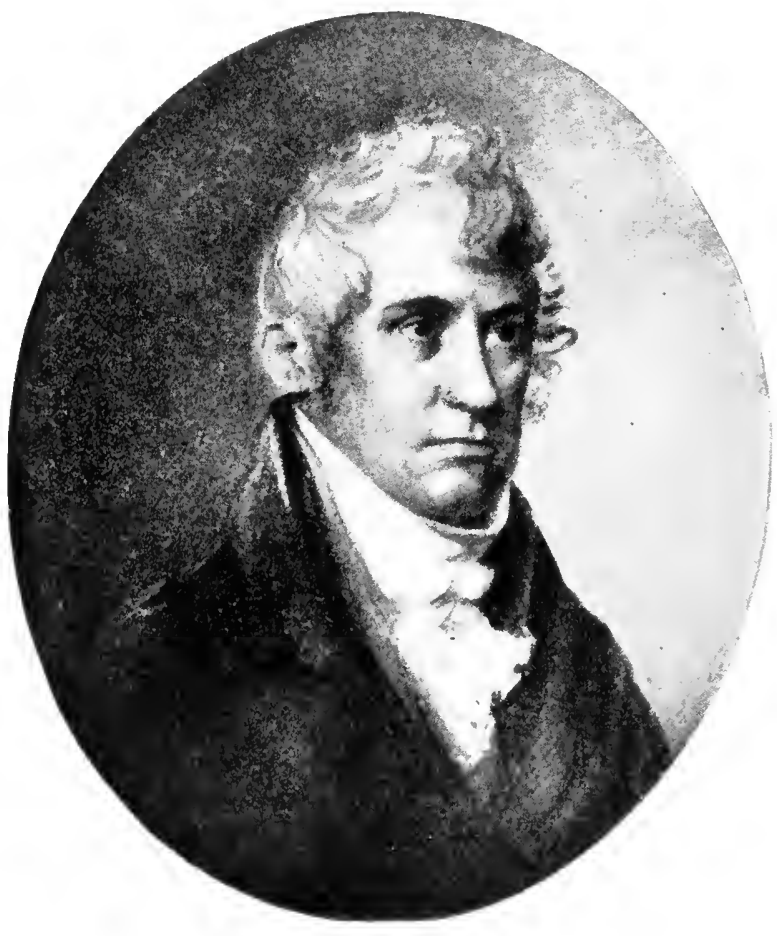

y

STEPHEN VAN RENSSELAER 
The sentiment was soon reflected in the press. In April, 1825, William O. Niles published a prospectus of a paper to be known as the Albany Journal and Mercantile Advertiser, and to have for its concern "the encouragement of Commerce, Domestic Industry and Internal Improvement." while at Saugerties some three years later there appeared the Ulster Palladium and Manufacturer's Journal devoted to the news about canals, machinery, railways and the tariff." The Patroon, catching the new spirit, determined to devote a portion of his hundred-thousand-dollar income ${ }^{3}$ to the founding and endowment of a Rensselaer School in Troy to instruct young persons in the "application of Science to the common purposes of life," an enterprise begun in I825." Others urged that New York follow Massachusetts in working out a system of public instruction in the uses of machinery." It was, then, the decade after 1825 , that saw the rise of manufactures, as well as the great development of commerce: ${ }^{5}$ and it was in this decade, we shall see, that the old conservatives, supplemented by some others, reorganized their party and took on the name of Whig.

Creating Home Markcts for the Sale of Ayricultural Production and Raw Materials, by the Introduction or Grozoth of .1rtizans and .Hannfactures, etc. (Philadelphia, 1829), in Library of Congress.

' Argits, April 29. 1825.

${ }^{2}$ Vol. i, no. I (May 3. 1828), is in the library of the N. Y. Historical Society.

" "Lette.s of a Traveller" to National Intclligencer, letter of Junc 36, 1825 ; T. F. Gordon, Ganettecr of New York, p. 651 .

"See "constitution" of the institute in the Albany . Aryus, Ipril 29. 1825.

'See Livingston Journal, quoted in Argus, April s. 1N25. commenting on the commission recently appointed $\mathrm{Ly}$ the Massachusetts legislature.

'The commercial progress of New York was continuous in this decade, though elsewhere there was a depression till after i $\varangle_{30}$ : sec Emory Johnson and others, History of the Foreign and Donestic Commerce of the United States (Carnegie Institution, Washington, Igi5), vol. i, p. 220. 
While this interest was deepening among the men of wealth and business enterprise. the legislature, where the Democrats were generally controlling, gradually withdrew its patronage. in spite of all appeals. There had been at first a hearty disposition toward encouragement. In January, I8I 7 , eight essays signed by ".In American " appeared in the Commercial Advertiscr, proving that the manufactures of the state deserved subventions from the government at Albany, and the following month an act was passed exempting textile mills from all taxation and their employees from certain jury and militia service. ${ }^{1}$ By 1823 this law had met with some objection from supporters of the Regency. ${ }^{2}$ and their senators in 182.4 put through a bill providing for repeal, though the People's Nen, who then had a majority in the assembly, refused their sanction. ${ }^{3}$ But the following winter, despite the opposition of John C. Spencer and his colleagues, the act was passed learing woolen manufactures only as exempted from taxation." Even in a few short

'Passed leb. 28, 1827: Laws of the State of Iea York, foth session. chap. 44. There had been a temporary law passed June 19, 1812, for the encouragement of woolen manufacture. many sections of which were revived in an act passed April 15, 1817, ibid., chap. 240. A law appropriating $\$ 10,000$ for the encouragement of household manufactures was passed in I819. ibid.. fand session, chap. 10\%. On the American Society for the Encouragement of Domestic Manufacture, see Thomas Jefferson to Dominick Lynch, Jr.. Monticello, June 26, 17. Corres pondence of Thomas Jefferson, 1778-1826 (Boston, 1916), p. 230.

'Remarks of Mr. Auger in the assembly, I: Y'. American, March 4. 1823. A new tax law made no mention of the exemptions (Lazes 46 th session, chap. 262 ), and during 1823 and 1824 there was a difference of opinion as to whether they were sill operative: see . V. $Y$. Senate Journal, 1824, pp. 87-89, 121.

"The bill passed the senate, Fel. 17. 1824. ibid., 1. 129: see remarks of Mr. MeIntyre, Albany Argus, March 4. 1825 . It is interesting to note that five of the seven opponents of the bill were People's Men.

Argus, Feb. 15, 25. March 1, 1825. In the course of the debate. Mr. McIntyre. a People's Man of Montgomery County, spoke in favor of 
years, it seems, the Democrats had come to realize that factories, like banks and docks, were not to be their citadels of strength.

Protection of American manufactures, for which there had been no considerable demand in the early days of the republic, was practically afforded on the most extensive scale by the restrictive laws that marked the eight years after $1807 .^{1}$ When the signing of the Peace of Ghent had cleared the seas for commerce, the manufacturers prayed for artificial aid to keep their factories rumning: and the farmers. especially in the fertile western counties of New York, who found themselves unable to supply the English market by reason of the corn laws, joined in the demand for high protective duties on manufactured goods. This seemed to them a measure of retaliation against England. and possibly a means to build up large industrial communities at home where their food-stuffs would be needed. ${ }^{2}$ Their flocks. which grew in number year by year and gained in value with improvements from Merino crossings, gave them so direct an interest in the progress of the woolen mannfacture, that they cordially supported the tariff of 1824 . Fur a short time they were apprehensive lest the demand for factory hands should raise the wages of farm labor, hut were soon assured that the mills would hire chiefly girls, and

continuing the exemptions, showing the famer's need of a home market in manufacturing towns, especially for his fine Merino wool: see ibid.. March 4, I825. Mr. Vanderheuval, of St. Lawrence also made a vigorous protest ; $N$. Y. American, Jan. 17, 1825. In many districts the manufacturing was still chiefly in the households.

I Of course, the principle was familiar in the eighteenth century, but except for Hamilton's report, "other subjects so absorbed the attention of public men that no distinct opinion appear in their utterance for or against protective duties," F. W. Taussig. The Tariff History of the United States (N. Y., I9I4 edition), pp. II-I7.

"V. S. Clark, History of Manufactures in the United States (Washington, I9I6), pp. 268-279. 
326 ARISTOCRACY IN THE POLITICS OF NEIV YORK

thus instead of vying with the farmer would afford employment to his daughters. Immigration and the farm machinery coming into general use also helped prevent antagonism between the wool-growers and the manufacturers until the eighteen-fifties. ${ }^{1}$ Iet the small farmer who had no such close connection with industries and cities listened more respectfully to true Democratic doctrine on the tariff. As to what this doctrine was and how it was developed we must now inquire.

${ }^{1}$ Clark, p. 270. See also E. Stanwood, American Tariff Controcersies in the Nineteenth Century (Boston, 190.3): O. L. Elliott, The Tariff Controversy in the United States (Palo Alto, Cal., 1802); Stephen Van Rensselaer to Van Buren, May 14, 1824, Van Buren Mss,, and Silas Wright to Van Buren, vol, vii, pp. of-go, ibid. 


\section{Political Distraction}

IN I 824 but little opposition to protection had developed among the New York Democrats: objection to such measures on the ground of legal right as well as of expediency. found expression only in an unimportant group of thoroughgoing Jeffersonians.' While England preached the principles of Arlan Smith but kept up tariff walls, the leaders readily admitted that America should give no heed." Indeed it was the American. Federalist in all but willingness to work with Clinton, which most bitterly opposed the tariff, for, it said, the patronage now held out to the manufacturer would be withdrawn from commerce. Higher prices would be paid by farmers, making up the great majority of the consumers, to pay profits to mill-owners, whose evident prosperity, increasing with each year, required no sacrifice from trade or agriculture." If farmers "have occasion to purchase anything of foreign growth or manufacture, and are able to pay for it, they can be quite independent whether the articles are manufactured in Old or New England, or elsewhere." + Protective tariff laws would stir resentment against the section where the manufacturing was carried on, and jeopardize the Union: even in that section they

'Remarks of Mr. Mallory in the N. Y. Senate, Araus. Feh. 2\%, 1824.

"National Intelligencer, quoted with approval by the Argus, Selt. 12, I823; $N$. Y. Amcrican, Feb. 23, I824.

${ }^{3}$ N. Y. American, Jan. 27, 1823.

"Ibid., Jan. 3r, I\$24 
would cause complaint against those who would seem to be the special beneficiaries. ${ }^{1}$ Protective schedules on this article and that would be included quite against the public interest, by the vicious practice of " $\log$ rolling." " Handicraftsmen would be out-competed by the great protected mills, which would draw their labor from the foreign rabble. cheap men devoid of skill, now flocking to our ports." " In grood time." lamented "A Consumer," " we shall become a nation of machines and machinery-a Chinese community. a manufacturing nation, nobly and exclusively aspiring to rival Brummagem and Sheffield in the manufacture of pepper boxes and crown glass." 4

Not all correspondents echoed the American's opinion: " J Jamilton," to name but one, contributed a letter to show that moneyed men properly desired home industries in which their capital could be advantageously applied, while fathers welcomed steady employment for their sons, a condition which encouraged marriage." But the editors went un writing free-trade argument about prerducing where production was the cheapest without regard to arbitrary lines upon a map: no one could persuade them, they declared, that "the vast ucean which rolls almost before our eyes was meant not for a highway, but for an impassible boundary to the intercourse of nations." " They indicated Mr.

1. Y. American, Feb. 18, 1823; Feb. 17, 23. 1824.

2 Ibid., Feb. 17,1824 . This is the first instance 1 have seen of the use of the expression "log-rolling." It is used again in this paper. November 31,1825 .

Ibid., March 5. 6 1824.

"Ibid., Feb. 21, 1824. " Brummagen" was, of course, the derisive epithet for Birmingham.

${ }^{5}$ Ibid., Feb. 22, 1823. He wrote also of the need for a balance of trade in America's favor, rather than the extravagant importations of 1822.

"Ibid., Feb. 25, 1823; March 4. 1824. 
Webster, who then in Washington preached the doctrine of low tariff, as their ideal of statesmanship. ${ }^{1}$ and cordially supported Gulian C. Verplanck, who strove in the assembly to control more strictly the incorporation of manufacturing companies." The Eicning Post, then still reckoned as a Federalist paper, joined in the complaint that "nearly seventy persons concerned in manufacturing establishments had been elected to the present Congress." where they had carried through "an anti-commercial and mischievous bill." : Federal votes assisted to elect three anti-tariff Congressmen in November. I 824 ; it was clear that the shipping element within the conservative party in the state was prejudiced at first against the manufacturers.

But there were several reasons why the New Yorth merchants could not comfortably hold this attitude. In the first place, their fellow-partisans within the upper Hudson and the Wohawk valleys found the new investments very profitable, as we have seen: by 1828 the Argus was complaining that the Albany central committee formed by tariff men was but a "Clintonian-Federal caucus," since out of twenty-five. but three were genuine Democrats." Their New England colleagues, also, soon decided that commerce, important as it was, could not wisely check the growth of industry: Daniel Webster in the vote of I 827 signalized this change of sentiment. The western farmers, with whom the city merchants had co-operated under Clinton, likewise wished a tariff. The Nea' lork Society for the Promotion of the irts and liamfactures declared its object was to give " re-

${ }^{1}$ N. Y. Americun, Jan. I, May I, 3, 1826.

'Ibid.. Feb. 23. 1824; Argus, March 12, I824.

'X. Y. American, Oct. 29. I824: see also Vational Adiocate. Nor. I. 1824.

'N. I. Evening Post. Nov. 6. 1824 .

- March 17, 20, 25, 27, 1828 . 
lief to the agricultural interests of the state, by encouraging the growth, introduction and stationary residence within it. of a manufacturing population adequate to the consumption of its agricultural produce and to the fabrication of its raw materials." "The staple farmers of the west who were near enough to the canal to market their surplus, it seemed, might seek to swing their party to support protection.

Then, ton, the New York merchants were pledged to Adams and his Secretary, Clay, who favored cheapening the inland transportation. But the administration more and more accepted the protective tariff as the leading feature if a broad program."

While the planter and the merchant and the shepherd and the husbandmen [averred the President] shall be found thriving in their occupations under the duties imposed for the protection of domestic manufactures, they will not repine at the prosperity shared with themselves by their fellow-citizens of the professions or denounce as violations of the Constitution the deliberative acts of Congress to shield from the wrongs of foreign laws the native industry of the Union. ${ }^{3}$

The historians of American ideals have given less attention than they should to the enthusiasm for material prosperity which characterized the devotees of the American system, not only in the times of Clay and Webster, but likewise in the later years when a new Republican party exalted the full dinner-pail." "An ideal," remarks a recent

1 Argus, April 9, I\&24; see also letter from a Mr. Tol, of Greenfiell. Saratoga Co., in N. Y. American, Feb. 22, I82;.

${ }^{2} \mathrm{Cf}$. comments of the Troy Sentincl and Vorthern Budgct, quoted in Argus, June II, July 9. I 82.4 .

${ }^{3}$ J. D. Richardson. Messages and Papers of the Presidents, vol. ii, pp. 4I3. 4I4.

E. D. Adams, The loaer of Ideals in American History ( New Haven, I9I3) : A. B. Hart, National ldeals Historically Traced (N. Y., $1907)$. 
writer. "is an emotionally colored conception of a state of things which would be better than the present." " Now the merchants of the great metropolis, as we have tried to show, belonged to the dynamic party with the program of development by intelligent extension of the sphere of government. If the tariff was a necessary item of this program, they must take it. They also, very likely, calculated on a benefit; if manufactures made the country rich, as had been claimed, there would be a brisk demand for unprotected articles imported from abroad. Whatever was their course of reasoning, the merchant wards in New Yurk city in the election of 1828 cast their votes for Adams although he was a tariff man. ${ }^{2}$

That a considerable portion of the capitalist party should seem willing that the tariff should be made a campaign issue. was a matter of some interest to the Regency. They became ingeniously evasive, and were accused of "non-committalism " by their adversaries." They replied that the question of domestic industry and its protection had no connection with party politics, and their newspapers reported the many tariff meetings without comment. ${ }^{4}$ They deprecated all attempts of Adams men to claim the measure as their own. When the Harrisburg Convention was announced. Marcy. who for some time was an advocate, warned the delegates through the columns of his Budget to "keep aloof from all party considerations; let them attend solely to the object for which the convention is called." 6

But this was ignorant advice, since Clay had planned the

${ }^{1}$ C. D. Burns, Greek Ideals (London, I917), pp. v-vi.

${ }^{2} N, Y$. Commercial Advertiser. Jan. I, I828. On the straiglit tariff vote of 1828 the New York congressmen voted against; see F. J. Turner, Rise of the New West (N. Y., 1906), pp. 242, 320.

: Albany Daily Advertiser. June 27, 1827

'Argus, June 23, 30. July 4, 21, 1827.

Ibid., July 16, 1827.

'Ibid., July 17. Nor. 29. I827. 
meeting as a nucleus of a reorganized, revitalized American party, and he and other leaders were quite willing that protection should become the leading question of political debate.' Van Buren avoided reference to the tariff when he could. but was known to be against protecting manufactures." Wright, Flagg and Hoffman favored tariffs for the farmer, if at all, while Marcy found his views so moderate that he opposed the high-protectionists." The Democrats in the assembly resolved that the wonlens bill of 1827 was too favorable to mill-owners. " Some manufacturers within the Democratic party, like Penjamin Knower, indignantly protested against this attitude and stanchly fought each proposition to investigate inclustrial profits, but they were impotent to change the party policy: "Peter R. Livingston left the party largely on this issue."

${ }^{1} \mathrm{~F}$. W. Taussig, Tariff IIistory, p. 85. The V. Y. Escuing Post. now Democratic, on Aug. I and 9, 1827 , charged that the convention was a political measure, though it admitted on Aug. II, that many who went were unaware of it. Clay's intentions are set forth in a letter to B. W. Crowninshield, March 18. 1827; see Quarterly Journal of Economics, July, 1888, pp. 490-49I. When the convention's proposals were introduced in Congress, there were $7 \&$ Alams men and 12 Jackson men for, and I4 Adams men and 100 Jackson men opposed, Niles Register, vol. xxxv, p. 57 (quoted by Taussig). Clay's first important speech in the campaign dealt largely with the tariff (C. Colton, life and Horks of Henry Clay (N. Y.. Igo4). vol. i, pp. xiv-xvii), though the "bargain and corruption" charges subsequently played a large part.

"Gabriel Mead to Van Buren, Feb. 13, 1827. Van Buren Mss.; George Bancroft, Martin I'an Buren, ก. 146.

${ }^{3}$ J. D. Hammond. Life of Silas Wright, pp. 105-108; Wright said able men could sustain themselves, but some manufacturers who had made mistakes "want Uincle Sam to help them out," Wright to Flagg. Jau. 16. 1828; Hoffman to Flagg. Feh. 3, 1828, Flagg .11ss.

4 Argus, Feb. 1, 1828.

Knower, Dudley and Olcott signed a circular letter calling for a tariff on the Harrisburg lines; for this controversy see Flagg to Wright, Jan. 10, 22, I828 and Wright to Flagg, Jan. 16, 28, I828, B. Knower to M. Van Buren, Jan. 27, I828, Van Buren Mss.

- Hoffman to Flagg, Feb. 3. 1828, ibid.. J. D. Hammond, Political History, vol. ii. p. 323-324. 
When a protectionist convention at Albany, in 1827 , declared it could not "but regret the zeal with which a portion of our southern brethren oppose a protection to other essential interests embracing vastly greater territory and population," 1 it touched the Democratic leaders where they were most sensitive. In March, the legislature of Virginia had called the tariff laws, "unconstitntional, unwise, unjust, unequal and oppressive." " and if the New York Democrats would hold their fellowship with the Virginians, it was clear that they must be an anti-tariff party. Yet the protective principle was so wiclely cherished throngh the north, that no pulitician from that section would essay a definite and open opposition on the floor of Congress. To meet the situation, the reader will remember, a hodge-podge of absurdities was carefully contrived upon a plan which Clay declared originated in Van Buren's fecund brain," and by which what seemed to be a measure of protection would have to be rejected by the votes of real protectionists, with no stigma fastened to the friends of Jackson.

Silas Wright, then a member of the House committee on manufactures, explained the trick to southern representatives. ${ }^{4}$ To win support (for to achieve success it must get votes from all except the honest friends of the American System) he called it an agricultural tariff. and declared, "The struggle is, no doubt, to be between the farmer and the manufacturer." But the manufacturers, who perceived

1 Argus, July 18, 1827 .

"Niles Register, vol. xxxii, pp. 16;-170.

'Clay's Works, vol. ii, p. 13.

'F. W. Taussig, Tariff History. p. 96, and his authorities.

5Wright to Flagg, March 21, 1828. On Van Buren's request Wright prepared quotations on the tariff from Washington, John Adams, Jefferson, Madison, etc., and an estimate of the condition of the wool trade in New York state. He estimated that there were 30 or 40 woolen factories employing $\$ 30,000$ or $\$ 40,000$ and between 15,000 and 


\section{4}

the springs within the trap, decided to accept the bill, although its schedules were ill-balanced and embarrassingly high, so that the principle of a protective tariff might be saved. The law was passed, to the disgust of its ingenious architects. From widely different causes, then, the support from New York state was unanimous, except for New York city and some counties on the lower Hudson. ${ }^{1}$ From that time forth the Democratic leaders threw off all pretence of protectionism.

But the slowly formulating sentiment upon the tariff was not the sole consideration of the Regency and their opponents. There were other factors which delayed a straight and strict alignment of two parties in the state-a rivalry of sections for grants of public money, a strange fanatical enthusiasm, and a personal loyalty - each of which must briefly be reviewed.

In i 800 , a correspondent writing Clinton on the prospects of a state canal, said that he had been informed of "an attempt to embarrass that project by a petition which originated in Kingston for a turnpike," and deplored "that contemptible locality of calculation" which cursed the plans of wise and able statesmen." When the subject was lebated in the legislature, "those opposing were the southern and middle counties, including Delaware.": Yet as the work proceeded to completion and success. "pposition in those sections which would not he served, changed into a

20,000 hands. He said there were probably $5,000,000$ sheep in the state. making about 30,000 men directly interested in selling wool. See Van Buren Mss., vol. vii, pp. $96-97$.

${ }^{1}$ F. J. Turner, Rise of the New West, p. 242 (map).

${ }^{2}$ From H. N. Butler, March 12, 1809. Clinton Mss.

${ }^{3}$ George Tibbits to Benjamin Tibbits, June 13, 1828, in D. Hosack, Memoir of Clinton. Appendix, pp. 488, et sey. Tibbits mentions opposition also from the eastern parts of Rensselaer and Washington Counties, with parts of others. 
strong desire for some similar accommodation. The achievements of Macadam in the north of England had aroused considerable attention in this country, ${ }^{1}$ and with promptings from the southern counties. Governor Clinton in his message of i 825 recommended the construction of a great state road to join the lower Hudson with Lake Erie. Opposition was immediately forthcoming. In the valleys traversed by the Erie and Champlain Canals the residents were satisfied with what the state had done and disliked to pay their share of taxes to build a turupike through the "southern tier": if Clinton had engaged to get the votes of the canal men for a road, as was alleged, ${ }^{2}$ he could not keep his bargain. However, a commission of inquiry was provided and a tentative survey begun." Mass-meetings and conventions. labored essays and long editorials, attested public interest in the southern counties: ${ }^{+}$but when the commissioners reported in 1826 , the northern members of the legislature were all the more confirmed in opposition."

Partisan connections seemed forgotten in this all-absorbing contest. While Gamaliel Barstow, a People's Man from Tioga County, and General Root, whose home lay on the line surveyed, were leading advocates, ${ }^{6}$ Francis Cran-

'Albany Argus, Sept. 4, I826.

${ }^{2}$ C. E. MacGill, History of Transportation in the United States to 1860 (Washington, 1917), p. 163.

"Hammond, who was one of the three commissioners, gives a full account of the matter in his Political History, vol. ii, pp. 201, 209. 219 $225,233,235,245$.

4Albany Argus, March I, June 16, July 15. 1825: May 29. June 2, 21. Aug. 30, Sept. 4. 1826; Albany Daily Adzertiser, May 26, I826.

${ }^{5}$ The charge that the canal party had managed that the survey be run through difficult and impracticable country, where the road would be of little service, which is accepted as true by Miss MacGill, loc. cit., seems to rest on slight evidence: $c f$. Hammond's account.

'Albany Daily Aderiser. Jan. 31. Feb. I. I827: Albany Argus. Jan. $2 \mathrm{C}, 1827$. 
ger, an Adams-Clinton member of assembly from Ontario County, and Colonel Young were the severest critics of the measure. Granger favored lateral canals which would connect not only the central lakes, but the Susquehanna, the Chenango, the Chemung, and even the Alleghany rivers, with the great trunk waterway from Buffalo to the Hudson. Road transportation, he maintained, was too expensive.' Colonel Young addressing the Phi Beta Kappa Society of Lnion College, conld feel no sympathy for southern tarmers; if their holdings were sequestered, they had probably been purchased at a price appropriately low: if values wuld be raised by such development, let private enterprise assume the risk. "Works of labor." asseverated this ex-commissioner of canals, "and the accumulation of wealth appertain to individuals, and not to governments. A government might manage a farm, a manufactory, or a mercantile concern : but it would always be a losing business." " The southern members naturally accused him of some prejudice in his political economy, and were not convinced. In I 826 they voted for Clinton, who had espoused their cause, and the Democratic candidate for lieutenant governor, Nathaniel Pitcher, who had pleased them as a road commissioner: their support, as we have seen, made possible success for both.

Each party tried to claim the project of the road, as well as those of the canals that were to lead to Pennsylvania. or to connect the St. Lawrence with the Nohawk or, across the north, with Lake Champlain." They searched for ideal

\footnotetext{
'Speech in the assembly, Adiertiser, Feb. I2, I827.

'Samuel Young. Discourse, delivered at Schenectady. July 25, 1826. before the Nei York Alpha of the Phi Beta Kappa (Ballston Spa, 1826).

3 Advertiser, May 26, 1826 , and Argus, May 29, 1826; Wright to Flagg. Nov. I9, 1826, Flagg Mss.; N. E. Whitford. History of the Canal System of Vea York. vol. i, pl. 610, 741. 742.
} 
candidates who might be thought exclusively in favor of each local scheme, and who could, as the phrase went, ride all the hobbies.' But the state road did not perplex the party managers for long, as in April, 1827 , the measure was defeated." Judge Hammond, counting over the sixtyfour opposing votes in the assembly, found that fifty-five were cast by representatives of districts bordering on the great canals." The southern counties were obliged to wait some years till with the building of the Erie Railroad they gained access to the markets of the world. ${ }^{+}$

But this distraction was as nothing in comparison with one which soon succeeded it.

On the IIth of September [runs a letter To the Public, printed by a citizens' committee of Bataria. in the autumn of 1826 ] Willian Morgan, a native of Virginia, who had for about three years past resided in this village, was, under pretext of a Justice's Warrant, hurried from his home and family, and carried to Canandaigua. The same night he was examined on a charge of Petit Larceny, and discharged by the Justice. One of the persons who took him away immediately obtained a warrant against him in a civil stit for an alleged debt of two dollars, on which he was committed to the jail of Ontario County. On the night of the I2th of September he was released by a person pretending to be his friend, but directly in front of the Jail, notwithstanding his cries of Murder, he was

${ }^{1}$ Governor Clinton is accused by Hammond of recommending in his message more improvements than could possibly be accomplisher, so as to please all sections, Political History, vol. ii, p. 2.t. See Michael Hoffman to Flagg, July 30, I828, where there are indecorous jests about "the all-yielding Lady Granger."

${ }^{2}$ Albany Argus, Feb. 15, April 7, 8, 1827.

${ }^{8}$ Political History, vol. ii, p. 245.

4 Miss MacGill in stating that DeWitt Clinton presented a report in favor of the railroad in 1832 (p. 595), like many others, confuses the governor with DeWitt Clinton. Jr. 


\section{ARISTOCRACY IN THE POLITICS OF NEW YORK}

gagged and secured and put into a carriage, and after travelling all night he was left (as the driver of the carriage says) at

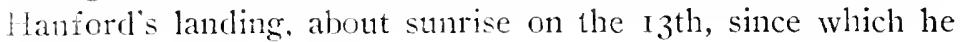
has not been heard from.'

This paragraph with its nightnare thrills, sounding like an extract from a penny-dreadiul, describes an incident which changed the politics of half a dozen states.

While the atthorities were searching for a motive for the crime, a rumor was recalled by neighbors in Batavia, that Captain Morgan had been abrut to issue from the press a bok revealing the Míasonic secrets. On the strength of this suspicion, writes a witness, some

implicated the whole masonic fraternity. This, however, was 110 at first the general public sentinent, but when, as the inrestigation proceeded, it was found that all those implicated in the transaction were masons: that with scarce an exception, 110 mason aided in the investigation; that the whole crime was marle a mater of ridicule by the masons, and even justified by them openly and publicly: that the power of the laws was defied by them, and committees taunted with their inability to loring the criminals to punisiment before tribunals, whose judges, sheriffs, jurors and witnesses were masons; that witnesses were mysteriously spirited away, and the committee themselves personally vilified and abused for acts which deserved commendation, the impression spread and seized a strong hold upon the popular judgment, that the masonic fraternity was in fact responsible for this crime.

I'This broadside, dated Oct. 4.1826 , is mounted with the Clinton Clippings, vol. iii. It seems particularly inappropriate that this should have taken place in "Sweet Canandaigua," remarked by all travelers for its tranquil loveliness; see Francis Lieber, Letters to a Gentleman in Germany (Philadelphia, 1834), p. 264, James Stuart, Three I'ears in North America, vol. i, p. 291, Basil Hall, Travels in North America, vol. i, pp. 42-43, 152, etc.

${ }^{2}$ I. D. Hammond, Political History', vol. ii, p. 373. The author having 
A conviction thus arrived at that the Masons ielt a livelier concern as to the fortunes of their order than as to the common safety of society, a movement toward political proscription made its way throughout the west. The reputation of this great fraternity in the Continental countries as a force opposed to true religion was remembered in America; the year before in Illinois a Baptist minister had been driven from the church because he held to Masonry. ${ }^{1}$ The Nasons seemed to take too prominent a part in public matters. It was estimated that most office-holders were members of the local lodges; they assumed the right to lay all corner-stones; ${ }^{2}$ a few years since at a convention of the order in Albany, the capitol building was reserved for their exclusive use, and none but Masons were allowed to enter. ${ }^{3}$ On that occasion the governor, with great solemnity, resigned the dignities of his grand-mastership to the greatest landlord in the state; power joined to mystery was dangerous.

Why were these tylers, sentinels and masters of the veil?

little immediate personal knowledge of this movement, secured a friend who had lived through it to contribute this chapter to his history. Ten chapters of Thurlow Weed's .4utobiography form the most circumstantial general account of the early history of the Anti-Masons, though it is colored by the writer's desire to present himself as consistent in his leadership in this cause from 1826 to 1834 . Hammond's informant says: "It is impossible, too, to say whether these movements were first commenced by opponents of freemasonry to put down the institution, or by the free masons to put down the committee," vol. ii, p. 378 .

1 Albany Argus, July 8, i825. Perhaps the New England communities in New York and elsewhere remembered the suspicion of secret societies which had developed in the Illuminati controversy in Massachusetts in the I79o's; $c f$. Vernon Stauffer, New England and the Bavarian Illuminati (Columbia University Studies in History, itc. 1918).

${ }^{2}$ Rochester Telegraph quoted in Argus, July 8, 1825.

'Handbill in Clinton's Clippings, vol. iii, p. 68, and Albany Gazctte, Oct. 4,1825 . 
What dire secrets could not bear the light of day? There were tales of high priests in their sacerdotal splendor, kings in velvet. "royal " officers of one name and another. Did not these things smack too much of monarchy? Such men could not be trusted with the people's liberties: they should be voted out of office. In many towns throughout the western counties in the spring of $I_{2} 7$ committees were appointed to conduct the agitation; and tickets from which Wasons were carefully excluded gained considerable success in spite of the desperate efforts of the order.

Missionaries took the "blessed spirit" into other sections of the state, and into parts of Massachusetts, Rhode Island and Connecticut, all through Vermont, into southern New Jersey, western Pennsylvania and northeastern Ohio; everywhere that the New England conscience was present to receive it, anti-Masonry became a power. ${ }^{1}$ For it was an idealistic movement, often taking up with revivalist religion, anti-slavery, temperance, nativism and other similar cnthusiasms, and spreading its strange gospel by means of lecturing and preaching, and tons of tracts and papers. Hysteria is not a lovely thing to contemplate, yet the historian who follows this infatuation knows not whether to be saddened or amused. "It is almost impossible," remarks a modern writer, "to believe that the actors in that curious extravaganza were our fathers, sober, earnest, Godfearing men." 2

Masons in the western counties, hopeless of elective office by the suffrages of neighbors, cried out in distress to Albany to be furnished with appointments by the Regency that they

${ }^{1}$ Charles MicCartly, "The Antimasonic Party," American Historical Association Report, 1902, vol. ii, pp. 365-574, is a thorough monographic study of this movement in its political aspect.

'A. W. Tourgee, Letters to a King (X. Y. and Cincinnati, I883), letter ix, p. IIS. 
be not lost beneath the overwhelning wave. ${ }^{1}$ A man in Rochester wrote Major Flagg: "In your part of the state the Inti-Masonic projects may appear chimerical-they are not thought so here." 2 But the Plattsburgh editor was soon receiving papers in exchange that showed how formidable was the invasion even in his section: the Republican, which worried Marcy in the town of Troy; the Herald, at Potsdam, where New-Englanders showed eager interest, and the Anti-Masonic Champion of Sandy Hill." Yet it was, of course, within the "infected district" in the west where this influence was strongest. Here delegates from several counties were convened in 1 \$27, nominations made, and fifteen men elected to the assembly. ${ }^{4}$

At first both parties shared in consternation, but circumstances soon combined to identify the Anti-Masons with the Adams men. The agitation started in a district where the President was popular, and naturally the majority of the new enthusiasts had been his followers: other Adams leaders through the state, hard-driven by the Regency, welcomed any aid however unexpected. When Francis Granger carried through a resolution in the legislature to inves-

${ }^{1} \mathrm{~S}$. Starkweather to Flagg. Dec. 27, I 827 . Flagg Mss. (Misc. Papers),

${ }^{2}$ Ebenezer Griffin to Flagg, July 30, I828, ibid.

3 J. H. French, Gasettecr of the State of New York, pp. 553, 573, 678; F. B. Hough, History of St. Lazrence and Franklin Countics, p. 346 .

4 These were distributed as follows: Chautauqua 2, Monroe 3. Otsego I of 3, Ontario 2, Orleans I, Genesee 2. Seneca 2, Wayne 2 of 3. Yates I: see Albany Argus, Nov. 21, I827. There were only I3 "Federal" members elected. This was the campaign when Thurlow Weed, whose story that a body found in Lake Ontario was that of Morgan was widely doubted, was reported as saying that it was "good-enough Morgan till after election." Weed denied using these words (Autobiography, p. 3I9), but admitted that he had said too many things he could not prove (Weed to Francis Granger, March 29 [I827]. Granger Mss.). 
tigate the crime, it was thought the Democratic state administration did not show a proper sympathy. Jackson and the governor, now joined in politics, were high "adhering Masons," while the President was not. Indeed, it was not long before the conscientions Adams was proposing to help tear off the veil that sheltered such iraternities by publishing the harmless secrets of Phi Beta Kappa. ${ }^{1}$

Among the leaders. Thurlow Meed, Francis Granger and Willian H. Seward soon recognized that Anti-Masonry might serve some other ends besides discrediting a ritual. Vieed. who in 1826 was still working as a journeyman in Kochester, not far removed from poverty, had been active in the movement from the first. and was a member of the central committee who directed propaganda. Supported by a fund contributed by converts, he had started the AntiMasonic Enquirir. which now preached the gospel to thousands of subscribers. When a meeting at Le Roy in March, 1828 , with many " seceding Masons" in attendance, decicied to form a general party and hold a state convention. IVeed was sent out on a roving commission to stir up interest and secure appointed delegates wherever possible."

The eastern Adams men, who saw what depletions the "blessed spirit" had accomplished in their party ranks, determined to recapture these western voters as soon as might be. They held their convention at Utica before the Anti-Masons, and, possibly on Weed's suggestion. they proposed for governor. Judge Smith Thompson, who took no stand on Masonry, with Francis Granger. an enthusiast, for second place. When the Anti-Masons came togethe: they resolved. however. in spite of all that IVeed could do.

${ }^{1} \mathrm{~J}$. Q. Adams, Letters on the Masonic Institution (Boston, 1847 edition).

${ }^{2}$ T. Weed. Autobiography, p. 34I. 
“ wholly to disregard the two great political parties," ' and in recomition of his work in the assembly, named Granger. as their candidate for governor. On Meed's advice, that gentleman declined, choosing the nomination by the Adams men, as first received. The radical element, disgusted with Weed's compromising, temporizing policy, nominated a fantastic person, Solomon Southwick, a seceding Mason; yet his following was but a remnant. It was ubrious to Democrats that Anti-Masons were now numbered with their foes; by May, the Argus was complaining loudly of their menacing activities, and soon referred to them as "Federalists." 2 The first days of bewilderment were past, and it was clear that the struggle in the state between the two old parties would not be interrupted, but would instead grow more intense.

One cther cause of the comfusion in the party politics of I 826 and I 827 was, as frequently before, uncertainty as to the position and the plans of Governor Clinton. How thoroughly and how long he could co-operate with Van Buren, and just how many personal followers he could count upon, were favorite themes of speculation in the lobbies of the capitol and in the conntry stores. It was felt that his hegira to the Regency would date no epoch, that his position was unstable and promoted anything but peace. The Democratic leaders found that his presence in the Jack-

1 Hammond, vol. ii, p. $38-$. "The Anti Masonic convention has just taken a recess of an hour to make up their minds on a resolution submitted by a committee appointed last evening "that it is expedient for the convention to disregard all national \& State politics \& to make an antimasonic nomination of Governor \& Lt. Governor.' This is the substance, I quote from memory. The resolution was reported by a decided majority of the committee, notwithstanding it is believerl that they were pressed to a different course by Weed \& Wm. A. King." John Willard to Flagg, Aug. 5 [1828].

2Albany Argus, May 12, I828, Feb. $26,1829$. 


\section{4

son forces chilled the loyalty of many who had long been trained to hate him. But in February, 1828 , these wrang. lings were unexpectedly concluded. On the eleventh of that month, while after a day's labor he sat talking with his sons, his head fell forward and he died: "his departure was as quiet as if he had dropped asleep."

Mingled with the awe at such a sudden taking off, there was an understanding that the future of the parties in the state could now be read more clearly.

I great change must necessarily take place in the politics of our State dependent upon the death of Gov. C. [wrote Silas Wright]; the greatest obstacle with our best men in taking the side of Gen'1 Jackson was the fear that his success might incline to the elevation of $\mathrm{Mr}$. Clinton, and but for that impression they would long since have espoused the Jackson cause openly. He has added something to the numbers, but unless I an much mistaken you will now find many a strong man's scruples at an end, and his hands loosed, and that the strength of Gen'l Jackson and of Democracy will be co-extensive in New York."

On the other hand, the cause of the " high-minded " schism in the old Federalist party was removed. And some Clinton men, who had hesitated when their leader had proclaimed himself for Jackson, could now rest content with old associates. Perhaps no other event conld have restored the clear distinctions of a dozen years before.

The historian, however, cannot dismiss the great governor with such words as these. He has oftentimes been numbered with the most successful politicians of our his-

1 James Renwick, Life of Clinton, p. 296 . Francis Granger, who arrived a few minutes after Clinton's death, wrote a graphic account to his mother, Feb. I2, I828, in Granger Mss.

${ }^{2}$ To Marcy, Feb. I8, I828. With Flagg Miss.; see also Albany Argus, Feb. 27, 1828. 
tory, ${ }^{3}$ but this estimate is founded on a hasty view of his career. When compared with Thurlow Weed, that master of adjustments, or with Van Buren, the suave and "noncommittal," his deficiencies in this respect are patent. Persuasiveness, the first requisite, he sadly lacked. He despised intrigue, and when he tried it, as in 18 i2, he fumbled so ineptly as to make him lasting enemies. He served no apprenticeship in politics, but by reason of his uncle's favor sprang to prominence at once: his natural hauteur was, therefore, never softened, and owning no superiors, his sarcastic wit went unadmonished. He was sparing in his thanks, and showed but small concern that his supporters should be favored; they were usually made to know that he could do without them. Personally incorruptible, he took no pains to hide a cynical belief that most other men were not. In his self-confidence he let the impression spread that every loyalty must center in himself. "His own aggrandizement," observed John Quincy Adams, " has been the only test of his party attachments, and he has, consequently, been a mere man of coalitions." 2 In all the arts which qualify a politician he was indifferent or singularly clumsy. A close associate admitted that he was "personally unpopular." s

Yet another friend declared him " the most popular man of his time." " And both were right, if " popularity" may have two meanings, since a man who cannot win affection

${ }^{1}$ E. g., S. P. Orth, Fiz'c Amcrican Politicians (Cleveland, 1906), chap. ii; and J. Schouler, History of the United States of America (N. Y., I894 edition), vol. ii, 409 ; E. Channing, History of the United States, vol. iv (N. Y., I917), p. 397.

${ }^{2}$ Mcmoir, vol. v, p. 38 .

${ }^{3}$ J. D. Hammond, Political History, rol. ii, p. 270.

4 Ambrose Spencer, Defence of Judge Spencer, quoted by J. S. Jenkins, Lic's of the Goicrnors. 
may yet be universally admired. Few public men could more deserve respect than he, for if he was no politician. he was more, a statesman: his interests were in measures, w, in majorities. He stooped to low devices on occasion, nut because he liked them. but that great ends might be served. Of his splendid services to New York state no recapitulation here is needed: by intellect and faith and perseverance, he built great public works, improved the comnion schools, encouraged every art that supported or embellished life, and devised fair laws as to the revenues and their expenditure, the military forces of the state, the careful supervision of the banks. sanitation in the cities, the care of the unfortunate, and the discipline and labor of the prisoners. ${ }^{1}$ He had the gift of prescience. Carried forward by no Slielleyan passion to renovate the world, he yet simmoned all his valiant energies to the creation of the common wealth, and showed the liberal's optimism in his confidence in education. His messages presented the program of a man who knew. As an administrator, both as nllayor and as governor, he was resourceful and efficient. such accomplishments entitle him to rank with the American statesmen, the only one. it may be said, who played no part of much importance in the federal government.

That he cannot be included with the greatest may be accounted for in a certain lack of composition in his principles and policies. Though he generally confessed a Democratic creed, he essayed to lead the Federalists, and, indeed,

${ }^{1}$ All these subjects were presented in the governor's messages in such a way as to result in legislation, see Messages from the Goi'ernors. vols. ii and iii, passim, especially the notes by the editor C. Z. Lincoln: also E. A. Fitzpatrick. The Educational l ieces and Influence of DelWitt Clinten. S. L. Mitchill, Discourse on the Character \& Scientific Attainments of DeWitt Clinton (N. Y., I828), G. de Beaumont and A. de Tocqueville, Du systìme pénitentiaire aur. États-Unis (Paris, 1836), T. 6. itc. 
in that time and place, his tastes associated him more naturally with the aristocracy. Hie expressed himself on all occasions, and no doubt sincerely, as the steadfast friend of states' rights, yet other interests that he cherished, such as the internal development of America and the growth of manufacturing, would prosper better under another theory of government: merchants, engineers and capitalists cannot see the boundaries of states. Having long disliked Virginia, he could not be successful in the Democratic părty: yet had his principles allowed him he conld not rise to leadership among the National Republicans, since that entailed a close co-operation with Adams, of whom he was inordinately jealous as his competitor for honors in the north. Death came, perhaps, when he had done what he was fitted best to do.

The campaign of I 828 was said by many to be the most exciting in the history of the state. ${ }^{1}$ It was the first in which the people had participated so directly in the election of a President; it presented a choice between two wellmarlied personalities, whose differences in governmental policies were defined more clearly than had been the case in any other closely fought political contest since the Revolution of ISoo. It was apparent to observers that Jackson was more popular than Adams, becautse he was "considered the sterner and more inflexible republican:" " he was. as the public were assured in an elegant inscription on the campaign banners, prepared to "go the whole hog." 3

His partisans accused the administration of intrigue to defeat the people's will, of extravagance, and of maintaining an aristocratic civil service. They deplored the cunning

${ }^{1}$ James Stuart, Three Years in North America, vol. i, p. 233.

${ }^{2}$ Ibid., vol. i, p. 76.

${ }^{3}$ Thomas Hamilton, Men and Manners in America (Philadelphia edition, 1833), vol. i, p. I8. 
by which the guileless Anti-Masons had been hoodwinked into a disgraceful coalition in the state. ${ }^{1}$ On the other hand, the Adams men expressed their admiration of the bold constructive platform of their leaders. At Ballston Spa, for instance, a meeting praised the high protective tariff, and drew up an address entitled "The American System ":

The present administration of the general government [they declared] is at the head of a great system of policy that promises to elicit the enterprise,-enlarge the resources,-increase the wealth,- and promote the independence of our country. .... It is for its adherence to this system of policy, so congenial to our situation,--so inseparable from our prosperity,and so honorable to our character,- that the present administration has been assailed."

The Regency, concerned as deeply in the outcome, at their Herkimer convention brought forward their best candidate for governor. Van Buren, the tactful chief who made no enemies; and they associated with him on the ticket Judge Enos T. Throop, who had lately sentenced the luckless kidnappers of Captain Morgan, but who disapproved of Anti-Masonry. The nomination of lieutenant govemor was considered of unusual importance, since if Jackson were successful, it was well known that Van Buren would be summoned to his cabinet. ${ }^{3}$ The canvass proved the

${ }^{1} E$. g., the resolutions of a Republican meeting at Edinburgh, N. Y., in Saratoga Sentincl, Oct. 7, 1828 .

${ }^{2}$ Ballston Spa Gazcttc. Nor. 3, 1828 .

- Silas Wright was considered for governor, but was dismissed as too young; see Ebenezer Griffin to A. C. Flagg, Rochester, July 30. 1828. Nathaniel Pitcher desired renomination, but he had been too much involved in the state road controversy, and was now in ill health. The Regency's experience with Mr. Crawford led them to attach importance to the latter consideration: see letters from Hoffman, July 30 , 1828, from R. H. Walworth, Nov. 17, 1828, and from John Targee, 
wisdom of the choice, for Van Buren was elected governor by a margin of some thirty thousand votes, though not by a majority. for of the total Solomon Southwick had about an eighth." The counties in the east voted on the old lines: "the real Federal counties have gone against us," wrote Michael Hoffman," and Van Buren acridly complained about the "manor influence." 3 The whole region around Albany, together with Nontgomery and Oneida, the north and northwest slopes (excepting Clinton), and Queens, were registered for Thompson, while of the country west of Cayuga Lake each party had about a third. ${ }^{4}$ In the city of New York, the three southern wards, constant in their Federalism from the first. now cast their votes for Thompson and the President." Adams and Rush, throughout the

Feb. IO, I829, Flagg Mss. Judge Hammond understood it was because of Pitcher's deficiencies in education, Political History, vol, ii, pp. 287-288.

${ }^{1}$ It was said that if the extreme apostles of the "blessed spirit" had been content to rote for Thompson, Van Buren would have been defeated; but this combination was impossible as they would have insisted on a thorough-going program which the adhering Masons among the followers of Adams and Clay would have refused to support. Hammond's judgment on this matter is uncharacteristically hasty; see Political History, vol. ii, p. 289. Weed had realized as early as August that there was little hope for Adams (Weed to Francis Granger, Aug. 26 [I828], Granger Mss.), and was certain of defeat when the Adams men would not nominate Granger for governor. Gerrit Smith wrote Judge Carroll ( March I 4, I 828 , ibid.) that Granger was too young, and this may have weighed with the Judge in bringing forth Thompson (see Weed to Granger, Oct. 26, ibid.).

To Flagg, Nov. 8, I828, Flagg Mss.

3 "The Manor influence here was exerted to an extent unknown for the last 20 years," Van Buren to C. C. Cambreling. Albany, Nor. 7, I828, Van Buren Mss. He said the Federalism of $g$ seemed risen from the dead.

"See maps in Cilarles McCarthy, The Antimasonic Party.

${ }^{5}$ E. Williams, New Jork Annual Register, IS30, p. 2IS; 1. I. Eveiting Post. Nov. IO, I828; $\mathrm{Y}$. Y. Horning Courier, Nov. II, I828. 
state, received only five thousand less than Jackson and Calhoun. ${ }^{1}$ The last President to be chosen on his record as a first-class statesman soon left the White House.

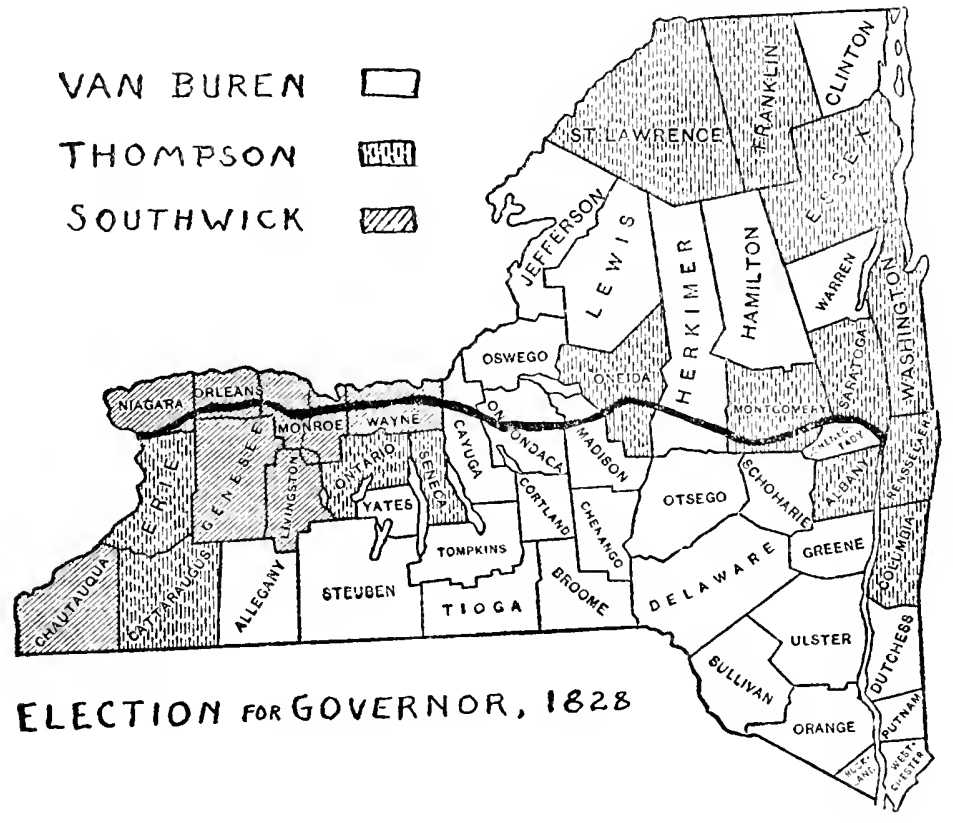

For all the bitterness of the campaign-the "Coffin Handbills," which set forth the cruelties ascribed to Jackson when he invaded Florida, the slanderous broadsides dealing with the General's marriage, and the reckless charges as to " bargain and corruption," were outstanding features ${ }^{2}-$ travelers remarked how decently the country elections were conducted; no Scotch drunkenness or shameless English bribery disgraced the voters at the polls. ${ }^{3}$ After the hurri-

1 See comment in J. S. Jenkins, Lie's of the Goiernors, p. 439.

2 See Thurlow Weel's Autobiography, pp. $307-30$ \&, for that politician's honorable course regarding these handbills.

"James Stuart. Three Jears in North Amcrica, vol. i, pp. 233-238. 
cane of oratory and deluge of print, society resumed its wonted way. "The morning after election all is quiet, the sea is calm as if a heavy rain had fallen upon it. There hang the staring handbills with their enormous imputations and caricature exaggerations, now lifeless, tasteless, and without any farther effect or use than haply to point a moral." " Tet many felt that the campaign. with its talk of the American System on the one hand and Democratic simplicity on the other, had drawn a clearer line between the parties.

The Aristocracy and the Democracy are arrayed against each other [wrote Nichael Hoffman the week the victory was announced]. If we will now avow our principles and reduce them to practice in a judicious system of reforms in the state and federal governments, the country will prosper and the Denocratic party prevail. We nust reduce both the number and the salaries of officers, civil, naval and military. Make them work harder, live more economically, and, of course. live longer. I fear only the excess of Government, and consider occasional reforms as indispensable."

But the "excess of Government." as Hoffman chose to call it. would nevermore be charged against the old aristocracy, as such, with their theories of political privilege and social precedence. $^{3}$ The aristocracy was already being rapidly transformed into a business party, who took political equality as an accomplished fact.

${ }^{1}$ F. Lieber, Letters to a Gentleman in Germany., pp. 25-26.

"Nichael Hoffman to A. C. Flagg, Nov. 8, I828, Flagg Miss.

"Cf. C. L. Becker, "Nominations in Colonial New York," American Historical Reriew, vol. vi, p. 26r. "The principal difference between the federalists and the Adams republicans was, that the former intended to be the guides, and the latter the exponents, of the people in carrying out the policy specified," Alexander Johnston, in Lalor's Cyclopedia, vol. iii, p. I IоI. 


\section{CHAPTER XII}

\section{Tom, Dick and Harry Take a Hand}

In the great debate of IS2 I the Federalist delegates had warned their innovating colleagues that novel and perplexing problems to the state would follow from a grant of universal suffrage, and that the newly enfranchised rabble of the towns would lay a spoiling hand upon the guaranties of property. Those who had survived in 1829 believed they saw a melancholy vindication of their fears. Industrial wage-workers, whose number had increased with such rapidity, had discovered that the " equality thus far attained was only equality before the ballot-box, not equality before the conditions of life, or even equality before the law." It was noticed that they felt themselves already a considerable portion of society. expected more importance, and were determined to exact some legislation in their own behalf.

There was a tendency, observable among employers, to standardize the working day in industry as from sun to sun, unfairly following the precedent of agriculture, while the workers claimed that more than ten consecutive hours at the bench partook of slavery. They wanted laws not only to insure these proper limits, but special statutes with respect to woman and child labor: they must have legal security of wages by mechanics' liens and protection against

${ }^{1}$ The section by Miss Helen L. Sumner in the History of Labour in the United States, by John R. Commons and associates (N. Y.. 1918). vol. i, pp. I69-335, sets forth the principal facts about the labor movement in New York politics between 1827 and 1833 . and may be considered as superseding previous accounts. 
seizure of their tools to satisfy their creditors. A bruader interest, which was given the foremost place in all their tables of demands, was their zeal for free and tax-supported schools. ${ }^{1}$ In New York city nearly half the children did not go to school, because their parents could not pay tuition fees of private institutions or would not take the bounty of the Public School Society." In spite of all the efforts of Clinton and his predecessors, eighty thousand children still remained unschooled throughout the state. ${ }^{3}$ Equality of education could alone make sure a democratic government. "It is false, they say, to maintain that there is at present no privileged order, no practical aristocracy, in a country where distinctions of education are permitted."

Another wrong the workers thought should speedily be righted was patent in the law and custom of imprisonment for debt. In 1830 five-sixths of those incarcerated in the jails of New England and the middle states were there upun complaints of creditors, the majority for debts of less than twenty dollars. In this oppression New York held a sad preëminence. ${ }^{5}$ To give but one example, it was reported that in Monroe county in a single year there was about one imprisoned debtor for each ten families. ${ }^{6}$ Caller together by the Spirit of the $.4 g c$, the radical paper of the

1 Commons, etc., vol. i, pp. 171, 181.

"W. O. Bourne, History of the Public School Society of the City of New York (N. Y., 1873), p. III, and Working Man's Adrocate, May I, 1830 .

${ }^{3}$ Mechanics' Magozine, August, I83,3, quoted in Commons, efc., vol. i. p. 182 .

4Thomas Hamilton, Men and Manners in America (Philadelphia 1833), vol. i, pp. 39, г6г.

"F. T. Carlton, "Abolition of Imprisonment for Debt in the Uniter? States," Yale Review, vol. xvii, pp. 339-344. and Reports of the Prison Discipline Society of Boston, especially for 1830 .

-Working Man's Advocate, Mar. 27, 1830. 
town of Rochester, a convention of the Friends of Liberal and Moral Principles bought the freedom of all debtors in the jail. ${ }^{3}$ It is hardly necessary to remark that a poor man might any day be victimized through malice or revenge; the reader will recall that William Morgan had been thrown into a debtor's cell for a trivial sum.

The workingmen protested against the ruinous competition of prison labor. and the masons of the city of New York refused to work with stone cut in the shops at Sing Sing." They bitterly complained of laws and doctrines that stamped their unions as conspiracies, and opened prison dors to those who struck for better wages or conditions. The militia system they unreservedly condemned. Not (mly were the training days a joke as far as military service was concerned. and more important for conviviality than for defence, but the loss of three days' wages was an item in the worker's budget. The rich man could stay away and pay twelve dollars fine, as many did, but the mechanic had his choice between the drill-field and the jail. It was computed that the system cost the workingman four times as large a fraction of his income as a capitalist who lived upon the proceeds of a hundred thousand dollars. ${ }^{3}$

The laboring classes cherished a suspicion of all banks. whose paper money of fluctuating value in their weekly pay caused such uncertainty. Auctioneers' monopolies kept prices higher than they should be, and were resented most hy those who had the least to pay." Witnesses and jurors should have a fairer compensation, and litigation should be

${ }^{3}$ J. B. McMaster, The Acquisition of the Political, Social and Industrial Rights of Man in America (Cleveland, 1903), pp. 106, Iog.

: N. Y. Evening Post, June 22, i 830 .

"Commons, etc., vol. i, p. I\&o.

"Cf. H. Secrist. "The Anti-Auction Movement of 1828 ," in Annals of Wisconsin Academy, vol. xvii, no. 2. 
made more speedy and less costly. ${ }^{1}$ All these survivals of the old prescriptive privileges which barred the way to true democracy and that universal justice which was certain to come with it, must be swept away, else of what avail were ballots? To insure these changes honest simple men must be entrusted with the office, and wise laws enacted; then crime and misery would straightway be diminished. "The aristocracy or men nominated for their influence are unfit 10 be legislators for the great mass of the people."

In April, I829, the workingmen in New York city held wme meetings to resist the movement of the employers to extend the working day beyond ten hours, and appointed a committee to effect their purpose. This common action was so formidable that the employers soon desisted, and the committee felt itself at liberty to use its prestige toward accomplishing political reforms. A party soon was organized upon the precedent of one which had been formed the previous summer in Philadelphia, the first labor party in the world. ${ }^{3}$ During October, resolutions were drawn up which embodied most of the demands that have here been rntlined, and a ticket for the assembly was devised, consisting of a printer, a house-painter, a brass-founder, a whitesmith, a cooper. a grocer. two machinists, two carpenters and a physician; the Working Man's Adrocate now apteared to preach the doctrines, with the motto: "All children are entitled to equal education, all adults to equal froperty, and all mankind to equal privileges." Some inroad was made into the ranks of Tammany, and one man was elected from the ticket, while others had considerable "1pport, the physician being last."

1. Commons, etc., vol. i, p. 282.

"Working Man's Adrocate, Oct. 31, I829.

a Commons, etc., rol. i, pp. I69, I95.

4A good account, shorter than Miss Sumner's, may be found in F. T. Carlton, "The Workingmen's Party of New York City," Political Science Quarterly, vol, xx (Ig07), pp. 40I-4I5. 


\section{ARISTOCRACY IN THE POLITICS OF NEW YORK}

The party first fell under the direction, or perhaps it were better said, the domination, of Thomas Skidmore, an ad mirer of Thonas Paine and an agrarian reformer of the most thorough-going type. In his plan " the equal division of the property of all who died in any given year was to be made among all those coming of age during the same year." ' But most "Workies," as the members of the party were inelegantly called, had no such revolutionary purpose. and Skidmore, taking off about a hundred followers, yielded place to Robert Dale Owen, Frances Wright, and George $H$. Evans, the editor of the Advocate. Owen soon outlined a scheme of guardianship in education by which parents would resign control of their children to the state, after the Platonic theory, and this extreme proposal likewise alienated many who desired only simple practical reforms." So there came to be three factions, each claiming to be orthodox and each in its own paper berating the two others.

But though disturbed by these internal quarrels, the movement spread, and in 1830 meetings were convened at Albany, Troy, Kingsbury, Lansingburgh. Hartford, Saratoga and Glens Falls, along the Mohawk at Schenectady and Utica, at Auburn and Salina, and in the western counties at Palmyra, Canandaigua, Ithaca, Geneva, Rochester, Batavia and Buffalo. ${ }^{3}$ Several local tickets were surprisingly successful, and a state convention nominated candidates for governor and other offices. "Workeyism" in New York city daily grew more formidable. When the common council planned to celebrate Evacuation Day, the workingmen decided to parade in honor of the July Revolution which had

1 Carlton, op. cit., p. 402.

"For this period of R. D. Owen's career see his Threading My lf'ay (London, I874).

${ }^{3}$ Commons, ctc., vol. i, pp. 260-26.3. 2SI: J. D. Hammond, Politicol History, vol. ii, pp. 330-33I. 
lately been repurted from Paris. The original proponents, with some reluctance, consented to a combination pageant, which is described in a somewhat mordant humor by the English Tory, Captain Hamilton :

Then came the trades. Butchers on horseback, or drawn in a sort of rustic arbor or shambles, tastefully festooned with sausages. Tailors with cockades and breast-knots of riband pacing to music, with banners representative of various garments, waving proudly in the wind. Blacksmiths, with forge and bellows. Caravans of cobblers most seducingly appareled, and working at their trade on a locomotive platform, which displayed their persons to the best advantage. . . . ${ }^{1}$

The captain could not approve of workingmen so conseyuential;

A butcher on his steed so trim, A mounted butcher was to him, And he was nothing more. ${ }^{2}$

Tet this undeniably represented voting power, and voting power must be respected. The Anti-Masons, hopeful of attracting their support. soon declared for the abolition of imprisonment for debt and a thorough reform of the militia system." But the Democrats could offer more than promises; their majority, in $I_{3} I$, finally wiped out the debtor's prisons, despite the opposition of the pettifogging lawyers. the state printer (who profited by the necessary legal advertisements), and the business men, especially rum-sellers. "

${ }^{1}$ Thomas Hamilton. Men and Manners in America, vol. i, pp. 39-40. Chapter $\mathrm{x}$ of this work, giving the author's view of the political changes which must come from the development of manufacturing, is unusually interesting.

${ }^{2}$ Ibid., p. 44 .

${ }^{3}$ C. McCarthy, "The Antimasonic Party." American Historical Association Reports, vol. ii, pp. 404-405.

"F. T. Carlton, "Abolition of Imprisonment for Debt," pp. 343, 344. The Anti-Masons, not numerically important in the legislature, were solidly for this measure, W. H. Seward, Autobiography, pp. I9I-Igz. There was a resolute but unsuccessful attempt in 1834 to repeal the law. 
When Tammany came out for a mechanics' lien law, it is estimated that about four thousand voters returned to the Democracy, from whose ranks they had originally seceded. ${ }^{\prime}$ An economist has observed that "the Democratic party from 1829 to $18_{4} 1$ was more truly a workingmen's party than has been the case with that party or with any other great party in the country since.".

Many Clay men who had no taste for Anti-Masonry, joined the Workingmen in an attempt to keep them independent of the Jackson party, ${ }^{3}$ and preached the benefit to labor of high protective duties. The evils of an unrestricted competition with the pauper mill-hands of Great Britain and the continent, became a favorite theme of orators. Now and again some critic pointed out that tariffs increased prices, and that workers had to purchase clothes as well as make them; nevertheless the impression grew throughout the northern cities that the workingman's chief ubject of solicitude should be the thickness of the envelope that held his pay, and that in some way this dimension was in direct proportion to the height of the protective tariff wall. ${ }^{*}$ So the wages argument found some favor for the American System among the laborers. as that of the home market had secured the grain-and wool-producing farmers, and a faction of Clay Workingmen in New York city in I 830 helped National Republicans to office, while elsewhere through the state there were coalitions. It was by such ais! in Auburn that William H. Seward, though not yet thirty

${ }^{1}$ G. Myers, History of Tammany Hall. p. 99. The law that was passed, however, applied only to Kew York city, Commons, ite., rol. i, p. 329.

'R. T. Fly, The Labor Movement in America (N. Y., 1900), pp. \$2-43.

'J. D. Hammond, Political History, vol. ii, pp. 330-33I.

-G. B. Mangold, The Labor Argument in the Anerican Protective Tariff Discussion (Univ. of Wisconsin Economics and Political Science Series, vol. v, no. 2), pp. 35-36, 7I, 79, 8 I. 
years of age, was elected to the senate of the state by a considerable majority, ${ }^{1}$ and in the campaign of 1832 a certain Samuel Stevens, a IVorkingman, was nominated for lieutenant governor by the Anti-Masons." In I834 Silas B. Stillwell was found by Whigs to be available for the same office, partly on the ground that he had been a shoemaker. ${ }^{3}$

Thus by quarrels among themselves, by the art of politicians, as well as by the imputations of religious unbelief as followers of the infidels. Skidmore. Owen, Evans and Miss Wright, the Workingmen were broken as a political organization, though, as is the case with most third parties, not until they had brought to pass or hastened several of the great reforms they earnestly desired. Besides the debtors' and mechanics' measures, which were actually enacted into law, educational reform received an impetus from their discussion, and the old militia system narrowly escaped annihilation by the legislature in 1830 and was reformed in $183 \mathrm{I}$, although it survived in law till $1870 .{ }^{*}$ The party could endure with equanimity the thundering denunciations of the old Federalist press, and the epithets of "mob" and "rabble" and the "dirty shirts," while they saw their efforts bring about such democratic gains."

${ }^{1}$ E. E. Hale, Jr., William H. Sczerd, p. 8o; F. W. Seward, Lifi of Seward, vol. i, p. 176 .

${ }^{2}$ W. H. Seward, Autobiography, pp. $78-79$; see also F. Granger to T. Weed, undated, pp. 28-29, in Granger Mss.

${ }^{3}$ D. S. Alexander, Political History. vol. i, p. 403.

- Chapter 80, Laws of 1870 . All military laws before this provided for assembly of the reserve militia at least annually but after $18+6$ there was no such assembly, as a law of that year prescribed only a nominal fee, of fifty cents, for absence. This operated in fact as a general poll tax. See Annual Report of Adjutant General for 1860 ; Chapter 350, Laws of 1840 ; Chapter 270 , Laws of 1846 ; and Chapter 447 . Laws of 1862.

'See N. Y. Commercial Advertiser, quoted in Working Man's Advo- 


\section{ARISTOCRACY IN THE POLITICS OF NEW YORL}

Meanwhile the ancient war went on between the Regency and an opposition which was itself divided. Weed, in I82S. had managed something like a coalition, but the Clay men, or the National Republicans, as they began to call them-elves, ${ }^{1}$ had been hesitant, and the Democrats (officially persisting in the name Republicans) had won a sweeping victory. In 1830 , Weed and Granger sought again to cast the blessed mantle of Anti-Masonry over all the discontented, after patching it with an assortment of new "principles". Internal improvement and the protective tariff were extolled to keep the Adams interest: " Hattering advances were made to Workingmen: New York city bankers might be won by promising to exempt their institutions from the Safety Fund law which had lately been put through by Van Buren: ${ }^{3}$ a sturdy championship of the Chenango Canal proposal was counted on to hold the voters centering in the towns of Norwich, Oxford, Greene and Binghamton." Thurlow Weed was brought to Albany at a salary of seven hundred and fifty dollars a year to edit an Anti-Masonic paper: and the Albany Evening Journal, on March 22, 1830, made its bow as thirty-third among the organs of that party in the state. ${ }^{5}$

cate, Nov. 7, I829; citations in J. B. McMaster, Rights of Man in America, pp. 102-103, and "A Century of Social Betterment," Atlantic Monthly, vol. lxxix, p. 72 ; and Commons, etc.. vol. i, p. $27 \mathrm{I}$

${ }^{1}$ Seward, in his Autobiography, p. 64, applies the name as early as 1826 , but this is doubtless due to a confusion in reminiscence, as the first use is found in the papers of 1829 ; see E. F. Hale. Ir., Seward, p. 62.

2Procedings of the Anti-Masonic Concention in the State of New York, August II, 1830 (pamphlet, Columbia University Library).

${ }^{3}$ R. E. Chaddock, "The Safety-Fund Banking System in New York State, 1820-1866," Sen. Doc. 6ist. Cong., 2nd Sess., vol. 34, p. 267.

"C. McCarthy, "The Antimasonic Party," pp. 396-400.

"T. Weed, Autobiography. p. 434; Frederick Hudson, Journalism in the United States (N. Y., I873), p. 398. There were at that time 2II papers altogether in the state. 
But their hopes were vain, for the Masons in the eastern counties, though they read the Daily Adicrtiser and might have followed Adams, cast their rotes for Throop, the Democratic candidate for governor. Francis Granger was defeated by eight thousand in a quarter of a million. "Old Van Rensselaer's name," wrote Weed to Granger, " acted as it was designed upon the Fraternity." "

Early in the following year the National Republicans took on a bold front, and gathered delegates at Albany, where they listened to a speech by their new convert, P. R. Livingston. The Patroon, Judge Spencer, and over thirty others were appointed to attend the national convention called to name Clay for the presidency, and some spirited resolutions were published by the secretaries. Oran Follett and Joseph Hoxie." The later correspondence of these secretaries shows the trend of party sentiment. They desired first to found a new state journal in Clay's interest, but they could not find the funds. ${ }^{3}$ Next they gravely talked of nominating as a candidate for governor, General Root, who had recently declared against the Regency, hoping thus to pose as independents with no more connection with the AntiMasons than with Democrats, but due to certain indiscretions of the General, they conld not get the press to advocate this policy. ${ }^{\text {But }}$ if the National Republicans cuuld not arganize their forces, the canny WVeed was willing to attempt it. In the spring of $I_{3} 2$ he was writing hopefully i. Follett that "All men opposed to Jackson and the Re-

${ }^{1}$ Nov. I3, I8.30, Granger Mss.

¿ I. D. Hammond, Political History, vol. ii, pp. 336-337.

${ }^{3}$ Oran Follett to Joseph Hoxie, Feb. 6, I8.32, Follett Correspondence, Quarterly Publication of the Historical and Philosophical Society of Ohio, vol. v, no. 2, pp. 53-54.

4Same to same, Feb. 13, I832, ibid., p. 56. 
gency seen determined to act together," wrote him of a conference at Albany where an arrangement had been made:

They did so meet, and the following plan was discussed and agreed upon, viz., that we lie still until the Anti[-Masonic] Convention shall have been held, at which an electoral ticket shall be nominated composed of $1 / 2$ of Antis and $1 / 2$ of Clay $m e n, \&$ probably Granger \& Strong for Gov. \& Lieut. Gov., the electoral ticket pledged to go against Jackson, and with the understanding that if the vote of New York will make Mr. Clay president. he is to have them all, if not the Antis may as well vote for Wirt [their presidential candidate] or not, as it will only send the choice to the House. This arrangement is satisfactory to our friends here [in New York city] generally, and I believe in the River counties. With a view to prepare the public mind for this you will have doubtless seen and observed the tone of our papers of late touching the "union of honest men," \&c. The Daily Advertiser and the E[vening $\mid$ Journal at Albany are no longer at logger-heads."

This "Siamese-twin scheme" was none too attractive to the Buffalo editor, Oran Follett, who had only lately written in disgust of "Anti-Masons (Bah!)," ${ }^{3}$ but leadership, must rest with talent and the Anti-Masons could not be outpointed. The National Republicans had little to lose, at any rate: Hoxie said, "A wag observed to me a few days since he thought we were looking up, being flat on our backs we could look 110 other way." 4

${ }^{1}$ He flattered Follett by referring to his paper, the Buffalo Daily Journal, as "the most leading and influential national paper out of the city of New York," May I0, 1832, Follett Correspondence.

"J. Hoxie to Follett, May 11,1832 . Granger and Stevens were again named for governor and lieutenant-governor.

${ }^{3}$ Follett to A. C. Flagg, in 1830 , Flagg Mss.

"To Follett, May 11, 1832, "When Masons of our standing, can be induced from considerations of duty, to make the sacrifices we have, and are making, our opponents must give us credit for devotion," Follett to H. D. Chipman, Aug. 6, 1832. 
The plan was carried through and the National Republicans officially endorsed the ticket of the Utica convention, though careful to set forth " that though they adopted AntiNasonic nominations, they were not anti-masons." County meetings and conmittees of correspondence sought to stir enthusiasm where they could. ${ }^{1}$ But the arrangement whereby the electors might cast their votes for Clay or possibly a part of them for William Wirt, was mocked at by the Regency, and did not please extremists in the two wings of the opposition. Thoroughgoing " Norgan men " asked inconvenient questions; Chancellor Kent, whose name was first upon the electoral ticket, soon was interrogated by enthusiasts like D. C. Miller, the Batavian printer, from whose press "The Book" had issued in 1826 , but he vouchsafed no answer. The New York Central Committee enjoined a cautious silence upon all the candidates associated with the chancellor, for kind words to Anti-Masons as to Wirt might be offensive to the Masons of the older faction. They admonished everyone that the time was not thought suitable to declarations or confessions, and wrote that "this Conmittee thinks it prudent that the communications with the electors should be oral and not by correspondence." 2 Already, then, among those who were soon to take the name of Whig, there was prescribed a smiling reticence as to the future.

But the Democratic party in the state was then better disciplined than ever before or since. Sagacious politicians had been sent into Chenango and Broome Counties to promise a canal, thus depriving Granger of an issue. and Senator

${ }^{1}$ H. Ketchum to State Corresponding Committee in Buffalo. Follett Correspondence, pp. 66-67.

${ }^{2}$ National Republican State Central Corresponding Committee to the State Corresponding Committee in Buffalo. Sept. I4. 1832. Follett Correspondence. 


\section{$3^{6} 4$ ARISTOCRACY IN THE POLITICS OF NEIV YORK}

Marcy, who had been named at Herkimer for governor, as well as Jackson and Van Buren, were voted into office by a large majority."

The paramount issue of the campaign, and a fatal one to Anti-Jackson men, had been the question of rechartering the Bank of the United States. Besides the general prejuclice against monopolies, by no means limited to Workingmen. and the reliable antipathy of poor men toward the rich, there was in New York a special jealousy of that great corporation as an institution of a rival city, Philadelphia. Some local bankers who sought riddance of this great competitor gave their aid to Jackson in his "war," unaware, as yet, that in his heart he cherished a distrust of banks in general." On the other hand, two "high-minded men" of much importance. Gulian C. Verplanck and Ogden Hoffman, who had remained within the Jackson party, now grew tired of "destructionists." and joined old friends among the National Republicans." and some business men of Tammany, like Moses H. Grimnell. R. C. IVetmore and Dudley Selden, ${ }^{4}$ realizing that a blow at credit anywhere was a dangerous beginning. likewise left the Democrats. But the opposition's greatest gain was in the Courier and Enquirer, the leading Jachson paper of the city, whose editors. Colonel Webb and Major Noah, were heavily concerned in bank

' J. D. Hammond, Political History, vol. ii. pp. 423-424. +29.

2"I do not dislike your Bank any more than all banks. But ever since I read the history of the South Sea Bubble, I have been afraid of banks," Jackson to N. Biddle, in I829. R. H. C. Catterall, The Second Bank of the United States (Chicago, 1903), p. I84.

${ }^{3}$ L. B. Proctor, Lices of Eminent Lawycrs and Statesmen of the State of New York (N. Y., I\&82), vol. i, p. I2, Verplanck was a debtor of the Bank; see Catterall, pp. 253, 273.

-G. Myers, History of Tammany Hall, pp. In6, Ifo-I4I ; and Proctor. op. cit., vol. i, p. Io. Selden had borrowed $\$ 8.000$ of the Bank. See "Apostrophe to Dudley Selden. hy a Poor Man." in the Man, March 22,1834 . 
stock speculations and had largely benefited by the institution's subsidizing loans. ${ }^{1}$ The Anti-Masons, for the most part, earnestly inveighed against the policy of the administration; Seward and Maynard in the senate and John Young and John C. Spencer in the assembly spoke zealously and often in the Bank's defense, while Fillmore and others framed memorials for public meetings."

But the vote in 1832 showed conclusively that whatever financiers or party leaders thought about a bank, the people would not have it. This was no surprise to Thurlow Weed. He believed as firmly as any of his colleagues that a Bank was " necessary to the commercial, manufacturing, mechanical, and agricultural interests of the country, and as a means of regulating its currency and exchanges," but he likewise realized how hopeless it would be as a campaign measure, and what opportunity its discussion would give the Regency for fanning up the hatred of the poor against the "moneyed aristocracy." When Chief Justice Spencer urged that Webster's arguments be published in the Journal, Weed admitted them unanswerable in the light of justice or of reason, but declared that the two sentences in Jackson's veto message that touched on European stockholders and the wickedness of special privilege. would win ten votes to one secured by all the eloquence and logic of the God-like Daniel. $^{3} \quad$ In general, he prevailed upon the Anti-Masons to put as little emphasis as possible upon this issue in the campaigns of the middle 'thirties. ${ }^{*}$

${ }^{1}$ Catterall, op. cit., pp. I80- $18 \mathrm{I}, 258-263.339,345$.

'W. H. Seward, Works, vol. ii, p. 223, and Autobiography. p. I5': J. D. Hammond, Political History, vol. ii, p. 352 ; Buffalo Historical Society Publication, vol. x, p. 86; N. Y. Evening Post, Feb. 7, 1832; T. Weed, Autobiography, pp. 372-373; L. L. Doty, History of Livingston County (Cenesee, I876), pp. 553-554.

${ }^{3}$ Autobiograply, pp. 371-373.

4 Horace Greeley, Recollections of a Busy Life (X. Y.. I87.3), D. 3 It. 
Thurlow Weed devised few laws and seldom meddled in the large concerns of public policy. Leaving principles to Seward and others he could trust, he specialized in finding votes for what they recommended, advising only as an expert on the likelihood of popularity of any given measure. In his domain he was as close a student, as unselfish and as patriotic a man as they were in theirs. As a young boy, like Huckleberry Finn, he had shared the woes of an itinerant father who could never overtake prosperity: and, struggling shwly up from cabin-boy and printer's devil, he had learned the hopes and fears of the great mass of men better than the scholarly Seward or the courtly Francis Granger. He dicl. it is true, lend countenance to bribery at the polls, but this was a folk-way with the Englich-speaking peoples more accepted in his day than ours: when he had become the powerful WVarwick of the state, he refused illicit profits for himself and had the confidence of honest men. His keen concern for popular opinion as to the policies of government. though the leader of a party not distinguished for democracy, shows how far hacl been the progress since the days of Jay and Hamilton and Colonel Varick and Judge Benson, when the mob were not consulted, and insolence went unrebuked.

By I 833 Weed had come to realize that if ever the Regency could be put down it would have to follow from the closest unity among its divers foes. Masonry had lost so many lodges that it now seemed a harmless thing indeed, anc a party to combat it had become quite useless. ${ }^{1}$ while the name and the weird lingo of the blessed spirit, which

"The poor were almost all against us before, and this course [of championing the Bank] will make them unanimously so," Weed to Francis Granger, Nov. 23, 1834. Granger Mss.

1 The statute of limitations made it futile to continue seeking for convictions in the Morgan case. 
still now and then appeared in its pronouncements, was offensive to many National Republicans. In consequence, "the Evening Journal went diligently and zealously to work organizing the elements of opposition throughout the State into what soon became the "Whig party." ' This name, thought to be so apt for those who criticized "King Andrew." and so bound up with the triumph of the Revolution as to be almost synonymous with "patriot," was first suggested for the united opposition by Colonel Webb. in his paper, the Couricr and Enquirer. It was strongly recommended, at a party gathering, by Philip Hone, the former mayor and the leader of polite society in the city of New York. gained acceptance by April, I834, and was used in the municipal elections of that month." The name had never disappeared from party controversy, and had been employed by Federalists and Jeffersonians, though chiefly by the latter. It had been affixed to newspapers and clubs and party tickets: ${ }^{3}$ and formally assumed by "Nationals"

'T. Weed, Autobiography, p. 425.

"T. W. Barnes, Memoir of Wecd, p. 48 ; B. J. Lossing. The Empire State (Hartford, 1888), pp. 477-478; A. Johnston in Lalor's Cyclopedia of Political Science (Chicago, I882), vol. i, p. 1103 . The honor of christening the party was also claimed by Philip Hone; see his Diary, vol. ii, pp. 34. 42; F. W. Seward, Life of Sezward, p. 46 . Lossing errs in the date. Nathan Sargent, in his Public Men and Evcnts (Philadelphia, 1875), vol. i, p. 262, claims credit for suggesting the name, and probably had much to do with its acceptance in Pennsylvania; but comyare C. McCarthy, "The Antimasonic Party," p. 459.

${ }^{3} \mathrm{I}$. Thomas, History of Printing in America (Worcester. ISIo), vol. ii, pp. 517-524. A pamphlet, Report of the Corresponding Committee of the New York Whig Club on the Communication of the "United Whig Club" Referred to them; Together with the Resolution of the New York Whig Club thereon (N. Y., I 809), discusses a broadside of the United Whig Club, N. Y., March 28, I809 (in N. Y. Pub. Lib.), which was issued by the old Burr faction. T. F. DeVoe, The Harket Book (N. Y., I862), vol. i, p. 299, mentions the use of the name by Anti-Federalists in 1793 , and Jonathan Cooley, in a pamphlet, $A$ 
and Anti-Masons, it seemed at last to exempt them from the state reproach of Federalism.

The charter elections in New York city attracted much attention, as for the first time the voters could express their choice directly as to mayor. Cornelius W. Lawrence, a merchant, had been named as a candidate by Tammany, though in standing for the policies of General Jackson he was considered recreant to the interests of his own class, while Gulian C. Verplanck. who had left the Democratic party after their attack upon the bank, had been selected by the Whigs. On the three days of election the merchants were tireless in their exertions; many closed their stores at noon in order to give more time to "the great business of reform at the polls," though some threatened with dismissal those of their clerks or workmen who openly campaigned for Lawrence. ${ }^{1}$ In the late afternoons they gathered in the Exchange to listen to reports, and vied in their huzzas with those of Jackson men who congregated in the streets. The Whigs secured the common council, and out of some thirty-five thousand votes they lost to Lawrence by about two hundred only. Such a demonstration of their power was considered as an earnest of greater fortune in the future, and thousands came together for a fête at Castle Garden, where three pipes of wine and forty harrels of beer were drunk in celebration." One hundred

View of Governor Jay's Administration (Goshen, I80I), p. II, by the Republicans. The latter party in the campaign of I8Io sometimes used the designation "Independent Whigs" (see $N$. Y. Journal, April 24, 28, I8Io), and, when in I8I3 Federalists were suspected of British sympathies, the name was popular again; see Address in Albany Argus, April 9, I8I3, and Richard Riker to P. R. Livingston, April II, I8I8, in Emmett Mss., N. Y. Public Library. An example of Federalist usage is found in a pamphlet. An Appeal ro the Old Whigs of Massachusetti: (Boston, 1806 ).

1 The Man, March 29, April 1, IB,31.

${ }^{2}$ Philip Hone. Diary. vol. i, w. 4,-68. 100-101. I01. 
gums were fired in Albany at the news: Buffalo made a gay affair with salvos from the battery and illuminations; Orange County Whigs gathered in great numbers in the town of Goshen: there was a general festival of hope among their fellow partisans throughout the state, as well as elsewhere. ${ }^{1}$ It was, they said, the Lexington of a new war against aggression. ${ }^{2}$

The new mayor's wealthy friends expressed their sympathy rather than congratulation on his coming to the office by the suffrages of the ignorant and unwashed rabble, and when somewhat later, on following the ancient custom of receiving New Year calls, he was forced to hick his doors against a friendly mob who sought to "use his hunse as at Five-Point Tavern." gentlemen shouk their heads in sorrow." They grieved because democracy had brought in not only vulgar manners, but umbounded ignorance as well. and, as in the bank affair, a reckless enmity to property and business. Where is the power, mournfully inquired Philip Hone, " which can bid the delicate machinery of individual credit and public confidence to resume its harmonious functions when once deranged and put out of tune by the hands "ff ignorance and misdirected power?" 3

The Whig hopes that were centered on the fall elections proved dehusive. The Democrats were not insensible that new "huzza strength" had been developed by the opposition in all its fulminations on the tyranny of General Jackson and the sycophantic flattery that he received from his supporters in New York state. The rejuvenated party, they realized. was held together by a common economic theory agreeable alike to the business men, the manufacturers, the

\footnotetext{
'Hone, op. cit., vol. i, p. 10.3.

?D. S. Alexander, Political History, vol. i, p for.

- Philip Hone Diary, vol. i. p. 241.
} 
staple farmers and the millers of the western counties, all uf whom desired a government faith ful in protecting credit and energetic in developing the natural resources.

Yet the politicians of the Regency apprehended quite as clearly that dissension might be sown between the AntiMasons of the west. whose late crusade had had its democratic elements, and the Federalists of the eastern cities. cool conservatives with antique prejudice against those really powerful persons, the Toms, the Dicks and the Harrys. They realized that a broadside of invective against the Whigs would arive the parts to closer union in a common feeling of resentment; so they struck their sharpest blows against their eastern enemies and poured their pity on true Anti-Masons, the honest stalwarts, who had been cheated by the faithless IVeed and Granger, when in 1832 the Siamese-twin electoral ticket would have sacrificed their strength to Clay had victory allowed. Let none of those deluded enthusiasts who had once been Republicans presume that their Federalist leaders cared a straw about the blessed spirit.

If [they said] the democratic Anti-Masons will take the trouble to make a list of the state senators and representatives in Congress, and to the State Legislature, who have been elected by their votes, we venture to predict that they will be astounded by the very inconsiderable number of their own class, who have in these respects found favor in the eyes of their own party. It is in perfect keeping with the aristocratic feelings of their federal allies, to confine the democratic Anti-masons to the enjoyment of town offices, whilst they themselves are pernitted to fill the high places within the reach of the Antimasonic rotes. ${ }^{1}$

'Address to the Republican Voters of the State of New York, drawn up at the state convention in 1834 . by John A. Dix and others, in Albany Argus, Extra. Sept. 14, 1834. 



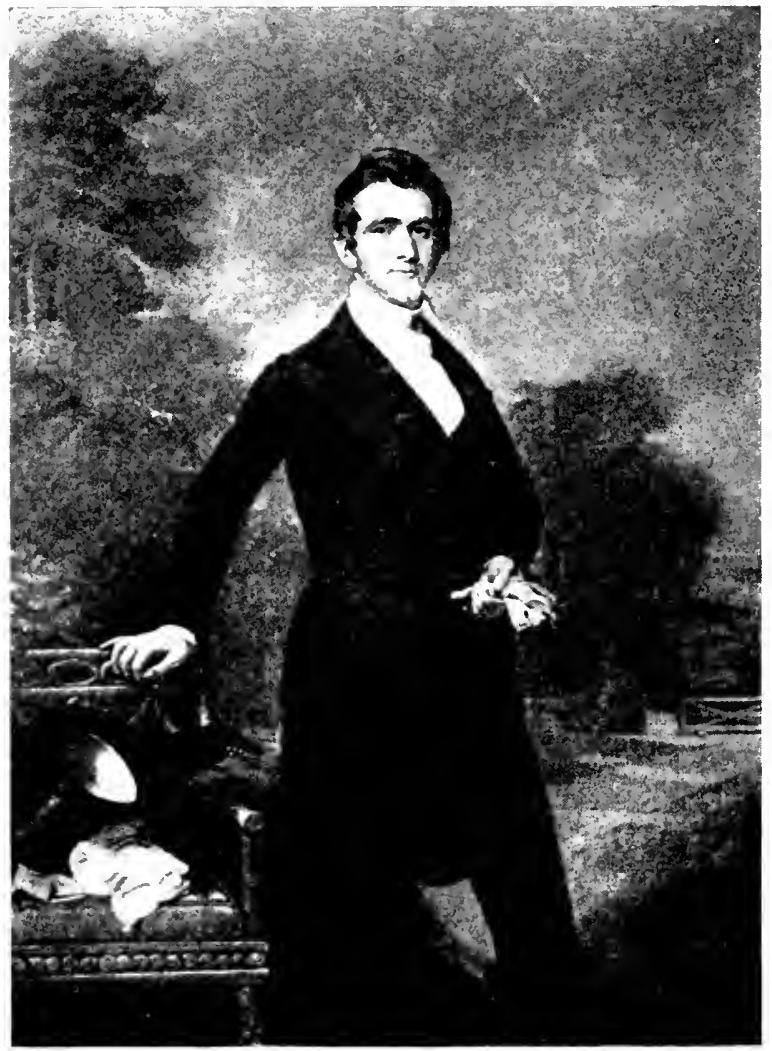


This adroit cajolery doubtless was of some effect, but it is not to this that the Denocratic victory must be attribnted. The argument with Andrew Jackson had rubbed and frayed the patience of Nicholas Biddle, president of the Bank of the United States, till by the end of 1833 , in a rash temper, he determined to let the people suffer with the bank, by withholding loans, especially in New York, whose Congressmen had cast their votes against him. The bank's wn friends could not defend this new manœuvre, and its enemies could ill conceal their glee at the general sense of wrong. Governor Marcy got the legislature to appropriate six millions, as a special credit for state banks, the very promise of which so stabilized the markets that the IVhigs could rail at this measure, which they dubbed the "Monster Mortgage Bill." with only half a heart. ${ }^{1}$

As the public feeling grew during the summer of $18_{34}$, the prospect of the IVhigs grew darker. They nominated the young senator William H. Seward, to the profound astonishment of Auburn, his home town, and the derision of the Regency; who poked fun at the youthful John Doe. candidate for governor." The contest went again for Marcy, who had been renominated, and seven senators of eight elected were Democrats. Thurlow IVeed, who on the declination of Gulian C. Verplanck, had suggested Seward. was so disheartened that he made some plans to move to Michigan. ${ }^{3}$ He stayed but to encounter fresh perplexities.

It will be remembered that for several years after i 806 . Rufus King and other Federalist leaders had found impla-

${ }^{1}$ W. H. Seward, Autobiography, pp. I53. I54. It was not necessary to draw on this fund, J. D. Hammond, Political History, vol. ii, p. $44 \mathrm{I}$.

${ }^{2}$ Address in Albany Argus, Extra. Sept. 14. 1834 ; see also F. Bancroft. Life of William H. Sezward (N. Y., 1900), vol. i, p. 54 , and E. E. Hale, Jr., Sezward, pp. Iro-nz.

${ }^{3}$ E. E. Hale, Jr., Seward, pp. I I0, II 3. 
cable opponents in the Irishmen. ${ }^{1}$ These immigrants had cume in greater numbers in the hard times after Waterloo, bringing wives and children oftener than was the case with ther racial groups," and in the early "twenties there came more. many of them seeking work upon the Grand Canal, along which they ultimately settled. By i 829 there were thirteen Catholic churches in the state, of which five were in New York and Brookly1 and seven in the towns along that waterway." During the next decade the number of their parishioners more than doubled." Thrift and sobriety are not the outstanding virtues of the Irishman, and he was soon accused of adding far more than his quota to the burden of crime and pauperism that New York city, in particular, had to bear. ${ }^{5}$ It was there complained that the cost of its almshouses. bridewell and penitentiary was more than half caused by the foreign element. ${ }^{6}$ But this condition was not confined to the metropolis: in Wayne and Niagara counties there were protests, and in Rochester the overseer declared that seven-eighths of those who sought relief had come from Europe. ${ }^{7}$

'See supra, chapter iii.

"W. I. Bromwell, History of Iinmigration to the United States. pp. 13, I4; Edward Young, "Special Report on Statistics of Immigration." with Ninth Census. This was despite Great Britain's attempts to limit emigration by law.

' J. G. Shea, History of the Catholic Church in .1merica. vol. ii. pp $[81,204,205$. These of course were placed among three million Protestants, ibid., p. 495 .

t Commons, itc. vol. i. 1. +13

- L. D. Scisco, Political Katia ism in Vea link State, p. 20.

- The state enacted that any ship-master who knowingly brought in a convict immigrant should be fined or imprisoned, N. Y. Laws of 1830 , Chapter 230, and N. Y. Assembly Documents, 1830, No. 260, quoted by Scisco. Many citizens now wished to apply this provision likewise to paupers.

'J. B. AcMaster, I/istory of the t'ople of the l'nited States $\mathrm{N}$. Y.. r883-), vol. vi. p. 427. 
In reflection of the contest which had recently been waged in England over giving Catholics seats in Parliament, clergymen and others in 1830 were beginning to inveigh against the menace of the Pope. Here was an alien church, they said, with alien loyalties, supported by a clannish people whe refused to adopt American ways, except to insist that in a land of liberty they had a right to do as they might please. Newspapers began to warn their readers of the danger in extending citizenship and the right of holding affice to such a separate people. ${ }^{1}$ Considering the disparity in their objects of allegiance, and the gross and patent inequalities in standards of necessities and comforts." which gave such gloomy prospect of continuance, here seemed to be the beginning of separate social castes, which yet, with universal suffrage, enjoyed political equality. Antagonisms such as these awaited only organization to make themselves the motives of effective force in politics.

In 1834.5 . F. B. Morse, the artist, who had recently returned from Europe, announced that in Vienna he had discovered a propaganda for forwarding the Roman Church in the United States, and published letters calling on all patriotic men to stand against the growing power of the hierarchy in our political affairs. ${ }^{3}$ Riots and violent en-

'See quotation in Mc.llaster, vol. vi, p. 85.

${ }^{2}$ Even among the Catholics, it was said, there were some "who dir not wish to be annoyed by the presence of an Irish mob," among which their servants were to be found, and who built a little church for their own use. Aristocracy in America, From the Sketch-Book of a German Nobleman, edited by F. J. Grund (London, I839), vol. i, p. 208.

: Morse had long shared with his friend Lafayette the dread of the Catholic Church as a political influence: see E. L. Morse. Samuel F. B. Morse, Letters and Journals (N. Y., I9I4), vol. ii, pp. 35-37. 330. His articles were first published in the $N$. Y. Observer during January and February, 1834, and the following year were printed in a small volume entitled Foreign Conspiracy. This work passed through seven editions. Morse regarded the St. Leopold foundation, referred to in the text, as a semi-political instrumentality of the Holy Alliance. 
counters "between the Irish and the Americans" in that year gave a fiercer aspect to the controversy, ${ }^{1}$ and there soon was formed a Protestant association, which naturally stirred up more rioting, till on one occasion it was necessary to call out a regiment and troop of horse to put it down. ${ }^{2}$ During March, 1835 , in some wards caucuses of nativists were held to draw up tickets wholly on this issue, while at a public meeting they considered "means to counteract the undue influence foreigners now possess over our elections," and eulogized the Revolutionary fathers. By October they had perfected a city urganization supposed to be nonpartisan as to the general issues of the state and nation."

Nevertheless the movement was regarded as a hostile one by Democrats, who since 1827 . when universal suffrage was at last in force, had assiduously cultivated immigrants, establishing a " naturalization bureau" where aid and coun sel had freely been dispensed. In Tammany Hall special meetings were arranged for Irish. French and Germans. and the sachens put some influential lrishmen upon their local tickets, remembering others in the disposition of the humbler posts in departmental offices and in labor contracts for the city. In the middle 'thirties, one-third of the eighteen thousand who made up their voting strength were said to be of foreign birtl.." In $18+1$ it was charged against Van Buren, by one who thought he was possessed of special information, that the President had systematically intrigued to draw support from Catholic priests. ${ }^{6}$

${ }^{1}$ Philip Hone. Diary, vol. i. p. Ioo.

2 Jbid., and L. D. Scisco, op. cit.. p. 22.

${ }^{3}$ Scisco, loc. cit.

'See account of meeting of Adopted Citizens, Dennis McCarthy, chairman, in the Man, March $3 \mathrm{I}$, April I, 5, I834.

${ }^{5} \mathrm{G}$. Myers, History of Tammany Hall, pp. 87, 119, 139-140, $15^{1-15+1 .}$

BJames A. Hamilton, Reminiscences, p. $3 \mathrm{I} 4$. 
On the other hand, most Whigs were of a station in society where contrary opinions and practices were certain to prevail. I contemporary book preserves a conversation which nay well illustrate with what surprise in such exclusive circles any sympathy with poor foreigners was generally received:

"Why, what singular notions you have. Mr. !" exclaimed the lady: "I hope you are not an advocate of the rabble?"

"Certainly not: I represent the people of my township."

"You do not understand me. When I speak of "the rabble," I mean those who have no interest in our institutions,--foreign paupers and adventurers, and particularly the Irish. I have no objection to liberty in the abstract. I think all men, with the exception of our negroes, ought to be free: but I cannot bear the ridiculous notions of equality which seem to take hold of our people. ...."

"I have always been a democrat."

"Oh! You are a dem-o-crat, are you?",

It was to be expected that Whigs would offer their encouragement to those whom they could well consider as allies. ${ }^{2}$ In some districts they deferred entirely to the nativists, while in others they engrafted anti-foreign resolutions

${ }^{1}$ F. J. Grund, Aristocracy in Almerica, vol. i, pp. $250-25 \mathrm{~T}$.

"'In the meantime the Native American Association made up of different parties, and having no other bond of union than the total exclusion of foreigners from office, have had a meeting and nominated an Assembly ticket, of whom I do not know an individual; but I like the ostensible object of this association, and am of an opinion that times may come and cases occur in which this influence may be faror. ably exercised," Philip Hone, Diary, vol. i, p. i69. Hone doubtless reflected the sentiment of his class when he complained that "These Irishmen. strangers among us, without a feeling of patriotism. or affection in common with American citizens, decide the elections in the city of New York." ibid., p. 184. 


\section{ARISTOCRACY IN THE POLITICS OF NEW YORK}

upun their own.' A fusion was effected with success on the nominations for the conmon council in 1836 , and the patronage pertaining to that body was appropriately distributed. At the general elections in November, the nativists presented a congressional ticket including good Whig names. which the older party in a caucus formally endorsed in lieu of separate nominations, and in 1837 , by complete co-operation. they succeeded in depriving Tammany of the chief magistracy of New York city. In the hour of triumpli the weaker organization was absorbed: " indeed, it was the Whig encouragement which first had made it formidable. The latter party's gain consisted in some religious enthusiasts and some workingmen who worried lest wages be depressed loy the influx of cheap labor: ${ }^{3}$ but chiefly they had benefited by a rallying cry for their own party.

The up-state Whigs were less stiff-necked in their conservatism than their colleagues in the city. Weed's attitude upon the bank, we have remarked; and he and Seward. together with their ally. Horace Greeley, who soon came into prominence. disliked the movement of proscription launched against poor foreigners. Governor Seward, a few years later. defiantly proposed a scheme which was interpreted as calling for a vote of money to the Catholic schools.

'L. D. Scisco, P'olitical Natizism, pp. 27-28. They refused support to Morse as Native American candidate for mayor, because he was a Van Buren Democrat.

'Ibid., pp. 29-31.

'This was not the attitude of most of the old Horkingmen's Party: their leading organ, now the Man, was sympathetic toward the Irish. e. g. on March 31, June 24, 1834, June 23. 1835 . The nativist movement abated after 1837 for a time due to the reduced immigration following the panic: see Commons, stc. wol. i, $1,+1,3$.

4.. The political leaders of the Native American party are opposed to naturalized citizens solely on the ground that these eitizens do not uniformly vote on their side." O. A. Brownson, Essays and Rerieats (N. Y.. 1852). p. 426 . His comment was written in 1844 . 
His supporters in the great metropolis were incensed, drew up statements in their meetings and wrote him stinging letters; ' when the bill was signed, though pruned of most of its offensive features, they threw party discipline aside and were nativists again. This was irritating to Seward, Weed and Greeley, who had hope of some support from Irishmen who lived along the Grand Canal, though even in those towns they met with disappointment."

The internal improvement policy. Seward declared, required unskilled labor quite as much as capital, and nothing should be said or done to check its flow from Europe." Dotthtless his concern, as well as that of Weed and Greeley, that foreigners should be received on equal footing with nld settlers, sprang from an honorable and sympathetic spirit, and when a Whig legislature passed the Registration Bill, which made it difficult for such new voters in the city of New York, he signed it with unfeigned reluctance." and

IF. W. Seward, Lifi of Scatard, vol, i, up. t71-7tz; H. Greeley. Recollections of a Busy Life, p. 129.

"Julius Winden, "The Influence of the Erie Canil," quoted at length by A. B. Hulbert, Historic Highways, vol. xiv, pp. 176-177; see also A. B. Johnson, Thoughts on the Vecessity for, and Actions of, The Approaching State Conicntion (Utica, I846), pp. 25-31.

: Messages from the liocernors, vol, iii, pp. 727-728.

* This right hand drops off before 1 do one act with the W'hig or any other party in opposition to any portion of my fellow-citizens, on the ground of the difference of their nativity or their religion," Seward, Works, vol. iii, p. 388; 11. Greeley, Recollections, p. 313. Greeley favored the bill. In 1834 , the Whig common council in New York city considered a proposal to put a similar measure into force, but it was objected that it was contrary to the constitution of the state for them to do so; see the Man. April 12, 15, 17, 1834. Seward and Weed were both active in "Repeal meetings," $i$. $c$. to express sympathy with Daniel O'Connell's fight in Parliament for the repeal of the Act of Union, and the establishment of home rule for Ireland; see F. W. Seward, Sczard, vol. i, pp. 697-698, and T. W. Barnes. Memoir of H'eed, pp. 114-115. 


\section{8}

ARISTOCRACY IN THE POLITICS OF NEW YORK

was glad indeed to see it soon repealed by Democrats. ${ }^{1}$ When the Whigs were beaten in $1 \&_{44}$, followers of these leaders charged it to the folly of the nativists, while their critics in the party claimed that they had themselves brought (n) humiliation by their fatal friendship for the foreigners and abolitionists. ${ }^{2}$

The last-named preference was imputed to the leaders in the rural counties, but very seldom to the wealthy merchants of New York, who thrived on trade connections with the south." While the great Whig papers of the city were accused of stirring up anti-negro riots. ${ }^{4}$ their inland partisans were lecturing on the crime of slavery. Many abolitionists in the New England regions of the state suppurted Seward in $1838 . "$ A letter of inquiry was addressed to both the candidates, and though Seward's reply was not considered satisfactory, it was less objectionable to his questioners than Marcy's, and his anti-slavery friends were vindicated in their faith by his firm stand with Virginia after his election. Luther Bradish, of Malone, whom the Whigs had nominated for lieutenant governor, came out strongly

${ }^{1}$ F. Bancroft, Life of Sezard, vol. i, p. 117.

${ }^{2}$ F. W. Seward, Seward, vol. i, p. 334: H. Greeley, The American Conflict (N. Y., I864-I866), vol. i, p. I68. "I assure you we have no strength to spare, especially since Charles King and other antediluvians of our party will not permit the Irish or the Dutch [Germans?] to vote the Whig ticket. Apropos, I am exceedingly indignant at this Native American movement, and the folly of our people in giving aid and countenance to disorganizers." Washington Huit to Weed, quoted in Memoir of II eed, p. 121.

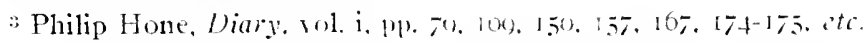

${ }^{4} N$. Y. Courier and Enquirer, quotei in the Man. June o, July 12. 1834; see N. Y. Journal of Commerce's comment on N. Y. Commercial Advertiser, June 20, I834, and the Man. July 17. I 834 .

${ }^{5} \mathrm{H}$. Wilson, Rise and Fall of the Slai'e Power in America (Boston, I872), vol. i, pp. 408, et seq. 
as an abolitionist.' A number of their Congressmen from western districts in the later 'thirties, like Abner Hazeltine of Jamestown," S. M. Gates of Warsaw," Philo C. Fuller of Geneseo, and Mark C. Sibley of Canandaigua," were well known as leaders of the movement, while even the Websterian Millard Fillmore then advocated freedom for the slaves within the District of Columbia and abolition of the trade between the states. ${ }^{.}$The Whigs were taunted in the West as being made up of " combined factions of Federalism, Abolitionism, and Conservatism," " but it was recognized that the country leaders were hardly as conservative as the "antediluvian" Federalists in New York city.

But the new wine of democracy had made sad havoc with the legal bottles of the eighteenth century; some witnessed the result with the sincerest consternation, while others welcomed it almost in ecstacy. Workingmen whose fathers had had no political existence, had come to have an equal share in sovereignty along with those who cherished manyquartered coats-of-arms: strong in numbers and in resolution, they had demanded that their fetters be struck off. and had seen with what alacrity their will was executed. Irishmen who had brought little with them to this country

${ }^{1}$ F. Bancroft, Life of Sezard, vol. i, pp. 7 r-72.

"Centennial History of Chautauqua County (Jamestown, rgo-4), rol i, p. $6 \mathrm{r} 2$.

- Bench and Bar of New York (N. Y., r 897 ), vol. i, p. 334.

' L. L. Doty, History of Livingston County, vol. i. p. 539.

'Ontario Messenger, Nov. 20, 1839.

'E. B. Morgan, Mr. Fillmore's Political History and Position (pamphlet, Buffalo, 1856).

'Ontario Messenger, Nov. I3, I839. They were charged with bargaining for abolitionist support, though they denied it; see Ontario Repository, May 6, I8.0. The Whigs even in the thirties suffered losses to the independent tickets; see letter from Francis Granger, undated. pp. 26-27, Granger Mss. 
380 AKISTOCRACY IN THE POLITICS OF NEH YORK

besides a high regard for freedom and equality had jauntily refused to pay the slightest homage to the " natural leaders of society," and had permanently cast their lot with those who formally professed a different set of principles. But this spirit of democracy had penetrated quite beyond the party with which it was associated, and, on the other hand. as we have seen, it had already forced out of that party certain elements that would not be imbued. Others were to follow. 


\section{CHAPTER XIII}

\section{Two Views of Vested Rights}

The Military and Civic Hotel, formerly located on the S. W. corner of Bowery and Broome Street. was a frame building of the olden time, not quite two stories high, and it appeared to have a friendly leaning towards the adjoining house, probably of long standing. Before entering the door, it was necessary to descend two or three steps below the pavement of the street to bring you on a level with the threshold. When you entered the door you would see that the Hotel was one of the most unostentatious of hotels in the world, for there was not the least appearance of aristocracy in the equipments of the bar, the unassuming landlord, or the guests to whom his services were devoted. Passing round the bar. you would find yourself at the foot of humble-looking stairs, lighter of evenings by a very humble-looking dark japanned lamp. . . . If you were desirous of seeing the temple of Loco-Focoism, and would go up the stairs, you would by ascending some six or eight steps, find yourself at the door of the sacred room. On crossing its threshold, you would find yourself under a low ceiling, and surrounded by walls of a smoky antique appearance. Two or four candles were wont to be stuck up around the room in tins attached to the walls. and, in the early days of the Loco-Foco party, two candles graced the table, until they were superseded by an embrowned lamp suspended from the ceiling. which sent up its columns of rich smoke. as if to indicate the aspiring fortunes of the Loco-Focos. There was a platform large enough for a small table and three or four chairs to stand on, and this humble enthronement was the only aristocratic or monarchic furnishment of the sanctorun. Yet it was here that true democracy was preached. . . . 
So writes the Recording Secretary, F. Byrdsall, in his Origin and History of the Loco-Foco Party, a tiny blackbound volume issued to the world in $1842 .{ }^{1}$

Those who now and then foregathered in this little "great room "were Democrats, distinguished for strict orthodoxy. They were enthusiastic partisans of Jackson in his assault upon the Bank of the United States, but felt that this was but a good beginning of a great crusade against all monopolies and chartered business institutions. They believed that their own party in its long control at Albany had forgotten its true principles, and that politicians in chartering scores of banks had sold the liberties of the people for shares of stock. The scandal of the Seventh Ward Bank. when thousands of such shares had been distributed, to each Tammany senator among the rest, was but a bit more glaring than the many others." "The cormorants could never be gorged," as Judge Hammond wrote; ${ }^{3}$ one had but $t$, glance across the pages of the legislative journals to realize how far the tendency had gone.' 'These banks but added to the public burdens; paper money, the reformers said, was hut a sign of fraud.

Individuals by special acts were granted their monopolies of receiving on deposit a quantity of hard-earned gold and silver. and then issuing to the public a mass of paper of face value greatly in excess of what it really represented in the vaults. And the few restrictions were disregarded; witness the bank at Ithaca where an investigation had disclosed hardly one dollar to redeem a hundred on a possible

${ }^{1}$ Pages 44-45.

${ }^{2}$ G. Myers, History of Tammany Hall. p. I15; the Man, Feb. 27, 1834 .

'Political History, vol. ii, p. 448.

"Cf. index in N. Y. Assembly Journal, 1834 ami 18,35; see also summary in the Man, March I, I834. 
demand. ${ }^{1}$ Then bankers solemnly explained the needs of credit, these critics were impatient. Credit, they replied, should rest entirely upon the reputation of the borrower. which anyone might learn; let the creditor beware. ${ }^{2}$ These views had lately found expression in the Evening Post. In March, 1834, it had presented a flattering review of Gouge's History of Banking - a work which argued to the point that. "The very act of establishing a money corporation destroys the natural equilibrium of society." ${ }^{3}$ - and had maintained that the government should take its money out of banks, institutions which produced more harm than grood. ${ }^{4}$ Admonitions from the other Democratic papers proved of no avail, and the Post, with its Utopian editors, was for a time disowned by the party. ${ }^{5}$

The Tammany Society was disturbel. The "antimonopoly faction," in March, I835, had wrested the control of a party caucus from the bankers, Gideon Lee and Preserved Fish." and might again prove formidable. The ticket. which the regular committee had planned to offer for endorsement at the county meeting in October, was not free from bankers, and a contest was expected. On the appointed evening, the committee and a company of their supporters early gained an entrance by a back door to the hall.

'Ithaca Chronicle and N. Y. Courier and Enquirer. quoted in the Wan, Feb. 20, March 20, 1834.

"F. Byrdsall, History of the Loco-Foco Party. pp. I48-149.

"W. M. Gouge, A Short History of Paper. Honey and Banking in the United States (Philadelphia, I833), p. 229. This book acquired infuence with the national administration, and its author is said to have suggested the Independent Treasury system; see 1). R. Dewey, Financial History of the United States (N. Y., 5th edition, I9I5), p. 235.

4 See comment in the Man, March I\%, 24, May 20, I834.

${ }^{5}$ 1. Y. Eu'ening Post, Sept. 19, 1835.

"G. Myers. "p. cii.. pp. II5-I20. 
and a bank president nominated as the chairman a wellknuwn bank director. But the upposition came in greater numbers, tore away the chair, placed within it a workingman who stood against monopolies, and claimed the meeting for themselves. The disgruntled leaders yielded to this force, and retired from the hall with their adherents; but as they left the building they gave a little vent to their enormous indignation by turning off the gas. The insurgents in their victory were not unprepared, for, having had some inkling of this stratagem, they had supplied themselves with candles and some "loco-foco" matches, then just coming inte use, so that by this weird illumination they brought to a conclusion the business of the evening. Next day the Courier and Enquirer dubbed the faction which had held the hall. the Loco-Focos, a name that never lost its prominence for ten years or more. ${ }^{1}$

The victory, however, was short-lived, for the committee, disdaining facts. gravely published that its candidates had been accepted, and the party discipline was such that ward committees dutifully followed: " the ligatures of selfinterest were drawn tight, and fears of extrusion from the party were awakened." : The protestants soon concluded that if their theories were to gain support by any organization, it would have to be their own, and consecuently at a formal gathering at the Military and Civic Ilotel, in January. Is $3^{\text {r. }}$ they took the name of "Friends of Equal Rights." It the same time they drew up a Declaration which, after due reference to the natural rights and duties of mankind, set forth their " uncompromising hostility to bank notes and paper money as a circulating medium, because gold and silver is the only safe constitutional currency:" likewise it condemned monopolies and vested

'F. Byrdsall, pp. 23-28: Niles Registir, Nov, $7,1835$.

"Byrdsall, p. 3I. 
rights, and declared that all charters of incorporation could be altered or repealed.' 'Two months later they put up their candidates for mayor and the common council, and in the spring election they polled almost half as many votes as did the Whigs, though Mayor Lawrence was re-elected. $Y$ et in all this they disclaimed the purpose of founding a new party. They were, they said, goud Democrats, more orthodox than the Tammany leaders; and, as it came about, these perfectionists were indeed the leaven which permeated the whole lump, and their very name at last was fastene! on the party throughout the nation."

" And now, gentle reader," quaintly writes the secretary. "you are requested to contemplate the glorious spectacle oi a little band of men contending against two great political parties for the sake of principles only." " It was made up largely of those undistinguished amateur political economists of robust conscience and unquenchable idealism who make a valuable constituent of society; their drastic criticism is wholesome, and for the questionable remedies by which they would reform the body politic, hard-headed men are forced to find a practicable substitute. Small grocers and shop-keepers who had felt the pinch of wholesale prices. together with mechanics who read books on Sunday, were most numerous, though there were some disgruntled officeholders, and at least a half-dozen physicians were important in their counsels. ${ }^{4}$

Though somewhat broader in its personnel, the LocoFinen movement had its impulse in the agitation of the

${ }^{3}$ Byrdsall, pp. 39-40.

${ }^{2}$ The independent ticket of the Loco-Focos drew off enough Demucratic votes to be in part responsible for the Whig and Native American victories in 1836 and 1837 .

Byrdsall, p. 50.

t The Man, .May 12, I834, and Byrdsali, passizi. 
Wirkingmen five years before. The old organization had heen bruken up in ${ }^{2} 8_{3} I$, as we have seen. and its member lirought into the Tammany Society. The sachems, in return, sent several Workingmen to Albany and one, Eli Moore a trade-umion presilent, to Congress. The hall was "pened now and then specially for gatherings of "useful citizens," "and "Workeyism" seemed absorbed. But the radicals had not been scothed into forgetfulness by all this hospitality. By I 834 they had come to meet sometimes intside the party temple, and there were comments in the press about a Military Hall Democracy, as well as that of Tammany." George H. Evans founded in their interest a penny paper called the $1 / \mathrm{an}$, which advised them to remain together: "workingmen," he said. "must not only become politicians, but they must minite as politicians." 3 They pledged the local Democratic candidates for office in the state to oppose the chartering of monopolies and to labor for a law prohibiting bank bills of less than twenty dollars, but all but four forgot their promise. ${ }^{4}$ The Workingmen were still loyal, and in 1834 . when hickory poles were raised, they sang as lustily as anyone the praises of the President. yet their tone was sometimes ominous:

Mechanics, Carters, Laborers,
Must form a close connection
And show the rich Aristocrats
Their powers, at this election

Yankee Doodle, smoke 'em out.

The proud, the banking faction.

None but such as Hartford Feds

Oppose the poor and Jackson."

'E. g. the Man. April 2. + 1834

"Ibid., May 16. 19. 22, 1834.

"Ibid., Ist number, Feb. I8. 1834 .

"Ibid.. May 17, 19, 1834: G. Myers, History of Tuminany Hall, np. 122, I31.

${ }^{5}$ The Han. March 25, 1834 . 
They were not much concerned in I 834 when the Bank of the United States attacked the credit of its rivals in the states; it was to them only "the old alligator eating the little ones." " Governor Narcy's six-million-dollar loan they grulgingly endorsed with an astonishing resolution:

Resolved, That, under the existing circumstances, the Mortgage Loan was needful to the State Institutions in order to paralyze the intended attack meditated by the British Bank. We, therefore, refrain from complaint. Still we believe that the act so direfully needed was a gross, flagrant, unconstitutional abuse of power-an act in turpitude like that of a gambler in desperate circumstances who blows ont his brains rather than see his ruined family. ${ }^{2}$

The Regency were welcome to make out of this what they could!

In the fall campaign the radicals were an element of much importance in the city, where Marcy's large majority was brought together with their help. But the Whigs consoled themselves with the shrewd observation that pure democracy would prove unpalatable to many respectable Democratic leaders.

The agrarian party, who have had things pretty much their own way [wrote Philip Hone] will not stop at Martin Van Buren. . . The battle had been fought upon these grounds of the poor against the rich, and this unworthy prejudice, this dangerous delusion, has been encouraged by the leaders of the triumphant party, and fanned into a flame by the polluted breath of the hireling press in their employ. . . " Down with the aristocracy!" mingled with the shouts of victory, and must have grated on some of their own leaders like the croakings of an evil-boding raven. ${ }^{3}$

1 The Man, March 29, I834

"Ibid., May 17, 1834.

"Diary, vol. i, p. II9. 
Whatever is, must prove its right to be-such might have been the Nihilist maxim of the Loco-Focos: ${ }^{1}$ it was, as Hone had said, a restless day for Democratic leaders. Evans, toiling in his narrow, murky office at No. I Mott Street, as editor, compositor and pressman, was one of the most influential men in New York city. Every issue of the Man contained a challenge. It deprecated aristocracy within the army, and published articles against West Point as a useless institution which fostered swaggering bravos. His paper was consistently and strongly anti-clerical; he desired to place church property upon the tax list, and would rid the prisons of their chaplains."

In this he but continued what had been begun by Miss Wright and R. D. Owen. The former in the later 'twenties had suspected that a union of church and state might be effected by the Protestant clergynen. ${ }^{3}$ The controversy as tu carrying mails on Sunday. she considered the beginning of a bitter contest, and in her lectures organized Christianity was analyzed with little sympathy. The address which Owen had delivered On the Influence of the Clerical Profossion, ${ }^{4}$ had been exceedingly offensive to the pious, and when he and Miss Wright elaborated all the points of atheism in their newspaper, the Free Enquirer." there was con

"Professor Edgar Dawson, in an article entitled "Beginnings in Political Education," presently to appear in the Historical Outlook. states his opinion that it was apprehension of fearful consequence of the ultra-Democratic movement that led authorities to introduce the formal study of politics into the schonls in the late thirties.

"The Man, Feb. 26, May 14, June 12, 18, 27, 1834 .

${ }^{3}$ S. A. Underwood, Heroines of Free thought (N. Y., I876). p. 213. Miss Wright became Mme. D'Arusmont in I833, but continued to be cilled Fanny Wright by the press. On her life see Memoir of Frances Wright (Cincinnati, 1855).

"In the Hall of Science. Oct., I831 ( $N$. Y.. I831).

N. Y., I820-1832. 
siderable comment on the infidel agrarians who preached subversion of our institutions. ${ }^{1}$ Thomas Hertell, a radical, whom the Democrats in New York city had sent to the legislature." after arduous debate finally carried through the assembly a bill providing that, "No person shall be deemed incompetent as a witness in any court, matter or proceeding, on account of his or her opinions on the matter of religion," but the senate could not be convinced. ${ }^{3}$ It

'See especially Abner Cunningham, An Address to the Consideration of $R$. D. Owen, Kneeland, Houston, and Others of the Infidel Party in the City of New York (N. Y., 1833), which tells of the tragic cleath of infidels in scores of cases, chiefly by violence; see also L. J. Everett, Exposure of the Principles of the "Free Enquirer" (Boston, I83I). The Workingmen in other sections of the state had formally repudiated these religious views as forming any part of the party creed (see Utica Mechanics' Press, July I7, 1830), and the atheistic leaders themselves had tried to keep the religious question free of politics (e. g. Working Man's Adr'ocate, Jan. 16, 1830). Yet those who found their religious opinions according to the Age of Reason were mostly members of the faction.

2 J. R. Commons, cte., History of Labour, vol. i, p. 267.

" N. Y. Assembly Journal, I835, pp. 49, 81, 747, 870; 1836, pp. 130, 137. 149, etc., etc. It passed the assembly Jan. 31, 1837: ibid.. p. 184. Scores of petitions were received on this matter. A specimen of Hertell's argument as to legislation on opinion is worth quotation: "Human thouglets are impressions made on the mind by evidence presented through the medium of the senses and the intellectual faculties. Man cannot avoid thinking, to a greater or less extent. He cannot resolve what he will not think, without instantly seeing the folly and the futility of the attempt to execute it; for then he will think the more. Human thoughts, therefore, are involuntary and irresistible. Man cannot govern his thoughts or restrain them. How can the legislature derive authority to do that which their constituents have not the power to do?" The requirement of the law which he wished to supplant was professed "belief in the existence of a Supreme Being and that he will punish false swearing." When it was charged that without religion there was no morality, Hertell replied that "rogues seldom professed unpopular creeds," and that infidelity was rare in Sing Sing: Thomas Hertell, Rights of Conscience Defended ... (N. Y., 1835). 0p. 7, I6, 29. $3 \mathrm{I}, 34,5 \mathrm{l}$. 
was a Demucratic legislature which ended the remuneration w1 the chaplains: ${ }^{1}$ it was in Tammany Hall that the " intidels " held their Sunday exercises." When a petition from the central counties was presented to the legislature, w. exclude clergymen from the schools, it was observed that the signers were nearly all of them Democrats." Under all these circumstances, it was not surprising that the Whigs could claim to be defenders of religion from the threatening " fannywrightism " of their enemies."

As long as the old Democratic leaders were willing to play at radicalism, the mechanics gave them their political allegiance, while they worked for an improvement in industrial conditions through trade unions. When in 1835 and 18,36 the active trading market had forced prices to new heights, many strikes were called throughout the state, by tailors. caulkers, iron-workers, carpenters and others, in hope of readjusting wages on a fairer scale." But a rude shock came to those who placed their hopes in combinations. At Geneva, in Ontario County, the journeyman shoemakers had formed a union and demanded higher compensation. A suit at law was instituted to test their right to do so, and after an appeal it came to trial in the supreme court of the state. There in ${ }^{8} 835$ the union was adjudged to be a confederacy wrongfully to injure others, and hence a misdemeanor. " "If journeyman boot-makers." asked Chief Jus-

'N. Y. Laws, I833, chap. 87; see also Moulton's Report in the New York Legislature Against the Employment of Chaplains (N. Y., I833).

${ }^{2} N$. Y. Journal of Commerce, July I6, I 834 .

'Springfield Republican and Journal, Feb. 17,1838 .

'Byrdsall constantly defends his wing of the radicals from this charge. The disestablishment controversy in New England, of course, had its bearing on these later contests.

${ }^{5}$ N. Y. Evening Post, Feb. 11. 12, 24, 27. March 2. 5, 7. 18.36.

- People as. Fisher, et al., I4 Wendell ro (1835). 
tice Savage, "by extravagant demands for wages, so enhance the price of boots made in Geneva, for instance, that boots made elsewhere, in Auburn, for example, can be sold cheaper, is not such an act injurious to trade?" According to the court the New York law, in as much as it accepted the old English custom, prohibited all price-fixing unions, though eleven years had passed since they had been legalized by statute in England. ${ }^{1}$ A few months later, in New York city. Judge Edwards took the same view and twenty tailors were sentenced to a heavy fine. ${ }^{2}$ Excitement ran to a high pitch and riots were narrowly avoided by the vigilance of the police.

The Evening Post prononnced it all a travesty of justice: it said that under this interpretation any temperance society, as a conspiracy against the rum trade, was illegal. Why should there not be "labor companies" as well as those of capitalists for manufacturing? The law must speedily be changed." But the Whig newspapers of the city expressed themselves as gratified that the majesty of the law had been vindicated. The American was glad to see a pause t" those destructive tendencies traceable to Fanny Wright. and the Star and the Commercial Advertiser took the same view. ${ }^{*}$ Many of the strikers were a dirty. loutish, foulmonthed set, remarked the Courier and Enquirer (apparently with much truth), and Judge Edwards had done gond service to the country (which, as the logicians say. was a nom scquitur)."

${ }^{1}$ The decision was based on a phrase of the English common law, which had been written into the statutes of New York in the codification of I829. See comment of N.Y. Courier and Enquirer, Narch 8, I836.

"The charge is found in full in N. Y. Journal of Commerce, May 31.

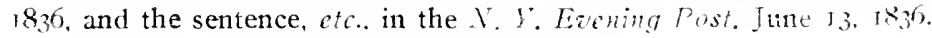

"Evening Post, May 31, June I, 6, 7, I836.

4 All of June 15,1836 .

5 May 31, I836. 
If the law was to be changed, the workingmen decided, it must be done through party politics. On june $13,183^{\circ}$, at a great meeting in the park, it was determined to form a "separate and distinct party, around which the laboring classes and their friends can rally with confidence." and a state convention was summoned to meet in Utica the following September. ${ }^{1}$ I committee soon published an address calling for the election of delegates, and declaring against chartered combinations, prison labor. "forced constructions of the statutes" and reliance on the precedents of British courts. They complained "that the leaders of the aristocracy of both the great political parties of the state. . have deceived the workingmen by false pretences of pulitical honesty and justice." " The Loco-Focos found themselves so heartily in accord with these sentiments that they joined the Workingmen at the Utica convention. and a coalition was effecter in the name of the Friends of Equal Rights. ${ }^{3}$

The philosophy of politics professed at the convention was one of rights, natural and equal, and never vested by a special act of government: " no man has a natural right to commit aggression on the equal rights of another, and this is all from which the law ought to restrain him." ${ }^{4}$ The state. then, was the individual's weapon of defense, not his instrument of construction. and certainly not existing for itself. Yet they charged the state with the responsibility for free and equal education: also, for a little time, it might be called upon energetically to redress the wrongs which it

${ }^{1}$ N. Y. Eirning Post. June 14,1836 .

${ }^{2}$ Ibid., July 23, 1836 .

"Byrdsall, History of the Loco-Foco Party. chap. v. It was birst called a "convention appointerl ly the farmers, mechanics, and others friendly to their views." p. 7 I.

"From the Declaration of Rights, ibid., p. 68. 
had fostered. All wealth they thought to be the accumulation of surplus labor, and should remain available to the producing classes. ' They took comfort in the spectacle of the decline of feudal privilege that marked the times in England, and were hopeful that the golden age throughwht all Christendom could be restured.

Colonel Young, whose sharp rebukes to his associates in the state senate had won him the regard of Equal Rights men, was invited to become the candidate for governor. He refused. but with such a strong endorsement of their principles that they used his letter as a tract. He knew, he said. that these principles were steadily advancing in the state, and wished them all success, but feared that in adopting a separate organization they might retard their progress. ${ }^{2}$ They did not follow his advice, but took a less distinguished leader. In the fall campaign they pledged their candidates for the assembly to work for the repeal of the restraining law and thus abolish the chartering of banks by special acts. and for the exclusion from circulation of all bank notes of less than ten dollars in value. They were obliged to vote for the election of judges by the people, and for short terms in office: for the repeal of any and all laws forbidding working-people to combine to fix their wages: and for an amendment making more effective the mechanics' lien law. They were also to obstruct all measures tending to restore imprisonment for debt: and to labor for a "more extended. equal and convenient system " of public school institutions."

The Equal Rights men took a hand in national affairs by submitting their "Declaration of Principles" to Martin Van Buren and Colonel R. M. Johnson, the national can-

Byrdsall, pp. 59, 62, 75.

"Ibid.. p. 62: J. D. Hammond, Political History, vol. ii. p. 457. They did nominate Isaac S. Smith, a Buffalo merchant.

"Byrdsall, p. 88. 
didates in the campaign of 1836 . 'The former's answer they declared evasive, but the latter's was deemed all they could desire. Colonel Johnson had long been a favorite with the workingmen. His efforts on behalf of debtors, and his views of banks in general, were most satisfactory, and they had frequently expressed the hope that he would be the nominee for President. ${ }^{2}$ Now they would gladly have cast their ballots for him as the second officer, while withholding them from his more illustrious colleague; but of this the electoral system did not admit, and in consequence they came out for a constitutional amendment that would allow the popular election of President and Vice President with separate indication. ${ }^{3}$

The Evening Post sent forth its daily fulminations against stockjobbing and monopolies. It took the Jeffersonian view that laws should not be framed for more than twenty years, and maintained that this should certainly apply to charters of incorporation. At any rate they should be freely altered when the public weal demanded it." The editors' enthusiasm in this matter sometimes befogged their sense of fitness; when Chief Justice Marshall, the steward of the Constitution, died in 1835 , they remarked that on the whole his removal was a cause of rejoicing." They gave tables of the profits of insurance companies, and expressed a deep abhorrence of these gambling enterprises."

1"A Kentuckian," Biographical Sketch of Col. Richard W. Jolnson (N. Y., I845).

2E. $g$. the Man, Feb. 26, 27, March I0, April 17, 23, 29. July ro, 22, etc., 1834 .

${ }^{3}$ Byrdsall, pp. 58-60.

${ }^{3}$ Evening Post, Jan. 7, 11, Feh. 19, June 15, 18.36.

"Ibid., July 8, I835; see comment of Philip Hone. Diary. vol. i, pl. I 4 S- I 49 .

- Post, June 16, 1836. 
They classed all banks with lotteries, and exhibited a holy passion in delivering their sentiments on the currency, such as marked the later greenback and free-silver days. So William Cullen Bryant and his brilliant partner, William Leggett, penetrated with heroic and most useful zeal, together with some nonsense, gained their title to the name of radicals, and reached readers that were not accessible to penny papers like the Transcript and the Man. ${ }^{1}$

There were pamphlets also in which the universe was fearlessly explored and shrewd suggestions made for its reordering. Clinton Roosevelt, whom the Loco-Fucos sent to the assembly, wrote upon The Mode of Protecting Domestic Industry Consistently with the Desires of Both the South and the North by Operating on the Currency," criticizing. tariffs with considerable perspicacity. and showing that it specie system which abolished all bank money, by lowering prices here would lessen the desire to buy commodities abroad because of their apparent cheapness. The chief service of his little monograph, which seems to have been widely read, was in calling the attention of mechanics to the falseness of the favorable comparisons between their wage: and those of countries where the currency was not inflated. Wages made a variable standard with which to gauge prosperity, he said; it were as well to measure lumber with an india-rubber tape. But though his propositions pointed to free-trade in general, he had no use for the self-interest arguments advanced by writers like McCulloch; let the community he served, he said, and individuals would not want. $^{3}$

'Parke Godwin, Biography of William Cullen Bryant (N. Y., I88,3), rol. i, pp. 253-262.

2N. Y., I833.

"Pages 4, 5, 7, 9, 13,37, 43. He objected to banks on seven pointi. He bad a personal animus against them, as his family's extensive property had been lost, he thought, because of unsound business conditions 
IVilliam H. Hale, who published Useful Knoreledge for the Producers of Wealth, ${ }^{1}$ agreed with Roosevelt as to banks, tariffs, currency and corporations, but, alarmed at the concentration of wealth, went forward (while Karl Marx was still in grammar school) to conclemn all " usury" to capital." Indeed, the locirfoco candidate for governor, Isaac S. Smith, of Buffalo, in accepting his nomination in ${ }_{1836} 6$, averred that "No person possessing mental or physical ability can have a nuoral right to consume that which he does not in some manner contribute to produce." and on the labor theory of value he excluded capital acquired by inheritance, gift or speculation from a share of income. The theory of class struggle had been clearly stated:

What distinguishes the present from every other struggle in which the human race has been engaged [Frances Wright had written]. is that the present is evidently, openly and acknowlerlgedly a war of class. . . . It is the ridden people of the earth who are struggling to overthrow the "booted and spurred riders" whose legitimate title to work and starve them will no longer pass current. ${ }^{4}$

The Loco-Focos, by withdrawing their support from the regular Democratic tickets in the state, insured the election of many Whigs." But the ferment they had generated had

due to banks. His social outlook had been much affected by Owen and Miss Wright. Byrdsall remarks of him that he had a mind "fertile either to construct systems. mechanical machines, or literary matter," History of Loco-Foco Party. 1. 93.

${ }^{1}$ N. Y., I 833 .

2 Pages $7,9,17-18,19,22$. He said that labor and the United States was actually taxed $\$ 50,000,000$ to support the bankers.

${ }^{3}$ Byrdsall, p. 75; see also John Commerford. Address to the Workingmen of New York (N. Y., I 840 ).

- Free Enquirer. May 3, 1830.

${ }^{5}$ This together with the Native American movement was responsible for the victories and the capture of the common council in New York in 1836 , and the election of a Whig mayor in 1837 . 
worked far within their own party; it spread to other states; not only Colonel Johnson, of Kentucky, but Colonel Benton, of Missouri, discovered that the Loco-Foco principles were sound, and. "following in the footsteps of his predecessor," Van Buren became suspicious of all banks and proposed his Independent Treasury.' The panic of 1837 seemed sadly to confirm the radicals evil prophecies; and Democratic leaders soon took up their tenets as to banks and currency as the doctrine of the party. The Albany Argus, which had anathematized them as "Jack Cades" and "Carbonari," came to preach their major principles." When, a few years later. President Van Buren visited New York city, he attended the Bowery Theater in company with Alexander Ming, but recently despised as the "agrarian " candidate for mayor, and other leaders of the Friends of Equal Rights." The amiable secretary, Byrdsall, might truly speak of the Loco-Foco Revolution, for the name and influence of the little group of " anti-monopolists " was for many years fastened on the Democratic party. ${ }^{*}$ Considering the issue, the somewhat long analysis of their principles and program has, it is believed, been warranted.

It is scarcely necessary here to review the terrors of the panic. when fear bred fear as in some great catastrophe of nature. The President in his message to the special session of Congress, found the cause was the "redundancy of credit" which had marked the times, though he forgot the bank war and the specie circular, and might well, in the Democratic interest, have made some reference to the neagre crops and failures in Great Britain. When credit

${ }^{1} \mathrm{Cf}$. H. von Holst, Constitutional History of the United States (Chicago, 1878), vol. ii, pp. 202-203.

2 Byrdsall, p. 54 .

"Philip Hone, Diary, vol. i, pp. 365-366; Byrdsall, p. I7.

4 Byrdsall, p. vi. 


\section{ARISTOCRACY IN THE POLITICS OF NEW YORK}

tightened in New York, the city had not yet recovered from the fire which had demolished more than twenty million d. llars worth of property some fourteen months before. In the spring of $I_{37}$ the disaster seemed complete. The Whigs declared this the result of Jackson's meddling with the bank, and demanded that it be rechartered, but the new President sought escape in quite the opposite direction. When he saw that the deposit banks suspended specie payment, as we have said, he proposed a Loco-foco remedy: he would take the government funds away from banks and lock them in the treasury vaults; he would refuse banknotes in all remittances to the nation and would not use them in payment to its creditors. It was this that made the LocoFocos orthodox, and the Tammany Society and the Regency were forced to listen to their homilies with at least the affectation of respect. ${ }^{1}$

But when the message was read in Congress and Silas Wright brought in the independent treasury bill which would divorce the government from banks, there were some Democrats who expressed surprise and indignation. In the great forensic contest which lasted intermittently throughout the next three years, a half dozen influential Democratic senators and more than twice as many members of the House were steadfast in their opposition. They would not countenance the Whig scheme to restore the Bank of the United States, but desired a continuation of the state banks as depositories, though under more restrictions than before $^{2}$ The leader of these men, who, with their followers throughout the country, were called "Conservatives," was

${ }^{1}$ It may be said that in the summer the feeling was still bitter. and some Democrats joined with the Whigs in wrongly attributing the flour riots in the city to the Loco-Focos.

${ }^{2}$ Niles' Register, vol. liii, pp. 75, 126, 365. vol. liv, pp. 75, 79, 285 ; Congressional Globe, vol. v, App. 205, 2ri, 2r3. Wright had first suggested buying state bonds with the surplus funds. 
Senator Nathaniel P. Tallmadge, who had begun the fight the previous June in the preliminary debate. ${ }^{1}$ He now argued on eleven points against the bill, defending the whole credit system as indispensable to business. ${ }^{2}$ The chief champion in the House of Representatives was John C. Clark of Bainbridge, in Chenango County. The muvement largely centered in New York, where by July, 1837. Tallmadge's arguments were approver by many Democrats."

The President's message of September had scarcely been reported, when a meeting of the Tammany General Committee of fifty-one was convened. When a resolution to endorse the independent treasury was presented, thirty-two walked out. but by the quorum that was left the motion was carried by a vote of eighteen to one." The Democratic Republican Young Men's Committee then came together and expressed the heartiest sympathy with the President in his demands, and the bankers of the organization, who had kept the friendship of the legislature in recent years by contributions of their time and money, finally withdrew." These Conservatives increased in number day by day as the settled purpose of Van Buren grew apparent. In Novemher, before election, they held a meeting under Judah Hammond, and drew up a statement of grievance and reproach. which the IVhigs hailed with delight. ${ }^{\circ}$ At a well-attended gathering on the second of January, 1838 , they organized a committee of their own, according to the custom, with a

${ }^{3}$ Cong. Debates, vol. xiii, p. 75.

${ }^{2}$ Cf. H. Greeley, Recollections, p. 123; Niles' Register, vol. liii. p. 75.

${ }^{3}$ Byrdsall, pp. $158-159$.

'G. Myers, History of Tammany Hall, pp. 132-134.

${ }^{3}$ N. Y. Evening Post, Sept. 26, 1837.

'N. Y. Commercial Advertiser, Nov. 3, 7. 1837. 
president, fifty-seven vice-presidents, fourteen secretaries, and a general committee of vigilance made up of representatives from every ward. They issued a stinging address against the Loco-Foco principles. '

But though the Conservatives were naturally stronger in the city, there were many scattered through the state. In October. Tallmadge. Clark and Hammond called a state convention, which met in Syracuse, and resolved by general vote firmly to support Seward, named by the Whigs for governor, against Marcy, whom they called the Loco-Foco candidate. $^{2}$ It was hinted that the bankers employed other means than those of oratory and resolves, and there was a general impression that they paid liberally for the fireworks and shouters. ${ }^{3}$ Their influence the Whigs acknowledged as a potent factor in the victory that followed, and in grateful recognition of the service. whose continuance they might secure, they re-elected Tallmadge to the Senate for six years more, in spite of the remonstrances of Fillmore, John C. Spencer and some others of the faith ful. whose ambitions were neglected. ${ }^{4}$

The following autumn the Conservatives again convened at Syracuse to pledge their loyalty to the Whig leaders in

'Proceedings and Address of the Democratic Republicans, Opposed to the Sub-Treasury (N. Y., 1838), pp. I-16.

3 J. D. Hammond. Political History. vol. ii, p. $₫ 86$.

${ }^{3}$ See Tallmadge's reply in Senate, Cong. Globe, vol. vi, p. 620, and D. S. Alexander, Political History of the State of New York, vol. ii. pp. 24-25.

-T. Weed, Autobiography, pp. 460-46r. Van Buren made out so plausible a case for the independent treasury that outside of New York state the Whigs generally lost ground. One factor besides the support of the Conservatives in securing Seward's victory was the resentment in the northern and western counties, who sympathized with the Canadian rebels of 1837 , and thought Van Buren's attitude needlessly severe: see J. A. Haddock, History of Jefferson County (Philadelphia, I894). p. 21 . 
the presidential campaign, with five lundred delegates, rep, resenting nearly every county. They felicitated New York state for rebuking the national leaders despite "the combined power of agrarianism and infidelity leagued in their support," set forth their arguments against the new financial policy and defended the state banks against the calumnies of the ignorant levellers. They referred to the inevitable sufferings of business if the nation's funds were withdrawn from investment and circulation. There would be a painful shortage if the government insisted on drawing a great part of the specie into its vaults. Trade demanded half a billion dollars in currency. "How much more freely. will you breathe when the screw of the President shall have brought you down to sixty million dollars?" " Such reflections brought the Conservatives to build up county organizations and work effectively in favor of their old opponents. After I 840 many stayed among the Whigs as a business party, though some gave support to Tyler in his opposition to a national bank. ${ }^{2}$

'Niles' Register, vol. 1vii, pp. 187-Igo. During this campaign Tallmadge made the charge, which though denied was widely quoted, that Marcy had privately expressed to him his strong disapproval of the administration's Loco-Focoism; see New Haven Palladium, Oct. 30, 1839, and Albany Argus quoted in the Canandaigua Ontario Messenger, Oct. 23,1839 .

2 There is scarcely a movement in history more susceptible of the economic interpretation, than that of the Conservatives. Mr. C. C. Latour of Columbia University has found by investigation that most of the leaders in New York city were lank officers or heavy stockholders E. g., see list in Proceedings and Address . . . January 2, 1838 , and the following: E. T. Perine, The Story of the Trust Co. (N. Y., I916), p. 15; P. G. Hubert, The Merchants' National Bank (N. Y., I903), p. 37; F. B. Stevens, History of the Savings Bank. Associations of Nere York (N. Y., 1915), p. 569; Walter Barrett, Old Merchants of New lork, vol. iii, p. 229: Byrdsall, History of the Loco-Foco Party. 1. 26; J. D. Hammond, Political History, vol. ii, p. 478. N. P. Tallmadge was a director of the Poughkeepsie Rank; see E. Platt, History of Poughkeepsie, p. I07. 
The Whig victory had begun in 1837 , when besides the mayoralty of New York they gained a hundred and one assembly seats to their opponents' twenty-seven. Six of eight senators elected were also of their party, but in the upper house they could not claim a clear majority until after the election of $1839 .{ }^{1}$ Many able men, like the scholarly D. D. Barnard, of Albany. General Porter, of Niagara, and D. B. Ogden, of New York, who had been in forced retirement for a dozen years, now were able to devote their talents once again to the affairs of state. They applied themselves to see what could be done for business. The Democrats in 1835 , moved somewhat by radical influence. had passed a law prohibiting the circulation as currency of bank bills of less than five dollars face value. ${ }^{2}$ In a country where there were few gold and silver mines, this was decidedly embarrassing to trade, and numerous petitions were presented praying for repeal, but the majority conld not be moved.

Scarcely had the legislature come together in 1838 , when a Whig brought in a measure to restore small bills, which was promptly endorsed by the assembly. But the Democratic senate would not yield the principle, and insisted on an amendment that suspended the prohibitory law for two years only. ${ }^{3}$ In the campaign of 1838 , the question figured prominently, as "small bill seward" was pitted against "Big Bill Marcy," and at the following session when the senate was more favorable, the old law was entirely re-

'J. D. Hammond, Political History, vol. ii, p. 517 .

2 Chap. 46 , Laze's of $I 835$; see also chap. 155 and resolution of April 20, I835, ibid.

${ }^{3}$ Chap. 5I, Law's of 1838 ; it provided for different dates of final retirement, $\$ \mathrm{I}, \$ 2$, and $\$ 3$ bills before July, I 840 . After Jan. I, I84I. there were to be no bills between $\$ 5$ and $\$ 10$.

4 F. Bancroft, Life of Seward. vol. i, p. 67 . 
pealed. ${ }^{1}$ The Democrats in their long period of power had. as has been said, incorporated many banks; but the majority of business men were irritated that these monopolies of issue were parcelled out to faithful politicians, rather than to serve legitimate commercial needs. ${ }^{2}$ The Whig assembly, therefore, in $18_{3} 8$, passed a general banking bill, devised by Willis Hall of New York city, ${ }^{3}$ which, when the opposition in the senate had been overcome, became a law. The shameful bartering of credit privilege, which had so long disturbed the state, was now over. ${ }^{4}$

The ways and means committee of the assembly in that year, true to the tradition of the party, brought in a report which outlined an elaborate scheme of internal improvement. It was written by the chairman. Samuel B. Ruggles. the New York banker, whom the Democrats considered an amateur. "silk-stocking" politician, but who was finally recognized as a competent American economist." He could not deny himself superlatives when he contemplated how trade would be benefited by more facilities for transportation, and was most optimistic as to the state's ability to furnish them. The success of the two principal canals had surpassed the boldest expectations; and while the revenues had been expended, they were not "gone," as Democrats maintained, but were "invested" in more public works. It was true that not all the creditors who had supplied the seven millions for the great waterway had been repaid, but this was clue to their reluctance to accept their payment be-

${ }^{1}$ Chap. 30, Laws of 1839 .

${ }^{2}$ R. E. Chaddock, History of the Safety Fund Banking System, p. 345 .

${ }^{3} \mathrm{H}$. Greeley, Recollections, p. I26; the Democratic votes were cast against the bill; J. D. Hammond, Political History, vol. ii, p. 484 .

${ }^{4}$ The restraining law had been modified under pressure of public opinion in 1837 ; see Chap. 20, Laws of 1837.

${ }^{5}$ F. W. Seward, Life of Seziard, p. 439 ; Appleton's Cyclopedia of American Biography. 
fore their bonds matured; the money had been put aside, and the constitutional objection that the further revenues could not be spent for other improvements till the last receipt was signed, was frivolous. Why not a ship-canal? Why should not the state construct more railroads?

Ruggles had no liking for the Jeffersonian maxim, that the government "should never borrow a dollar without laying a tax in the same instant for paying the interest anunally, and the principal in good time." Jefferson had lived in a time when expenditure was usually for war, which was a waste: he had not realized that a government could make investments. If the state desired to be forehanded, the canal tolls would warrant an indebtedness of $\$ 40,000,000$. "It is evident," he said, "that $\$ 500,000$ of revenue will serve as a basis of finance for \$10,000,000 debt." Commerce must be served. ${ }^{1}$ Azariah C. Flagg, who was still the state comptroller, made a firm remonstrance. He maintained that the net revenues were overestimated and in Whig computations no account was taken of necessary canal expense and repairs. It was going to the verge of prudence, certainly, to borrow money with provision for the interest only. ${ }^{2}$ But despite the protests of the comptroller and the governor, the Whig assembly virtually met the heavy demands of Ruggles, though the senate would allow a loan of but $\$ 4,000,000 .^{3}$

${ }^{1} \mathrm{~S} . \mathrm{B}$. Ruggles, Report upon the Finances and Internal Improvements of New York (N. Y., 1838). A law of 1835 had directed the canal commissioners to enlarge the Erie Canal, setting no limit. The commissioners had felt themselves restrained, however, believing that constitutionally they could not contract for improvements for which they could not pay in cash from surplus revenues from the canal. An application to the legislature had produced $\mathrm{Mr}$. Ruggles' report; see J. H. Dougherty, Constitutional History of the State of New York (N. Y., 1915), pp. 151-I52.

2 Annual Report. Comptroller, 1838, p. 2I.

${ }^{3}$ Cf. Messages from the Governors. vol. iii, p. 544 
William H. Seward, elected governor in November, was not expected to be moderate when the development of natural resources was concerned. He had two heroes, Clinton and John Quincy Adams, both of whose biographies he wrote in terms of highest admiration for their " magnificent conceptions." It was one of the disappointments of his administration that Democratic opposition in the legislature prevented the erection of a monument to the great governor, in whose service he had entered politics. ${ }^{1}$ As senator he had been tireless in advocating more improvements; when out of public office he had been actively concerned in the movement for the state-supported Erie Railroad; ${ }^{2}$ now, as chief executive, he had his greatest opportunity to recommend his policy.

In the first message he advised the annual expenditure for ten years of $\$ 4,000,000$, for which the tolls of the canal would furnish payment before $1865^{\circ}$. His hearers were responsive and voted generous appropriations, providing only for the payment of the interest, ${ }^{4}$ and " owners of property, contractors, brokers, builders and expectants of all classes created a coalition strong enough to control the activities of the legislature, and plunged the state deeper and deeper into debt." ‘ The Democrats before him had not entirely refrained from similar enterprises, but they had been stung to action most sharply by the taunts of parsimony

'F. IW. Seward, Life of Sewurd, p. 426.

IIbid., pp. 341-344.

${ }^{3}$ Messages from the Governors, vol. iii, p. 735; Seward, Works, vol. ii, p. 609; F. Bancroft, Life of Sezeard, vol. i, p. 88.

" "To avoid the necessity of direct taxation, however small, the obvious and sound rule of our financial policy will be to adjust the loans of each year so that the annual interest on the whole debt may always fall within the clear income of the state." Senate Document, no. 96, 1839. p. 12.

5 D. C. Sowers, Financial History of New York State, p. 66. 
Hung at them by their opponents. Public sentiment had been stimulated by a society which first met at Albany in January, 1836 , and which was principally officered by Whigs. ${ }^{1}$ Probably most Democrats, in 1838 , approved the attitude of Comptroller Flagg. while some. like Colonel Young, were even more intolerant. "Man alone." said he, " sells his offspring to speculators and monopolists, and this by a gross desecration of terms is denominated Internal Improvement." "

In the campaign of I 840 the Whigs were called the " forty-million-dollar party," a name which they could not shake off for many years." But the charges of extravagance could not defeat them. The larger cities, in the hope of trade, generally gave Whig majorities, and it has been ascertained that in those sections where the staple farmers most desired an outlet to the city markets, Governor Seward was overwhelmingly preferred. ${ }^{*}$ As his party was returned to power, the "more speedy enlargement" policy was continued, but the heavy debts contracted depressed the credit of the state. Complaints from those who were not beneficiaries so grew in volume that the Democrats controlled the legislature of ${ }_{1} \$_{42}$, and Flagg, again appointed as comptroller, ${ }^{5}$ declared that the state must abandon its reliance on the future tolls of the canals, or come to bankruptcy. Thereupon the "stop-and-tax law" was enacted

'J. D. Hammond, Political History, vol. ii. f. $457 ; N$. Y. Ei'ening Post, Jan. 19, I836.

${ }^{2} \mathrm{~F}$. Byrdsall, History of the Loco-Foco Party, p. 63 . Hale in his Useful Knowledge, pp. 25-27, and the N. Y. Evening Post, Jan. 7. 1836 . take a similar view.

${ }^{3}$ Albany Argus, Sept. 25, 1840; Ontario Messenger, July 2I, I839: N. Y. Evening Post, Oct. 3I, Nov. 3, I846.

"Julius Winden, "The Influence of the Erie Canal." pp. I7I. I73-I75.

"This and similar state officers were then appointed by the legislature. 
under Michael Hoffman's leadership; the public works were soon suspended, and short-time bonds, well-covered by taxation, were issued to repay the debts the I'higs had brought upon the state. ${ }^{1}$ That the people took a like view was eviclenced in the elections of 1842 and 1844 , and by their call for a convention to revise the constitution, which, among some other changes, would set a limit to the state debt.

The great enthusiasm for internal improvements at the public cost had run its course. In a country of magnificent distances, means of transportation were properly considered indispensable: men of enterprise could well regard delay in their construction as a kind of crime. Yet, however plausible the generalization, individual enterprises were oftentimes regarded as risky experiments. Much capital was required to complete them; rich men in America reasonably hesitated to entrust their money to local companies at a time when credit lists were not available; and even if they had been willing, there was not enough accumulated surplus wealth in this young country to have satisfied a half of the demands. But in Europe, and especially in England, where manufactures were so profitable, there was capital enough, which, now in times of peace when nations had cut down their borrowing. was ready to be loaned on good security. These capitalists, however, were naturally even more reluctant than the few American millionaires to lend to individuals or joint-stock corporations so far away. The solution was in government responsibil-

1 Annual Report, Comptroller, IS+3, pp. II, I3, 2I, 22; J. H. Dougherty, Constitutional History, p. I54. A portion of the Democratic party (the "Hunkers") in the next few years took a Whiggish view, and desired to devote the surplus to improvements rather than to the payment of the debt, but Gov. Silas Wright in 1846 prevented such a law by his veto; see J. D. Hammond, Life of Silas Wright, pp. 286 , et seq. See also J. A. Roberts, A Century in the Comptroller's Office (Albany, I897), pp. 40-4I. 
ity, which, after the Erie Canal commenced its phenomenal earnings, seemed sufficient for entire safety, and on this guaranty millions upon millions in foreign bills of credit had been issued for American improvements. Not only on financial grounds the state's initiative seemed necessary, but state control of stone roads and canals, which anyone could use who had a cart or boat, seemed quite appropriate.

But in the early 'forties conditions had changed. State responsibility was no longer the magic key to foreign coffers, since Mississippi and some other commonwealths had defaulted on their interest payments and talked openly of repudiation.' Now that the experimental stage was over, domestic capital, augmented by industrial earnings, was ready for investment in private enterprises, especially in railroads, which were destined before the decade was completed to supersede canals. A railroad with its special rolling stock, in spite of Governor Seward's opinion. could not be considered as an open highway. So for them state support no longer seemed necessary, nor state control appropriate, and business men instead of lobbying to induce the state itself to develop its resources, came to fear the state's curtailment of their profits, and after their charter privileges were received they resented legislative interference.

'See G. W. Green's article in Lalor's Cyclopedia of Political Science, vol, iii, pp. 603-6rз. 


\section{CHAPTER XIV}

\section{Who Were the Whigs?}

THE campaign of I 840 began directly after the inauguration of Van Buren. The Whigs in 1836 had been able only to annoy the enemy with local candidates, but with their practice in co-operation they were determined that four years later the Jackson dynasty should end. It was learned with apprehension that Mr. Webster might resign his seat in the Senate and D. B. Ogden, Philip Hone, Chancellor Kent and others of his New York friends planned a demonstration to dissuade him. On March $1_{5}, 1837$, he visited the city, and was escorted to the spacious "saloon" in Niblo's Garden, at Broadway and Prince Street, where before a large and distinguished audience he delivered one of the greatest campaign speeches of our history, and certainly the greatest of his own career. ${ }^{1}$ His summary of the "reign of Andrew Jackson "was a model of partisan narrative. The "executive encroachment," the drilling of the office-holders, the destruction of the currency and the disturbance of exchange, he reviewed with dignity and seeming impartiality, avoiding stricture and invective, yet presenting his selected evidence with such consummate skill as to convict the administration of incredible stupidity. He recommended the internal improvement of the west by national aid, either by direct subventions or by a thoroughsoing distribution of the revenues from the sale of public

' H. C. Lodge, Daniel Webster (Boston, I883). pp. 238-239: E. Ruggles, A Picture of New York in 1846 (N. Y., I846); D. Webster. Writings (National Edition), vol. ii, pp. I8g-230. 
lands, according to the population of the states. ${ }^{1}$. Is soon as the compromise arrangement would allow, he favored a high tariff. which would protect the manufacturers and workingmen " against the cheaper, ill-paid, half-fed, and pauper labor of Europe." In his grand style he defended the Bank of the United States, and implied that it should speedily be rechartered.

Not often were the Whigs so clear and frank in the outline of their policy, for south was south and north was north, and no program would be pleasing to both sectionsin fact. the southern partisans, quite out of place in their association with old Adams men, did not take kindly to programs at all. In the north, it was to be a campaign of criticism of the financial policy of the administration. When the occasion seemed propitious. the orators spoke cautiously against the annexation of Texas, and condemned the Seminole War as merely an expedient to save the slaves of fron-

${ }^{1}$ This would, of course, enable the states more easily to pay their debts, many of which were owed to British creditors on account of loans for internal improvement. The proposition afforded the ground. however slight, for the Democratic contention that Webster and his party were arguing for an assumption of state debts by the federal treasury. "Because we saw that ... British Bankers who had been foolish enough to speculate in then [the securities], became at first suspicious, then inquisitive, and at length clamorous on the subject of their final redemption. and were silenced only by the assurance of the 'God-like Daniel' that the general government could assume the liabilities of the states ... because we saw something suspicious in the mission to England at such enormous expense to his party [in 1839], and his sudden abandonment while at London of his claims to the Presidency . . . because we knew that such was the manifest tendency of the 'Distribution' system, so zealously advocated by the party at large - for these and other reasons we more than suspected that the 'whigs' were secretly in favor of a direct assumption of the State debts by pledging the credit of the country for their redemption." Troy Budgct. Extra (Columbia University Library); see also Rough Hewer, Sept. 3. I\&40, on "British gold." Seward had strongly favored the measure; see Works, vol. i, pp. 415-416. 
tier southerners from capture by the Indians. The defalcations of the Democratic office-holders, in the New York customs house and in the western land-offices, was a grateful theme to discourse upon at intervals; but the chief and constant issue was the suffering of business, and the proved wrong-headedness and incompetency of those who had tampered with the delicate machinery of credit. That is, the financial argument was paramount so long as questions of governmental policy were seriously debated. But the campaign of I 840 was not distinguished for serious debate.

It is not necessary here to rehearse the story of how Harrison and Tyler were selected as the party candidates. Clay could not win the abolitionists and Anti-Masons of New York or the militant free-traders of the south, and Webster had offended state-rights men: Thurlow Weed, more than any other, brought about the choosing of the western general. But Webster was rejected on another ground; he was " aristocratic." This consideration showed how completely the old order had changed. The men of wealth well realized, now liberty and equality had shown their power, that in enthusiastic profession of fraternity lay their only course of safety. Property rights were secure only when it was realized that in America property was honestly accessible to talent, however humble in its early circumstances. The Whigs found it needful to disavow as vehemently as they could any and all pretensions to a caste superiority in political life. Mr. IVebster, at Patchogue, offered to strike with his great fist any man who called him an aristocrat, though Benjamin F. Butler repeated this ugly charge without enduring any violence save that of $\mathrm{Wel}^{-}$ ster's thundering invective. ${ }^{1}$

A fierce rivalry in simplicity sprang up between the par-

${ }^{1}$ Rough Hewer. Oct. 8, 1840. 
ties. Charles Ogle, of Pennsylvania, made a speech in Congress arraigning President Van Buren as a sybarite, who drank Madeira wine and had made a palace of the people's White House by his enormous expenditures for decoration. ${ }^{1}$ This speech, spread broadcast through the country, was the Whigs most effective tract. It was true, of course, that the presidential mansion had been gradually furnished since rebuilding after the "late war," and the papers, therefore, could point contrasts between the present state and that of former days when Adams had received his visitors in an East Room of almost Spartan bareness." They circulated drawings of the President, pictured as the model of sartorial perfection, seated at his table heaped with massive gold and silver service. ${ }^{3}$ What could be expected of a chief magistrate who was reputed to cologne his whiskers? John Quincy Adams shuddered as Van Buren grew inordinately fat. $^{4}$

Administration men defiantly retorted that the "Democracy is principally composed of the tillers of the ground. and the mechanics." " and founded Rough Hewers' Associations to offset the Tippecanoe Clubs which were multiplying through the country. ${ }^{6}$ But it was vain for Democrats to gibe at opponents as silk-stockings, for the Whigs immediately pointed to the offensively luxurious Van Buren, and sang:

'Congressional Globe, vol. viii, p. 327. On the early consideration of this policy among the Whigs, see J. C. Spencer to Weed, Sept. 2I, I832, T. W. Barnes, Memoir of Weed, p. 44.

${ }^{2}$ E. g. New Haren Palladium. April Io, 1840.

${ }^{3}$ Ibid., Feb. 17, I840; see also issues of March 20 and April 3

"Memoir, vol. x, p. 176 .

- Elder John Leland in Rough Hezer. July 16, 1840.

'Ibid., April 23, 27, 1840. 
"We've tried your purse--proud lords, who love In palaces to shine:

But we'll have a ploughman President Of the Cincinnatus line." 1

Eminent statesmen sitting on the platform at the rallies swayed to the rhythm of such exalted strains: Joseph Hoxie, a distinguished New York merchant, grew famous as the greatest choral leader of the campaign. ${ }^{2}$ The Regency in despair dubbed their opponents the "sing-sing party," and abandoned rivalry for criticism of such methods. ${ }^{3}$

When a Democratic paper in an ill-starred monent made a jest about the obscure Harrison, who, if left alone, would be content with his log cabin and hard cider, the Whigs realized that their opportunity had come. It mattered not that the general really was in fairly comfortable circumstances and had recently been drawing an annual stipend of six thousand dollars: he was to be the log-cabin candidate. It was observed that the Democrats should be discreet in choosing a vice-presidential candidate, for "Mr. Van Buren. in consequence of his course of luxurious living to which he is addicted. may pass off any day without a moment's warning." ' Compare all this, exclaimed the outraged Whigs, with the severe simplicity of Harrison, the farmer of North Bend, whom visitors had recently discovered flail in hand. threshing out his grain upon his barn floor."

I have been in his log cabin [said Webster]. He lives in it

${ }^{1}$ From "Should Good Old Cider Be Despised?", Log Cabin Songbook (N. Y., I840), p. 15.

${ }^{2}$ D. M. Fox. History of Political Parties (Des Moines, I895), p. II6; W. Barrett, Old Merchants of New York, vol, ii, pp. II4, II6-II7.

${ }^{3}$ Log Cabin, June 13, 1840 .

'Richmond Whig, Aug. 7. 1840.

'Nere Haien Palladium, Feb. 7, i840. 
still. And he has made an addition to it, as many of us do. He keeps a horse. Well, I found him to be a very hospitable gentleman; the string of his latch is not pulled in. And I gave him my confidence. ${ }^{1}$

It was useless to argue about treasury notes or the recondite details of public revenues; if they could keep this picture before the people by speeches, songs and drawings, they conld win. In good hard cider they toasted

"The hard-fisted Farmer,

The honest old Farmer;

We go for the Farmer that's work'd the farm well." 2

To qualify before the great electorate, Governor Seward traveled in an old green-painted wagon, and chose to ride in row-boats, even when steam ferries were available. ${ }^{3}$ The Whigs erected their $\log$ cabins in nearly every village to dispense hard cicler and enthusiasm, and they were enormously successful, though the Democrats referred to them as " groggeries,' and stirred the apprehension of the temper. ance societies at the amount of this liquor consumed, sometimes, they said, "diluted with whiskey." In rebuke they drank their toasts in pure cold water. ${ }^{4}$

Mr. Webster, in his Saratoga speech, apologized profusely because the house of his nativity had not been made of logs: but he was quick to claim that honor for his elder brothers and sisters. "If I am ever ashamed of it . . . ," he fervently exclaimed, "may my name and the name of

${ }^{1}$ Writings, vol. xiii, p. I41.

"From "Come to the Contest," Log Cabin Songbook, p. 29.

${ }^{3}$ Ontario Messenger, July 19, 21, 1829. Seward had suffered somewhat earlier in his career because of a report that while travelling in Europe he had met too many aristocrats; see F. Bancroft, $W . H$. Sezurd, vol. i, p. 44 .

${ }^{4}$ Rough Hewer, May 26, Aug. 13. Sept. 10, and Mohawk Courier, quoted in ibid., June I8, I840. 
my posterity be blotted from the memory of mankind!" In a country where most people still made their homes in $\log$ cabins," such sentiments were popular. It was felt to be the blessing of America, not that all should stay $\log$ cabin dwellers through their lives, but that anyone beginning in humble circumstances could by dint of application become as great a man as Mr. Vebster. The log-cabin, coon-skin pageantry expressed the feeling of fraternity deepened by the confident individualism which characterized American society in the nineteenth century. ${ }^{3}$

Confronted with so prevalent and indigenous a sentiment. the theory of class war, advanced by Frances Wright, seemed a curious exotic phenomenon, confined to industrial cities which were then not typically American. In the victorious campaign of 1840 , the old aristocracy surrendered its pretensions to prescriptive rights, which had long since become absurd. Some scions of old families came down

1 Writings, vol. iii, p. 30 .

? W. E. Dodd, E.rpansion and Confict (N. Y., I9I5), p. 20 S.

${ }^{3}$ It was an evidence of the democratization of American society that women took so prominent a part in the campaign of 1840 , being present in large numbers at the great rallies and sometimes the object of special attention from the orators; see T. H. Benton. Thirty Y'ears' View, vol. ii, p. 206; A. C. Coleman, Life of John J. Crittinden (Philadeiphia. 1873), vol. i, p. 127; N. Y. Express, May 9, I840. Clay dreaded the influence of women on the abolition movement. He said: "I intreat that portion of my country-women who have given their countenance to abolition, to remember that they are ever most loved and honored when moving in their own appropriate and delightful sphere" (IVorks, vol. viii, p. 159). Women in politics presented a phenomenon bewildering to southern statesmen. "By the bye," wrote A. P. Powers to Howell Cobb, Oct., I840, "this making politicians of women is something new under the sun" (A. C. Cole, The Whig Party in the South, Washington, 19I3, p. 6I). Possibly the new education for women was making a difference; see Albany Argus, May 8, 13, I828; A. W. Calhoun, Social History of the American Family (Cleveland, 1917-), vol. ii, p. I88; Menoir of Frances Wright: Commons, etc., History of Labor, vol. i, pp. 354-356; F. W. Seward, Life of Sexard, p. 388. 
like commoners to fight their way in the political arena, while others, feeling that they stood no better at the polls than did their servants, withdrew to the secure serenities of inconspicuous but comfortable houses, filled with old mahogany, old wines, old friends, and memories of ancient power.

Such is the broad view which confronts the historian today, though, no doubt, few saw it then. They knew it only as a furious campaign, replete with novelty. And there was novelty enough! When old caste distinctions had been softened, and before the great immigration of the later 'forties, the American people were homogeneous, likeminded, and, in consequence, uncritical. They were thus susceptible to slight suggestions, which with cumulative force carried them to queer extravagances.

The aristocracy, as such, no longer took a part in politics. "As they cannot occupy in public a position equivalent to what they hold in private life," observed De Tocqueville. "they abandon the former. and give themselves up to the latter: and they constitute a private society in the state, which has its own tastes and pleasures." ' In New York, as in other large commercial cities, social lines were drawn by some with a ridiculous assumption of finality, and snobbery was practised as an art, though it brought a smile to old-world visitors. ${ }^{1}$ It was fashionable to contemn the politics of the time. but many who took this pose made little

${ }^{1}$ A. de Tocqueville, Democracy in America (Cambridge, I863), vol. i, p. 228.

"T. Hamilton, Men and Manners in America. vol. i, p. 65. H. Martineau, Society in America (2nd edition, London, I839), vol. i, p. I3; F. J. Grund, Aristocracy in America, vol. i, p. I6I. Some who had recently acquired wealth, now by the ostentatious leisure and extravagant dress of their ladies set up pretensions as aristocrats; see A. W'. Calhoun, Social History of the American Family (Cleveland, 19r8), rol. ii, chap. $x$. 
secret of their fond belief that democracy would finally overreach itself, and that talent, property and station woul! again be given proper influence. ${ }^{1}$ With opinions unchanged, they did not, however, give them voice in public, lest they be insulted."

Captain Marryat, after visiting the United States. declared that this great society must disintegrate, unless a political aristocracy were reconstituted.

I do not mean an aristocracy of title; I mean an aristocracy of talent and power which wealth will give-an aristocracy which will lead society and purify it. How is this to be obtained in a democracy?-simply by purchase. . . In a country like America where the suffrage is universal, the people will eventually sell their birthright. . . I I say it has been done already, for it was done at the last New York election. The democratic party was sure of success, but a large sum of money was brought into play . . and the Whigs carried the day. ${ }^{3}$

${ }^{1}$ F. J. Grund, op. cit., vol. i, pp. 27, 220-221, 309-311.

${ }^{2}$ T. Hamilton, op. cit., vol. i, p. 156; F. Marryat. Diary in America. second series (Philadelphia, I840), p. I2 I. Capt. Marryat says: "That the morals of the nation have retrograded from the total destruction of the aristocracy, both in the government and in society, which has taken place within the last ten years, is most certain," pp. I22, I49. He found the New York merchants nearest his ideal in America, pp. I33, 140. For an example of pessimism as to the political future, see J. Fenimore Cooper, The American Democrat (Cooperstown, 1838), p. 6.

${ }^{3}$ F. Marryat, Diary, second series, p. 15\%. The captain refers to the lavish expenditures by Moses H. Grinnell, R. M. Blatchford, R. C. Wetmore, and other business men, who hired about 200 "floaters" from Philadelphia at $\$ 22$ each in the campaign of 1838 . The business seems to have been thoroughly done. When in I 840 these leading Whigs were brought before the recorder's court, they pleaded that the Philadelphians had been engaged only to insure the purity of the election against Democratic floaters who were coming from New Jersey. On these representations the case was dismissed! See Rough Hower. Oct. 30, I840, and G. Myers, History of Tammany Hall. pp. Ifo-IfI. It is, perhaps, appropriate to speak a further word on Whig campagn finance. 
But the future of tmerica as foreseen by Captain Marryat and the gentlemen with whom he had conversed came n! nearer to the truth than that which Frances IVright had prophesied. In the middle of the nineteenth century we were not to see a ruling gentry or a war of classes. The aristocrats of birth, when unsupported by wealth or talent, aropped into a respectable obscurity, while the well-to-do among them were soon inoculated with the feverish desire. cummon in a bounteous but undeveloped country, to accumulate more property and by this means ontshine their fellows. As manufacturers, railroads and finance absorbed their interest, they found the game too fascinating to allow them leisure actively to take a part in politics. They, of course, voted the Whig ticket, and ladies boasted that they could easily convert a wealthy Democrat into a Whig; ${ }^{1}$ but they contented themselves with making the government afe for business by generous contributions to the camfaign funds. When, indeed. they did discuss affairs of state. the great ideals of the anti-slavery crusade and "manifest destiny." elicited their praise or condemnation. The

Even then the conservative yarty drew large contributions into its chest. "I hope our rich men will shell ont," wrote H. Ketcham to Follett in 1832, and confident appeals were addressed to such men as General Porter (Follett Correspondence, Sept. I3, 1832); in that campaign it was complained that the National Republicans had unlimited resources (G. Myers, op. cit., pp. 107-108). Marcy wrote to Jesse Hoyt, that he feared the U. S. Bank would use $\$ 50,000$ in the state (D. S. Alexander, Political History, vol. i, p. 395), Weed tells how R. B. Minturn, Grinnell, Blatchford, and others brought him $\$ 8.000$ for distribution, a few days before the election of 1839 , and pays tribute to the broad view taken by the New York merchants, on this and other occasions (Autobioaraphy, pp. $448,476-477,503,504)$. On the other hand, the Whigs did take great pains to check illegal voting in the interest of Tammany; see, for example, mss. record of Fifth Ward Whig Committee of New York City, Oct. I6. I $8_{40}$ (N. Y. Pub. Lib.).

'F. I. Grund, Aristocracy in Anerica, vol. i, p. 22I. 
economic questions which had stirred the yeasty thirties were for a time forgotten.

Although the wildest projects for rejuvenating all socitiy marked the next decade, there was no concerted movement of artisans against the capitalists as had been loudly heralded by the Workingmen and Friends of Equal Rights The expected crisis, whose frightful shadow had been cast upon the pulpit and the press, did not arrive. In the first place, many of the changes for which the workmen had contended in their parties, were vouchsafed them by shrewd Democratic and Whig leaders, eager for their votes. The panic of ${ } 8_{37}$ had temporarily deprived many of employment, but when those nervous days were over, the agitators, also, found that the Texas problem, the petitions of the abolitionists to Congress and their pamphlets in the mails, had fixed the attention of the public mind, in place of matters which a few years before had been engrossing. Eut agitation not only went unnoticed; it was unnecessary as well, for the condition of the working class steadily inproved.

Despite the opposition of the eastern manufacturers, the western lands were made cheaper for the settler, ${ }^{1}$ and railroads joining the canals or extending into the northwest made them day by day more easily accessible. Even distant and mysterious Oregon was opening to settlement. It was generally realized that labor had here an alternative, and before the great influx of foreigners later in the century, employers had to offer large inducements to meet the competition of the western opportunity. Fur a generation wages were advanced more rapidly than prices." Then, too, thrown backward from the west, there was the influ-

1 The preëmption laws became permanent in I 84 I.

${ }^{2}$ Senate Documents, 52nd. Cong., 2nd. Session, Report 1394 (Report of Mr. Aldrich from Committee on Finance, I893), part i, pp. Io, I4. 
ence of that fierce individualism of the pioneer, who has created wealth from wilderness, and who knows that the same economic opportunity awaits every man or family in the east who will take like trouble. Socialism is professedly a scheme to keep comfortable existence always within the reach of honest toil; it is plausible alone in those societies where there are many who seem permanently denied a share in property: in America with her free lands there was nu such exclusion. ${ }^{1}$

In surveying the political conditions of New York state in 1800 , we took occasion to analyze the composition of the Federalist party." It is proper now, perhaps, to attempt a similar examination of the Whigs. They had assumed their name as resistants to "King Andrew," and, taking north and south together, this was, no doubt, their only bond of union. But in New England and the middle states their dislike of this executive encroachment was grounded chiefly on the fact that they were excluded from the executive offices." As old Elder Leland, of Cheshire, put it, " Strip) a man of office and he will talk like a whig: put him into office and he will be a tory." " This may account for the professions of the party in New York, but it does not reveal its constituent parts.

On no question, in the noisy days of 1840 . was there more recrimination than as to where the old Federalists were to be found. The Democrats, of course. pinned the

I It may be said the laborers bettered their condition when they cease I attempting to reconstruct society, and through their trade union attended strictly to raising their own wages.

'See supra. chapters $\mathrm{i}$ and ii.

${ }^{3}$ For an explanation of the Whig party largely on this basis. see Edgar Dawson, "The Origin of the American Whig Party," History Teachers' Magazine, vol. ii, pp. 160-16r.

'John Leland to G. N. Briggs. Jan. 12, 1836, Writings of the Late Elder John Leland (N. Y., I845), p. 675. 
black cockade of 'ninety-eight upon their enemies. But the great Henry Clay attempted to repel the charge that the Federalists had changed their name for that of Whigs, and instanced fellow senators who had once been followers of Hamilton and Adams, but who had now transferred their fealty to Jackson and Van Buren. ${ }^{1}$ A New York congressman supported him by citations in the House of Representatives; ${ }^{2}$ papers printed similar lists, ${ }^{3}$ and a favorite campaign song rehearsed the names of fifteen Democratic leaders formerly members of the discredited party. ${ }^{4}$ Willis Hall, speaking in the assembly, referred to eighteen Federalist families in the city of New York who now were represented in the ranks of the administration." Conversely, General Root pointed to the seven survivors of the New York senators who had voted for Jeffersonian electors in 1801 : six of them, he said, were Whigs in $18400^{\circ}$

However, Hamlet's mother showed but common shrewdness when she said, "The lady doth protest too much, methinks." The Whigs, in their diligent researches for names of Jackson Federalists, evidenced a too violent desire to allay suspicion. In this they were not successful. As we have tried to show, the old group, though dwindling, had largely kept together in New York, and formed the core of the rechristened party of the 'thirties. Once, when a certain politician's orthodoxy was impugned, Greeley remonstrated, "Is it not monstrous that anybody should fear

${ }^{1}$ Works, vol. viii, pp. 205-206.

${ }^{2}$ Remarks of Mr. Christopher Iforgan of N. Y. . . March 26, I840 (N. Y., I840).

${ }^{3}$ E. g. Springfield Republican, Sept. 29. Oct. 6, I3. Nov. I0, 1838, June I, 1839 .

4"When This Old Hat Was New", Log Cabin Songbook. p. 66.

${ }^{5}$ Quoted in Springficld Republican, Feb. 10,1838 .

-Quoted in New Haz'en Palladium. June 1, I840. 
the man ... who is heartily supported by such Whigs as James Kent, David B. Ogden, Philip Hone, John A. King, \&c., \&c.?" ' Denials of Federalist origin were distasteful to such staunch old partisans as Colonel Stone of the Commercial Advertiscr, for they were as useless as they were absurd. ${ }^{2}$ The great majority of the Federalists of ${ }^{8} \mathrm{I}_{2}$, who had survived, were Whigs in 1840 .

But this remnant never could have carried an election. Most Clintonian Republicans, like Archibald McIntyre and Pierre Van Cortlandt, had remained with Seward and Granger, as champions of internal improvement for the nation and the state. Some People's Men, like Dr. Barstow, who was named for lieutenant governor in 1836 , likewise stayed with those who fought the Regency. Some Democratic Anti-Masons, like John C. Spencer and John Young, who was to be made governor, formed with Veed and others ties too strong to make it easy to rejoin their former party when the blessed spirit had subsided. The Democratic leaders, who had been so long in power, had been unable to minister to the ambitions of all their party workers, and some disgruntled politicians, like General Root, General Pitcher and Major Noah, as well as Jesse Buel, an exstate-printer, who was chosen as the candidate for governor in the hopeless campaign of 1836 , came over to the opposition out of hopelessness or spite. As men like General Porter and P. R. Livingston had developed economic interests which would be served by the American System and internal improvement, they naturally joined the party of the business man. This was a kind of motive even more obvious in the case of those merchants, like Wetmore and Grinnell, who appreciated the useful service of the Bank of

'N. Y. Tribune, Nov. 3. I8 4 .

${ }^{2} \mathrm{H}$. Greeley to W. L. Stone. Jr. in the latter's "Life of William L. Stone," p. 98; Rough Hewer. Aug. I3, I8 to. 



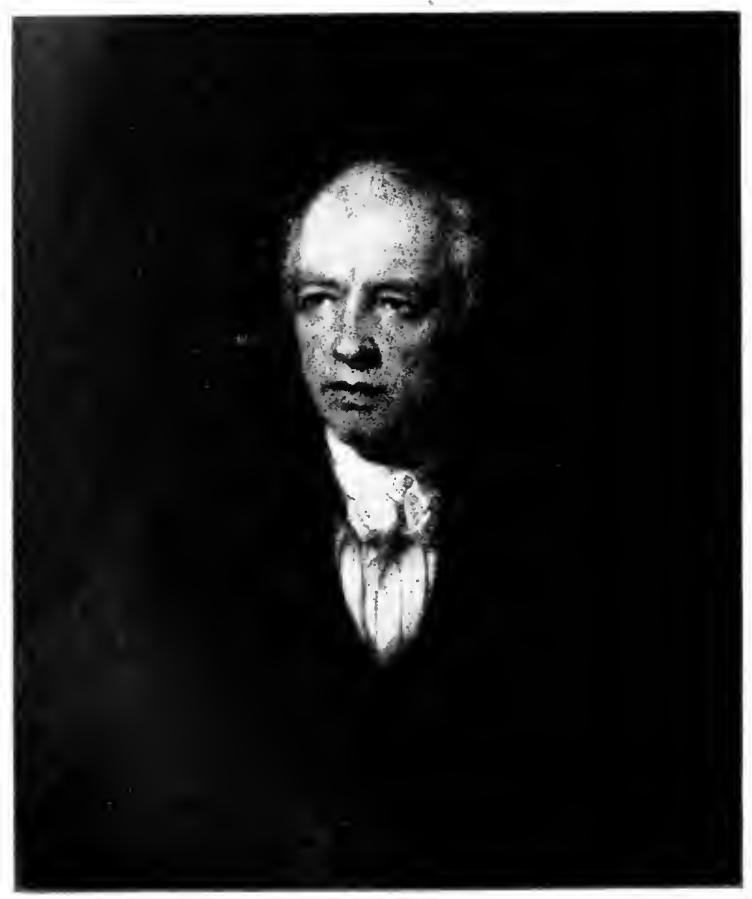

JAMES KENT

(c) Charles barmore, Publisher New York 
the United States: or of those bankers, like Tallmadge and the rest of the Conservatives. who became convinced that private credit was not effectually protected by the Denucratic party. It was but natural that the Whigs should welcome these accessions as they came, and grant distinction: to their new adherents which would possibly draw others t; their standard. On the electoral ticket of r8fo in New York, for example. six places were assigned apparently with this in view. ${ }^{1}$ Besides all these, of course, there were many other voters caught and sometimes held by argument or song, as the "Panic Whigs" of 1838 and the "Log-Cabin Whigs" of I840.

That the solidarity of parties was maintained is, no doubt, in part to be attributed to the influence of leaders. Personalities like those of Seward. Weed and Greeley, are lodestones to attract the uncertain. The material and social interests of the northern counties, for example. were clearly similar, their farmsteads rising one by one as the New England pioneers cut back the great south woods. The Concord coach. that labored over the rough way from Lake Champlain to the St. Lawrence, satisfied the needs of travel, while ox-drawn carts seemed adequate to hatl the infrequent freight. No pet bank, no state road or canal, no basic staples, claimed their local loyalties. Yet in the ten years beginning in 1832 . St. Lawrence and Clinton Counties were steadfastly Democratic, while their intervening neighbor, Franklin, was as safely counted for the opposition. This cannot be explained unless one calls to mind that the former counties were the homes of Silas IVright and A. C. Flagg, and the latter of the popular and influential Luther Bradish. who presided over the two houses of the legislature, first one and then the other. However, few historians

${ }^{1}$ Isaac Ogden. Gideon Lee. P. B. Porter, Pierre Van Cortlandt, James Burt and P. R. Livingston. 


\section{4}

would argue that personal factors were the chief cause of the party loyalties at large.

A thesis has lately been advanced and supported with much scholarly research, that the two great parties of our history represent respectively two kinds of property interest, personal and real. If a student will cast up the sums of the assessments in the thirty-three counties regularly Democratic in the times of Jackson and Van Buren, and with due reference to the population, carefully compare his figures with those he has obtained from twenty-four Whig counties, his laborious computation will convince him that this thesis is not supported by the statistics. ${ }^{1}$ It should be said, however, that the test has not been fair, as the interpretation is intended to apply to the whole country broadly separated into economic sections.

But our student, by constructing state election maps, will ubserve how constant was the western section in its loyalty to Whig principles. Here were farmers of New England stuck who brought their grain and wool to the canal at places such as Buffalo, Lockport or Rochester, consigning it to the "home market." which they believed the American System was developing in the east. Here, too, were wealthy and conservative communities like Canandaigua and Geneva, and other towns like Warsaw, Batavia, Angelica. Fredonia and Geneseo, whose citizens apparently had

II the realty assessments the counties contribute to no striking parallels with the election returns. It is found that of the 57 " upstate" counties, approximately half show an average assessment on personal estate of $\$ 12$ or more per person. According to the theory these should be Whig counties. But investigation shows that there are ig of them which are Democratic, and only ro Whig. The counties where personal estate is found in smallest quantity per capita are most of them among the staunchest Whig strongholds in the west: Chautauqua, Cattaraugus, Allegany, Broome. Erie, Genesee, Cortland, Niagara and Orleans. See E. Williams, New York Ammal Register (N. Y., $1830-1843)$. 
brought with them a loyalty to the policies of the Adams family, and who had cherished gratitude to Clinton for opening their county to world commerce. It had been the fire of Anti-Masonry which had fused the western counties into an almost solid section, but the allegiance to Weed's party was retained because the young industrial communities and the commercial farmers found Whig policy comported with their interest.

Separate from the mass of the people [ran a Democratic address to the voters] the tories of the revolution and most of their descendants-the Hartford Convention men of the late war and most of theirs-the church and state men-the bankites and monopolists of every description - the operators in money who see in government nothing but a business transaction, more or less valuable according to the share they get of the profits, and who find more virtue in a price-current than they can in the Declaration of Independence-in fine, all who stand ready booted and spurred to jump into the public saddle -and you have in the residue the Democratic party. ${ }^{1}$

One scarcely looks for justice from the enemy; yet it is interesting to inquire if property was, as they implied, unequally divided between the two parties.

"By whom was the general surrounded?" asked the American, when Jackson visited New York city in I828. "Did the oldest and most respectable inhabitants crowd around him? Did the judges of the different courts, the leading barristers, the presidents of banks, the collector and others of the government flock toward him?" No, it answered; it was generally mechanics and not men from the better walks of life who shouted their applause." "The merchants were generally Federalists, as were most of the

1Albany Argus, Extra. Sept. 14, 1834.

${ }^{2}$ Quoted in Argus, March 3, IS28. It is well to remenher that officeholders were not necessarily partisans of the President as yet. 
lawyers," wrote Thurlow Weed of New York city after I 8 I $5 \cdot{ }^{1}$

It is a very common fact [declared a chronicler of trade, looking backward from the sixties] that for thirty-four years ( since 1828 ) very few merchants of the first class have been Democrats. The mass of large and little merchants have, like a flock of sheep, gathered either in the Federalist, Whig, Clay, or Republican folds. The Democratic merchants could have easily been stored in a large Eighth avenue railroad car.'

It seems, then, that there was an economic line that corresponded with the borders of political opinion. The testimony is clear enough, though perhaps too slight to warrant a definite conclusion. But there is the far more certain witness of statistics.

The circulation lists of party newspapers in New York city repay examination. In the thirties the penny press. having proved its power in London, made its appearance in the United States. ${ }^{3}$ The decent, ponderous, respectable "six-pennies" " were scandalized; their readers, no doubt, shared their contempt and disgust for these "scurrilities" hawked about by newsboys. But the penny papers multiplied in previously untilled fields, where there was room for anything that was cheap, and they soon spread in circulation to reach numbers far exceeding those of the class whose opinions followed the lines of editorial leaders from the pens of Colonel Stone and Colonel Webb, Mr. King anci Mr. Bryant. If men are judged according to the company

1 Autobiography, p. 55 .

"W. Barrett, Old Merchants of Acw Fork, vol. i, p. 8r.

${ }^{3}$ F. Hudson, History of Journalism in the United States, p1. 415-123.

4 These papers, which had held the field practically unchallenged in I834, were so designated from the price of the papers over the counter. The subscription by the year was $\$ 10.00$; see E. Williams $N$. Y. Annual Register, $18_{35}$. p. I29. 
they keep, an index no less nice as to their taste and thought and size of purse is found in the newspapers they buy. They reflect as well as form opinion. The circulation of the six-penny newspapers we may suppose to have been chiefly among the well-to-do, and thus by finding what they chose to read, we may infer with fairness how this sort of people thought and voted.

According to statistics compiled for $1842,{ }^{1}$ the circulation of the cheap dailies had reached 62.500 . It was th work among this larger class that Greeley's Tribune had been started the year before, and had now about ro,ooo readers, representing, probably, the proportion of Whig strength there to be found." The circulation of the "Wall Street papers "was 32.200 , or less than half of that reached by the other group. ${ }^{3}$ What were the politics of those journals which were desired by this fortunate third? This is a

${ }^{\mathrm{I}} \mathrm{F}$. Hudson, Journalism in the United States, p. 525.

"Ibid., and H. Greeley, Recollections, pp. 136, г 37 . The party, leaders had realized the need of propaganda, even if expensive, among the poorer voters, and in $I 834$ had proposed issuing a cheap edition of the Albany Evening Journal and the N.Y. Courier and Enquirer to compete with the penny papers, but the plan had not been carried out (The Man, July 25, 26, r834). However, the panic offered hopeful opportunity to the Whigs; Thurlow Weed devised the scheme of the campaign paper for this purpose and brought young Greeley to Albany to edit the Jeffersonian (Feb. 17, I838-Feb. 9, 1839; Greeley, Recollections, pp. 125, $\left.{ }^{133^{-1}} 34,316\right)$, and in 1840 the same editor was entrusted with the $\log$ Cabin (May 27, 1840-Nov. 20, 1841), which was made popular by means of music score and pictures as well as what is now called a “magazine page." D. D. Barnard edited a Whig campaign paper at Albany in that year, known as the Mincrea (see Howell and Tenney. History of Albany, p. 367). The Democrats seeing that these papers were successful established the Rough Hezver (Feb. 20-Dec. 24. 1840) at Albany with A. C. Flagg as editor. There were Log Cabin songbooks, and a Tippecanoe Text-book (published by W. O. Niles at \$io a hundred).

${ }^{3}$ The merchants advertised almost exclusively in these ten-dollar papers: W. Barrett, Old Merchants, vol. i, p. 25. 
question which presents no difficulty, since that was a time when to preach the party doctrine was the chief reason of a newspaper's existence, and when its bills were often paid by generous appropriations from the party chest. ${ }^{1}$

The Journal of Commorce wished to be considered neutral and emphatically commercial, ${ }^{2}$ and, therefore, its 7,500 may be neglected. The Couricr and Enquirer, edited by Colonel Webb, was at this time strongly Whig, and of the most conservative wing." The Express had been founded in $1 \& 36$ by Willis Hall, who later was attorney general under Governor Seward, and was considered as a leader of the party; the paper's circulation had lately been increased by the merging with it of the Daily Advertiser, which had been edited by Theodore Dwight, renowned as secretary of the Hartford Convention. ${ }^{4}$ The American " belonged to the strictly aristocratic and financial circles of the metropolis," "and edited by Charles King, the admired ideal of Federalist gentlemen, was, of course, consistently and firmly Whig. Of that party, also, was the old Commercial Adiertiser, founded to support John Jay. Born in a New England manse, its editor, Colonel Stone. had never faltered in the political faith he there imbibed, and distin-

${ }^{1}$ F. Hudson, op cit., pp. 345, 397, 4I I (I. C. Bray), Hemoir of James Gordon Bennett (N. Y., 1855), pp. I60-163, I70-172; W. L. Mackenzie, The Lives and Opinions of B. F. Butler and Jesse Hoyt (Boston, I845), pp. 90, 93; E. E. Hale, Jr., William H. Seward, p. 97. Oren Follett writes to Joseph Hoxie, Feb. 6, I 832 (Follett Correspondence, Quarterly Pub. of Hist. and Phil. Soc. of Ohio, vol. v, no. 2): "And who is it gives voice to the people? It is the humble man of types and paper, who is himself controlled by cash. Plant deep the 'root of all evil,' and good will spring from it."

'Wm. Hallock, Life of Gerard Hallock (N. Y., I86n), p1. 63-64.

${ }^{3}$ F. Hudson, or cit., pp. $344-362$.

$4 /$ bid., pp. 517-520.

5Ibid., p. 412. 
guished for the "spicy and vigilant vindication " of these principles, he had from time to time published party papers in five different towns. ${ }^{1}$ (He spoke sarcastically of " universal suffrage folks": "I am no Jacobin-no democrat," he said; "I hate the mob.")" These four Whig papers served 19,800 subscribers. The others among these journals which satisfied New Yorkers who took less thought of pennies, the Evening Post and the Standard, which had supported Jackson and Van Buren, could muster only 2,900 on their lists. Indeed, the latter of these two had kept its hold on life wholly by grace of subsidies from Washington. Though one may perhaps claim more significance for such deductions than they warrant, from these premises it seems fair to conclude, that of those who could afford to subscribe for the more expensive party papers, seven-eighth: were Whig. ${ }^{3}$

${ }^{2}$ W. L. Stone, Jr., "The Life and Writings of William Leete Stone," (published with W. L. Stone, Sr., Life and Times of Red Jacket, N. Y., I866), pp. 9. II, I2, I6, I8.

2 "New York to Niagara." Buffalo Hist. Soc. Pub., vol. xiv, p. 240; W. L. Stone, Jr., op. cit., p. 25.

${ }^{3}$ The preponderance of Whigs among this class of readers recalls a like condition with their Federalist predecessors. In 1816 there were seven daily papers in New York city, reaching in all their circulation 8,89o subscribers (F. Hudson, op. cit., p. 226). In that day an annual subscription to a daily newspaper was an indulgence afforded only by the rich. Subtracting from the seven the Mercantile Advertiser, which professed neutrality (I. Thomas, History of Printing, vol. ii, p. 5I9) and served 2,000 patrons with extracts from other journals, we find that of the remaining six, four, totalling 5,290 in circulation were Federalist, while there were $\mathrm{I}, 700$ subscribers to the Republican dailies. In I816, then, 76 per cent of those sufficiently well-to-do to subscribe patronized the Federalist papers, and 24 per cent the Republican. Indeed, many of the 825 readers of the Columbian, here credited to the Republicans. were probably not orthodox members of that party, as DelVitt Clinton, whom it supported, was very friendly to the Federalists. (Ibid., and Encyclopedia Britannica, IIth edition, article "Newspapers"; National Cyclopedia of Am. Biog., article on B. Gardenier, owner of the Courier. vol. xiii, p. 433; American Almanac, Boston, 1835, p. 282; Hudsoin, pp. $225,282)$. 
It is interesting in passing to cite the opinion of a contemporary observer, that the papers of that day which were published on a costly and ambitious scale tended to become Whig, because of the dependence on the merchants' adver:isements, a source of income more reliable that subvention from the party:

You may always doubt a democratic editor's sincerity when his advertisements begin to increase. He is then sure of making himself agreeable to a certain portion of the commercial community, and to meet soon with the proper reward of his new political faith. You may then expect to see him promoted in society and on 'change; and ten chances to one he will be able to settle with his creditors. After that he begins to differ on one point or another with the leading principles of the democratic party (for it is seldom that a man changes at once from a democrat to a Whig), until by degrees he renounces the whole doctrine as unworthy of a "gentlenian and a scholar." 1

Fortunately there can be added other evidence as to the character of parties in the state eighty years ago. Our survey according to the counties did not contribute to support the economic hypothesis. but perhaps it was because within a section like a county it is impossible to find how property was distributed. In examination of the cities, ward by ward through several years, however, will yield more interesting results; for here we may safely infer a general eccnomic character to each small locality.

If we turn attention to the metropolis of the state and of the country. We find no way of correlating the political sta-

${ }^{\prime}$ F. J. Grund, Aristocracy in America ( 1839 ), vol. ii. p. I25. Also on advertising see $\mathrm{W}$. Barrett, Old Merchants, vol. i, p. 25. Grund says that there are generally considerably more Whig papers than Democratic in a city, "which I take for the best possible proof that talent loves to be rewarded, and in republics, as well as monarchies, naturally serves those who are able to reward it," op. cit., vol. i, p. 3II. 
tistics of the wards throughout the dozen years from $1 \delta_{2} S$ to 1840 , except by use of maps; ${ }^{1}$ for new wards, created from time to time within the interval, cunfuse the tables for the purpose of comparison. Yet the character of the residents in the various localities themselves, we are informed, generally remained about the same until after i 8 4o." Considering the wealth per capita in each ward together with its politics throughout the period, a striking parallel may be cherved." The "aristocratic" first three wards and the fifteenth were inhabited, in general, by the richest menand the most stalwart Whigs. But lest in some wards wealth might have been very unequally distributed, it is well to seek some index as to the economic ontlook of the inciviluals according to their occupations. ${ }^{*}$

Note on data presented in accompanying maps: The elections of I 810 and I8I6 were typical closely contested elections in the last days of Federalism as a party. The mayoralty eiections of 1834 and 1840 were also closely fought, while that of 18.37 is given to show the extent of the Anti-Tammany vote when the panic, and the Native American and Loco-Foco movements were factors. The authorities are as follows: Wards in 1810 and 1816 , D. Longworth, Explanatory Map and Plan of New York City (N. Y., I8I7); election returns, N. Y. Ez'ening Post, April 30, I8Io, and May 4. I8I6. For wards 1828-1840: D. A. Burr, Map of the City and County of New York (N. Y., 1832), Map of City of New York (N.Y., I840) ; D. T. Valentine. Manual of the Corporation of New York (N. Y., I842). For election returns: E. Williams, New Fork Anunal Registor (N. Y., 1831-I840): O. L. Holley, Now Yort State Register (Albany, I843) ; N. Y. Eacning Post, Nov. I0, I828, Nov. 12, Nov. 26. 1836; N. Y. Morning Courier. Nov. II, 1828. The presidential vote corresponded with the state ticket vote.

${ }^{2}$ W. A. Pelletreau, Early New York Houscs, P. 78 , and other atithorities cited supra, pp. 22-25.

${ }^{3}$ The following figures are computed from the tables in D. T. Valentine's, Manual of the Corporation of New York, 1841, pp. 49, r84. See Table, page +32 .

${ }^{4}$ From the Census of the State of New York, 1845 , as given in O. L. Holley, New York State Register, 1846, fage iog, excepting, of course, the column of percentages which are computed. See Table, page 432. 


\section{ARISTOCRACY IN THE POLITICS OF NEW YORK}

Footnote 3, page 431, continued

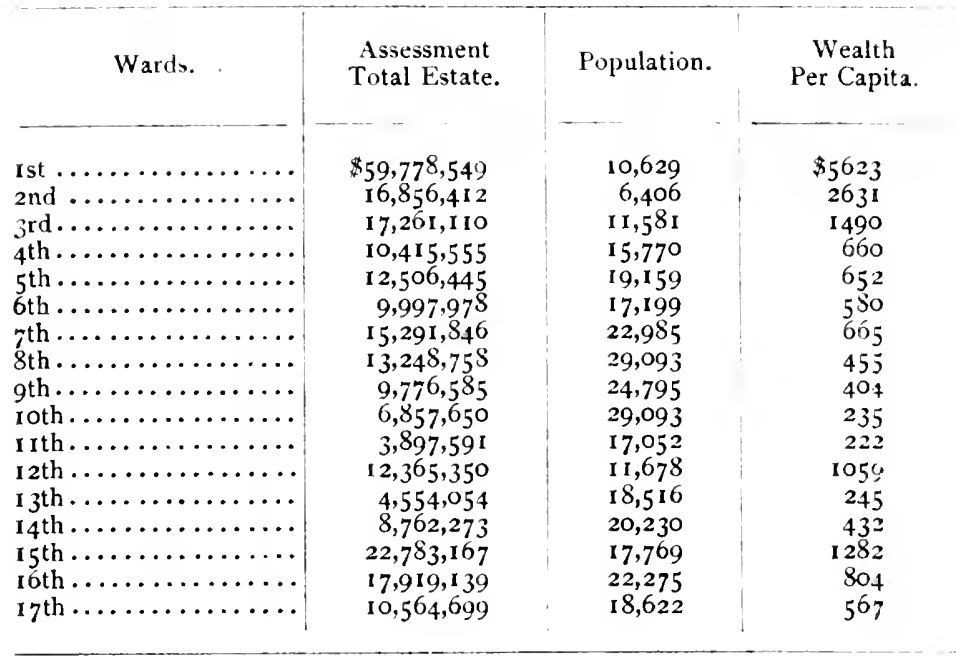

Footnote 4, page 43I, continued

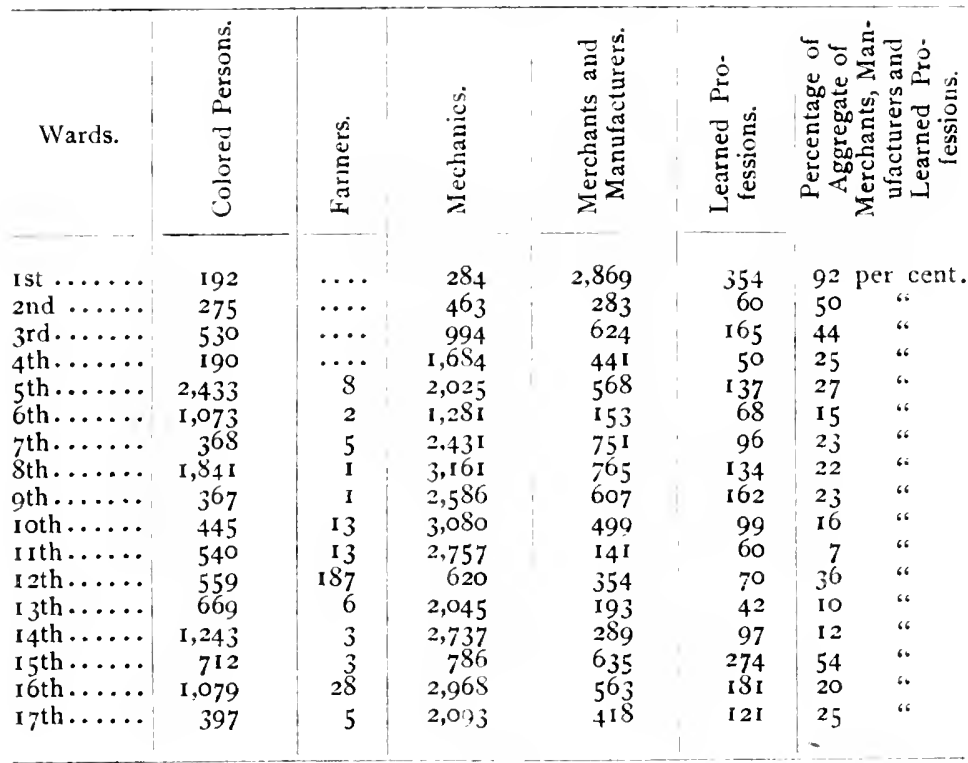



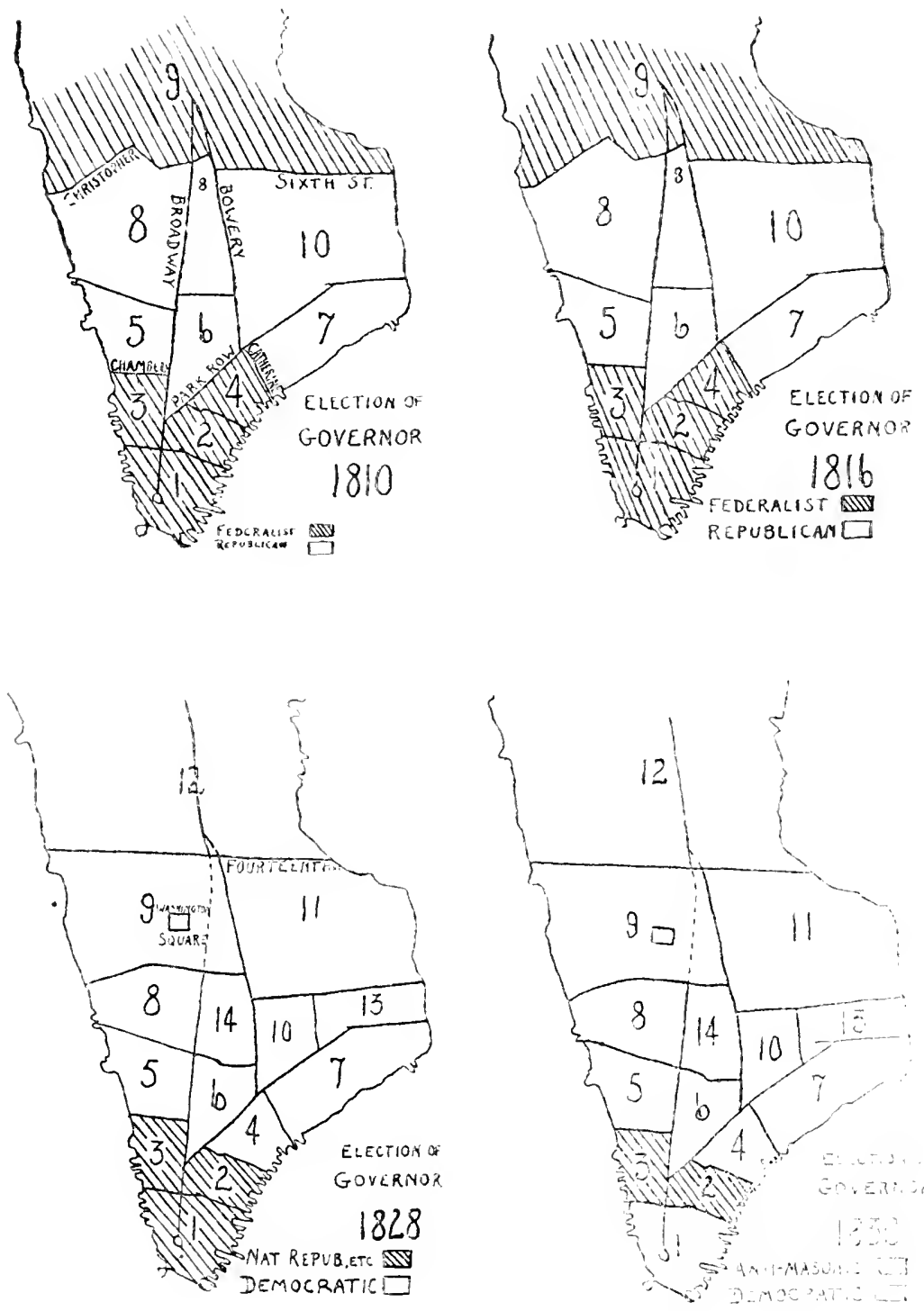
4.34 ARISTOCRACY IN THE POLITICS OF NEW YORK
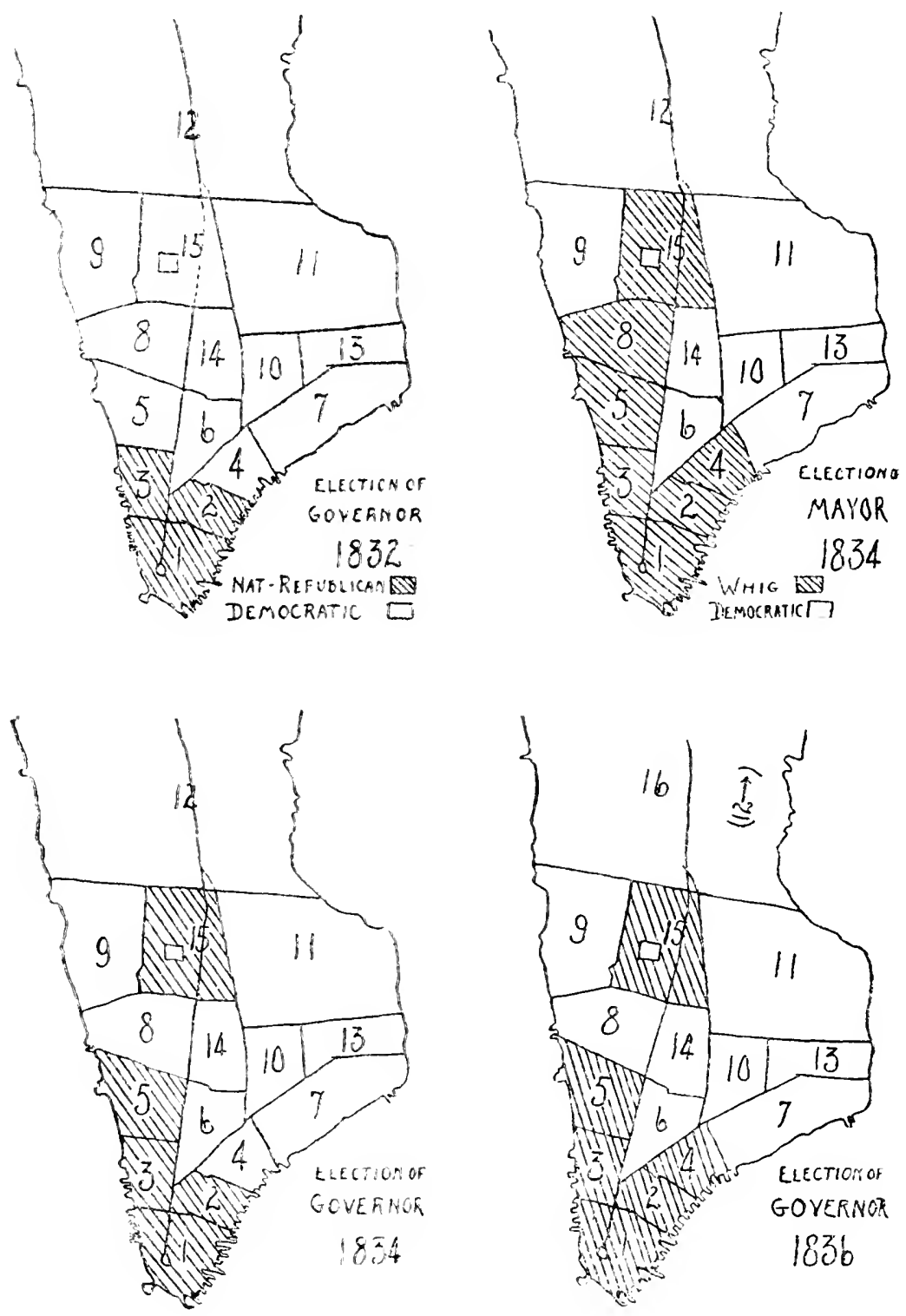

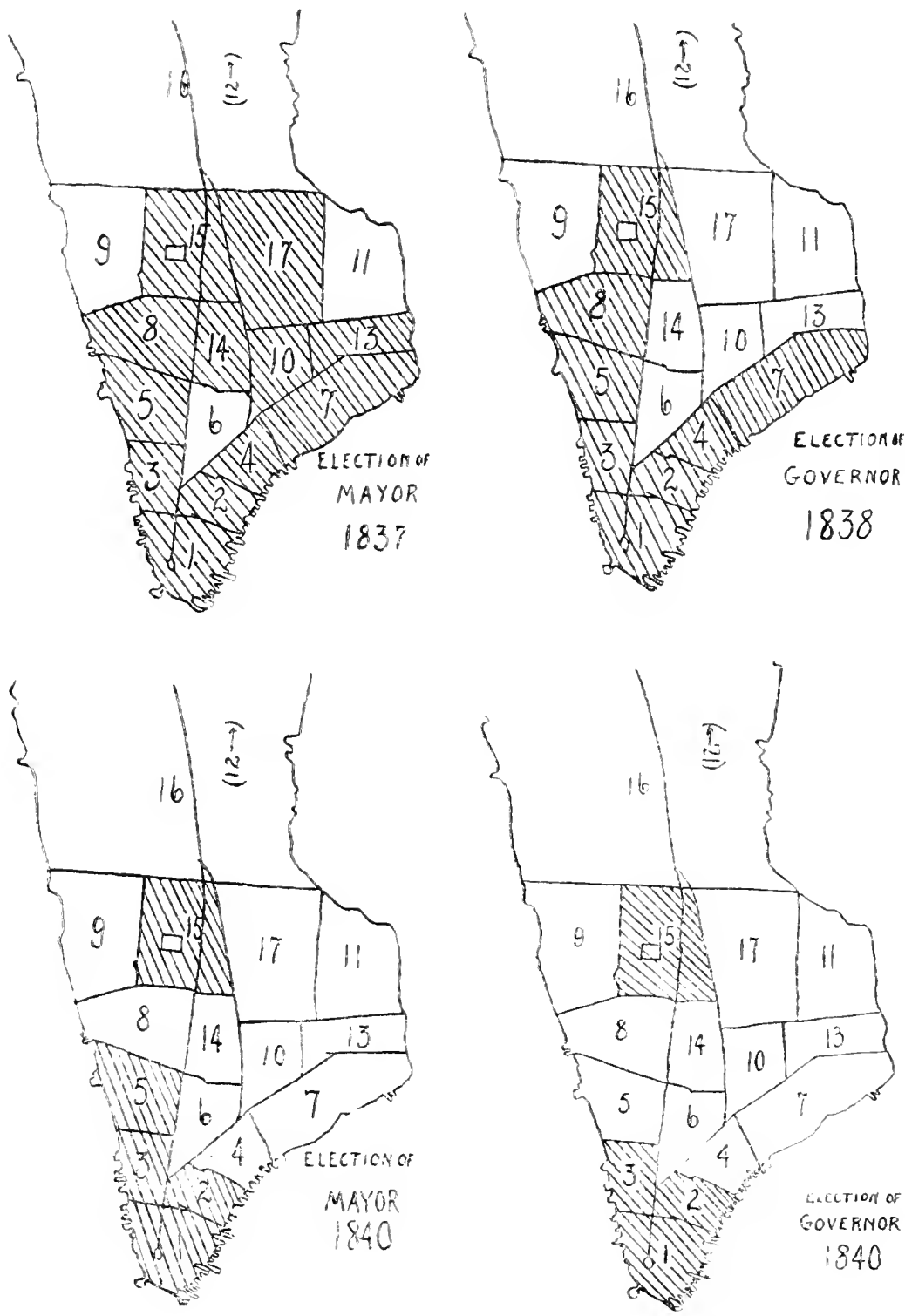
Depending on the figures of the nearest census where these data are presented, we find the previous conclusions perfectly supported: the reliable Whig wards, which showed as well the largest wealth compared with population, are seen likewise to have contained the largest proportion of merchants, manufacturers and members of the learned professions. ${ }^{1}$ The fifth and eighth wards, the majority of whose inhabitants were poor mechanics, several times presented Whig majorities. But the residents here who actually voted were in more comfortable circumstances than would at first appear: for reference to another column will disclose that here a considerable proportion of these workingmen were colored, and hence without the ballot, except for those who were possessed of property worth two hundred and fifty dollars. And the negroes who were thus qualified, as we have seen, were likely from historic reasons to support the Whigs." It is interesting also to observe. that the southern section of the city which was Whig, had likewise been Federalist, though many merchants and bankers of the fourth ward, when the fever of I 822 made their old residence untenable, had moved out to the "quiet, dreamy Greenwich village," which became the fifteenth. ${ }^{3}$

Turning to the other larger cities of the state and using what statistics can be found, we discover, in general, a similar condition. Where the property per capita was relatively large, the ward was IVhig. Albany, Brooklyn. Buffalo and Troy all contribute figures to establish that wherever thirty per cent of the population were merchants, manufacturers

${ }^{1}$ The defalcation of the first ward in 1830 was doubtless due to the fact that "Anti-Masonry was completely repudiated in the city of New York," Seward's Autobiography, p. 78 .

${ }^{2}$ See supra, note appended to chapter viii.

"T. F. De Voe, The Market Book, pp. foo-for: E. Bisland, "Old Greenwich," in Historic New York. First Series, pp. 290-29I. 
and professional men, the vote showed more Whigs than were found in other wards. Conversely, where mechanics made their home, Democratic candidates generally were certain of election. ${ }^{1}$ Rochester, alone, refuses to yield support to these conclusions; but the traditions of that city were so strongly Whig that it scarcely furnishes the evidence for our inquiry. ${ }^{2}$

It seems warrantable to conclude that, after due regard for other factors, there remains an " economic interpretation " of the Whig party in New York state, as it was constituted in the early 'forties of the nineteenth century.

They had an interest in protecting property, but it was a kind of property which was theoretically accessible to all who had the industry and enterprise to gain'it. Anything that savored of the feudal system found small support even from the Whigs. On the twenty-sixth of January, 1839 , Stephen Van Rensselaer, the last of the patroons, died, mourned and eulogized by everyone who had known him. The thousands of his tenants had tacitly agreed to refrain from protest while he lived, but when his heirs attempted to collect arrearages which he had allowed to grow, they started a campaign of violence, which lasted for nearly a dozen years. They claimed that during centuries of occupation of the land as lease-holders, hard-working farmers had paid more than enough of quarter-sales and covenanted fees, and had suffered more than was right from the onerous restrictions as to wood and water, minerals and mill streams. They refused to pay. Many men of property realized that vested rights, in general, were jeopardized by this defiance, and Governor Seward called out the militia to cnerce the tenantry along the Helderberg, near Albany.

" Farmers" in a city are truck-gardeners or persons of small fortune, who should be counted with mechanics.

${ }^{3}$ The tables and explanation for these five cities are printed in the appendix. 
But no gun was fired; even the most conservative Whigs, while lamenting Loco-Foco anarchy, admitted that huge estates in land did not serve the public welfare, and only deprecated the illegal form in which the tenants made their protest. The governor, himself, spoke of " their petitions for relief from tenures oppressive, anti-republican, and degrading." ' The contemptuous resistance to undoubtedly legal claims spread to similar estates in other counties, notably Columbia and Delaware, and tenants, banded on the roads as "Injuns," reviled, belabored, and on some occasions killed the luckless constables who sought to arrest them. Yet the Whigs as a party did not protest, and Greeley's Tribune openly expressed its sympathy. It was a Whig governor who cleared the jails of anti-renters, and Whig legislators did not as a group oppose the measures by which the ancient privileges of the great landlords were diminished one by one. They were as willing to attract five thousand voters as were the Democrats. Not thus would Egbert Benson, Jonas Platt, Elisha Williams or James Kent have acted in their period of power. But times had changed: the rigid castes of the eighteenth century with all their " rights" were gone.

The influence of the old aristocracy as such had nearly disappeared, but its mantle had fallen upon capital and business enterprise, with their faithful pensioners of talent. Their party had no other steady principle than this: that business should go on. But in a country of such splendid possibilities as the United States, this was not necessarily mean and sordid, for it looked to a development that would, perhaps, bring comfort and prosperity to all, and prestige to the nation. Part of the legacy of Federalism to its successors was, of course, made up of some personal ideals-

${ }^{1}$ Messages from the Governors, vol. iii, p. 84t. 
distinction of deportment, appreciation of arts and letters, and other qualities of culture - and this gave the party a prestige beyond that of its numbers.

Of the two great parties [wrote Emerson], which at the moment almost share the nation between them, I should say that one has the best cause, and the other contains the best men. The philosopher, the poet, or the religious man will, of course, wish to cast his vote with the democrat for free trade, for wide suffrage, for the abolition of legal cruelties in the penal code, and for facilitating in every manner the access of the young and the poor to sources of wealth and power. But he can rarely accept the persons whom the so-called popular party proposes to him as representative of these liberalities. [The spirit of our American radicalism is destructive and aimless.] On the other hand, the conservative party, composed of the most valuable, most moderate, able and cultivated part of the population. is timid, and merely defensive of property. ${ }^{1}$

${ }^{1}$ Essay on Politics. 


\section{APPENDIX}

\section{(to Chapter XIV)}

\section{Statistics of Party Politics and Economic Interest}

\begin{tabular}{|c|c|c|c|}
\hline \multicolumn{4}{|c|}{$\begin{array}{l}\text { ALBANY } \\
\text { WEALTH }\end{array}$} \\
\hline Wards. & $\begin{array}{c}\text { Aggregate } \\
\text { Assessment on } \\
\text { Property, } 1849 .{ }^{1}\end{array}$ & $\begin{array}{l}\text { Number of } \\
\text { Voters, } 1844 .{ }^{2}\end{array}$ & $\begin{array}{l}\text { Average } \\
\text { Assessnient } \\
\text { per Voter. }\end{array}$ \\
\hline 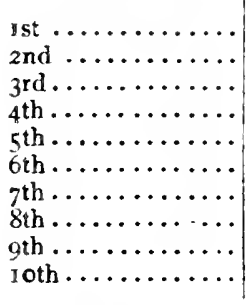 & $\begin{array}{r}\$ 405,335 \\
618,740 \\
912,515 \\
1,593,114 \\
3,708,546 \\
553,500 \\
531,935 \\
358,660 \\
877,993 \\
810,865\end{array}$ & $\begin{array}{l}549 \\
605 \\
963 \\
956 \\
547 \\
592 \\
604 \\
593 \\
867 \\
636\end{array}$ & $\begin{array}{r}\$ 738 \\
1,023 \\
95^{8} \\
1,656 \\
6,780 \\
935 \\
880 \\
605 \\
1,012 \\
1,275\end{array}$ \\
\hline
\end{tabular}

${ }^{1}$ Computed from tables in Joel Munsell, Annals of Albany (2nd edition, Albany, I870), vol. ii, pp. 361-362.

${ }^{2}$ Computed from following table. 
ELECTIONS I $842-1846^{1}$

\begin{tabular}{|c|c|c|c|c|c|c|c|c|}
\hline \multirow[b]{2}{*}{ Wards. } & \multicolumn{2}{|c|}{$1 \delta_{4} 2^{2}$} & \multicolumn{2}{|c|}{$1844^{3}$} & \multicolumn{2}{|c|}{$1846^{4}$} & \multicolumn{2}{|c|}{$\begin{array}{c}\text { Anti-Slavery } \\
\text { Vote. }\end{array}$} \\
\hline & 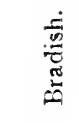 & $\frac{\dot{x}}{0}$ & $\dot{\pi}$ & $\stackrel{\dot{y}}{0}$ & $\stackrel{0}{\Xi}$ & 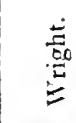 & 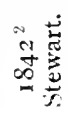 & 过 \\
\hline Ist ..... & I 78 & $27 I$ & $20 I$ & $34^{8}$ & 312 & 437 & 2 & 3 \\
\hline 2nd .... & 244 & 275 & 268 & 337 & $34^{2}$ & 351 & I & 3 \\
\hline 3 rd..... & 480 & 400 & $5^{16}$ & 447 & 468 & 518 & 5 & II \\
\hline $4^{\text {th }} \ldots \ldots$ & 545 & 339 & 572 & 384 & 624 & 504 & 10 & 8 \\
\hline $5^{\text {th }} \ldots .$. & 337 & $23^{0}$ & 299 & 248 & $33^{8}$ & 249 & 5 & 8 \\
\hline 6 th..... & 305 & 195 & 359 & 333 & 478 & 406 & 7 & 10 \\
\hline $7^{\text {th }} \ldots .$. & 216 & 251 & 262 & 342 & 324 & 416 & I & 4 \\
\hline 8 th...... & 222 & 286 & 219 & 374 & 316 & 462 & I & 5 \\
\hline$g^{\text {th }} . . .$. & $47 I$ & 274 & 520 & 347 & 625 & 364 & 3 & 6 \\
\hline roth.... & 278 & 247 & $35^{8}$ & 278 & 405 & 342 & 8 & 10 \\
\hline
\end{tabular}

Percentage of Whigs

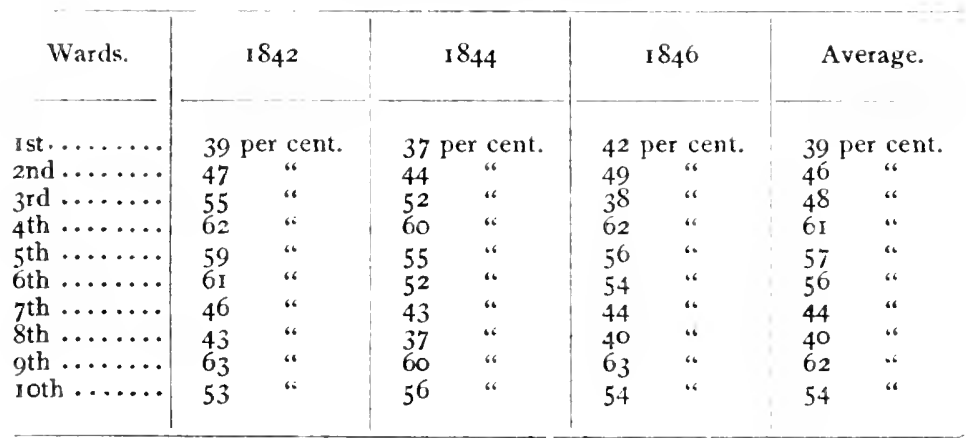

1 Elections for a somewhat later period are here considered than with New York and Brooklyn for want of assessment figures for the earlier years.

2 From O. L. Holley, New York State Kegister, I843, p. 69.

3 From O. L. Holley, New York State Register, I8 45, p. 69.

${ }^{4}$ The only data at hand on this election was the report in the New York Tribune, November 4, 1846 (received from Albany Argus message slip) which gave only the majorities by wards. Assuming the gain in all wards between $I 844$ and $I 846$ to have been at the same rate as between I 842 and I 844 , the totals for I 846 were computed. From these, with the majorities given, the probable votes of each party were computed as well. 
OCCUPATIONS, ETC., $1845^{1}$

\begin{tabular}{|c|c|c|c|c|c|c|c|}
\hline Wards. & 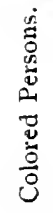 & 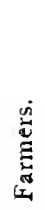 & 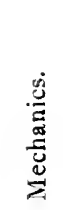 & 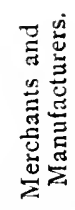 & 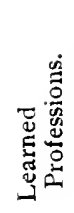 & \multicolumn{2}{|c|}{ 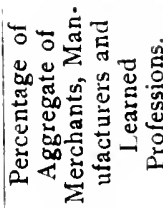 } \\
\hline & 142 & .. & 263 & I & 4 & & cent. \\
\hline and..... & 63 & I & 313 & 71 & 23 & $2 I$ & \\
\hline $3^{\mathrm{rd}} \ldots \ldots$ & 112 & 4 & 520 & 125 & 30 & 23 & " \\
\hline $4^{\text {th }} \ldots \ldots$ & 71 & .. & 446 & 220 & 62 & 39 & “ \\
\hline $5^{\text {th }} \ldots \ldots$. & 80 & .. & 141 & 44 & 55 & 41 & " \\
\hline 6 th $\ldots \ldots$ & 33 & .. & 260 & 117 & 40 & $3^{8}$ & “ \\
\hline $7^{\text {th }} \ldots \ldots$ & 7 & .. & 248 & 37 & 7 & 15 & “ \\
\hline Sth $\ldots . .$. & 38 & .. & 201 & 11 & 10 & 10 & " \\
\hline gth ..... & $S_{7}$ & 15 & $43^{8}$ & 97 & 35 & 30 & “ \\
\hline Ioth ..... & 155 & 20 & 379 & 82 & $3 I$ & 25 & " \\
\hline
\end{tabular}

Examination of the wards according to intensity of wealth shows seven wards, the 2nd, $3^{\text {rd, }} 4^{\text {th. }} 5$ th, 6th, gth and Ioth, where the average assessment was over $\$ 900$. Turning to the table giving the average percentage of IVhigs during these years, we find that 5 out of 7 of these regularly show a Whig vote of at least $4.5 \%$ (probably the sudden drop in the Whig vote in the 3 rd ward is to be attributed to some local circumstance, for there is no other such eccentric fluctuation). In fact, all but the 2nd and 3 rd are well above half. As a whole, where the property-holding average is high, the ward is Whig. The table setting forth the numbers engaged in four general groups of occupations (which may be supposed to include a very large proportion of the voters, as comparison with the total vote for 1844 will show), shows that wherever the proportion of merchants, manufacturers and professional men amounted to $30 \%$ or more, as in the 4 th, 5 th, 6 th and 9 th, the ward was Whig. But there are some Whig wards, as the rst

${ }^{1}$ From the Census of the State of New York, I845, as given in O. L. Holley, New York State Register, IS 76, p. 107, excepting the percentages which are computed. 
and the Ioth, where the number in this class seems insufficient to account for the number of Whigs. But it may be seen that these two wards contain the largest number and the largest proportion of colored persons. Most of these did not vote, because of the peculiar franchise restrictions. Those who could qualify probably voted Whig; see supra. chapter viii, note. Only the second ward does not contribute support to the "economic interpretation."

\section{BROOKLYN}

\begin{tabular}{|c|c|c|c|}
\hline \multirow[b]{2}{*}{ Wards. } & \multicolumn{2}{|c|}{ Wealth } & \multirow[b]{2}{*}{$\begin{array}{c}\text { Average } \\
\text { Assessment } \\
\text { per Voter. }\end{array}$} \\
\hline & $\begin{array}{c}\text { Aggregate } \\
\text { Assessment on } \\
\text { Property. }\end{array}$ & $\begin{array}{c}\text { Number } \\
\text { of Voters } \\
1840 .\end{array}$ & \\
\hline rst $\ldots \ldots \ldots \ldots \ldots$ & $\$ 2,720,150$ & 303 & $\$ 8,977$ \\
\hline and.............. & $3,498,685$ & $76 \hat{S}$ & 4,554 \\
\hline $3^{\mathrm{rd}} \ldots \ldots \ldots \ldots \ldots$ & $4,448,000$ & 546 & 8,117 \\
\hline $4^{\text {th }} . . . \ldots \ldots \ldots$ & $3,077,575$ & 964 & $3,19 I$ \\
\hline $5^{\text {th }} \ldots \ldots \ldots \ldots \ldots$ & $1,525,75^{\circ}$ & 910 & 1,676 \\
\hline 6th $\ldots \ldots \ldots \ldots \ldots$ & $5,331,310$ & 480 & 11,107 \\
\hline $7^{\text {th }} \ldots \ldots \ldots \ldots \ldots$ & $2,982,935$ & 626 & 4,764 \\
\hline 8 th $\ldots \ldots \ldots \ldots$ & 970,060 & 117 & $8,29 \mathrm{I}$ \\
\hline $9^{\text {th }} \ldots \ldots \ldots \ldots$ & $1,092,051$ & 120 & 9,100 \\
\hline
\end{tabular}

1 Assessment figures are from the Tax Rolls, Series 1840 , mss. in the office of the Deputy Receiver of Taxes, Borough of Brooklyn, Department of Finance, New York city. The number of votes is computed from table in O. L. Holley, N. Y. State Register, I843, p. 82. No tax lists are available for years previous to 1840 . 
ELECTIONS $1834-1840^{1}$

\begin{tabular}{|c|c|c|c|c|c|c|c|c|}
\hline \multirow[b]{2}{*}{ Wards. } & \multicolumn{2}{|c|}{$1834^{2}$} & \multicolumn{2}{|c|}{$1836^{3}$} & \multicolumn{2}{|c|}{$188^{4}$} & \multicolumn{2}{|c|}{$1840^{\circ}$} \\
\hline & 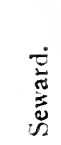 & $\frac{\dot{0}}{2}$ & 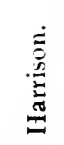 & 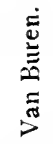 & 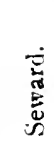 & $\begin{array}{l}\bar{J} \\
\text { J } \\
\text { 之े }\end{array}$ & 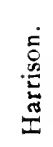 & 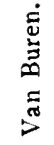 \\
\hline Ist $\ldots \ldots$ & $x^{1}$ & 78 & 147 & $9^{2}$ & 167 & 85 & 213 & 90 \\
\hline 2nd. .... & 227 & 322 & 282 & 300 & 273 & 243 & 359 & 409 \\
\hline $3^{\text {rd }} \ldots \ldots$ & 216 & 146 & 294 & 123 & $34^{2}$ & 137 & 410 & $13^{5}$ \\
\hline $4^{\text {th }} . . . .$. & 278 & 401 & 384 & 353 & 424 & 371 & $55^{8}$ & 406 \\
\hline $5^{\text {th }} . \ldots \ldots$ & 109 & 329 & I 35 & 403 & 178 & 463 & 254 & 656 \\
\hline 6 th...... & 88 & 102 & 84 & $15^{8}$ & 158 & 136 & 284 & 196 \\
\hline $7^{\text {th }} \ldots \ldots$ & 68 & 128 & 128 & 207 & $25^{\circ}$ & 228 & 327 & 299 \\
\hline 8 th . ..... & 21 & 68 & 21 & 63 & 28 & 52 & 35 & 82 \\
\hline gth ...... & 24 & 16 & 39 & 26 & 54 & 38 & 87 & 33 \\
\hline
\end{tabular}

Percentage of Whigs

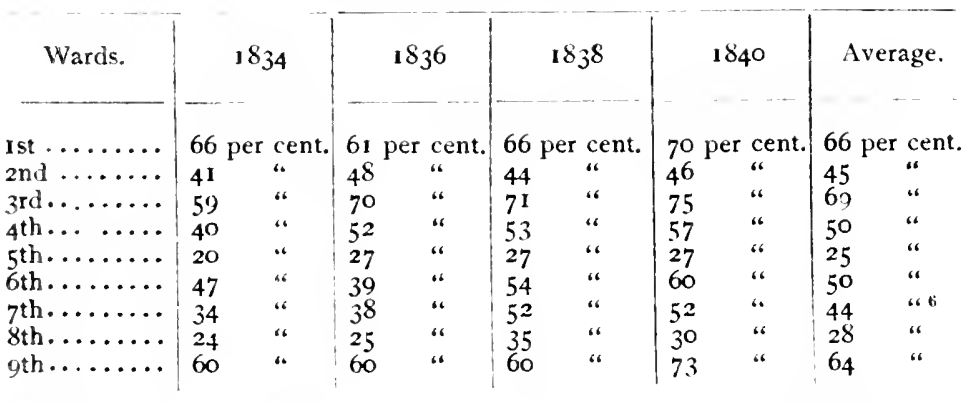

${ }^{1}$ Figures are given for vote for president in 1836 and 1840 , and for governor in 1834 and 1838 .

2 From Edwin Williams, New York Annual Register, I836, p. 95.

${ }^{3}$ The only data at hand on this election was the report in the $N . Y$. Evening Post, November 4, I836, which gave only the majorities by wards. Assuming the gain or loss in population to have been at the same rate between 1834 and 1838 , the number of voters in 1836 was computed, and with the majorities given, the probable vote of each party was computed as well.

${ }^{4}$ From Edwin Williams, New York Annual Register, I840, p. 222.

"From O. L. Holley, New York State Register, I843, p. 82.

- If the table were continued, this percentage would be decreased as this ward returned to its former Democratic majority in I842. See O. L. Holley, New York State Register, I843. p. 82. 
It is observed that there are five wards where the average assessment is relatively high and four where it is low. Comparing these figures with the percentage of Whigs. we find that in wards $1,2,3,5,7$ and 9 the economic interpretation is supported, while the percentage in the 6th, and especially the 8th, seems too low, and that in the $4^{\text {th }}$ too high. Six out of nine might be accounted a sufficient preponderance to establish a presumption, but the three cases which show contrary evidence are now to be examined again in connection with other data. In order to check any grossly unequal distribution of property within the wards, let us examine the table of occupations, etc., which affords a personal index.

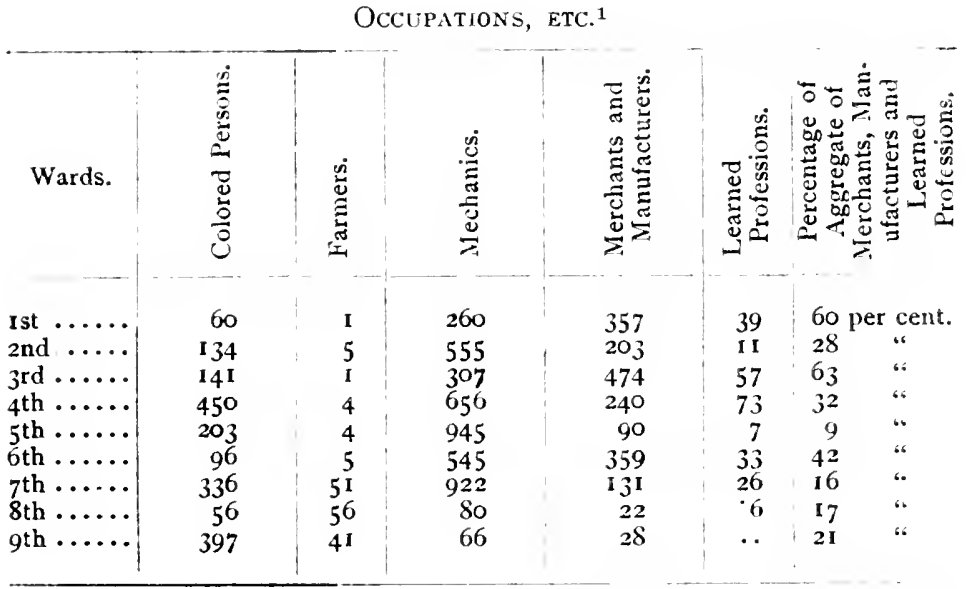

Comparing the percentage of merchants, manufacturers and professional men with that of IVhigs, we find a striking parallel. The apparent solidarity of this class was due to social tradition as well as community of economic interest. The Ist. 2nd, $3^{\text {rd. }} 5^{\text {th, }} 6$ th and 8 th, in general, show quantities where

${ }_{1}^{1}$ From the Census of the State of New York, I845 (the first where such data is presented), as given in O. L. Holley, New York State Register, 1846 , p. 107, excepting the column of percentages which are computed. 
they might be expected. In the 4 th, 7 th and 9 th, there seems too few of this class to account for the larger percentage of ithigs, but they probably bore a higher ratio to the voting total than they do to the total of those listed in occupations. because of the large number of negroes in these wards.

BUFFALO

ELECTIOX OF $1844^{1}$

\begin{tabular}{|c|c|c|c|c|}
\hline Wards. & Clay. & Polk. & Birney. & $\begin{array}{c}\text { Percentage of } \\
\text { Whigs. }\end{array}$ \\
\hline 1st....... & 282 & 487 & 4 & 37 per cent. \\
\hline and ....... & 542 & 336 & 21 & 60 \\
\hline 3rd $\ldots .$. & 326 & 152 & $\delta$ & 67 \\
\hline $4^{\text {th }} \ldots .$. & 325 & 602 & 14 & 34 \\
\hline $5^{\text {th }} \ldots \ldots$ & 327 & 325 & 16 & 49 \\
\hline
\end{tabular}

OccLPations, etc., I $845^{2}$

\begin{tabular}{|c|c|c|c|c|c|}
\hline Wards. & 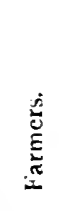 & 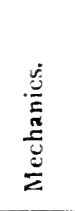 & 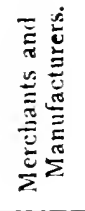 & 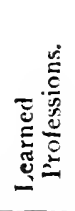 & 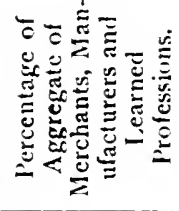 \\
\hline $\begin{array}{l}\text { ist } \ldots \ldots \\
\text { 2nd } \ldots \ldots \\
3^{\text {rd }} \ldots \ldots \\
4^{\text {th }} \ldots \ldots \\
\text { sth }^{\text {th }} \ldots\end{array}$ & $\begin{array}{r}356 \\
3 \\
8 \\
\cdots \\
4\end{array}$ & $\begin{array}{r}798 \\
474 \\
351 \\
1011 \\
258\end{array}$ & $\begin{array}{r}461 \\
263 \\
148 \\
2 \\
42\end{array}$ & $\begin{array}{l}15 \\
67 \\
39 \\
38 \\
32\end{array}$ & $\begin{aligned} 23 & \text { per cent. } \\
40 & \text {. } \\
34 & . \\
4 & . . \\
23 & . .\end{aligned}$ \\
\hline
\end{tabular}

I The election of $18+4$ is chosen because it is the only one prior to $18+5$ (the date of the occupation statistics) available for the figures by wards. The data for rotes is taken from O. L. Holley, I. Y. State Register, 1845, p. 76 .

2O. L. Holley. .1. Y. State Register, 18+6. p. 103. excepting, of course. the percentage.

Here where the ward statistics show more than 30 per cent were members of the specified class, the ward was most heavily Whig. iihere the mechanics were most numerous, in the 4 th, the ward was most strongly Democratic. 


\section{ROCHESTER}

ELECTION OF $1846^{1}$

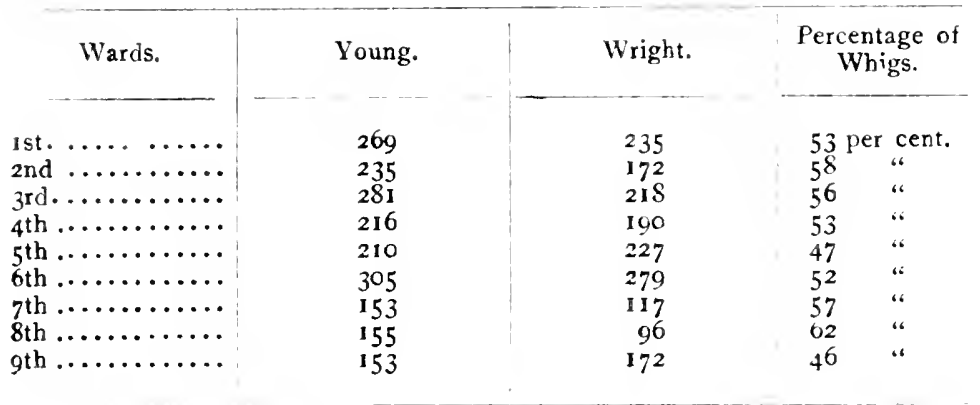

\begin{tabular}{|c|c|c|c|c|c|c|}
\hline \multicolumn{7}{|c|}{ OcCUPATIONS IN I $845^{2}$} \\
\hline Wards. & 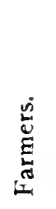 & 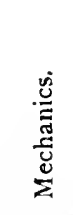 & 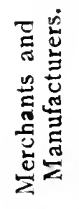 & 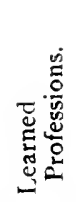 & \multicolumn{2}{|c|}{ 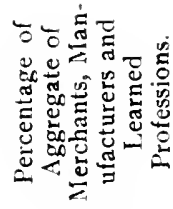 } \\
\hline & & 205 & 184 & 20 & & r cent. \\
\hline & .. & 376 & 131 & 11 & 27 & “ \\
\hline rd.............. & 7 & 250 & 56 & 38 & & “ \\
\hline $4^{\text {th. }} . \ldots \ldots \ldots$ & 10 & 395 & 77 & 36 & & “" \\
\hline $5^{\text {th. }} . \ldots \ldots \ldots$ & 7 & & 17 & 10 & & “ \\
\hline 6 th.............. & 52 & $3^{8}$ & 53 & 22 & & \\
\hline $7^{\text {th. }} . . . \ldots \ldots$ & 35 & 127 & 4 & 3 & & \\
\hline 8 th............. & 16 & 165 & 3 & 7 & & \\
\hline gth...... & 27 & 312 & 42 & 6 & & \\
\hline
\end{tabular}

1 The vote here recorded is taken from the Rochester Daily Adzertiser, November 5, 1846 , on file in the office of the Rochester Union and Advertiser. The majorities, but not the total vote for 1848 , are given in the Rochester Dcmocrat, November 8, 1848 (Reynolds Library, Rochester). The Whig vote was then apparently much higher in proportion, the majorities for the first three wards being I6I, I5I, I62, etc. These figures in comparison with those of the following table show no connection between economic interest and politics. The traditions of this city, renowned for Anti-Masonry and manufacturing and anxious for a restoration of Whig canal policy, made its statistics hardly as useful as evidence, as those of other cities.

2 From the Census of the State of New York, I845, as given in O. L. Holley, New York State Register, I846, p. I09, excepting the column of percentages which are computed. 
TROY

Election of $1842^{1}$

\begin{tabular}{|c|c|c|c|c|}
\hline Wards. & Bradish. & Bouck. & \multicolumn{2}{|c|}{$\begin{array}{c}\text { Percentage of } \\
\text { Whigs. }\end{array}$} \\
\hline Ist $\ldots \ldots \ldots \ldots \ldots$ & 234 & 241 & 49 & r cent. \\
\hline and $\ldots \ldots \ldots \ldots$ & 310 & 285 & 55 & " \\
\hline $3^{\mathrm{rd}} \ldots \ldots \ldots \ldots \ldots$ & 323 & 142 & 69 & .* \\
\hline $4^{\text {th }} \ldots \ldots \ldots \ldots \ldots$ & 322 & $23 I$ & $5^{8}$ & “. \\
\hline $5^{\text {th }} \ldots \ldots \ldots \ldots \ldots$ & 57 & $5 j$ & 52 & " \\
\hline 6 th.$\ldots \ldots \ldots \ldots$ & 107 & 67 & 61 & “ \\
\hline $7^{\text {th }} \ldots \ldots \ldots \ldots$ & 222 & 262 & 46 & . \\
\hline sth............. & 107 & 63 & $6 \mathrm{I}$ & “. \\
\hline
\end{tabular}

Occupations, etc., I $845^{*}$

\begin{tabular}{|c|c|c|c|c|c|c|}
\hline Wards. & 苞 & 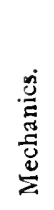 & 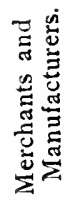 & 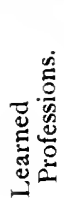 & 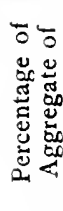 & 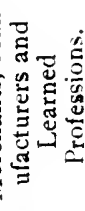 \\
\hline Ist . & .. & 182 & 18 & 4 & & er cent. \\
\hline and..... & 8 & 285 & 104 & 42 & $3^{1}$ & “ \\
\hline $3^{\mathrm{rd}} \ldots \ldots \ldots$ & I & 190 & 47 & 32 & 29 & “ \\
\hline $4^{\text {th }} \ldots \ldots \ldots \ldots$ & 1 & 251 & 127 & 22 & 34 & “ \\
\hline $5^{\text {th }} \ldots \ldots \ldots \ldots$ & 10 & 107 & 325 & 4 & 74 & $" 6$ \\
\hline 6 th $\ldots \ldots \ldots$ & 16 & 273 & 18 & 3 & 7 & “ \\
\hline $7^{\text {th }} \ldots \ldots \ldots \ldots$ & .. & 167 & .. & 2 & I & " \\
\hline 8th ............ & I & 37 & 37 & 18 & 59 & "“ \\
\hline
\end{tabular}

The evidence from Troy is not so striking as in some cities, as it seems to have been a Whig stronghold by tradition. Only once in the decade of the 'forties can we find more than one

1 The election of $18_{42}$ is the only one in this period when more than one ward showed a Democratic majority. The figures for the votes are taken from the report in O. L. Holley, New York State Register, 1843, p. 92, excepting those for percentages which are computed.

${ }^{3}$ From the Census of the State of New York, I845, as given in O. L. Holley, New York State Register. I8.66. p. II4, excepting the column of percentages which are computed. 
ward going Democratic. However, from this election, when the lines were most tightly drawn, deductions can be made which support the "economic interpretation." There were four wards which had more than $30 \%$ per cent of its workers engaged in manufacturing, commerce or the learned professions. These wards are all Whig. There are three wards which have less than $15 \%$ in this occupational class; the two Democratic wards are contained within this group. The seventh ward, which has the lowest percentage in this class, has also the lowest percentage of Whigs. It was the only ward which went Democratic more than once during the decade; see tables in E. Williams, N. Y. Annatal Register, I840, page 229, and O. L. Holley, N. Y. State Register, 1845, page 9r. 



\section{INDEX}

Abolitionism, 378-380

Adams, John, I I5-I I6

Adams, J. Q., deplores Federalist snobbery, 85 ; as politician in I8Io, i 5 ; leads old Federalists, 149 ; on internal improvements, 308-310; on tariff. 330-331; on Anti-Masonry, $34 \mathrm{I}-342$; on Clinton, 345

Adirondack country, thinly populated in 1821,230

Albany, politics of, 3I-36: effect of canal upon, 304 ; effect of manufacturing on. $319-320$; workingmen in, 356; Whigs in, 369 ; election figures of, appendix

Albany Argus, on parties, 275276 ; against conventions, $20 \mathrm{I}$; alleges Federalists are Clintonians, 208: scorns "People's Men" as lobbyists, 307; on tariff, 329; on Anti-Masonry, 343; on Loco-Focos, 397; on Whigs, 425

Albany Daily Advertiser. 36I

Albauy Evening Journal, 360

"Albany Regency," 281-286; in campaign of I824, 286-299; calls convention in 1826,297 ; on manufactures, 324

Allen, Peter, I87, I90

American System, 308-310, 358

Ames, Fisher, 5

Angelica, 306n, 424

Anti-clericalism, 359, 388-390

Anti-Masonry, 337-343; party seeks workingmen, 357 ; in 1832 , $360-363.365$; party in west counted by Regency, 370

Anti-rent riots, $437-438$

"Aristides" (W. P. Van Ness), 59

Aristotle, on democracy, 268

Armstrong, John, 166, I69

Aspinwall, Gilbert, 152
Auburn, 356, 358

Auctioneers' monopolies, 354

Bacon, Ezekiel, in convention of I82I, 243, 259, 261

Bancroft, George, quoted, 24I, 249

Bank of America, 226-228

Bank of U. S., 36+-365, 371

Bankers, 20-2I

Bank, Merchants, 69 ; opinion of workingmen on, 354; safetyfund and, 360 ; criticized by Loco-Focos, 382-383

Banyar, G., I52

Barnard, D. D., to2

"Barrett, Walter" (J. A. Scoville), on parties, 426

Barstow, Gamaliel, 335, 422

Bataria, 356, 424

Bayard, IVm., 123, I54. 2 I4

Benson, Egbert, I6, 18, I00, 170, I82, I 85, 299

Benson, Egbert, Jr., I34

Benton, T. H., 397

Biddle, Nicholas, $37 \mathrm{I}$

Binghamton, 360

Bleecker, H., 34, I82, I88n

Bleeckers, I 23

Bogardus, Robert, I7

Bogert, C. I., 108

Bradbury, J., quoted, 230

Bradish, Luther, 378

Brasher, Philip, 22, 124, I57, 2 It

Brooklyn, election figures of. Appendix

Broome, John, I64

Broome County, 157, 363

Bryant, W. C., 395, 426

Bucktail Bards, 215-218

Buffalo, politics in, 51 ; effect of canal upon, 229, 303; workingmen in, 356: Whigs in, 360 , 424,446

Bunner, R., 2I8n

Burr, Aaron, 12, 57-69 
Burt, James, 62, 423n

Butler, B. F., member of "Regency," 55,282 ; on Webster, 4I I

Butler, H. N., 334n

Byrdsall, F., 382, 385, 397

Cady, D., 178

Canals, I 48-159, 302-306, 334-337. $360,403-408$

Canandaigua, politics in, 5I ; workingmen in, $35^{6}$; a Whig center, 424

Catholic churches, 372

Chaumont, Le Ray de, 53, 306n

Cheeseborough, Robert, i9

Cheetham, James, 59. 80

Chenango County, 157,363

Child labor, 352

Clark, J. C., 399, 400

Clarkson, D. M.. I24

Clarkson, Matthew, I9, 20, I68, I82, 2 I 4,237

Clarksons, 131. 137, I57

Clay, Henry, and "Regency," 283 ; in campaign of 1824,286 , $288,299,300$; on American System, 330-333: some followers join workingmen. 358 ; in campaign of 1832,361 ; in campaign of I840, +II $42 \mathrm{I}$

Clinton, De IVitt, did not invent spoils system, 6n, IIo; on Council of Appointment, 58 ; in canpaign of I804. 62: interest in Manhattan Co., 69; favorite with Irish, 76,233 ; seeks U. S. aid for canal, 153 ; in campaign of I8I2, I64-172; as mayor, I74. I83; suspected by some Federalists, I9I ; elected governor, I94Ig6; policy of, I97-I9s: supported by most Federalists, I9s200 ; lack of affability, 200-201; his "family," zoI: scientific and literary interests, 202-203; and Verplanck, 203-205; attitude toward Federalists, 206, 220 ; and N. Y. American. 209. 213; and Bucktail Bards, 2142I8; G. Granger's defense of. 219-220: and "High-minded Federalists," 22I-223; opposes constitutional convention in 1818 , 232 ; seeks to limit constitutional reform, 233; attempt to post- pone convention, 234; popular in western counties, 252 ; defends custom of addressing legislature, 271; not a candidate in $1822,280 \mathrm{n}$; removed from office of canal commissioner, 292 ; nominated for governor in IS24, 293-294: effect on People's Party, 295-296; elected, 298 ; celebrates opening of canal, 302; thanked by merchants, 305 ; advised building more canals, 306; followers for Adams, $309,315,316$; on national internal improvements, 3II-3I2; re-elected governor, 3 I 3 ; on presidential candidates, 3I4-317; death and character, $343-347$.

Clinton County, 349, 428

Clinton family, 64,65

Clinton, George, 4. I2, 100, I75

Clintonians, disband as party, 275

Cock, Wm., Ios

Colden, C. D., I4, I23, I54, I99, $218,237,299$

Coleman. Wm.. 79, г6г, I9I

Coles, I. V., I 83

Coles, John B., I8, I8I, I8z

Columbia College, 29-30, 162-165

Columbia County, 39-46, 237, 266

"Coodies," 203-205, 2II

"Coody, Abimelech" (see Verplanck. G. C.)

Cooper, C. D., 20 I

Cooper, J. F., I 39

Cooper. Wim., I36-I37, I38, I40-14I

Conservative Democrats, 398-402

Constitution of I82I, movement for, 230-239; delegates to convention, 239-244: rebates in convention. 244-266; accepted, 267

Council of Appointment, 5n, 230232,246

Council of Revision, 235. 236; $244-245$

Crolius, Clarkson, 322

Croswell, Edwin, 282

Croswell, Harry, 44

Danton, 269

Dash. J. B., I9

Delatield, John, I24, I 28

Delancey, John, Ios, i $2 S$ 
Delaware County, 47

Democratic leaders (see "Albany Regency")

De Peyster, F., 2I, I24, I57

De Tocqueville, A., 416

De Witt, Simeon, $175^{n}$

Dietz, J. J., 34

Duane, James, I22, 123

Duer, John, I8Sn, $218 n$; in convention of I $\& 2 \mathrm{I}, 253 \mathrm{n}, 263$

Duer, W. A., president of Columbia College, 30 ; on navy in $\mathrm{V}$ ar of 1812,181 ; on secession, 185 ; opposes Clinton, 207-208, 214; and N.Y.American, 212; supports King for Senator, $22 \mathrm{I}$; becomes judge, 226

Duers, 39, 122

Dunscombe, W., I63

Dutch aristocracy, 3 I- 36

Dwight, Theodore, I88, 428

Dwight, Timothy. I60

Education, interest of workingmen in, 353,355

Edwards, Ogden, 232, 240, 263

Election of I800, 2-4; of I804. 5769 ; of $1807.74-81$; of I809, I09; of I8IO, II2-II6; of I8I2, I64I72; of $1813,172-173,175-176$; of $1815,186-187$; of $1816,187-$ 192 ; of 1817 , I96; of $1820,233^{-}$ 234 ; of $1822,279-280$; of 1824 . $286-299$; of $1826,312-314$; of 1828, 347-351 ; of 1830, 360-361 ; of $1832,36 \mathrm{I}-365$; of $1834,37 \mathrm{I}$; of 1836 and 1837 , in New York city, 376,402 ; of $1838,402-405$; of 1840 , chap. xiv

“Electoral Bill," 288-290, 293, 296

Elmendorf, L., 47, 155

Embargo, 99, 100, I02

Emerson, R. W., on parties, 439

Emmett, T. A., 76, 78, I I 5

Emott, James, 46-47, 123, 155, 210

Episcopal church, 25-29, I37, I38

Erie R. R., 337, 405

Evans, G. H., 356, 359, 386, 388

"Federalists, High-minded," 214, 222

Fellows, Henry, i87

Fillmore, Millard, 400

Fine, John, I29

Fish, Nicholas, a bank-president,
20 ; alderman, 22 ; candidate for lieutenant governor in 1810 , 1 I2; land-holder, I23, I57; in Coody's pamphlet, I60; candidate for lieutenant governor in I8II, 164; opposed to War of I8I2, I7O; candidate for Congress, I8I; defeated for delegate to convention of 1821,237

Fish, Preserved, 383

Flagg, Azariah C., member of "Regency." 28 I ; loyalty to "Regency," 283; leads Democrats against Electoral Bill, 289; on tariff, 332; and Anti-Masonry, $34 \mathrm{I}$; opposes internal improvement, $403-407$

Folger, Reuben, 40

Follett, Oran, 36I

Ford, David, I29

Ford, Nathan, 128, 129

Fredonia, 424

"Friends of Equal Rights" (see "Loco-Focos")

Fuller, P. C., 379

Furman, Gabriel, 21

Gardenier, B., 47, IOI, I6I, 210 . 214. 226

Gates, S. M., 379

Geneseo, 424

Genêt, "Citizen," 81, 105

Geneva, 27, 51, 356, 390, 39I, 429

Gold, T. R., 5I, IO3, I 53,322

Gouge, W. M., 383

Gracie, Archibald, 20, 182

Granger, Francis, 220; on state road, 335-336; and AntiMasonry, 34I-344; defeated for governor, 361 ; and Chenango Canal, 363

Granger, Gideon, 219, 220

Greeley, Horace, 376, 377, 421, 423, 427

Greene, 360

Greenwich Village, 436

Grinnell, M. H., 364,422

Grosvenor, T. P., $45 n, 46$

Grund, F. J., 430

Hale, W. H., 396

Hall, Willis, 403, 42I, 428

Hamilton, Alexander, opposes Jefferson's election in New York, 2-3; on democracy, 6; 
importance in party, 8; on Burr, $60-61,68$; on political clubs, 8788; a land-holder, 123

Hamilton, Alexander, Jr., 210, 214

Hamilton, J. A., 210,214

Hamilton, Thomas, 357

Hammond, J. D., on constitution of 1821,267 ; on parties, 276 ; on campaign of $1826,3 \mathrm{I} 3$; on state road contest. 337; on Clinton. 345

Hammond, Judah, 399, 400

Harison, Richard, importance and character, I2-13; as a lawyer. 29; a Tory, Jo8; familiar with New York city charter, II ; comptroller of Trinity Parish, I.37: investments in canals, I5I; petition for St. LawrenceChamplain canal, 157 ; for peace in $1812,168,170$

Harison, Richard, Jr., I32, I.37

Harrisburg Convention, 331-3.32

Harrison. IV. H., 41.3-114

Hartford (N. Y.), 356

Hasbrouck, L., I 29

Hatfield, Richard, 214

Hazeltine, Abner, 379

Henderson, Wm., i8, I34

Herkimer, 297

Hertell, Thomas, $3 \& 9$

Hobart, Bishop, 1.38

Hodgson, Adam, 230

Hoffman, Josiah O., importance and character, I3-14; candidate for assembly, is; a Tory, Ios; a land-holder, 124. I28; works for Clinton in 1812, $167-168$; for peace in IS12, 178; supports Clinton in $1817,108:$ abandons Clinton in I8I9, 206: co-operation with Tammany Society, 214

Hoffman, Michael, member of "Regency," 282, 283; on tariff, 332 ; on campaign of 1828,351 ; carries through "stop-and-tax law," $406-407$

Hoffman, Ogden, 29, 364

Hoffman, 122

Hopkins, Roswell, 53

Hopkins, S. M., 22, 90, 93, I $\varepsilon_{2 n}$

Hone, 20

Hone, Philip, invests in Washington Hall, of: hearls merchants' canal committee, 305 ; on manufactures, 322 ; and name of Whig party, 367 ; bewails Democratic vulgarity, 360,387 ; in campaigning of 1840,409 ; an orthodox Whig, 422

Hosack, David, 202n, 218

Hoxie, Joseph, 36I-362, 4I3

Hudson, 39-46, 55

Huntington, Henry, 274, 279-280

Imprisonment for debt, 353-354, 357

Independent Treasury bill, 308

Infidelity, 359, 388-390

Inman, IVm., I 52

Irish, $75-81,115,233,371-376$

Ithaca, $35^{6}$

Jackson, Andrew, and N. Y. politics, 286, 288, 2099, 314-3I8, 344, 3.47

Jay, Joln, refuses to interfere in election of ISOI, 2-t; on Council of Appointment, 5n, importance in party, 9; on campaign of $\mathrm{I} 8 \mathrm{C}$, $8_{2}$; and spoils system, IIo; on Napoleon, is2: on War of isi2, 184; and Clinton, 199; a framer of constitution of 1777,229

Jay, P. A., addresses Washington Benevolent Society, 93, 97, 98; supports king for governor in $1816,188 \mathrm{n}$; appointed recorder of New York city, 206; in convention of $1821,243,247$; on negro suffrage, 269n; a "People's Man," 200

Jefferson County, 52.53

Jeffersonian principles, 1, 2, 229 , $264,278,308,404$

Johnson. R. M., .393-394. 397

Jones, Elbert, 168

Jones, Samuel, I2, 29, I8I, 237

Kent, James, on beneficence of property-holders, 34 : on the trustworthiness of freeholders, I 4.3; supports King for governor in 1816.188 ; friendship for Clinton, Ig ; in convention of $1821,2.37,241,245,247,251,253-$ 25.5, 2.57: criticized in convention, 264-265: a "People's Man," 200 : in 1832,363 ; in campaign of 1840,400 ; an orthodox Whig, 422 
Kent, Moss, I34, I82n

King, Charles, president of Columbia College, 30; opposes War of 1812 , I80; becomes captain, 183; commissioner to investigate Dartmoor prison, igo; founds N. Y. American, 209; as a Whig editor, 426,428

King, Cyrus, I 49

king, John A., in War of 1812 , 183 ; supports his father for Senator, 207-209; opposes Clinton, 221-222; elected to legislature by "Bucktails," 226; attempt to have executive journal published, 272; orthodox Whig, 422

King, J. G., 183

King, Rufus, importance and character, 9 ; solicited to be a candidate for governor in I804. 6I62 ; reluctant to co-operate with Lewis, 7o: named for governor in 1807,75 ; assailed by Irish, 78; candidate for President. 101 ; on land taxation, I 26-127; canal investments, 152; on Clinton's candidacy for President, I68-17I: chosen Senator, I73174; on Napoleon, 182 ; on War of ISI2, IS3, I84; named for governor in $18 \mathrm{f} 6$, ISS-192; returned to Senate, 207-208, 2II, 220-22I ; in convention of 1821 , 240, 263: opposes Solomon Van Rensselaer's appointment, $279 n$

Kingsbury, 39. 356

Knickerbocker, H., 37, 102

Knower, Benjamin, 36, 283n, 322, 332

Knox, Henry, I24

Labor ( see "Workingmen")

Lansing. J. G., I88n

Lansing. John, 62

Lansingburgh, 38,356

Lawrence, C. W.. 368, 369. 385

Lawrence, John, 17, 29, 152

Law rence, R. M., 157

Lawyers, II-I7

Lee, Gideon, 383, 423n

Lefferts, John, 274

Leggett, W Wm., 395

Leland, John, 420

Le Roy, 20, I34, I37, I57, I 83
Le Roy, Bayard \& Co., 124, 152, 157

Lewis, Morgan, 63, 64, 69, I06

Lewis County, 5.3

Livingston, P. R., 155; character of, 240 ; in convention of 1821 , $245,247,248,265$; leaves Democratic party, 332 ; speaks before National Republicans, 36r ; as a Whig, 422, 423n

Livingston, R. L., 102, I45

Livingston, R. R., 229

Livingstons, $47,62,63,64,65$, 69, 71

Locke. John, 249-250

Lockport. +24

"Loco-Foco" party, 381-402

Low, Cornelins, I37

Low, Nicholas, 21, 51, 124, 134, 156,183

"Low Salary Men," 200

Lynch, D., 153

NcCormick, D., I57

McEvers, Charles, 21, 157

NcIntyre, A., 175n, +22

Madison, James, $300-301$

Manufacturing. 302 et seq., $318-326$

Marcy, W. L., supports Rufus King for U. S. Senator, 22I; member of "Regency," 281 ; defends " spoils system," 284 ; on tariff, 331 ; made governor, 364 ; succeeds himself in I834, 37I; on abolitionism, 378; and six million-dollar-loan, 387 ; defeated for governor in 1838 , $402-705$

Marryat, Frederick, 4I7-418

"Martling Men," 7 I

Mason, J. M., I62, 163, I64, I68, 182 214,226

Maxwell. Hugh, 163, 203, 210, 214,226

Mechanics' lien law, 352, 351

Merchants, I8-20, 22, 426

Mesier, Peter, 22

Military and Civic Hotel, 381, 384

Militia system, 354, 357

Miller, D. C., 363

Miller, M. S., 5I, I0I, 18211, 222

Ming. Alexander, 397

Minturn, 20

Mitchill, S. L.. 2I 8

Moore, Eli, 386

Morgan, Christopher, 421 
Morgan, Wm., 337-338

Morris, Gouverneur, on democracy, 6; importance and character of, 11 ; on Burr, 60; on embargo, 104: a landholder, I24; on land taxation, 125-I26; on universal suffrage, I +3 : early agitation for canal, I50, I53. 210; on secession in 1812,167 , I85; opposed to War of 1812. I65, 177, 184, I85; on Napoleon, 182 ; on King's candidacy in 1816 , 89 ; indifference to parties, 192 ; a framer of constitution of 1777,229

Morris, Jacob, I35, I38, 188

Morris, Thomas, 157

Morse, S. F. B., 373-374

Morss, John, 27I-272

Munro, P. J., 73, 265

Murray, John i., 20

National Advocate, 234

National Republicans, 360, 36r

Nativism, 75-81, I I 5, 37 I-376

Negro suffrage, 260-27on

Newburgh, 48

Newspapers, 426-429

New York American, founded, 209-213; advocates general constitutional convention in 1820 , 234; moderation on the suffrage, 263; favors Adams in 1824, 286; on tariff, 323; on strikes. 39r; on Democrats, 425

New York city, politics of, chap. ii ; remarkable growth, 230 ; effect of canal upon, 304-305; classes and vote in, chap. xiv

New York Commercial Advertiser, 39 I

New York Courier and Enquirer, $364,367,384,391$

New York Evening Post, 383. 391, 394-395

Niagara County, 372

Nicholas, John, 73

Niles, Wm. O., 323

Noah, M. M., 364, 422

North, Wm., 237

Norwich, 360

Oakley, T. J., a Poughkeepsie Federalist, 47; on the Erie Canal, 155 ; importance in Con- gress, I82n; supports King for governor in 1816 , I88; supports Clinton in 1817, 198; opposes King for Senator, 208; appointed attorney-general, 2II ; assailed by $N . Y$. American, 2II-2I 2 ; supports Clintonian candidate for speaker in I820, 221

Ogden. David A., 17, 130, 137

Ogden, David B., I7, 29, I68, I70, $177,181,189,299,402,409,422$

Ogden, Gouverneur, 13I

Ogden, Isaac, 290, $423 \mathrm{n}$

Ogden Samuel, I 28

Ogle, Charles, 4I2

Oneida County, 50, 52, 230, 3I8, 320

Otis, H. G., 100, 17I

Owen, R. D., $356,359,388$

Oxford, 360

Palmyra. 356

Parish, George, I32-133, I37

Parties, philosophy of, $275-278$, 285, 300-30I, 392-393

Patroon, the (see Van Rensselaer, Stephen )

Peck, Jedediah, I 35

Pendleton, Nathaniel, I7, I I I, I 54

People's Party, 273. 288, 291. 307308

Pierpont. H. B., 157

Pitcher. Nathaniel, 274, 3I3, 422

Platt, Jonas, importance in party, 51: on embargo, IO3: campaign for governor in 1810, II2-1I6; seeks to continue "fagot voting," I47; on Erie Canal, 174; supports Clinton in 1817, 196, 198; in convention of $182 \mathrm{I}, 242$, $244,264-265$; opinions recalled, 274 ; a "People's Man," 299; on manufactures, 322

Platt. Zephaniah, I34

Porter, P. B., 62, 196, 402, 422, $423 n$

Poughkeepsie, $46-47,319$

Prison labor, 354

Quincy, Josiah, 94

Radcliffe, Jacob, II I, I74, 203, 256

Radcliffe, Peter, 170, 174, 203

Railroads, 306

Ray, Cornelius, 19, 20, I6r 
Ray, Robert, 183

Raymond, Benjamin, I29

Remsen, Henry, 21, 156,157

Renwick, James, 202n

Rhinebeck, 56

Riggs, C. S., Izon

Robinson, Beverly, 29, 30

Rochester, 5I; effect of canal upon, 229, 303; manufactures in, 320 ; labor movement in, 354, 356 ; Irish in, 372 ; a Whig center, $424,437,447$

Rochester, Wm. B., 312-313

Roosevelt, C., 395

Root, Erastus, affability of, 200 ; opposes Clinton, 214; endorses Rufus King, 22I ; desires constitutional reform, 233; characterization of, 240 ; in convention of $1 \& 21,245,247,260-261,262$, 265; candidate for lieutenant governor in 1822,279 ; elected, 280; opposes canal policy, 307; on state road, 335 ; suggested by National Republicans for governor, 361; in campaign of 1840 , 421 ; as a Whig, 422

Ross, Dr., 260

Ross, Wm., I8I

Rough Hewers' Associations, 4II

"Royal Party," 225

Ruggles, Samuel B., 403-404

Safety-fund law, 360

St. Lawrence County, 52, 423

Salem, 39

Salina. 356

Sanford, Nathan, 251

Saratoga, 356

Savage, John, 390-391

Schermerhorn, C., I83

Schuyler, Philip, 3, 3I, 32, I24, I50-15 I

Scriba, F., I52

Sebring, Isaac, 20, 89, 95

Sedgwick, T., $180 n$

Selden, Dudley, 364

Seventh Ward Bank, 382

Seward, Wm. H., and AntiMasonry, 342; and Workingmen, 358 ; nominated for governor in 1834,371 ; and nativism, 376-378; and abolitionism, 378380 ; elected governor in is 38 . 402-405; studied simplicity of,
414; attractive personality of. 423 ; and anti-rent riots, $437-438$

Sharpe, Peter, 260, 322

Shepherd, Z. R., I90, 222

Sherred, 20

"Siamese-Twin ticket," 362,370

Sibley, Mark C., 379

Skidmore, Thomas, 356, 359

Skinner, Roger, I94n

Slidell, John, 22

Smith, Gerrit, writes Peoples' Party address, 294

Socialism, fails to attract Americans, $419-420$

Southwick, Solomon, 343, 349

Spencer. Ambrose, as Clintonian leader, 67; breaks with Clinton, I66. I69, I74; reconciled with Clinton, 195, I06; and "Coodies," 203: assailed by N. Y. American, 213; assailed by "Bucktail Bards," 216; in convention of $1821,237,242,244,247,251$, $252,253,256,257$; loses judgeship, 264-265; a "People's Man," 209; on manufactures, 322; on Clinton, 345 ; on U. S. Bank, 365

Spencer, John C., attempts to delay constitutional reform, 236 ; on manufactures, 324 ; supports Clay in $18.32,361$; senatorial aspirations of, 400 ; as a Whig, 422

State road. 334-337

Stevens, John, advises railroad building. 306

Stevens, Samuel, 359

Stevenson, Tohn B., 162

Stillwell, S. B., 359

Stone, IVm. L., supports Clinton, Iog; ridicules Morss's antititle bill, 272: favors Adams in 1824,286 ; as a IVhig, 426, 428429

Strikes, 300-392

Strong, Selah, is

Suffrage, landlords and, I39-148; agitation for extending, 233, 2.37-2.39: in convention of 1821 , 248-264; becomes universal among men, 273-274

Sullivan, Wm., g8, izo

Swartwout, John, 7o

"Swiss Federalists," 207 


\section{Syracuse, 52}

Talcott. Samuel A., 282

Tallmadge, N. P., 399-402, 403

Tammany Society, becomes Jeffersonian, 88. 89, 91 ; moves from Martling's Tavern to Tammany Hall, 95; tardily supports canal project, I55-156; opposes Clinton in 1817 , 198, I99: supports King for Senator, 207: joined by "high-minded Federalists," 2I4; on constitutional convention of $182 \mathrm{I}, 233-234$; and naturalized citizens, 374 ; and Loco-Focos, 383-390

Tariff, $325-334,358$

Tayler, John, I06, I66, I69, I75

Ten Broeck, A., 152

Ten Broeck, Dirck, 34

"Ten-hour day," 352

Thompson. Smith, 342. 347-351

Throop, Enos T.. 348

Tibbits, Elisha, 2I. 157

Tibbits, George, 38, I55, I85, 222.

“ 322 Tickler, Toby," 66

Tippecanoe Clubs, 4 II

Tocqueville, A. de. +16

Tompkins, Daniel D., nominated for governor in $1807,74.82$ : renominated in I8IO. II2: prorogues legislature in ISI2, I66: and Van Rensselaer, 172, I73, I76; as war governor, I79, I90, 224: renominated in $18 \mathrm{I} 6, \mathrm{I} \& 9$; nominated for Vice President. 19I. I96; attractive manners of. 200,201 ; president of constitutional convention of 1821,239 ; in convention, 245. 260; opposes Solomon Van Rensselaer's appointment. $278-279$

Tontine Coffee House, 2I

Tories, 12, I06-I09

Townsend, John, I9

Trenton Falls, 56

Troup, Robert, on spoils system, 6 ; importance and character, I415; as an Episcopal, 27, I36n, I37: on Burr, 60; on politics in I806, 70, 72, 73; on American ticket. 80 : as land-agent, IO3, I34; on Tories, 107-108; on politics, in I8Io, III; canal in- vestments of, I5I; on Erie Canal, I54: in War of 1812,133 ; on manufactures, 322

Troy, politics in, 36-38, 56: workingmen in, 356 : as a Whig center, $44^{8}$

Ulshoeffer, Michael, 236

Ulster County, 47

Utica, politics of 50-5I, 55-56; scene of Anti-Regency conventions, 297. 3I2, 392; workingmen in, 356

Van Buren, Martin, as political lieutenant of Clinton, 145: welcomes "High-minded Federalists," 2I3: supports Rufus King for Senator, 221: in convention of I82I, 240-241, 246, 247, 258 , $262,263,266$; opposes Solomon Van Rensselaer's appointment. 278-279: leader of the " Regency," 281 ; opposes internal improvement, 3 IO- $3 \mathrm{II}$; in campaign of 1826.313 ; joins with Clinton in supporting Jackson, 3I4-3I8; on tariff, 332, 333; as a politician. 345 ; in campaign of 1828 , 348-351; carries through safetyfund law. 360: and Catholics, 374: and Loco-Focos, 393-394. 397-399: his alleged luxuriousness, +12-4I3

Van Cortlandt, Pierre, I75n, 20I, 422, 423n

Van der Heyden, 27,38

Van Horne, G., I24, I57

Van Ness. WV. P., 59, 70

Van Ness, iV. W., importance and character, 43-44; supports Lewis, $7 \mathrm{I}, \quad 73$; appointed to supreme court, 8I ; in campaign of ISos, IO2: continues as judge, I 87: in Bank of America scandal. I89, 226-228: supports Clinton, in 1817 . I96, I98; and "Bucktail Bards," 216: on "High-minded Federalists," 225: in convention of $1821,242,247$, $252,255,258,259,26 \mathrm{I}, 262$; loses judgeship, $264-265$; on manufactures, 322

Van Rensselaer, 50

Van Rensselaer, H., I32

Van Rensselaer. J. R., importance 
and character, 44-45; as speculator and lobbyist, 46, 154 ; in campaign of I808, I02; on Napoleon, I82; as general, I83; on secession. I 85 ; supports King for governor in ISI6, I88; supports Clinton in $1817,196,198$; in Bank of America scandal, 226-228; in convention of IS2I, $242,247,250,255,258,259$; a “People's Man," 299; on manufactures, 302

Van Rensselaer, Jeremiah, in

Van Rensselaer, K. K., IO2

Van Rensselaer, Solomon, affair with John Tayler, I04, I07; during War of $1812,175,176$; controversy over appointment as post-master of Albany, 278-279

Van Rensselaer, Stephen, candidate for governor in I8OI, 4; influence of, $3 \mathrm{I}$ : character of, 32 ; as land-holder, I24, I4I. I42; on canals, I55; in War of ISI2, I72, I73; as candidate for governor in I8I3, I75-I76; on Napoleon, I82; supports King for governor, I8S-I89; supports Clinton, I99; elected to convention of 1821,237 ; favors convention, 238; in convention, 242 . 247, 259: a "People's M̀an," 299 ; founds Rensselaer School, 323; on Masonry, 36r

Van Schoonhoven, J., 34, I52

Van Vechten, Abraham, importance and character of, 33-34; on politics in 1807,72 ; on coalition with Clintonians in I808, I00: and spoils system, IIo; on New York mayoralty, III; on Erie Canal, I54, 155; on free speech, Ison; on Napoleon, I82; on secession. I85; elected to constitutional convention of $I 8_{2} I$, 2.37 ; in convention, 242, 247, 255. 259, 261, 265: a " People's Man," 299

Van Wyck, P. C., 2OI, 2I4

Van Zandt, Wyant, 18

Varick, Richard, I5, 2I, 89, III, I63, I68, I 8 I

Verplanck, Gulian, 2 I

Verplanck, Gulian C., founds Washington Benevolent Society,
89, 94; opposes Clinton in $18 \mathrm{I}$, I60-I65; literary controversy with Clinton, 203-205; associated with N. Y. American, 209, 210; author of Bucktail Bards, 2I42I8; elected to legislature, 226; leaves Democratic party, 364 ; nominated for mayor of New York city, 368; declines nomination for governorship, $37 \mathrm{I}$

Verplanck. Johnston, 209

Vining, W. H., I3I

Walker, Benjamin, 50

Warsaw, 424

V'ashington Benerolent Society, 89-99

Washington County, 39

Watts, John, Io 8

Wayne County. Irish in, 372

Webb, J. W., leaves Democratic party, 364; suggests name of Whig party, 367 ; as a Whig, 426, 428

Webster, Daniel, 95; on tariff, 329; on U. S. Bank, 365; in campaign of $1840,409-410,4 I$, 4I $4-415$

Webster. Noah, 86

Weed. Thurlow, contrives election of Adams electors, 300; on Clinton's adherence to Jackson, 3I6; and Anti-Masonry, 342343 ; as a politician. $345,360-$ $362,363-367$; on nativism, 376378 ; in campaign of IS40, 4 II; attractive personality of, 423 ; on Federalists, $425-\$ 26$

WVells, John, I7, 29. I90, 237

Western counties, 30I

Wetmore, R. C., 364, 422

Wheaton. Henry, attempts to protect judges in IS2I, 265; AntiClinton "People's Man." 200

Wheeler, Melanchthon. 262-263

Whig party, $367-368$, chap. xiv

Whitestown, 50, 5I

Williams, Elisha, importance and character of, $4 \mathrm{I}-43,55$; ambitious for wealth, 46 : in campaign of I8O8, IO2: deeds property to make voters, I46; supports canal measure. I55; supports Clinton in I8I7, I96, I98; assailed by N.Y. American, 2I2; 
opposes King for Senator, 22I ; in Bank of America scandal, 226-228; in convention of I821, $242,247,248,250,252,255,256$, 259, 26I, 262, 266; a 'People's Man," 299

Williams, John, 39

Williams, Robert, I Ion, $265 \mathrm{n}$

Villiams, William, 55

Wirt, Wm., 362, 363

Wolcott, Öliver, 2I, I60, I6 3

Woman labor, 352

Wood, John, $5 \mathrm{~S}$

Woodworth, John, on party strife, 56 ; loses judgeship, $264-26_{5}$

Woolsey, W. W., $2 \mathrm{I}$

Workingmen, grow in importance after I812, 229; political activity of, 352-359; and Loco-Focos, $385-387$

Wright, Frances, 356, 539, 388, 4I.5. 418

Wright, Silas, Jr., opposes Ambrose Spencer's candidacy for U. S. Senator, 273; drafts manhood suffrage bill, 274; member of "Regency," $28 \mathrm{I}$; loyalty to the "Regency," 283 ; as political manager, 284-285; against the Electoral Bill, 289-29I ; opposes internal improvement, 307; on tariff, 332-33t; on Clinton's death. 344 ; manages Independent Treasury bill, 398

Yates, J. V. N., 62

Yates, Joseph, loses judgeship, 264-265; elected governor in IS22, 279-280; nominates Platt and Spencer for judges of the supreme court, 280 ; calls special session of the legislature, 289; candidate for governor in I824, 290

Young, John, 422

Young, Samuel, 22I ; characterization of, 239-240; in convention of $1821,247,264$; on state road, 336 ; refuses Loco-Foco nomination. 393: opposes internal improvement, 406

Young Men's Conventions, first held in 1824.297 


\section{VITA}

The writer was born in Potsdam. N. Y., December 7, I887. He was graduated from the Potsdam Normal School in February, I907. In I9I I he received the degree of $\mathrm{A}$. B., and in I9I2 that of A. M., both from Columbia. He took courses in the School of Political Science of that university in I9I I-I2 and I9I2-I3, chiefly under Professors Dunning. Osgood, Beard, Shotwell, Robinson and Seager. In I9I2 he was appointed Lecturer in Politics and in I9I3 Instructor in History, which position he now holds. 






